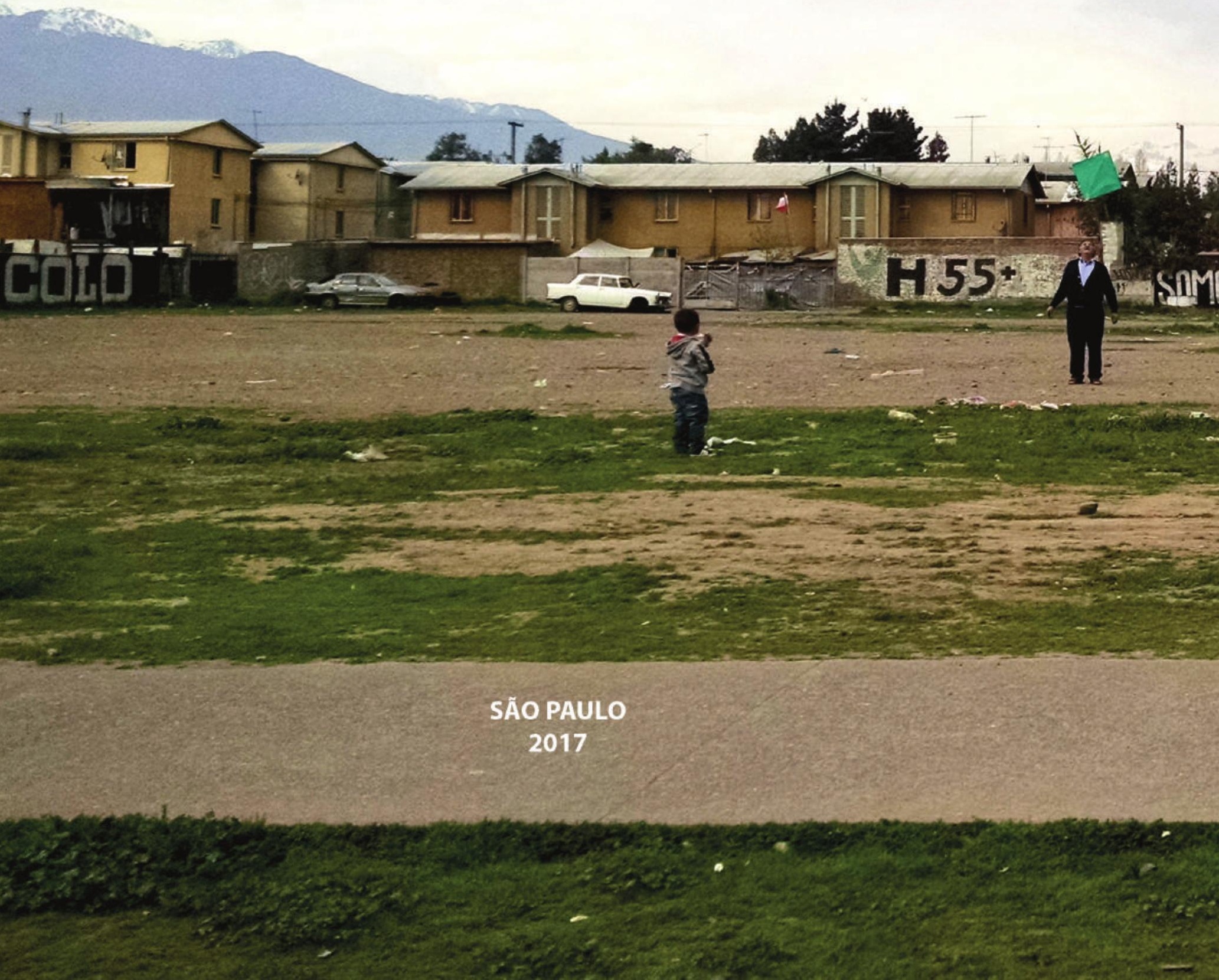




\section{PAISAGEM E COTIDIANO EM HABITAÇÃO SOCIAL NAS REGIÕES METROPOLITANAS DE SÃO PAULO E SANTIAGO DO CHILE}






\section{UNIVERSIDADE DE SÃO PAULO}

Faculdade de Arquitetura e Urbanismo

\section{Verônica Garcia Donoso}

Paisagem e cotidiano em habitação social nas Regiões Metropolitanas de São Paulo e Santiago do Chile 


\section{Verônica Garcia Donoso}

Paisagem e cotidiano em habitação social nas Regiões Metropolitanas de São Paulo e Santiago do Chile

Tese apresentada ao Programa de Pós-Graduação em Arquitetura e Urbanismo, Área de Concentração Paisagem e Ambiente, da Faculdade de Arquitetura e Urbanismo da Universidade de São Paulo, como exigência para a obtenção de título de Doutora em Ciências.

Orientação: Prof. Dr. Eugenio Fernandes Queiroga 
AUTORIZO A REPRODUÇÃO E DIVULGAÇÃO TOTAL OU PARCIAL DESTE TRABALHO, POR QUALQUER MEIO CONVENCIONAL OU ELETRÔNICO, PARA FINS DE ESTUDO E PESQUISA, DESDE QUE CITADA A FONTE.

E-mail:vgdonoso@yahoo.com.br

veronica.donoso@usp.br

Donoso, Verônica Garcia

D687p Paisagem e cotidiano em habitação social nas regiões metropolitanas de São Paulo e Santiago do Chile / Verônica Garcia Donoso. -- São

Paulo, 2017.

321 p. : il.

Tese (Doutorado - Área de Concentração: Paisagem e Ambiente) FAUUSP.

Orientador: Eugenio Fernandes Queiroga

1.Espaços livres 2.Habitação social 3.Cotidiano 4.Práticas sociais 5.(Des)prática I.Título

CDU 712.25 
Nome: DONOSO, Verônica Garcia

Título: Paisagem e cotidiano em habitação social nas Regiões Metropolitanas de São Paulo e Santiago do Chile

Tese apresentada à Faculdade de Arquitetura e Urbanismo da Universidade de São Paulo, para a obtenção de título de Doutora em Paisagem e Ambiente.

Aprovado em: 

A mis abuelos. 


\section{AGRADECIMENTOS}

Uma das grandes alegrias em completar um ciclo de pesquisa é relembrar as pessoas que colaboraram no desenvolvimento do trabalho e poder dizer obrigado a elas.

Não há palavras para agradecer ao apoio dos meus pais, irmã e família chilena, alicerce e inspiração para a realização desse trabalho.

Também não existem palavras para agradecer ao meu orientador, Eugenio Queiroga, que me acompanha desde o Mestrado na FAUUSP, e cuja postura exemplar como docente tem me inspirado a seguir a jornada acadêmica.

Reconheço o indispensável apoio financeiro da Fundação de Amparo à Pesquisa do Estado de São Paulo, por conceder Bolsa de Doutorado que permitiu, por meio de Bolsa regular no país e Bolsa Estágio de Pesquisa no Exterior (BEPE), não só o desenvolvimento desta pesquisa no Brasil, mas também a parte do trabalho realizado no Chile. Também agradeço às instituições de ensino que sediaram esta pesquisa, a Universidade de São Paulo, que me abriga como aluna desde a graduação, e a Universidad de Chile, que me recebeu como pesquisadora convidada durante estágio no exterior.

Devo gratidão especial a Silvio Macedo, que incentiva e orgulha os que estão ao seu redor graças a sua energia e à paixão que demonstra pelo ensino e pela pesquisa da paisagem.

Também segue um grande agradecimento aos excelentes pesquisadores e docentes da Universidad de Chile, Ricardo Tapia Zarricueta e Paola Jirón Martínez, que acompanharam e orientaram a pesquisa em Santiago.

Sinto-me grata aos professores João Sette Whitaker Ferreira e Catharina P. C. dos Santos Lima pelos relevantes comentários na banca de qualificação, a maioria aplicados na finalização deste trabalho, e aos professores da banca examinadora final.

Também agradeço a Chris Botosso, pela revisão textual da tese. 
Meus agradecimentos mais que sinceros aos grandes pesquisadores do Laboratório QUAPÁ (FAUUSP): Ana Cecília de Arruda Campos, Fabio Mariz Gonçalves, Fany Galender, Francine Sakata, Helena Degreas, Isabela Sollero Lemos, João Meyer, Leonardo Loyolla Coelho e Vanderli Custódio; e do Instituto de la Vivienda (UCHILE): Carlos Lange Valdés, Jorge Larenas Salas, Luis Campos Medina, Mariela Gaete Reyes, Orlando Sepúlveda Mellado, Rebeca Silva Roquefort, Rodrigo Toro Sánchez e Walter Imilan Ojeda.

Aos "pasantes" INVI: Raúl Holguin Ávila, Maura Chavez Farias, Ana Itzel López Santaruz, Edlin Jazmin Vargas García, meu muito obrigada por partilharem suas pesquisas e me ensinarem sobre a habitação social no México.

Também agradeço aos alunos estagiários do QUAPÁ, especialmente a Mateus Campos Oliveira, Caroline de Paula e Tiago Andrade Regueira, pelo interesse na pesquisa.

Agradeço a Carolina Besoain por me permitir participar do grupo de discussões junto a outros pesquisadores: Lais Carvalho Pinto, Rodrigo Morales, Alejandro Soto, Vicente Bernal Santibañez, Ismael Fernández Posada, Karla Hidalgo. Meu muito obrigada por me receberem e partilharem conhecimentos comigo.

Meus sinceros agradecimentos a Camila Cociña, por compartilhar reflexões de sua tese, tão próxima à minha; a Sofía Covarrubias, que me recebeu e me permitiu participar como voluntária da Fundación Mi Parque; a Ignacio Moulian Muniaga, David Herrera Chacana e Paula Gajardo Martinez pelos conhecimentos partilhados sobre a política habitacional chilena; a Lorena Segura Riviera, por me acompanhar na visita a Bajos de Mena e me relatar o cotidiano na comuna de Puente Alto.

Agradeço ao apoio dos colegas do PEABIRU, em especial a Rafael Borges Pereira e a Maria Rita de Sá Brasil Horigoshi, além dos moradores e líderes comunitários dos casos estudados na tese, que me receberam e me permitiram conhecer seu cotidiano.

Meu muito obrigada a todos os colegas, amigos e familiares, pelo constante apoio. 


\section{RESUMO}

Esta tese discute a paisagem gerada por políticas de habitação social latino-americanas, observando especificamente casos da Região Metropolitana de Santiago do Chile (RMS) e da Região Metropolitana de São Paulo-SP (RMSP). Foca-se a análise nas práticas sociais em espaços livres de empreendimentos de habitação social, observando resultados de 2009 a 2016 da faixa 1 do Programa Minha Casa Minha Vida na RMSP e de 2006 a 2016 dos Programas de Bairro na RMS. Observam-se as práticas sociais nos espaços livres, tanto públicos quanto privados, pelo olhar da paisagem, que possibilita à análise ser ampliada para as relações sociais cotidianas que ocorrem nesses espaços. Para tanto, observa-se a formação de ambas as Regiões Metropolitanas, o histórico das políticas habitacionais, o modus operandi de produção habitacional social que concentrou empreendimentos em trechos sem cidade, analisando o impacto de modelos urbanos e arquitetônicos aplicados em situações de vulnerabilidade social e econômica para o cotidiano das práticas sociais. O cotidiano intramuros, resultado do modelo de condomínio habitacional social, amplamente aplicado em ambos os países, é confrontado com os programas chilenos de bairro, que se focam nas práticas sociais em espaços livres públicos. As análises demonstraram que, apesar de diversas alterações nos programas políticos, mantêm-se as práticas de construir conjuntos habitacionais pautados nos aspectos quantitativos, em um modelo de inspiração neoliberal, ou de mitigar os impactos do modelo com programas de recuperação de bairros, que esbarram em dificuldades pelo contexto vulnerável do local, resultando em espaços pouco representativos para a completude das práticas sociais. Salienta-se a necessidade de se criarem ações voltadas para as práticas sociais, em que haja a possibilidade de se superar o dia a dia alienado, e apontam-se as qualidades e fragilidades das políticas de ambos os países para os cotidianos praticados ou (des)praticados.

Palavras-chave: espaços livres, habitação social, cotidiano, práticas sociais, (des)prática.

\section{ABSTRACT}

This thesis discusses the landscape created by Latin American social housing policies, specifically cases related to the Metropolitan Region of Santiago de Chile (MRS) and the Metropolitan Region of São Paulo-SP (MRSP). The analysis focuses on social practices in open spaces of social housing projects, considering results from 2009 to 2016 of the first data compilation of the federal government's housing program Minha Casa Minha Vida in the MRSP and from 2006 to 2016 of the Neighborhood Programs in the MRS. Social practices in the public and private open spaces are observed, in light of the view of the landscape, which allows expanding the analysis to the everyday social relations that occur in these spaces. Therefore, the formation of both Metropolitan Areas is observed, as well as the history of housing policies, the modus operandi of social housing production which concentrated developments in fringe areas without a city, analyzing the impact of urban and architectural models applied in situations of social and economic vulnerability for the daily life of social practices. The intramural daily life, a result of the gated community social housing model and widely applied in both countries, is compared with Chilean neighborhood programs which focus on social practices in public spaces. The analysis evidenced that, despite a number of changes in the political programs, the practices of constructing housing projects based on quantitative aspects, a neoliberal inspired model, or based on mitigating the impacts of the model with neighborhood rehabilitation programs continue, notwithstanding the difficulties they face due to the location's vulnerable context and which result in spaces that are not really representative of social practices. It is necessary to create actions aimed at social practices, with the possibility of overcoming the alienated day-to-day reality, and identify the qualities and weaknesses in the policies of both countries for the daily practices which are practiced or un-practiced.

Keywords: open spaces, social housing, daily life, social practices, un-practice. 


\section{SUMÁRIO}

Introdução: Aprendendo com nós mesmos

Capítulo 1: Territórios (des)praticados - práticas sociais nos espaços livres de conjuntos de habitação social

- Participação cidadã e redes sociais

- Gestão

- Inserção urbana p. 48

- Adequação microclimática p. 50

- Diversidade morfológica e flexibilidade funcional

- Visibilidade

- Dimensão

- A (des)prática: limitações das práticas sociais

Capítulo 2: As políticas de habitação social no Brasil e no Chile a partir de 1964

- Introdução

- Antecedentes às ditaduras militares p.66

- Período das ditaduras militares p. 67

- Políticas pós-ditadura militar e o retorno à democracia no Chile e no Brasil

- De 2000 a 2010

Capítulo 3: Sobre as Regiões Metropolitanas: formação e fragmentação visível e invisível

- Suporte biofísico

- Evolução urbana

- Dados atuais em tabelas comparativos

- Os territórios de inclusão periférica 
Capítulo 4: O Programa Minha Casa Minha Vida

- Particularidades do PMCMV

- O Programa Minha Casa Minha Vida - Entidades (PMCMV-E)

- Histórico

- Atuação

- Características

- O Programa Minha Casa Minha Vida na RMSP

- Dificuldades de inserção de um grupo social em um modelo condominial imposto

- Mudanças no cenário político brasileiro após o impeachment da presidenta Dilma Rousseff

Capítulo 5: "Modus operandi" de grandes concentrações de habitação social no Chile e no Brasil

- Bajos de Mena

- Cidade Tiradentes

Capítulo 6: Cotidiano intramuros

- Condomínio Residencial Parque Estela - Guarulhos (PMCMV-E)

- Condomínio Residencial Vila Pimentas I - Guarulhos (PMCMV)

Capítulo 7: Cotidiano de bairro

p. 258

- O Programa Quiero Mi Barrio e o Programa Fondo Solidario

- Las Viñitas e Lomas del Prado - demolições e novos desenhos urbanos com o Programa Fondo Solidario de Vivienda

Considerações: Contribuições para o desenvolvimento do habitat de interesse social 


\section{LISTA DE ABREVIATURAS E SIGLAS}

AMMO - Associação dos Mutuários e Moradores da COHAB I

AMS - Área Metropolitana de Santiago

APP - Área de Preservação Permanente

BID - Banco Interamericano del Desarrollo

BNH - Banco Nacional de Habitação

CADÚNICO - Cadastro Único do Governo Federal

CASEN - Caracterización Socioeconómica Nacional

CCRL - Construtora Camargo Rodrigues Ltda

CDHU - Companhia de Desenvolvimento Habitacional e Urbano

CETESB - Companhia Ambiental do Estado de São Paulo

CEU - Centro de Educação Unificado

$\mathrm{ClA}$ - Central Intelligence Agency

CMPC - Compañia Manufacturera de Papeles y Cartones

COHAB/SP - Companhia Metropolitana de Habitação/São Paulo

CORVI - Corporación de la Vivienda

CVD - Consejo Vecinal de Desarrollo

D.S. - Decreto Supremo

DENATRAN - Departamento Nacional de Trânsito

EDIF - Departamento de Edificações

EGIS - Entidad de Gestión Inmobiliaria Social

EMEF - Escola Municipal de Ensino Fundamental

EP - Entidade Patrocinante

FAR - Fundo de Arrendamento Residencial

FAUUSP - Faculdade de Arquitetura e Urbanismo da Universidade de São Paulo

FCVS - Fondos Concursables para Proyectos Solidarios

FDS - Fundo de Desenvolvimento Social

FGTS - Fundo de Garantia por Tempo de Serviço

FNHIS - Fundo Nacional de Habitação de Interesse Social

FOSIS - Fondo de Solidariedad e Inversión Social

FPT - Futuros para el Tenis

FSV - Fondo Solidario de Vivienda 
Habi - Superintendência de Habitação Popular

HABISP - Sistema de informações para habitação social na cidade de São Paulo

IAPs - Institutos de Aposentadoria e Pensões

IBGE - Instituto Brasileiro de Geografia e Estatística

IDHC - Índice de Desarrollo Humano Comunal

IDHM - Índice de Desenvolvimento Humano Municipal

IMH - Ingreso Municipal por Habitante

INE - Instituto Nacional de Estadísticas

INOCOOP - Instituto de Orientação às Cooperativas Habitacionais

INVI - Instituto de la Vivienda, Universidad de Chile

Laboratório QUAPÁ - Quadro do Paisagismo no Brasil, FAUUSP

MDM - Movimento pelo Direito à Moradia

MDS - Ministério do Desenvolvimento Social e Combate à Fome

MIDEPLAN - Ministerio de Planificación y Cooperación

MINVU - Ministério de Vivienda y Urbanismo

MMC - Movimento de Moradia dos Encortiçados, Sem Teto, Catadores de Papelão da Região Central de São Paulo

MPL - Movimiento do Pobladores en Lucha

MPST - Movimiento Pueblo sin Techo

MST Leste 1 - Movimento dos Trabalhadores Sem Terra Leste 1

OCUC - Observatorio de Ciudades

OGU - Orçamento Geral da União

PAC - Programa de Aceleração do Crescimento

PAR - Programa de Arrendamento Residencial

PC do B - Partido Comunista do Brasil

PCB - Partido Comunista Brasileiro

PCS - Programa Crédito Solidário

PES - Praças de Equipamentos Sociais

PET - Programa Especial para Trabajadores

PGO - Plan de Gestión de Obras

PGRC - Plan de Gestión de los Recursos Complementarios

PGS - Plan de Gestión Social 
PHS - Plan de Habilitación Social

PIB per capita - Produto Interno Bruto per capita

PlanHab - Plano Nacional de Habitação (PlanHab)

PLHIS - Plano Local de Habitação de Interesse Social

PMB - Programa Mejoramiento de Barrios

PMCMV - Programa "Minha Casa Minha Vida”

PMCMV-E - Programa "Minha Casa Minha Vida" Entidades

PNUD - Programa de las Naciones Unidas para el Desarrollo

PP - Partido Progressista

PPPF - Programa de Protección del Patrimonio Familiar

PQMB - Programa "Quiero Mi Barrio"

PSAT - Prestador de Servicios de Asistencia Técnica

PSDB - Partido da Social Democracia Brasileira

PT - Partido dos Trabalhadores

PVB - Programa Vivienda Básica

PVP - Programa de Vivienda Progresiva

RMS - Região Metropolitana de Santiago

RMSP - Região Metropolitana de São Paulo

SBPE - Sistema Brasileiro de Poupança e Empréstimo

SEHAB - Secretaria Municipal de Habitação

SEREMI - Secretaría Regional Ministerial

SERVIU - Servicio de Vivienda y Urbanización

SESC - Serviço Social do Comércio

SFH - Sistema de Financiamento Habitacional

SNHIS - Sistema Nacional de Habitação de Interesse Social

SUBDERE - Subsecretaria de Desarrollo Regional y Administrativo

TCU - Tribunal de Contas da União

TTS - Trabalho Técnico Social

UF - Unidad de Fomento

UMM - União dos Movimentos de Moradia

VSDsD - Programa Vivienda Social Dinámica sin Deuda

ZEIS -Zonas Especiais de Interesse Social 


\section{LISTA DE FIGURAS}

\section{Capítulo 1}

Figura 1: Ponto de ônibus em Cidade Tiradentes, São Paulo-SP. Fotografia da autora, de maio p. 38 e 39 de 2016.

Figura 2: Academia ao ar livre sendo instalada na área comum do condomínio. Empreendimento Residencial Portal Flora, em Guarulhos - SP. Fotografia da autora (2015).

Figura 3: Inserção do Centro Educacional Unificado (CEU) na cidade de São Paulo, parte de política educacional municipal criada nos anos 2000 - 2004, durante a gestão de Marta Suplicy, como proposta de inclusão social por meio de ensino, esporte, cultura e extensão. A política consistiu na construção de equipamentos de uso múltiplo em regiões com carência educacional, social e cultural. Ao todo, foram construídos 45 equipamentos, como previsto no projeto original, sendo que a maioria se encontra nas zonas leste (18 equipamentos) e sul (17 equipamentos). Fonte: Acervo QUAPÁ (2012).

Figura 4: Relação edifícios habitacionais e espaço livre. Fonte: elaborada pela autora (2016).

Figura 5: Ausência de muros e grades fazem parte do desenho urbano de várias ruas das comunas de Las Condes e Vitacura, setores que concentram população de alta renda. Fotografia da comuna de Las Condes, fotografia da autora (2015).

Figura 6: Fechamento com grade permite visibilidade no empreendimento de habitação social Lomas del Prado na comuna Cerro Navia. Fotografia da autora (2015).

Figura 7: Cenário típico de regiões de renda média da Região Metropolitana de São Paulo, com condomínios de prédios, lotes unifamiliares, calçadas estreitas e arborização intraquadra pontual. Fonte: elaborada pela autora (2016).

Figura 8: Cenário típico de regiões de alta renda de Santiago, onde edifícios habitacionais com varandas generosas tem seu térreo integrado ao passeio público. A restrição do acesso ao edifício é feita pelo desenho urbano e pelo paisagismo. Fonte: elaborada pela autora (2016).

Figura 9: Cenário típico de regiões de baixa renda de Santiago, com edifícios habitacionais e habitações unifamiliares padronizados. Ampliações irregulares são comuns tanto nas unidades térreas quanto nos edifícios habitacionais, apesar dos terremotos constantes. Fonte: elaborada pela autora (2016).

Figura 10: Empreendimento do Programa Minha Casa Minha Vida em São Carlos-SP. Unidade habitacional típica do programa, que é imediatamente fechada pelos moradores. Vegetação urbana e intraquadra praticamente ausente. O cenário resultante, de muros contínuos, não é favorável à apropriação do espaço público. Fonte: Acervo QUAPÁ (2014).

Figura 11: Expansões irregulares das unidades habitacionais já são parte da paisagem das comunas de menores recursos de Santiago. Fotografia de conjunto habitacional Los Quillayes, na comuna de La Florida. Fotografia da autora (2015).

Figura 12: Projeto do Conjunto Pudahuel, do Escritório de Arquitetura Elemental, em Santiago do Chile. Fonte: Fotografia de Murilo Navarro (2010).

p. 60 


\section{Capítulo 2}

Figura 13: Extremo leste de São Paulo-SP. Fotografia da autora, de outubro de 2016.

p. 64 e 65

Figura 14: Vila Luís Tarquínio, edificada no final do século XIX no Bairro de Boa Viagem, em p. 68 Salvador, pelo empresário Luís Tarquínio, fundador do Empório Industrial do Norte. (BONDUKI, 2014). Fonte: <http://www.usp.br/pioneiros/zp/index.php?album=volume3\%2F02Tarquinio\&image=Vila+Oper\%E1ria+07.jpg>. Visualizado em 02 nov. 2014.

Figura 15: Vila Matarazzo, em São Paulo. Casas geminadas e espaços coletivos sem equipamento. Fonte: BONDUKI, 2014, p. 26.

Figura 16: Población Miguel Dávila, na comuna San Miguel, em Santiago, realizada no ano 1956. Fonte: MINVU; DITEC, 2004, p. 110.

Figuras 17 e 18: Población Santa Anita, construída nos anos 1980 na comuna Lo Prado. Esse conjunto foi realizado para a erradicação de habitações irregulares principalmente da ocupação Che Guevara. São 880 habitações, cujas varandas são utilizadas tanto para circulação exterior e acesso aos apartamentos como também como espaço de serviço, onde as famílias penduram roupas e se encontram socialmente. Fonte: MINVU; DITEC, 2004, p. 176-7.

Figura 19: Población Marta Colvin, na comuna de Recoleta, construída durante o governo militar. Fonte: SEPÚLVEDA, 2001, apud MINVU; DITEC, 2004, p. 217.

Figura 20: Conjuntos habitacionais financiados pelo BNH na Zona Leste de São Paulo-SP. Fonte: Bonduki, 2014, p. 66-7.

Figura 21: Conjunto Habitacional realizado pela Cohab/SP e BNH, em Itaquera, nos anos 1970. Fonte: Prefeitura Municipal de São Paulo (1979, apud RAMALHOSO, 2013 p. 102).

Figuras 22 e 23: Projeto do escritório de arquitetura Elemental, na Comuna de Renca, realip. 69 p. 70 p. 71 zado durante os governos da Concertación. A implantação das residências, proporcionando um pátio interno, e a visibilidade criada com o portão de grades metálicas, auxilia a gerar melhores relações de vizinhança. Os moradores são estimulados a personalizar sua unidade básica alterando também a fachada. Fonte: <http://www.elementalchile.cl>. Acessado em maio 2014.

Imagens 24 e 25: Projetos realizados por meio de mutirões em São Mateus (à esquerda) e em Guaianazes (à direita), ambos na Zona Leste de São Paulo. Fotos dos anos 1990. Fonte: BONDUKI, 2014, p. 92 e 93.

\section{Capítulo 3}

Figura 26: Habitações irregulares próximas à Rodovia dos Imigrantes. Fotografia da autora, p. 86 e 87 de jul. 2016.

Figura 27: Comunas da Região Metropolitana de Santiago. Fonte: elaborada pela autora, a p. 90 e 91 partir de mosaico de imagens Google Earth (2016).

Figura 28: Municípios da Região Metropolitana de São Paulo. Fonte: elaborada pela autora, p. 92 e 93 a partir de mosaico de imagens Google Earth (2016).

Figura 29: Cajón del Maipo. Fotografia de Manuel Jose Costabal Donoso, jun. 2016.

p. 95 
Figura 30: Vila de Paranapiacaba na Região Metropolitana de São Paulo. Fotografia da autora, set. 2016.

Figura 31: Resíduos na represa Billings, próximo à estação de tratamento de água da SABESP no município de São Bernardo do Campo. Fotografia da autora, set. 2016.

Figura 32: Infográfico da expansão da mancha urbana principal das Regiões Metropolitanas de São Paulo e Santiago. Fonte: Donoso (2016), sob dados do Google Earth e SHLOMO et al (2012).

Figura 33: Rua da comuna de Vitacura. Destacam-se recuos generosos, transparência nos p. 105 fechamentos e muitos edifícios habitacionais sem fechamento para a rua, com delimitação do público e privado com jardins e desenho de piso. Fotografia da autora, jun. 2016.

Figura 34: Foto aérea do município de São Paulo, mostrando bairros com predomínio residencial de alto padrão, como o Jardim Europa, próximo ao Parque Ibirapuera, e verticalização dos bairros Paraíso, Bela Vista e Jardins até a região central. Fotografia da autora, fev. 2016.

Figura 35: Vista de Santiago, mostrando as comunas de Vitacura e Las Condes, que concentram alta renda, e o eixo de expansão urbana ao sul. Fotografia da autora, dez. 2015.

Figura 36: Dados coletados espacializados na RMSP. Fonte: elaboração da autora, 2016.

p. 120 e 121

Figura 37: Dados coletados espacializados na RMS. Fonte: elaboração da autora, 2016.

Figura 38: Agência bancária no bairro Butantã, em um dia frio no mês de março de 2015. Pessoas passavam pela agência, sacavam dinheiro nos caixas eletrônicos, enquanto um mendigo se protegia do frio. O existir não é necessariamente ser visto, e a violência pela inclusão marginal cotidianamente banal ficou tragicamente clara. Fotografia da autora, maio 2015.

Figura 39: Cena - infelizmente - tradicional do Centro de São Paulo, dos moradores de rua que trabalham informalmente como catadores de papelão. Fotografia da autora, maio 2016.

\section{Capítulo 4}

Figura 40: Crianças brincam no espaço livre do Conjunto Habitacional São Marcos Baviera, p. 136 e 137 em Embu das Artes. Fotografia da autora, abr. 2014.

Figura 41: Empreendimento do PMCMV no município de Maceió-AL. Fonte: Acervo QUAPÁ - FAUUSP, 2013.

Figura 42: Empreendimento do PMCMV no município de Uberaba-MG. Fonte: Acervo QUAPÁ - FAUUSP, 2013.

Figura 43: Empreendimento do PMCMV no município de Maceió-AL. Fonte: Acervo QUAPÁ - FAUUSP, 2014.

Figura 44: Empreendimento do PMCMV no município de Uberlândia-MG. Fonte: Acervo QUAPÁ - FAUUSP, 2013. 
Figura 48: Distribuição dos empreendimentos do PMCMV Faixa 1 (Empresas, FAR e Entidades) aprovados na Região Metropolitana de São Paulo. Fonte: elaborada pela autora, com dados do Ministério das Cidades (2014).

Figura 49: Conjunto Habitacional São Marcos Baviera, empreendimento da construtora ESE$\mathrm{CON}$ em Embu das Artes. Acesso no segundo pavimento do edifício permitiu construção de mais pavimentos sem o uso do elevador. Fotografia da autora, abr. 2014.

Figura 50: Via condominial do Conjunto Habitacional São Marcos Baviera em Embu das Artes. Fotografia autora, abr. 2014.

Figura 51: Entorno de empreendimentos do PMCMV em Embu das Artes, de habitação informal. Fotografia da autora, abr. 2014.

Figuras 52 e 53: Residencial Portal Flora antes de ser entregue aos moradores. Fotografia da autora, de 16 abr. 2015.

\section{Capítulo 5}

Figura 54: Ocupação em terreno na Cidade Tiradentes, São Paulo-SP. Fotografia da autora, p. 170 e 171 de out. 2016.

Figura 55: Bajos de Mena. Fotografia da autora, de 20 set. 2015.

Figura 56: Localização de Bajos de Mena, na Comuna de Puente Alto. Fonte: elaborado pela autora, sob base OCUC - Observatorio de Ciudades (2003) e Google Earth (2015).

Figura 57: Fotografia do Regimento de Ferrocarril de Puente Alto. Fonte: <www.patrimoniopuentealto.cl>. Acesso em 14 set. 2015.

Figura 58: Fotografia da construção da "Población Papelera" nos anos 1930, projeto habitacional desenvolvido pela Compañia Manufacturera de Papeles y Cartones (CMPC) para seus trabalhadores. Fonte: <www.patrimoniopuentealto.cl>. Acesso em 14 set. 2015.

Figura 59: Fotografia das habitações construídas pelas indústrias em Bajos de Mena. Fotografia da autora, 20 set. 2015.

Figura 60: Localização dos condomínios de prédios em Bajos de Mena dos anos 1980 a 2002 e seu respectivo ano de construção. Fonte: elaborado pela autora, sob base Google Earth (2015).

Figura 61: Avenida de Bajos de Mena. Fotografia da autora, 20 set.2015.

Figura 62: Algumas das estratégias do Plan Integral Bajos de Mena. Demolições, novos conjuntos habitacionais, parque urbano, intervenções viárias, criação de centros de serviços públicos, além de equipamentos de educação e saúde. Fonte: elaboração da autora, com base em informações do Plan Integral Bajos de Mena.

Figuras 63 e 64: Um dos edifícios habitacionais do Conjunto Habitacional Francisco Coloane em processo de demolição. A presença de famílias resistentes causou uma pausa no proces- 
so de demolição, e aqueles que ainda permanecem no local vivem em meio aos escombros. Fotografias da autora, out. 2015.

Figura 65: Pichação em parede de casa: "Volcao 3, queremos solução, não remendos. Minha p. 186 2a oportunidade agora" Fotografia da autora, 20 set. 2015.

Figura 66: "Casas Copeva": má construção provocou infiltração de água durante chuvas do p. 188 ano de 1997. Solução temporária foi cobrir as casas com uma lona plástica. Fonte: Diario La Tercera.

Figura 67: Escombros da Villa El Volcán II, ainda em processo de demolição, em setembro de p. 189 2015. Depósito de lixo e ocupações irregulares. Fotografia da autora, 20 set. 2015.

Figura 68: A ocupação irregular nos escombros do Conjunto Francisco Coloane. Fotografia da autora, 28 out. 2015.

Figura 69: Nos escombros da Villa El Volcán II, chama a atenção a ocupação irregular junto p. 190 e 191 às ruínas. A bandeira chilena remete ao patriotismo durante a Semana da Pátria. Fotografia da autora, 20 set. 2015.

Figura 70: Recém entregue conjunto habitacional Villa Teresa de Calcuta em Bajos de Mena, em modelo de condomínio. Fotografia da autora, 20 set. 2015.

Figura 71: Recém entregue conjunto habitacional Villa Teresa de Calcuta em Bajos de Mena. Fotografia da autora, 20 set. 2015.

Figura 72: Mais do mesmo. O recém entregue conjunto habitacional Jesús de Nazareth em Bajos de Mena. Fonte: Plan Integral Bajos de Mena.

Figura 73: Área pública de convívio social em conjunto habitacional social localizado em Bajos de Mena. Ao fundo, notam-se ocupações irregulares no espaço de copropriedade de um dos conjuntos habitacionais. Fotografia da autora, 20 set. 2015.

Figuras 74 e 75: Praças de bairro entre as residências unifamiliares e espaços esportivos no p. 194 entorno dos conjuntos habitacionais verticais: deterioração e pouco uso cotidiano. Fotografias da autora, 20 set. 2015.

Figuras 76 e 77: Calçadas amplas e edifícios recuados em relação ao leito carroçável: esses espaços livres têm grande potencial para o convívio social. Fotografias da autora, 20 set. 2015.

Figura 78: Terreno que antes era ocupado por conjuntos habitacionais é apropriado pelos vizinhos tanto para práticas de convívio social, como para descarte irregular de lixo doméstico. Fotografia da autora, 20 set. 2015.

Figura 79: Área livre tradicional de Bajos de Mena. Calçadas estreitas, ausência de usuários e desconfiança do espaço de uso coletivo. Fotografia da autora, 20 set. 2015.

Figura 80: Pregação ambulante com amplificadores invade o cotidiano internalizado dos moradores dos conjuntos habitacionais sociais. Fotografia da autora, 20 set. 2015. 
Figura 82: Localização de Cidade Tiradentes, no município de São Paulo-SP. Fonte: elaboração da autora, sob base QUAPÁ (2016).

Figuras 83, 84, 85 e 86: Construção dos conjuntos habitacionais na Cidade Tiradentes. Fonte: CDTED COHAB-SP, apud SOUZA, 2014.

Figura 87: Localização dos empreendimentos da COHAB-SP e do PMCMV em Cidade Tira-

dentes. Fonte: elaboração da autora, sob base Google Earth.

Figura 88: Espaço livre usado como campo de futebol em Cidade Tiradentes. Fotografia da autora, maio 2016.

Figuras 89, 90, 91 e 92: Construção deteriorada da Construtora Coan em Cidade Tiradentes. A utilização de uma nova técnica, com incorporação do gesso com o cimento, fez com que a estrutura entrasse em decomposição pela ação das chuvas. Fonte: CDTED COHAB-SP, apud SOUZA, 2014).

Figura 93: Conjunto Habitacional Paulo Freire. Fotografia da autora, maio 2016.

Figuras 94 e 95: Garagens e comércio em Conjuntos Habitacionais de Cidade Tiradentes. Fotografias da autora, maio 2016.

Figura 96: O Conjunto Habitacional Unidos Venceremos e seu entorno. O fora e o dentro do Condomínio Habitacional. Diferenciação em relação ao outro e alteridade no cotidiano. Fotografia da autora, maio 2016.

Figura 97: A Cidade Tiradentes produzida pela própria população. Fotografia da autora, maio 2016.

Figura 98: Rua da Escola Municipal de Ensino Fundamental - EMEF Elias Shammass, no Conjunto Sítio Conceição, Cidade Tiradentes. Fotografia da autora, out. 2016.

Figura 99: Cenário típico de Cidade Tiradentes. Fotografia da autora, out. 2016.

Figura 100: Grafite em Cidade Tiradentes. Fotografia da autora, out. 2016.

p. 219

Figuras 101 e 102: Condomínio Residencial Pirassununga após ocupação e depredação. Fotografias da autora, out. 2016.

p. 221,222

Figura 103: Conjunto Habitacional Florestan Fernandes em obra.

Figura 104: Conjunto Habitacional Florestan Fernandes em obra. A altura dos edifícios, acentuada pela topografia, pode causar estranhamento pelos outros moradores. Fotografias da autora, de maio e de out. 2016 (respectivamente).

Figura 105: Conjunto Habitacional Florestan Fernandes e José Maria Amaral em obra com mutirão. Fotografia da autora, maio 2016.

\section{Capítulo 6}

Figura 106: Muro de escola em Cidade Tiradentes. Fotografia da autora, out. 2016. 
base arquivo QUAPÁ.

Figura 108: Localização dos empreendimentos Parque Estela, Vila Pimentas I e II, São Judas I, II, III e IV. Fonte: Elaboração da autora, sob base Google Earth.

Figura 109: Rua Mucugeo, em frente ao Condomínio Residencial Vila Pimentas I, e seu espap. 232 ço nada planejado para o pedestre. Fonte: Fotografia da autora (2016).

Figura 110: Fachada parcial de um dos blocos habitacionais do Condomínio Residencial Parque Estela. Fonte: Fotografia da autora (2016).

Figura 111: Cerimônia de entrega das chaves. Fonte: acervo PEABIRU (2013).

Figuras 112, 113, 114 e 115: Oficinas participativas para a definição das áreas comuns condominiais. Fonte: Acervo Peabiru (2012).

Figuras 116 e 117: Parque infantil. Fonte: fotografia da autora (2016).

Figura 118 e 119: áreas livres do empreendimento e corredor de acesso aos blocos. Fonte: Fotografias da autora (2016).

Figura 120: Área comum do Condomínio Residencial Vila Pimentas I, em Guarulhos-SP. Fonte: fotografia da autora, nov. de 2016.

Figura 121: O espaço projetado. Espaços livres projetados no Condomínio habitacional Vila Pimentas I. Fonte: fotografia da autora (2016).

Figura 122: O espaço apropriado. Espaços livres residuais no Condomínio habitacional Vila Pimentas I. Fonte: fotografia da autora (2016).

Figura 123: Crianças e jovens jogam bola na única quadra esportiva. Fonte: fotografia da autora (2016).

Figura 124: Crianças e jovens ocupam os espaços livres e observam as partidas de futebol. Fonte: fotografia da autora (2016).

Figura 125: brinquedos improvisados junto ao comércio de Rosângela. Fonte: fotografia da autora (2016).

Figura 126: Rua em obra do futuro empreendimento São Judas I, II, III e IV. Fonte: fotografia da autora (2016).

\section{Capítulo 7}

Figura 127: Feira livre em Cerro Navia, Santiago. Fotografia da autora, de nov. 2015.

p. 258 e 259

Figura 128: Localização de Lomas del Prado, na Comuna de Puente Alto. Fonte: elaborada pela autora, sob base OCUC - Observatorio de Ciudades (2003) e Google Earth (2015).

Figura 129: Foto aérea da implantação do conjunto habitacional Las Viñitas. Fonte: material cedido pelo MINVU e Google Earth (2007).

Figura 130: Croqui da implantação do conjunto habitacional Las Viñitas com a delimitação das áreas de Bem Nacional de Uso Público e das confusas áreas de copropriedade de cada conjunto. Fonte: elaborada pela autora, sob dados do MINVU. 
Figura 131: Espaço de copropriedade ocupado por moradores. Fonte: <http://www.plataformaurbana.cl/archive/2009/07/01/las-vinitas-y-la-incertidumbre-por-posible-demolicion-de-viviendas/>. Visualizado em maio de 2014.

Figura 132: Crianças brincam no espaço livre do conjunto habitacional Las Viñitas. Fonte: material cedido pelo MINVU, sem data.

Figura 133: Ampliações no conjunto habitacional Las Viñitas. Fonte: material cedido pelo MINVU, sem data.

Figura 134: Localização da antiga población Las Viñitas, do novo bairro Lomas del Prado, e do futuro Parque La Hondonada. Fonte: elaborada pela autora, sob base Google Earth (2015).

Figuras 135, 136, 137, 138, 139, 140, 141, 142, 143: Cronologia do processo de demolição de Las Viñitas e construção de Lomas del Prado, de 2008 a 2015. Fonte: Google Earth.

Figura 144: Edifícios habitacionais e áreas condominiais. Fechamento transparente é característica do projeto original de delimitação das áreas de copropriedade condominiais. Fotografia da autora, de jan. de 2014.

Figura 145: Edifícios habitacionais e áreas condominiais em Lomas del Prado. Transparência permite melhor relação visual do morador com a rua. Fotografias da autora, jan. de 2014

Figura 146: Conjunto Habitacional Lomas del Prado entregue aos moradores. Vista de uma das áreas livres, composta de diversos equipamentos esportivos e de lazer. Fotografia da autora, de jan. 2014.

Figura 147: Conjunto Habitacional Lomas del Prado entregue aos moradores. Vista de uma das áreas livres, composta de diversos equipamentos esportivos e de lazer. Fotografia da autora, de nov. 2015.

Figura 148: Calçadas estreitas nas ruas entre condomínios habitacionais de prédios em Lomas del Prado. Fotografia da autora, de nov. de 2015.

Figura 149: Praças de bairro entre as unidades residenciais em Lomas del Prado. Fotografia da autora, de nov. de 2015.

Figura 150: Descarte de lixo em terreno onde existia Las Viñitas. Fotografia da autora, de jan. de 2014.

Figura 151: Entorno do Parque Mapocho Poniente, em Cerro Navia. Recuos entre a rua e as p. 281 unidades habitacionais proporcionam espaço livre generoso, apropriado com piscinas de armação e repouso de animais particulares no verão chileno. Fotografia da autora, de jan. de 2014.

Figura 152: Piscinas de armação nas áreas condominiais de Lomas del Prado, no verão chileno. Fotografia da autora, jan.de 2014.

Figura 153: Localização de Santa Adriana na Comuna Lo Espejo. Fonte: elaboração da autora, sob base OCUC - Observatorio de Ciudades (2003) e Google Earth (2015).

Figura 154: Setor residencial de Santa Adriana já com intervenções do Quiero Mi Barrio. Fotografia da autora, de jul. 2015.

Figura 155: Ampliações irregulares na Villa Las Palmeras em Santa Adriana. Fotografia da 
autora, jul. 2015.

Figura 156: Villa Las Palmeras em Santa Adriana. Fotografia da autora, jul. 2015.

Figura 157: Localização dos setores, alguns equipamentos, apropriações e intervenções do

Quiero Mi Barrio. Fonte: elaboração da autora, sob base Google Earth.

Figuras 158, 159, 160, 161, 162, 163, 164, 165, 166, 167: O antes e depois da intervenção p. 293 e 294 urbana do Programa Quiero Mi Barrio em Santa Adriana. Fonte: Quiero Mi Barrio (2010), editado pela autora.

Figura 168: Melhorias físicas nos passeios públicos realizados pelo programa Quiero Mi Barrio em Santa Adriana e o excesso de mobiliário urbano decorativo. Fotografia da autora, jul. 2015.

Figuras 169 e 170: Oficina para a pintura do muro da escola Santa Adriana com o artista plástico “Mono” Gonzalez Fonte: Quiero Mi Barrio (2009).

Figuras 171 e 172: Jornada familiar "Santa Adriana Limpia: Acción Ecológica y Cultural" com o objetivo de identificar e intervir nos locais de depósito de lixo para conscientização da comunidade, finalizando a jornada com culinária típica e apresentação de bandas de rock, punk e folclore nacional do setor. Fonte: Quiero Mi Barrio (2009).

Figura 173: Ações de divulgação do Plan de Gestión Social (PGS) para atividades participativas de fortalecimento organizacional e atividades de identidade e cultura no espaço público. Fonte: Quiero Mi Barrio (2009), editado pela autora.

Figuras 174 e 175: Deterioração dos espaços reformados pelo programa Quiero Mi Barrio em Santa Adriana e apropriação de grupos sociais identificados pela utilização de cores. Fotografia da autora, jul. 2015.

Figuras 176 e 177: Melhorias físicas realizadas pelo programa Quiero Mi Barrio ainda não estimulam o uso e apropriação do espaço no cotidiano. Fotografia da autora, jul. 2015.

Figura 178: Apropriação da generosa calçada do setor residencial de Santa Adriana para ampliação da unidade habitacional, realizando uma garagem particular no espaço público. Fotografia da autora, jul. 2015.

Figura 179: Memorial em homenagem a um jovem vítima de tiroteio. Fonte: LUNECKE, 2012.

Figura 180: Quadras de tênis em Santa Adriana. Fotografia da autora, de jul. 2015.

Figura 181: Cerimônia de inauguração das quadras, em parceria com a SEREMI de Vivienda p. 301 y Urbanismo, Municipalidad de Lo Espejo e escola "Futuros para el Tenis". Fonte: SEREMI, 2015

\section{Considerações}

Figura 182: Paisagem na beira da Rodovia dos Imigrantes, São Paulo. Fotografia da autora, p. 302 e 303 de jul. 2016. 


\section{LISTA DE TABELAS}

\section{Capítulo 3}

Tabela 1: organizada pela autora, a partir de dados do Ministério das Cidades (2014) e IBGE p. 111, 112 (2003, 2010, 2011 e 2013), DENATRAN (2014) e Secretaria da Segurança Pública (2014).

Tabela 2: organizada pela autora, a partir de dados do INE (2014), MIDEPLAN (2006), PNUD (2003), e Carabineros Chile (2014).

Tabela 3: Realizada com dados do Programa Minha Casa Minha Vida, disponíveis em:

$<$ http://www.caixa.gov.br/poder-publico/programas-uniao/habitacao/minha-casa-minha-vida>, consultados em mar. 2014.

Tabela 4: realizada com dados do Programa Minha Casa Minha Vida, disponíveis em: $<$ http://www.caixa.gov.br/poder-publico/programas-uniao/habitacao/minha-casa-minha-vida>, consultados em mar. 2014.

Tabela 5: realizada com dados do Programa Minha Casa Minha Vida, disponíveis em: <http://www.caixa.gov.br/poder-publico/programas-uniao/habitacao/minha-casa-minha-vida>, consultados em mar. 2014.

Tabela 6: realizada com dados da segunda fase do Programa Minha Casa Minha Vida, disponíveis em: <http://www.caixa.gov.br/poder-publico/programas-uniao/habitacao/minha-casa-minha-vida>, consultados em mar. 2014.

Tabela 7: realizada com dados da segunda fase do Programa Minha Casa Minha Vida, disponíveis em: <http://www.caixa.gov.br/poder-publico/programas-uniao/habitacao/minha-casa-minha-vida>, consultados em mar. 2014.

Tabela 8: Valor de Operação para o Estado de São Paulo para a segunda fase do PMCMV-E. Realizada com dados do Programa Minha Casa Minha Vida, disponíveis em: <http://www. caixa.gov.br/poder-publico/programas-uniao/habitacao/minha-casa-minha-vida>, consultados em mar. 2014.

\section{Capítulo 5}

Tabela 9: Condomínios de prédios em Bajos de Mena, na Comuna de Puente Alto, Santiago do Chile. Fonte: DELGADO VALVERDE, 2013, sob dados do Servicio Regional de Vivienda y Urbanización Región Metropolitana.

Tabela 10: Empreendimentos do PMCMV em Cidade Tiradentes

\section{Capítulo 7}

Tabela 11: Características de Las Viñitas e Lomas del Prado. Fonte: SUR Profesionales Consultores (2015). 
Introdução - Aprendendo com nós mesmos 
Ser capaz de mirar lo que no se mira, pero que merece ser mirado, las pequeñas, las minúsculas cosas de la gente anónima, de la gente que los intelectuales suenen

despreciar. Ese micro mondo donde yo creo que de veras alienta la grandeza del universo, y al mismo tiempo ser capaz de contemplar el universo, desde el ojo de la cerradura, o sea, desde las cosas chiquitas a sumarme, a las cosas que son más grandes, a los grandes misterios de la vida 
O propósito desta tese é estudar as práticas sociais nos espaços livres de conjuntos de habitação social nas Regiões Metropolitanas de São Paulo-SP (RMSP) e de Santiago do Chile (RMS), analisando, conforme as possibilidades da paisagem, as práticas nos espaços livres para observar as relações sociais que ocorrem nesses espaços.

A Região Metropolitana de São Paulo (RMSP) é um território de proporções muito maiores que a Região Metropolitana de Santiago, abrigando mais população que todo o Chile ${ }^{1}$. Assim, a comparação não poderá ser direta, nem pelo âmbito da cultura, nem do território, nem da economia, nem da sociedade.

Inserida no contexto do esforço coletivo de investigação, esta pesquisa foi realizada em colaboração com duas Universidades: a Universidade de São Paulo, através do Laboratório QUAPÁ, e a Universidad de Chile, através do Instituto de la Vivienda - INVI.

O interesse em desenvolver este trabalho surgiu devido às recentes alterações na paisagem de cidades brasileiras, principalmente após a criação do Programa "Minha Casa Minha Vida" - PMCMV, em 2009². O Programa acentuou o processo de criação de conjuntos habitacionais sociais em áreas de expansão urbana, com características muito marcantes e similares, mantendo-se a construção de condomínios de prédios e loteamentos de residências de pequenas dimensões como um modo de fazer habitação social em grandes concentrações. Contudo, o questionamento que se impõe é: já não seria o momento dessa lógica produtiva ser alterada, transformando-se em soluções mais adequadas ao cotidiano das famílias e das cidades?

A euforia construtiva para a produção de habitações voltadas ao "segmento econômico" se iniciou antes do surgimento do PMCMV, mas é, sem dúvida, a partir dele que atinge novas proporções no país, inclusive atribuindo a produção de habitação social à iniciativa privada, o que antes era incumbência do Estado. O PMCMV, através da dinamização da atividade da construção civil, originou em todo o Brasil uma proliferação de novos bairros, em áreas distantes e muitas vezes sem infraestrutura, enfileirando residências ou edifícios habitacionais de forma urbana e arquitetônica questionáveis.

1 Segundo estimativa do IBGE (2015), a população da Região Metropolitana de São Paulo é de 20.775.114 habitantes. Já segundo estimativa do INE (2015), a população total do Chile é de 18.006.407 habitantes.

2 A análise dessa produção em nível nacional foi possível através da participação da autora no Laboratório QUAPÁ (Quadro do Paisagismo do Brasil) da Faculdade de Arquitetura e Urbanismo da Universidade de São Paulo desde 2009. O QUAPÁ pesquisa a forma urbana e o Sistema de Espaços Livres em cidades brasileiras e realiza diversas oficinas em todo o país, nas quais os pesquisadores, juntamente com técnicos locais e estudantes, desenvolvem estudos sobre a morfologia urbana, os agentes produtores da forma, a relação sistêmica dos espaços livres e os impactos da legislação local para a produção do tecido urbano.

A partir dos anos 2010, as oficinas adquiriram um novo tom sobre a discussão da cidade, com a constante inserção do Programa Minha Casa Minha Vida nas observações dos participantes e dos pesquisadores, já que o Programa, principalmente em algumas regiões metropolitanas e cidades médias, vinha alterando o cenário urbano e rural. Novos conjuntos habitacionais passaram a surgir em todo o território nacional, sendo responsáveis pela imagem de produção de baixa qualidade arquitetônica e urbanística do PMCMV. 
A política habitacional elaborada durante o segundo mandato do governo Lula (2007-2011) inspirou-se em políticas latino-americanas, como a chilena e a mexicana, ainda que de forma muito superficial, baseando-se apenas no modelo econômico de financiamento e na parceria público-privada para o provimento das demandas sociais, sem observar o impacto que esse tipo de modelo já tinha manifestado nas cidades latinas "inspiradoras".

A pesquisadora, por ser nascida no Brasil e descendente de chilenos, sempre teve contato com a cultura e paisagem de cidades brasileiras e chilenas, nas quais a diferença e a segregação socioespacial sempre marcaram o cenário urbano, principalmente nas Regiões Metropolitanas de ambos os países.

A inspiração para a tese surgiu do conhecimento e da vivência de ambas as realidades, acrescida da vontade de colaborar com os estudos latino-americanos comparados, aprendendo com nós mesmos, no sentido não somente de observar os processos similares que ocorrem em cidades latino-americanas, mas também reconhecendo as particularidades históricas, socioculturais e políticas que impactam na paisagem.

A discussão aqui proposta não se limita aos aspectos gerais da política e da paisagem das regiões metropolitanas estudadas, mas se aprofunda nos estudos de caso, pretendendo-se a aproximação necessária com a particularidade de cada lugar, desde "el ojo de la cerradura", como coloca Galeano (2009), das práticas sociais cotidianas. Reconhecendo a particularidade frente à generalização, enfatiza-se que as recentes transformações espaciais são, inevitável e particularmente, heranças históricas dos movimentos socioeconômicos de grupos sociais ao longo dos anos, apresentando-se espacialmente tanto nas formas materiais como nas sociais e simbólicas.

Devido às heranças históricas, os primeiros questionamentos foram sobre a evolução das políticas habitacionais de ambos os países que influenciaram a produção atual. Nesse processo, o Chile se destacou pelo amadurecimento de alguns programas habitacionais para além da simples produção numérica, apresentando programas de bairro e mesmo de melhoramentos urbanos. Nesse sentido, incomodava o fato de o Brasil ter se apoiado somente no modelo neoliberal do programa habitacional, no momento em que se inspirou no caso chileno para desenvolver o PMCMV.

Observando os resultados chilenos a partir desses programas de bairro, preliminarmente parecia haver melhores resultados no que tange às áreas de convívio, e questionou-se se isso teria ocorrido pela ação dos programas de bairros ou pelas maiores exigências dos programas chilenos ou ainda pela cultura chilena de utilização e valorização dos espaços livres.

Porém, aprofundando-se o olhar no cotidiano dos espaços produzidos pelos programas de bairro chilenos, observou-se, ainda, uma insuficiência desses resultados para as práticas sociais: independentemente das melhorias urbanas (visíveis), o invisível continuava igual, as práticas sociais continuavam fragmentadas, segregadas, socialmente homogêneas e limitadas.

A partir desse reconhecimento, desenvolveu-se a hipótese deste trabalho, estimulada pela inquietação de ver além do que está sendo visto e, consequentemente, ir além do que já está sendo estudado em relação à produção habitacional social. Busca-se demonstrar a importância de se considerarem as práticas sociais e o projeto dos espaços livres em políticas de habi- 
tação social. Reconhece-se que, mesmo que os programas que dão maior atenção às práticas sociais nos espaços livres não sejam suficientes para resolver as diversas questões surgidas em contextos de vulnerabilidade urbana e social, eles são a chave para possibilitar maiores mudanças. Há a necessidade de se considerar a relação social criada e possibilitada pelos espaços livres, que precisam ser pensados para a prática social.

Embora a apropriação nem sempre esteja relacionada à qualidade dos espaços, surge a necessidade de se estabelecerem critérios qualitativos para sua análise. Porém, é complexo definilos sem cair na armadilha de impor uma solução externa ao cotidiano do grupo social, desenvolvendo-se de forma impositiva, como mecanismos de controle social.

Estarão fadadas ao fracasso as novas áreas habitacionais que continuarem marginalizadas, não só pela sua localização, mas também por estarem às margens do processo de elaboração e construção, ou seja, aquelas que mantiverem as áreas pensadas por um olhar externo, que não se aproxima do cotidiano da população, determinando as necessidades do outro sem que ele possa ser o sujeito da ação, o que agride a liberdade e individualidade de cada grupo social.

A paisagem pode ser analisada por várias dimensões sociais que se interpenetram, pois ela, enquanto expressão de uma sociedade, é reveladora de seus costumes e características sociais, sendo resultado dinâmico da interação entre os processos sociais - econômicos, culturais e políticos - e os processos naturais, estando sempre em constante modificação, dado que é resultado da junção, no tempo e no espaço, do ser humano e do seu ambiente (MAGNOLI, 1982 apud QUEIROGA, 2006). Segundo Santos (1997), a paisagem é um conjunto heterogêneo de formas naturais e artificiais, formada pela fração de ambas, e o espaço resulta do casamento da sociedade com a paisagem.

Como paisagem, dessa forma, entende-se o resultado formal de processos sociais e naturais sobre um meio biofísico por uma determinada sociedade, e toda ação sobre ela resultará em alterações formais, parciais ou totais. A paisagem, adicionalmente, é resultante e participante dos processos que nela ocorrem, expressando os desejos e limitações de uma sociedade em modificar uma porção territorial para suas atividades.

Os espaços livres, elementos da paisagem, são os espaços não ocupados por volumes edificados (MAGNOLI, 1982). A relação desses espaços forma um sistema de elementos que se relacionam funcionalmente (e não necessariamente de modo físico) e que estrutura o conjunto de espaços livres. Assim, esses espaços podem possibilitar e intensificar relações sociais, sendo, portanto, carregados de potencial transformador, característico da simultaneidade e da heterogeneidade do urbano (QUEIROGA; BENFATTI, 2007).

Em relação aos estudos latino-americanos na área da arquitetura e urbanismo, estes se iniciaram timidamente no final do século XIX, e ganharam impulso a partir dos anos 1920 (MEDRANO, 2003). Porém, apesar da existência de estudos latinos referentes ao ambiente urbano - principalmente sobre a história do urbanismo e das cidades -, ainda são escassos os estudos na área da paisagem urbana latino-americana.

O cotidiano é uma categoria adequada para a compreensão de um modo de vida em um momento histórico específico, pois, por meio de sua observação, é possível constatar as interações entre os espaços e seus agentes sociais, expressados através das relações interpessoais, 
dos locais, dos costumes e da produção material e simbólica.

A cidade de São Paulo já há décadas não pode ser analisada de maneira isolada em relação à Região Metropolitana, principalmente quando a análise busca uma maior compreensão da expansão habitacional no território. Além disso, a metrópole apresenta em seu território situações muito diversas e realidades socioespaciais totalmente diferentes umas das outras e que precisam ser levadas em consideração.

Tanto na RMSP quanto na RMS, a discrepância da concentração de renda é muito elevada, sendo resultado de processo histórico particular de cada formação sociocultural e econômica, explicado pela estrutura e pelo funcionamento tradicional das sociedades brasileira e chilena nas suas distribuições/concentrações de renda e poder.

A fragmentação invisível, por sua vez, é resultado da nossa história latino-americana, em que a construção das cidades já estava associada ao ato de segregar socialmente os menos favorecidos. Somado a isso, a lógica patrimonialista (FERREIRA, 2012) de produzir e agir, somada à visão elitista que estimula a manutenção do cenário sem que haja mudança a interferir em sua hegemonia, são responsáveis por acentuar e, inclusive, camuflar a fragmentação social. Assim, ser pobre, ser negro, ser indígena, enfim, ser considerado uma minoria nas cidades latino-americanas significa ser parte de um fragmento, que não se integra no todo ou, ao menos, que não pretende ser integrado inteiramente.

No sentido urbano, estar segregado espacialmente e desenvolver sua vida cotidiana em um mesmo local que outros similares é a parte visível. É estar na periferia - não necessariamente física -, ser associado a cenários de violência urbana, habitar espaços públicos deteriorados, seja pelos próprios moradores que se indignam com a sua situação de impotência frente à hegemonia, seja pelo descaso do poder público, que foca investimentos nos "espaços de luminosidade", como diria Milton Santos (1994), e deixa os espaços opacos para que os homens lentos tentem buscar a sua superação ${ }^{3}$.

Desta forma, o visível é também o invisível: estar particularizado enquanto minoria, seja essa minoria a classe alta ou o grupo social com histórico de luta de classes, é também uma diferenciação social, que separa gêneros, classes econômicas e etnias em fragmentos da sociedade, em margens físicas e existenciais.

As cidades latino-americanas continuam perpetuando práticas de reprodução social e de dominação hegemônica (RIBEIRO, 2013), e a fragmentação visível e invisível das práticas sociais é mais uma maneira de se observar a inclusão periférica em nosso cotidiano.

3 Para Santos (1994), os espaços opacos representam a oposição aos espaços luminosos que, por sua vez, são os espaços que acumulam dinâmicas de grande fluidez técnica e informacional, atraindo cada vez mais conteúdos e capital. Já os espaços opacos são os territórios ausentes de maiores investimentos e densidades técnicas e informacionais.

O homem lento é o sujeito que resiste ao agir hegemônico e o supera, buscando táticas para inverter os códigos segregacionistas através da prática do território. 
A observação dos espaços livres é chave para entender as práticas sociais. É nesses lugares que a fragmentação física e subjetiva se esclarece, onde se observa quem representa a parte hegemônica, quem é o outro e quais as ações coletivas e individuais que surgem na contra lógica.

Assim sendo, a intranquilidade gerada pela observação da produção habitacional dos primeiros anos do Programa Minha Casa Minha Vida estimulou a ideia deste trabalho, no qual se analisam o impacto de políticas habitacionais sociais de inspiração neoliberal, em um cenário já plenamente marcado por diferenças, disputas e discórdias, como é o caso das cidades latino-americanas, especificamente as Regiões Metropolitanas de São Paulo e de Santiago do Chile, cenários onde a pesquisadora tem possibilidade de contribuir, pela sua história, origem e convívio cotidiano.

Os primeiros anos do PMCMV foram destinados a construir, acabar com o déficit de moradias, estimular o mercado imobiliário e evitar a crise econômica. Não houve praticamente nenhuma atenção ao habitat, foi uma simples produção de unidades habitacionais. Isso também ocorreu no Chile, porém décadas antes, no período da ditadura militar.

Desta forma, quando o Programa brasileiro foi criado, o Chile já tinha avançado na produção, sem mais objetivando superar déficits, mas direcionando recursos para programas habitacionais mais qualitativos para as cidades, o que significou, muitas vezes de maneira drástica, demolir muito do que foi produzido nos primeiros anos de atuação da política habitacional social neoliberal.

De maneira a apresentar as práticas sociais nos espaços livres de conjuntos habitacionais e a complexidade envolvida no tema, a tese foi estruturada em sete capítulos:

- No capítulo 1 (Territórios (des)praticados), apresentam-se ao leitor conceitos e provocações sobre as práticas sociais nos espaços livres de conjuntos de habitação social, além da subjetividade presente nessas práticas. Esse capítulo é o eixo condutor conceitual da tese, com contribuições teóricas da sociologia, da arquitetura e da psicologia, as quais explicam as relações visíveis e invisíveis no cotidiano em habitação social. São abordados elementos de receio e estranhamento em relação ao outro, a subjetividade nas práticas sociais, o individualismo, as relações de poder e dominação, as condutas individuais e coletivas, as práticas cotidianas e as lutas de classes, dentre outros aspectos.

A provocação da (des)prática sintetiza o fio condutor: por um lado, há o potencial transformador dos espaços livres através da apropriação cotidiana, que supera o dia a dia, mas, por outro, há o contexto socioeconômico e cultural, associado à subjetividade e às condutas individuais, que fazem com que haja dificuldade na superação do dia a dia alienado. Com isso, a prática social fica limitada, incompleta, ou seja, (des)praticada.

Também nesse capítulo, esboçam-se critérios e parâmetros para analisar os espaços criados em habitação social, levantando-se pontos urbanísticos, paisagísticos e arquitetônicos que devem ser considerados no desenvolvimento do habitat, com o cuidado necessário em não 
impor regras, mas sim em levantar aspectos que precisam ser analisados em cada caso e que parametrizam as análises dos estudos de caso;

- O capítulo 2 traz o histórico das experiências brasileira e chilena na elaboração de políticas habitacionais, destacando-se pontos de inflexão comuns de 1964 a 2010, com o objetivo de familiarizar o leitor com o contexto político de cada país e com os aspectos mais relevantes do período de análise. Essa contextualização é chave para a compreensão das políticas mais recentes de ambos os países, pois a herança do modo de produzir é derivada da história da política de habitação social;

- O capítulo 3 apresenta a leitura das Regiões Metropolitanas de São Paulo e de Santiago a partir do olhar da formação do território e de sua fragmentação visível e invisível. São apresentados dados para a caracterização de ambas regiões, considerando o suporte biofísico, a evolução urbana e aspectos sociais e econômicos.

Também se desenvolve, nesse capítulo, a definição do conceito de inclusão periférica, a qual refuta a costumeira expressão "exclusão social", pois os grupos desfavorecidos pelo sistema são também parte do ciclo econômico, que só se verifica por existirem tais diferenças de classe. Assim, os desfavorecidos não estão excluídos, mas sim incluídos perifericamente no sistema;

- O capítulo 4 traz ao leitor as particularidades do Programa Minha Casa Minha Vida. Discorre-se sobre o programa nacional e expõe-se o funcionamento da vertente Entidades (PMCMV-E), na qual atuaram entidades sem fins lucrativos, como ONGs, movimentos de moradia e entidades de assistência técnica. Essa atuação, embora em pequena escala, quando em comparação ao programa nacional, tem importância para este trabalho, pois são projetos realizados com participação popular e que possibilitam melhores resultados em relação às práticas sociais pelo envolvimento do grupo social enquanto ator da ação.

Esse capítulo também traz o mapeamento da produção da faixa 1 do PMCMV na RMSP, demonstrando a continuidade da localização periférica dos empreendimentos lançados até 2013. Além disso, discorre-se sobre as dificuldades da inserção de um grupo social em um modelo condominial imposto, adotado em quase todos os casos dos empreendimentos da faixa 1 na RMSP, e que acabam por limitar as práticas sociais dos grupos envolvidos, ou (des)praticá-los por meio da imposição do modelo urbano em um cenário de vulnerabilidade urbana e social;

- No capítulo 5, iniciam-se os estudos de caso do cotidiano, apresentando o modus operandi de produção de grandes concentrações de habitação social em ambos os países, apresentando estudos sobre Bajos de Mena, em Santiago, e Cidade Tiradentes, em São Paulo, dois casos bastante extremos e exemplares da criação de vastas extensões de habitação social com impactos severos;

- O capítulo 6 aborda estudos aproximados do cotidiano intramuros, com análises de dois recentes empreendimentos do Programa Minha Casa Minha Vida em Guarulhos (RMSP), um 
no formato Entidades, com participação popular (o Condomínio Residencial Parque Estela) e outro no formato empresarial sem participação (o Condomínio Residencial Pimentas).

Destaca-se que, apesar dos aspectos positivos da participação no formato Entidades, a (des) prática permanece, devido ao modelo imposto de produção habitacional de condomínios de prédios e ao contexto de vulnerabilidade urbana e social, que acabam por dificultar a aproximação dos moradores com os espaços públicos, limitando as práticas sociais para espaços intramuros, controlados e normatizados. O modelo condominial estimula a exclusividade em trechos urbanos, contribuindo diretamente para o agravamento do receio frente ao espaço externo aos muros e limitando as relações com o outro e as trocas cotidianas;

- O capítulo 7 trata do olhar para o cotidiano de bairro, baseando-se em dois casos chilenos: as ações do Fondo Solidario para criação de um novo bairro em Cerro Navia e o Programa Quiero Mi Barrio em Santa Adriana. Reconhecendo as limitações do programa, propõe-se uma reflexão sobre as maiores possibilidades que o bairro oferece para a superação do dia a dia, dado que busca deslocar as práticas cotidianas, já excessivamente interiorizadas em espaços fechados, para os espaços livres públicos, onde há maiores possibilidades de práticas sociais completas devido ao convívio, ao encontro com o outro e à experiência de sociabilidade.

Destaca-se, nesse capítulo, dentre os programas habitacionais sociais mais qualitativos chilenos, o Programa Quiero Mi Barrio (PQMB), que tem atuado em comunas e populações com altos índices de problemas sociais. Essa atuação envolve participação popular junto a uma equipe multidisciplinar, formada por arquitetos, sociólogos, assistentes sociais e outros profissionais que atuam com a comunidade, melhorando os espaços públicos e buscando reavivar a identidade, a cidadania e o sentido de coletividade. Embora esbarre em muitas dificuldades de atuação, é uma boa aposta da política chilena em estimular a mudança social pela identificação e apropriação dos espaços livres.

Enfim, após todas as considerações, pôde-se perceber que, apesar dos avanços políticos obtidos na RMS com esses programas mais atentos às práticas sociais em espaços livres públicos, a estrutura de inclusão social periférica é parte do dia a dia alienado e, possivelmente, ainda mais drástica que no caso brasileiro, o que não o coloca à frente, enquanto exemplo de caso bem-sucedido, mas ao lado, com ambas as regiões metropolitanas lutando por melhores cenários urbanos e sociais, mas com a vantagem de o Chile já ter passado pelo questionamento que o Brasil poderá passar nos próximos anos: após décadas de produção de habitação de inspiração neoliberal, qual o cenário desenvolvido? Quais os programas políticos que precisaram ser criados para amenizar os problemas criados?

Há um paradoxo entre a ação dos programas sociais, pois estes não conseguem agir contrariamente à reprodução social e à fragmentação visível e invisível. Mesmo ações com maior atenção às práticas sociais não têm capacidade agregadora e inclusiva e continuam a perpetuar a reprodução da estrutura hegemônica histórica.

O equívoco, tanto brasileiro como chileno, é a imposição de modelos urbanísticos e de gestão 
sem a participação da população na definição dos seus interesses, agravados pela inserção urbana em contextos de vulnerabilidade social e econômica.

O quadro complexo das práticas sociais em habitação social é fruto do ambiente urbano criado, não apenas derivado da desigualdade social e de cenários de inclusão periférica e insegurança em relação ao outro, mas, principalmente, da administração e da manutenção dessa desigualdade. O modus operandi de construção de conjuntos habitacionais concentrando classes econômicas, sem atenção às práticas sociais e sem estimular os grupos sociais a serem atores em seus próprios contextos é uma prática que precisa ser superada. 
Capítulo 1: Territórios (des)praticados - práticas sociais nos espaços livres de conjuntos de habitação social

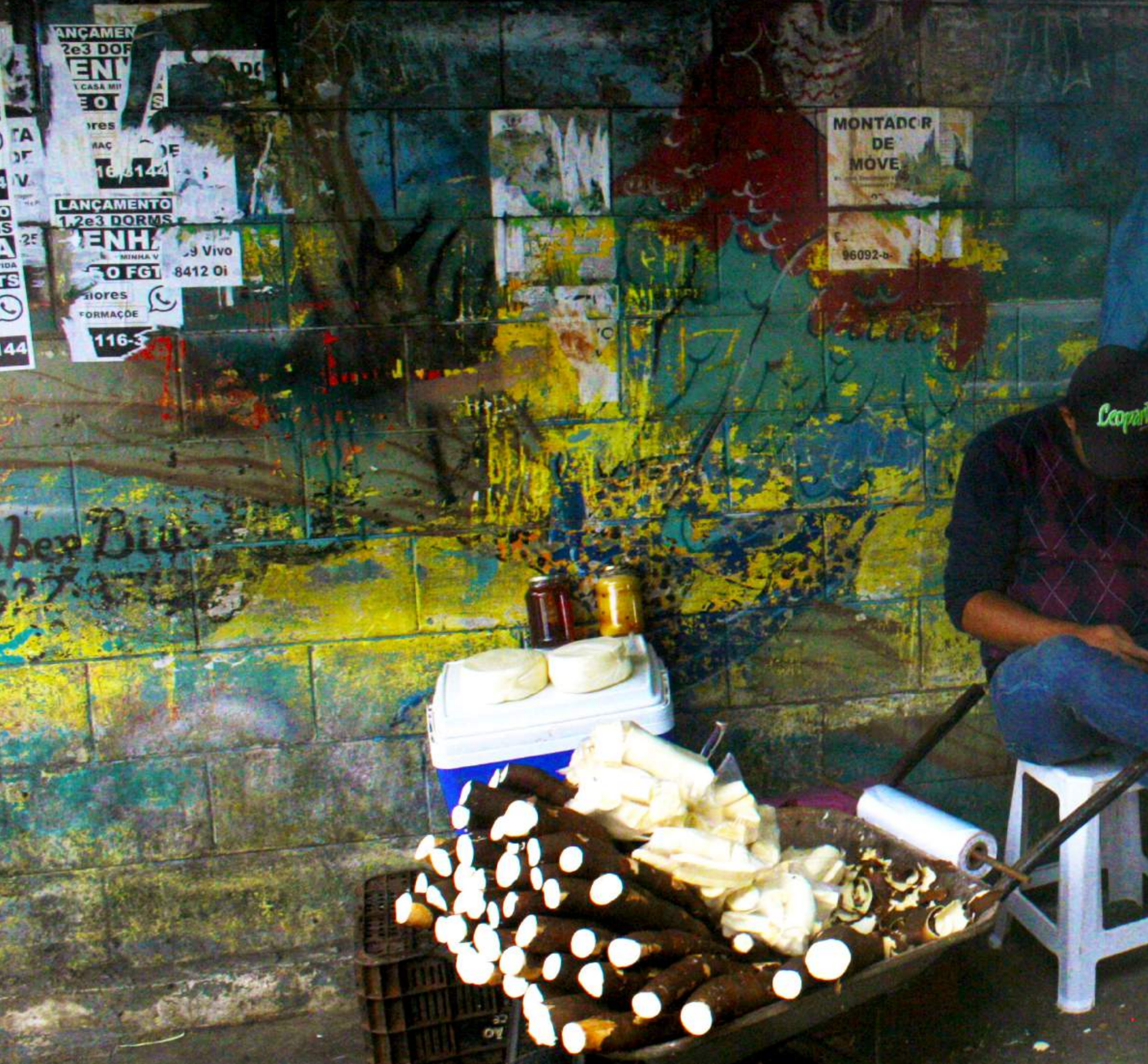

Figura 1: Ponto de ônibus em Cidade Tiradentes, São Paulo-SP. Fotografia da autora, de maio de 2016. 
ana vê alice

como se nada visse

como se nada ali estivesse

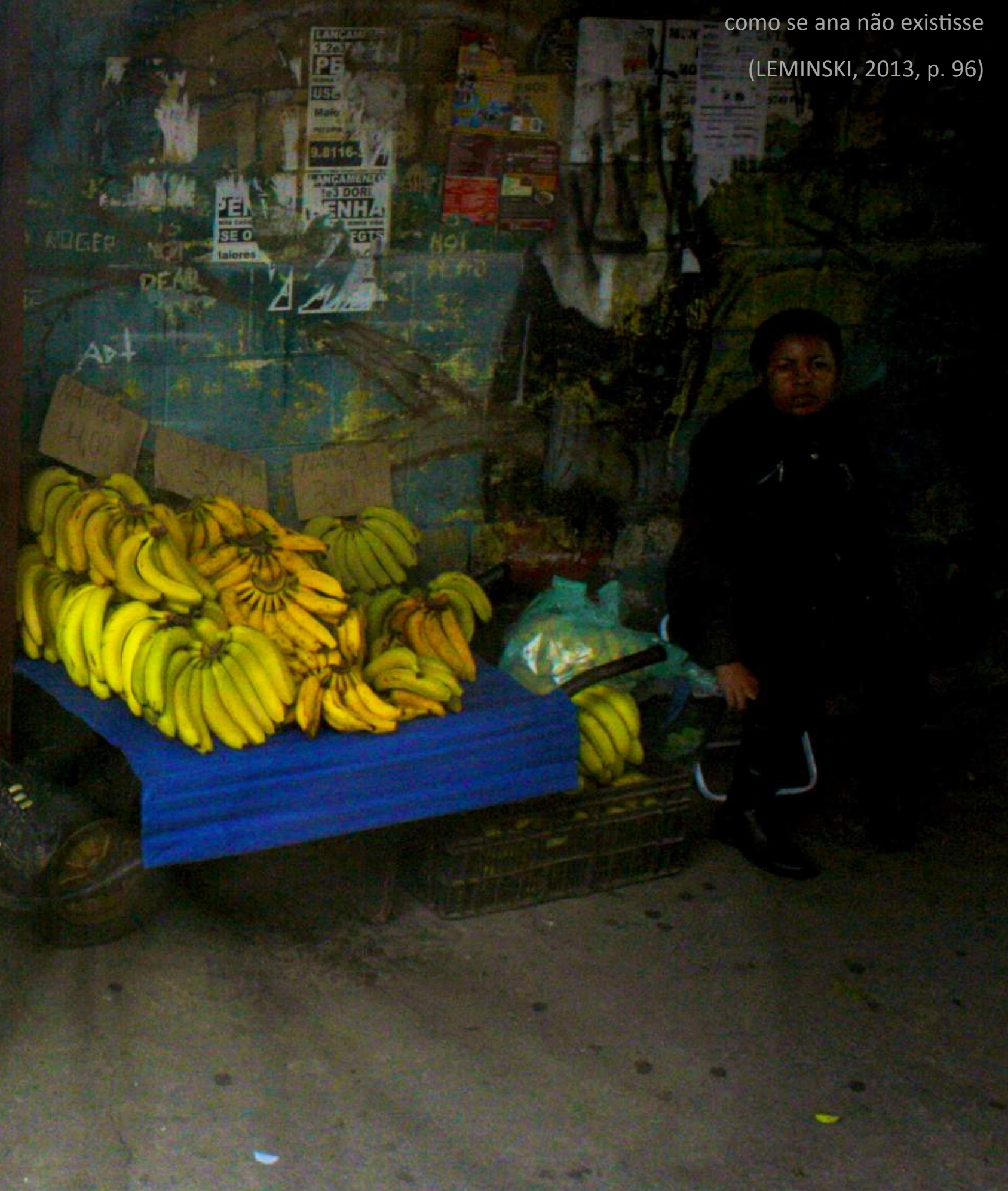


Este capítulo traz o eixo condutor do raciocínio que permeia a tese: a limitação das práticas sociais em conjuntos de habitação social. Busca-se compreender a complexidade do urbano e das práticas sociais a partir do estudo de questões estruturais, que envolvem outras escalas para além das cidades e metrópoles, envolvendo a formação socioespacial dos países e sua inserção no sistema capitalista global, acrescidos fundamentalmente da percepção, da sensibilidade, da observação e do olhar. Essa sensibilidade, provocativamente, se prenuncia no neologismo utilizado no título do capítulo: os territórios (des)praticados.

O eixo condutor foi pensado baseando-se em diversos interlocutores teóricos e atravessando diferentes áreas do saber, adotados com o cuidado necessário, para entender a utilização do espaço livre pelos grupos sociais, ou seja, o "território usado" miltoniano (SANTOS, 1999, RIBEIRO, 2013 ${ }^{4}$ ), aqui chamado de território praticado ou (des)praticado. Como são as práticas nos espaços livres de conjuntos de habitações sociais? Quais são os elementos visíveis e invisíveis que orientam - consciente e inconscientemente - essas práticas?

Utiliza-se (des)prática pois busca-se demonstrar que, nas habitações sociais, muitas vezes as práticas ocorrem de uma maneira limitada, seja por elementos visíveis, como muros, quanto invisíveis, como imposições sociais e culturais que regem as ações.

Alguns autores das áreas da psicologia e da psicanálise foram chave para este trabalho: Besoain (2012), psicóloga chilena, reflete sobre a subjetividade existente nos processos de aquisição de uma habitação; Dunker (2015), psicanalista brasileiro, aborda o aspecto psicanalítico da vida em condomínio. Ambos tratam do estranhamento em relação ao outro, o que explica a subjetividade existente nas práticas sociais nos espaços livres.

O embasamento teórico também atravessa o campo da sociologia, a partir do trabalho de Bourdieu $(1989,2001)$, que coloca a gênese social na estruturação das relações, orientadas por mecanismos de dominação. Embora em um outro contexto, a construção de Bourdieu também se ancora na subjetividade, já que as condutas individuais, em sua análise, são dependentes de um sistema de relações. O seu conceito de habitus trata da dominação e da luta de grupos sociais que seguem inconscientemente determinadas condutas individuais e coletivas.

O termo latino habitus se origina da noção aristotélica de hexis, que, por sua vez, designa o conjunto de disposições dos agentes em que as práticas se convertem em princípio gerador de novas práticas (GARCÍA INDA, 2001). Essas disposições, organizadas em sistemas e reguladas por um ambiente socialmente estruturado, tanto estruturam quanto são estruturadas, sendo princípio e produto das práticas, percepções e ações dos agentes, um "estado habitual" (BOURDIEU, 2001). Esse ambiente estruturado e estruturante tanto pode ser o entorno físico quanto afetivo das relações sociais e de classe, as quais orientam e determinam as práticas sociais.

Em relação à sensibilidade na análise, seria impossível realizar essa complexa rede de influências teóricas sem o trabalho de Ana Clara Torres Ribeiro ${ }^{5}$. Socióloga, interlocutora de Milton Santos, Ribeiro $(2013,2014)$ foi a principal referência para a reflexão das práticas cotidianas. Seu trabalho deixou enorme legado sobre a construção do espaço, as lutas de classe, os confli-

4 Território brasileiro: usos e abusos. Pequena reflexão sobre categorias da teoria crítica do espaço: território usado, território praticado, vol. 3, p. 141-152.

5 A leitura do trabalho de Ribeiro foi feita a partir de coletânea de organização póstuma, que reuniu suas últimas reflexões e artigos em cinco volumes. Como são muitos os assuntos tratados, optou-se por nomear individualmente os artigos utilizados neste trabalho, reconhecendo a particularidade de cada um e visando orientar possíveis leitores interessados em sua obra. 
tos, a consciência coletiva e as marcas dos processos no território e na sociedade.

É a partir do tripé de contribuições da sociologia, da psicologia e da arquitetura que se desenvolve, neste trabalho, a linha de raciocínio sobre as práticas sociais e o cotidiano em habitação social.

Não obstante, a contribuição do arquiteto é também de natureza propositiva e analítica do espaço. Isso posto, de modo a se aproximar às possibilidades do urbano, definem-se também neste capítulo alguns critérios de qualidade para auxiliar na análise dos espaços coletivos em habitação social, os quais também são alguns dos aspectos a serem aprofundados para haver maior possibilidade de produção de espaços livres que se tornem lugares cotidianos da vida social.

A (des)prática representa a dialética que tais reflexões têm estimulado: se, por um lado, temos o território com sua possibilidade de transformar-se por meio do uso, do pertencimento e do combate ao cotidiano alienado, por outro, temos, nos conjuntos que concentram habitação social, uma dificuldade em aproximar o sujeito dos espaços públicos e das práticas sociais. Assim, a (des)prática se refere a uma prática limitada. Não é que ela não exista, mas ocorre de forma incompleta, devido à vulnerabilidade e subjetividade presente no frágil contexto social, e também pela imposição de modelos urbanos, normas de conduta ou controle por líderes dentro do grupo social.

Essa situação é mais clara nos territórios que concentram habitação social de ambos os países, exemplos da produção massiva de habitação social. Desde a produção das ditaduras militares brasileira e chilena, a possibilidade de (des)prática territorial tem se tornado cada vez mais presente, com situações bastante particulares para o caso do Brasil, já que não é da natureza física, climática e cultural brasileira se afastar dos espaços livres de uso coletivo.

As práticas sociais atuais em habitação popular são muito influenciadas pela subjetividade e pelo individualismo, já que o estímulo causado pela luta individual por acesso à moradia tem particularizado a celebração da conquista coletiva. Celebra-se individualmente o logro de cada família, e não a conquista do grupo social (BESOAIN, 2012), salvo as exceções que ocorrem nos movimentos de moradia, submetidos às políticas neoliberais de produção, mas em um formato que ainda apresenta particularidades.

É no lugar que as práticas cotidianas ocorrem em cooperação e conflito, e se permite que a vida social ocorra superando o dia a dia. Por mais singelos que os lugares sejam, a complexa rede de relações que ali se desenvolvem possibilita a troca espontânea da diferença (RIBEIRO, 20136; SANTOS, 1996).

A superação do dia-a-dia, que é a resistência do cotidiano, não ocorre sem contradições, sem negociações de interesses, generalizações de demandas e valores uniformizadores, mas é na ação cotidiana que está o recurso valioso da vivacidade urbana.

As relações de dominação não são integralmente absorvidas pelos lugares, dado que essa submissão implicaria a anulação da experiência social urbana e a inexistência de movimentos de resistência (RIBEIRO, 2013) ${ }^{7}$ e mesmo de compromissos políticos dos governos mais atentos às práticas locais, o que não ocorre nem no caso brasileiro nem no chileno. A memória e a cultura dos lugares são parte do território usado, fruto das práticas populares e da resistência

6 O desenvolvimento local e a arte de "resolver" a vida. vol. 5, p.75-89.

7 Ação e seleção social: impulsos globais em contextos metropolitanos. Vol. 4, p.137-148. Leituras de movimentos: conjuntura, ação e poder. vol. 4, p.193-207. 
cotidiana crítica, agindo como uma oposição à tendência da apatia contemporânea.

O cotidiano subentende as relações e redes sociais, as quais são reforçadas pelas práticas dos usuários, de maneira a exacerbar a alienação do dia a dia, possibilitando ao outro ${ }^{8}$ o pensamento crítico e a ação transformadora que permite a superação do mero dia a dia.

O estudo do cotidiano observa o senso comum, a prática dos outros, enquanto sujeitos atores da sua própria ação. A análise social do cotidiano é uma troca de saberes entre o observador e o observado, utilizada para entender o território praticado a partir de todos os agentes que o praticam. Essa troca não pode ter sua importância diminuída, o que por vezes acaba por acontecer mesmo de forma inconsciente, por exemplo, ao se usar a palavra "excluído" para designar a noção de exclusão social. A denominação "excluídos" traz a falsa noção de que o outro não tem potência alguma com a sua própria ação (RIBEIRO, 2014). Neste trabalho não se utiliza o termo exclusão social pois entende-se que, de fato, o que ocorre é uma inclusão periférica, já que os "excluídos" são, na realidade, parte do sistema, em um paradoxo amargo de manutenção das desigualdades, assunto que será tratado no capítulo 3.

Goffman (1985) analisa o cotidiano a partir de uma visão teatral, na qual todos os sujeitos são atores representando um papel, ou mesmo um personagem, definido pelo sistema e pelo meio onde eles se encontram e com o qual interagem. Embora relacionadas com a sociedade anglo-americana dos anos 1970 e com um quadro bastante focado nos ambientes internos, muitas das suas análises podem se aplicar para espaços externos atuais, pois se relacionam às regras sociais definidas e sustentadas pelos próprios usuários. Assim, para Goffman, o componente expressivo da vida social é dado pelas impressões dadas e recebidas pelo outro, em um jogo de representações criadas e, na maioria das vezes, falsamente representadas. Segundo o autor, "(...) todo homem está sempre e em todo lugar, mais ou menos conscientemente, representando um papel... É nesses papéis que nos conhecemos uns aos outros; é nesses papéis que nos conhecemos a nós mesmos." (1985, p. 27)

Essa teatralidade do cotidiano se relaciona com a reprodução social, processo que é garantido por relações de dominação com o inconsciente de manutenção das estruturas sociais, embora com possibilidades remotas de escapar dessa mesma estrutura social. Essa reprodução orienta práticas e legitima condições de dominação, em um processo cíclico sem alteração da condição preestabelecida. Esse processo, para Bourdieu $(1989,2001)$, se relaciona ao habitus e à estrutura de campo que, embora prendam o sujeito em uma realidade preconcebida, não impedem a superação de sua condição.

O habitus, enquanto estrutura estruturada, é um produto social, adquirido de maneira inata. Enquanto estrutura estruturante, é um produtor social, que opera inconscientemente orientando as práticas e o espaço social.

Produto e produtor de uma mesma história, incorporada como sistema de disposições, o habitus funciona em relação ao campo social e é parte da conduta do indivíduo que se traduz corporalmente em atitudes, maneiras (hexis) e apreciações morais (ethos), retidas e reprodu-

8 A grafia do conceito de outro varia de acordo com as referências bibliográficas utilizadas nesta tese. Ana Clara Torres Ribeiro utiliza a grafia "outro", enquanto Christian Dunker utiliza tanto "outro" como "Outro", ambos termos lacanianos, sendo que o primeiro se refere ao ser humano narciso, que vê no outro a sua própria imagem refletida, e o segundo, ao grande "Outro", que é uma metáfora referente aos discursos de linguagem que nos nomeiam e nos influenciam. Neste trabalho, optou-se por grafar o conceito com inicial minúscula, utilizando tanto o conceito de Ribeiro quanto o de Dunker, no sentido de pessoas com as quais nos relacionamos e que podem ser reflexo de nós mesmos. 
zidas nas práticas sociais.

Os campos sociais específicos são analisados como âmbitos de socialização, em que agentes, consciente ou inconscientemente, se relacionam política, econômica, social e simbolicamente a partir de temas de interesse específico. Em uma metáfora de Bourdieu, a estrutura do campo é como a de um jogo, onde cada jogador tem fichas das diferentes espécies de capital - econômico, cultural, social e simbólico - o que define a sua posição estratégica (BOURDIEU, 2001). Dessarte, os campos sociais são definidos a partir de áreas de interesse e de posições de classe e são determinados por fatores históricos de formação da vida social, sendo, portanto, contraditórios e marcas de privilégio de agentes sociais específicos. Assim, a relação de dominação (e a reprodução da dominação) entre os agentes define a estrutura social.

O habitus é a forma de agir inconsciente originada por uma posição ocupada dentro dessa estrutura social e por um condicionamento que estimula a reprodução das circunstâncias sociais, orientando as ações a partir de uma internalização inconsciente de posição social, status, classe, gênero, origem étnica, entre outros aspectos. Nesse sentido, todas as ações cotidianas são socialmente situadas. O habitus se manifesta em relações sociais, ações, práticas esportivas, modo de se vestir e falar, postura, entre outros.

Até mesmo o esporte é resultado de uma especificidade social e histórica, uma herança cultural inconsciente que faz parte de uma estrutura social. Vejamos o gosto pelo futebol, e mais ainda por um time de futebol específico, que pode ser socialmente orientado e transmitido, muitas vezes, por relações familiares. O mesmo ocorre com a prática de skate em grupos sociais de menor renda e com a prática de tênis em grupos sociais economicamente favorecidos, todos com reprodução simbólica de um habitus de classe que expressa status social, condição que pode ser superada, como será demonstrado no estudo de caso da población Santa Adriana em Santiago do Chile, apresentado no capítulo 7.

Para Bourdieu (2001), a vida social pode ser analisada tanto a partir do conjunto de condições geográficas que definiram a individualização desigual e a combinação de grupos sociais em campos específicos, quanto pela análise de campos territoriais onde diferentes processos de identificação local ocorrem. Desse modo, a vida social acontece espacialmente segundo forças produtivas das relações de produção e reprodução dos agentes.

As práticas sociais no contexto latino-americano se realizam dentro do contexto histórico no qual questões sociais guardam relação direta com a cultura e a ideologia, sendo característicos de uma determinada ordem social. Com efeito, o espaço percebido pelas práticas espaciais (LEFEBVRE, 1974) não é só produzido, mas seus rearranjos socioespaciais são resultado da ação do tempo, que materializa as práticas apropriadas.

Isso posto, a incumbência do planejamento urbano conservador é também de controle do espaço percebido. No entanto, o espaço concebido pelos técnicos do urbano tende a uma regulação que, muitas vezes, altera a produção social do espaço, por atuar tanto com a percepção de um grupo social como com as ordens dominantes. Como resultado, há o espaço vivido (LEFEBVRE, 1974) que, de certa maneira, engloba os espaços percebido e concebido, possibilitando-se a resistência à ordem dominante. ${ }^{9}$

9 O espaço concebido se refere ao espaço planejado pelos técnicos, como arquitetos e urbanistas, que projetam um espaço para determinado uso, enquanto que o espaço percebido é o da relação dos usuários com o espaço em ações do dia a dia. Já o espaço vivido é o apropriado pelos usuários, onde o cotidiano ocorre pela superação das condições impostas (LEFEBVRE, 1974). 
Sob o ponto de vista das práticas sociais, a importância do planejamento da paisagem para a qualificação dos espaços livres de edificação é muito grande. As práticas sociais podem estar associadas diretamente à disponibilidade e à qualidade dos espaços livres, e é no cotidiano inconsciente (LEFEBVRE, 1991) que ação e discurso se unem no momento da convivência humana. A ação e o discurso só se manifestam se há uma esfera pública, no compartilhamento das ações entre seres humanos em conjunto. E é em conjunto que o poder de um grupo social se exacerba contra narrativas preestabelecidas (ARENDT, 2001).

Os espaços livres (MAGNOLI, 1982) são todos os espaços sem edificação, independentemente de sua jurisdição ou da presença ou não de vegetação. Logo, praças, parques, ruas, quintais, terrenos baldios, matas, praias, e inclusive áreas de plantio agrícola (DONOSO, 2011) são espaços livres de relevância para as cidades.

Todos os espaços livres são interconectados em um sistema complexo, que se inter-relacionam com outros sistemas urbanos em relação de complementaridade, sobreposição e conexão. Não é a conexão física e visual que tem maior relevância para o sistema, pois esses espaços têm múltiplos papéis, tanto na questão ambiental quanto social.

O Sistema de Espaços Livres (SEL) permite o convívio público, a livre circulação de seres vivos, as relações e práticas sociais. Esse sistema pode ser decorrente de planejamento específico ou se apresentar por apropriação espontânea.

Os espaços livres representam o maior percentual de área das cidades brasileiras e, independentemente da presença ou ausência de vegetação, qualidade ambiental e urbana, estética e jurisdição, têm potencial para abrigar a esfera pública, ser palco de manifestações políticas, festas populares, feiras livres, do cotidiano do encontro com o outro (RIBEIRO, 2014). Justamente por isso, deveriam ser foco de políticas habitacionais sociais.

Isso não significa que não sejam considerados no momento presente das políticas habitacionais, porém a ênfase não tem sido a geração de espaços livres para as práticas cotidianas dos grupos sociais envolvidos, principalmente no caso brasileiro.

Segundo Segovia (2005), algumas características comuns podem ser identificadas em conjuntos habitacionais sociais, podendo ser observadas em vários contextos latino-americanos: localização periférica quando construídos, desconexão entre o desenho urbano do conjunto e o entorno imediato, densidade líquida superior ao restante da cidade. Considerando essas características, supõe-se que os moradores estejam também desconectados da cidade e concentrados em áreas isoladas.

A manutenção da prática de construção de conjuntos habitacionais sociais com essas características mostra uma desarticulação entre as análises acadêmicas e os avanços políticos e institucionais, resultando na inexistência de estratégias para conseguir efetivamente aplicá-los. Construir habitat, com espaços livres e construídos articulados, espaços públicos, infraestrutura urbana e equipamentos, formando bairros e continuidades urbanas ainda não é uma prática corriqueira em projetos sociais.

O equívoco, tanto no caso brasileiro como no chileno, ocorre também em relação ao modelo de habitação. Mesmo nos conjuntos com participação popular, o modelo implantado é condominial, isto é, com espaços livres e cobertos de uso comum dos moradores de um mesmo condomínio. Nesse modelo, a prática coletiva restringe-se aos muros do empreendimento, similarmente ao que ocorre em condomínios de habitação de alta renda. Fora do condomínio de Habitação de Interesse Social (HIS) não há maiores interações entre grupos, e as relações 
de medo e receio do outro se reproduzem.

Dunker $(2015,2016)$ destaca que a experiência de civilidade é anterior às obras urbanas de planejamento dos espaços públicos. É preciso tratar a cidade como princípio, onde os territórios não sejam excessivamente defensivos, individualizados, com relações de posse por classe social ou perfil econômico.

A relação com o outro precisa ser estabelecida: o reconhecimento do outro, das trocas de discurso, que permitam o que Dunker (2016) chama de "experiências produtivas de indeterminação", nas quais o indeterminado, o desconhecido, leva à possibilidade de superação. 0 indeterminado é o sujeito que não é interpretado pela sua aparência, pelo seu discurso, pela sua textualidade corporal em nenhum grupo social ou classe, eliminando o preconceito da experiência social. Para o psicanalista, a indeterminação é um dos princípios de cidade.

No entanto, como defesa frente ao indeterminado, em nome da insegurança que o estranhamento do outro causa, criam-se espaços protegidos que concentram grupos com interesses similares, onde o conflito com o indeterminado possa ser administrado. O psicanalista traz o conjunto de mal-estares que caracterizam a sociedade contemporânea e que fazem parte das psicopatias da vida urbana: insegurança, intolerância e isolamento dos outros, prevenidos a partir da lógica de condomínio (DUNKER, 2015).

Essa perspectiva do condomínio, para Dunker (2015), é uma associação de mal-estares contemporâneos evitados sob uma gestão. O condomínio pode ser habitacional, empresarial, comercial e mesmo de saúde, como os hospitais, já que é a administração do uso e do "agir" no espaço que caracteriza o condomínio, ou seja, as regras e princípios que buscam evitar a experiência social completa e indeterminada.

Com ações determinadas e baseadas em medos e regras, o condomínio traz, então, a classificação e o isolamento de grupos sociais, excluindo-se outros. O psicanalista toma como exemplo o conto "O alienista" de Machado de Assis, no qual se evidencia essa relação humana de classificar e isolar pessoas. O protagonista do conto chega a se ver sozinho, do lado de fora do asilo de loucos que administrava, o que demonstra, com ironia, a relação humana de classificar e isolar grupos, excluindo-se a diferença e demonstrando todas as patologias que o conviver em condomínio pode gerar.

Sobre a vida em condomínios habitacionais, o que pode ser analisado no âmbito da baixa e da alta renda, o psicanalista relembra que, em condomínios brasileiros, o código de conduta não é derivado de uma origem comunitária, como no caso das gated communities norte-americanas, mas em uma partilha, por um grupo social, de um território a ser defendido.

Na busca de precedentes para a forma condominial brasileira, Dunker (2015) não encontra nenhum modelo anterior que se assemelhe à vida planejada, administrada e ascética. $O$ precedente mais próximo que o autor encontrou foram os hospitais psiquiátricos de meados do século XIX, como antigos leprosários e hospícios, onde a promessa de recuperação e reconstrução da experiência perdida ocorre em um protótipo de cidade, com regulamentos e espaços planejados.

Por outro lado, o condomínio habitacional é uma realização de um ideal de moradia. Esse modelo urbano, murado, produz um efeito subjetivo de segurança, cuja sensação é causada pelo convívio entre iguais, ou seja, por grupos sociais com poder econômico similar. Juntamente com a exclusão da diferença, há também, segundo Dunker (2016), a satisfação humana inconsciente de se sentir invejado pelos outros, além da relação individual com a autoridade, 
com o poder de definir regras para o convívio de seus iguais, ainda que, para o psicanalista, a vida em condomínios, com suas restrições e regulações da vida, também gere certo mal-estar advindo da perda da liberdade.

As alterações na paisagem precisam ser projetadas com o pensamento de quais práticas precisam ser valorizadas naquele espaço. E essa alteração precisa ser feita a partir do olhar do que é melhor para a prática social do outro. Para Ribeiro (2014), o planejamento da paisagem é um enorme mecanismo de controle social quando não há a presença do outro acrescentando conhecimento ao corpo técnico, ou seja, quando não há participação social. Há uma dialética entre se trabalhar a técnica de diagnosticar, planejar, projetar e o observar e diferenciar as necessidades e carências sociais de um espaço e seus usuários.

De maneira a estruturar a discussão dos espaços livres e a parametrizar aspectos qualitativos para os estudos de caso da tese, destacam-se algumas categorias relevantes para o pensamento dos espaços livres em habitação social. Não se pretende limitar a qualidade habitacional a partir dos aspectos destacados, nem tampouco gerar uma série de itens que precisem ser atingidos em todos os casos, pois as categorias são intercambiáveis e não há relação direta entre a existência desses aspectos e a produção de espaços que superem a diferença social e a fragmentação invisível.

Explicitadas as devidas limitações, selecionaram-se algumas categorias para auxiliar na análise, e mesmo no desenho de políticas públicas de projetos de espaços livres em conjuntos de habitação social: participação cidadã e redes sociais, gestão, inserção urbana, adequação microclimática, diversidade morfológica e flexibilidade funcional, visibilidade e dimensão. A seguir, cada categoria será explicitada.

\section{- Participação cidadã e redes sociais}

Uma das categorias principais para habitação social é a consideração das redes sociais, dos trabalhos sociais e da participação comunitária. É com a participação que se consegue observar a necessidade do outro e se reestruturar a rede cidadã, muitas vezes perdida no tempo e no espaço.

Em conjuntos habitacionais novos, com moradores provenientes de diferentes bairros da cidade, a já fragilizada rede social tende a não se consolidar, já que os interesses individuais prevalecem sobre o coletivo, e a subjetividade presente na luta pela casa própria se limita ao espaço privado, estimulando o desinteresse pelo espaço externo à habitação. Nesses conjuntos, a participação popular fica limitada a poucos moradores, que não conseguem representar o todo, o que dificulta a elaboração de projeto dos espaços livres que se sustente no tempo e espaço para as práticas cotidianas.

A participação e a consideração das redes sociais para o provimento de habitação social evitam que a conquista da casa própria seja apenas individual, o que subjetivamente orienta as práticas também para o interior da residência. Com a conquista coletiva, há a possibilidade de que a população se aproprie dos espaços, com maior possibilidade cotidiana de superação das adversidades.

O deslocamento de famílias para conjuntos habitacionais independentemente do local de moradia original causa muitos prejuízos, visíveis tanto no caso brasileiro como no chileno. A simples entrega da habitação pela construtora, com pouca ou nenhuma presença posterior 
do Estado é preocupante. As famílias vivenciam um processo de mudança do seu cotidiano e habitat para outro desconhecido, e deveria haver, por parte do Estado, iniciativas para auxiliar a inserção delas em seu novo contexto.

Simplesmente entregar a unidade habitacional com um manual sobre a arquitetura do edifício, que é o usual em empreendimentos do "Fondo Solidario" no Chile (o que será detalhado no capítulo 7), não é suficiente, pois os habitantes terão, mesmo que inconscientemente, uma percepção de abandono e exclusão social.

Já os conjuntos habitacionais que tiveram participação social têm experiências que possibilitam maior integração das famílias. A cooperação em diversas instâncias do processo de aquisição de uma casa própria é peça chave para a construção de uma identidade coletiva, que pode criar uma memória histórica de luta dos grupos, juntas de vecinos e movimentos sociais que vão, inconscientemente, atuar na construção de um pertencimento territorial, espacial e de apropriação das áreas comuns. A celebração dos grupos envolvidos nos processos de participação fortalece a identidade socioespacial, como o que possibilita o Programa "Minha Casa Minha Vida" Entidades (PMCMV-E), a modalidade do PMCMV que regulamenta a participação de ONG's e movimentos de moradia, que será apresentado no capítulo 6.

Sobre participação popular, em Santiago, são muitos os trabalhos de organização social com participação coletiva para resgate da memória dos habitantes como, por exemplo, a recuperação de fatos históricos das ocupações de terreno e posteriores conquistas de aquisição de casa própria, o que contribui para a integração das famílias. Essa integração se reflete no uso dos espaços coletivos, como é o caso da Población Santa Adriana e dos vários anos de atuação do "Quiero Mi Barrio" (vide capítulo 7), fortalecendo-se a história do local, as organizações sociais e os espaços coletivos.

Em conjuntos onde já há uma união comunitária, como no caso dos empreendimentos realizados para grupos sociais já organizados, há maiores chances de se estimular a participação cidadã no projeto dos espaços livres e realizar uma intervenção adequada aos interesses coletivos do grupo social.

A participação cidadã é imprescindível nos projetos de bairro, mas essa participação deve partir do interesse dos moradores em se reunirem em prol de um benefício comum. Somente assim a participação será realmente ativa e capacitará os moradores a implementar o projeto e dar continuidade à união do grupo social.

Por conseguinte, somente a participação comunitária não é suficiente como critério de qualidade para a produção de espaços coletivos em habitação social: é preciso que a participação seja antecedida por uma base comunitária forte, de organização, liderança e confiança.

\section{- Gestão}

De nada adianta a participação cidadã na definição da habitação social e dos espaços livres se não for pensada a gestão desses espaços.

No caso dos conjuntos habitacionais sociais no modelo de condomínio de prédios (que se realiza em ambas as regiões metropolitanas estudadas neste trabalho) os moradores, em geral, não estão familiarizados com regras de condomínio e rateio de custos, o que significa que o interesse inicial em manter os espaços comuns é apenas temporário, ocorrendo em alguns momentos específicos de melhor organização social. Infelizmente, ao longo dos anos as áreas 
comuns são abandonadas pela dificuldade de mantê-las.

A falta de identificação e familiaridade com o modelo de condomínio leva à ruína dos espaços comuns, com depredações e apropriações individualizadas, o que acaba restringindo o convívio aos espaços internos diminutos das residências. Se não há identificação e não há facilidade em administrar as áreas comuns, como se pretende que estas sejam mantidas?

Em muitos novos empreendimentos habitacionais da Região Metropolitana de São Paulo, verifica-se que as exigências da Caixa Econômica Federal ${ }^{10}$ para as áreas comuns são cumpridas, pois a instituição exige que sejam realizados playgrounds, equipamentos de ginástica, quiosques, espaços para rede ("redários"), churrasqueiras e demais itens presentes em condomínios de prédios de classe média e alta, que são usados como modelo para os conjuntos habitacionais sociais.

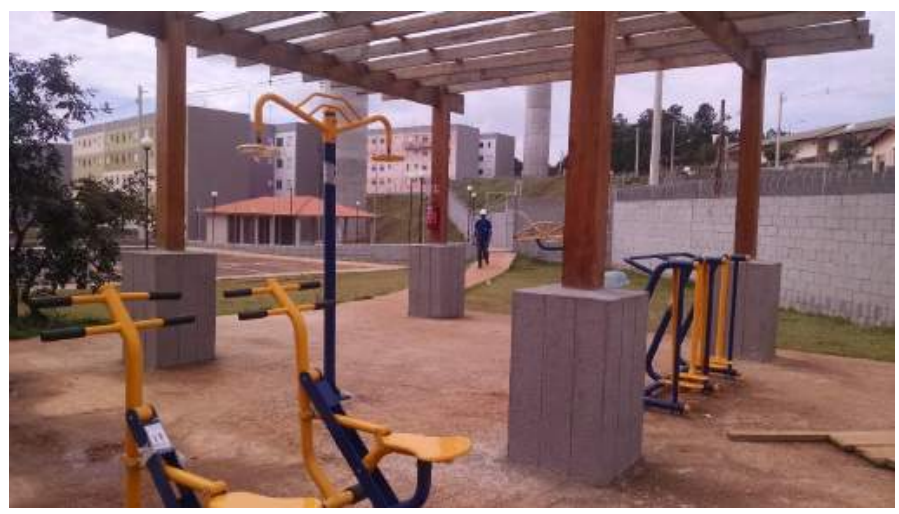

Figura 2: Academia ao ar livre sendo instalada na área comum do condomínio. Empreendimento Residencial Portal Flora, em Guarulhos - SP. Fotografia da autora (2015).

Claro, entre a dificuldade de se construírem espaços públicos, ou seja, externos aos muros dos condomínios por parte da iniciativa municipal, e a possibilidade de exigir dos construtores que realizem áreas de convívio dentro dos conjuntos habitacionais, a segunda possibilidade é mais rápida e econômica para os governos e para os empreendedores.

O modelo de vida condominial é um grande problema na produção de habitação social. Além do fato de que é uma estratégia totalmente contestável replicar um modelo habitacional de média e alta renda para um grupo com menos recursos econômicos, a inserção urbana dramática dos condomínios de habitação social na Região Metropolitana de São Paulo e Santiago só contribui para um maior receio no uso dos espaços externos aos muros do condomínio. $\mathrm{O}$ outro é visto como ameaçador, diferente do seu grupo social.

Além da dificuldade de gestão do condomínio para moradores de habitação social, a longo prazo o resultado é ainda mais trágico do que só haver áreas em desuso e depredadas no condomínio, pois se afeta diretamente a vida cotidiana do bairro.

\section{- Inserção urbana}

(...) Santiago ha visto desarrollarse un levantamiento de murallas internas o fronteras dentro de la ciudad, como sustento de una dinámica relacional que presenta como fin la horizontalidad, o la relación con un igual, y el distanciamiento del distinto. La ciudad queda convertida, de esta forma, en un conjunto de ciudadelas (BESOAIN, 2012, p. 32).

10 Instituição financeira responsável pela operacionalização e definição dos critérios para empreendimentos do Programa "Minha Casa Minha Vida". Maiores informações sobre o funcionamento do Programa podem ser encontradas nos capítulos 2 e 3. 
No caso de Regiões Metropolitanas de tecido urbano mais complexo, somente criticar a localização periférica de empreendimentos de habitação social não é suficiente. Em territórios como o da Região Metropolitana de São Paulo não há uma relação direta entre periferia e pobreza, nem entre periferia e má inserção urbana. Dessa maneira, um empreendimento de habitação social pode estar localizado em uma região periférica ao centro histórico da cidade de São Paulo, mas isso não significa estar às margens da cidade e da sociedade, o que é ainda mais evidente considerando-se a área urbana da metrópole, onde a divisão municipal muitas vezes desaparece no contínuo urbano.

Portanto, para poder parametrizar qualitativamente a inserção de um conjunto habitacional em regiões metropolitanas, é mais eficiente observar aspectos como a conexão urbana, a distância aos locais de maior concentração de empregos, a facilidade de acesso ao transporte público, os trajetos cotidianos dos moradores e mesmo a relação com o suporte biofísico.

Da mesma forma, uma inserção urbana positiva subentende a proximidade com equipamentos urbanos diversos, como escolas, creches, centros médicos, equipamentos culturais e outros, que possam atender aos moradores dos novos conjuntos e do entorno, de preferência, assistindo à população de diferentes segmentos econômicos.

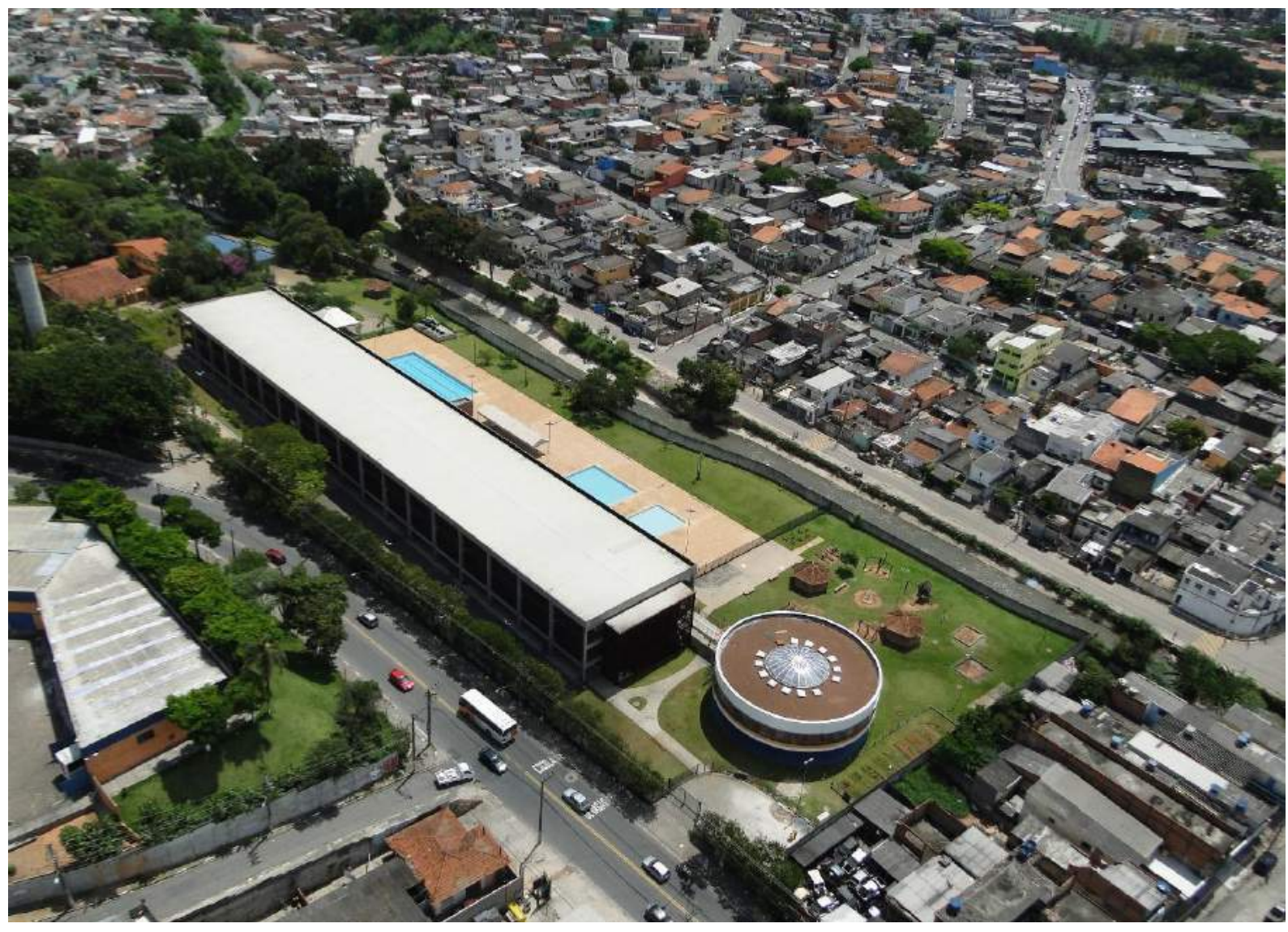

Figura 3: Inserção do Centro Educacional Unificado (CEU) na cidade de São Paulo, parte de política educacional municipal criada nos anos 2000 - 2004, durante a gestão de Marta Suplicy, como proposta de inclusão social por meio de ensino, esporte, cultura e extensão. A política consistiu na construção de equipamentos de uso múltiplo em regiões com carência educacional, social e cultural. Ao todo, foram construídos 45 equipamentos, como previsto no projeto original, sendo que a maioria se encontra nas zonas leste (18 equipamentos) e sul (17 equipamentos). Fonte: Acervo QUAPÁ (2012). 


\section{- Adequação microclimática}

Aspectos climáticos estão presentes nas preocupações das políticas sociais chilenas, principalmente em relação à qualidade arquitetônica das unidades habitacionais produzidas: pela variação térmica nas diferentes estações do ano, há a necessidade de se exigir que as unidades habitacionais sejam parametrizadas para que se adaptem a esse clima. No caso brasileiro, a variação térmica é ampla, com Estados do Nordeste do país enfrentando temperaturas totalmente distintas do Sul, mas não há exigências, na política habitacional atual, em se considerar os aspectos climáticos.

A vegetação tem papel importante para gerar microclima urbano, pois é responsável pela proteção contra sol e ventos, pela absorção de ruídos e pelo contraste morfológico entre diferentes escalas de elementos construídos, dentre outros aspectos. A criação de microclima com os espaços livres tem capacidade de favorecer a utilização pela população em diversos momentos do ano, além de atuar na maior ou menor capacidade de receber avifauna.

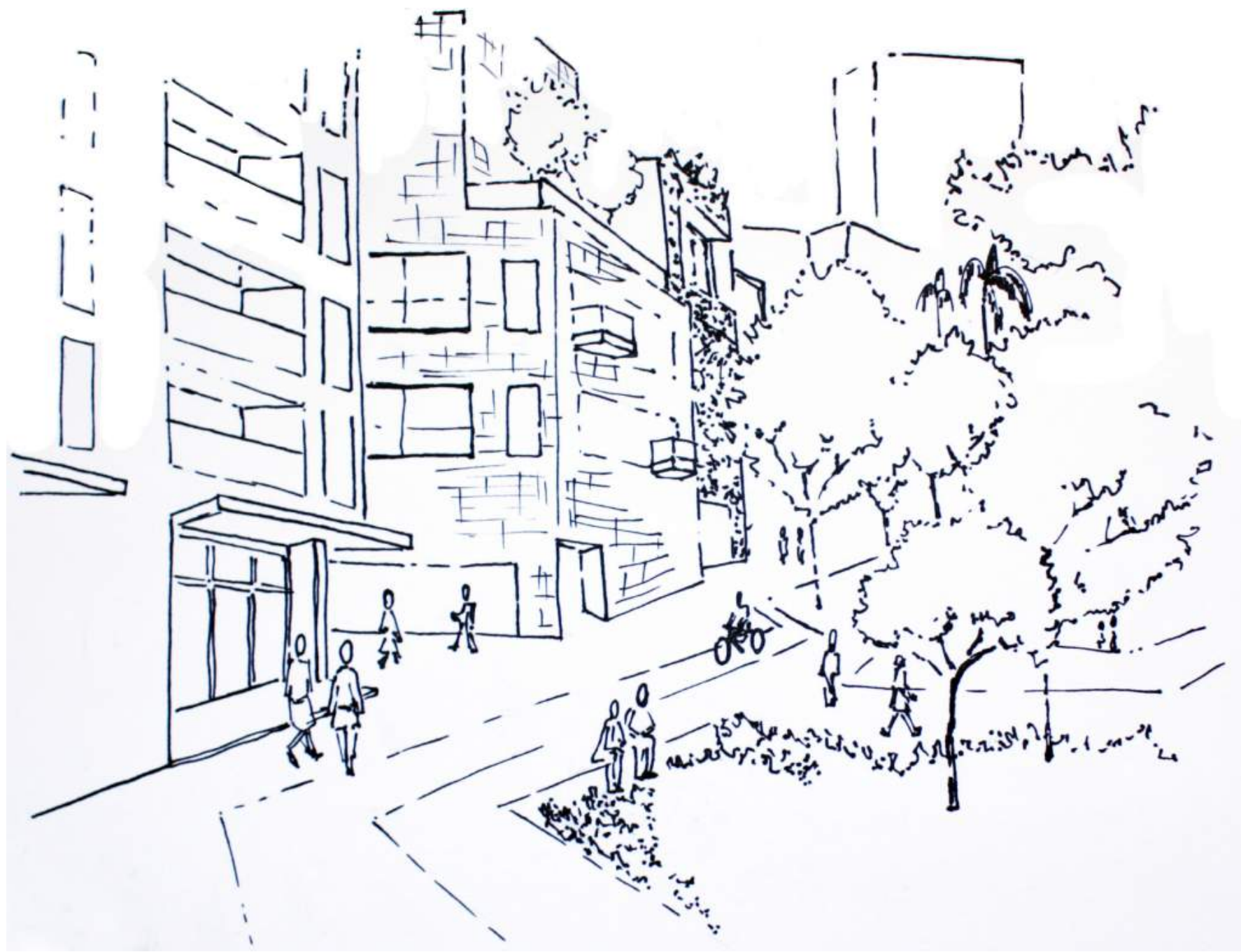

Figura 4: Relação edifícios habitacionais e espaço livre. Fonte: elaborada pela autora (2016). 


\section{- Diversidade morfológica e flexibilidade funcional}

Como já comentado, a política social precisa ser de criação de habitat, e não de habitação. A produção de territórios homogêneos de habitação social em conjuntos e condomínios que não apresentam nada mais que habitação e espaços residuais não traz nenhum aspecto positivo, nem aos moradores do conjunto, nem à cidade.

É necessário pensar os conjuntos enquanto bairros, inseridos no contexto urbano e apresentando diversidade morfológica, com habitações para diferentes perfis econômicos, comércio, serviços, equipamentos diversos, espaços de convívio social, espaços de preservação ambiental, além de distribuição equitativa desses elementos urbanos.

Também é relevante a flexibilização de espaços livres, já que estes têm capacidade de ser multifuncionais e receber diferentes práticas sociais em situações espaço temporais e culturais diferentes.

Uma grande dificuldade, nos casos estudados nesta tese, está na consideração de espaços de comércio nos novos e antigos conjuntos de habitação social. Seja por dificuldade no gerenciamento e na definição dos proprietários para essas áreas, seja por outras dificuldades que surgem em cada caso, é preciso considerar a importância das áreas de comércio não só para o atendimento dos moradores, mas também pelo seu potencial de reforçar economias locais.

Além da diversidade morfológica, há a necessidade da diversidade sociocultural e econômica. Não há nenhum benefício em isolar grupos de moradores de perfil socioeconômico similar. $\mathrm{Na}$ homogeneidade, perde-se a riqueza pública do encontro com o diferente, e o distanciamento e o isolamento físicos implicam também um isolamento social, em que as barreiras atuam diretamente nas percepções cotidianas, no desenvolvimento socioafetivo e no processo de construção de identidade.

\section{- Visibilidade}

A acessibilidade visual é elemento importante para a percepção de segurança dos espaços coletivos. Barreiras visuais e físicas devem ser diminuídas e, se possível, evitadas. A transparência no fechamento dos conjuntos e habitações individuais precisa ser estimulada, pois é na visibilidade entre os espaços privados, públicos e de copropriedade que se gera maior sentido de segurança e coletividade.

Em relação ao fechamento por muros, no caso chileno, é possível ver nas comunas de maiores recursos, como Vitacura e Las Condes, edifícios habitacionais totalmente abertos à cidade, sem nenhum tipo de fechamento do seu limite, onde a diferenciação entre a área privada e a área pública é feita unicamente por meio do desenho urbano e do paisagismo. Também é possível ver edifícios habitacionais com algum fechamento, mas são majoritariamente com grades que permitem a visibilidade.

Nos conjuntos habitacionais sociais chilenos, os fechamentos são em geral transparentes e, nos casos dos edifícios, é possível verificar cercas em diversos pontos além da divisa do lote com a rua, como em passagens, escadas e acesso, bloqueando a livre circulação com justificativa de maior segurança para os moradores, quando na verdade é responsável também por maior controle visual e social. 


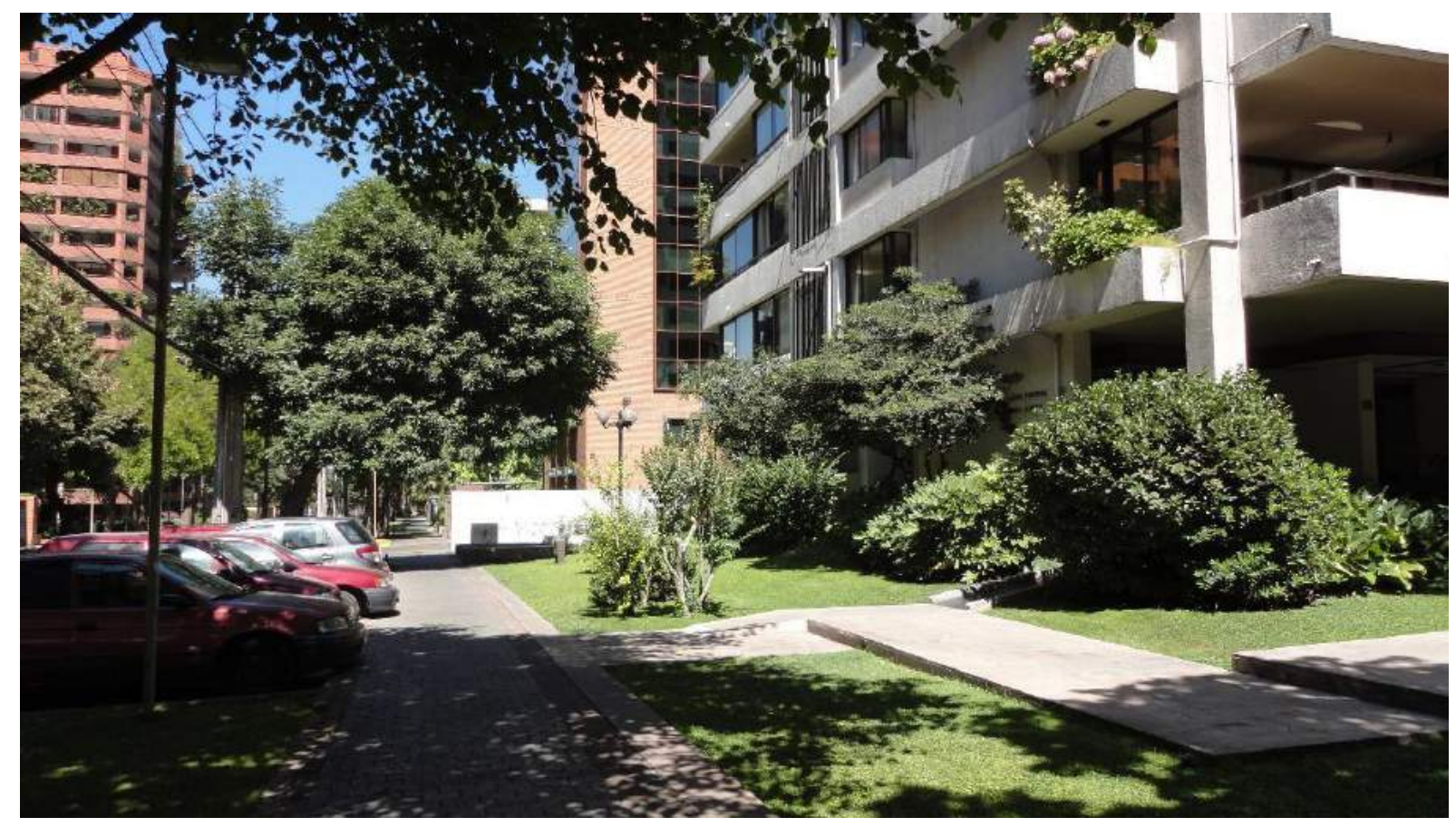

Figura 5: Ausência de muros e grades fazem parte do desenho urbano de várias ruas das comunas de Las Condes e Vitacura, setores que concentram população de alta renda. Fotografia da comuna de Las Condes, fotografia da autora (2015).

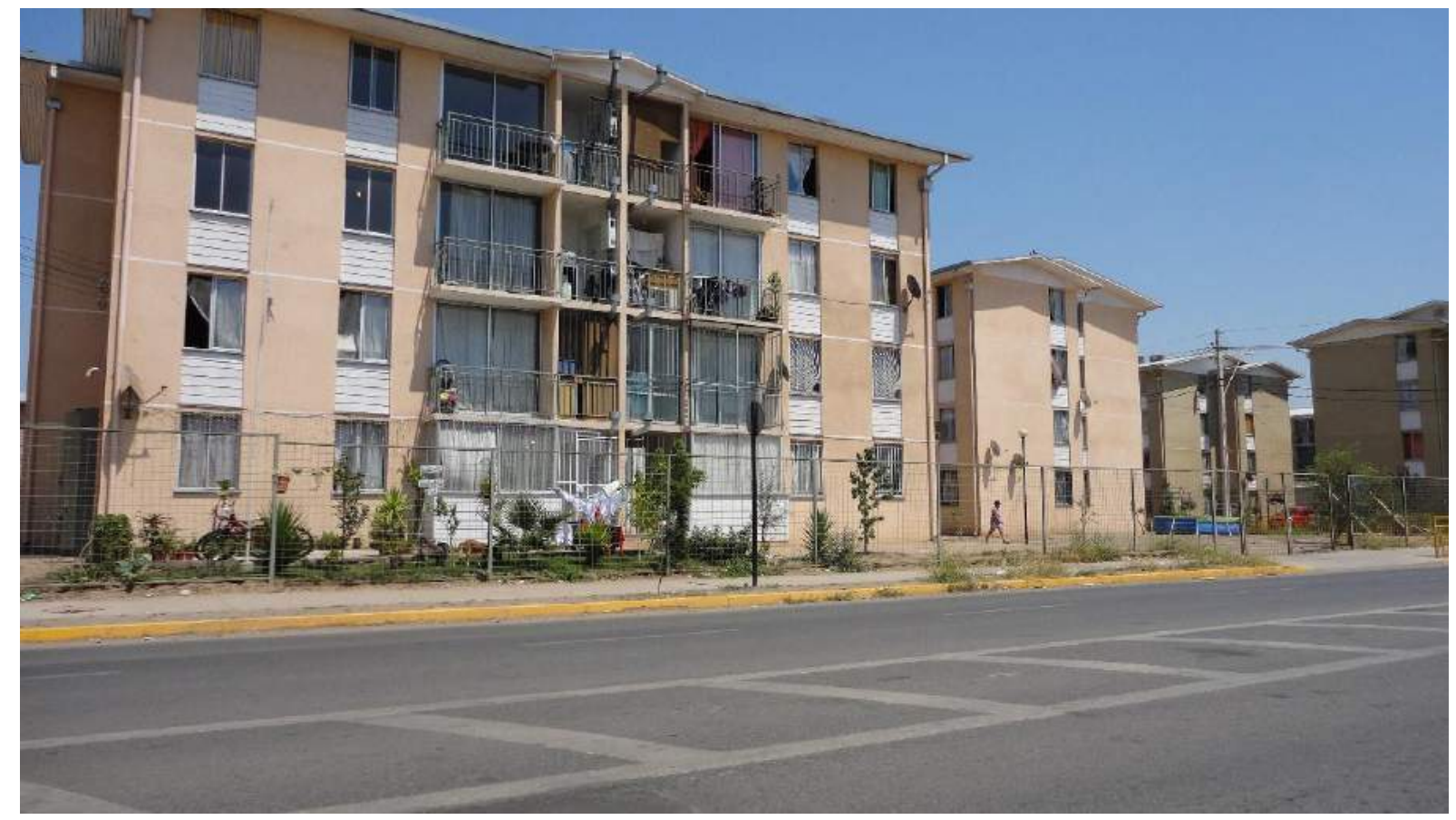

Figura 6: Fechamento com grade permite visibilidade no empreendimento de habitação social Lomas del Prado na comuna Cerro Navia. Fotografia da autora (2015). 
No caso brasileiro, o fechamento é feito com muros altos, que bloqueiam totalmente a visão da unidade, tanto para habitações de alta quanto de baixa renda. São poucos os exemplos de edifícios habitacionais de classe média e alta com fechamento que permita visibilidade.

Isso posto, fechar ou não (e como fazê-lo) é cultural e, para as habitações sociais, há uma tendência de se seguir o modelo de renda média. É de se esperar que, nos casos paulistas, as habitações sociais sejam imediatamente fechadas por muros ou cercas, da mesma forma como é feito na maioria dos bairros de classe média e alta da Região Metropolitana de São Paulo. Também é de se esperar que, no caso chileno, tal fechamento seja feito principalmente por grades, com permeabilidade visual, modelo que é inclusive estimulado pelos manuais do Ministério de Vivienda y Urbanismo - MINVU.

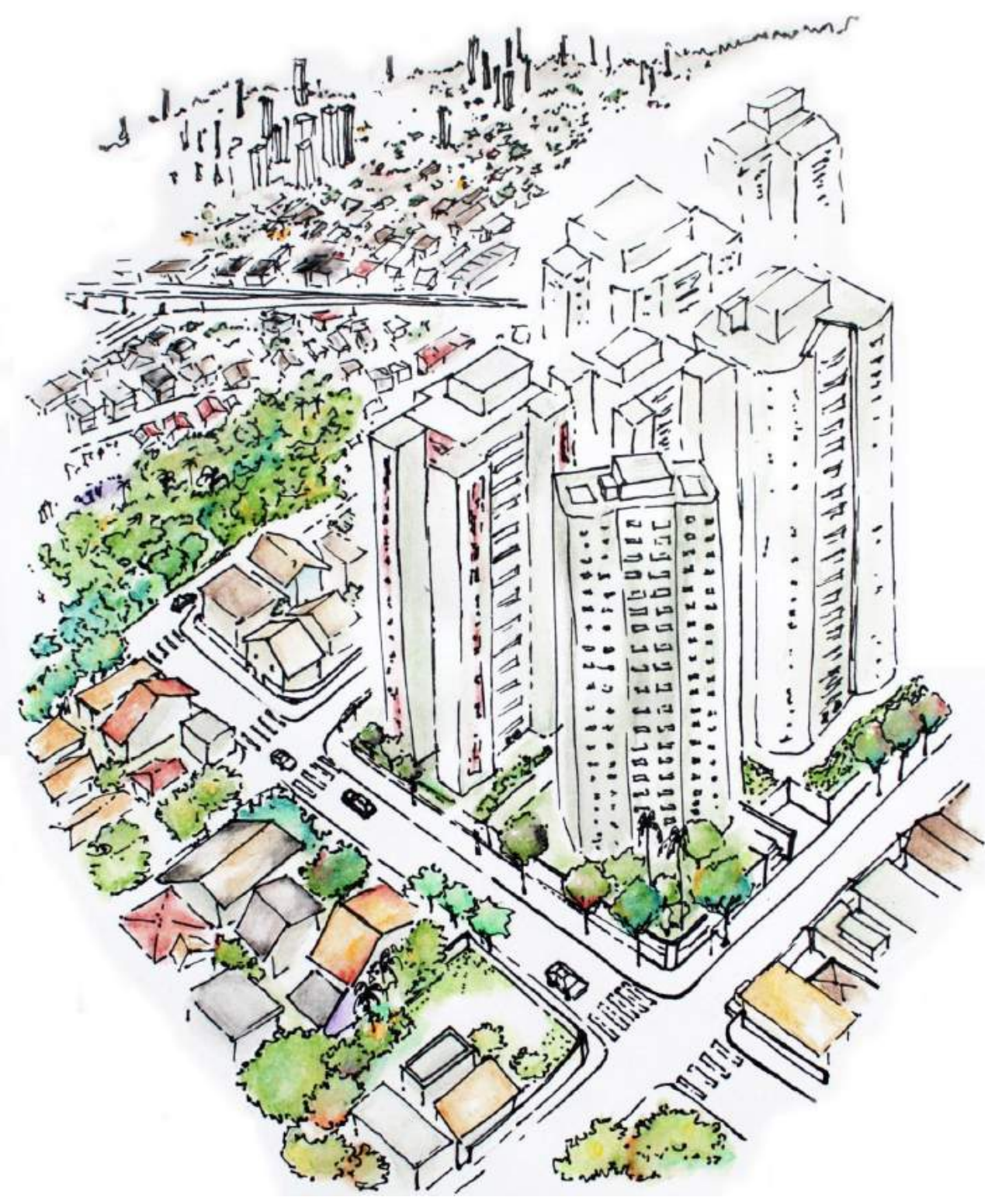

Figura 7: Cenário típico de regiões de renda média da Região Metropolitana de São Paulo, com condomínios de prédios, lotes unifamiliares, calçadas estreitas e arborização intraquadra pontual. Fonte: elaborada pela autora (2016). 


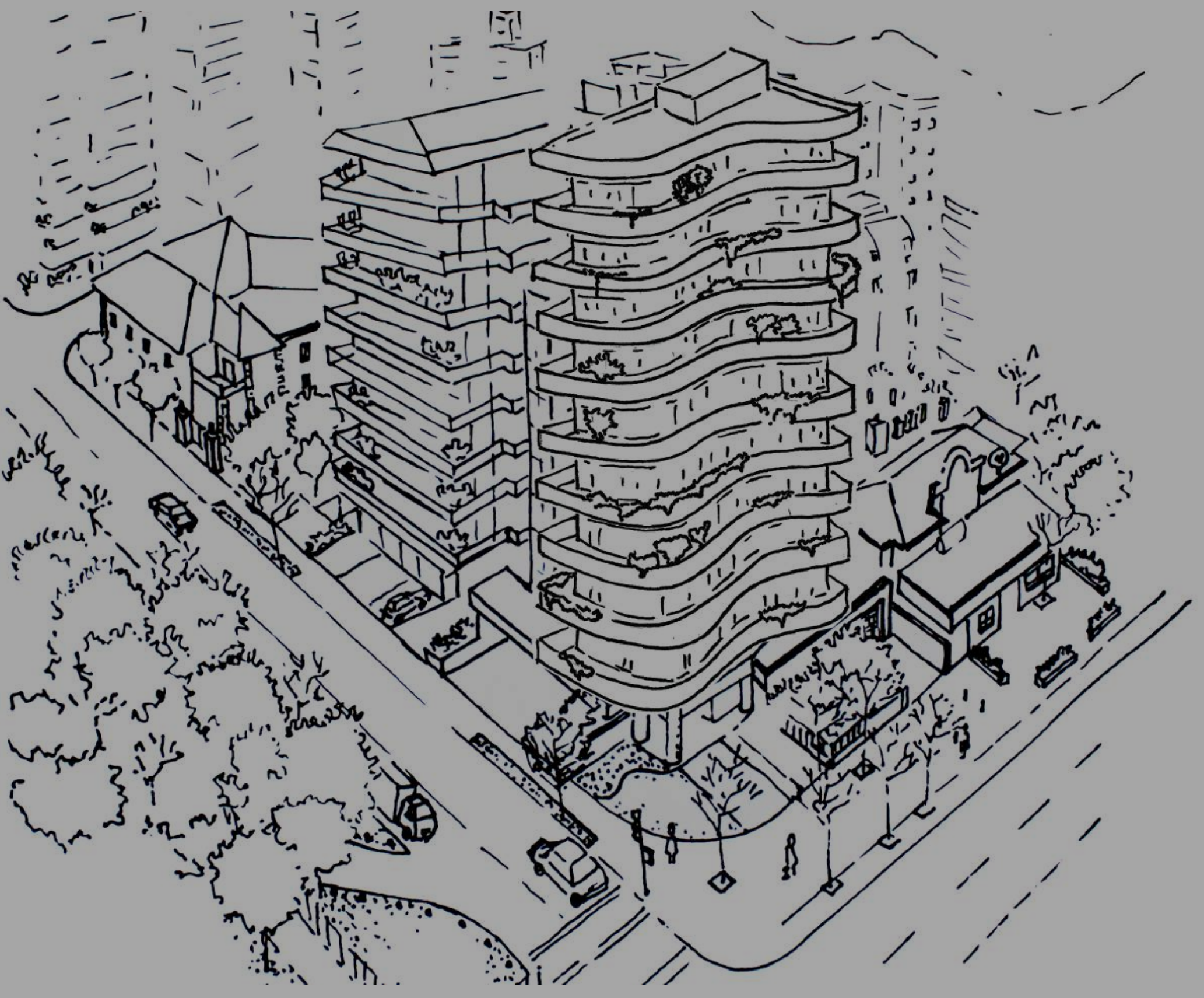

Figura 8: Cenário típico de regiões de alta renda de Santiago, onde edifícios habitacionais com varandas generosas tem seu térreo integrado ao passeio público. A restrição do acesso ao edifício é feita pelo desenho urbano e pelo paisagismo. Fonte: elaborada pela autora (2016). 


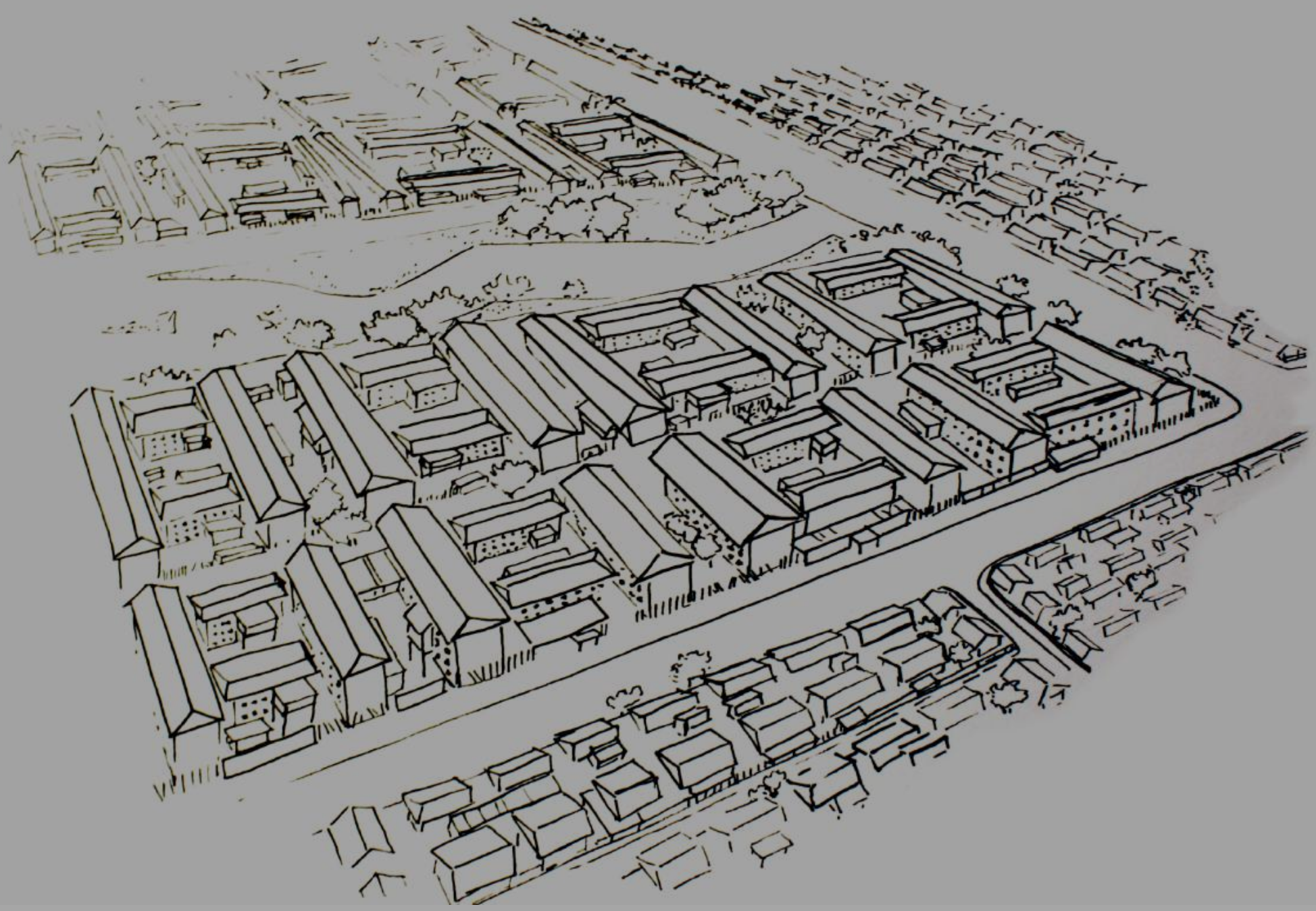

Figura 9: Cenário típico de regiões de baixa renda de Santiago, com edifícios habitacionais e habitações unifamiliares padronizados. Ampliações irregulares são comuns tanto nas unidades térreas quanto nos edifícios habitacionais, apesar dos terremotos constantes. Fonte: elaborada pela autora (2016). 
Segundo Segovia (2005), a percepção de exclusão está diretamente relacionada com o fechamento, pois a permanência dentro de espaços limitados construtivamente reforça a situação objetiva de estar fora das possibilidades de trabalho, estudos, cultura e mesmo convívio. Os muros e cercas, para a autora, se relacionam simbólica e emocionalmente com a ideia de estar às margens da cidade e da sociedade:

Desde la perspectiva del conjunto y su relación con la ciudad, el encierro emerge por la inexistencia de medios comunicantes entre el adentro y el afuera, entre el conjunto y la ciudad. La distancia es la primera barrera objetiva; la falta de continuidad urbana refuerza la percepción de 'separación'; y al listado de carencias se agregan los costos de transporte y la falta de los medios necesarios para generar todo tipo de conexiones - sociales, educacionales o laborales - con el afuera. La resultante: la percepción de 'darse vueltas' como prisioneros en la monotonía de lo conocido, sin posibilidades de elección, marginados por la propia ciudad. Una 'ciudad' que tampoco transciende las fronteras, no participa en la vida del conjunto, no considera a sus habitantes ni como 'mercado' ni como 'beneficiarios' (ni lleva ayuda, ni entretención, ni servicios, etc.). No se comunica. Permanece al otro lado de la frontera (SEGOVIA, 2005, p. 89).

Do mesmo modo, a falta de identificação com áreas comuns e a falta de desenho dos espaços livres contribuem para a sensação de insegurança do espaço coletivo. Essa insegurança é tanto presente em conjuntos habitacionais de lotes individuais quanto em condomínios de prédios.

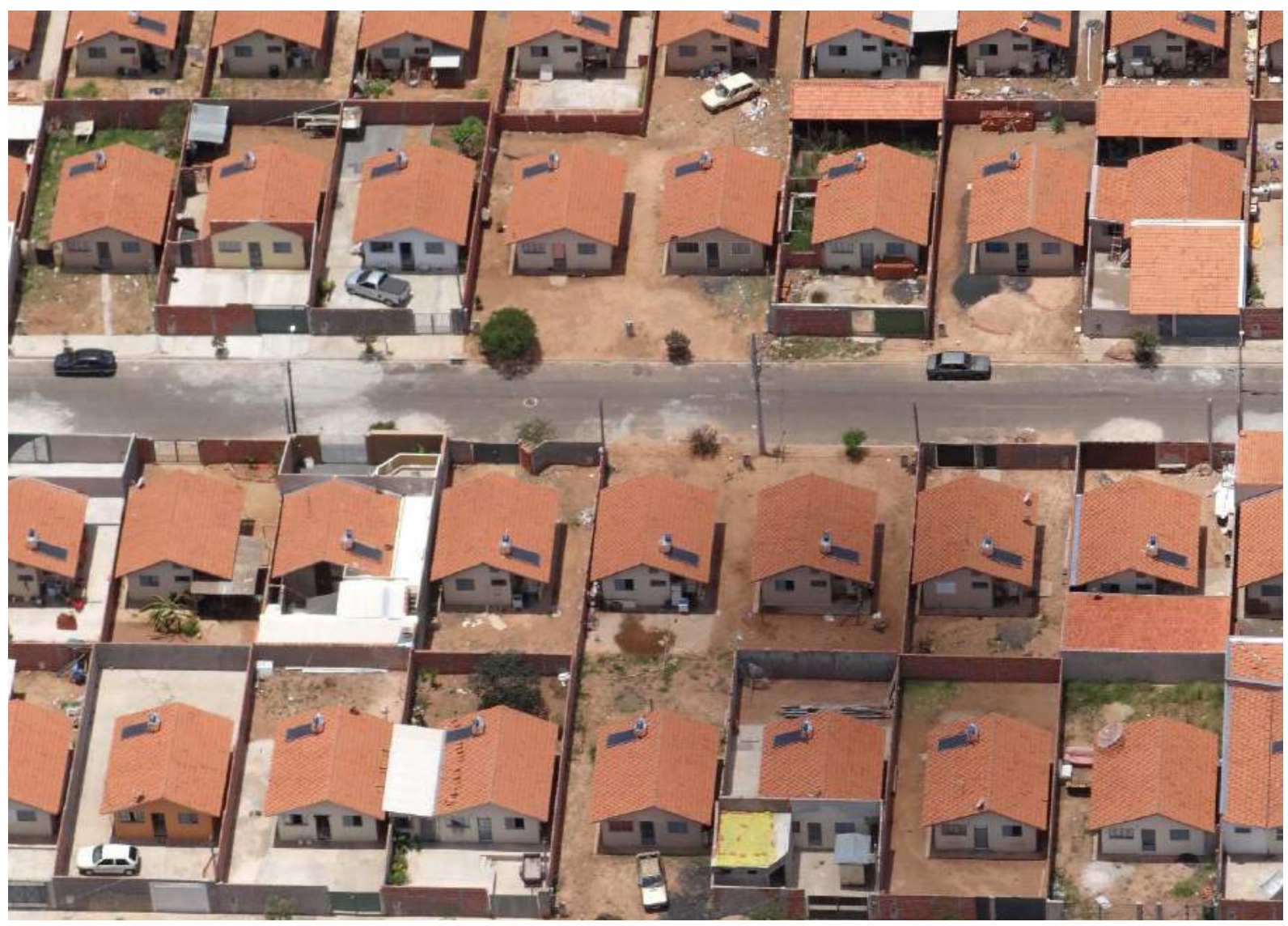

Figura 10: Empreendimento do Programa Minha Casa Minha Vida em São Carlos-SP. Unidade habitacional típica do programa, que é imediatamente fechada pelos moradores. Vegetação urbana e intraquadra praticamente ausente. O cenário resultante, de muros contínuos, não é favorável à apropriação do espaço público. Fonte: Acervo QUAPÁ (2014). 
Para Ribeiro (2013, vol. 4), a observação das mudanças do universo dos valores é indispensável para estudar a morfologia urbana. Esses valores, como o individualismo e o consumismo, estilos de vida difundidos - ou criados - pelo mercado imobiliário e marketing, legitimam situações urbanas, como a fragmentação socioespacial, e sustentam modelos baseados em dinâmicas mundiais, segundo as quais o fechamento para o espaço interno da residência tem sido privilegiado em detrimento do espaço externo coletivo. Para a autora: "Como reconhecer os obstáculos à afirmação de sujeitos de direitos, nas sociedades latino-americanas, sem conhecer os valores que sustentam a estratificação social?" (RIBEIRO, 2013, p. 224 ${ }^{11}$ ).

Arendt (2001) relembra que, na Grécia antiga, havia a esfera da polis e a esfera da família, sendo que a esfera da polis representava a liberdade. Na esfera pública, não havia o conceito de domínio e submissão ao governo e poder no sentido que conhecemos hoje; esses conceitos eram considerados como pré-políticos e pertencentes à esfera privada. Também a noção de liberdade não era igual à noção atual, pois significava estar junto ao seu semelhante, entre seus pares, não tendo o sentido de liberdade individual e privada que se valoriza atualmente no ocidente.

No ambiente da esfera da polis, a liberdade era seguida da igualdade, não havendo posição social de poder. Já no ambiente da família e na esfera privada, a liberdade era anulada pela posição familiar de dominação. Hoje essa relação entre esfera pública e privada é alterada pela subjetividade das práticas sociais.

A psicóloga Carolina Besoain, em sua tese de doutorado sobre os processos de subjetivação em famílias que moram em habitação social em Santiago, demonstra que a chegada da habitação transforma os valores das famílias, dentro de um projeto subjetivo de tramas marcado pela privatização da luta pela unidade habitacional.

La llegada a la vivienda social marca el advenimiento de un nuevo modo de relacionarse consigo mismo y con los otros. Junto con los muros y el suelo nace un novedoso sentido de propiedad y autonomía, en el que se despliegan nuevas configuraciones subjetivas y relaciones con la alteridad. La vivienda social inaugura un límite, sus muros se inscriben como frontera a partir de la cual se configuran nuevos espacios y nuevas temporalidades. (BESOAIN, 2012, p. 138)

O olhar da psicóloga é focado nos processos de subjetivação que ocorrem na cena social chilena, buscando indagar sobre as transformações das identidades e subjetividades por meio de estudos de narrativas individuais. Esses relatos possibilitam a identificação individual, cujos sujeitos, identificados, são leitores de suas próprias narrativas e histórias de vida.

A subjetividade é um processo de natureza social e discursivo (BESOAIN, 2012), e nas narrativas analisadas pela autora se verifica a ambivalência entre a celebração da nova intimidade da casa adquirida - o que se relaciona a um pensamento voltado ao espaço privado -, e a nostalgia de um momento anterior à aquisição da nova moradia.

Esse processo, mediado pelos programas de habitação social em ambos os países, deixa visível a capacidade individual e a autodeterminação, subjetivamente direcionando os indivíduos a uma cidadania individual e privatizada, já que o coletivo, o social, é eclipsado durante o processo.

Os próprios programas habitacionais, quando transferem para a ação individual uma respon-

11 Dimensões culturais da ilegalidade. Vol. 4, p. 223-238. 
sabilidade estatal de provimento de habitação social, transferem também o que era um direito para um bem de consumo de caráter individual.

A subjetivação se dá em um processo ambíguo, que congrega ao mesmo tempo tanto a celebração da conquista como o medo do novo espaço de moradia, o que leva ao fechamento das famílias no espaço privado e à fantasia de retornar à moradia irregular anterior. Esse processo dá visibilidade à capacidade individual de conquistas e eclipsa o espaço social, econômico e político coletivo, incorporando a individualidade que colabora com processos de fragmentação social (BESOAIN, 2012).

Márquez (2004, apud BESOAIN, 2012) coloca que a política habitacional desencadeou um paradoxo, pois, junto com a conquista de uma moradia, pioram as condições de sociabilidade, integração e coesão social dos habitantes, produzindo mais estratificação socioeconômica. Esse processo gera uma cidadania cada vez mais privada, que deixa vulnerável o ambiente externo.

Essa tendência à individualização é vista por Besoain (2012) como um dos resultados da liberalização econômica, que alterou os estilos de comportamento:

El 'nosotros', entendido como la identidad y la confianza, se ha resquebrajado, produciéndose una retracción de la sociabilidad. Los referentes identificatorios de las personas se han restringido cada vez más a los círculos íntimos de familiares y amigos. Lo público, en este contexto, aparece como un espacio ocupado por 'otro' anónimo y en ocasiones amenazador (2012, p. 33).

\section{- Dimensão}

O dimensionamento dos espaços livres tem importância para a qualidade da habitação social, seja no desenho morfológico das ruas, praças, passeios e parques, seja no planejamento das conexões dos espaços para as práticas cotidianas, sem resíduos que possam transmitir insegurança aos usuários.

Também há a necessidade de se dimensionarem os espaços livres relacionando a quantidade de usuários dos espaços comuns de condomínios habitacionais, estimulando-se a apropriação dos grupos, a organização dos vizinhos e a manutenção das áreas.

A melhor situação de desenho urbano para os conjuntos habitacionais sociais ocorre quando os espaços livres de convívio estão externos às áreas do condomínio, fazendo parte das áreas públicas urbanas com manutenção sob responsabilidade pública. Passar a responsabilidade da manutenção das áreas de convívio para os moradores dos conjuntos habitacionais sociais é muito complexo, devido aos custos e à imposição de modelos urbanísticos, que pode levar ao desinteresse e abandono das áreas de convívio.

Sabe-se que o tamanho das unidades habitacionais é insuficiente para abrigar a maioria das famílias que recebem uma habitação social, tanto no Brasil quanto no Chile. Essa discrepância entre o tamanho da unidade habitacional e a real necessidade das famílias, no Chile, resulta em ampliações irregulares mesmo em edifícios habitacionais, ocupando os espaços comuns e modificando as fachadas dos edifícios. Essas ampliações são frequentes desde os anos 1980 na RMS, mesmo com riscos de desmoronamento devido a terremotos e incêndios. 


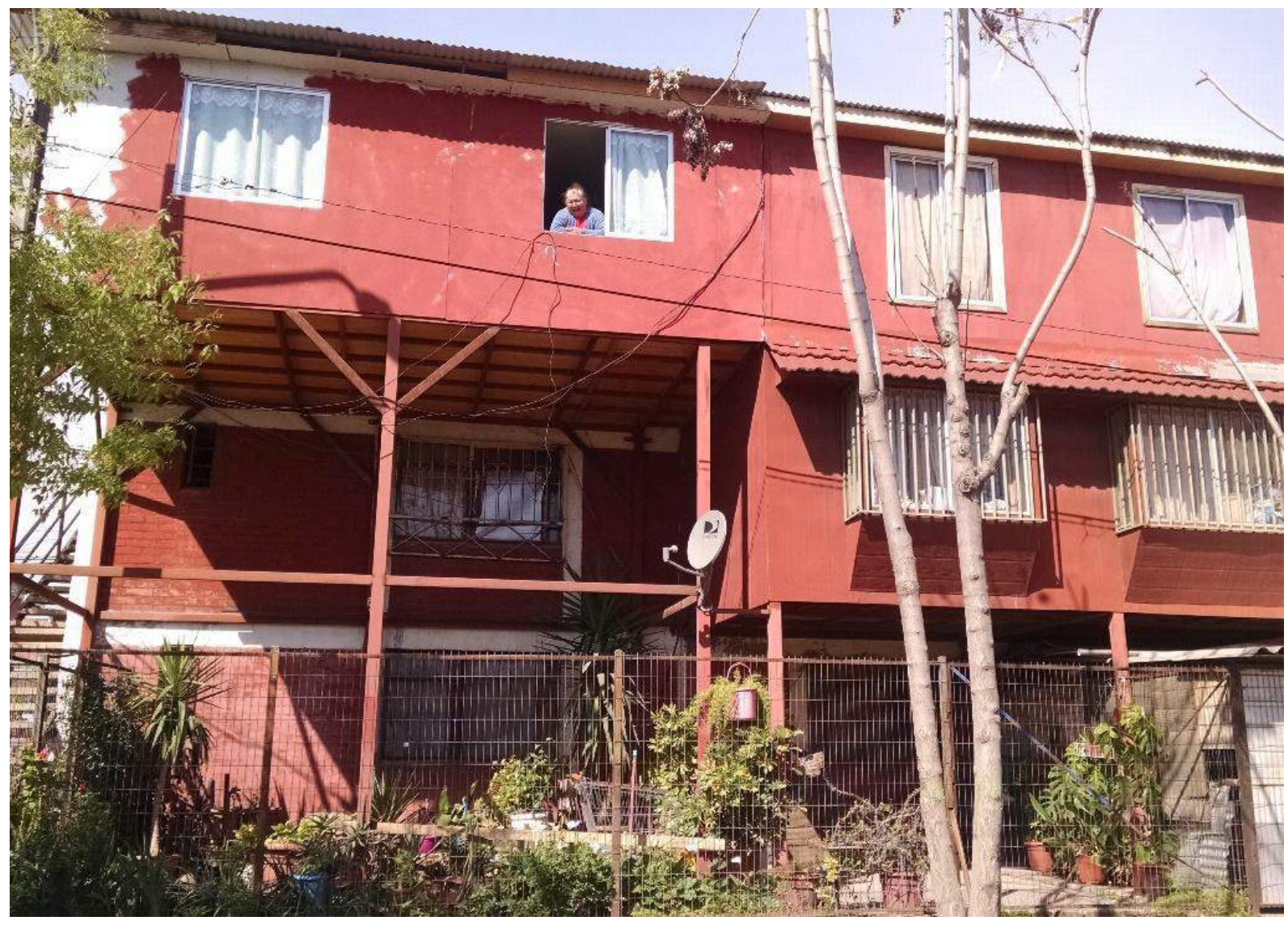

Figura 11: Expansões irregulares das unidades habitacionais já são parte da paisagem das comunas de menores recursos de Santiago. Fotografia de conjunto habitacional Los Quillayes, na comuna de La Florida. Fotografia da autora (2015).

Os exemplos mais recentes mostram unidades habitacionais cada vez menores, seja em lotes residenciais, seja em apartamentos, em ambos os países. Isso se deve a diversos fatores, como custo de produção e mesmo modus operandi de produção de habitação social, associando-se as habitações menores a menor poder aquisitivo. Porém, se existe a consciência de que as unidades são pequenas e não há possibilidade de fazer unidades maiores, dever-se-ia pensar as unidades e os espaços livres para que os moradores possam fazer a ampliação necessária de acordo com suas necessidades familiares, como já foi realizado no Chile pelo arquiteto Alexandre Aravena. Embora sejam casos específicos, com conjuntos habitacionais de poucas unidades, é exemplo das possibilidades que o projeto arquitetônico tem de aportar adequação às diferentes realidades das famílias.

Nos projetos de habitação social de Aravena, as ampliações são pensadas para que possam ser feitas de acordo com a necessidade de cada família, assim como ocorre com a personalização da fachada, que possibilita a identificação dos moradores com o conjunto e com sua unidade em particular, reconhecendo a individualidade e personalidade de cada grupo familiar. 


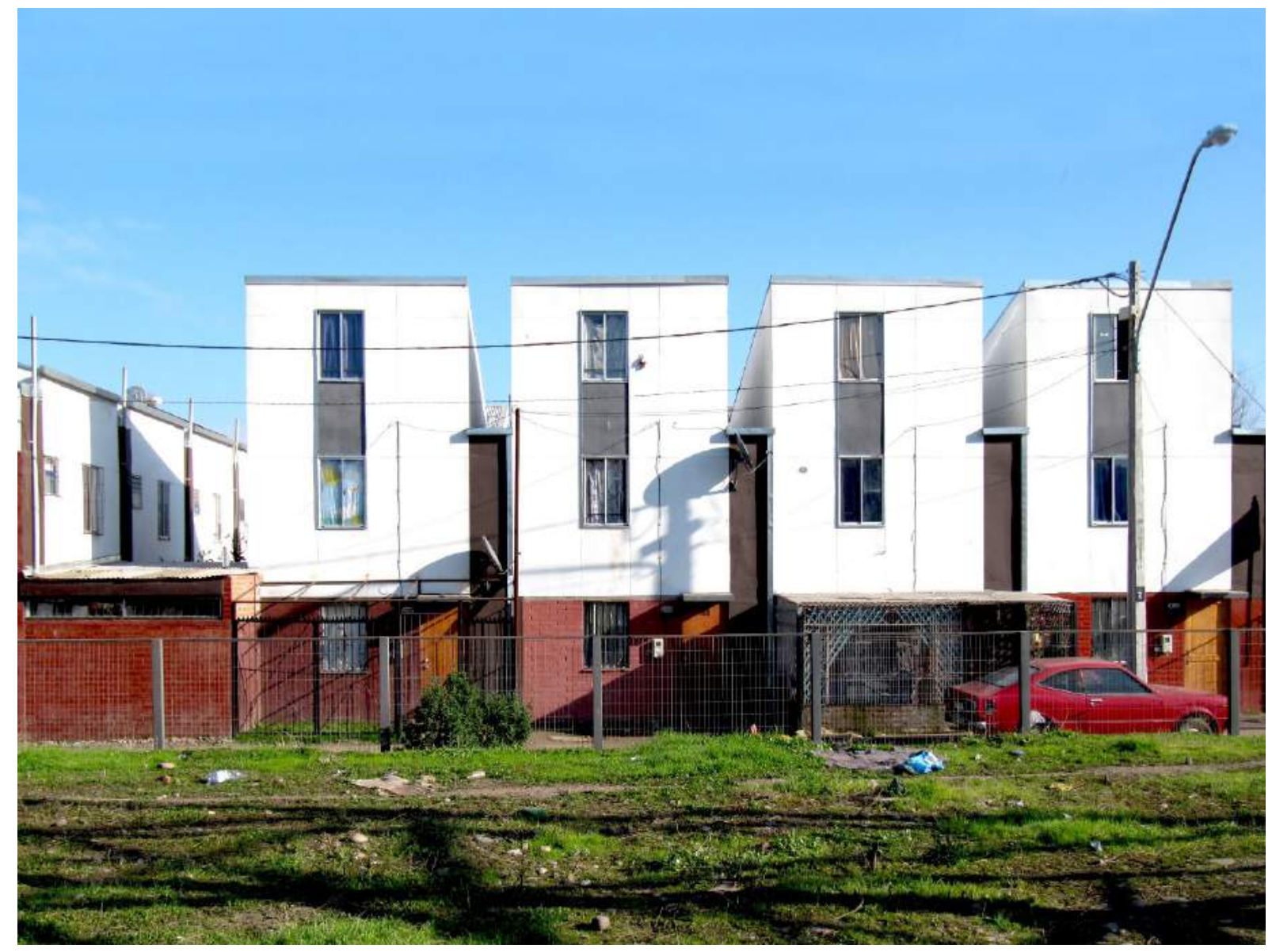

Figura 12: Projeto do Conjunto Pudahuel, do Escritório de Arquitetura Elemental, em Santiago do Chile. Fonte: Fotografia de Murilo Navarro (2010).

Pensar em soluções que tragam maior identidade dos usuários e maior adequação da unidade à necessidade de cada família é possível, porém isso é mais facilmente obtido em conjuntos habitacionais menores. É mais simples pensar na expansão da unidade em lotes individuais, mas não há impedimento técnico para a criação de apartamentos flexíveis, embora essas soluções possam ter custos maiores. Porém, o custo social da falta de identidade em conjuntos homogêneos é também considerável.

(...) La mano del arquitecto debe seguir de cerca el diseño preexistente y la construcción debiera facilitar la intervención de los residentes. (...) reconocer que cualquier proyecto residencial acarrea consigo una visión de mundo que no siempre se condice con sus destinatarios y que, como consecuencia de su aplicación, se derivan efectos indeseados (SKEWES, 2005, p. 122).

Sobre a densidade dos conjuntos habitacionais, os projetos convocados pelo Ministério de Vivienda y Urbanismo (MINVU) e construídos em terrenos particulares podem chegar a ter mais de duas mil habitações, com densidades superiores a 600 habitantes por hectare (RODRÍGUEZ; SUGRANYES, 2005). No caso do PMCMV, os conjuntos habitacionais também podem chegar a 
mais de mil habitações.

Muitas vezes, a continuidade de habitações sem espaços livres articulados não permite um cenário que estimule uma relação afetiva com o lugar. A importância do espaço livre no desenho urbano está justamente na possibilidade de articular elementos construídos, onde se inserem unidades habitacionais, condomínios de prédios, áreas comerciais ou de uso misto e equipamentos urbanos, entre outros, através da criação de praças, acessos, passeios, calçadas, escadas e vegetação, de maneira a estabelecer uma unidade visual para os usuários do espaço, que facilite a identificação com o entorno e estimule seu uso e apropriação.

No geral, o que se verifica é uma debilidade dos espaços livres nas áreas de habitação social, sendo tratados como resquícios, que não são relevantes para gerar uma identidade espacial positiva.

A relação da escala dos conjuntos é também essencial para a identificação. É possível estruturar grandes conjuntos habitacionais em torno de um desenho único que possibilite identidade espacial como, por exemplo, a partir da reunião de elementos construídos com espaços comuns menores que estruturem o todo. Porém, para isso, os espaços livres devem ser pensados em sua função social de convívio, circulação e apropriação, e exigências precisam ser feitas para que sejam projetados e construídos.

Os espaços livres estão diretamente associados ao contexto territorial e espacial que afeta a vida cotidiana de usuários de determinado espaço. Ignorá-los, tratá-los como sobras e não parametrizar exigências que qualifiquem o desenho urbano é não avançar na criação de espaços identitários.

\section{A (des)prática: limitações das práticas sociais}

O corpo técnico pode ser um instrumento para conduzir e garantir a hegemonia dos interesses da classe dominante (RIBEIRO, 2014), garantindo a reprodução da situação atual. Por isso, deve-se ter muita atenção nas orientações propostas e impostas, e no embate pouco consciente entre os valores culturais dos técnicos e dos grupos sociais envolvidos. Os interesses dominantes transformam negativamente a imagem do lugar de moradia do pobre num lugar desprovido de valor (RIBEIRO, $2013^{12}$ ) e sentido, ao mesmo tempo em que é provido de violência.

Como solução simples, mas equivocada, está a imposição de valores e modelos urbanísticos das classes médias e altas para classes baixas, aceitando-se acriticamente o comportamento das classes dominantes como manifestação bem-sucedida de civilização e urbanidade, sem investir na definição de estruturas espaciais que valorizem a experiência urbana do outro sem reproduzir nem modelos de áreas privilegiadas da cidade nem de áreas pobres.

Na maioria das sociedades parece haver um sistema principal ou geral de estratificação e em muitas sociedades estratificadas existe a idealização dos estratos superiores e uma certa aspiração, por parte dos que ocupam posições inferiores, de ascender às mais elevadas (Deve-se ter cuidado de compreender que isto implica não apenas no

12 Dimensões culturais da ilegalidade. Vol. 4, p.223-238. 
desejo de uma posição de prestígio, mas também no desejo de uma posição junto ao centro sagrado dos valores comuns da sociedade). (...). Talvez a peça mais importante do equipamento de sinais associado à classe social consista nos símbolos do status, mediantes os quais se exprime a riqueza material. (GOFFMAN, 1985, p. 41-2)

As diferenças entre a população não se resumem em desigualdades econômicas e sociais e no acesso à melhores condições materiais de vida. As diferenças também são resultado de níveis distintos de resistência social e aprendizado da história de luta herdada. Assim, nem sempre habitantes de um mesmo lugar experimentam uma temporalidade idêntica, pois desconhecem essas diferenças históricas que se reproduzem na prática social. Esse desconhecimento, ou mesmo esquecimento e negação, amplificam o risco de inclusão periférica e de resignação à segregação socioespacial.

Há um habitus social (BOURDIEU, 1989, 2001) que conduz a maneira de agir e de pensar o cotidiano. Essa conduta é regida por um código cultural hegemônico que é, muitas vezes, profundamente hierárquico e elitista (RIBEIRO, 2014). Com isso, a consciência crítica e política dos arquitetos e urbanistas é, muitas vezes inconscientemente, regida por uma codificação elitista, segundo a qual se imagina que uma parte da população deseja possuir aquilo que outras classes sociais possuem.

É a mesma relação entre o eu e o outro, quando o outro só é entendido dentro de um olhar para si mesmo. A dificuldade maior é se desconectar desse universo hegemônico que permeia a dialética do eu e do outro, permitindo que as ideias para o planejamento da paisagem sejam realizadas a partir de propostas novas e livres das amarras da codificação cultural dominante (RIBEIRO, 2014).

A esfera cotidiana é a mais próxima da vida social, e é nela que se esboça a possibilidade de ruptura da produção e da reprodução alienada. A associação do cotidiano à vida social o coloca em uma relação com a totalidade da estrutura social, que permite a sua percepção enquanto "cara oculta" (RIBEIRO, $2013^{13}$, p. 90) da vida social frente à estrutura de dominação.

O planejamento urbano tem uma força que pode alterar a dinâmica urbana e cultural de um determinado território, o que Bourdieu (1994, apud RIBEIRO, 2013 ${ }^{11}$ ) define como a Lógica lógica, que é o modo de pensar técnico, o qual pode se sobrepor e se subordinar à Lógica prática, aquela das práticas sociais cotidianas que permitem trocas simbólicas. Com isso, o capital social tem força para destruir o próprio capital social (RIBEIRO, 2013 ${ }^{14}$ ).

Para Ribeiro $\left(2013^{15}\right)$, alguns valores não podem deixar de ser fundamentados para a produção de conhecimento sobre o urbano, entre eles: o resgate da história e da singularidade das formações sociais latino-americanas; a leitura interdisciplinar da questão urbana; a inclusão de outros saberes e a valorização de contextos e lugares; a resistência à reprodução acrítica de paradigmas e modelos. Necessário também lembrar que a história da urbanização brasileira é diretamente relacionada à história da segregação socioespacial. O privilégio urbanístico das camadas de renda média e alta nas cidades brasileiras é carregado de herança histórica, que

13 Modernidade e risco nas metrópoles brasileiras. Vol. 2, p. 85-99.

14 O desenvolvimento local e a arte de "resolver" a vida. Vol.5, p. 75-89.

15 Declaração de Buenos Aires. Vol. 5, p. 171-177. 
agrupa interesses minoritários acima do coletivo.

A partir desse pensamento, Ribeiro $(2013)^{15}$ coloca que uma cidade justa será aquela em que se respeitam a identidade e a dignidade; em que se garanta igualdade de oportunidades; em que haja participação popular na criação de normativas sociais e políticas urbanas; em que se reconheça o uso dos espaços públicos para as práticas democráticas com livre expressão; em que coexistam as diferenças sem discriminação, marginalização e estigmatização; em que se promova a economia social com recursos públicos e distribuição equitativa de riqueza; em que se reconheça o valor de uso do espaço urbano acima do seu valor de mercado; em que se permita a expressão espontânea e livre das pessoas na sua experiência urbana.

Considerando os itens comentados de categorias para qualificar as análises das habitações sociais, e retomando a limitação do campo arquitetônico, cuja definição de espaços não supera a fragmentação invisível das práticas sociais nem a subjetividade presente no processo, retoma-se a noção da (des)prática, das limitações das práticas sociais.

A pouca ou nenhuma participação social no desenho de políticas públicas e na definição das necessidades dos grupos sociais, o controle por poucos líderes comunitários, a imposição de modelos urbanísticos e de gestão, a inserção urbana em contextos de vulnerabilidade social, econômica e cultural, a pouca relação entre o espaço interno da habitação e o espaço público e, mesmo, coletivo, fazem com que as práticas sociais fiquem, também, (des)praticadas, ou seja, limitadas e incompletas.

O quadro complexo do cotidiano em habitação social, com diferentes tipos de sofrimento, como isolamento, inclusão periférica, solidão, paranoias, compulsões de poder por grupos e líderes, e os permanentes sentimentos de estranhamento, insegurança e violência, têm relação com o ambiente urbano criado. O crescimento de violência urbana, da hostilidade entre grupos e do receio no uso do espaço público não é derivado apenas de desigualdade social, mas, principalmente, da sua administração (DUNKER, 2015), o que é um tema de responsabilidade pública. 


\section{- Introdução}

Para a análise da habitação social proposta nesta tese, considera-se o contexto das experiências que marcaram as políticas habitacionais no Brasil e no Chile, e que resultaram na conjuntura atual, salientando-se a elaboração de políticas atentas - ou não - às práticas sociais.

Em relação às experiências brasileira e chilena, alguns pontos de intersecção são comuns, destacando-se: as experiências anteriores ao período militar, singelas e relacionadas ao início do período de maior crescimento urbano; as grandes produções do governo militar, com a construção de conjuntos habitacionais em áreas periféricas; a retomada da democracia, com cisão - no caso brasileiro -, e manutenção - no caso chileno - da estrutura da política habitacional criada no período militar; e o momento atual, com novos programas nas políticas habitacionais, mas que ainda não tem conseguido alterar o modelo de produção de habitação social em nenhum dos países, mantendo resultados que não atendem aos parâmetros qualitativos elaborados no capítulo 1.

Baseando-se principalmente nos trabalhos de Bonduki (2011 e 2014) e Greene (2004), dividem-se as políticas habitacionais brasileiras e chilenas em quatro principais períodos:

10 - Anterior a 1964: Nesse período, em ambos os países, as iniciativas relativas às políticas habitacionais buscaram atender a um momento de maior demanda por conta do crescimento urbano e do aumento da produção de habitações informais. No Chile, destaca-se a criação da Corporación de la Vivienda (CORVI), o primeiro programa de erradicação de ocupações irregulares. No Brasil, destacam-se a construção de vilas para operários e a atuação dos IAPs (Institutos de Aposentadoria e Pensões).

20 - De 1964 a 1990: No Brasil, esse período corresponde à época da ditadura militar (1964 a 1985) e aos primeiros anos de retorno à democracia. Durante a ditadura brasileira, destaca-se a criação do Banco Nacional de Habitação (BNH) e do Sistema de Financiamento Habitacional (SFH). No Chile, esse período corresponde aos governos de Eduardo Frei (1964-1970), de Salvador Allende (1970-1973) e do general Augusto Pinochet (1973-1990), destacando-se a criação do Ministerio de Vivienda y Urbanismo (MINVU) e do Servicio de Vivienda y Urbanización (SERVIU), além do estímulo neoliberal durante o governo militar, com iniciativa privada atuando na produção de habitação social. Em 1983, foi criado o Programa Mejoramiento de Barrios, que atua no Chile até hoje. Em ambos os países, se iniciavam as principais ações governamentais para solucionar a crescente demanda por habitação social. Tanto no Chile quanto no Brasil, essa produção foi marcada por ênfase quantitativa, buscando-se suprir a enorme demanda de unidades habitacionais devido ao crescimento urbano intenso, embora tenha resultado numa produção qualitativamente débil e urbanisticamente frágil.

30 - De 1990 a 2000: No Brasil, o início dos anos 1990 corresponde ao período de redemocratização, marcado pela crise do sistema de financiamento criado no período militar, que levou ao fim do BNH e à descentralização da política habitacional, com importantes, porém pontuais, projetos de participação popular, que incluem programas de urbanização de favelas e construções por mutirão, dentre outros, desvinculados de uma política nacional e associados à iniciativa de municípios. No Chile, o período corresponde ao fim da ditadura militar e ao iní- 
cio dos governos Concertación de Aylwin (1990-1994) e Frei (1994-2000). Diferentemente do caso brasileiro, no Chile, a estrutura política criada no governo militar para a produção de habitação social se manteve durante os governos democráticos, embora aprimorada por novos programas e por alterações em outros já existentes. Destacam-se a continuidade do Programa Mejoramientos de Barrios; a criação do Programa Vivienda Progresiva, no governo Aylwin; a criação do Programa Chile Barrio no final do governo Frei.

40 - De 2000 a 2010: A política habitacional chilena dos anos 2000 a 2010 foi marcada tanto pela continuidade de alguns programas criados no período anterior, como o Programa Chile Barrio, quanto pela criação de outros, como o Programa Vivienda Social Dinámica sin Deuda y Fondos Concursables no governo Lagos (2000-2006). O início do governo de Michelle Bachelet (2006-2010) representou a continuidade das ações criadas pelo governo Lagos. A ênfase na participação, na ampliação das políticas de melhoramento de bairros e na negociação de dívidas adquiridas com aquisição de casa própria são destaques desse período. No Brasil, destaca-se o restabelecimento de uma Política Nacional de Habitação, com a criação de diversos órgãos, planos e programas, como o Ministério das Cidades, o Plano Nacional de Habitação (PlanHab), o Programa de Aceleração do Crescimento (PAC), o Programa Minha Casa Minha Vida (PMCMV) e o Estatuto da Cidade. Apesar do grande número de instrumentos e normativas, a produção desse período, principalmente a partir de 2008, é similar ao período BNH: grande número de unidades produzidas, mas de qualidade e inserção urbana questionáveis. Também chama a atenção a inserção da iniciativa privada na produção de habitações sociais, seguindo um modelo de política habitacional que guarda semelhanças com a política vigente no Chile, sem, porém, considerar os melhoramentos realizados nos anos de política habitacional social chilena sob a iniciativa privada.

De modo a familiarizar o leitor com os contextos de ambos os países, serão apresentados neste capítulo aspectos relevantes do histórico das políticas brasileira e chilena, considerando-se esses períodos de análise.

\section{- Antecedentes às ditaduras militares}

Pode-se dizer que, tanto no Brasil quanto no Chile, os anos de 1964 e 1965 foram caracterizados por importantes iniciativas que marcaram a constituição da política habitacional de cada país.

No caso brasileiro, o ano de 1964 foi marcado pelo início do regime militar e pelas primeiras grandes intervenções em termos de políticas habitacionais. Antes do período militar, a atuação do Estado para a produção de habitações sociais foi singela, marcada por uma política higienista praticada pelo setor privado de construção de habitações (BONDUKI, 2011) e pela atuação dos IAPs - Institutos de Aposentadoria e Pensões. Embora pouco expressiva, essa produção foi incentivada por um maior crescimento urbano nos anos 1930 e 1940 (CARDOSO; ARAGÃO, 2012).

No Brasil, as primeiras experiências para habitação foram as vilas operárias, construídas por companhias privadas. Foram os primeiros conjuntos urbanos de produção seriada de unida- 
des habitacionais (BONDUKI, 2014). Interessante perceber que muitas vilas não continham somente moradias, apresentando também equipamentos sociais e coletivos, tais como igrejas, escolas, pequenos comércios, entre outros, que buscavam garantir controle dos operários, introduzindo hábitos de acordo com a ideologia do empresário. Segundo Bonduki (2014),

A implantação de equipamentos sociais junto às moradias teve um papel relevante no âmbito da trajetória das ações habitacionais no país por introduzir a ideia de que o núcleo residencial não devia ser constituído apenas por unidades habitacionais, mas requeria uma gama de serviços coletivos a serem prestados para os moradores, requisito que até hoje não tem sido atendido nos projetos. (p. 21)

Até 1930, a construção de habitações ocorria por iniciativa de particulares, muitas vezes sob o controle da burguesia cafeeira, embora a produção de habitações pelo Estado já estivesse sendo debatida em algumas instituições públicas. A construção de vilas era vista como uma alternativa salubre e também uma tentativa do Estado em mostrar ações populares, tendo sido, naquele momento, adotada em diversas regiões do Brasil.

A presença de equipamentos sociais trazia melhor qualidade às moradias nas vilas, porém os hábitos controlados e o excesso de imposições ideológicas faziam delas um ambiente conservador, dominado e isolado, que comprometia a liberdade dos operários.

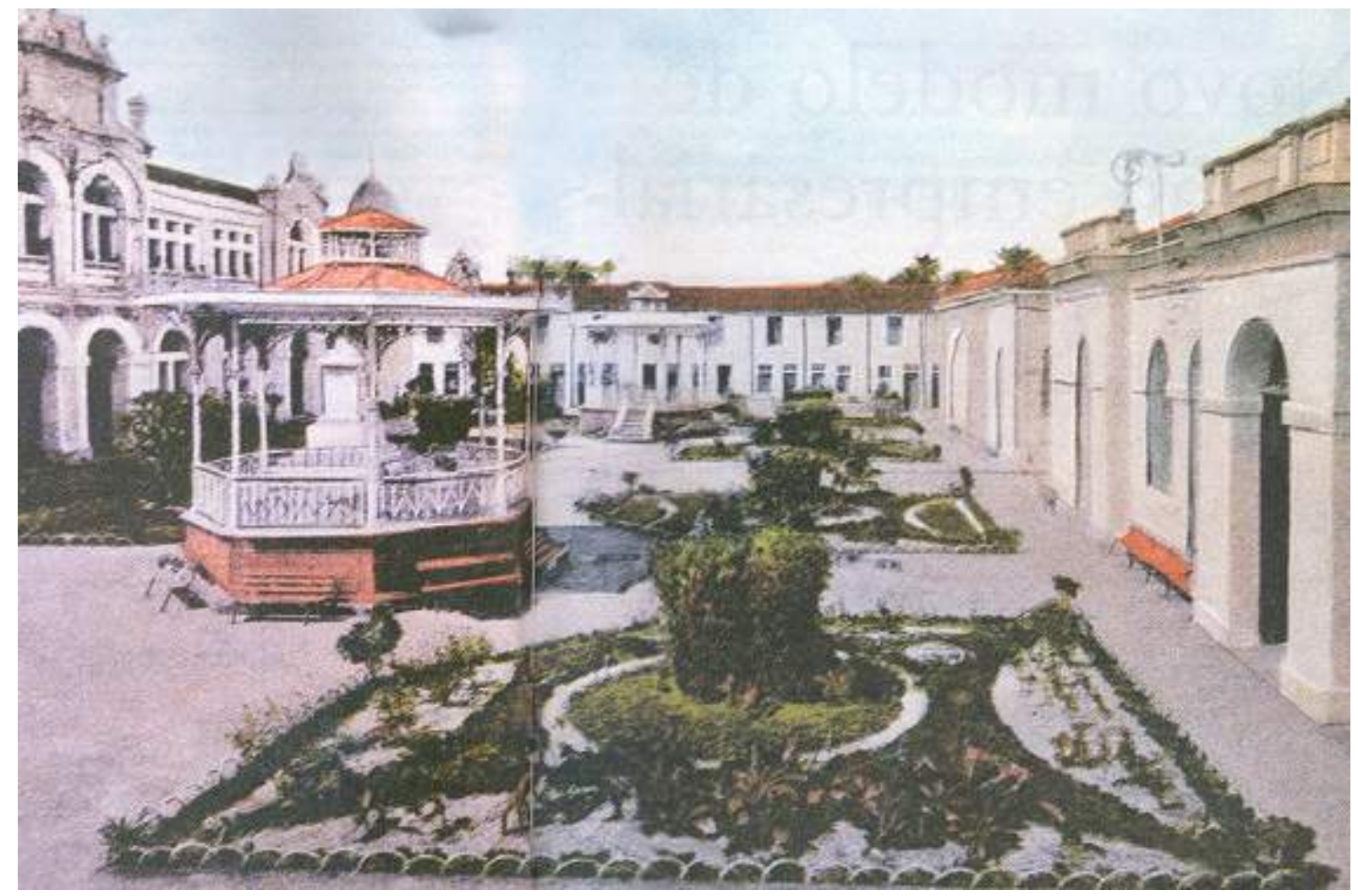

Figura 14: Vila Luís Tarquínio, edificada no final do século XIX no Bairro de Boa Viagem, em Salvador, pelo empresário Luís Tarquínio, fundador do Empório Industrial do Norte. (BONDUKI, 2014). Fonte: <http://www.usp.br/pioneiros/zp/index.php?album=volume3\%2F02Tarquinio\&image=Vila+Oper\%E1ria+07.jpg>. Visualizado em 02 nov. 2014. 


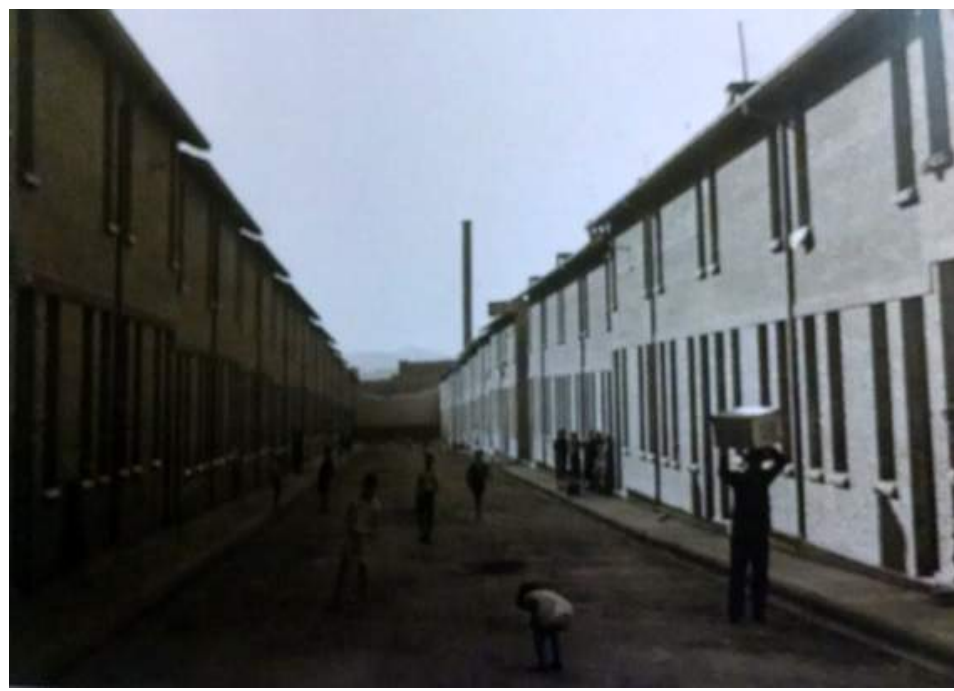

Figura 15: Vila Matarazzo, em São Paulo. Casas geminadas e espaços coletivos sem equipamento. Fonte: BONDUKI, 2014, p. 26. áreas livres dos cortiços, quando existentes, eram utilizadas coletivamente para atividades do dia a dia, como secagem de roupas, devido à falta de espaço interno nas unidades.

\begin{abstract}
Muitos trabalhadores, entretanto, não tinham renda para pagar o aluguel em uma dessas vilas. Surgia, assim, uma gradação descendente das vilas operárias mais sofisticadas, com sobrados ornamentados à moda acadêmica, aos cortiços mais precários, refletindo a escala social - da classe média ao trabalhador com pior remuneração, informal ou desempregado. Entre a solução mais sofisticada e a mais precária, havia uma infinidade de intermediárias, de diferentes tipos, qualidades e preços. (BONDUKI, 2014, p. 27)
\end{abstract}

No caso chileno, o ano de 1965 é marcado pelas principais ações do Estado em relação aos problemas habitacionais, com a criação do Ministerio de Vivienda y Urbanismo, o MINVU (TAPIA ZARRICUETA, 2011). O Ministerio coordena as políticas sociais chilenas e, para a coordenação em nível regional, foi criado o Servicios de Vivienda y Urbanización (SERVIU), uma entidade que administra os diversos programas habitacionais criados e modificados ao longo das administrações presidenciais. Antes da criação do ministério, houve momentos importantes e marcantes para a experiência habitacional chilena, mas foi a partir da criação do MINVU que as políticas foram coordenadas em nível nacional e regional.

As primeiras experiências chilenas começaram após o terremoto devastador em Valparaíso em 1906, quando foram instituídas as primeiras leis higienistas para regular a construção de habitações para operários. Posteriormente, foram implementados programas habitacionais para responder ao crescente déficit habitacional, de maneira que os enfoques ideológicos e econômicos nos governos que se seguiram foram diversos, até serem drasticamente modificados durante o período da ditadura militar chilena e a implantação do modelo neoliberal, o que ocorreu a partir de 1975.

Nos anos 1950, no governo de Carlos Ibánez del Campo (1952-1958), formulou-se o Plan de 
Vivienda e criaram-se instituições para desenvolvê-lo, destacando-se a criação da Corporación de la Vivienda (CORVI), instituição de responsabilidade do Estado incumbida por fomentar e executar a construção de bairros e conjuntos de habitação social (OPAZO, 2014), a qual substituiu a Caja de Habitación, que atuou de 1936 a 1953. Exemplo de criação desse período é a población Miguel Dávila (figura 16), que marca a transição da Caja para a CORVI.

Contudo, o intenso processo de urbanização no Chile dos anos 1950 e 1960, e principalmente na Área Metropolitana de Santiago, fizeram com que as soluções apresentadas naquele período não fossem suficientes para atender à demanda. Nesse período, acelera-se a ocupação ilegal do solo urbano, tanto devido ao crescimento populacional quanto aos movimentos migratórios com destino à capital do país. Para controlar a ocupação do solo urbano e a expansão descontrolada, foi criado, nos anos 1960, o Plan Regulador Intercomunal de Santiago.

Durante o governo de Eduardo Frei Montalva (1964-1970), implementou-se a Operación Sitio, formada por um programa estatal de crédito para a aquisição de lotes urbanos unifamiliares, com serviços e equipamentos básicos. Com a Operación, foram entregues entre 70.000 e 110.000 soluções em todo o país (GREENE, 2004).

Durante o governo de Salvador Allende (19701973), a Operación Sitio não teve continuidade. Assim, naquela época, acentuou-se o crescimento periférico com habitações informais, com muitas ocupações de terrenos, o que foi

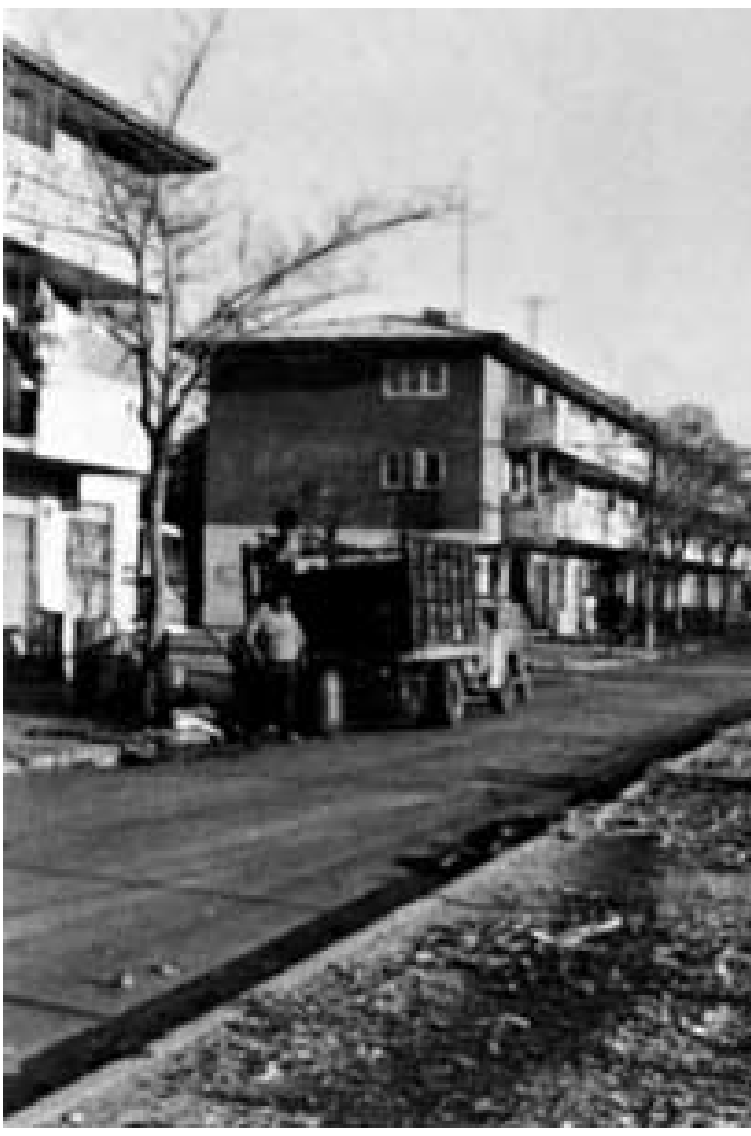

Figura 16: Población Miguel Dávila, na comuna San Miguel, em Santiago, realizada no ano 1956. Fonte: MINVU; DITEC, 2004, p. 110. abruptamente interrompido com o governo militar (GREENE, 2004).

\section{- Período das ditaduras militares}

Apesar de existirem ações estatais para equacionar os problemas de crescimento urbano, como no caso de Santiago, as grandes ações em relação às políticas habitacionais ocorreram de fato durante o governo do General Augusto Pinochet (1973 a 1990), com uma primeira grande mudança: a participação da iniciativa privada no provimento da habitação social.

Essa participação não ocorreu somente na política habitacional, mas também em diversas frentes em que a ação do Estado tinha grande peso: saúde e educação também passaram por 
grandes modificações, fruto da política neoliberal e do ideário de diminuição do gasto público e de aumento da eficiência do Estado.

A finales de la década de los setenta, el diagnóstico del gobierno en materia de vivienda señalaba que el problema de la vivienda en las clases más pobres consistía en un desajuste entre el mercado inmobiliario y las necesidades de este grupo. La causa principal era el bajo poder adquisitivo de esta población, que no le permitía acceder a una vivienda por sus propios medios. (OPAZO, 2014, p. 17-8)

Com isso, a nova política de habitação social chilena passa a ser desenhada nos anos 1970, retirando-se das mãos do Estado a tarefa de construir as habitações e transferindo-a para a iniciativa privada. O Estado, dessa forma, passa a ter a função de intermediar a relação entre mercado e famílias candidatas às habitações sociais (devidamente pontuadas em relação à sua condição de pobreza, para serem selecionadas conforme montantes distintos de subsídio), abrindo licitações para a contratação de particulares para a construção das habitações sociais, que, por sua vez, seriam subsidiadas pelo Estado. Para levar a cabo essa política, foi criado o SERVIU, responsável por materializar os planos e programas desenhados pelo Ministerio de Vivienda y Urbanismo (OPAZO, 2014).

Por el lado de la oferta, las empresas privadas que entraban a competir con sus proyectos de viviendas sociales debían satisfacer dos requerimientos para poder participar en las licitaciones: debían tener reservas de tierra que estuvieran dentro de los presupuestos de la política de vivienda y debían poseer un fondo financiero suficiente que sirviera de garantía del proyecto ofrecido y obligara al cumplimiento del contrato. (OPAZO, 2014, p. 18)

A primeira ação fomentada pela política foi um programa conhecido como Erradicación de Campamentos (OPAZO, 2014), ou seja, de erradicação de assentamentos ilegais, o que também se relacionava ao interesse militar em eliminar organizações sociais populares, diretamente associadas pelo governo aos movimentos comunistas (figuras 17 e 18).

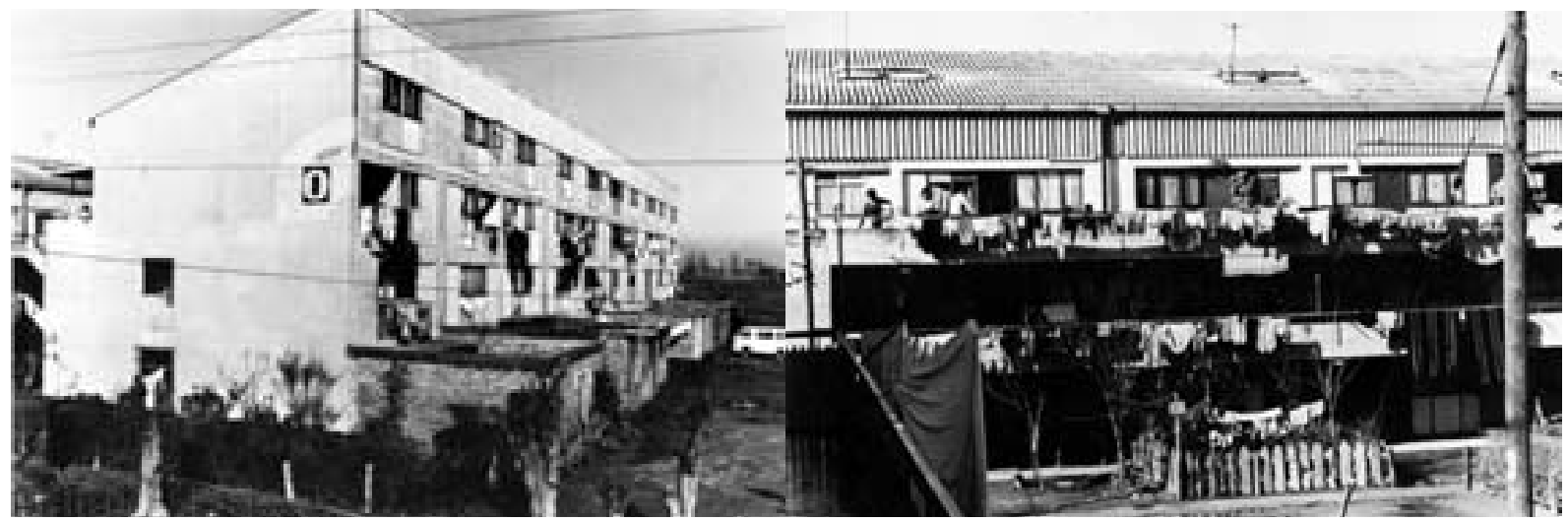

Figuras 17 e 18: Población Santa Anita, construída nos anos 1980 na comuna Lo Prado. Esse conjunto foi realizado para a erradicação de habitações irregulares principalmente da ocupação Che Guevara. São 880 habitações, cujas varandas são utilizadas tanto para circulação exterior e acesso aos apartamentos como também como espaço de serviço, onde as famílias penduram roupas e se encontram socialmente. Fonte: MINVU; DITEC, 2004, p. 176-7. 


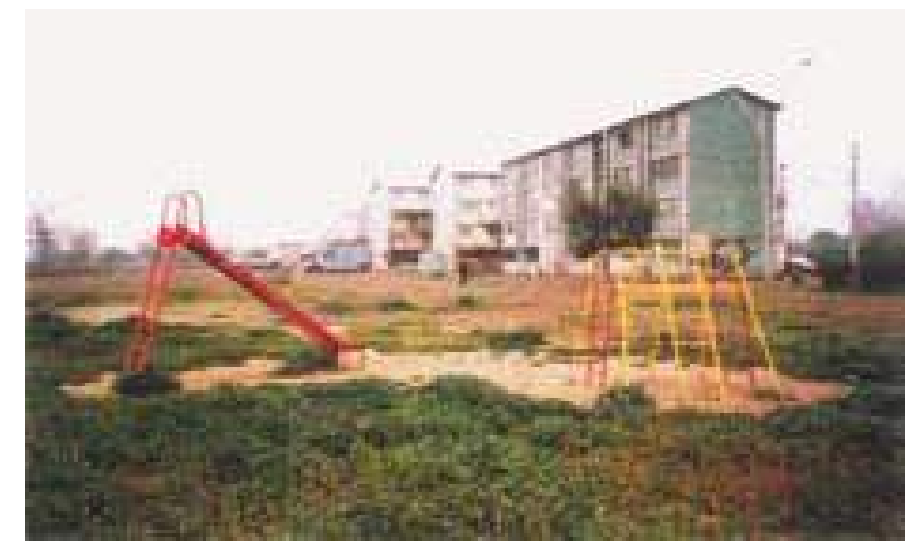

Figura 19: Población Marta Colvin, na comuna de Recoleta, construída durante o governo militar. Fonte: SEPÚLVEDA, 2001, apud MINVU; DITEC, 2004, p. 217.
Interessante ressaltar também que a política elaborada pelo governo Pinochet também foi acompanhada por uma política urbana, a Política de Desarrollo Urbano, de 1979, que aumentou a possibilidade de se construir indiscriminadamente em áreas urbanas periféricas a partir da flexibilização da alteração de solo agrícola para urbano, entre outros fatores.

No caso da ditadura militar no Brasil (1964 a 1985), para resolver a questão das habitações, decidiu-se centralizar a política no Estado e elaborar um siste-

ma de financiamento para a produção de moradias populares, alocado pelo Banco Nacional de Habitação (BNH) e viabilizado pelo Sistema de Financiamento Habitacional (SFH).

Segundo Bonduki (2011), esse período marca, de fato, a origem das políticas habitacionais no Brasil, com recursos de financiamento habitacional direcionados aos trabalhadores urbanos formais, o que significou, por outro lado, que os trabalhadores ligados à informalidade do mercado de trabalho não tiveram reconhecido o direito de aquisição de habitações (nem Ihes foi oferecida tal possibilidade), o que acabou por aumentar a produção informal de moradias.

A partir de 1980, após um longo processo de crescimento econômico (1940-1980) ${ }^{16}$, a economia brasileira entra em declínio, pressionada pela crise fiscal (MARICATO, 2013), bem no momento em que os movimentos sociais e operários intensificavam a luta contra o governo ditatorial, elaborando as bases para mudanças políticas com propostas programáticas.

Dessa forma, novos partidos políticos foram criados na década de 1980, como o PT (Partido dos Trabalhadores), enquanto outros saíram da clandestinidade, como o PC do B (Partido Comunista do Brasil) e o PCB (Partido Comunista Brasileiro). Além dos partidos políticos, novos movimentos sociais urbanos surgiram, recuperando as propostas sociais elaboradas na década de 1960, no contexto das lutas revolucionárias latino-americanas (MARICATO, 2013).

No cenário político e urbano brasileiro da década de 1980, estavam presentes mobilizações sociais, sindicatos e partidos políticos; na produção acadêmica, pesquisadores desvendavam a cidade real e a construção simbólica e ideológica; nos governos municipais, novas agendas com programas sociais eram experimentadas, principalmente nos municípios onde haviam eleições diretas para prefeito (MARICATO, 2013).

A produção habitacional durante o regime militar brasileiro foi intensa: foram construídas 4,3 milhões de unidades habitacionais (BONDUKI, 2009a). Apesar desse número expressivo, a pro-

16 Em quarenta anos, o crescimento do PIB se manteve em cerca de 7\% em média ao ano, entrando em queda a partir de 1980. Sobre as causas da desaceleração econômica do Brasil, sugere-se a leitura do trabalho de BACHA e BONELLI (2005). 
dução não satisfez o déficit habitacional, de maneira que houve, novamente, outro período de crescimento das habitações informais em áreas rejeitadas pelo mercado, sendo grande parte delas em áreas de risco e produção ambiental, com moradias construídas sem nenhum apoio técnico ou financeiro do governo (BONDUKI, 2011).

Além de não atender ao déficit, a produção massiva realizada por meio do BNH foi também pobre, no sentido da qualidade das habitações fornecidas à população (figuras 20 e 21). Com o foco nitidamente voltado para a quantidade e não para a qualidade das construções, grande parte das habitações entregues não se adequavam às necessidades individuais das famílias, dificultando a apropriação dos espaços de uso comum. Assim, a produção do período BNH não atendeu à demanda da população.

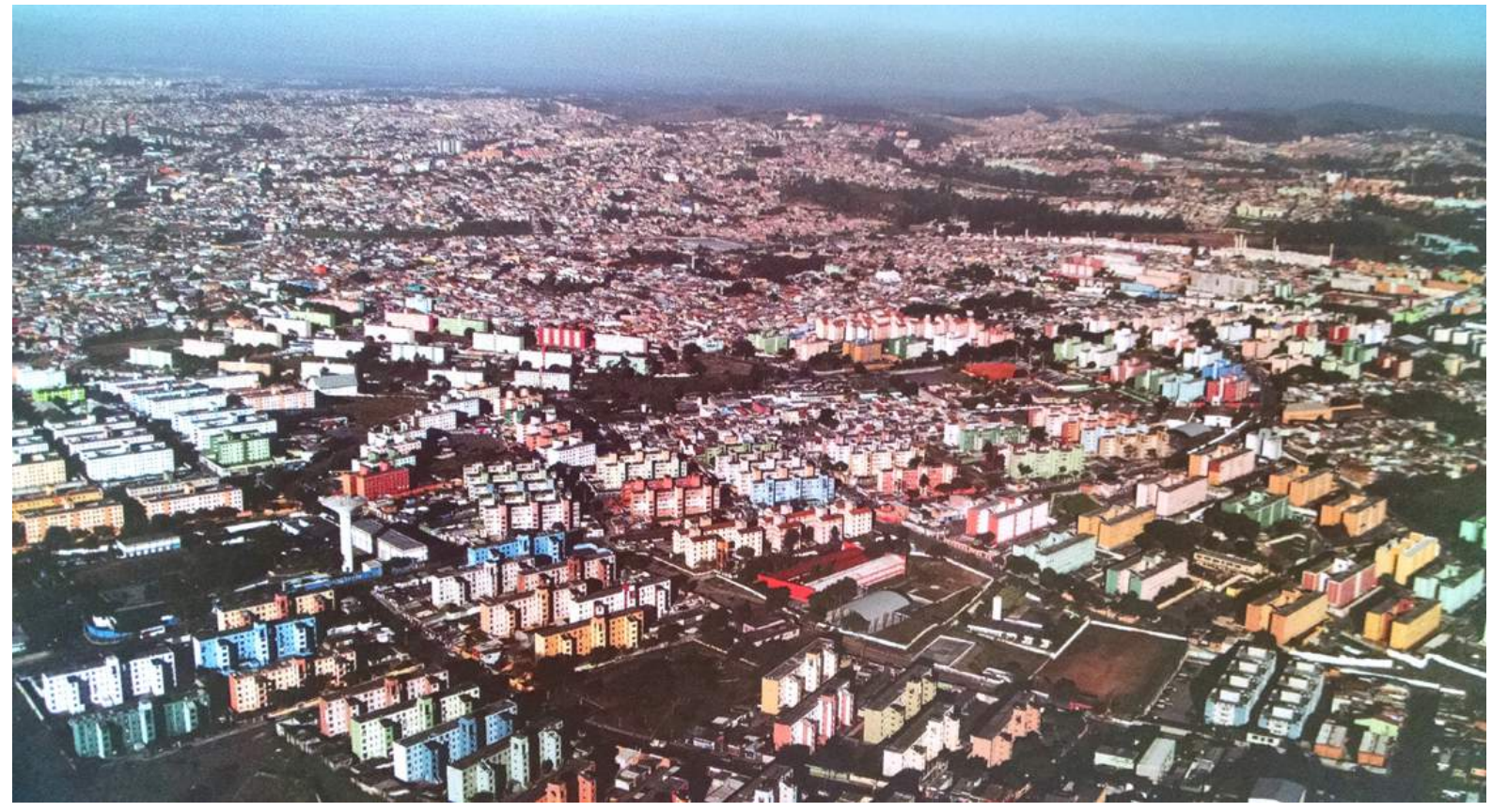

Figura 20: Conjuntos habitacionais financiados pelo BNH na Zona Leste de São Paulo-SP. Fonte: Bonduki, 2014, p. 66-7.

Isso gerou, tanto na comunidade acadêmica quanto na população em geral, uma péssima imagem da política pública praticada pelo $\mathrm{BNH}$, com a produção, em áreas periféricas das cidades, de gigantescos condomínios de prédios idênticos, que não apresentavam quaisquer equipamentos ou qualidade nas áreas livres e que se repetiam como estampa por todo o país.

Essa produção do período BNH pretendia apresentar resultados baseados na arquitetura modernista da Carta de Atenas ${ }^{17}$, de acordo com a qual a unidade do lote deveria ser extinta, e

17 A Carta de Atenas foi elaborada durante no IV Congresso Internacional de Arquitetura Moderna (CIAM), reunindo o resultado das proposições do modelo urbanístico moderno racionalista, como o zoneamento funcional e os conjuntos habitacionais, com ênfase na preocupação habitacional, incorporando contribuições de propostas desde o socialismo utópico até as da Bauhaus. Foram organizadas e anonimamente publicadas por Le Corbusier em 1941, sob o título de "A Carta de Atenas", com acréscimo de suas reflexões. Outras versões foram, posteriormente, publicadas, mas a principal referência da Carta de Atenas é a ata das conclusões do IV Congresso. 
as ruas e massas vegetais adquiririam novos significados dentro de uma nova composição que organizaria os edifícios livremente em grandes superfícies. Nessa concepção, os espaços livres são grandes protagonistas no resultado formal da composição, pois predominam em relação aos espaços construídos e são responsáveis pela conexão entre os volumes edificados, além de não terem restrição de acesso e serem pensados para o uso coletivo (BENVENGA, 2011). No entanto, as construções oferecidas pelo BNH acabaram por não adotar todos os princípios modernos, o que resultou em uma proliferação de conjuntos habitacionais pouco funcionais e inadequados.

Quando esse ideário foi aplicado em conjuntos habitacionais populares realizados pelo BNH, muitas falhas ocorreram, já que a realidade socioespacial brasileira é bem distinta da descrita na Carta de Atenas. Para que o modelo modernista preconizado por ela fosse aplicado no caso brasileiro, deveriam ter sido pensadas adaptações, as quais, por sua vez, não foram nem idealizadas, nem realizadas.

(...) a perda do conceito urbanístico de agrupamento dos prédios, em unidades de vizinhança com porte delimitado, equipamentos de lazer e comércio destinado a um grupo específico de moradores e outras simplificações, como a inexistência do espaço dos pilotis, sob os blocos, teve consequências negativas na percepção do espaço pelos moradores e sua apropriação, como espaço urbano de qualidade (...). (BENVENGA, 2011, p. 68)

A simplificação da planta e repetição dos blocos de edifícios sem grandes critérios causou alteração negativa na aplicação do ideário modernista para a produção popular. Mas um dos aspectos que mais empobreceu as propostas foi a falta de projeto para as áreas livres, em geral deixadas como resquícios dos volumes edificados e não como parte integrante da conexão entre os volumes, muito menos enquanto área para sociabilização da comunidade (figura 21).

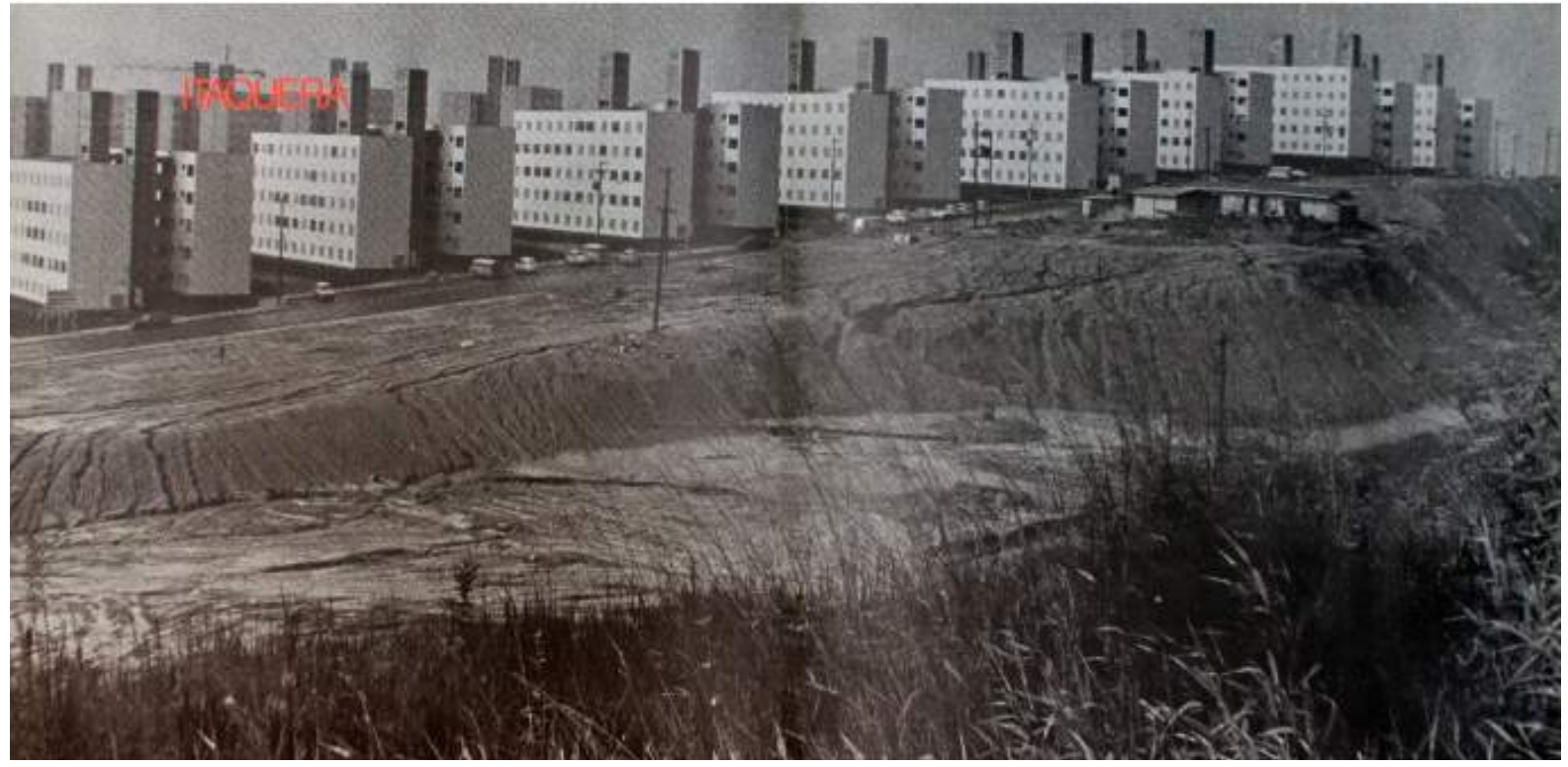

Figura 21: Conjunto Habitacional realizado pela Cohab/SP e BNH, em Itaquera, nos anos 1970. Fonte: Prefeitura Municipal de São Paulo (1979, apud RAMALHOSO, 2013 p. 102). 
No caso dos conjuntos do BNH, houve uma produção em série do padrão, o que gerou grande repetição de edificações (em blocos de apartamentos de poucos pavimentos ou em casas geminadas térreas ou assobradadas), que abrigaram, em grandes áreas, uma monofuncionalidade totalmente distinta da realidade urbana das famílias que foram deslocadas para esses conjuntos. Com isso, não houve, por parte da população, apropriação e interesse em manter as áreas livres comuns dos conjuntos (as quais deveriam ser um grande ponto positivo dos projetos), resultando em depredações e/ou ocupações particulares dessas áreas livres, o que será mais detalhado no capítulo 5. Obviamente, parte dessas apropriações deriva da falta de espaço dentro das unidades habitacionais, em grande parte inadequadas para o tamanho das famílias que passaram a habitá-las.

Os espaços livres desses conjuntos verticais eram sempre espaços coletivos, não compartimentados e não distintos, isto é, espaços livres abundantes de domínio público, não hierarquizados e residuais da implantação dos edifícios. Outra característica desses espaços livres era a falta de definição e proposição de usos e de tratamento paisagístico específico. (BENVENGA, 2011, p. 55)

As críticas ao modelo BNH são diversas, principalmente pelos resultados formais que se concretizaram horrivelmente por todo o país. No entanto, em termos de política habitacional, há que se verificar seu lado positivo, visto ter feito parte de uma consistente estratégia enquanto Política Nacional de Habitação o que, até então, inexistia no Brasil. Segundo Bonduki (2009a),

Con el fin del $\mathrm{BNH}$, se perdió una estructura de carácter nacional que, bien o mal, había acumulado una enorme experiencia en el área, formado técnicos y financiado la mayor producción habitacional de la historia del país. La política de vivienda del régimen militar podía ser equivocada, como ya resaltamos, pero estaba articulada y era coherente. En la redemocratización, en vez de una transformación, tuvo lugar un vaciado de competencias y se puede decir que dejó de existir propiamente una política nacional de vivienda. (p. 101)

Assim, tanto no caso brasileiro quanto no chileno, as políticas habitacionais desenvolvidas durante os governos militares obtiveram avanços na quantidade de habitações construídas, ainda que tivessem sido realizadas por meio de um massacre social e cultural. No caso chileno, o governo de Pinochet foi marcado por estratégias autoritárias de controle, as quais, visando à pacificação dos movimentos populares localizados principalmente em regiões periféricas, foram responsáveis por danos sociais inestimáveis.

Em ambos os países, a intensa atividade de construção civil durante os regimes autoritários foi uma estratégia para dinamizar a economia, o que foi feito, no Brasil, a partir da disponibilização de uma parte do fundo público originalmente destinado para a construção de habitações.

Segundo Bonduki (2009a), o papel econômico da política habitacional do BNH foi o que ganhou mais força, pois as reivindicações por moradia contemplaram principalmente aqueles que puderam pagar o crédito concedido, o que não foi o caso da grande maioria das famílias sem moradia.

No Brasil, como nos demais países periféricos, os conflitos em torno da provisão da moradia foram relativamente esvaziados graças a um ardil responsável por grande impacto social e territorial: a provisão informal da moradia. A maior parte da população 
urbana "se vira" para garantir moradia e um pedaço de cidade, combinando o loteamento irregular ou a pura e simples invasão de terra, com autoconstrução. (MARICATO, 2009, p. 42)

A produção de habitações sociais durante os períodos militares de ambos os países é responsável, desse modo, por marcas históricas nas políticas habitacionais: maior centralização da política pelo Estado e criação de estratégias de financiamento dessas habitações, seja através da criação de um fundo, como é o caso brasileiro, seja através da iniciativa de particulares, como é o caso chileno.

Os vestígios dos períodos militares são tanto visíveis quanto invisíveis. São visíveis no que diz respeito à criação de um modelo de desenho urbano para habitações sociais, utilizado até hoje (ainda que amplamente criticado) e que já faz parte de um "modo de construir" habitação social (a ser apresentado no capítulo 5), sem vislumbrar espaços com maior qualidade urbana devido ao histórico de produção muito aquém de critérios qualitativos.

De maneira invisível, as marcas do período militar são derivadas dos anos de opressão com intensa violência política e perseguição aos movimentos populares. Isso ocorreu na grande maioria dos países da América do Sul, com incentivo do governo dos Estados Unidos, sob pretexto de combate ao comunismo. Contudo, a política habitacional desenvolvida pelo governo Pinochet e a constante eliminação de movimentos populares sob o preceito de erradicação de habitações irregulares eram consideradas modelos ideais por organismos internacionais como o Banco Interamericano del Desarrollo (BID).

A chamada Operação Condor, criada em 1975 sob liderança de Pinochet com apoio da Central Intelligence Agency (CIA), reuniu os governos militares do Chile, Brasil, Uruguai, Paraguai, Argentina e Bolívia numa operação que permitiu troca de informações, perseguição, captura e morte de ativistas inimigos, independentemente de fronteiras geográficas ou políticas em um período de suspensão dos Direitos Humanos (DINGES, 2005).

As atividades da Operação Condor ainda são, em grande parte, pouco veiculadas pela mídia dominante, o que contribui para que caiam no esquecimento, seja pelo grande número de opositores aos governos militares que morreram e não tiveram depoimentos registrados, seja pelo silêncio dos envolvidos nas ações, seja pela pouca investigação dos governos atuais para punir fatos do passado militar. Consequências sociais desse período são, dessa forma, inevitáveis.

\section{- Políticas pós-ditadura militar e o retorno à democracia no Chile e no Brasil}

Após a vitória da campanha do "Não"18, incentivada pela pressão política internacional e nacional, foi aprovado no Chile, em 1988, um referendum à Constituição que negou a renovação

18 Essa campanha antecedeu o plebiscito convocado pelo governo ditatorial em 1988. Enquanto Pinochet buscava o apoio da população para se manter no poder, os movimentos contrários criaram a campanha do "Não", que convenceu a população a acabar com o regime militar, apesar do medo que esse apoio ao fim da ditadura traria. Para conhecer mais sobre esse período, aconselha-se o filme chileno "No", de Pablo Larrain, lançado em 2012. 
do mandato de Pinochet.

Com a saída do General, iniciou-se o retorno à democracia, com quatro governos seguidos da Concertación de Partidos por la Democracia entre 1990 e 2010: Patricio Aylwin Azócar (1990 a 1994), Eduardo Frei Ruiz-Tagle (1994 a 2000), Ricardo Lagos Escobar (2000 a 2006) e Michelle Bachelet Jeria (2006 a 2010).

No Brasil, o movimento das Diretas Já, em 1984, antecipava o fim da ditadura com a tomada das ruas pelo movimento que lutava pela aprovação de uma emenda no Congresso para o restabelecimento das eleições diretas. Embora a emenda tenha sido derrotada, o descontentamento com o regime militar levou a um acordo para que ocorressem eleições em 1985, com a escolha do próximo presidente nas mãos do Congresso Nacional por meio de eleição indireta. A chapa de Tancredo Neves e José Sarney foi a vencedora, tendo Sarney governado de 1985 a 1990 devido à morte de Tancredo Neves antes da posse.

Após o governo Sarney, iniciam-se os governos eleitos por voto popular, começando com Fernando Collor de Mello (1990 a 1992), o qual, após impeachment, teve o seu vice Itamar Franco empossado, governando de 1992 a 1995. Seguiram-se os governos de Fernando Henrique Cardoso (1995 a 2003), Luiz Inácio Lula da Silva (2003 a 2011) e Dilma Rousseff (2011 a 2016, com posse do vice Michel Temer após controverso processo de impeachment).

Com o processo de redemocratização que ocorreu em ambos os países após os regimes militares, foram necessárias diversas mudanças no âmbito das políticas sociais para o retorno aos direitos civis e políticos que, no caso brasileiro, consolidaram-se com a Constituição Federal de 1988.

A política habitacional no período pós-ditadura no Brasil foi marcada por uma ruptura política, enquanto que, no Chile, deu-se a manutenção do modelo neoliberal.

Assim, finalizado o período de governo militar no Brasil, os primeiros anos de redemocratização não trouxeram nenhum avanço para a estruturação da política habitacional. Na verdade, desencadearam uma crise na política de habitação e no sistema de financiamento, que culminou com o fim do BNH em 1986. Houve, com isso, uma fragilização da política, somada à desarticulação institucional e à redução da capacidade decisória, devido à pulverização em distintos órgãos públicos das competências antes executadas pelo BNH. Além disso, o país viveu um período de elevada inflação e de baixo crescimento econômico.

Durante as décadas de 1980 e 1990, o país cresceu apenas 1,3\% e 2,1\%, respectivamente, não incorporando sequer todos os ingressantes ao mercado de trabalho. 0 baixo crescimento acentuou as mazelas urbanísticas (relacionadas ao solo) e influiu no aparecimento de novos aspectos negativos nas grandes cidades: o desemprego e a violência. Esta era praticamente desconhecida nas cidades até o início dos anos 1970. (MARICATO, 2006, p. 212)

No Chile, embora os governos que se seguiram ao período Pinochet tenham modificado muitos aspectos urbanos desencadeados pelo regime militar, em relação à política habitacional não houve grandes mudanças, pois a essência da política e do modelo financeiro foram mantidos (TAPIA ZARRICUETA, 2011). 
A política habitacional chilena conserva, até o período atual, a estruturação delineada na década de setenta durante o governo Pinochet, baseada em um subsídio à demanda, diferente dos subsídios tradicionais por proporcionar a famílias de recursos escassos adquirirem uma habitação dentro de um conjunto habitacional construído por uma empresa privada, selecionada por meio de uma licitação e financiada por fundos públicos para a construção de habitações sociais.

Recuperada la democracia en 1990, un temor importante de las autoridades en Chile era volver a la situación, un tanto descontrolada, de ocupación irregular de terrenos por parte de la población pobre que había caracterizado al gobierno de Salvador Allende. Por lo demás, el país se encontraba en una situación bastante difícil con un 38,6\% de la población en situación de pobreza y el déficit habitacional en su punto más alto. La solución más rápida y eficaz fue continuar con el sistema de subsidio habitacional diseñado durante la dictadura militar y profundizar su implementación. Esto llevó a que la década de los noventa se convirtiera en el período más productivo de construcción de viviendas sociales de la historia de Chile y a que esta política se convirtiera en un ejemplo para otros países y para organismos internacionales como el BID y Banco Mundial. (OPAZO, 2014, p.9)

Segundo Opazo (2014), embora a política com mecanismos neoliberais tenha sido criada durante o regime militar, foi durante o período dos governos da Concertación que se iniciou o período mais intenso de construção de habitações sociais da história do Chile, o que permitiu reduzir o déficit habitacional do país e colocá-lo entre os países da América Latina com experiências inovadoras, como os projetos do escritório de arquitetura Elemental (figuras 22 e 23).

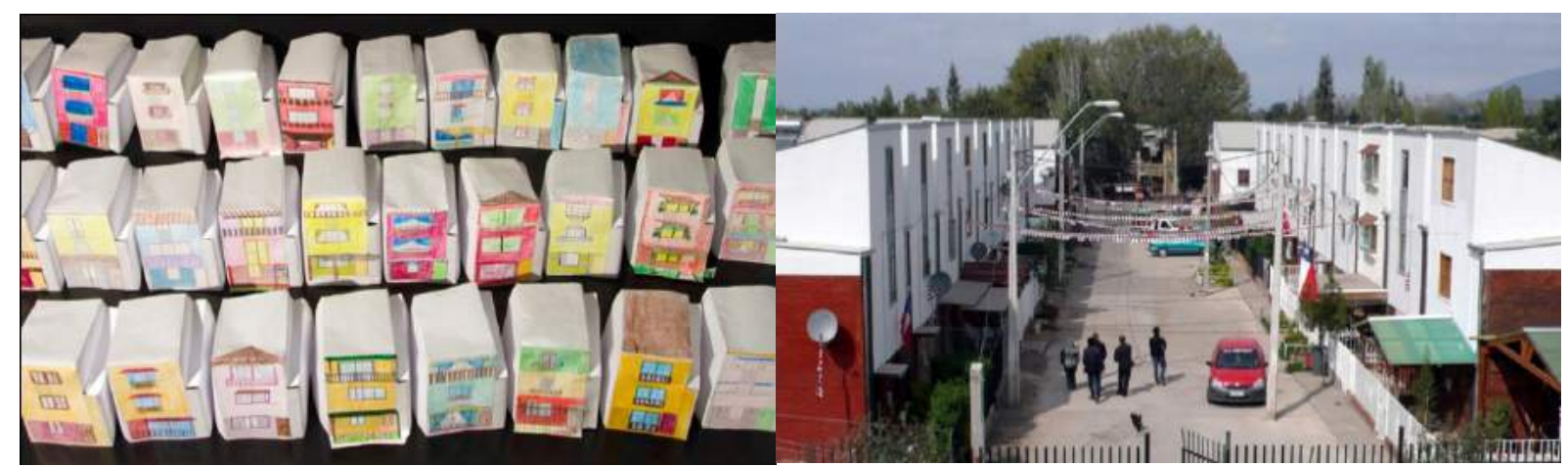

Figuras 22 e 23: Projeto do escritório de arquitetura Elemental, na Comuna de Renca, realizado durante os governos da Concertación. A implantação das residências, proporcionando um pátio interno, e a visibilidade criada com o portão de grades metálicas, auxilia a gerar melhores relações de vizinhança. Os moradores são estimulados a personalizar sua unidade básica alterando também a fachada. Fonte: <http://www.elementalchile.cl>. Acessado em maio 2014.

Foram diversos os programas criados no contexto de políticas habitacionais a partir do governo militar e nos governos que se seguiram, como o Programa de Vivienda Progresiva (PVP), elaborado durante o governo Aylwin em 1990; o Programa Vivienda Social Dinámica sin Deuda (VSDsD), criado no governo Lagos; o Programa Mejoramiento de Barrios (PMB) e o Programa Chile Barrio, ambos elaborados no final dos anos 1990; o Programa Quiero Mi Barrio, criado durante o governo Bachelet, dentre outros. 
O PMB é um dos programas habitacionais que obteve maior cobertura para a região metropolitana de Santiago do Chile e ainda é vigente em todo o país. Esse programa é administrado pela SUBDERE (Subsecretaria de Desarrollo Regional y Administrativo) e pelos governos regionais, tendo como objetivo específico reduzir o déficit na cobertura de abastecimento de água nas áreas rurais e urbanas, procurando soluções sanitárias para a população de recursos escassos (TAPIA ZARRICUETA, 2011). Assim, é um programa urbano, com ênfase no saneamento. Segundo Greene (2004),

La herencia de asentamientos informales con infraestructura sanitaria precaria que rodeaban las grandes ciudades y los problemas de salud que afectaban a su población, obligaron a las autoridades a implementar un masivo programa de saneamiento. Así con el apoyo del BID se inicia en Chile en 1982 el Programa de Lotes con Servicios, el cual más tarde se llama Programa de Saneamiento y eventualmente - y hasta hoy pasa a llamarse Programa de Mejoramiento de Barrios (PMB). (p. 15)

Na mesma linha de atuação de programas urbanos, surge, em 1998, o Programa Chile Barrio, inovando os programas anteriores ao acrescentar componentes de melhora urbana com a criação de equipamentos comunitários, de saúde e educação, além de acompanhamento social e participação comunitária (GREENE, 2004).

O PVP se iniciou nos anos 1990 e permaneceu em atividade até 2007, atendendo a famílias em áreas urbanas e rurais em condição de pobreza (OPAZO, 2014) e inovando ao atender as famílias em condição de allegados ${ }^{19}$ e sem teto (GREENE, 2004). O Programa atuava em duas etapas, sendo que na primeira entregava uma habitação básica às famílias, que poderiam optar por um subsídio para melhorar e ampliar a sua habitação na segunda parte do programa, caso não tivessem o montante para fazer as melhorias necessárias. Porém, muitos grupos não tinham a possibilidade de implementar o projeto da primeira etapa, principalmente pelas dívidas relacionadas à aquisição da unidade básica. Esse aspecto foi resolvido posteriormente com o VSDsD (ALFARO MALATESTA, 2006).

La operatoria del (PVP) tomó como punto de partida los procedimientos utilizados por el programa de vivienda básica del SERVIU utilizado desde (1987), donde las empresas constructoras desarrollaban los proyectos de viviendas de bajo costo y aportaban el terreno para implementar la construcción (...) Con el tiempo la oferta de terrenos bien ubicados y factibles de urbanizar aportados por las empresas constructoras se hicieron más escasas (...) (ALFARO MALATESTA, 2006, p. 173).

O Programa atuou com operação do SERVIU e como operação privada: na modalidade SERVIU, eram abertas licitações para empresas de construção e as famílias eram selecionadas por critérios de pontuação; já na modalidade privada, o beneficiário ou grupo apresentava o terreno adquirido ao SERVIU, que cooperava com o financiamento do projeto, destacando-se a atuação das organizações não governamentais (GREENE, 2004).

En general la acción de las ONG se centra en asesorías en procesos de organización de la demanda a la postulación, en dar apoyo técnico, en motivar la progresividad, coo-

19 Os allegados e o fenômeno de allegamiento fazem parte de uma situação típica latino-americana e que recebe especial atenção por parte do governo chileno: são as unidades habitacionais que, devido a situações adversas, como pobreza, são habitadas por mais de um núcleo familiar. 
perar con la inspección técnica de las obras e inclusive en participar en la construcción de algunas soluciones. Por su parte las Fundaciones en general entregan ayuda a los beneficiarios - ya sea financiera o de apoyo - en la gestión de las postulaciones. Algunas, como la Fundación San José de La Dehesa, entregan ayuda monetaria para complementar los subsidios estatales y así lograr una vivienda de mayores dimensiones o mejor calidad. El Hogar de Cristo, por su parte actúa como ente privado que organiza la construcción de viviendas y agrega ayuda financiera (por ejemplo para completar el ahorro necesario para la postulación) con lo cual complementa el subsidio del SERVIU. (GREENE, 2004, p. 21 e 22)

Surpreendentemente, a dimensão da habitação social no PVP era muito diferente na modalidade SERVIU e na modalidade privada: na primeira, as unidades básicas entregues tinham entre $6 \mathrm{~m}^{2}$ a $15 \mathrm{~m}^{2}$ predominantemente, considerando-se que eram entregues para serem ampliadas pelos moradores, como já comentado anteriormente; já na segunda, a unidade entregue tinha, na maior parte, até $35 \mathrm{~m}^{2}$.

O financiamento do PVP se dividia em três processos: subsídio habitacional, recursos dos beneficiários e crédito hipotecário. Os valores para cada processo se alteraram ao longo dos anos e da etapa de atuação do programa e da região do país. Na primeira etapa, o subsídio variou entre 100 a 132 UF $^{20}$ entre 1990 e 2002, enquanto o crédito hipotecário diminuiu de 17 a zero nesses mesmos anos e os recursos das famílias variaram de 3 a 8 UF. O crédito hipotecário foi eliminado do financiamento, visto ter sido constatada a dificuldade das famílias em quitar a dívida e consolidar a habitação. Assim, em 1996, o crédito hipotecário foi suprimido e o subsídio aumentou (GREENE, 2004). Portanto, os valores de financiamento se alteraram de acordo com as dificuldades encontradas pelo programa.

Já o Programa Vivienda Básica, que se iniciou em 1984 com a atuação do SERVIU durante a ditadura, permaneceu atuante até 2004, entregando habitações básicas, em geral em conjuntos habitacionais de características similares (OPAZO, 2014).

Havia também o Programa Especial para Trabajadores (PET), que consistia em um subsídio para compra de uma habitação nova básica, mas solicitada por membros de uma coletividade (OPAZO, 2014).

No Brasil, como a centralização e o autoritarismo eram encarados como vestígios da ditadura, a descentralização (obtida com a constituição de 1988, que distribuiu a autoridade política em diferentes níveis de governo) passou a ser auxiliar no processo de redemocratização e retomada das bases federativas do Estado brasileiro.

Segundo Rolnik (2009), a partir da Constituição de 1988 desencadearam-se diversos avanços institucionais no direito à moradia e à cidade, estruturando a noção de função social da cidade e da propriedade e reconhecendo os direitos dos cidadãos, inclusive no processo decisório

20 A UF (Unidad de Fomento) é a moeda de câmbio criada em 1968 e utilizada no Chile até o período atual. A UF é indexada ao IP (Indice de Precios al Consumidor), sendo constantemente ajustada à inflação e ao dólar. Em 01/01/1996, o UF estava em 12.483,21 pesos (29,63 dólares, considerando-se a cotação do dólar em 1996, quando 1 dólar correspondia a 421,27 pesos), enquanto que em 01/01/2015 estava em 24.627,10 (38,97 dólares, considerando-se a cotação do dólar em 21/03/2015, quando 1 dólar correspondia a 632 pesos). Fonte: Base de Dados Estadísticos - Banco Central de Chile. 
das políticas urbanas. Também nesse período foi criado o Fórum Nacional de Reforma Urbana, uma articulação de entidades que se formou em 1987 para atuar na luta pela democratização da gestão urbana, pelo direito à cidade e por melhores condições de vida para a população.

A descentralização das políticas públicas ocorreu em diversas áreas de atuação nesse período pós-ditadura, porém foi realmente implementada a partir do Governo Fernando Henrique Cardoso (FHC). Segundo Arretche (2002),

No Governo Fernando Henrique Cardoso, foi significativamente alterada a distribuição de competências entre municípios, estados e governo federal para a provisão de serviços sociais. Das 44 companhias municipais criadas pelo $\mathrm{BNH}, 12$ fecharam e mais de 20 redirecionaram suas atividades para a área de desenvolvimento urbano. A política social de habitação deixou de ser dominantemente produzida por intermédio de companhias municipais de habitação e passou a operar segundo linhas de crédito ao mutuário final. Abriu-se uma onda de privatizações das companhias estaduais de saneamento. Em conjunto, essas mudanças apontam para a desestatização dos serviços habitacionais e de saneamento. Além disso, a totalidade dos serviços de atenção básica foi transferida para os municípios, assim como se operou uma significativa municipalização da oferta de matrículas no ensino fundamental. Em conjunto, essas mudanças implicam expressiva transferência de funções de gestão para os municípios. (p. 31 e 32)

As reformas que ocorreram durante o Governo FHC tiveram como estratégia a descentralização da política e dos recursos, o que na política social de habitação também significou alteração no financiamento da produção, com introdução de mecanismos de mercado na gestão das políticas de desenvolvimento urbano (ARRETCHE, 2002).

Assim, em 1995, o financiamento da habitação e do saneamento foi retomado e houve uma tentativa de reestruturação da política habitacional com duas linhas de financiamento, o Programa Pró-Moradia e o Programa Carta de Crédito Individual. O primeiro, que pode ser considerado uma continuidade do modelo $\mathrm{BNH}$, voltava-se à população com rendimentos de até três salários mínimos e o segundo, à população de até doze salários mínimos (ARRETCHE, 2002).

Dentre os resultados positivos da produção habitacional popular do período denominado de pós-BNH (BONDUKI, 2009), destacaram-se as iniciativas pontuais surgidas após a descentralização da política, muitas delas derivadas de grande pressão popular, devido ao crescimento dos movimentos sociais e de luta pelo direito à habitação. Graças à junção dos movimentos populares e das ações de municípios e estados que, a partir da Constituição de 1988, receberam parte das atribuições das políticas públicas de habitação, tais iniciativas tiveram resultados positivos, embora pontuais e pouco articulados.

Dos resultados positivos, destacam-se as experiências municipais do Programa de Habitação Social do Município de São Paulo, desenvolvido pela Superintendência de Habitação Popular (Habi) durante o governo de Luiza Erundina (1989-1992), que contava com iniciativas inovadoras de atuação em parceria com os movimentos de moradia e mutirões autogestionários (figuras 24 e 25), além das experiências em Santo André/SP, durante a administração do prefeito Celso Daniel (1997-2002), com obras que iam além da provisão de habitação social, consolidando serviços, equipamentos e áreas livres. 


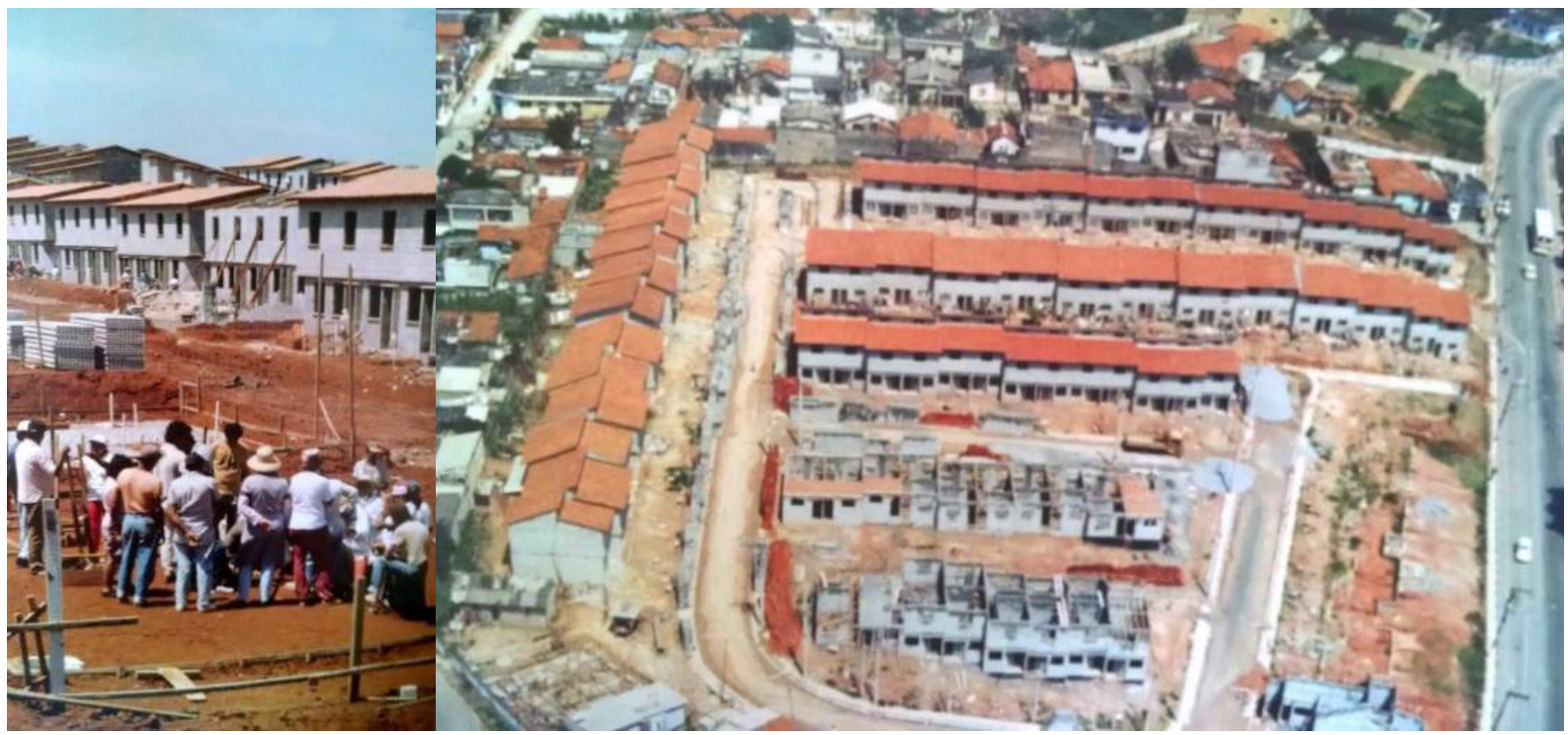

Figuras 24 e 25: Projetos realizados por meio de mutirões em São Mateus (à esquerda) e em Guaianazes (à direita), ambos na Zona Leste de São Paulo. Fotos dos anos 1990. Fonte: BONDUKI, 2014, p. 92 e 93.

A desarticulação ocorrida pós-BNH faz com que esse momento seja caracterizado por alguns autores como um período de transição, mas com bons resultados ainda que fragmentados, principalmente no âmbito de projetos com certo nível de participação popular, de programas de urbanização de favelas, de construção de moradias por mutirão, de projetos autogestionários, entre outros, embora, como já enfatizado, essas ações tivessem sido pontuais, desarticuladas de uma política nacional e com reduzida capacidade de influência no cenário nacional.

\section{- De 2000 a 2010}

Os impactos da produção habitacional chilena criada durante o período militar ainda são sentidos no período atual, com grande endividamento da população e continuidade do modus operandi de produção habitacional em regiões periféricas (DONOSO, 2013).

No governo de Ricardo Lagos (2000-2006), a política habitacional esteve focada na inclusão social e na proteção ao meio ambiente (ALFARO MALATESTA, 2006), dando continuidade às principais estratégias dos Governos da Concertación, porém implementando estratégias que procuraram minimizar as deficiências dos programas habitacionais anteriores.

Dentre os principais programas operantes durante o governo Lagos, estavam o já citado Vivienda Social Dinámica sin Deuda (VSDsD), o Fondos Concursables para Proyectos Solidarios (FCVS) e o Programa Chile Barrio.

O VSDsD, criado durante o governo Lagos, consistiu em um avanço da modalidade privada do PVB. Destinava-se a pessoas sem possibilidade de obter crédito em entidades financiadoras, 
atuando também com a combinação de unidade básica e autoconstrução. A unidade básica tinha aproximadamente $25 \mathrm{~m}^{2}$, com possibilidade de chegar a $50 \mathrm{~m}^{2}$, em conjuntos habitacionais de até 300 unidades organizados em subconjuntos de 60 unidades com equipamento comunitário. O programa dividia os subsídios para a construção e para o terreno, e a unidade habitacional tinha valor máximo de 300 UF. As famílias deveriam ter no mínimo 10 UF para poderem se candidatar ao programa, que dava um subsídio quase integral aos beneficiados (GREENE, 2004).

O Programa Chile Barrio atuou muitas vezes associado ao Programa de Mejoramiento de Barrio (ALFARO MALATESTA, 2006) que, no primeiro mandato do governo Bachelet, passou a se chamar Programa Quiero Mi Barrio.

Também durante o governo Lagos, um programa de atuação foi criado na escala do bairro, o "Un Barrio para mi familia", com o objetivo de auxiliar as famílias transferidas a conjuntos habitacionais sociais a se inserirem social e fisicamente naquele espaço. Esse programa foi um projeto piloto, executado em parceria com o MINVU e articulado com o Fondo de Solidariedad e Inversión Social / FOSIS (ALFARO MALATESTA, 2006).

Fica bastante claro o estabelecimento de um programa de bairro que vai se aprimorando ao longo dos governos da Concertación, começando com atuações na escala de melhorias de infraestrutura até alcançar ações mais consistentes para melhorar a qualidade dos bairros não apenas fisicamente, mas também quanto aos aspectos de vulnerabilidade social.

No Brasil, o ano de 2001 tem grande importância para as políticas urbanas: nesse ano foi aprovado o Estatuto da Cidade, que estava há onze anos em tramitação no Congresso Nacional. O Estatuto, sancionado pelo presidente Fernando Henrique Cardoso, regulamentou a utilização de instrumentos urbanísticos para os municípios atuarem em diversas frentes da reforma urbana, com destaque para a inserção da participação popular. Embora a aplicação do plano dependa da correlação de forças políticas e de interesses locais, além de conhecimentos técnicos, o avanço da sua regulamentação foi de grande importância para o planejamento urbano.

No entanto, a política habitacional brasileira somente encontrou a articulação em nível federal a partir do governo Lula, com a criação de um arranjo institucional focado no compromisso de priorizar a área da habitação por meio de uma política federal de habitação rearticulada, com uma perspectiva descentralizada, através da participação da União, estados e municípios, coordenados pelo Ministério das Cidades, criado em 2003 (TATAGIBA et al., 2013).

A proposta do Ministério das Cidades buscou suprir o vazio institucional que ocorreu após o fim do regime militar. Embora a centralização imposta pelas políticas da ditadura tenha obtido resultados questionáveis, a descentralização que se sucedeu e a pulverização de atribuições também não trouxeram melhores resultados.

Com a criação do Ministério das Cidades, surge novamente uma instância federal voltada para políticas urbanas, mas ligada à luta pela democratização do país, e com a função de coordenar, 
fomentar, capacitar e financiar estudos e ações nas principais frentes sociais a serem aprimoradas na cidade: moradia, saneamento ambiental, mobilidade e trânsito. Para Maricato (2006),

As inúmeras propostas de política urbana que não saíram do papel após 1985 e a pouca eficácia que teve a política autoritária do regime militar reforçam a convicção de que apenas uma formulação que resulte de um pacto social e um pacto federativo teria a durabilidade, a legitimidade e a eficácia para as transformações pretendidas. Para a equipe que coordenou os primeiros passos da Política Nacional de Desenvolvimento Urbano (PNDU) no Ministério das Cidades, tratava-se de construir uma nova "cultura" para ocupar um vazio de propostas práticas abrangentes, dar espaço para a emergência dos conflitos, constituir pactos em torno de conceitos, programas e linhas de ações. Buscou-se edificar um espaço público participativo que pudesse resistir à cultura de privatização da esfera pública, bem como ao avanço das imposições antissociais da globalização. (p. 215)

Segundo Rolnik (2009), a criação do Ministério das Cidades representou, para todos aqueles ligados ao movimento pela reforma das cidades, uma possibilidade de avançar na democratização da gestão urbana, com maior abertura para a participação popular, seguindo os resultados de experiências em âmbito local. Com isso, o Ministério constituiu um Conselho Nacional das Cidades, em que atores dos três níveis de governo se articulam em formulações e negociações de políticas com segmentos da sociedade civil, com representantes de todas as frentes eleitos em assembleias realizadas em Conferências Nacionais.

Um dos pontos atendidos pelo Ministério desde sua criação é o direito à moradia, que foi incorporado à política do Ministério através do financiamento da produção habitacional, assim como ocorreu com a urbanização e a regularização fundiária de assentamentos precários. Essa política se realizou a partir da criação do Sistema Nacional de Habitação de Interesse Social, que articula recursos de subsídio de orçamentos em vários níveis governamentais e os direciona para a promoção de Habitação de Interesse Social.

O Mistério não procura agir contrariamente às orientações de descentralização da Constituição Federal de 1988, que definiu grande autonomia aos municípios para lidar com competências de uso e ocupação do solo, de acordo com as regulações do Estatuto da Cidade. O Ministério, evitando centralizar atribuições, busca atuar em outras frentes, como desenhando o novo Sistema Nacional de Habitação e gerindo os recursos da União e do FGTS para as questões de moradia, saneamento e transporte urbano, operados pela Caixa Econômica Federal.

Essa mudança na política habitacional a partir de uma nova dimensão institucional se deu de forma acelerada nos primeiros anos de gestão do Ministério das Cidades, mas seguiu em passos lentos após uma mudança interna na gestão do Ministério, com a saída, em 2005, do ministro Olívio Dutra (do PT) e a posse de Márcio Fortes (do Partido Progressista-PP) (TATAGIBA et al., 2013). Com o início do primeiro mandato do governo da presidenta Dilma Rousseff, o cargo de Ministro das Cidades é transmitido a Mário Negromonte, também do PP, o qual deixa 
o ministério em 2012 após divulgação de supostas irregularidades. O cargo foi posteriormente assumido por Aguinaldo Ribeiro, novamente do PP.

A criação do Ministério das Cidades, a implantação do Conselho das Cidades com participação popular e a possibilidade de incorporação dos instrumentos do Estatuto da Cidade nos Planos Diretores municipais trouxeram avanços consideráveis às políticas urbanas brasileiras, mas atuaram minimamente no âmbito de levar a discussão da reforma urbana para a agenda dos municípios.

A dificuldade em discutir propostas de reforma urbana pode ocorrer devido tanto às raízes históricas da formação do espaço urbano brasileiro como às ações municipais, quase sempre fragmentadas por disputas internas de poder e marcadas por clientelismo, além da presença de um Estado patrimonialista e de casos de corrupção. Devido a esses fatores, apesar da presença de diversos membros com reais intenções de promover mudanças e atender às reivindicações da população, as ações ficam limitadas, por estarem inseridas em um contexto político muitas vezes conivente com a manutenção da desigualdade urbana e social, sem que se desenvolvam transformações sociais mais significativas para as cidades (FERREIRA, 2010).

Foi a partir da segunda gestão do governo Lula, mais precisamente em 2007, que o Plano de Aceleração do Crescimento foi criado, com o objetivo de retomar investimentos para a execução de grandes obras de infraestrutura, o que foi fundamental para a economia durante os anos de crise financeira mundial, entre 2008 e 2009.

No início do período da crise, em 2008, o setor imobiliário paralisou-se, situação essa que foi resolvida por meio da política de reaquecimento da economia interna e de geração de emprego, iniciada pelo PAC e reafirmada pelo Programa Minha Casa Minha Vida (PMCMV), que surge em 2009. Segundo Maricato, "com o primeiro a atividade de construção pesada começa a decolar e com o segundo é a construção residencial que decola" (MARICATO, 2013, p. 38), já que o PAC se destinava a financiar infraestrutura e o PMCMV retomava a visão empresarial da política habitacional.

Mais aspectos sobre o PMCMV serão detalhados no capítulo 4, apresentando as particularidades do programa, suas diferentes fases e faixas econômicas atendidas e as características dos empreendimentos construídos pela faixa 1 do programa na Região Metropolitana de São Paulo até o final do governo Dilma Rousseff. 
Capítulo 3: Sobre as Regiões Metropolitanas: formação e fragmentação visível e invisível

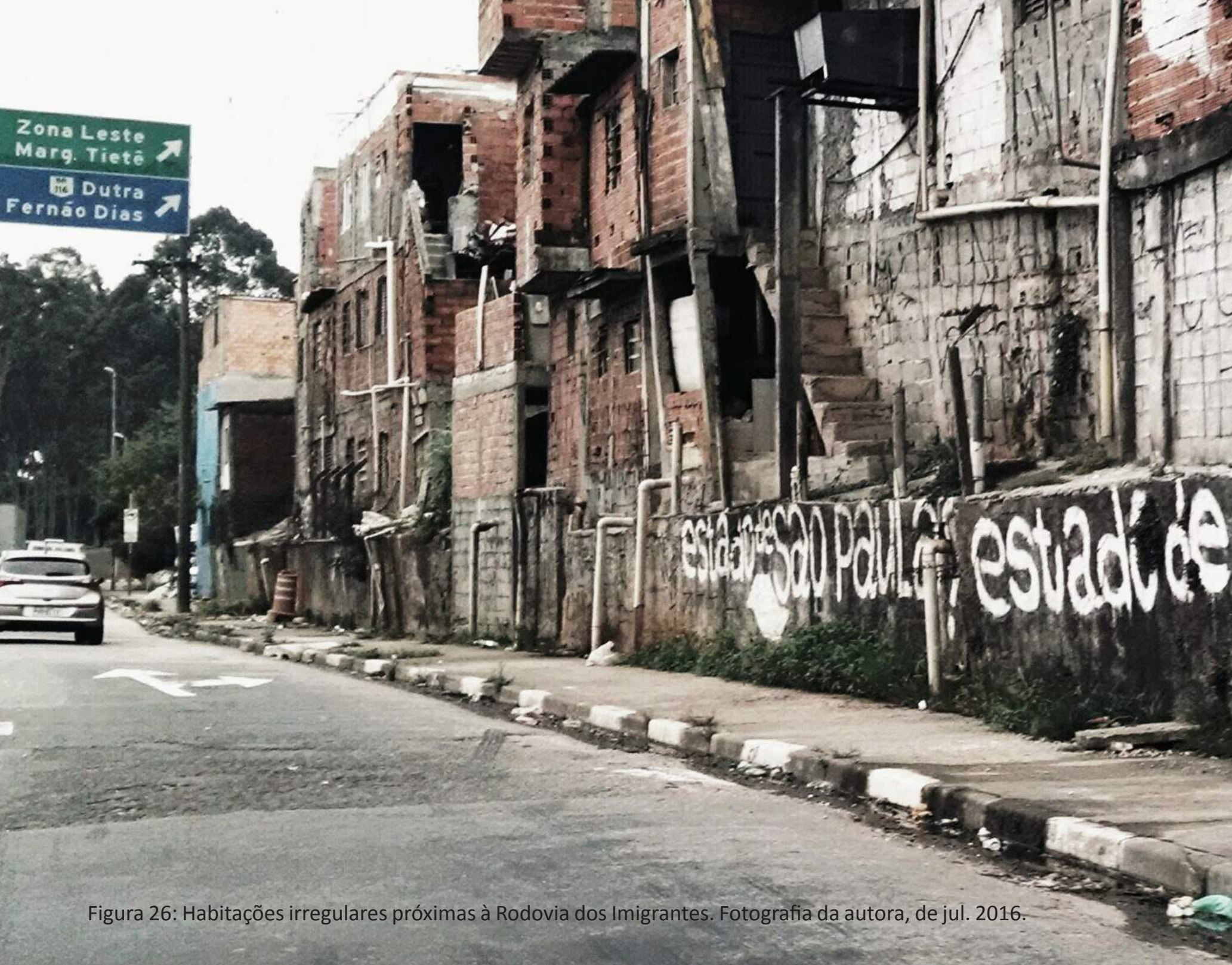




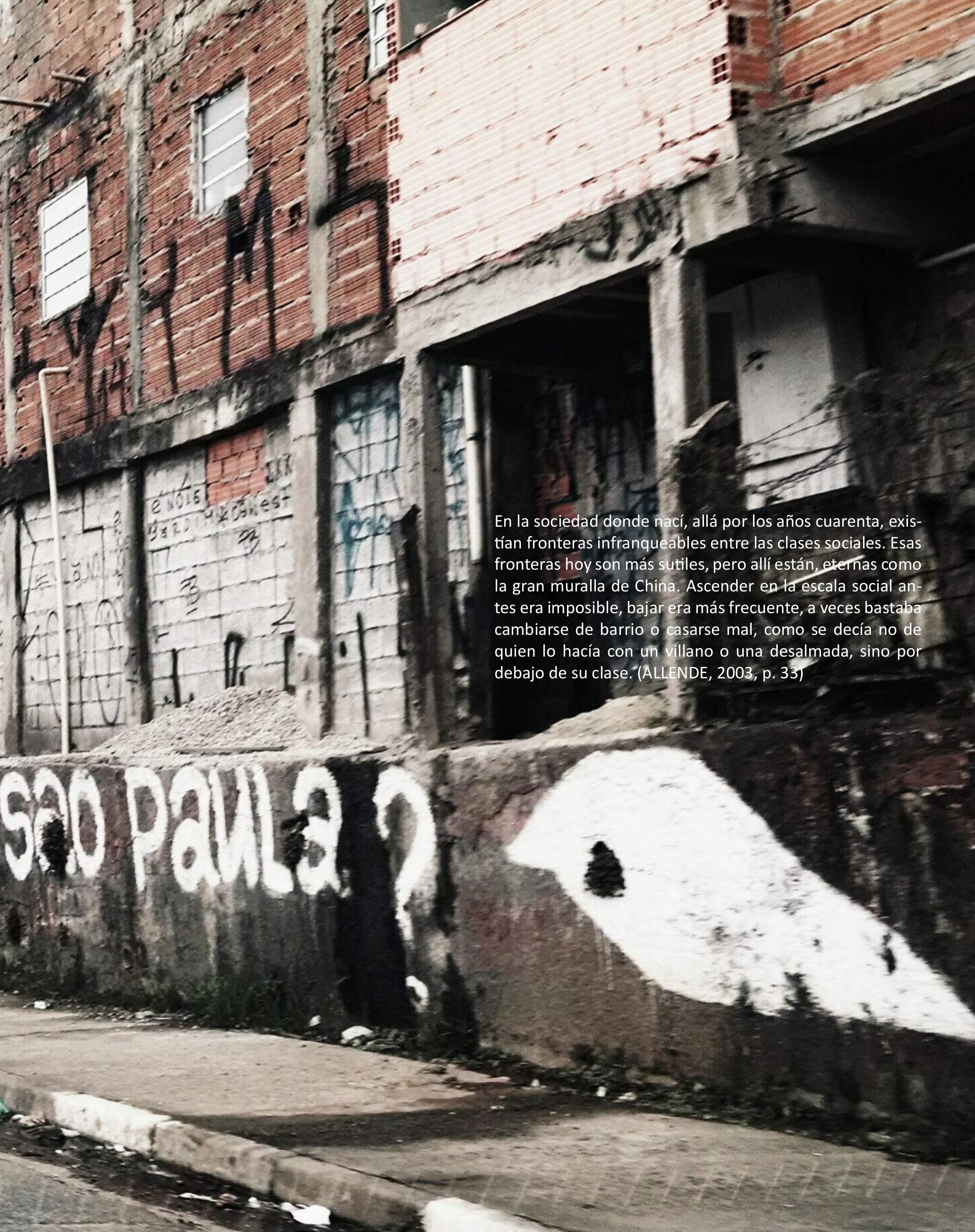


As Regiões Metropolitanas de São Paulo (RMSP) e de Santiago (RMS) são, atualmente, centros urbanos de grande representação para seus países e para a América do Sul. Contextualizar esses territórios trará relevante contribuição para este trabalho. Para isso, analisam-se os aspectos históricos e culturais responsáveis pela formação socioespacial atual, que provocam concentrações de habitação social até hoje (2016).

Para organizar os diferentes assuntos tratados no amplo levantamento comparativo entre a RMSP e a RMS, separaram-se informações e dados relativos ao suporte biofísico, à evolução urbana, aos territórios de inclusão periférica e aos dados atuais em quadros comparativos, conforme pobreza, segregação e violência urbana.

Os processos de expansão urbana em regiões metropolitanas ocorrem conforme a renda e a mobilidade populacional, com o poder econômico e elitista organizando as relações urbanas. A expansão populacional do estrato de maior poder aquisitivo ocorre em regiões bem conectadas aos centros econômicos principais, e caracteriza-se pela presença de espaços livres qualificados e de interesse imobiliário. Já as expansões habitacionais de baixa renda são caracterizadas pela maior dificuldade de conexão urbana, muitas vezes em terrenos pouco apropriados para urbanização, como áreas com restrição ambiental de topografia acidentada e que acabam sendo primeiramente ocupados de forma irregular, exatamente o que ocorre na RMSP.

Existem outras definições geográficas para os territórios em estudo, como o caso da Área Metropolitana de Santiago (AMS), que delimita a concentração e mancha urbana principal da Região Metropolitana de Santiago. Neste trabalho, optou-se por abordar ambos os casos pela regionalização oficial, mostrando além das áreas de urbanização contígua. Na delimitação regional, estão tanto municípios e comunas ${ }^{21}$ bastante inseridos na dinâmica metropolitana quanto outros com inserção mais tímida, o que faz com que o sistema de espaços livres de ambas as regiões seja bastante variado, com contrastes entre paisagens urbanas, rurais, remanescentes vegetais originais e outros.

A Grande Santiago, utilizada em alguns dados do Instituto Nacional de Estadísticas (INE), considera somente a população urbana das comunas que formam a aglomeração urbana, o que dificulta a análise histórica da evolução demográfica da RMS, já que as comunas que formam o território atualmente não são as mesmas dos anos 1980 ou antes.

A Grande Santiago, que está inserida na Região Metropolitana, é zona geográfica composta por 34 comunas, dentre as quais 32 formam a província de Santiago, enquanto outras duas, a comuna de Puente Alto e a comuna de San Bernardo, pertencem a outras províncias, Cordillera e Maipo respectivamente, mas se incorporam à Grande Santiago pela sua integração física e socioeconômica.

A Região Metropolitana de Santiago (RMS) só passou a ser considerada a partir de 1993, com a Lei Orgânica Constitucional 19.175 que instituiu os Governos Regionais e a Administração

21 A comuna é a menor unidade administrativa do governo chileno, dirigida por um conselho comunal presidido por um alcalde. A quantidade de membros do conselho é dependente da dimensão populacional da área administrada. A esfera de ação do governo comunal é similar à de um município brasileiro, atuando em âmbitos de saúde, educação, habitação, espaços livres, entre outros aspectos (RODRÍGUEZ, 1993). 
Regional, descentralizando a administração. Composta por 6 províncias e um total de 52 comunas (ver figura 27), sendo a maioria em zonas urbanas e somente dezoito em zonas rurais, a RMS é formada, dessa forma, pelas comunas das Províncias de Santiago, Cordillera, Talagante, Maipo, Chacabuco e Melipilla22, com uma população estimada de 6.069.678 habitantes (INE, 2014).

A província de Cordillera, composta pelas comunas de Puente Alto, San José de Maipo e Pirque, faz divisa com a Argentina e apresenta grande variação em sua paisagem: da comuna de Puente Alto, que apresenta a maior porcentagem de população de todo o Chile, faz parte Bajos de Mena, região que abrigou grande contingente de habitação social, cujo estudo de caso será apresentado no capítulo 5; San José de Maipo, a comuna de maior superfície da Região Metropolitana, que se localiza na cota $967 \mathrm{~m}$ acima do nível do mar (conhecida pelo potencial turístico do Cajón del Maipo); Talagante, a sudoeste da Região Metropolitana, que se encontra em meio aos vales e tem grande produção rural, formada pelas comunas de El Monte, Isla de Maipo, Padre Hurtado, Peñaflor e Talagante; a província de Maipo, ao sul, composta pelas comunas de São Bernardo, Calera de Tango, Buin e Paine, que se destaca pela reserva ambiental Altos de Cantillana; Chacabuco, formada pelas comunas de Colina, Lampa e Til-Til, que se caracteriza por sua forte atividade agrícola; Melipilla, composta pelas comunas de Alhué, Curacaí, María Pinto, Melipilla e San Pedro, com a maior superfície rural, fazendo divisa com vales do setor agrícola exportador de produção de vinhos, como o vale de Casablanca.

O processo de reforma administrativa que instituiu os governos regionais, municipais e comunais no Chile buscou ampliar, em teoria, a atuação local no âmbito do planejamento territorial e social, mas, na prática, a distribuição dos recursos para cada atuação tem papel restrito. Esses recursos, no âmbito municipal, são derivados de duas fontes: uma fonte externa, o Fondo Común Municipal, responsável por distribuir recursos de localidades mais ricas às mais pobres (HARDY; LEGASSA, 1989) e a arrecadação municipal por impostos e patentes locais.

Embora não se pretenda entrar nos méritos da distribuição dos recursos, competências e atribuições de cada atuação, destaca-se que há uma dependência política das comunas para conseguir esses repasses, ainda que a distribuição seja facilitada por planos específicos para direcionar recursos a municípios e comunas com problemas sociais. Portanto, a administração comunal também é relevante para a desigualdade socioeconômica, pois, caso não houvesse a compensatória advinda do Fondo Común Municipal, ela seria ainda mais acentuada.

Sobre a Região Metropolitana de São Paulo, esta só foi estabelecida oficialmente em 1973, durante o governo militar, que criou nove regiões metropolitanas brasileiras como estratégia desenvolvimentista. Porém, já nos anos 1960, embora ainda não existisse legalmente, a RMSP já demonstrava sua formação, com alguns municípios já conurbados ao município de São Paulo, caso principalmente do $\mathrm{ABC}^{23}$.

22 Segundo estimativa do censo de 2014, a população das Províncias era de 4.675.039 habitantes na Província de Santiago, 522.856 habitantes em Cordillera, 217.449 habitantes em Talagante, 378.444 habitantes em Maipo, 132.798 habitantes em Chacabuco e 143.092 habitantes em Melipilla, perfazendo um total de 6.069.678 habitantes.

23 Segundo os Censos Demográficos de 1960 (IBGE), São Bernardo do Campo contava com 81.255 habitantes, Santo André com 242.920 habitantes e São Caetano do Sul com 113.233 habitantes. Diadema, na época, contava apenas com 12.287 habitantes. Outros municípios com população em grande crescimento no período eram Guarulhos, com 100.760 habitantes, e Osasco, com 113.547 habitantes. 


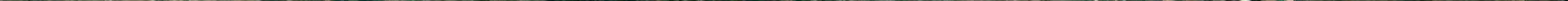





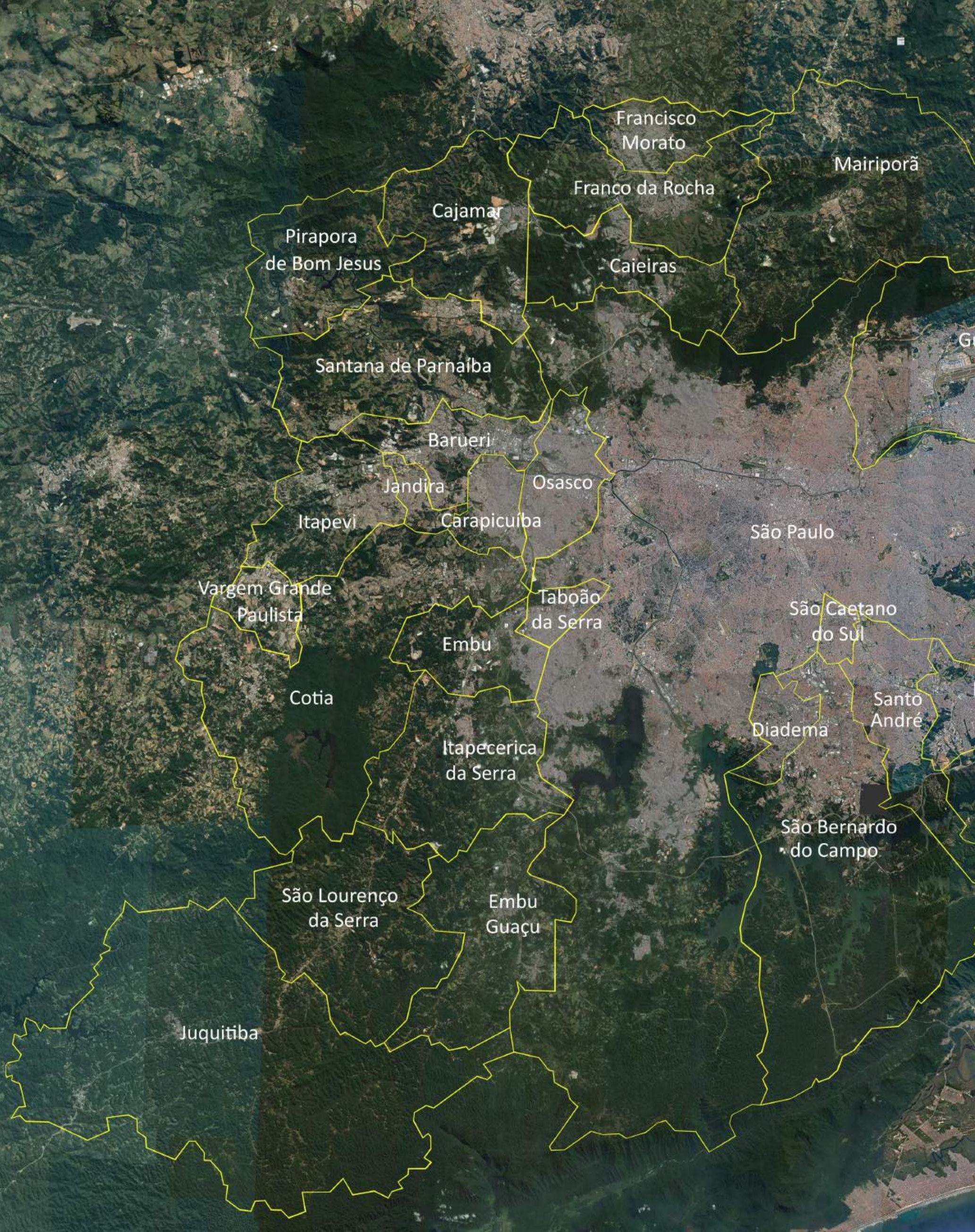



Langenbuch (1971), ao analisar a Região Metropolitana de São Paulo, destaca a imprecisão dos limites externos da metrópole e a multiplicidade de processos em que se deu a expansão metropolitana, com a conformação de diversos arredores não urbanizados, espaços livres que se veem estruturados pela metrópole e para a metrópole.

A Região Metropolitana de São Paulo, com uma população estimada de 20.935.204 habitantes (IBGE, 2014), é composta por 39 municípios, divididos em sub-regiões (figura 28). A Norte, estão os municípios de Caieiras, Cajamar, Francisco Morato, Franco da Rocha e Mairiporã. A Leste, estão Arujá, Biritiba-Mirim, Ferraz de Vasconcelos, Guararema, Guarulhos, Itaquaquecetuba, Mogi das Cruzes, Poá, Salesópolis, Santa Isabel e Suzano. A Oeste, ficam Barueri, Carapicuíba, Itapevi, Jandira, Osasco, Pirapora do Bom Jesus e Santana de Parnaíba. A Sudeste, estão Diadema, Mauá, Ribeirão Pires, Rio Grande da Serra, Santo André, São Bernardo do Campo e São Caetano do Sul. A Sudoeste, localizam-se Cotia, Embu, Embu-Guaçu, Itapecerica da Serra, Juquitiba, São Lourenço da Serra, Taboão da Serra e Vargem Grande Paulista. O município de São Paulo integra todas as sub-regiões, e é a principal metrópole nacional.

Alguns municípios da RMSP têm economia predominantemente rural, como é o caso de Embu-Guaçu, presente em área de manancial. Outros municípios, como São Lourenço da Serra, Biritiba-Mirim e Guararema são praticamente cidades-dormitório, com uma população que se desloca cotidianamente para os municípios mais dinâmicos.

Com protagonismo e importância nacional (no sentido econômico, cultural, comercial, político), a RMSP tem muitos desafios, principalmente no que concerne em melhorar sua coesão e mobilidade urbana e social. São diversas paisagens contrastantes em seu território, que demonstram as desigualdades socioespaciais e os diferentes cotidianos de grupos sociais diversos.

\section{Suporte biofísico}

A RMS tem uma delimitação extremamente extensa, abarcando: à leste, o limite da Cordilheira dos Andes em divisa com a Argentina; a oeste, a Cordilheira da Costa, em território mais próximo ao litoral chileno, limite com a Região de Valparaíso; ao norte, a região montanhosa de Chacabuco e ao Sul pela depressão topográfica de Angostura de Paine, que divide a RMS de Santiago com o território da cidade de Rancagua. A paisagem da RMS é rica em diferenças, tanto na paisagem física, quanto cultural e econômica.

Dentro da RMS, estão áreas rurais de cultivo diverso das áreas do vale central, áreas de preservação ambiental, com predomínio de bosques e paisagens de cordilheira. A cobertura vegetal original é variada, com áreas desprovidas de vegetação, áreas de vegetação andina, além de lagos formados pelo degelo da neve, como as incríveis paisagens dos cajones cordilleranos. Destaca-se ainda o Cajón del Maipo (figura 29), formado pelo curso d’água do Rio Maipo, importante afluente que atravessa a Região Metropolitana. Suas águas nascem à beira do Vulcão Maipo, recebem água de outros tributários andinos e atravessam o território chileno até desaguar no Oceano Pacífico. O vale formado pelo curso d’água desse rio é conhecido pela sua paisagem de solo rico para o cultivo de uvas, com grande tradição vitivinícola. 


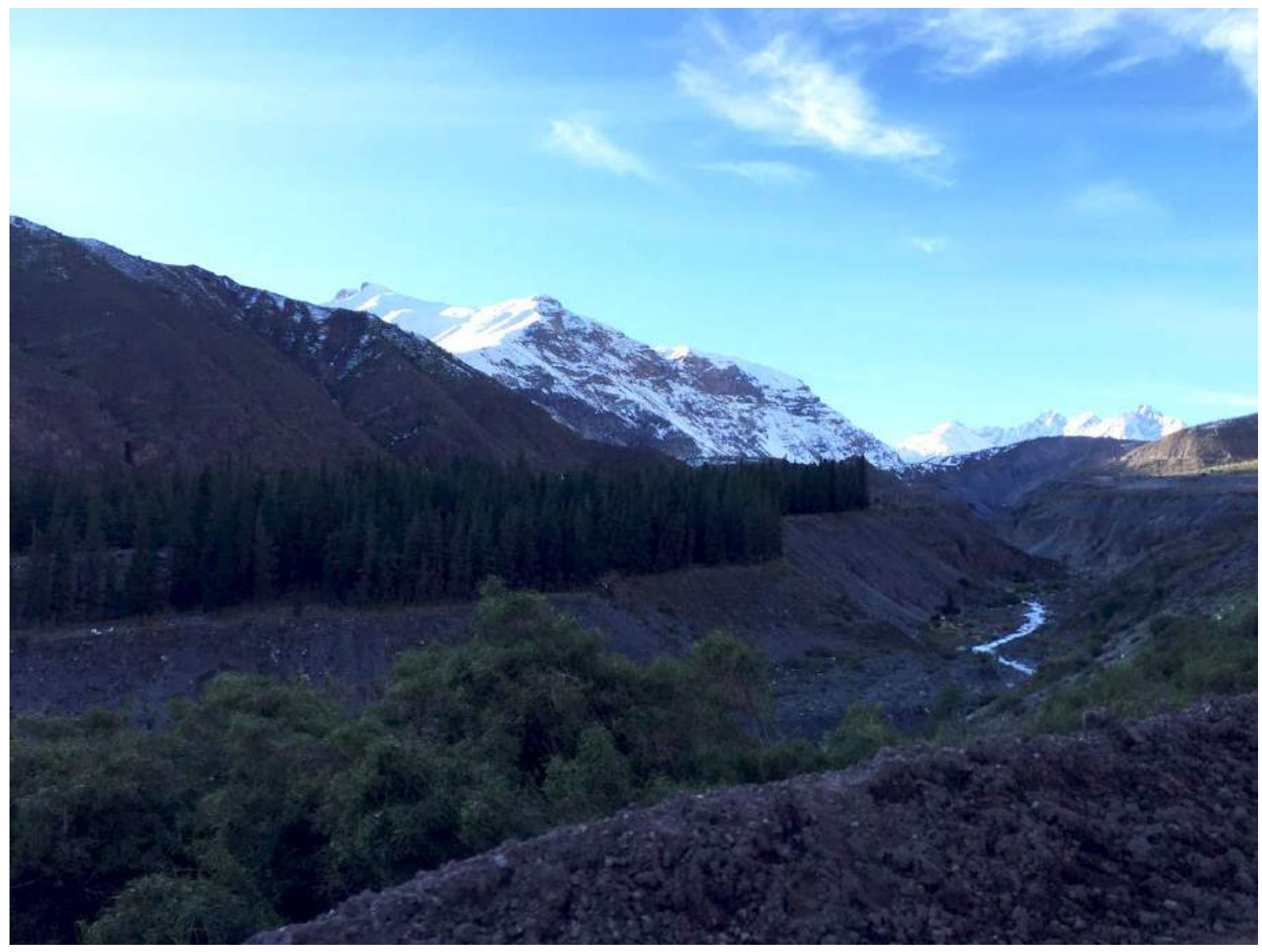

Figura 29: Cajón del Maipo. Fotografia de Manuel Jose Costabal Donoso, jun. 2016.

A RMSP também apresenta recorte amplo em relação à principal mancha urbana, apresentando municípios mais distantes da mancha e que apresentam cotidiano similar ao de cidades do interior do Estado.

O embasamento físico de São Paulo caracteriza-se por uma bacia sedimentar com serras e morros ao norte-noroeste e sul, com vegetação nativa bastante diversa, com áreas de Mata Atlântica e Cerrado. Essa vegetação original foi bastante impactada pela urbanização, mas existem muitos fragmentos dela preservados, como nas áreas do extremo sul e norte da RMSP, a exemplo da Serra da Cantareira e do Parque Estadual do Jaraguá, porções de relevo mais notáveis da região, com pontos que ultrapassam a altitude de $1.000 \mathrm{~m}$, e no extremo sul, onde se encontram a Área de Proteção Ambiental Capivari Monos e trecho do Parque Estadual da Serra do Mar.

Dentre os elementos que marcam a paisagem da RMSP estão também os bens de interesse cultural, que fazem parte da memória da formação do território, como a Estação e Vila de Paranapiacaba (figura 30), no município de Santo André, remanescente da estrada de ferro da São Paulo Railway, que ligava o litoral ao interior paulista. 


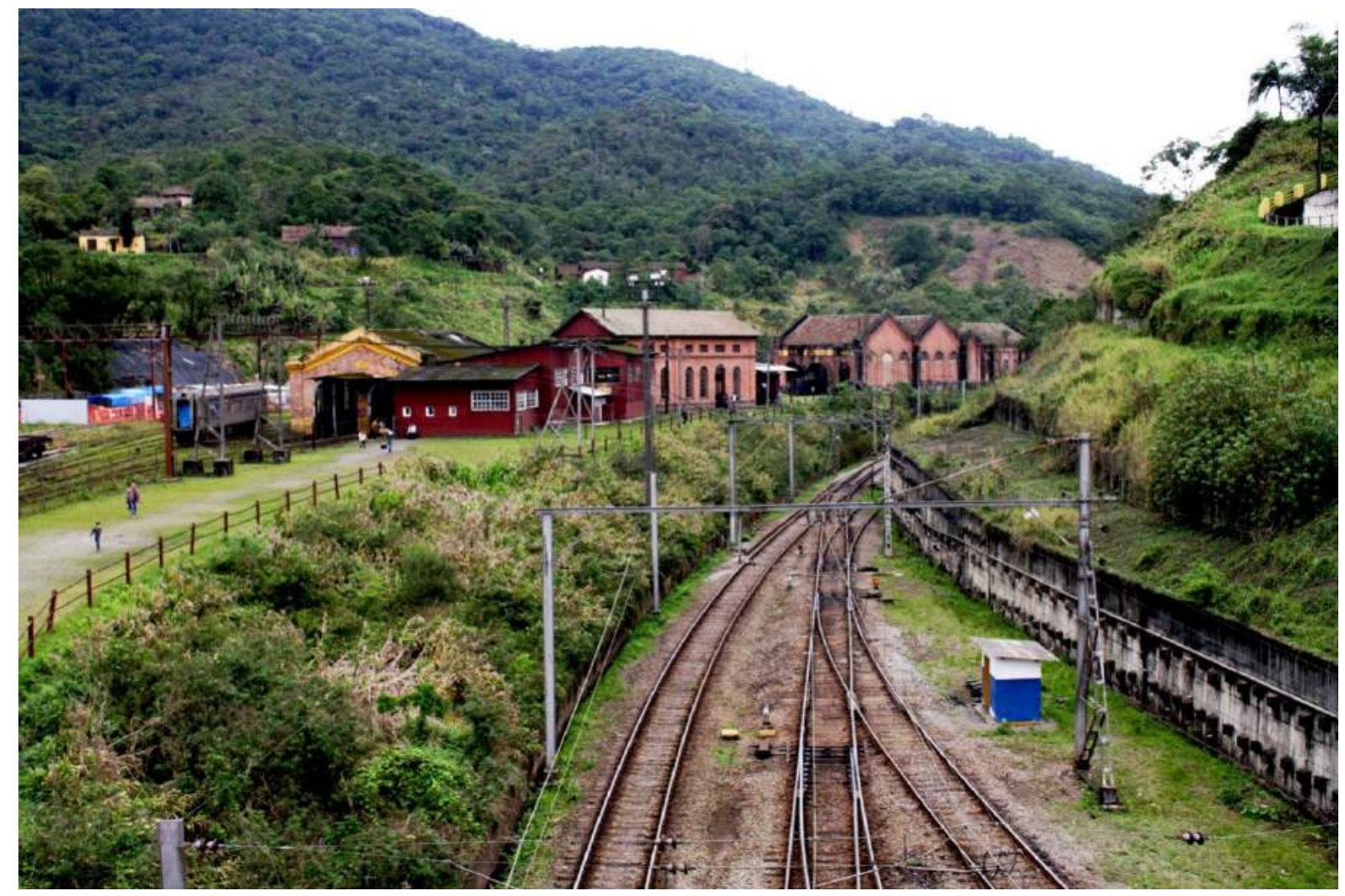

Figura 30: Vila de Paranapiacaba na Região Metropolitana de São Paulo. Fotografia da autora, set. 2016.

Junto a um rico sistema hídrico, a RMSP concentra a principal porção do seu território na bacia do Alto Tietê, formada pelo rio homônimo, que nasce à leste da Região Metropolitana, no município de Salesópolis. Desse sistema, fazem parte rios bastante presentes no cotidiano da metrópole, como o Pinheiros, o Tamanduateí e o Aricanduva, além dos reservatórios da Billings e da Guarapiranga, que formam a paisagem da porção sul do município, entre outros.

Embora de grande potencial paisagístico e hídrico, os rios que atravessam a RMSP são particularmente comprometidos pela contaminação, o que limita tanto o uso recreativo como para abastecimento. Responsável pela crise hídrica que assolou a metrópole nos anos 2014 e 2015, a poluição e a má administração dos recursos hídricos são temas delicados, e que se camuflam por períodos de escassez ou abundância de chuvas (CUSTÓDIO, 2015).

Somado à questão do abastecimento da RMSP, está o histórico de urbanização com ocupação de fundos de vale e canalização e tamponamento de rios. O processo de degradação do meio biofísico da Região Metropolitana se inicia principalmente a partir dos anos 1960, com dois processos simultâneos: a expansão urbana periférica e a urbanização com retificação e canalização dos cursos d'água. Foi a partir da primeira gestão de Prestes Maia (prefeito de São Paulo entre 1938-1945 e 1961-1965) que rios foram modificados, com aterramento de áreas de várzeas para aumento de solo a ser urbanizado, desmatamento, impermeabilização do solo e eliminação de vegetação ciliar, o que causou alterações na drenagem e grande impacto nas áreas de mananciais (JACOBI, 2004). 
Esse modelo de urbanização, que não deu a devida atenção ao futuro do meio ambiente urbano (JACOBI, 2004) acarreta impactos que até hoje são sentidos em toda região metropolitana: inundações, poluição, assoreamento dos rios e córregos, insuficiência e deficiência da rede de esgotos e outras convivências perigosas com danos ambientais derivados do uso e ocupação do solo sem condicionantes ambientais.

Exemplo disso é a ocupação da área de manancial das sub-bacias Billings e Guarapiranga, reservatórios formados nas primeiras décadas do século $\mathrm{XX}$, que tiveram sua área ocupada por loteamentos irregulares e sem infraestrutura urbana, onde ligações clandestinas elevam ainda mais a carga poluidora de importante área de abastecimento para a Região Metropolitana (figura 31).

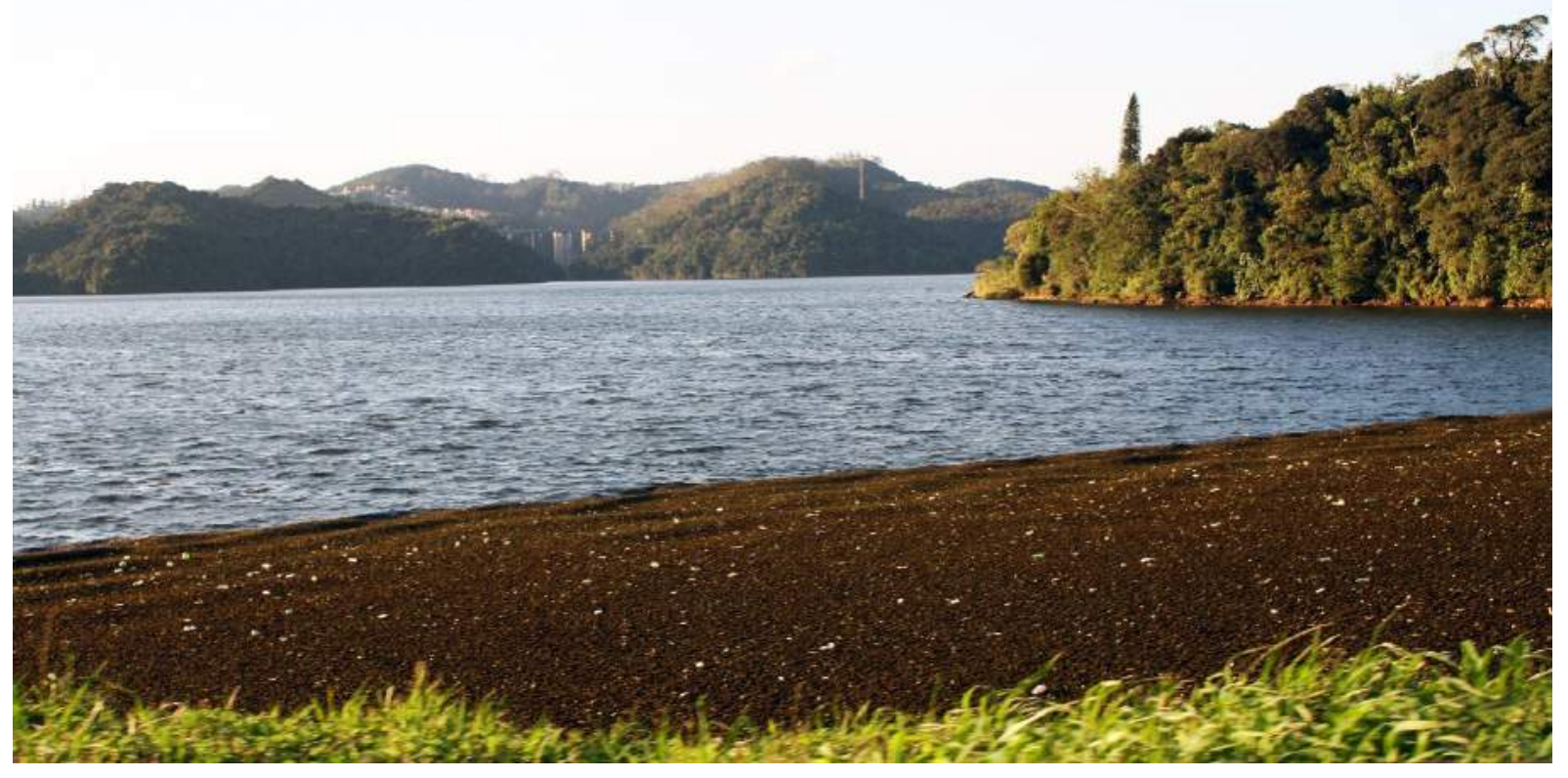

Figura 31: Resíduos na represa Billings, próximo à estação de tratamento de água da SABESP no município de São Bernardo do Campo. Fotografia da autora, set. 2016.

\section{Evolução urbana}

A formação de ambas as regiões metropolitanas tem pontos em comum, com períodos de crescimento urbano associados a ciclos econômicos, marcados por intensa expansão urbana principalmente a partir dos anos 1970. O infográfico a seguir (figura 32) mostra a evolução das manchas urbanas do período de formação do primeiro núcleo urbano a partir de 1900 até 2000, comparando o crescimento de ambas as regiões na mesma escala.

Verifica-se, no infográfico, as diferentes décadas que representaram as principais evoluções urbanas. As décadas de 1950 a 1970 mostram uma expansão periférica e multidirecional das manchas urbanas, já apresentando fragmentações consideráveis. Esse período de crescimento (1950-1970) é o que caracterizou o grande aumento da metrópole paulista em comparação à metrópole chilena. Os anos que se seguiram consolidaram ambas as manchas urbanas com ainda mais expansões periféricas contínuas e fragmentadas. 


\section{REGIÃO METROPOLITANA DE SÃO PAULO}

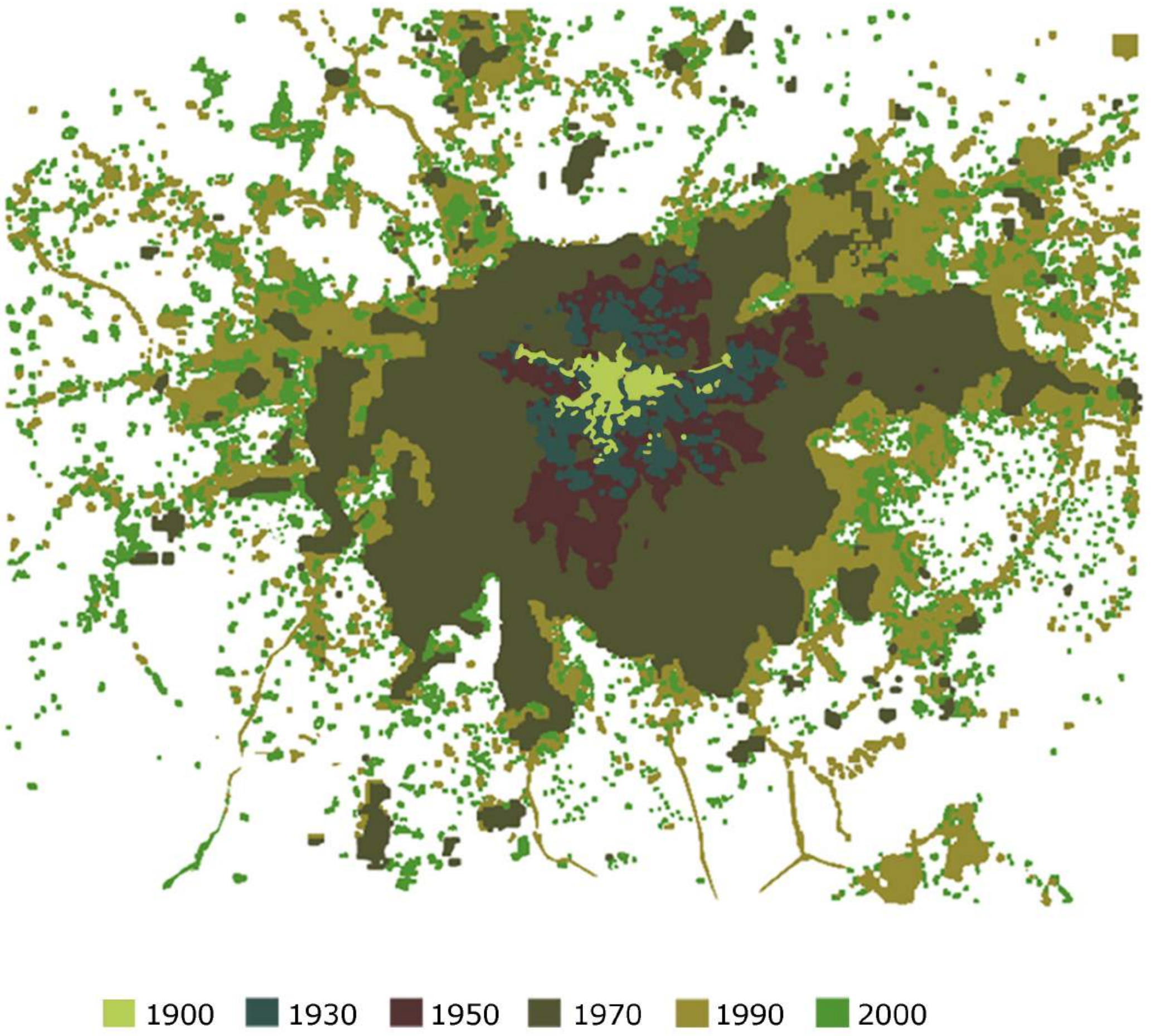

Figura 32: Infográfico da expansão da mancha urbana principal das Regiões Metropolitanas de São Paulo e Santiago. Fonte: Donoso (2016), sob dados do Google Earth e SHLOMO et al (2012). 

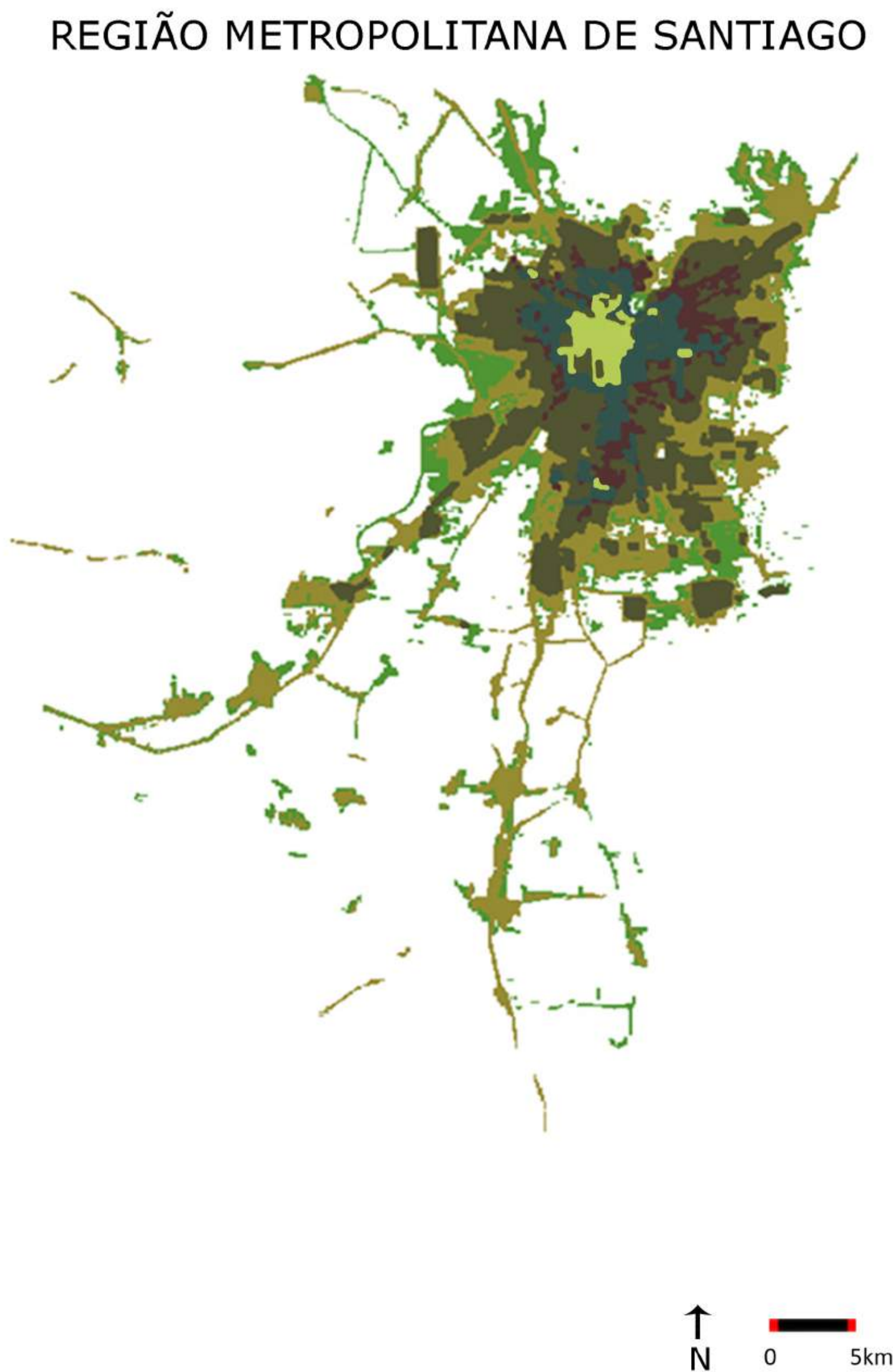
O crescimento urbano da RMSP, de uma maneira geral, foi resultante do incremento das atividades econômicas derivadas de ciclos produtivos diversos, como ocorreu no período anterior a 1930, quando a economia cafeeira possibilitou o acúmulo de capital necessário para o investimento industrial inicial, o qual, por sua vez, gerou o próximo ciclo produtivo, nos anos 1930 a 1950, com a industrialização, que se acelerou até a década de 1970, desconcentrando-se da Região Metropolitana de São Paulo entre os anos 1970 e 1990 para outras regiões do interior do Estado e mesmo do país (NOBRE, 2008).

Foi entre 1899 e 1930 que a cidade de São Paulo confirmou seu caráter industrial, após a perda de autonomia da economia cafeeira e a consolidação do estado de São Paulo como principal polo econômico e industrial do país, com sua capital, São Paulo, sendo o foco dessa mudança. Posterior a esses dois períodos de ciclos produtivos, vieram os anos de acelerada industrialização e recuperação pós-crise de 1929, quando se consolidou o processo de metropolização, considerando-se a expansão da malha urbana e a conurbação entre municípios vizinhos a São Paulo, alterando-se os limites municipais, a paisagem e o cotidiano dos moradores.

Essa paisagem industrial, de plantas fabris e vilas operárias, concentrou-se principalmente no município de Osasco, e nos bairros de São Paulo da Água Branca, Brás, Belenzinho, Mooca, Ipiranga e Vila Prudente, associados às ferrovias e seguindo o trajeto dos trilhos da Estrada de Ferro Sorocabana, da São Paulo Railway e da Estrada de Ferro Central do Brasil, formando uma periferia industrial a partir dos anos 1930 (GUNN; CORREIA, 2004).

Meyer (2004), observando a expansão das áreas industriais na Região Metropolitana entre 1930 e 1997, ressalta o espraiamento destas a partir dos principais eixos de mobilidade em direção a outros municípios, como o eixo Anhanguera com a conexão com Jundiaí e Campinas. Essa expansão industrial é processo de dispersão urbana (REIS FILHO, 2006) característico da busca de terrenos de maior porte com facilidade de acesso para escoamento de produtos, facilitada por incentivos fiscais e rodoviários, o que acarretou a maior mobilidade urbana viabilizada pela rede de rodovias e o incentivo para produção e aquisição de automóveis pelas classes média e alta a partir da segunda metade da década de 1950 (COELHO, 2015; MEYER, 2004).

L. O. da Silva (2004) denomina a expansão urbana da Região Metropolitana de São Paulo de padrão extensivo de desenvolvimento urbano, configurado por expansão horizontal, a mesma que caracteriza grande parte dos processos de urbanização brasileiros. Esse padrão é caracterizado por parcelamento constante e ocupação das periferias, tanto por loteamentos novos quanto por autoconstrução, demanda constante de infraestrutura e implantação de sistema de transportes baseado em veículos automotivos.

Essa expansão horizontal se materializou com a transformação da cidade, que antes tinha grande parte do seu transporte coletivo funcionando sobre trilhos, e passa a ter suas rotas projetadas para pneus, com incentivo da crescente indústria automobilística. Essa mudança se inicia nos anos 1930 e 1940, estruturando a base de raciocínio que seria responsável pelas características urbanas da metrópole que se consolidava: a do incentivo ao transporte viário.

A RMSP se forma conjuntamente ao processo de urbanização intenso que São Paulo e municípios vizinhos apresentaram principalmente a partir dos anos 1950. Em sessenta anos, de 1950 a 2010, o município de São Paulo teve um crescimento demográfico muito grande ${ }^{24}$.

24 Nos anos 1950 e 1970, a população passou de 2.151 .313 a 5.924 .615 respectivamente. Nos anos seguintes esse crescimento foi menos acentuado, chegando, em 2010, a 11.253.503 habitantes (IBGE, Censos Demográficos de 1950 a 2010). 
Principalmente a partir dos anos 1970, o crescimento urbano atinge também os municípios vizinhos à cidade de São Paulo, em um processo de expansão da periferia e da mancha urbana da RMSP $^{25}$.

Incentivados pela industrialização e pela migração interna motivada por fatores regionais (NOBRE, 2008), o grande incremento populacional ocorrido nas cidades da RMSP e que se seguiu até os anos 1990 representou taxas médias de crescimento populacional mais elevadas que a média da nação e do estado ${ }^{26}$.

A expansão da mancha urbana da Região Metropolitana de São Paulo foi mais significativa a partir dos anos 1960. Esse processo ocorreu principalmente ao longo de principais rodovias já existentes (e de outras que foram criadas), além de estradas férreas, induzindo a ocupação conforme os eixos de mobilidade, que tiveram grande relevância. Uma dessas rodovias é a Rodovia Castelo Branco, que estruturou, em 1973, o surgimento do conglomerado Alphaville-Tamboré nos municípios de Barueri e Santana de Parnaíba (COELHO, 2015; CAMPOS, 2008) ${ }^{27}$.

O crescimento de distritos periféricos ocorre no mesmo momento em que os distritos centrais, como Sé, Brás e Santa Cecília apresentaram decréscimo populacional de até $2 \%$ ao ano. Por outro lado, os distritos centrais têm nova fase de crescimento populacional nos anos 20002010.

Em quase todos os eixos de expansão da RMSP há uma paisagem que mistura áreas industriais e de serviços, regiões urbanas de perfil socioeconômico diverso, com áreas de alta e média rendas assim como bairros populares e habitações irregulares. Em termos gerais, as regiões leste e extremo leste de São Paulo foram historicamente formadas por bairros de setores de renda média e baixa, com grande concentração de habitação irregular e projetos sociais princi-

25 Guarulhos, por exemplo, que em 1950 apresentava 34.683 habitantes, em sessenta anos teve sua população aumentada em 35 vezes, chegando a 1.221.979 habitantes em 2010. Similarmente, São Bernardo do Campo teve sua população aumentada em 29 vezes, passando de 26.262 habitantes em 1950 para 765.463 habitantes em 2010. Já Osasco passa de 41.326 habitantes em 1950 para 666.740 habitantes em 2010, enquanto Santo André de 106.605 em 1950 para 676.407 habitantes em 2010 (IBGE, Censos Demográficos de 1950 e 2010).

Francisco Morato e Diadema são municípios que, nos anos 1950, apresentavam população inferior a 15 mil habitantes, sendo 324 habitantes em Francisco Morato (que até então era um distrito de Franco da Rocha, passando a ser município em 1964) e 3.023 habitantes em Diadema. A população de Francisco Morato, em 2010, passou a 154.472 habitantes, e em Diadema, a 386.089 habitantes. Diadema, atualmente, é o município com a maior densidade demográfica da RMSP: são 12.537 habitantes $/ \mathrm{km}^{2}$ (IBGE, 2010, disponível em <http://cidades.ibge.gov.br/xtras/perfil.php?codmun=351380>. Acessado em 5 dez. 2016).

26 Considerando as taxas de crescimento geométrico para os municípios da RMSP, no intervalo de 60 anos, temos São Paulo com 3,36\%; Guarulhos, com 7,38\%; São Bernardo, com 6,98\%; Osasco, com 5,72\%; Santo André, com 3,76\%. Francisco Morato apresenta a maior taxa de crescimento geométrico dos municípios da Região Metropolitana para o período indicado, sendo de 13,13\%. Logo em seguida está Diadema, com 10,19\%. Já a menor taxa de crescimento geométrico é de São Caetano do Sul, de apenas 1,85\% para os anos de 1950 a 2010.

27 Barueri, atualmente, concentra empresas, incentivadas por política fiscal, e empreendimentos de luxo, em uma paisagem de contrastes entre construções fechadas, como loteamentos industriais e habitacionais de alta renda, e a cidade tradicional. 
palmente no extremo leste, como é o caso de Cidade Tiradentes ${ }^{28}$, apresentada no capítulo 5.

O incremento populacional, somado à falta de políticas habitacionais eficientes para atender os segmentos de menor renda, fez a expansão urbana ser marcada por habitações informais, inclusive em regiões inadequadas à urbanização. Com isso, se deteriora não apenas a qualidade de vida, mas também o meio biofísico, devido a processos urbanos em áreas ambientalmente frágeis.

Santiago do Chile também passou por períodos de crescimento urbano associados a ciclos econômicos. O primeiro deles foi a produção agrícola de trigo e extração de salitre, diversificando-se na segunda metade do século XIX, com mais produtos agrícolas e exploração mineral. Similarmente a São Paulo, são os anos 1930-1950 que marcaram uma expansão da mancha urbana representativa do recebimento de incremento populacional nos centros urbanos. É nesse momento que os centros urbanos, principalmente Santiago, recebem um maior contingente de trabalhadores. Nesse período, Santiago se consolidava como o principal centro econômico, financeiro e político do país.

A urbanização de Santiago, desde os tempos de sua fundação, foi realizada por hierarquia socioespacial, marcada pelo "acima" do Rio Mapocho (ao norte), local de moradia da elite, inicialmente mais próximo ao centro, e depois se expandido para áreas mais distantes do setor norte e nordeste, e "abaixo" (ao sul), onde se consolidavam os bairros populares. Essa delimitação foi formalizada por um primeiro planejamento urbano, em 1870, o Plan Regulador, que marcou a passagem de cidade primário-exportadora para centro econômico e financeiro do país.

O Plano delimitou urbanisticamente um divisor, chamado de "camino de cintura", medida também higienista, que criou uma barreira vegetal no entorno dos bairros de elite e terrenos a serem ocupados por sua expansão, que hoje corresponde, ao norte, à beira do rio Mapocho; ao sul, às avenidas Matta e Blanco Encalada; no oriente, à Avenida Vicuña Mackenna e, no poente, à Avenida Matucana. Por outro lado, o Plan Regulador também buscava realizar bairros operários "saudáveis" em setores distantes do "camino de cintura" (ESPINOZA, 1988).

Após a crise de 1929, inicia-se uma mudança de orientação econômica no Chile, buscando reduzir a dependência do país da economia internacional. Essas orientações foram visíveis não só na economia, mas também na política social, com diversas medidas de corte que favoreciam os setores médios, como os arranjos institucionais para os trabalhadores. Segundo Espinoza (1988), o período de crise dos anos 1930 consolidou a relevância de Santiago como principal centro urbano, com grande incremento populacional.

Esse crescimento habitacional em Santiago, espacialmente, teve grande conexão com a indústria que se estabelecia em localizações periféricas ao centro, o que estimulou a expansão viária. Já os setores com habitação de alta renda se expandiam na direção do oriente, enquanto os setores populares se expandiam nas zonas sul e norte, convertendo progressivamente terrenos agrícolas em solo urbano, seguindo um modelo de expansão horizontal. Segundo Espinoza (1988),

28 O distrito de Cidade Tiradentes, no extremo leste de São Paulo, teve um crescimento populacional de $8 \%$ a 18\% nas décadas de 1980 a 1990 (ROLNIK, 2004), abrigando principalmente população de menor renda em conjuntos de habitação social e loteamentos irregulares, acentuando a desigualdade e uma inclusão social periférica. 
La tendencia al crecimiento en extensión puede apreciarse a partir del examen de las tasas de crecimiento intercensal por comunas. Mientras en el período 1907-1920, de las 17 comunas de Santiago siete crecieron a tasas anuales superiores al promedio, en el período 1920-1930 fueron doce las comunas que lo superaron. (...) Providencia refleja el desplazamiento de los sectores de alto ingreso hacia la zona oriente, mientras Ñuñoa, San Miguel y Quinta Normal corresponden a asentamientos de sectores de ingreso mediano y bajo. (p. 124)

O Censo de 1940 mostrou que Santiago tinha 1.268 .505 habitantes, passando, em 1952, a 1.754.954 habitantes e, em 1960, para 2.437.42529. Segundo Rodríguez (1993),

(...) Entre 1940 y 1970, la población del Gran Santiago creció a un ritmo superior al 3 por ciento anual, aunque en la década de los años 50 tuvo un promedio levemente superior al 4 por ciento anual. Desde el censo de 1970 en adelante se registra una atenuación de la velocidad del crecimiento demográfico de la ciudad, coincidente con la moderación del incremento de la población nacional, producto del descenso generalizado de la fecundidad (...) la tasa media anual de crecimiento de la población entre 1970 y 1982 alcanzó a un 2.6 por ciento y se redujo a 1.7 por ciento entre 1982 y 1992 (p. 100).

Nos anos 1950 e 1960, com o impulso do crescimento urbano e populacional derivado da industrialização, a política pública passou a realizar operações nas comunas onde se concentravam os setores populares e as maiores ocupações de terrenos. Em Cerro Navia, por exemplo, uma das primeiras operações ocorreu com a ocupação popular Callampa Colo-Colo, nos terrenos da Chácara Lo Amor, resultando em um programa de construção de habitações (GALLEGUILLOS et al., 1992).

A precariedade habitacional aumentava em Santiago juntamente com seu crescimento, havendo, em 1960, 12\% da população vivendo em habitações irregulares - compostas de acampamentos e conventillos ${ }^{30}$-, número que cresce para $16 \%$ em 1970, quando se intensificaram as ocupações de terrenos (ESPINOZA, 1988). Essas ocupações, realizadas por famílias organizadas, foram também responsáveis pela expansão da mancha urbana para áreas periféricas, com ocupações de antigas chácaras, sítios e outros terrenos rurais que, posteriormente, foram loteados legalmente para abrigar essas e outras famílias.

Como exemplo de ocupações, as chamadas tomas de terreno, pode-se citar o caso de Cerro Navia, cujo estudo de caso, o conjunto habitacional Las Viñitas, será apresentado no capítulo 7. Cerro Navia é uma comuna localizada no setor noroeste da região metropolitana, que tem sua origem nas ocupações de terrenos rurais.

Nos governos populares de Frei e Allende (1964 a 1973), estimularam-se, nas comunas periféricas, a participação social e o desenvolvimento de grupos populares, o que levou ao desenvolvimento de sindicatos e à promulgação da Lei de Juntas de Vecinos (lei 16.880, de 1968) ${ }^{31}$.

29 Disponível em: < http://www.ine.cl/canales/chile_estadistico/censos/censo_poblacion_vivienda.php>. Acessado em 5 dez. 2016.

30 Habitações coletivas em formato de inquilinato.

31 Essa lei reconhece as diversas organizações comunitárias como representantes sociais e políticas, inclusive com presença de mulheres pela participação dos Centros de Madres. A lei, atuante até os dias de hoje, contribuiu para o maior reconhecimento legal das organizações. 
Nos anos 1960 e 1970, as ocupações aumentaram devido ao rápido crescimento populacio$\mathrm{nal}^{32}$.

Muitas comunas foram oficializadas em 1981 no processo de reformulação comunal da Grande Santiago, período em que o número de comunas aumentou de 17 para 33. Coincidentemente, essa nova divisão acentuou ainda mais a segregação socioespacial, já que os critérios não eram necessariamente físicos ou econômicos, mas principalmente classistas, separando comunas com população mais pobre ou rica, como ocorreu com Peñalolén e Cerro Navia (CERRO NAVIA, 2012).

Similarmente, Hardy e Legassa (1989) e De Mattos (1999) comentam que, a partir do golpe militar (1973) e da instalação do modelo neoliberal (1975), altera-se a estrutura socioeconômica e populacional, agravando desigualdades e atuando em favor de uma maior homogeneidade socioeconômica nas comunas.

A liberalização econômica também estimulou a concentração populacional, industrial e de negócios na metrópole, impulsionando a expansão dos limites urbanos. Mesmo que o crescimento econômico tenha contribuído para uma relativa diminuição dos níveis de pobreza, os anos que se seguiram foram de concentração de estratos de renda similares em setores urbanos, o que acentuou a segregação socioespacial (DE MATTOS, 1999).

Esse padrão de concentração de estratos de renda passa também a se consolidar, nos anos 1990, com a criação dos primeiros projetos imobiliários fechados, primeiramente em comunas de menores recursos, como Puente Alto, Peñalolén e Huechuraba, e que passaram para comunas de maiores recursos, como Las Condes, Providencia, La Reina, Lo Barnechea, Ñuñoa e Vitacura, criando condomínios de habitações unifamiliares e condomínios de prédios de pequena e grande escala, de alta renda, principalmente nas comunas do setor oriente, e de média e baixa renda, nos outros setores (HIDALGO, 2004).

Nos anos 1990-2000, o padrão condominial habitacional se distribui também em comunas da Região Metropolitana, como Pirque, Calera de Tango, Padre Hurtado, Lampa e Colina, com ofertas de diferentes agentes e para todos os setores econômicos. A alta renda, assim, passa também a comunas que antes concentravam menores recursos o que, se por um lado diminuiu a distância física entre ricos e pobres, por outro, não diminuiu a segregação social, acentuada por novos muros (HIDALGO, 2004).

A RMS dos anos 2000 se configura em comunas de alta renda, com espaços livres bastante qualificados e bem distribuídos, e comunas de média e baixa renda, com espaços livres pouco qualificados, mas relativamente bem distribuídos. São muitos os espaços livres fragmentados em ambas regiões metropolitanas com potencial para espaços de recreação, conexão, preservação e conservação ambiental.

A herança da ocupação anterior de um espaço condiciona, muitas vezes, a sua ocupação futura. S. Carvalho (2011) define "herança" como todos os aspectos que ainda se desenvolvem no cotidiano, como a forma de morar, de construir, os padrões morfológicos e as regulações urbanas, dentre outros aspectos materiais e imateriais.

32 Na região da Comuna Cerro Navia, antiga Barrancas, por exemplo, esse crescimento significou o surgimento de diversas ocupações, entre elas: Neptuno (1962), Herminda de la Victoria (março de 1967), Violeta Parra (fevereiro de 1969) e Montijo (agosto de 1969) (GALLEGUILLOS et al., 1992). 
Essa herança condicionada e condicionante do espaço pode ser especialmente identificada em áreas ocupadas pelos opostos econômicos: grupos sociais de alta renda e de baixa renda. Assim, áreas de ocupações irregulares históricas por população de baixos recursos acabam por se consolidar urbanisticamente e se transformar em zonas urbanas que concentram setores econômicos similares.

Também áreas de alta renda, que se consolidaram em momentos de expansão urbana das regiões metropolitanas em bairros planejados e ajardinados, caso do Jardim Europa (figura 33) em São Paulo e da comuna Vitacura (figuras 34 e 35) no Chile, se mantêm densamente arborizados e com lotes de maiores dimensões, apesar de pressões urbanas pelo contrário, graças à força política e econômica que essas elites possuem. Em setores de Vitacura, a pressão imobiliária já conseguiu maior verticalização, com edifícios habitacionais destinados à população de alta renda, diferentemente do que ocorre no Jardim América, Europa e similares, que se mantém horizontalizados, como consequência do poder político de moradores de elite que bloqueiam mudanças na regulamentação urbanística dos bairros jardins de São Paulo.

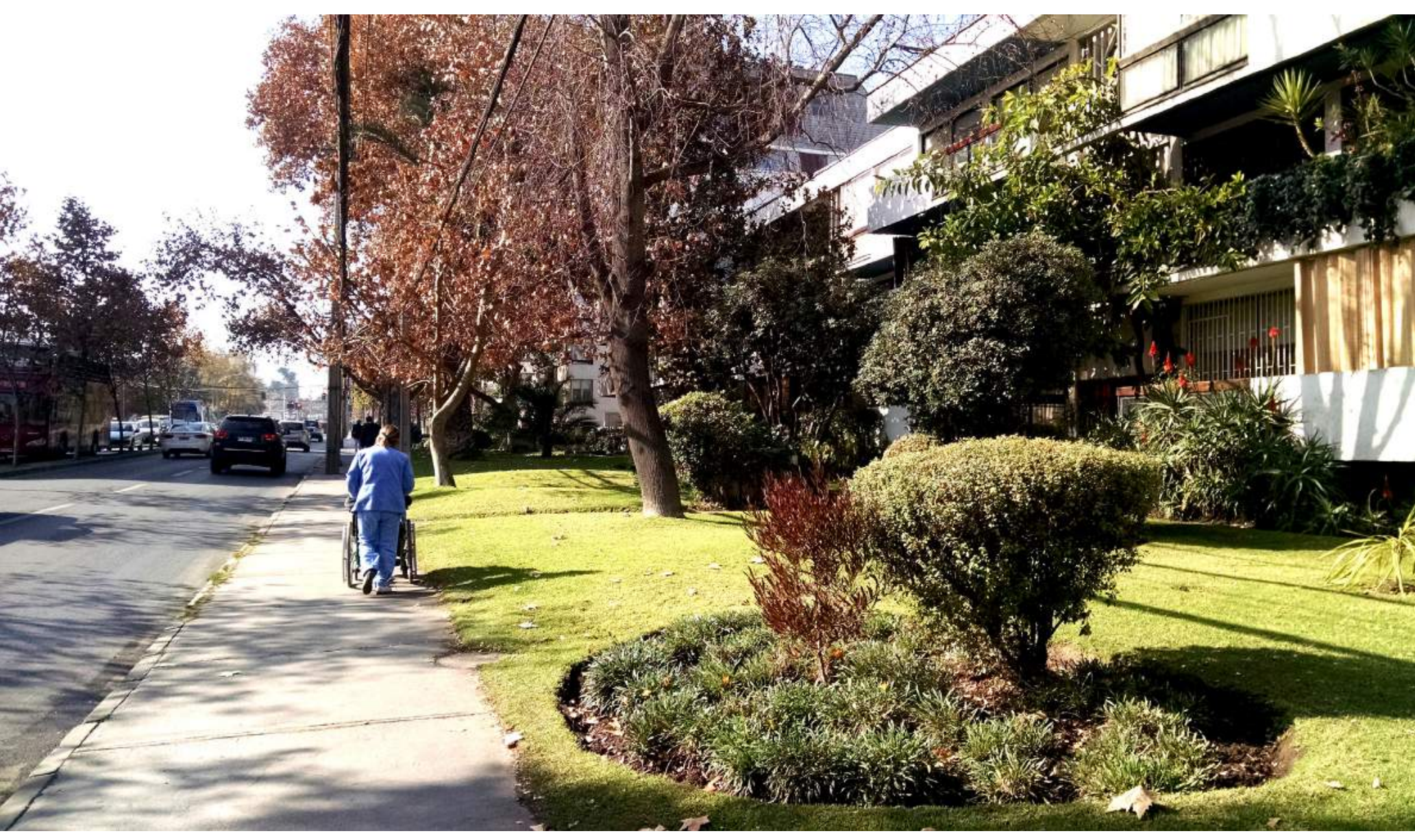

Figura 35: Rua da comuna de Vitacura. Destacam-se recuos generosos, transparência nos fechamentos e muitos edifícios habitacionais sem fechamento para a rua, com delimitação do público e privado com jardins e desenho de piso. Fotografia da autora, jun. 2016. 
Whos:

H.

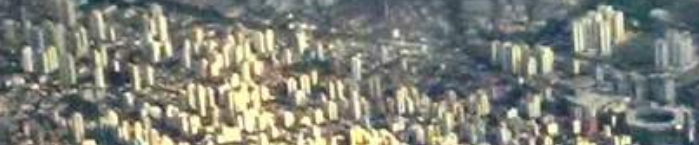

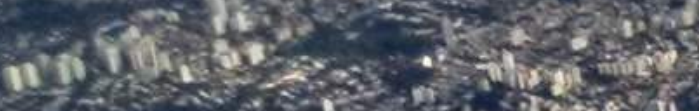
15.

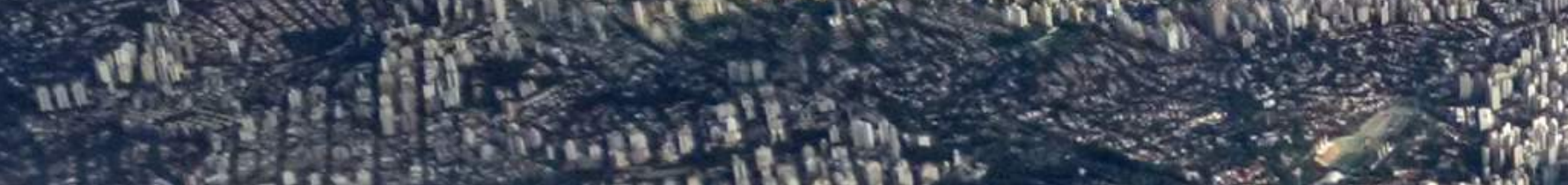

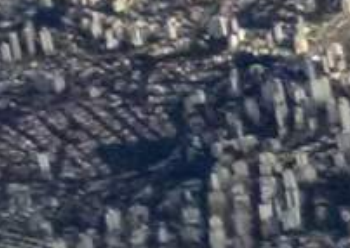

atention

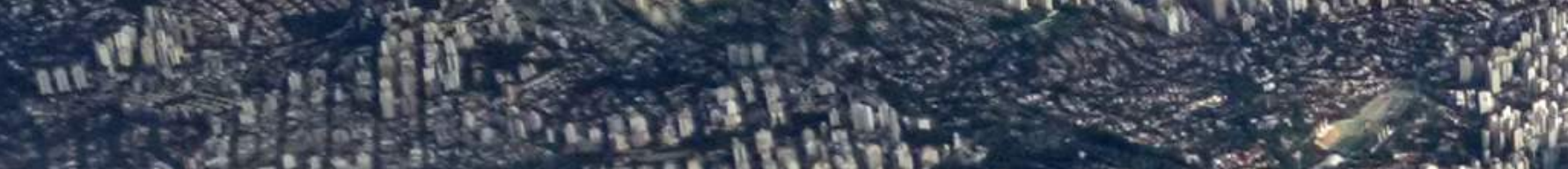

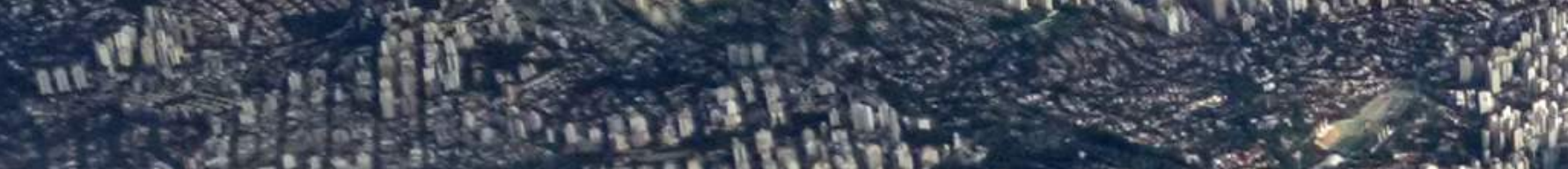
intwich

60

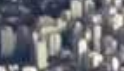
$6 x^{2}$ Nonothen. 25.

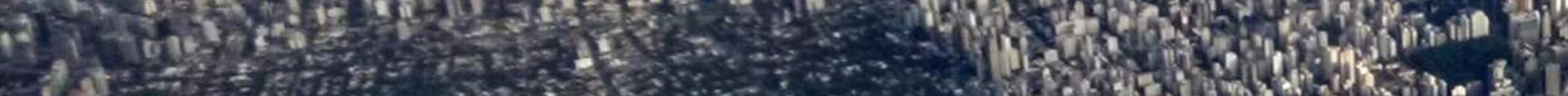
(2)

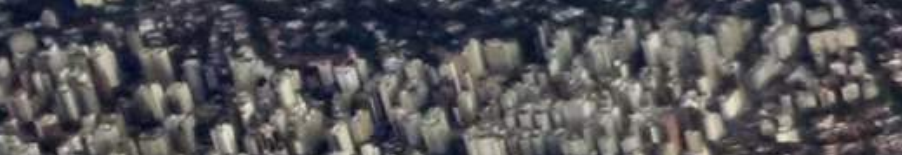

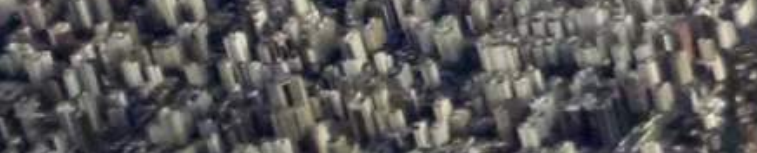

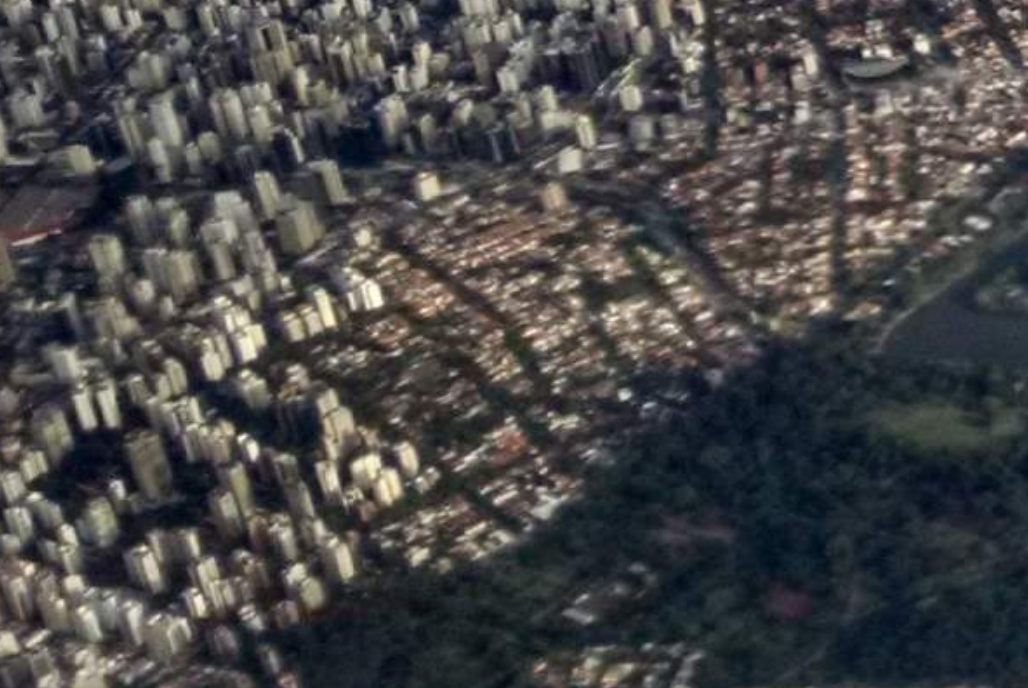

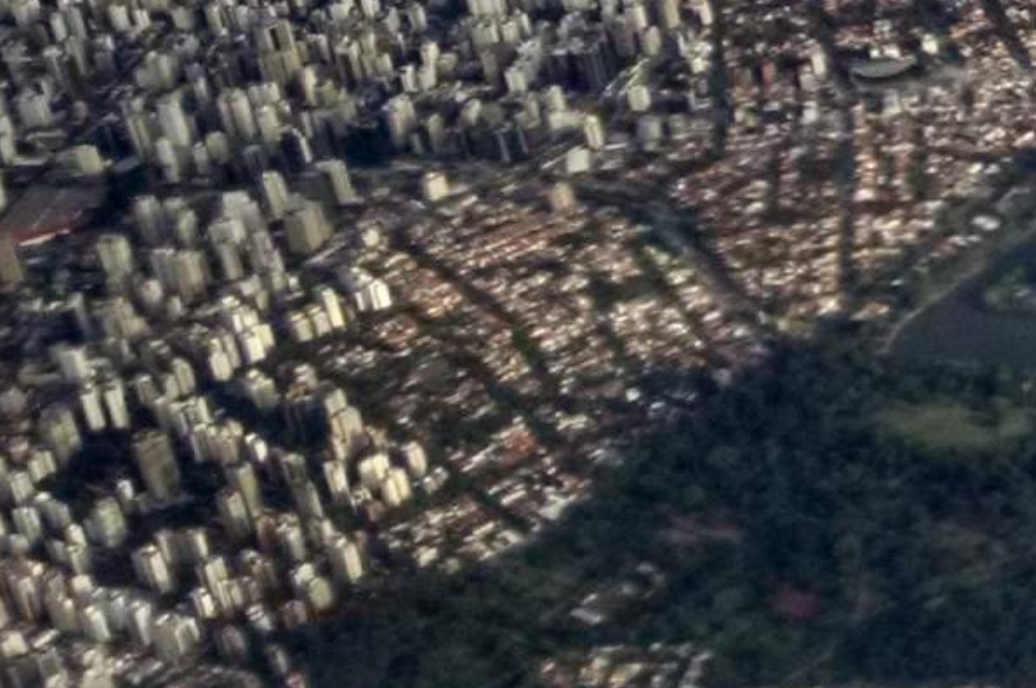

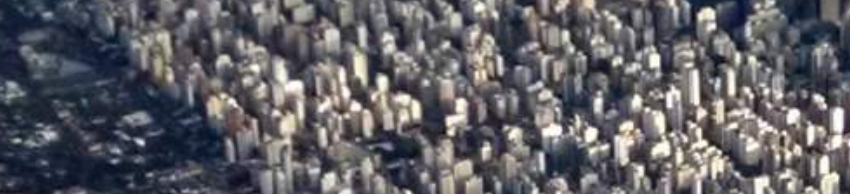

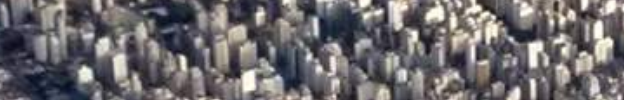

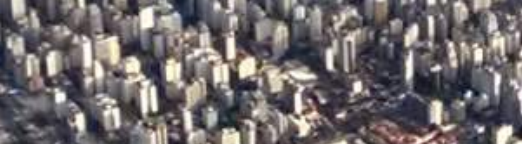

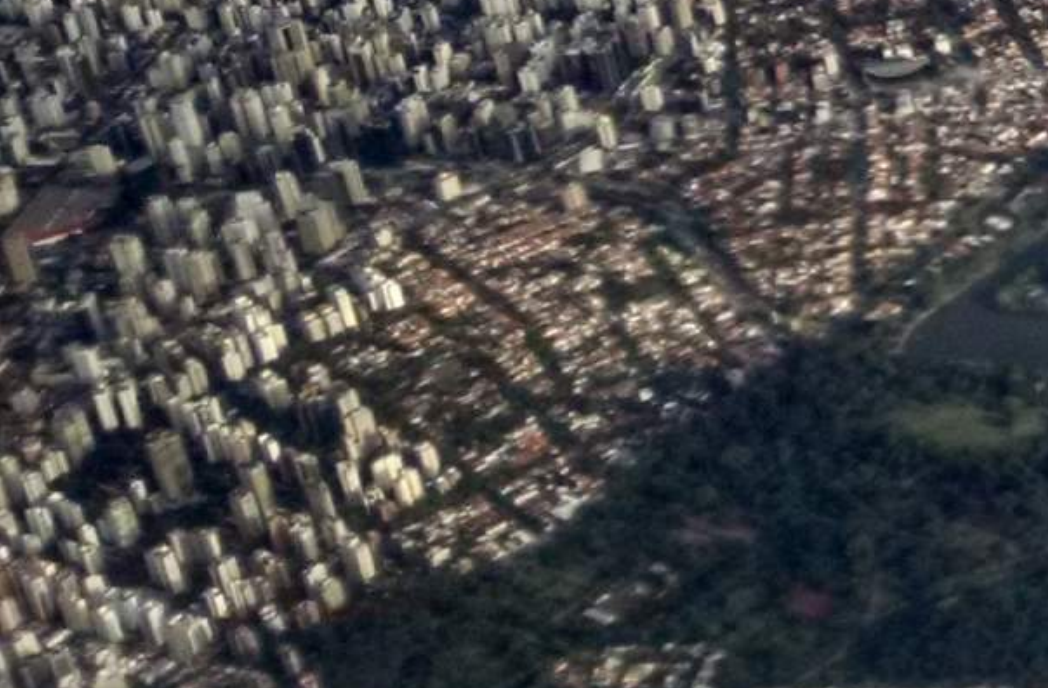

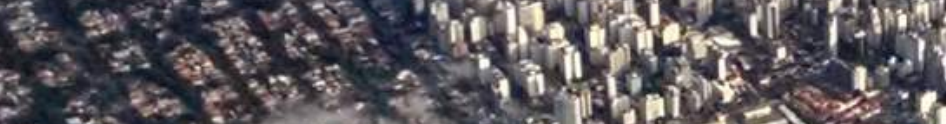

\subsection{0 .}

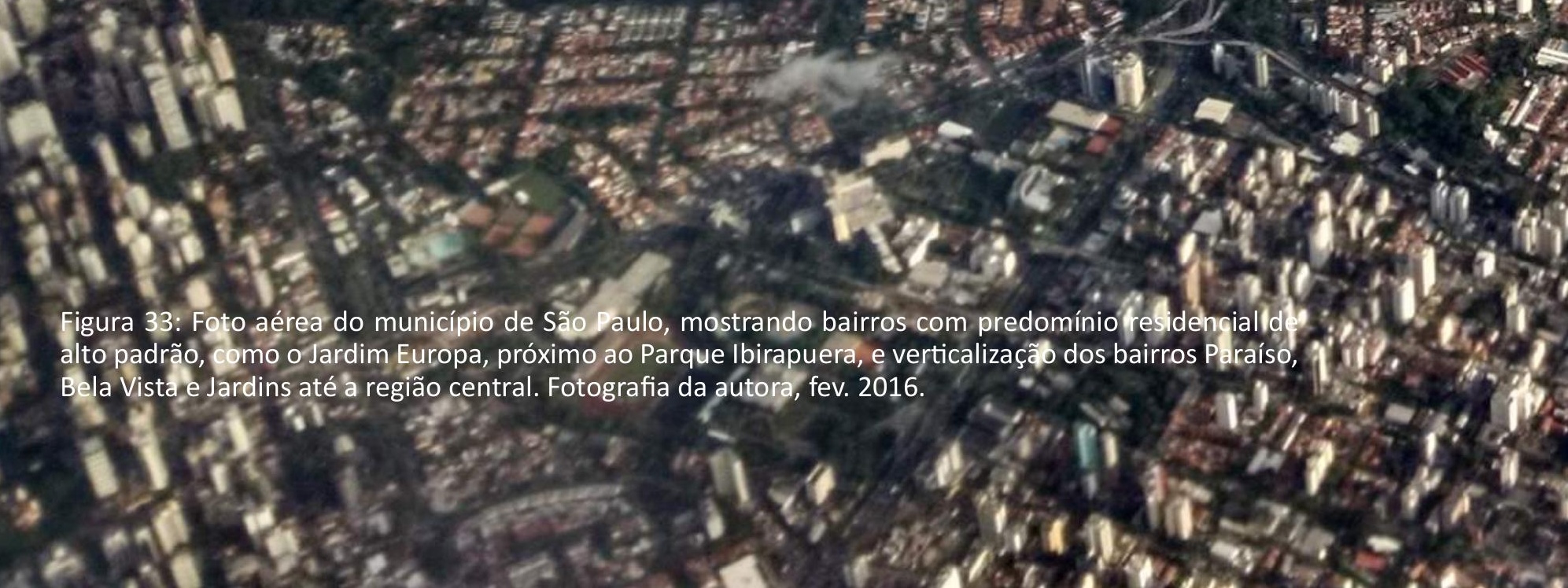




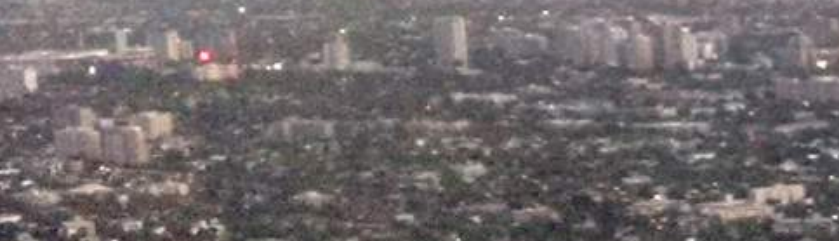

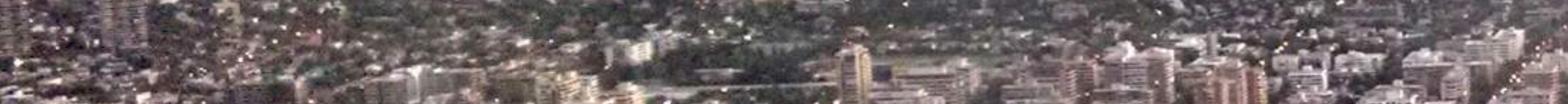

(4)

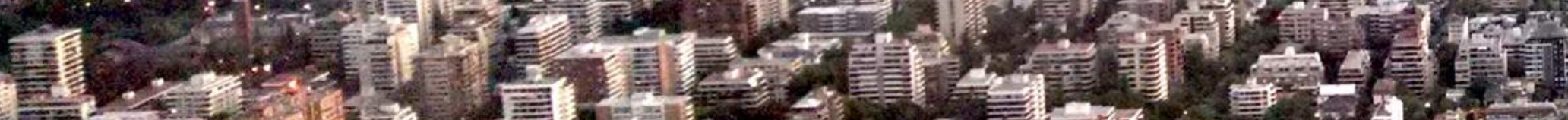

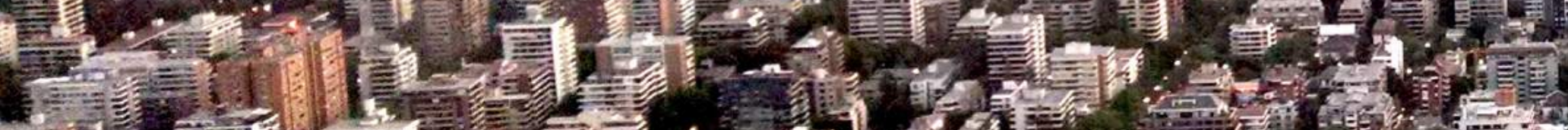
H.




Estimulada, até os dias atuais, pela elite, ambas as regiões metropolitanas têm suas decisões urbanas orientadas por interesses particulares, mesmo que isso signifique, muitas vezes, dificultar o cotidiano de classes menos favorecidas e, consequentemente, aumentar o abismo que separa as classes sociais.

Em ambas as regiões, destacam-se a fragmentação e a dispersão urbana também por novos lugares de moradia, com o deslocamento da população - de todas as classes econômicas - por vias expressas, incentivando o transporte particular e o desejo de aquisição de um automóvel para facilitar os deslocamentos cotidianos. Essa dispersão habitacional já era um processo que Langenbuch (1971) destacou nos anos 1970 na RMSP, com a busca de terrenos com ares campestres para habitação das classes média e alta, e que continua a ocorrer em ambas as metrópoles.

\section{Dados comparativos atuais em tabelas}

A seguir, serão apresentadas tabelas comparativas entre ambas as regiões metropolitanas (Santiago e São Paulo). Quando se mapeiam dados de renda, é possível verificar que os municípios e comunas que concentram maiores rendas concentram também maiores índices de desenvolvimento humano (IDHM no Brasil e IDHC no Chile) e menor porcentagem de pessoas em situação de pobreza. Também é possível relacionar essa alta renda com outros dados, como em relação à frota de automóveis: quanto maior a renda, maior o número de veículos por mil habitantes.

Neste sentido, buscou-se associar diversos dados coletados, quando possível, no mesmo ano, para ambas as regiões metropolitanas, de maneira a permitir análises de correlações e algumas análises comparativas ${ }^{33}$. Foram reunidos dados de PIB/per capita a preços correntes (IBGE, 2013), Ingreso Monetario ${ }^{34}$ (MIDEPLAN, 2006), Incidência de pobreza (IBGE 2003), Porcentagem de pessoas em situação de pobreza por ingresso (Chile, 2013), frota de automóveis e motos (DENATRAN, 2014 e INE, 2014) e número de ocorrências policiais anuais de delitos violentos ${ }^{35}$, tráfico e porte de drogas (Secretaria de Segurança Pública do Estado de São Paulo), 2014 e Carabineros Chile, 2014). No caso dos dados de frota de automóveis e motos foi possível utilizar a mesma variável de análise para ambos os países, o que permite, para esses dois dados, a análise comparativa direta.

33 Foram privilegiados dados de 2014 pela facilidade de coletá-los em ambos os países. Porém, alguns dados se encontram defasados, como em relação ao Ingreso Monetario de Santiago e à incidência de pobreza no Brasil. Por outro lado, a defasagem desses dados pode ser complementada pelos dados de frota de veículos.

34 O Ingreso Monetario é um dado chileno composto pela somatória dos Ingresos Autónomos (que são todos os pagamentos que recebe o lar, tais como salários, renda por trabalho independente, pensões, aposentadorias) e dos Subsídios Monetarios (composto por subsídios do Estado, tais como Pensión Asistencial de Ancianidad - PASIS, Subsidio Único Familiar - SUF, Subsidio al Agua Potable - SAP, subsídios do Estado para aposentadoria e para auxílio na educação dos filhos, as chamadas asignaciones familiares).

35 Por delitos violentos incluem-se os casos de homicídio doloso (incluindo homicídio doloso por acidente de trânsito), latrocínio, lesão corporal dolosa e estupro. O Carabineros Chile agrupa em delitos violentos os casos de roubo com violência, roubo com intimidação, roubo por surpresa, lesões, homicídios e violações. 


\begin{tabular}{|c|c|c|c|c|c|c|c|c|}
\hline Municípios & $\begin{array}{c}\text { População } \\
\text { estimada } \\
\text { (IBGE } \\
2014 \text { ) }\end{array}$ & $\begin{array}{c}\text { PIB/per capita } \\
\text { a preços cor- } \\
\text { rentes (IBGE } \\
2013)\end{array}$ & $\begin{array}{c}\text { Índice de } \\
\text { Desenvolvimento } \\
\text { Humano } \\
\text { Municipal IDHM } \\
\text { (IBGE 2010) } \\
\text { Desenvolvimento } \\
\text { Humano } \\
\text { Municipal IDHM } \\
\text { (IBGE 2010) }\end{array}$ & $\begin{array}{l}\text { Incidência } \\
\text { de Pobre- } \\
\text { za (IBGE } \\
\text { 2003) }\end{array}$ & $\begin{array}{c}\text { Frota de } \\
\text { automóveis } \\
\text { (DENA- } \\
\text { TRAN, } \\
\text { dezembro } \\
\text { de 2014) e } \\
\text { número de } \\
\text { automóveis } \\
\text { por mil } \\
\text { habitantes } \\
(2014)\end{array}$ & $\begin{array}{l}\text { Frota de } \\
\text { motos (DE- } \\
\text { NATRAN, } \\
\text { dezembro } \\
\text { de 2014) e } \\
\text { número de } \\
\text { motos por } \\
\text { mil habitan- } \\
\text { tes (2014) }\end{array}$ & $\begin{array}{c}\text { Número e } \\
\text { porcentagem } \\
\text { de ocorrên- } \\
\text { cias policiais } \\
\text { anuais regis- } \\
\text { tradas de de- } \\
\text { litos violentos } \\
\text { (Secretaria } \\
\text { da Segurança } \\
\text { Pública, 2014) }\end{array}$ & $\begin{array}{c}\text { Número e } \\
\text { porcentagem } \\
\text { de ocorrên- } \\
\text { cias anuais } \\
\text { registradas } \\
\text { de tráfico } \\
\text { e porte de } \\
\text { entorpecente } \\
\text { (Secretaria } \\
\text { da Segurança } \\
\text { Pública, 2014) }\end{array}$ \\
\hline Arujá & 82.651 & $\mathrm{R} \$ 35.344,96$ & 0,784 & $50,75 \%$ & $\begin{array}{c}30.473 \\
369\end{array}$ & $\begin{array}{c}5.516 \\
67\end{array}$ & $\begin{array}{c}413 \\
(0,50 \%)\end{array}$ & $\begin{array}{c}32 \\
(0,04 \%)\end{array}$ \\
\hline Barueri & 259.555 & $\mathrm{R} \$ 171.831,09$ & 0,786 & $45,46 \%$ & $\begin{array}{c}98.028 \\
378\end{array}$ & $\begin{array}{c}21.231 \\
82\end{array}$ & $\begin{array}{c}884 \\
(0,34 \%)\end{array}$ & $\begin{array}{c}273 \\
(0,11 \%)\end{array}$ \\
\hline $\begin{array}{l}\text { Biritiba-Mi- } \\
\quad \text { rim }\end{array}$ & 30.830 & $\mathrm{R} \$ 18.663,68$ & 0,712 & $60,93 \%$ & $\begin{array}{c}7.097 \\
230\end{array}$ & $\begin{array}{c}1.559 \\
51\end{array}$ & $\begin{array}{c}185 \\
(0,61 \%)\end{array}$ & $\begin{array}{c}46 \\
(0,15 \%)\end{array}$ \\
\hline Caieiras & 94.516 & $\mathrm{R} \$ 30.206,05$ & 0,781 & $44,93 \%$ & $\begin{array}{c}26.668 \\
282 \\
\end{array}$ & $\begin{array}{c}5.146 \\
54\end{array}$ & $\begin{array}{c}421 \\
(0,45 \%)\end{array}$ & $\begin{array}{c}31 \\
(0,03 \%)\end{array}$ \\
\hline Cajamar & 70.710 & $\mathrm{R} \$ 125.437,27$ & 0,728 & $56,52 \%$ & $\begin{array}{c}21.684 \\
307\end{array}$ & $\begin{array}{c}4.561 \\
65\end{array}$ & $\begin{array}{c}416 \\
(0,60 \%)\end{array}$ & $\begin{array}{c}50 \\
(0,07 \%)\end{array}$ \\
\hline Carapicuíba & 390.073 & $\mathrm{R} \$ 11.442,26$ & 0,749 & $46,74 \%$ & $\begin{array}{c}114.039 \\
292\end{array}$ & $\begin{array}{c}30.615 \\
78\end{array}$ & $\begin{array}{c}1009 \\
(0,26 \%)\end{array}$ & $\begin{array}{c}414 \\
(0,11 \%)\end{array}$ \\
\hline Cotia & 225.306 & $\mathrm{R} \$ 44.735,74$ & 0,780 & $45,80 \%$ & $\begin{array}{c}83.657 \\
371\end{array}$ & $\begin{array}{c}16.616 \\
74\end{array}$ & $\begin{array}{c}604 \\
(0,27 \%)\end{array}$ & $\begin{array}{c}146 \\
(0,07 \%)\end{array}$ \\
\hline Diadema & 409.613 & $\mathrm{R} \$ 33.015,67$ & 0,757 & $43,81 \%$ & $\begin{array}{c}119.182 \\
291 \\
\end{array}$ & $\begin{array}{c}37.554 \\
92 \\
\end{array}$ & $\begin{array}{c}1.048 \\
(0,26 \%)\end{array}$ & $\begin{array}{c}332 \\
(0,08 \%)\end{array}$ \\
\hline $\begin{array}{l}\text { Embu das } \\
\text { Artes }\end{array}$ & 259.053 & $\mathrm{R} \$ 31.635,32$ & 0,735 & $49,58 \%$ & $\begin{array}{c}62.858 \\
243\end{array}$ & $\begin{array}{c}18.749 \\
72 \\
\end{array}$ & $\begin{array}{c}525 \\
(0,20 \%)\end{array}$ & $\begin{array}{c}120 \\
(0,05 \%)\end{array}$ \\
\hline $\begin{array}{c}\text { Embu-Gua- } \\
\text { çu }\end{array}$ & 66.792 & $\mathrm{R} \$ 13.076,70$ & 0,749 & $53,86 \%$ & $\begin{array}{c}20.472 \\
307\end{array}$ & $\begin{array}{c}4.888 \\
73\end{array}$ & $\begin{array}{c}189 \\
(0,28 \%)\end{array}$ & $\begin{array}{c}48 \\
(0,07 \%)\end{array}$ \\
\hline $\begin{array}{c}\text { Ferraz de } \\
\text { Vasconcelos }\end{array}$ & 182.544 & $\mathrm{R} \$ 14.377,76$ & 0,738 & $57,38 \%$ & $\begin{array}{c}43.034 \\
236\end{array}$ & $\begin{array}{c}8.036 \\
44\end{array}$ & $\begin{array}{c}560 \\
(0,31 \%)\end{array}$ & $\begin{array}{c}53 \\
(0,03 \%)\end{array}$ \\
\hline $\begin{array}{c}\text { Francisco } \\
\text { Morato }\end{array}$ & 166.505 & $\mathrm{R} \$ 7.415,68$ & 0,703 & $66,89 \%$ & $\begin{array}{c}27.220 \\
163\end{array}$ & $\begin{array}{c}7.514 \\
45\end{array}$ & $\begin{array}{c}358 \\
(0,22 \%)\end{array}$ & $\begin{array}{c}80 \\
(0,05 \%)\end{array}$ \\
\hline $\begin{array}{c}\text { Franco da } \\
\text { Rocha }\end{array}$ & 143.817 & $\mathrm{R} \$ 16.407,64$ & 0,731 & $53,46 \%$ & $\begin{array}{c}32.100 \\
223\end{array}$ & $\begin{array}{c}7.734 \\
54\end{array}$ & $\begin{array}{c}649 \\
(0,46 \%)\end{array}$ & $\begin{array}{c}116 \\
(0,08 \%)\end{array}$ \\
\hline Guararema & 28.016 & $\mathrm{R} \$ 60.943,13$ & 0,731 & $49,56 \%$ & $\begin{array}{c}8.965 \\
320\end{array}$ & $\begin{array}{c}2.559 \\
91\end{array}$ & $\begin{array}{c}148 \\
(0,53 \%)\end{array}$ & $\begin{array}{c}22 \\
(0,08 \%)\end{array}$ \\
\hline Guarulhos & 1.312 .197 & $\mathrm{R} \$ 38.016,46$ & 0,763 & $43,21 \%$ & $\begin{array}{c}401.570 \\
306\end{array}$ & $\begin{array}{c}76.946 \\
59\end{array}$ & $\begin{array}{c}3.507 \\
(0,27 \%)\end{array}$ & $\begin{array}{c}690 \\
(0,05 \%)\end{array}$ \\
\hline
\end{tabular}




\begin{tabular}{|c|c|c|c|c|c|c|c|c|}
\hline Itapevi & 220.250 & $R \$ 39.198,54$ & 0,735 & $61,86 \%$ & $\begin{array}{c}53.448 \\
243\end{array}$ & $\begin{array}{c}15.980 \\
73\end{array}$ & $\begin{array}{c}808 \\
(0,37 \%)\end{array}$ & $\begin{array}{c}225 \\
(0,10 \%)\end{array}$ \\
\hline $\begin{array}{l}\text { Itapecerica } \\
\text { da Serra }\end{array}$ & 165.327 & $\mathrm{R} \$ 19.213,78$ & 0,742 & $54,62 \%$ & $\begin{array}{c}42.743 \\
259\end{array}$ & $\begin{array}{c}12.035 \\
73\end{array}$ & $\begin{array}{c}432 \\
(0,26 \%)\end{array}$ & $\begin{array}{c}171 \\
(0,10 \%)\end{array}$ \\
\hline $\begin{array}{l}\text { Itaquaque- } \\
\text { cetuba }\end{array}$ & 348.739 & $\mathrm{R} \$ 14.687,81$ & 0,714 & & $\begin{array}{c}67.722 \\
194 \\
\end{array}$ & $\begin{array}{c}16.437 \\
47\end{array}$ & $\begin{array}{c}1.627 \\
(0,47 \%)\end{array}$ & $\begin{array}{c}256 \\
(0,07 \%)\end{array}$ \\
\hline Jandira & 117.457 & $\mathrm{R} \$ 25.055,27$ & 0,760 & $50,81 \%$ & $\begin{array}{c}31.817 \\
271\end{array}$ & $\begin{array}{c}8.693 \\
74\end{array}$ & $\begin{array}{c}524 \\
(0,45 \%)\end{array}$ & $\begin{array}{c}97 \\
(0,08 \%)\end{array}$ \\
\hline Juquitiba & 30.443 & $\mathrm{R} \$ 13.858,41$ & 0,709 & $52,16 \%$ & $\begin{array}{c}7.967 \\
262\end{array}$ & $\begin{array}{c}2.228 \\
73\end{array}$ & $\begin{array}{c}154 \\
(0,51 \%)\end{array}$ & $\begin{array}{c}8 \\
(0,02 \%)\end{array}$ \\
\hline Mairiporã & 90.627 & $\mathrm{R} \$ 16.367,14$ & 0,788 & $39,74 \%$ & $\begin{array}{c}28.828 \\
318\end{array}$ & $\begin{array}{c}7.446 \\
82\end{array}$ & $\begin{array}{c}419 \\
(0,47 \%)\end{array}$ & $\begin{array}{c}58 \\
(0,06 \%)\end{array}$ \\
\hline Mauá & 448.776 & $\mathrm{R} \$ 23.012,73$ & 0,766 & $46,61 \%$ & $\begin{array}{c}135.556 \\
302\end{array}$ & $\begin{array}{c}30.993 \\
69\end{array}$ & $\begin{array}{c}906 \\
(0,20 \%)\end{array}$ & $\begin{array}{c}227 \\
(0,05 \%)\end{array}$ \\
\hline $\begin{array}{l}\text { Mogi das } \\
\text { Cruzes }\end{array}$ & 419.839 & $\mathrm{R} \$ 31.133,55$ & 0,783 & $43,60 \%$ & $\begin{array}{c}141.491 \\
337 \\
\end{array}$ & $\begin{array}{c}25.503 \\
61 \\
\end{array}$ & $\begin{array}{c}975 \\
(0,23 \%)\end{array}$ & $\begin{array}{c}269 \\
(0,06 \%)\end{array}$ \\
\hline Osasco & 693.271 & $\mathrm{R} \$ 80.265,37$ & 0,776 & $38,75 \%$ & $\begin{array}{c}264.334 \\
381\end{array}$ & $\begin{array}{c}57.128 \\
82\end{array}$ & $\begin{array}{c}2.369 \\
(0,34 \%)\end{array}$ & $\begin{array}{c}470 \\
(0,07 \%)\end{array}$ \\
\hline $\begin{array}{l}\text { Pirapora do } \\
\text { Bom Jesus }\end{array}$ & 17.372 & $\mathrm{R} \$ 18.952,62$ & 0,727 & & $\begin{array}{c}3.812 \\
219 \\
\end{array}$ & $\begin{array}{c}1.186 \\
68\end{array}$ & $\begin{array}{c}50 \\
(0,29 \%)\end{array}$ & $\begin{array}{c}42 \\
(0,24 \%)\end{array}$ \\
\hline Poá & 112.917 & $\mathrm{R} \$ 46.993,02$ & 0,771 & $47,21 \%$ & $\begin{array}{c}32.612 \\
289\end{array}$ & $\begin{array}{c}6.123 \\
54\end{array}$ & $\begin{array}{c}487 \\
(0,43 \%)\end{array}$ & $\begin{array}{c}87 \\
(0,08 \%)\end{array}$ \\
\hline $\begin{array}{l}\text { Ribeirão } \\
\text { Pires }\end{array}$ & 119.644 & $\mathrm{R} \$ 22.380,19$ & 0,784 & $36,27 \%$ & $\begin{array}{c}43.228 \\
361 \\
\end{array}$ & $\begin{array}{c}6.002 \\
50 \\
\end{array}$ & $\begin{array}{c}400 \\
(0,34 \%)\end{array}$ & $\begin{array}{c}32 \\
(0,03 \%)\end{array}$ \\
\hline $\begin{array}{l}\text { Rio Grande } \\
\text { da Serra }\end{array}$ & 47.731 & $\mathrm{R} \$ 11.057,29$ & 0,749 & $61,04 \%$ & $\begin{array}{c}11.169 \\
234\end{array}$ & $\begin{array}{c}2.294 \\
48\end{array}$ & $\begin{array}{c}207 \\
(0,44 \%)\end{array}$ & $\begin{array}{c}32 \\
(0,07 \%)\end{array}$ \\
\hline Salesópolis & 16.576 & $\mathrm{R} \$ 10.021,33$ & 0,732 & $47,22 \%$ & $\begin{array}{c}5.245 \\
316 \\
\end{array}$ & $\begin{array}{c}1.919 \\
116\end{array}$ & $\begin{array}{c}91 \\
(0,55 \%)\end{array}$ & $\begin{array}{c}11 \\
(0,07 \%)\end{array}$ \\
\hline Santa Isabel & 54.363 & $R \$ 24.355,09$ & 0,738 & $44,82 \%$ & $\begin{array}{c}14.599 \\
269\end{array}$ & $\begin{array}{c}5.046 \\
93\end{array}$ & $\begin{array}{c}234 \\
(0,43 \%)\end{array}$ & $\begin{array}{c}51 \\
(0,09 \%)\end{array}$ \\
\hline $\begin{array}{c}\text { Santana de } \\
\text { Parnaíba }\end{array}$ & 123.825 & $\mathrm{R} \$ 60.939,87$ & 0,814 & $43,13 \%$ & $\begin{array}{c}45.076 \\
364\end{array}$ & $\begin{array}{c}8.989 \\
73\end{array}$ & $\begin{array}{c}337 \\
(0,28 \%)\end{array}$ & $\begin{array}{c}78 \\
(0,06 \%)\end{array}$ \\
\hline Santo André & 707.613 & $R \$ 35.503,52$ & 0,815 & $26,73 \%$ & $\begin{array}{c}352.905 \\
499\end{array}$ & $\begin{array}{c}61.095 \\
86\end{array}$ & $\begin{array}{c}1.915 \\
(0,27 \%)\end{array}$ & $\begin{array}{c}264 \\
(0,04 \%)\end{array}$ \\
\hline $\begin{array}{l}\text { São Ber- } \\
\text { nardo do } \\
\text { Campo }\end{array}$ & 811.489 & $\mathrm{R} \$ 59.149,80$ & 0,805 & $28,03 \%$ & $\begin{array}{c}380.166 \\
468\end{array}$ & $\begin{array}{c}64.877 \\
80\end{array}$ & $\begin{array}{c}1.816 \\
(0,22 \%)\end{array}$ & $\begin{array}{c}329 \\
(0,04 \%)\end{array}$ \\
\hline $\begin{array}{l}\text { São Caeta- } \\
\text { no do Sul }\end{array}$ & 157.205 & $\mathrm{R} \$ 97.889,94$ & 0,862 & $12,18 \%$ & $\begin{array}{c}99.921 \\
636 \\
\end{array}$ & $\begin{array}{c}11.219 \\
71 \\
\end{array}$ & $\begin{array}{c}244 \\
(0,16 \%)\end{array}$ & $\begin{array}{c}23 \\
(0,01 \%)\end{array}$ \\
\hline $\begin{array}{l}\text { São Louren- } \\
\text { ço da Serra }\end{array}$ & 15.028 & $\mathrm{R} \$ 14.826,63$ & 0,728 & $52,41 \%$ & $\begin{array}{c}4.667 \\
311\end{array}$ & $\begin{array}{c}1.082 \\
72\end{array}$ & $\begin{array}{c}50 \\
(0,34 \%)\end{array}$ & $\begin{array}{c}6 \\
(0,04 \%)\end{array}$ \\
\hline
\end{tabular}

112 


\begin{tabular}{|c|c|c|c|c|c|c|c|c|}
\hline São Paulo & 11.895 .893 & $\mathrm{R} \$ 48.275,45$ & 0,805 & $28,09 \%$ & $\begin{array}{c}5.160 .727 \\
434 \\
\end{array}$ & $\begin{array}{c}833.664 \\
70 \\
\end{array}$ & $\begin{array}{l}36.223 \\
(0,31 \%)\end{array}$ & $\begin{array}{c}9.187 \\
(0,08 \%)\end{array}$ \\
\hline Suzano & 282.441 & $\mathrm{R} \$ 32.193,16$ & 0,765 & $53,99 \%$ & $\begin{array}{c}79.669 \\
282\end{array}$ & $\begin{array}{c}13.568 \\
48\end{array}$ & $\begin{array}{c}927 \\
(0,33 \%)\end{array}$ & $\begin{array}{c}195 \\
(0,07 \%)\end{array}$ \\
\hline $\begin{array}{c}\text { Taboão da } \\
\text { Serra }\end{array}$ & 268.321 & $\mathrm{R} \$ 27.899,50$ & 0,769 & $39,84 \%$ & $\begin{array}{c}76.131 \\
284\end{array}$ & $\begin{array}{c}20.141 \\
75\end{array}$ & $\begin{array}{c}467 \\
(0,18 \%)\end{array}$ & $\begin{array}{c}108 \\
(0,04 \%)\end{array}$ \\
\hline $\begin{array}{l}\text { Vargem } \\
\text { Grande } \\
\text { Paulista }\end{array}$ & 47.879 & $\mathrm{R} \$ 31.841,52$ & 0,770 & $53,80 \%$ & $\begin{array}{c}17.031 \\
356\end{array}$ & $\begin{array}{c}3.139 \\
66\end{array}$ & $\begin{array}{c}200 \\
(0,42 \%)\end{array}$ & $\begin{array}{c}37 \\
(0,08 \%)\end{array}$ \\
\hline
\end{tabular}

Legenda de cores:

$P I B$
$R \$ 7.000-R \$ 20.000$
$R \$ 21.000-R \$ 50.000$
$R \$ 51.000-R \$ 90.000$
$R \$ 91.000-R \$ 110.000$
Acima de $R \$ 111.000$

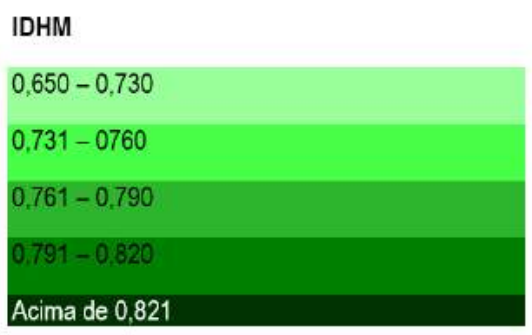

\section{Incidência de Pobreza}

$0-26 \%$

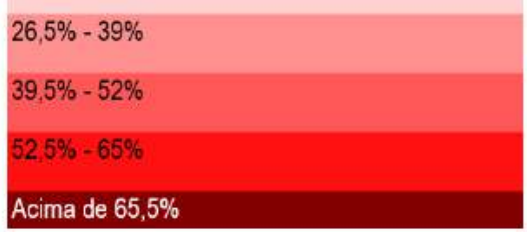

Automóveis por mil habitantes

Motos por mil habitantes

Menos de 250 automóveis por mil habitantes

De 251 a 350 automóveis por mil habitantes

De 351 a 450 automóveis por mil habitantes

De 451 a 550 automóveis por mil habitantes

Acima de 551 automóveis por mil habitantes

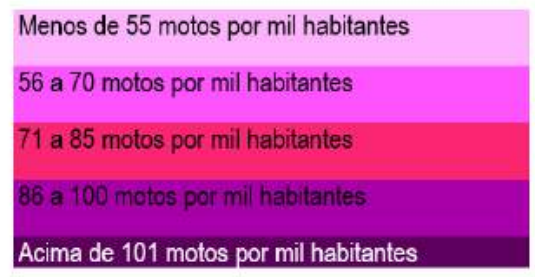

Porcentagem de ocorrências anuais de tráfico

Porcentagem de delitos violentos

e porte de entorpecente em relação ao

em relação ao número de habitantes

número de habitantes

$0,10 \%-0,20 \%$
$0,21 \%-0,30 \%$
$0,31 \%-0,40 \%$
$0,41 \%-0,50 \%$
Acima de $0,51 \%$

$0,01 \%-0,03 \%$
$0,04 \%-0,07 \%$
$0,08 \%-0,10 \%$
$0,11 \%-0,15 \%$
Acima de $0,16 \%$

Tabela 1: organizada pela autora, a partir de dados do Ministério das Cidades (2014) e IBGE (2003, 2010, 2011 e 2013), DENATRAN (2014) e Secretaria da Segurança Pública (2014):

População Estimada: Segundo dados do IBGE, disponíveis em <http://www.ibge.gov.br/home/estatistica/populacao/estimativa2014/estimativa_dou.shtm>. Visualizado em dez. 2016.

PIB per capita: Segundo dados do IBGE, disponíveis em < http://www.ibge.gov.br/home/estatistica/economia/ pibmunicipios/2010_2013/default.shtm>. Visualizado em dez. 2016.

IDHM: Segundo dados do IBGE, disponíveis em < http://www.cidades.ibge.gov.br/>. Visualizado em dez. 2016.

Frota de automóveis e motos: Segundo dados do Ministério das Cidades, DENATRAN, disponíveis em < http:// www.denatran.gov.br/index.php/estatistica/253-frota-2014>. Visualizado em dez. 2016.

Número de ocorrências policiais: Segundo dados do ESTADO DE SÃO PAULO, Secretaria da Segurança Pública, disponíveis em < http://www.ssp.sp.gov.br/novaestatistica/mapas.aspx>. Visualizado em dez. 2016. 


\begin{tabular}{|c|c|c|c|c|c|c|c|c|c|}
\hline Provincia & Comuna & $\begin{array}{l}\text { Estimativa } \\
\text { Población } \\
\text { (INE 2014) }\end{array}$ & $\begin{array}{c}\text { Ingreso } \\
\text { Monetario } \\
\text { (MIDE- } \\
\text { PLAN } \\
\text { 2006) }\end{array}$ & $\begin{array}{c}\text { Índice de } \\
\text { Desarrollo } \\
\text { Humano } \\
\text { Comunal } \\
\text { - IDHC } \\
\text { (PNUD } \\
2003 \text { ) }\end{array}$ & $\begin{array}{c}\text { Porcen- } \\
\text { tagem de } \\
\text { pessoas } \\
\text { em situa- } \\
\text { ção de } \\
\text { pobreza } \\
\text { (2013) }\end{array}$ & $\begin{array}{c}\text { Frota de } \\
\text { Automó- } \\
\text { veis e sta- } \\
\text { tion wagon } \\
\text { e número } \\
\text { de automó- } \\
\text { veis e sta- } \\
\text { tion wagon } \\
\text { por mil } \\
\text { habitantes } \\
\text { (INE 2014) }\end{array}$ & $\begin{array}{l}\text { Frota de } \\
\text { Motos e } \\
\text { similares } \\
\text { e núme- } \\
\text { ro de } \\
\text { motos e } \\
\text { similares } \\
\text { por mil } \\
\text { habitan- } \\
\text { tes (INE } \\
2014 \text { ) }\end{array}$ & $\begin{array}{c}\text { Casos re- } \\
\text { gistrados } \\
\text { e porcen- } \\
\text { tagem de } \\
\text { delitos } \\
\text { violentos } \\
\text { (Carabine- } \\
\text { ros Chile } \\
2014 \text { ) }\end{array}$ & $\begin{array}{c}\text { Casos re- } \\
\text { gistrados } \\
\text { na Lei de } \\
\text { Drogas e } \\
\text { porcenta- } \\
\text { gem (Ca- } \\
\text { rabineros } \\
\text { Chile 2014) }\end{array}$ \\
\hline Chacabuco & Colina & 77.815 & 598.463 & 0,726 & $7,3 \%$ & $\begin{array}{l}20.721 \\
266 \text { / mil } \\
\text { hab }\end{array}$ & $\begin{array}{c}1.364 \\
18 / \mathrm{mil} \\
\mathrm{hab}\end{array}$ & 1.435 & 148 \\
\hline Chacabuco & Lampa & 40.228 & 398.395 & 0,697 & $8,5 \%$ & $\begin{array}{r}9.468 \\
235 \\
\end{array}$ & 642 & $(2,46 \%)$ & $\begin{array}{c}64 \\
(0,16 \%)\end{array}$ \\
\hline Chacabuco & Til Til & 14.755 & 465.580 & 0,706 & $9,8 \%$ & $\begin{array}{c}2.369 \\
161\end{array}$ & 151 & & $\begin{array}{c}11 \\
(0,07 \%)\end{array}$ \\
\hline Cordillera & Pirque & 16.565 & 651.509 & 0,807 & $2,7 \%$ & $\begin{array}{c}10.851 \\
655\end{array}$ & $\begin{array}{l}551 \\
33\end{array}$ & $\begin{array}{c}142 \\
(0,86 \%)\end{array}$ & $\begin{array}{c}11 \\
(0,07 \%)\end{array}$ \\
\hline Cordillera & $\begin{array}{c}\text { Puente } \\
\text { Alto }\end{array}$ & 492.915 & 706.717 & 0,773 & $14,6 \%$ & $\begin{array}{c}82.617 \\
168\end{array}$ & $\begin{array}{c}4.663 \\
9\end{array}$ & $\begin{array}{c}6.925 \\
(1,40 \%)\end{array}$ & $\begin{array}{c}478 \\
(0,10 \%)\end{array}$ \\
\hline Cordillera & $\begin{array}{l}\text { San Jose } \\
\text { de Maipo }\end{array}$ & 13.376 & 584.709 & 0,759 & $10,6 \%$ & $\begin{array}{r}3.358 \\
251\end{array}$ & 15 & $\begin{array}{c}165 \\
(1,23 \%)\end{array}$ & $\begin{array}{c}5 \\
(0,04 \%)\end{array}$ \\
\hline Maipo & Buin & 63.419 & 475.844 & 0,731 & $12,1 \%$ & $\begin{array}{c}10.885 \\
172\end{array}$ & 801 & $\begin{array}{c}581 \\
(0,91 \%)\end{array}$ & $\begin{array}{c}140 \\
(0,22 \%)\end{array}$ \\
\hline Maipo & $\begin{array}{c}\text { Calera de } \\
\text { Tango }\end{array}$ & 18.235 & 807.540 & 0,792 & $13,4 \%$ & $\begin{array}{l}8.311 \\
456\end{array}$ & 26 & $\begin{array}{c}293 \\
(1,61 \%)\end{array}$ & $\begin{array}{c}31 \\
(0,17 \%)\end{array}$ \\
\hline
\end{tabular}




\begin{tabular}{|c|c|c|c|c|c|c|c|c|c|}
\hline Maipo & Paine & 50.028 & 407.254 & 0,718 & $16,7 \%$ & $\begin{array}{r}9.187 \\
184 \\
\end{array}$ & $\begin{array}{l}749 \\
15 \\
\end{array}$ & $\begin{array}{c}542 \\
(1,1 \%)\end{array}$ & $\begin{array}{c}32 \\
(0,06 \%)\end{array}$ \\
\hline Maipo & $\begin{array}{c}\text { San Ber- } \\
\text { nardo }\end{array}$ & 246.762 & 485.065 & 0,712 & $17,9 \%$ & $\begin{array}{c}28.672 \\
116\end{array}$ & $\begin{array}{c}2.095 \\
8\end{array}$ & $\begin{array}{l}4.831 \\
(2 \%)\end{array}$ & $\begin{array}{c}280 \\
(0,11 \%)\end{array}$ \\
\hline Melipilla & Alhué & 4.435 & 369.290 & 0,700 & $19,6 \%$ & $\begin{array}{l}734 \\
166\end{array}$ & $\begin{array}{l}48 \\
11\end{array}$ & $\begin{array}{c}25 \\
(0,56 \%)\end{array}$ & $\begin{array}{c}2 \\
(0,05 \%)\end{array}$ \\
\hline Melipilla & Curacaví & 24.298 & 651.590 & 0,7100 & $7,4 \%$ & $\begin{array}{c}3.846 \\
158\end{array}$ & $\begin{array}{c}318 \\
13\end{array}$ & $\begin{array}{c}298 \\
(1,23 \%)\end{array}$ & $\begin{array}{c}61 \\
(0,25 \%)\end{array}$ \\
\hline Melipilla & $\begin{array}{l}\text { María } \\
\text { Pinto }\end{array}$ & 10.343 & 315.852 & 0,698 & $14,0 \%$ & $\begin{array}{l}3.067 \\
297\end{array}$ & $\begin{array}{l}255 \\
25\end{array}$ & $\begin{array}{c}86 \\
(0,83 \%)\end{array}$ & $\begin{array}{c}5 \\
(0,05 \%)\end{array}$ \\
\hline Melipilla & Melipilla & 94.540 & 472.212 & 0,735 & $19,5 \%$ & $\begin{array}{c}13.642 \\
144\end{array}$ & $\begin{array}{c}1.095 \\
12\end{array}$ & $\begin{array}{c}1.464 \\
(1,55 \%)\end{array}$ & $\begin{array}{c}114 \\
(0,12 \%)\end{array}$ \\
\hline Melipilla & $\begin{array}{l}\text { San Pe- } \\
\text { dro }\end{array}$ & 9.476 & 346.463 & 0,701 & 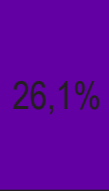 & $\begin{array}{l}1.043 \\
110\end{array}$ & $\begin{array}{l}45 \\
5\end{array}$ & $\begin{array}{c}36 \\
(0,38 \%)\end{array}$ & $\begin{array}{c}2 \\
(0,02 \%)\end{array}$ \\
\hline Santiago & Cerrillos & 71.906 & 672.600 & 0,743 & $6,8 \%$ & $\begin{array}{c}18.314 \\
255 \\
\end{array}$ & 1.159 & $\begin{array}{l}1.350 \\
(1,88 \%)\end{array}$ & $\begin{array}{c}105 \\
(0,15 \%)\end{array}$ \\
\hline Santiago & $\begin{array}{l}\text { Cerro } \\
\text { Navia }\end{array}$ & 148.312 & 416.789 & 0,683 & $15,4 \%$ & $\begin{array}{c}10.422 \\
70\end{array}$ & 8 & $\begin{array}{c}1.531 \\
(1,03 \%)\end{array}$ & $\begin{array}{c}148 \\
0,10 \%)\end{array}$ \\
\hline Santiago & Conchalí & 133.256 & 526.254 & 0,707 & $10,0 \%$ & $\begin{array}{c}16.870 \\
127\end{array}$ & $\begin{array}{c}1.746 \\
13\end{array}$ & $\begin{array}{c}1.895 \\
(1,42 \%)\end{array}$ & $\begin{array}{c}133 \\
(0,10 \%)\end{array}$ \\
\hline Santiago & El Bosque & 175.594 & 470.128 & 0,711 & $13,2 \%$ & $\begin{array}{c}18.109 \\
103\end{array}$ & 1.515 & $\begin{array}{c}2.155 \\
(1,23 \%)\end{array}$ & $\begin{array}{c}130 \\
(0,07 \%)\end{array}$ \\
\hline
\end{tabular}




\begin{tabular}{|c|c|c|c|c|c|c|c|c|c|}
\hline Santiago & $\begin{array}{c}\text { Estación } \\
\text { Central }\end{array}$ & 130.394 & 653.451 & 0,735 & $11,5 \%$ & $\begin{array}{r}19.371 \\
149\end{array}$ & $\begin{array}{c}1.731 \\
13\end{array}$ & 3.702 & $\begin{array}{c}198 \\
(0,15 \%)\end{array}$ \\
\hline Santiago & $\begin{array}{c}\text { Huechu- } \\
\text { raba }\end{array}$ & 74.070 & 692.874 & 0,737 & $5,2 \%$ & $\begin{array}{r}20.422 \\
276\end{array}$ & $\begin{array}{c}1.569 \\
21\end{array}$ & $\begin{array}{c}1.283 \\
(1,73 \%)\end{array}$ & $\begin{array}{c}83 \\
(0,11 \%)\end{array}$ \\
\hline Santiago & $\begin{array}{l}\text { Indepen- } \\
\text { dencia }\end{array}$ & 65.479 & 615.762 & 0,709 & $14,2 \%$ & $\begin{array}{c}11.946 \\
182\end{array}$ & $\begin{array}{c}1.363 \\
21\end{array}$ & $\begin{array}{c}1.442 \\
(2,20 \%)\end{array}$ & $\begin{array}{c}143 \\
((0,22 \%)\end{array}$ \\
\hline Santiago & $\begin{array}{l}\text { La Cister- } \\
\text { na }\end{array}$ & 85.118 & 735.258 & 0,775 & $7,2 \%$ & $\begin{array}{c}12.023 \\
141\end{array}$ & 829 & $\begin{array}{c}1.718 \\
(2,02 \%)\end{array}$ & $\begin{array}{c}64 \\
(0,08 \%)\end{array}$ \\
\hline Santiago & La Granja & 132.520 & 443.538 & 0,689 & $20,0^{\circ}$ & $\begin{array}{c}8.828 \\
67\end{array}$ & $\begin{array}{c}884 \\
7\end{array}$ & $\begin{array}{c}1.872 \\
(1,41 \%)\end{array}$ & $\begin{array}{c}154 \\
(0,12 \%)\end{array}$ \\
\hline Santiago & La Florida & 365.674 & 903.621 & 0,773 & $6,9 \%$ & $\begin{array}{c}59.518 \\
163\end{array}$ & $\begin{array}{c}3.888 \\
11\end{array}$ & $\begin{array}{c}4.891 \\
(1,34 \%)\end{array}$ & $\begin{array}{c}349 \\
(0,10 \%)\end{array}$ \\
\hline Santiago & $\begin{array}{l}\text { La Pinta- } \\
\text { na }\end{array}$ & 190.085 & 410.688 & 0,679 & $17,0 \%$ & $\begin{array}{c}11.054 \\
58\end{array}$ & 6 & $\begin{array}{c}2.534 \\
(1,33 \%)\end{array}$ & $\begin{array}{c}260 \\
(0,14 \%)\end{array}$ \\
\hline Santiago & La Reina & 96.762 & 1.278 .042 & 0,883 & $1,3 \%$ & $\begin{array}{c}35.129 \\
363\end{array}$ & $\begin{array}{c}1.884 \\
19\end{array}$ & $\begin{array}{c}709 \\
(0,73 \%)\end{array}$ & $\begin{array}{c}97 \\
(0,10 \%)\end{array}$ \\
\hline Santiago & $\begin{array}{l}\text { Las Con- } \\
\text { des }\end{array}$ & 249.893 & 2.047 .148 & 0,933 & $1,3 \%$ & $\begin{array}{c}88.901 \\
356\end{array}$ & $\begin{array}{c}4.456 \\
18\end{array}$ & $\begin{array}{c}1.780 \\
(0,71 \%)\end{array}$ & $\begin{array}{c}143 \\
(0,06 \%)\end{array}$ \\
\hline Santiago & $\begin{array}{l}\text { Lo Barne- } \\
\text { chea }\end{array}$ & 74.749 & 1.634 .668 & 0,912 & $4,2 \%$ & 583 & $\begin{array}{c}1.841 \\
25\end{array}$ & $\begin{array}{c}722 \\
(0,97 \%)\end{array}$ & $\begin{array}{c}29 \\
(0,04 \%)\end{array}$ \\
\hline Santiago & Lo Espejo & 112.800 & 419.922 & 0,657 & $7,0 \%$ & $\begin{array}{c}8.325 \\
74\end{array}$ & 7 & $\begin{array}{c}1.551 \\
(1,38 \%)\end{array}$ & $\begin{array}{c}72 \\
(0,06 \%)\end{array}$ \\
\hline
\end{tabular}




\begin{tabular}{|c|c|c|c|c|c|c|c|c|c|}
\hline Santiago & Lo Prado & 104.316 & 512.741 & 0,715 & $7,1 \%$ & $\begin{array}{c}12.205 \\
117 \\
\end{array}$ & $\begin{array}{r}1.099 \\
11 \\
\end{array}$ & $\begin{array}{r}1.150 \\
(1,10 \%)\end{array}$ & $\begin{array}{c}104 \\
(0,10 \%)\end{array}$ \\
\hline Santiago & Macul & 112.535 & 574.894 & 0,806 & $6,1 \%$ & $\begin{array}{c}29.683 \\
264\end{array}$ & $\begin{array}{r}2.543 \\
23\end{array}$ & $\begin{array}{c}1.198 \\
(1,06 \%)\end{array}$ & $\begin{array}{c}189 \\
(0,17 \%)\end{array}$ \\
\hline Santiago & Maipú & 468.390 & 776.369 & 0,782 & $3,9 \%$ & $\begin{array}{c}76.185 \\
163 \\
\end{array}$ & $\begin{array}{c}4.346 \\
9 \\
\end{array}$ & $\begin{array}{r}3.460 \\
(0,74 \%)\end{array}$ & $\begin{array}{c}289 \\
(0,06 \%)\end{array}$ \\
\hline Santiago & Ñuñoa & 163.511 & 1.432 .320 & 0,860 & $0,6 \%$ & $\begin{array}{c}44.329 \\
271\end{array}$ & $\begin{array}{r}2.393 \\
15\end{array}$ & $\begin{array}{r}2.243 \\
(1,37 \%)\end{array}$ & $\begin{array}{c}292 \\
((0,18 \%)\end{array}$ \\
\hline Santiago & $\begin{array}{c}\text { Pedro } \\
\text { Aguirre } \\
\text { Cerda }\end{array}$ & 114.560 & 550.521 & 0,708 & $8,0 \%$ & $\begin{array}{r}13.330 \\
116 \\
\end{array}$ & $\begin{array}{r}1.617 \\
14 \\
\end{array}$ & $\begin{array}{r}1.322 \\
(1,15 \%)\end{array}$ & $\begin{array}{c}166 \\
(0,14 \%)\end{array}$ \\
\hline Santiago & Peñalolén & 216.060 & 721.674 & 0,743 & $9,4 \%$ & $\begin{array}{c}79.576 \\
368\end{array}$ & $\begin{array}{c}4.117 \\
19 \\
\end{array}$ & $\begin{array}{c}2.361 \\
(1,09 \%)\end{array}$ & $\begin{array}{c}141 \\
(0,07 \%)\end{array}$ \\
\hline Santiago & $\begin{array}{l}\text { Providen- } \\
\quad \text { cia }\end{array}$ & 120.874 & 1.626 .489 & 0,911 & $3,0 \%$ & $\begin{array}{c}73.237 \\
606\end{array}$ & $\begin{array}{c}4.496 \\
37\end{array}$ & $(2,79 \%)$ & $\begin{array}{c}241 \\
(0,20 \%)\end{array}$ \\
\hline Santiago & Pudahuel & 195.653 & 597.928 & 0,735 & $9,3 \%$ & $\begin{array}{c}18.640 \\
95\end{array}$ & $\begin{array}{c}1.766 \\
9\end{array}$ & $\begin{array}{c}2.884 \\
(1,47 \%)\end{array}$ & $\begin{array}{c}314 \\
(0,16 \%)\end{array}$ \\
\hline Santiago & Quilicura & 126.518 & 651.718 & 0,782 & $9,2 \%$ & $\begin{array}{c}30.056 \\
238\end{array}$ & $\begin{array}{c}2.848 \\
23\end{array}$ & $\begin{array}{c}2.566 \\
(2,03 \%)\end{array}$ & $\begin{array}{c}212 \\
(0,17 \%)\end{array}$ \\
\hline Santiago & $\begin{array}{l}\text { Quinta } \\
\text { Normal }\end{array}$ & 104.012 & 542.076 & 0,723 & $9,5 \%$ & $\begin{array}{c}17.055 \\
164\end{array}$ & $\begin{array}{c}1.454 \\
14\end{array}$ & $\begin{array}{c}1.966 \\
(1,89 \%)\end{array}$ & $\begin{array}{c}114 \\
(0,11 \%)\end{array}$ \\
\hline Santiago & Recoleta & 148.220 & 469.294 & 0,697 & $10,7 \%$ & $\begin{array}{c}16.917 \\
114\end{array}$ & 14 & $\begin{array}{c}3.803 \\
(2,57 \%)\end{array}$ & $\begin{array}{c}522 \\
(0,35 \%)\end{array}$ \\
\hline
\end{tabular}




\begin{tabular}{|c|c|c|c|c|c|c|c|c|c|}
\hline Santiago & Renca & 133.518 & 522.670 & 0,709 & $9,0 \%$ & $\begin{array}{r}14.073 \\
105 \\
\end{array}$ & $\begin{array}{c}1.569 \\
12 \\
\end{array}$ & $\begin{array}{r}2.063 \\
(1,55 \%) \\
\end{array}$ & $\begin{array}{c}141 \\
(0,11 \%)\end{array}$ \\
\hline Santiago & $\begin{array}{l}\text { San Mi- } \\
\text { guel }\end{array}$ & 78.872 & 1.200 .056 & 0,765 & $4,6 \%$ & $\begin{array}{r}22.494 \\
285\end{array}$ & $\begin{array}{c}1.518 \\
19\end{array}$ & $\begin{array}{c}1.780 \\
(2,26 \%)\end{array}$ & $\begin{array}{c}122 \\
(0,15 \%)\end{array}$ \\
\hline Santiago & $\begin{array}{l}\text { San Joa- } \\
\text { quín }\end{array}$ & 97.625 & 577.469 & 0,719 & $5,6 \%$ & $\begin{array}{r}21.772 \\
223 \\
\end{array}$ & $\begin{array}{c}1.518 \\
16\end{array}$ & & $\begin{array}{c}519 \\
(0,53 \%)\end{array}$ \\
\hline Santiago & $\begin{array}{c}\text { San } \\
\text { Ramón }\end{array}$ & 94.906 & 419.810 & 0,679 & $9,6 \%$ & $\begin{array}{c}13.466 \\
142\end{array}$ & $\begin{array}{l}954 \\
10\end{array}$ & $\begin{array}{c}589 \\
(0,62 \%)\end{array}$ & $\begin{array}{c}76 \\
(0,08 \%)\end{array}$ \\
\hline Santiago & Santiago & 200.792 & 866.627 & 0,807 & $6,4 \%$ & $\begin{array}{r}50.931 \\
254\end{array}$ & $\begin{array}{r}5.351 \\
27 \\
\end{array}$ & $\begin{array}{c}7.807 \\
(3,89 \%)\end{array}$ & $\begin{array}{c}1.213 \\
(0,60 \%)\end{array}$ \\
\hline Santiago & Vitacura & 88.065 & 3.120 .820 & 0,949 & $0,3 \%$ & $\begin{array}{c}76.702 \\
871\end{array}$ & $\begin{array}{c}3.909 \\
44 \\
\end{array}$ & $\begin{array}{c}768 \\
(0,87 \%)\end{array}$ & $\begin{array}{c}20 \\
(0,02 \%)\end{array}$ \\
\hline Talagante & El Monte & 26.459 & 526.828 & 0,688 & $9,6 \%$ & $\begin{array}{l}7.096 \\
268\end{array}$ & $\begin{array}{c}242 \\
9\end{array}$ & $\begin{array}{c}154 \\
(0,58 \%)\end{array}$ & $\begin{array}{c}76 \\
(0,29 \%)\end{array}$ \\
\hline Talagante & $\begin{array}{l}\text { Isla de } \\
\text { Maipo }\end{array}$ & 25.798 & 431.261 & 0,724 & $15,4 \%$ & $\begin{array}{l}4.770 \\
185 \\
\end{array}$ & $\begin{array}{r}312 \\
12 \\
\end{array}$ & $\begin{array}{c}185 \\
(0,72 \%) \\
\end{array}$ & $\begin{array}{c}98 \\
(0,38 \%)\end{array}$ \\
\hline Talagante & $\begin{array}{l}\text { Padre } \\
\text { Hurtado }\end{array}$ & 38.768 & 431.930 & 0,728 & $13,2 \%$ & 253 & 17 & $\begin{array}{c}431 \\
(1,11 \%)\end{array}$ & $\begin{array}{c}39 \\
(0,10 \%)\end{array}$ \\
\hline Talagante & Peñaflor & 66.619 & 527.871 & 0,753 & $8,9 \%$ & $\begin{array}{r}13.572 \\
204 \\
\end{array}$ & 702 & $\begin{array}{c}726 \\
(1,09 \%)\end{array}$ & $\begin{array}{c}331 \\
(0,50 \%)\end{array}$ \\
\hline Talagante & Talagante & 59.805 & 791.543 & 0,749 & $9,8 \%$ & $\begin{array}{c}9.760 \\
163 \\
\end{array}$ & 8 & $\begin{array}{c}606 \\
(1,01 \%) \\
\end{array}$ & $\begin{array}{c}87 \\
(0,15 \%)\end{array}$ \\
\hline
\end{tabular}


Legenda de cores:

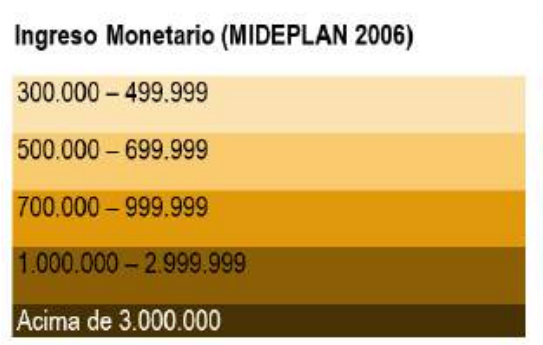

Automóveis por mil habitantes

Menos de 250 automóveis por mil habitantes

De 251 a 350 automóveis por mil habitantes

De 351 a 450 automóveis por mil habitantes

De 451 a 550 automóveis por mil habitantes

Acima de 551 automóveis por mil habitantes
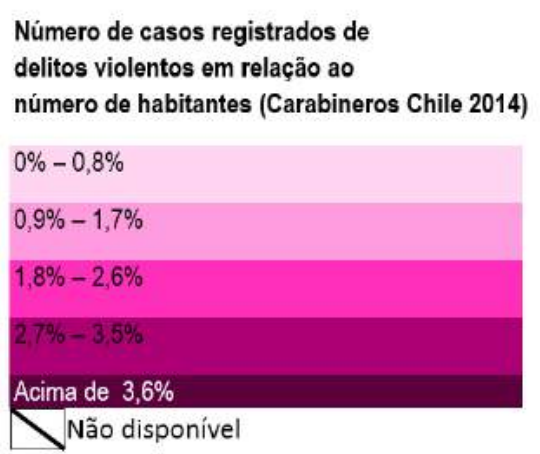

Índice de Desarrollo Humano Comunal

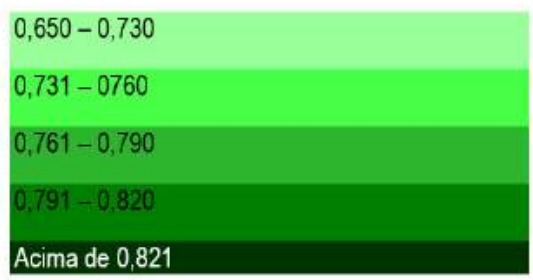

Motos por mil habitantes

0 a 10 motos por mil habitantes

11 a 24 motos por mil habitantes

25 a 39 motos por mil habitantes

40 a 55 motos por mil habitantes

Porcentagem de ocorrências anuais

de registros na Lei das Drogas

(Carabineros Chile 2014)

em relação ao número de habitantes

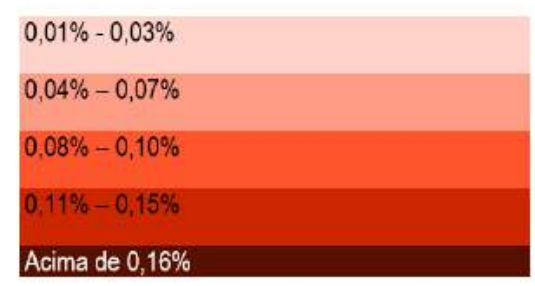

Porcentagem de pessoas em

situação de pobreza por ingresso (2013)

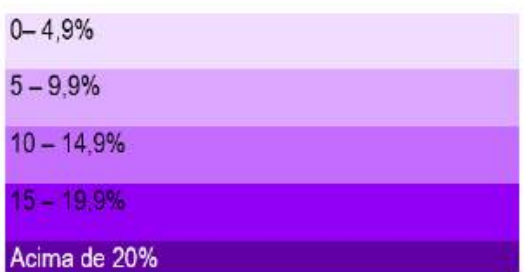

Tabela 2: organizada pela autora, a partir de dados do INE (2014), MIDEPLAN (2006), PNUD (2003), e Carabineros Chile (2014):

Estimativa Población: Segundo dados do INE, disponíveis em < http://www.ine.cl/canales/chile_estadistico/ familias/demograficas_vitales.php>. Visualizado em dez. 2016.

Ingreso Monetario: Segundo dados do Atlas Regional Región Metropolitana, 2009, disponível em: < https:// www.gobiernosantiago.cl/wp-content/uploads/2014/doc/informacion/Atlas_Regional_Region_Metropolitana,_2009.pdf>. Visualizado em jan. 2017.

Índice de Desarrollo Humano Comunal-IDHC: Segundo dados do Programa de las Naciones Unidas para el Desarrollo (PNUD). Índice de Desarrollo Humano Comunal, disponíveis em: < http://desarrollohumano.cl/idh/ download/IDHC\%20con\%20portada.pdf>. Visualizado em 2 dez. 2016.

Porcentagem de população em situação de pobreza: A estimativa considera a população residente em habitações particulares ocupadas, segundo projeções demográficas INE da Encuesta Casen 2013. Dado gerado através de estimativa para áreas pequenas (SAE) e imputação de médias por conglomerados (IMC), considerando a nova metodologia de medição de pobreza por ingresso divulgada pelo Ministerio de Desarrollo Social em 2015. Disponível em < http://observatorio.ministeriodesarrollosocial.gob.cl/documentos/Sintesis-Estimacion-de-la-pobreza-por-ingresos-en-comunas-2011-2013(nuevametodologia)07092015.pdf>. Visualizado em dez. 2016.

Frota de automóveis e station wagons e motos: Segundo dados do INE, disponíveis em < http://www.ine.cl/ canales/chile_estadistico/estadisticas_economicas/transporte_y_comunicaciones/parquevehiculos.php $>$. Visualizado em dez. 2016.

Casos registrados de Delitos Violentos e Lei das Drogas: Segundo dados do Carabineros Chile, disponíveis em: <http://centroestudios.carabineros.cl/>. Visualizado em 1 dez. 2016. 


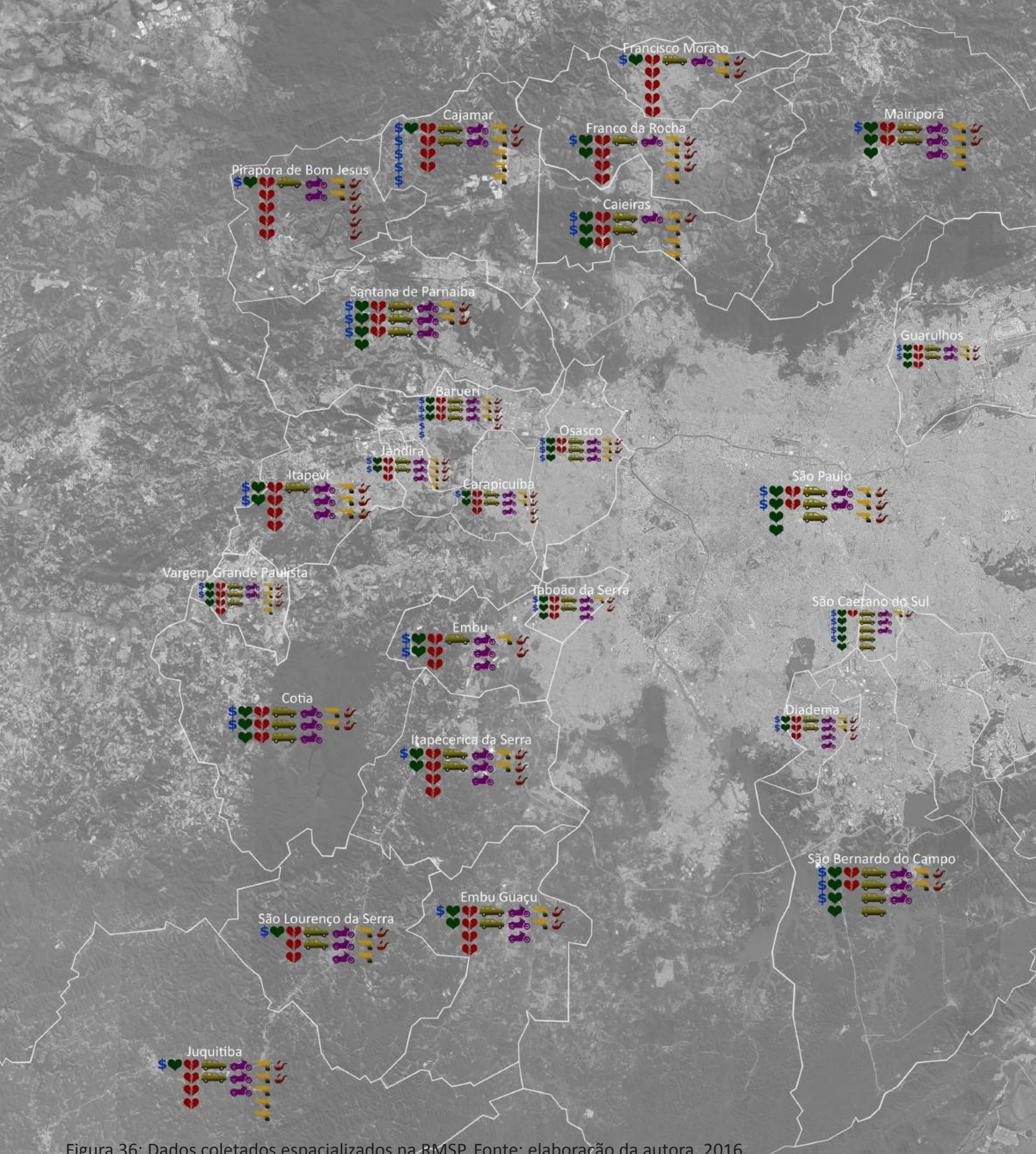

Figura 36: Dados coletados espacializados na-RMSP. Fonte: elaboração da autora, 2016.

PIB ${ }^{1}($ IBGE 2013)

$R \$ \$ 7.000-R \$ 20.000 \quad \$$

R $\$ 21.000-R \$ 50.000 \$ \$$

$R \$ 51.000-R \$ 90.000 \$ \$ \$$

$R \$ 91.000-R \$ 110.000$ \$\$\$

Acima de R 1111.000 \$\$\$ \$
IDHM (IBGE 2010)

$0,700-0,730$

$0,731-0,760$

$0.761 \cdot 0,790$

$0,791-0,820$

Acima de 0.821
Incidencia de Pobreza (IBGE 2003)

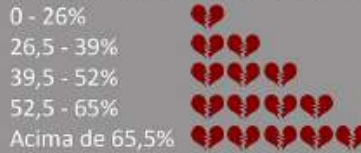

Automóveis por mil habitantes (IBGE e DENATRAN 2014) Menos de 250

De 251 a $350 \rightleftharpoons$

De 351 a $450 \leftrightarrow$

De 451 a $550 \leftrightarrow$

Acima de 551 मु 


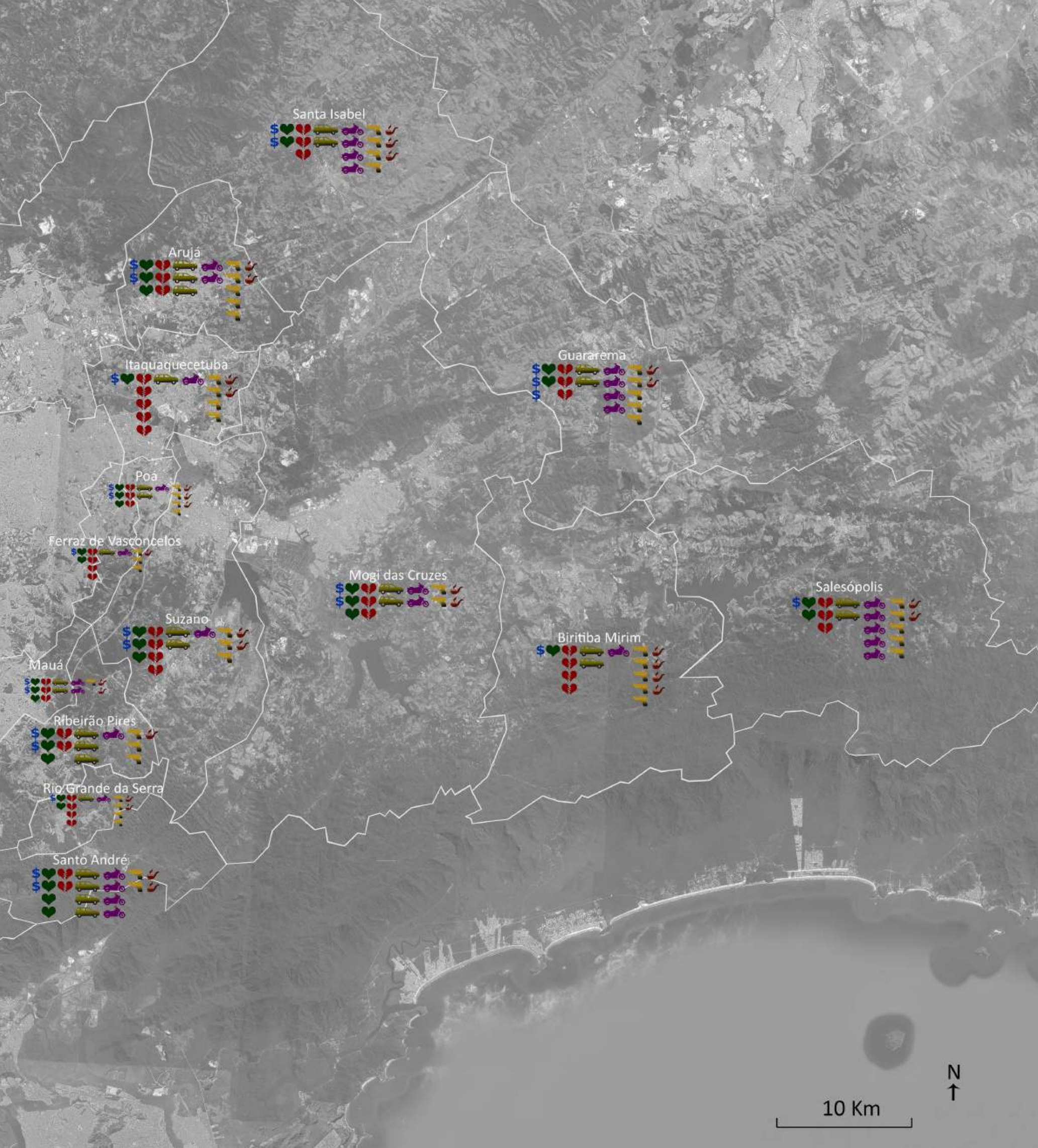

Motos por mil habitantes (IBGE e DENATRAN 2014)

Menos de 55 .

56 a 70 की

71 a 85 का

86 a 100

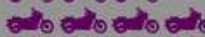

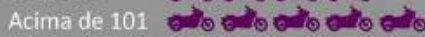

Porcentagem de delitos violentos

(SECRETARIA DE SEGURANCCA PÚBLICA 2014)

$0,10 \%-0,20 \%$

$0,21 \%-0,30 \%$

$0,31 \%-0,40 \%$

$0,41 \%-0,50 \%$

Acima de $0,51 \%$

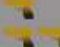

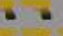

$-\infty$

$-a$
Porcentagem de ocorrências de tráfico e porte de entorpecente (SECRETARIA DA SEGURANCA PUBLICA 2014) $0,01 \%-0,03 \%$ $0,04 \%-0,07 \%$

$0,08 \%-0,10 \%$

$0,11 \%=0,15 \%$

Acima de $0,16 \%$

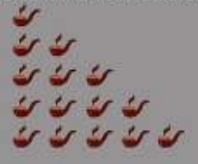

Coleta de dados e grafismo: Donoso (2016) 



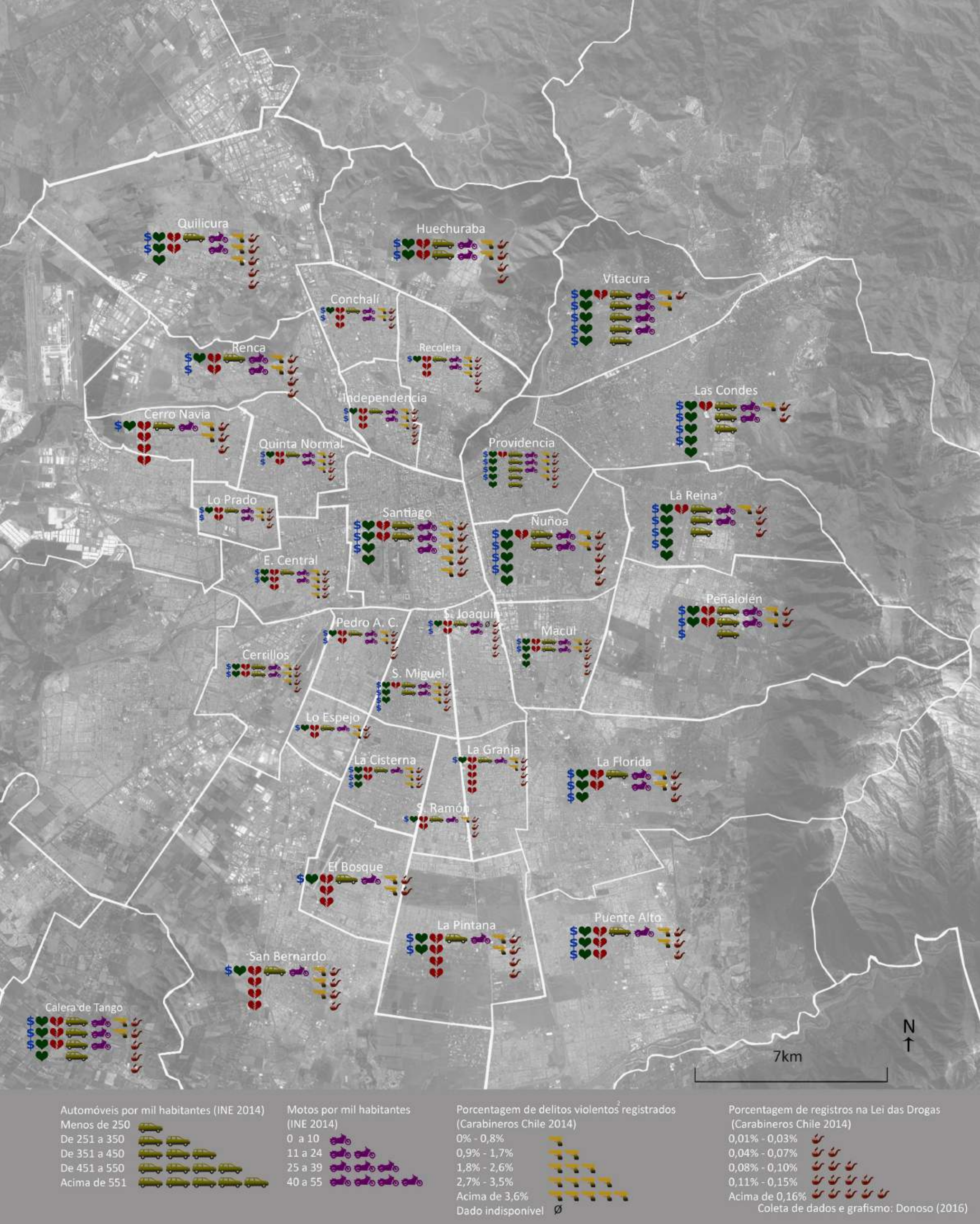


Analisando-se os dados apresentados em ambas as tabelas, pode-se constatar que, no caso chileno, destaca-se a comuna de Vitacura, que, com 88.065 habitantes (2014), concentra o maior Ingreso Monetario da RMS, de 3.120 .820 pesos chilenos (2006); o maior Índice de Desarrollo Humano Comunal da RMS, de 0,949 (2003); a menor porcentagem de pessoas em situação de pobreza da RMS, de 0,3\% (2013) e, consequentemente, a maior relação de automóveis e station wagon por mil habitantes, alcançando o valor elevadíssimo de 871 automóveis por mil habitantes (2014), quase um automóvel por pessoa, e a maior relação em ambas as regiões metropolitanas.

Na situação oposta está La Pintana, comuna no extremo sul da RMS, com uma população de 190.085 habitantes, porcentagem de pessoas em situação de pobreza de $17 \%$ (2013) e uma relação de 58 automóveis e station wagon por mil habitantes (2014), a menor relação de automóveis de ambas as Regiões Metropolitanas. Em seguida, está a comuna vizinha, La Granja, com 67 automóveis e station wagon por mil habitantes (2014).

Na Região Metropolitana de São Paulo, o município que apresenta maior PIB/per capita é Barueri, com R\$171.831,09 (2013), pois, como já foi comentado, abriga empreendimentos Alphaville e Tamboré, iniciados nos anos 1970 e que marcaram o ramo imobiliário com um modelo de ocupação urbana que se proliferou em outras cidades brasileiras: o dos loteamentos fechados, em maiores proporções, integrando áreas residenciais, comerciais, de serviços e industriais. ${ }^{36}$

Em seguida, vem o interessante caso de Cajamar, que apresenta o segundo maior PIB per capita metropolitano, de $\mathrm{R} \$ 125.437,27$ (2013), apesar da elevada incidência de pobreza, de $56,52 \%$ (2003). Esse alto rendimento tem origem principalmente pelo setor de serviços, pela forte presença do setor terciário, sobretudo em função de áreas de logística, e também industrial, com a presença de várias indústrias de ramos diversos, como metalurgia, tintas, embalagens e outros.

Essa industrialização também foi estimulada com a construção, em 2012, de um condomínio industrial, o Cajamar Industrial Park, localizado próximo ao Rodoanel Mário Covas e à Rodovia Anhanguera e realizado em parceria entre uma das maiores empresas do ramo logístico, a Prologis, e uma das maiores empresas do ramo imobiliário, a Cyrela. Cajamar apresenta 307 automóveis por mil habitantes e 65 motos por mil habitantes (2014).

São Caetano do Sul apresenta o terceiro maior PIB per capita da metrópole paulistana, de $\mathrm{R} \$ 97.889,94$ (2013), e também o maior IDHM, de 0,862. O pequeno município, de apenas $15,33 \mathrm{~km}^{2}$, também apresenta a menor incidência de pobreza, de 12,18\% (2003) e, consequentemente, a maior relação de automóveis por habitantes, com 636 automóveis por mil habitantes (DENATRAN, 2014). Além disso, o município apresenta as menores porcentagens de ocorrências policiais de delitos violentos e de registros de tráfico e porte de entorpecentes, de $0,16 \%$ e $0,01 \%$, respectivamente (2014).

Salesópolis é o município com o menor PIB per capita da RMSP, com R\$10.021,33 (2013), também apresentando a maior relação de motos, com 116 motos por mil habitantes. A maior fonte econômica é rural, principalmente com produção de eucaliptos.

Na RMSP, no geral, os municípios com menor renda per capita têm uma relação alta de motos por mil habitantes. Esse fato se justifica pela necessidade de deslocamento na metrópole e

36 Para maior estudo sobre o caso Alphaville e Tamboré em Barueri e Santana do Parnaíba, aconselha-se a leitura de Campos (2008). 
pelo menor custo de aquisição de uma moto, quando comparado a um automóvel. Isso pode ser verificado nos municípios do extremo leste, noroeste e norte: Santa Isabel, Salesópolis, Mairiporã; e também do extremo oeste, sudoeste e ABC: Jandira, Carapicuíba, Taboão da Serra, Cotia, Itapecerica da Serra, São Lourenço da Serra, Embu-Guaçu, Juquitiba, Diadema, Santo André.

No entanto, essa relação entre a menor renda e o número de motos não ocorre na RMS: $21 \%$ das comunas apresentam menos de 20 motos por mil habitantes, sendo que a comuna com menor relação é San Pedro, com 5 motos por mil habitantes, e maior é Vitacura, com 44 (2014).

As comunas da RMS apresentam dinâmica diferente: no geral, a maioria das comunas apresenta baixos índices de automóveis e motos por mil habitantes. As concentrações de automóveis e motos ocorrem nas comunas de alta renda: Vitacura, como já comentado, Providencia, Lo Barnechea e Pirque. Essa última, localizada na província de Cordillera, tem apenas 16.565 habitantes e uma baixa porcentagem de pessoas em situação de pobreza: 2,7\% (2013). Já a frota de automóveis é a segunda maior da metrópole, com 655 automóveis por mil habitantes, enquanto que a de motos é de 33 por mil habitantes.

\section{Os territórios de inclusão periférica}

O largo emprego do termo "exclusão social" parece somente lamentar os problemas sociais de diferenciação socioespacial sem, no geral, explicar a origem do problema. Assim, dada a imprecisão que a expressão traz embutida, optou-se, nesta tese, pela criação e uso do termo "inclusão periférica". Baseando-se em Ribeiro (2014), Martins (2002) e Maricato (1996), amplia-se o conceito de exclusão social a partir da observação das causas, dos modos da produção e reprodução da sociedade e dos impactos do sistema no cotidiano de grupos sociais.

Os grupos sociais ditos "excluídos" do sistema na verdade estão incluídos, contribuindo para a manutenção dos baixos salários e para os altos níveis de extração da mais-valia em nossa formação socioespacial capitalista. Esses grupos sociais desfavorecidos pelo sistema são não somente exército de reserva de mão-de-obra, mas também produto da desigualdade da distribuição da riqueza gerada, ou seja, são parte do sistema econômico e social e, logo, não podem ser denominados simplesmente como "excluídos".

Ribeiro (2014), influenciada pelas análises de Milton Santos sobre "inclusão marginal" e "homem lento", comenta o problema do termo "excluído", cujo significado subentende que o outro não tem potência ou consciência crítica sobre as questões a serem superadas, o que não é verdadeiro.

Maricato (1996) afirma que o paradoxo entre os desfavorecidos do sistema, a herança patrimonialista, a legislação urbana e o poder de classes ou instituições são partes de uma "contravenção sistemática", que é a base do padrão de urbanização brasileiro, conforme o qual a expansão urbana e a expulsão da população de menores recursos resultou no crescimento de uma cidade oculta, aquela que não se vê e não quer se ver, das famílias que vivem na ilegalidade, em um cotidiano sórdido de expropriados do sistema, ainda que sejam parte dele.

A expansão urbana controlada por interesses políticos e econômicos deixou ainda mais marcante a distorção entre a demanda real e os interesses que regem os processos urbanos (ROLNIK, 2004). Assim, a reprodução de territórios de inclusão periférica é parte de um ciclo que produz e aprofunda diferenças econômicas e sociais, assim como situações de vulnerabilida- 
de. A exclusão, portanto, além de não existir, não é um acidente circunstancial.

Na RMSP, os principais agentes promotores de habitação de interesse social até 2009 foram a COHAB/SP (Companhia Metropolitana de Habitação/São Paulo) e a CDHU (Companhia de Desenvolvimento Habitacional e Urbano).

Segundo dados de Nobre (2008), até 2006 ambas haviam construído por volta de 290 mil unidades habitacionais na Região Metropolitana de São Paulo, a maioria em conjuntos habitacionais periféricos.

O Estado, administrado conforme herança dos padrões coloniais de comando, não só consente que a cidade oculta exista, como, através de instrumentos diversos, incentiva a ocupação ilegal do solo, ordenando o planejamento conforme as conveniências do mercado e as informalidades do clientelismo. Essa "contravenção sistemática" (MARICATO, 1996), de ciclo ambíguo, presidiu a história urbana brasileira e as disputas de interesses.

De acordo com Martins (2002), "excluído" e "exclusão" são termos do discurso dos beneficiados da sociedade, ou seja, os que não estão incluídos à periferia.

Com os novos instrumentos urbanísticos e novo marco legal a partir do "Estatuto da Cidade", criado em 2001, tentou-se reverter o processo histórico de inclusão periférica, garantindo-se acesso à terra e regularização fundiária, embora sem conseguir se sobrepor à estrutura política, econômica e social que fragiliza as mudanças, como será pormenorizado no capítulo 4.

As contradições do cotidiano urbano criam, constantemente, situações de favorecimento e desfavorecimento, que são reações do próprio sistema, com os grupos sociais participando desse ciclo contraditório causado pelos processos sociais, políticos e econômicos. Nesse sentido, utilizar a noção de "excluído" é incorreta, pois os grupos sociais menos favorecidos não estão fora do sistema, mas sim incluídos perifericamente, em um processo perverso que mantém a desigualdade.

\section{Pobreza, segregação e violência urbana}

Sobre a violência na RMSP, Villaça (2004) relembra que, até os anos 1960, os índices de criminalidade eram muito baixos quando comparados aos de hoje. Os anos 1960 e 1970 marcam o período de inflexão, que demonstra o aumento da criminalidade. Segundo dados coletados pelo autor ${ }^{37}$ :

De 1920 a 1950 - em trinta anos, portanto -, o índice de homicídios por milhão de habitantes aumentou apenas de 40,8 para 46,4, ou seja, 15\%. Entre 1950 e 1970 - em vinte anos -, entretanto, esse número dobrou, pulando de 46,4 para 98,7. Entre 1970 e 1980, o crescimento acelerado do índice acentuou-se, subindo de 98,7 para 173 (p. 152).

Esse aumento da violência tem relação direta com o aumento da desigualdade e das periferias urbanas, o que passa a afetar a convivência urbana e estimular o medo do espaço coletivo e do outro.

(...) Según el Banco Interamericano de Desarrollo, América Latina es una de las regiones más violentas del mundo, la segunda después de África. La violencia en la sociedad

37 O autor elaborou os índices a partir de dados dos censos demográficos do caderno especial "SP 450" da Folha de São Paulo, de 28 nov. 2003, p. 5. 
empieza en los hogares; no se puede eliminar el crimen en las calles si no se ataca el maltrato doméstico, ya que los niños golpeados se convierten a menudo en adultos violentos. (ALLENDE, 2003, p. 83)

Essa realidade, cada vez mais estimulada por práticas enclausuradas, por relações humanas cada vez mais impessoais devido ao desenvolvimento tecnológico, pelo incentivo ao transporte individual, entre outros aspectos, contribui para o receio quanto ao uso dos espaços livres, principalmente em cenários de violência urbana e maiores desigualdades que, segundo Rolnik (2004), são fronteiras internas que "assumiram a materialidade física dos muros, grades e guaritas, sitiando a cidade e confinando os cidadãos a uma vida apenas entre familiares e iguais, impedindo a troca e a interação" (p. 177).

É fato que a concentração de pobreza e de riqueza em áreas urbanas distintas gera impactos, muitas vezes, inconscientes. Tanto jovens que crescem em zonas urbanas de concentração de pobreza, quanto jovens que crescem em bairros com índices que demonstram maior concentração de riqueza, partilham de um cotidiano fictício, ou de uma natureza artificializada, como é o caso dos condomínios de diferentes classes sociais afastados dos centros urbanos.

A não possibilidade de se relacionar com a diferença social faz com que esses jovens cresçam dentro de uma realidade urbana débil ou, como diria Dunker (2015), em uma bolha temporal. Percursos cotidianos da relação casa, escola, trabalho são mais interessantes quando há a possibilidade de se conhecer a realidade urbana tal como ela é: com suas diferenças sociais, ambientais, culturais e econômicas. Quando esses percursos ocorrem de maneira limitada, a relação do usuário com o espaço é de (des)prática, pelo cotidiano reduzido a uma situação urbana irreal e incompleta.

No cotidiano, convive-se, compartilham-se e experimentam-se pressupostos de sociabilidade. Assim, quanto maior a homogeneização social e econômica, menor a possibilidade de se experimentar a sociabilidade. Igualmente, a carência e até mesmo ausência de espaços urbanos que possibilitam o convívio também atua diretamente na dificuldade de se desenvolverem relações sociais.

Os novos equipamentos urbanos de convívio baseados em consumo e o excesso de homogeneização social e econômica têm redesenhado as interações sociais, também intensificadas pelas ferramentas de transmissão de dados como a internet, que têm modificado as relações e os locais - no sentido não apenas físico de localização geográfica - em que as (des)práticas sociais ocorrem.

Porém, os encontros inesperados que os espaços públicos proporcionam fazem parte do acaso cotidiano, que é o exato contrário do que pretendem os projetos urbanos segregacionistas, os quais acabam por gerar um mal-estar criado pela ilusão de que a classificação, a inclusão marginal e a segmentação são melhores.

Segundo Guimarães (2011):

Prevalece a tese do "isolamento social dos pobres", a segregação na vida urbana, na qual o mundo da integração social composto por laços imediatos de vínculos aponta para o seu funcionamento para dentro, no interior dos bairros, territórios e comunidades que representam os seus próprios limites, porque não abrem a possibilidade de mobilidade entre as classes sociais (p. 102).

Marques, Castello e Bichir (2011-2012) colocam a segregação para além dos atributos socioeconômicos e de raça, acrescentando-Ihe a integração relacional, ou seja, da rede de relações sociais. Os autores coletaram dados representativos em São Paulo para compreender como se organizam as redes sociais de indivíduos pobres, como é a sua estrutura familiar, sua in- 
serção no mundo do trabalho, as formas de sociabilidade específicas (como, por exemplo, a frequência a templos e igrejas), relacionando redes pessoais e de sociabilização à segregação e à reprodução da pobreza.

Como resultado, os autores encontraram uma grande heterogeneidade de situações, com forte localismo nas redes analisadas (ou seja, com vínculos que ocorrem numa determinada área) e fortemente associados a situações de vulnerabilidade social, em que melhores condições sociais levaram a redes sociais mais variadas.

Recente estudo de Anderson et al. (2012) demonstra, através de estudo de caso em Los Angeles, que há relação entre zoneamento urbano e taxas de criminalidade. Refutando, em alguns pontos, as análises de Jane Jacobs (2000) sobre a visibilidade das ruas comerciais, o estudo demonstrou que, em bairros de Los Angeles com zonas exclusivamente residenciais, as taxas de criminalidade são menores, diferentemente do que ocorrem em bairros que concentram usos comerciais e que apresentam maiores taxas de criminalidade. Já os bairros com uso misto também apresentam menor criminalidade em relação às zonas exclusivamente comerciais ${ }^{38}$.

Para o levantamento metropolitano deste trabalho, foram selecionados alguns dados de criminalidade em ambas as Regiões Metropolitanas. Como metodologia de análise, utilizaram-se novamente os dados analisados nas tabelas de municípios e comunas, que foram estudados dentro de seu contexto nacional, e não comparativamente, já que existem variações nos dados coletados de cada país devido às diferentes metodologias no registro de delitos. Assim, esses dados de criminalidade são úteis para analisar cada região metropolitana em seu contexto, e não para análise comparativa entre países.

Somam-se, para o caso do município de São Paulo, também alguns índices de criminalidade de acordo com alguns bairros.

Para ambas as Regiões Metropolitanas adotaram-se dados de 2014 acerca de delitos violentos, agrupando-se, no caso chileno, casos de roubo com violência, lesões, homicídios e violações e, no caso brasileiro, casos de homicídio doloso (incluindo homicídio doloso por acidente de trânsito), latrocínio, lesão corporal dolosa e estupro. Também se coletaram registros de tráfico e porte de entorpecentes, no Chile chamados de delitos envolvidos na "Lei de Drogas" 39 .

No caso chileno, é na comuna de Santiago, no centro, que se concentram as maiores proporções de delitos violentos e tráfico de drogas, com uma proporção de 3,89\% de delitos violentos e $0,60 \%$ de casos cadastrados na Lei das Drogas (2014).

Já a comuna com menos registros em ambos os casos é San Pedro, com 0,36\% de delitos violentos e 0,02\% de delitos cadastrados na Lei das Drogas por mil habitantes (2014). San Pedro, também conhecida como San Pedro de Melipilla, pela sua localização nessa província, tem 9.476 habitantes (2014), Ingresso Monetario singelo de 346.463 pesos chilenos e uma porcentagem de pessoas em situação de pobreza por ingresso elevada, de 26,1\% (2013).

Outra comuna com poucos registros na Lei das Drogas é Vitacura, também com apenas 0,02\%.

No caso brasileiro, as ocorrências anuais registradas de delitos violentos apontam Biritiba-Mirim como o município com mais casos registrados, com 0,61\%. Logo em seguida está Cajamar,

38 Seria interessante poder verificar essa associação entre maiores taxas de criminalidade com zonas exclusivamente comerciais no caso brasileiro, porém foge ao objetivo desta tese.

39 Como metodologia, para cada comuna ou município foram somados os números de casos registrados por ano e relacionados com a população, de maneira a se encontrar a porcentagem de ocorrências policiais (relativas a casos de violência e de drogas). 
com 0,60\%. Salesópolis também apresenta índice elevado, de 0,55\%. Já o menor índice está em São Caetano do Sul, com 0,16\% (2014).

Em relação às ocorrências anuais registradas de tráfico e porte de entorpecentes, Pirapora do Bom Jesus apresenta o maior índice: 0,24\% (2014). Esse município, de apenas 17.372 habitantes (2014), também apresenta a maior incidência de pobreza da metrópole, de 67,84\% (2003). O município com menor relação de registros é, novamente, São Caetano do Sul, com 0,01\% ocorrências de tráfico e porte de entorpecentes (2014).

Segundo dados da Secretaria de Estado da Segurança Pública de São Paulo de março de 2015, coletados e disponibilizados pelo jornal O Estado de S. Paulo (Criminalidade bairro a bairro) ${ }^{40}$, os cinco bairros de São Paulo que apresentaram maiores índices de roubo na data analisada foram Capão Redondo, Campo Limpo (ambos na zona sudoeste do município), Sé (centro), Jardim Míriam (sul) e São Mateus (leste). Já os menos violentos foram Alto da Mooca, Vila Formosa, Vila Carrão, Parque da Mooca (sudeste) e Belém (leste).

Considerando os dados apresentados para março de 2015, há uma grande incidência de criminalidade na região central de São Paulo, com destaque para os bairros Sé e Santa Ifigênia ${ }^{41}$. No geral, a partir desses dados, não é possível localizar a violência em zonas específicas do município de São Paulo, mas em bairros que se distribuem em diversas regiões ${ }^{42}$.

A inclusão social periférica, quando é vista como algo banal, ou seja, quando a diferença não é mais sentida e não mais choca o cotidiano das pessoas que convivem entre si, é outra forma de violência silenciosa, como se destaca nas figuras 38 e 39.

40 Infográfico disponível em: <http://infograficos.estadao.com.br/cidades/criminalidade-bairro-a-bairro/>. Acessado em 7 maio 2015.

41 Em relação aos furtos, os bairros com maior número dessas ocorrências foram Sé, Santa Ifigênia, Pari, Consolação (todos no centro e centro expandido) e Santo Amaro (sul). Já aqueles que registraram menor número de furtos foram Parque Bristol, Sacomã (sudeste), Parque São Rafael, Jardim Noemia e Jardim Robru (leste).

Os bairros com maior número de homicídios foram Parque Novo Mundo (nordeste), Capão Redondo, Parque Santo Antônio, Campo Limpo (sudoeste) e Jardim Herculano (zona sul). Já os com menor número de homicídios foram Artur Alvim, Belém (leste), Bairro do Limão (norte), Brás (centro-leste) e Cambuci (centro).

Em relação ao tráfico de drogas, os bairros com maior incidência foram Santa Ifigênia (centro), Vila Nova Cachoeirinha, Jaçanã, Vila Guilherme (norte) e Capão Redondo (sudoeste). Os com menor incidência foram Alto da Mooca, Parque da Mooca, Vila Carrão (sudeste), Jardim Aricanduva (sudeste) e Cidade Monções (sul).

42 Há grande incidência de furtos nos bairros Consolação, Paulista, Perdizes, Pinheiros, Lapa, bairros de renda média alta e alta da zona oeste, além dos centrais Sé e Santa Ifigênia, que concentram principalmente atividades comerciais. Segundo dados do Censo Demográfico de 2010 (disponível em: http://censo2010.ibge.gov.br/. Acesso 10 dez. 2016), o bairro de Perdizes apresentou 19,5\% da sua população recebendo de 2 a 5 salários mínimos e 20,2\% da sua população com 5 a 10 salários mínimos. Já o bairro de Pinheiros apresentou $18,9 \%$ da sua população com 2 a 5 salários mínimos, e 18,7\% da sua população recebendo de 5 a 10 salários mínimos. Já em relação à população que recebe mais de 20 salários mínimos, Perdizes apresentou 7,2\% e Pinheiros 8,5\% respectivamente.

Em relação aos dados sobre roubos, que diferem dos furtos por serem praticados com violência ou ameaça, as ocorrências na data analisada se deram principalmente em bairros periféricos, como Capão Redondo e Campo Limpo. Segundo dados do IBGE de 2010, Capão Redondo tinha 30,1\% da sua população recebendo de 1 a 2 salários mínimos, enquanto que Campo Limpo apresentou 27,7\%. Em relação à população que recebeu de $1 / 2$ a 1 salários mínimos, Capão Redondo apresentou 13,7\% e Campo Limpo, 12,7\%; em relação à faixa entre 2 a 5 salários mínimos, Capão apresentou 13,9\% e Campo Limpo 16,7\% da população, respectivamente. 


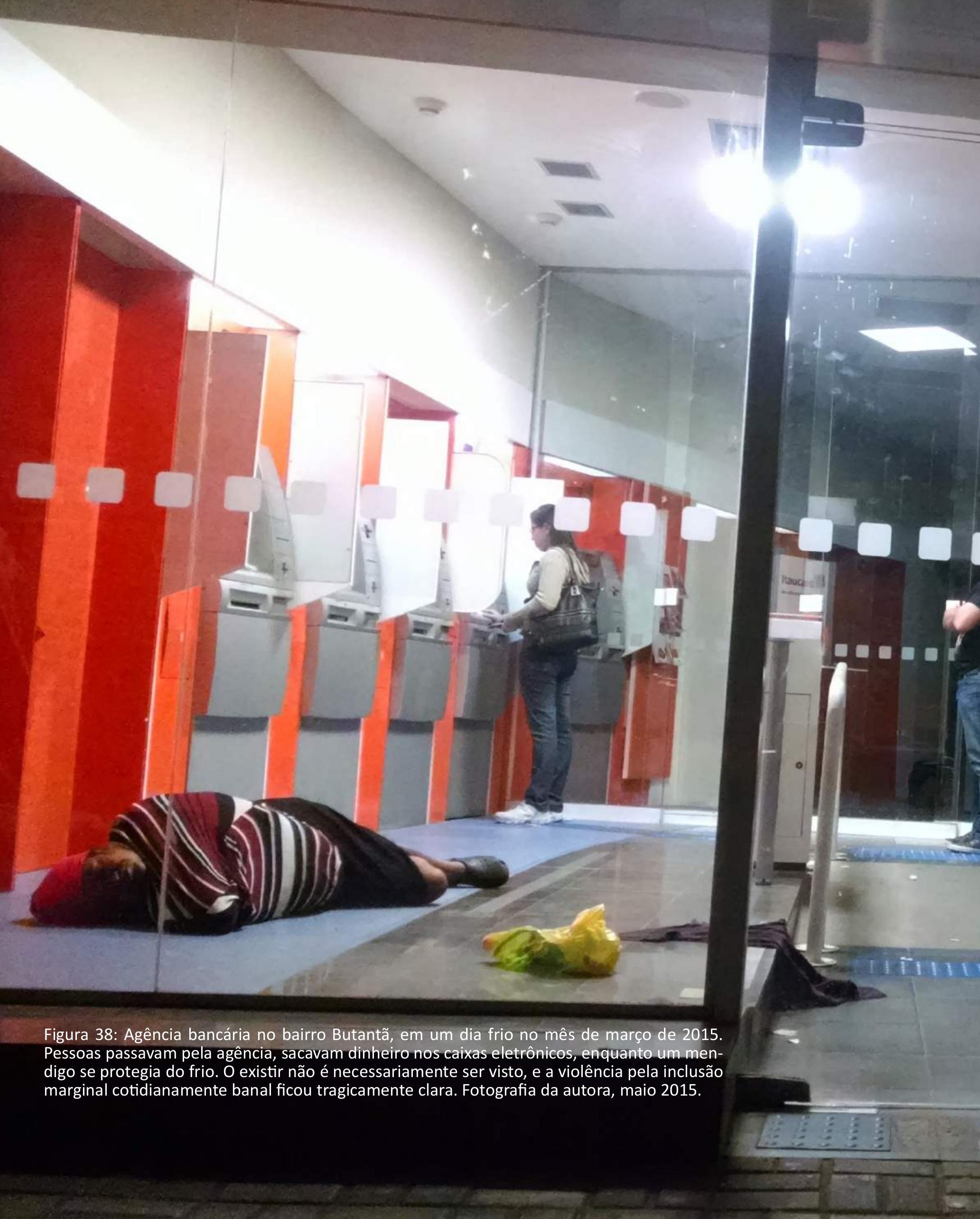



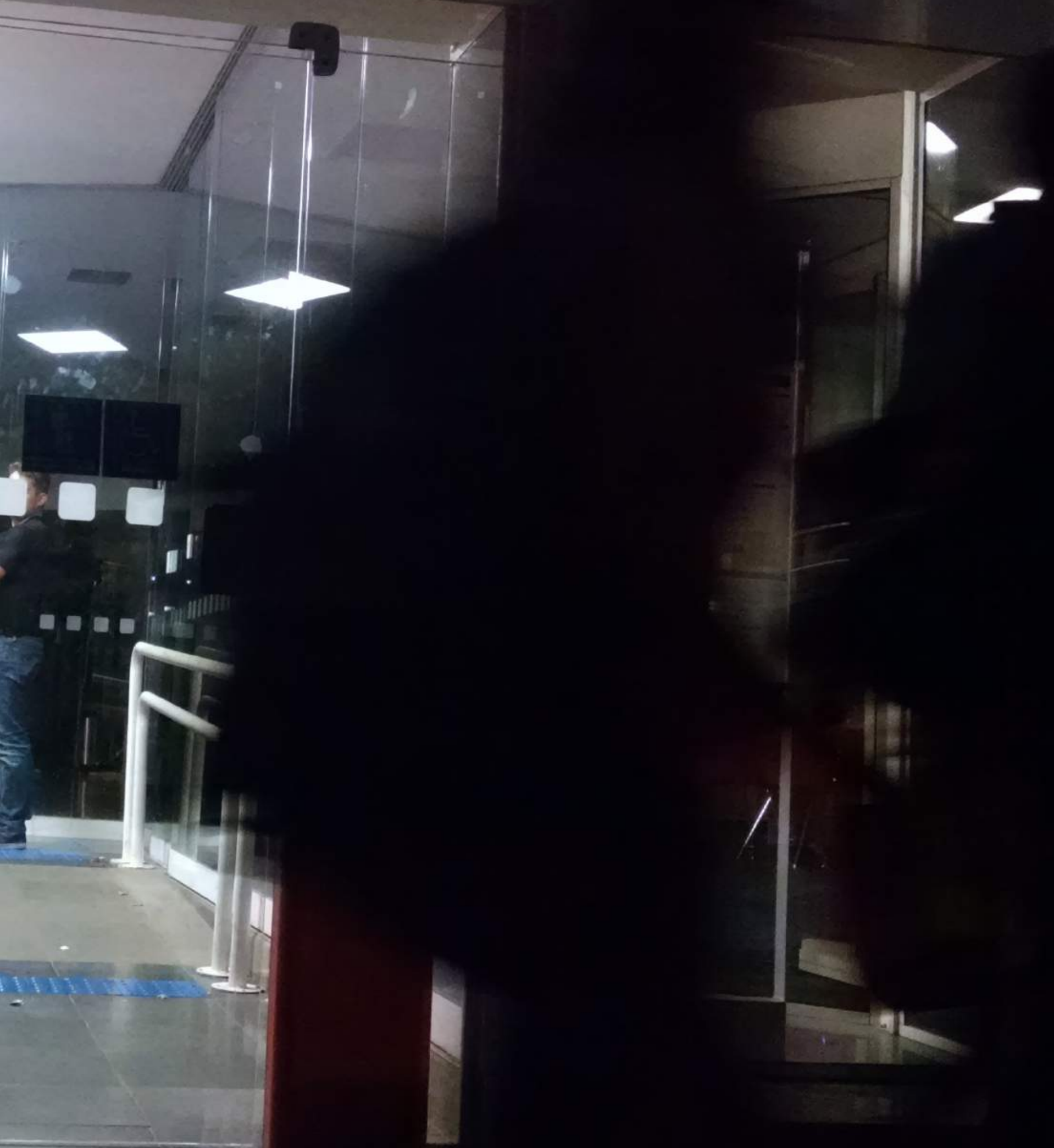




Figura 39: Cena - infelizmente - tradicional do Centro de São Paulo, dos moradores de rua que trabalham informalmente como catadores de papelão. Fotografia da autora, maio 2016.

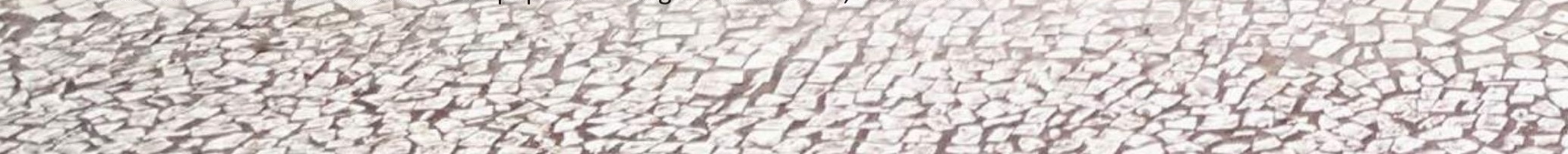




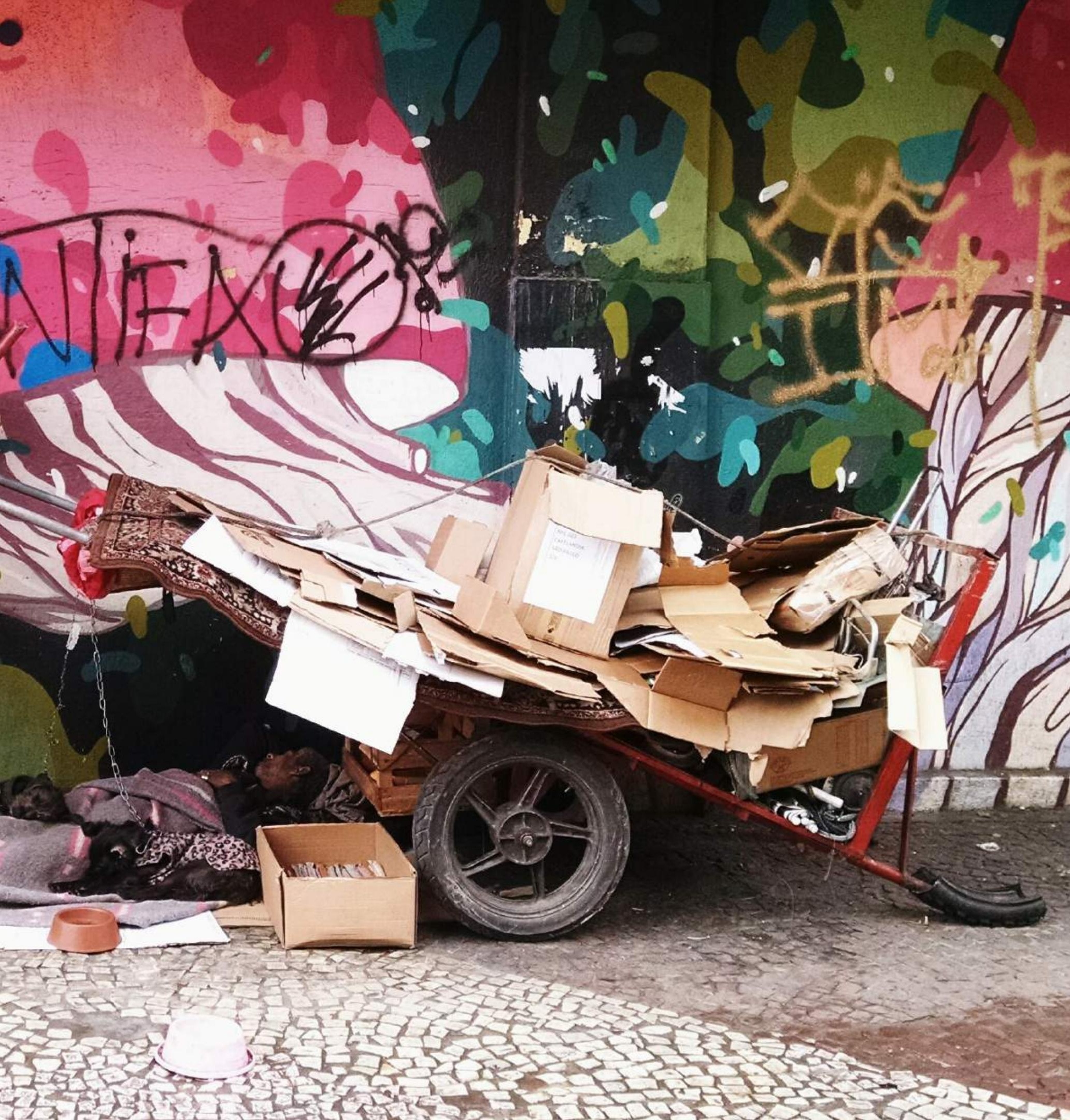


A formação urbana de ambas as regiões metropolitanas, intrinsecamente associadas com o poder da elite em se manter em uma contínua produção e reprodução de dominação e hegemonia (BOURDIEU, 1989), tem como resultado urbano visível a segregação socioespacial, muitas vezes associada com a limitação das práticas sociais, que leva ao aspecto invisível da segregação, a qual separa, inconscientemente, não só fragmentos e trechos de cidade, mas também grupos sociais.

É no cotidiano inconsciente (LEFEBVRE, 1991) que há a possibilidade de o sujeito se posicionar contrariamente à imposição de valores, papéis, personagens, enfim, modelos de vida coletiva espetacularizada (RIBEIRO, 2013). Essa luta contra o habitus imposto representa alternativas e táticas para superar o fragmento social e praticar o território de maneira menos limitada.

Estudos como o de Dunker (2015) e Caldeira (2000) demonstram o impacto de áreas homogêneas de loteamentos fechados de alta renda em diversas cidades brasileiras. Como são, ainda, produções urbanas recentes, talvez os índices de criminalidade não sejam capazes de demonstrar se há aumento da violência por conta do excesso de homogeneização econômica agravado pela presença de loteamentos fechados e empreendimentos de alto padrão. Contudo, é possível que essa relação exista, já que muros, cercas e vigilância privada não são eficientes para conter a violência, podendo inclusive ter efeito inverso. Ao invés de proteger, a distinção destaca a diferença, gerando uma falsa ideia de segurança.

Da mesma maneira, as áreas extremamente homogêneas de baixa renda também podem apresentar índices de criminalidade altos, também associados ao crime organizado, um dos fatores que mais originam violência e opressão, como demonstrará o estudo de caso do Condomínio Residencial Pimentas, no capítulo 6.

A homogeneização estimula a diferenciação e a visível exclusão e exclusividade em trechos urbanos, o que só colabora para o aumento da indignação social, levando ou à maior alienação ou à extremismos de luta e criminalidade. Porém, a heterogeneidade, processo segundo o qual classes com diferenças sociais possam conviver sem se fecharem continuamente frente ao diferente, é uma idealização difícil de ser concretizada para estratos de renda muito distantes. 


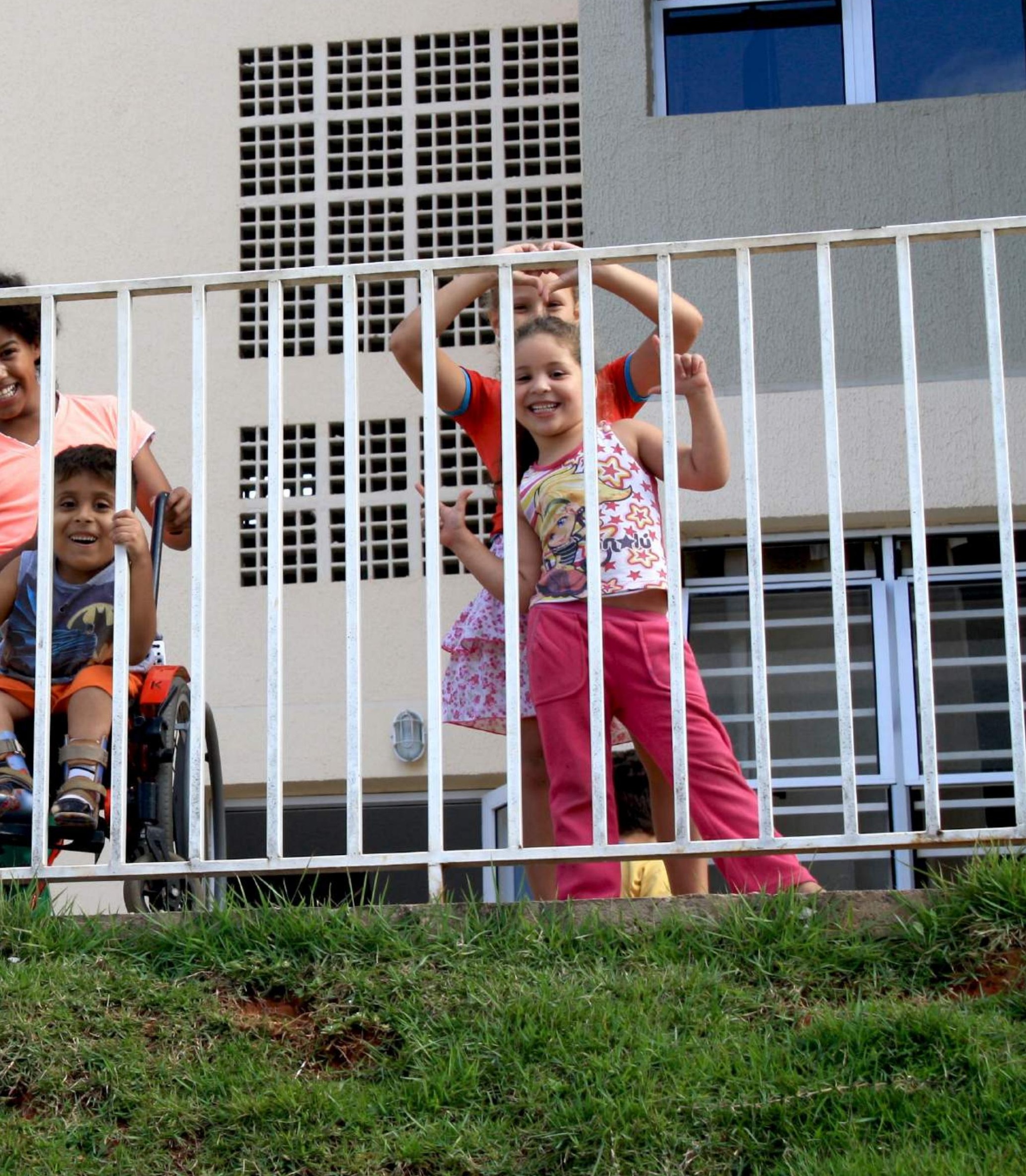


Constituição de 1988. Política Urbana e função social da cidade e da propriedade. Processos participativos. Reconhecimento dos assentamentos informais. Estatuto da Cidade. Conselho Nacional das Cidades. Sistema Nacional de Habitação de Interesse Social (SNHIS). Planos Diretores Participativos. Zonas Especiais de Interesse Social (ZEIS). Ministério das Cidades. Agenda da Reforma Urbana. Programa Minha Casa Minha Vida (PMCMV). PMCMV-Entidades. Programa de Aceleração do Crescimento (PAC)... Dentre tantos outros instrumentos legais criados desde os anos 1980, todos esses fazem parte do chamado "avanço brasileiro". Um avanço legal e constitutivo, certamente, mas qual seria o avanço prático e real?

Os progressos jurídicos, com potencial para ações urbanas sociais, não conseguem desafiar a realidade: a grande dependência de forças, de interesses políticos e de mercado, que atuam mais para a manutenção do modelo de desenvolvimento urbano perifericamente inclusivo do que pela democratização da cidade. Esse paradoxo permanece presente mesmo com investimentos públicos e de financiamento nunca antes experimentados no país para as famílias com menores recursos.

O problema brasileiro é genético, de origem de formação territorial e social, e o recente PMCMV provém do mesmo circuito de "avanços que não avançam".

Deak (1999) destaca essa genética dos poucos avanços sob o conceito de "acumulação entravada", relacionada ao processo específico de reprodução social desde a Independência do Brasil e até o fim dos anos 1970, e que deixou, socialmente, a reprodução social, mesmo após a Independência, dependente dos requisitos e das condições de dominação da elite antes colonial.

No contexto do final dos anos 2000, o PMCMV surgiu unindo os objetivos sociais de construção de moradias e de combate ao déficit habitacional ao objetivo econômico de alavancar a economia, afastando o país da crise mundial. Tendo sido criado com intuito econômico, obviamente esbarra em dificuldades no que tange à sua atuação no setor social.

Neste trabalho, para efeito de análise do PMCMV, selecionou-se o período de 2009 a 2015, o qual abarca as duas primeiras fases do programa e o início da terceira, antes das mudanças políticas instituídas pelo impeachment da presidenta Dilma Rousseff. Para a análise dos estudos de caso, apresentados no capítulo 6, a análise se estendeu até o final de 2016.

O PMCMV tem seus méritos, principalmente quantitativos, na produção de unidades habitacionais, além do inegável aquecimento da construção civil, gerando crescimento econômico e milhares de postos de trabalho em todo o Brasil. Outro aspecto importante foi o atendimento, por meio da iniciativa privada, de uma parte da população que até então não era assistida pelo mercado para obter a casa própria, já que a construção civil atuava, até antes do lançamento do programa, quase que exclusivamente para os setores de renda média e alta, com pequenos momentos de exploração do mercado voltado para classes de renda baixa, como durante a década de 1990 com o Plano $100^{43}$ (FERREIRA, 2012).

43 O Plano 100 fez parte de soluções buscadas pelos empresários devido à escassez do financiamento imobiliário dos anos 1990. Esse plano foi uma criação de uma incorporadora imobiliária, a Rossi, e consistiu em vender e financiar prédios residenciais para classe média baixa em São Paulo, realizando financiamento direto com os clientes. 
Também no âmbito dos méritos do PMCMV está a sua abrangência nacional, tendo também sido acompanhado de um arcabouço institucional importante para a constituição das políticas sociais do país. Contudo, além da já comentada dificuldade de aplicação de instrumentos legais para maiores ações urbanas sociais, há também a complexidade de traçar uma política nacional que considere as diversidades do país.

Apesar da grande produção de unidades habitacionais, o déficit brasileiro subiu após o início do Programa ${ }^{44}$, o que pode ser analisado como resultado da lógica da inclusão periférica do capital imobiliário, que movimenta o círculo vicioso de valorização do solo urbano e a contínua expulsão das famílias que não conseguem arcar com os constantes aumentos do custo de vida.

Um dos principais equívocos da política foi tratar a habitação como produção e não como moradia. A ênfase numérica não atende às necessidades habitacionais do país, e a meta dos últimos governos em produzir para suprir o déficit tem apresentado resultados tão questionáveis quanto os produzidos no período BNH.

Essa característica de produção é histórica, assim como a pouca importância dada à qualidade urbana dos espaços voltados para as práticas sociais, refletindo um modo de produção já há muito tempo criticado, em uma repetição dramática e previsível de erros de desenho urbano.

Se, por um lado, o programa apresentou diversos avanços para a condução de uma política de habitação, os resultados produzidos não têm nada de novo, apenas mantêm a histórica e questionável produção similar ao período do $\mathrm{BNH}$, construindo sem grandes preocupações com a qualidade urbana e arquitetônica (figuras 41 a 47). Desde o início do Programa, demonstrava-se uma grande vontade de suprir o déficit habitacional, dando mais atenção à produção de unidades habitacionais. Tentava-se substituir um número por novos números, como se a política pudesse ser tratada como um produto a ser produzido e consumido.

A política do PMCMV, ao articular a participação da iniciativa privada no processo, colocou a produção habitacional como responsabilidade do mercado imobiliário. Para as faixas de renda médias e altas, não há nenhuma novidade nesse processo, mas para a produção de habitação social o fato foi inédito, já que ela, até então, sempre havia sido realizada sob iniciativa do Estado.

Vale ressaltar que, antes do lançamento do Programa, as mais atuantes incorporadoras da produção imobiliária abriram capital na Bolsa de Valores de São Paulo (CARVALHO, H. R.S. 2011), como foi o caso da Cyrela Brasil Realty S.A., da Gafisa S.A. e da PDG Realty S.A., o que possibilitou a essas empresas viabilizarem empreendimentos, principalmente para o setor econômico, através da compra antecipada de terrenos e da criação de novas frentes de atuação para o mercado popular por meio de parcerias e expansão de atividades pelo território nacional, já antecipando o período de grande construção que viria com o PMCMV.

44 Segundo o Ministério das Cidades, em 2008, o número de famílias sem moradia no país era de 5.546.000. Mesmo com a produção de 1 milhão de moradias pelo PMCMV, no final de 2010, o número de famílias sem moradia era de 6.940.000. Ou seja, após 1 milhão de casas produzidas, o déficit ainda aumentou em praticamente 1,5 milhão (RIBEIRO; BOULOS; SZERMETA, 2014). 
Com a formulação da nova Política Nacional de Habitação e a criação do PMCMV, o Brasil retomou uma produção maciça de habitações que, similarmente ao período militar, salvo as devidas exceções sociais, continuou mantendo um modelo urbano de habitação social de questionável qualidade arquitetônica e inadequada inserção urbana (figura 45). Com isso, a segregação socioespacial nas cidades brasileiras só se acentuou, além da produção massiva não ter sido suficiente para enfrentar a carência de moradia.

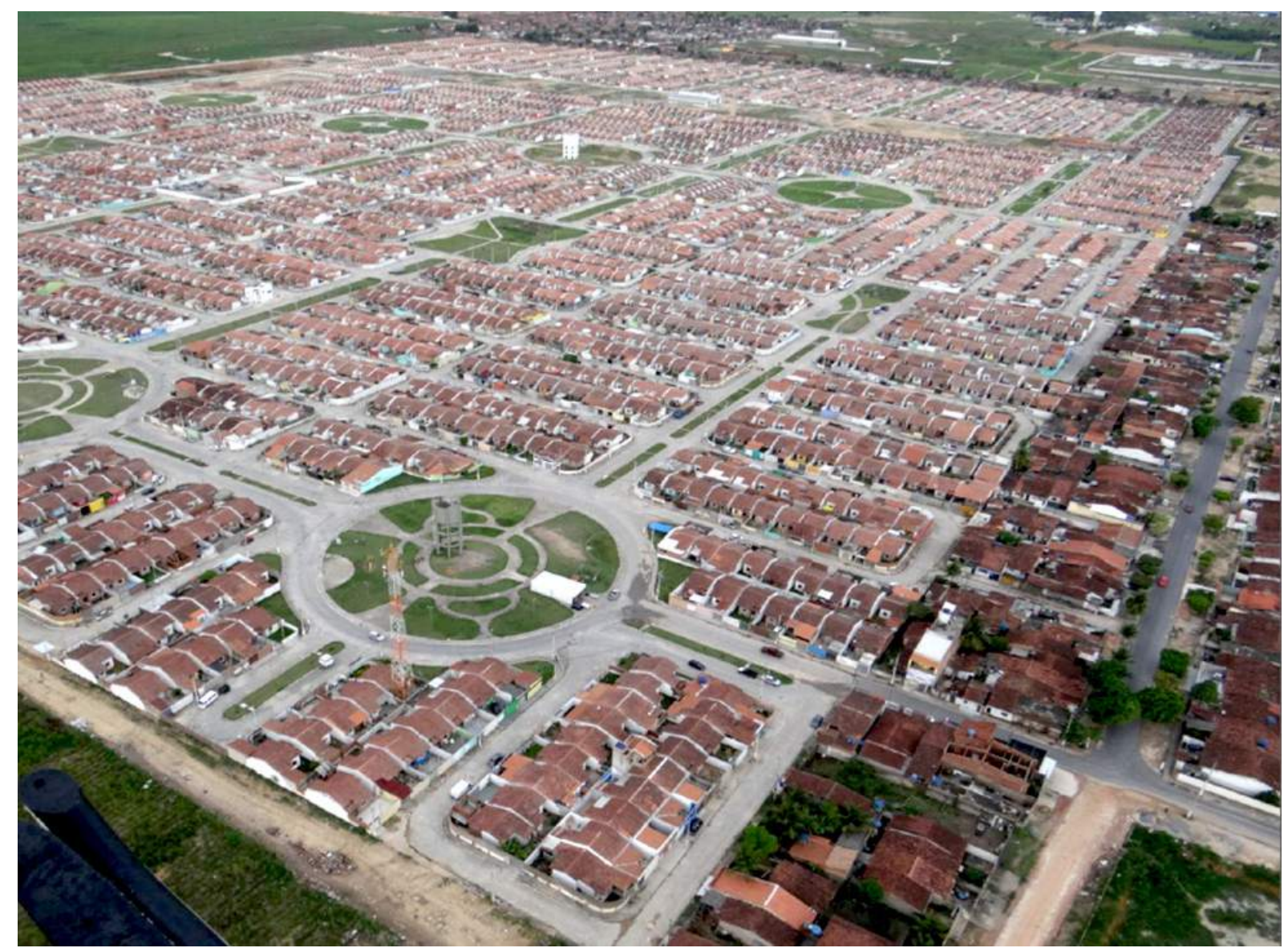

Figura 41: Empreendimento do PMCMV no município de Maceió-AL. Fonte: Acervo QUAPÁ - FAUUSP, 2013.

Para a faixa 1 do programa, que atende a famílias de rendimento de até três salários mínimos, a produção é bastante regulamentada, com a participação de diversos agentes públicos e privados, além do órgão financiador. Dentre as instâncias, estão o Governo Federal, estados, municípios, bancos (como agentes financeiros), empresas de construção imobiliária, entidades não governamentais e movimentos sociais.

Do papel do Governo Federal e, consequentemente, do Ministério das Cidades, destaca-se a elaboração de diretrizes gerais para as políticas urbanas e habitacionais vigentes, tendo sido responsável pela elaboração do PMCMV e pela definição das estratégias de operacionalização 
do Programa. O Governo Federal também estabelece o montante de recursos mobilizados e sua forma de distribuição para atender a necessidades específicas. Segundo Ferreira (2012), devido ao papel da União em estabelecer diretrizes e regras para o PMCMV, caberia a ele a maior exigência de parâmetros de qualidade arquitetônica e urbanística, o que poderia ser condicionado inclusive ao financiamento dos recursos.

Já os estados atuam principalmente na aplicação de leis estaduais sobre parcelamento, uso e ocupação do solo, como em relação às áreas de proteção ambiental, respondendo pela aprovação de projetos quando há impacto em Áreas de Preservação Permanente (APPs), em mananciais, ou em áreas que envolvem mais de um município. Em áreas ainda não atendidas por serviços urbanos, os estados também podem ser responsáveis pela infraestrutura para esses novos empreendimentos, embora essa responsabilidade possa ser repassada ao loteador, cabendo às concessionárias de serviços públicos a ligação das redes gerais de fornecimento de energia, de água e coleta de esgoto.

Desde a Constituição de 1988, os municípios com mais de vinte mil habitantes são responsáveis pela elaboração de Planos Diretores e pelas leis de uso e ocupação do solo urbano e devem construir os mecanismos necessários para implementar os instrumentos urbanísticos do Estatuto da Cidade. Com isso, os municípios acabaram por ter muita importância no PMCMV, pois atuam diretamente no mercado de terras e de valorização do solo urbano, junto aos construtores e empreendedores.

Além de se submeterem a aprovações estaduais e mesmo federais, os empreendimentos novos, tanto os destinados à alta renda como aqueles de habitação social, também precisam ser aprovados no âmbito municipal, muitas vezes dependente de interesses políticos e econômicos, a depender do tamanho do empreendimento e de suas especificidades quanto às leis de diferentes instâncias. Um exemplo ocorre no caso das aprovações de loteamentos em áreas ambientalmente significativas, que exigem aprovação pela Secretaria Estadual do Meio Ambiente, nos casos em que o município não está autorizado a realizar o licenciamento ambiental. Via de regra, o processo de parcelamento do solo no Brasil é bastante complexo e moroso, dependendo de aspectos legais e de interesses diversos.

A Caixa Econômica Federal, que age através de diversas agências regionais em todo o país, foi o principal agente financeiro que concedeu financiamento dentro do PMCMV, atuando tanto diretamente com a pessoa física interessada em adquirir o imóvel como com construtoras e incorporadoras. Outros bancos privados também atuaram, nas primeiras fases do PMCMV, como agentes financeiros, mas a Caixa foi predominante no programa.

Para aprovar o financiamento de empreendimentos, a Caixa definiu critérios técnicos, de maneira a verificar a viabilidade dos projetos. A maioria das normas utilizadas por ela para avaliação é relacionada aos aspectos arquitetônicos construtivos de maneira geral, focando principalmente na unidade habitacional. Isso direcionou o empreendedor a realizar conjuntos 
habitacionais dentro de um mesmo padrão, o que, por sua vez, facilita a aprovação do financiamento e aumenta a reprodução de soluções homogêneas.

Dessa forma, fica claro que faltam critérios de inserção urbana, por não se exigirem, para um novo empreendimento habitacional, relações diretas com aspectos como acessibilidade, integração à malha urbana, acesso à infraestrutura e serviços urbanos. Também faltam exigências quanto ao projeto de implantação, não relacionando a proporção do empreendimento com o impacto imediato na vizinhança, seja esta de vegetação intensa, como ocorre em muitos casos do Programa Minha Casa Minha Vida faixa 1, seja com o entorno de bairro.

Deveriam ser pensados e propostos exemplos de ocupação urbana com integração com a malha urbana existente, adequação de fluxo de tráfico novo às ruas existentes, relação entre os espaços livres, de circulação e de convívio, adequação paisagística ao suporte biofísico (como ocorre nos terrenos acidentados), entre outros aspectos, que poderiam ser explicitados com cadernos de boas práticas de formas de ocupação do terreno, além de exigências mínimas e máximas de implantação, densidade e dimensão.

De uma maneira geral, observam-se, nos empreendimentos produzidos do PMCMV Faixa 1 até 2016, uma tendência ao espraiamento urbano, com a formação de áreas de habitação desarticuladas da malha urbana, e sem diversidade funcional e social, com pouca - ou nenhuma - exigência de infraestrutura urbana e serviços para os novos empreendimentos, principalmente durante a primeira fase do programa.

Um padrão tipológico de ocupação do solo urbano recorrente nas fases 1 e 2 do PMCMV é o loteamento habitacional com residências unifamiliares, em quadras extensas, em ruas mal dimensionadas, direcionando muito espaço para o automóvel e pouco para o pedestre, que recebe calçadas mínimas (figura 42 e 43). Os espaços livres são predominantemente residuais, entre terrenos destinados a áreas públicas - que nunca são entregues no mesmo momento em que as residências às famílias - e APPs. Esse modelo de ocupação se repetiu em cidades brasileiras de todos os portes e de todas as regiões do país, muitas vezes em ocupações em morros (figura 45), sempre bastante distantes do núcleo principal das cidades.

Foram construídos empreendimentos de ocupação padronizada como carimbos nas franjas das cidades, com falhas de acessibilidade e de fluidez urbana bastante severas, além de uma ausência de pensamento nos espaços livres de uso coletivo, principalmente em empreendimentos de unidades habitacionais térreas. Essa produção, reforçada pela própria legislação, fez arranjos pré-definidos de fácil implantação, independentemente das características topográficas, possibilitando a "racionalização" da produção, no sentido de produção eficaz que minimiza custos, e não no sentido de produção urbanística racional, pensada para ser interessante para os usuários. 


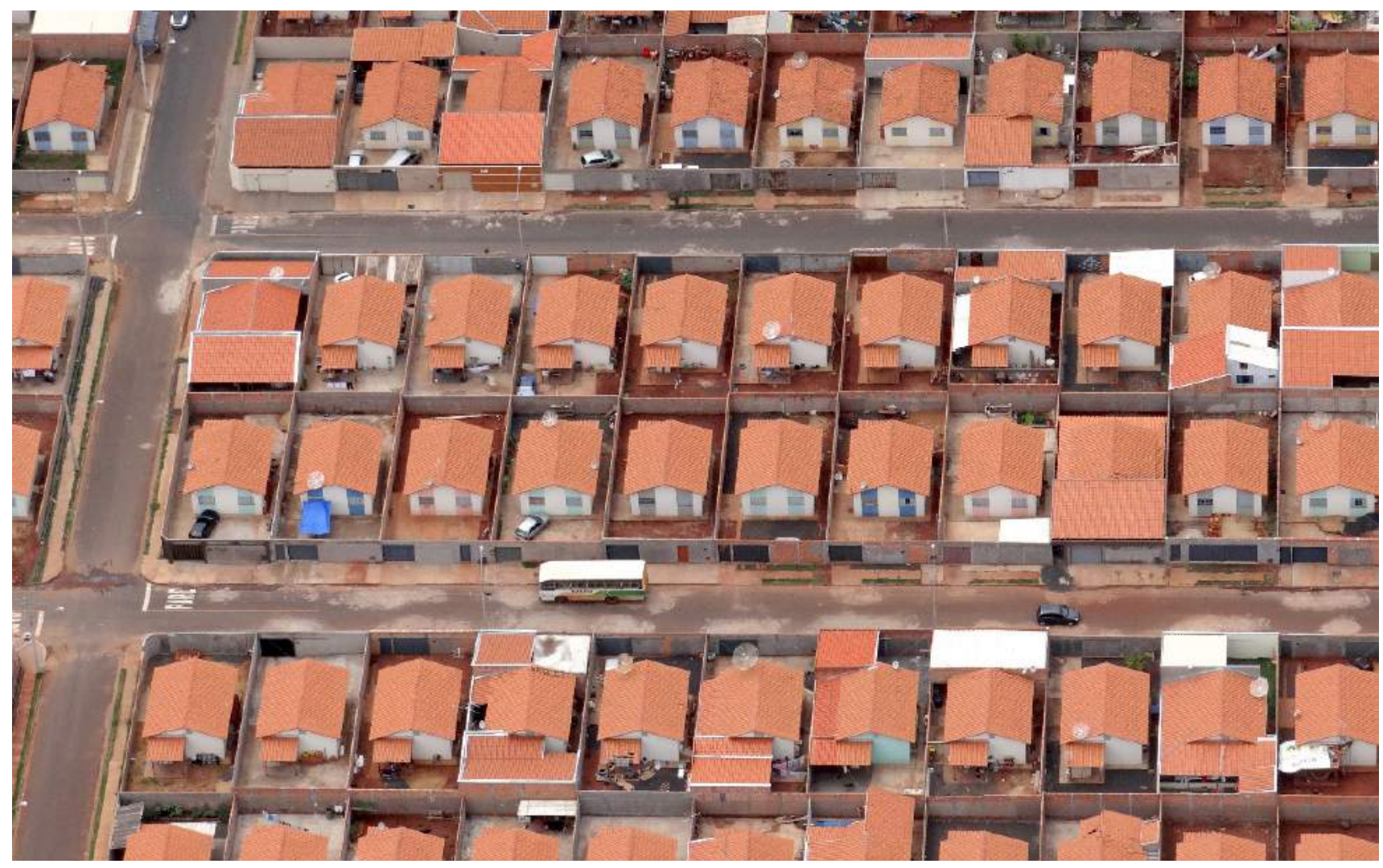

Figura 42: Empreendimento do PMCMV no município de Uberaba-MG. Fonte: Acervo QUAPÁ - FAUUSP, 2013.

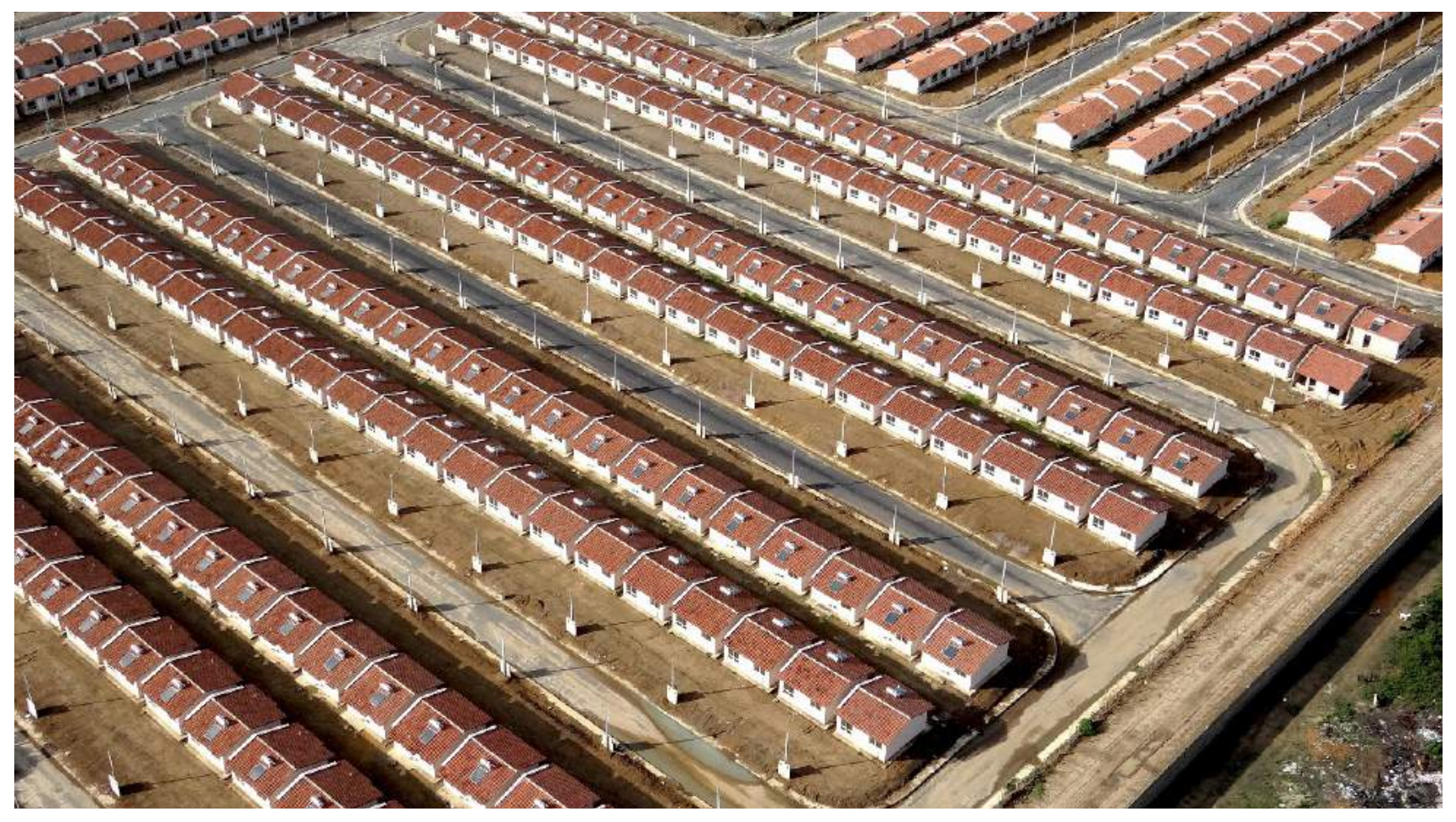

Figura 43: Empreendimento do PMCMV no município de Maceió-AL. Fonte: Acervo QUAPÁ - FAUUSP, 2014. 


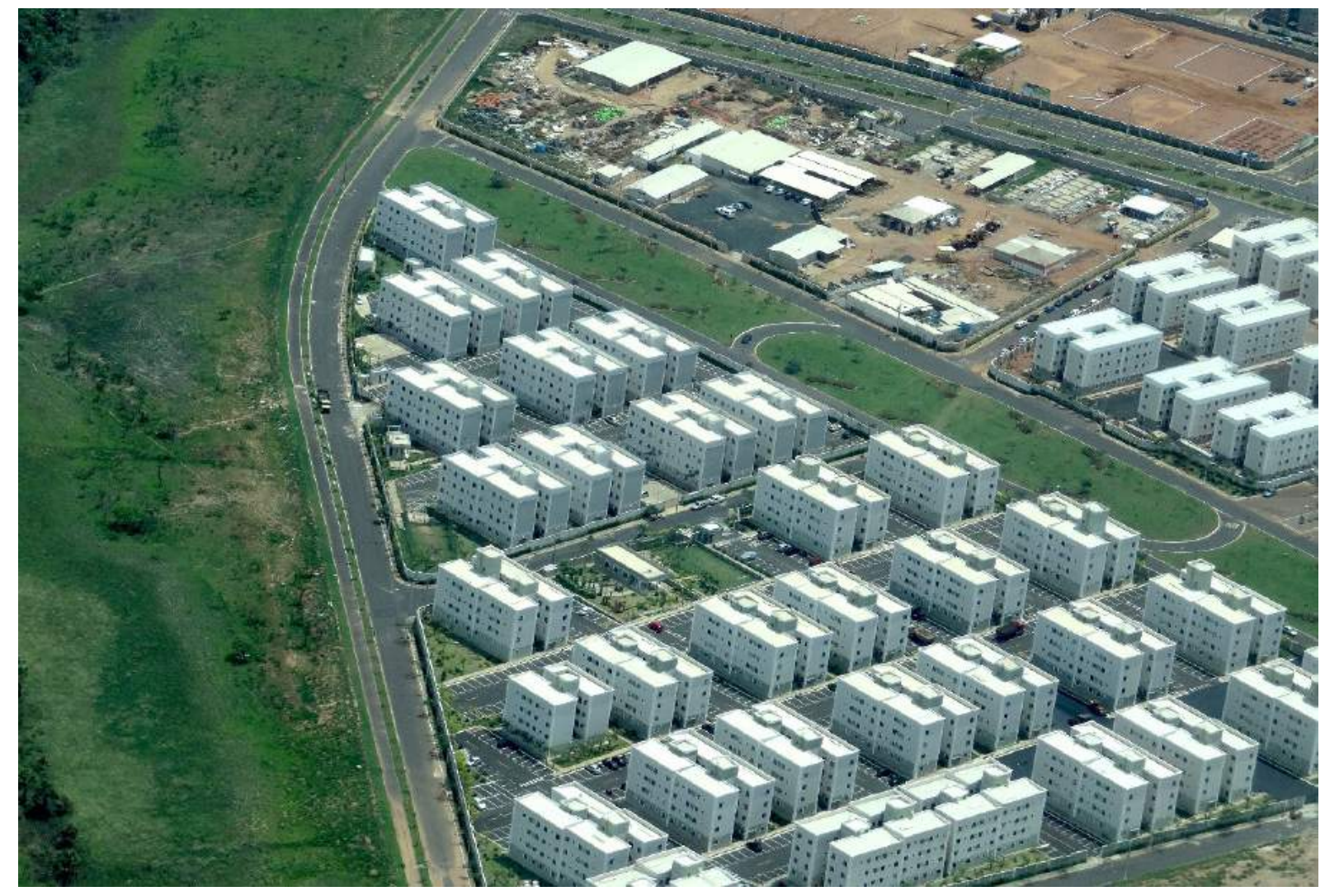

Figura 44: Empreendimento do PMCMV no município de Uberlândia-MG. Fonte: Acervo QUAPÁ FAUUSP, 2013.

A tipologia arquitetônica de condomínio de prédios, predominante em regiões metropolitanas, apresenta apartamentos desde o pavimento térreo e grande porcentagem de impermeabilização do solo, devido à ocupação das áreas térreas por estacionamento de veículos, já que é inviável - economicamente - construir garagens subterrâneas (figura 44). Em terrenos com topografia acidentada, as áreas livres são ainda mais impermeabilizadas, pois, além das áreas destinadas a estacionamento, são também impermeabilizados outros espaços livres para adequação de implantação dos edifícios em patamares e construção de rampas acessíveis.

Sobre a estereotipada tipologia arquitetônica de conjuntos habitacionais periféricos, Queiroga (2012) comenta:

Embora haja experiências de produção de habitação de interesse social em várias cidades brasileiras, a produção contemporânea promovida pelo Estado é, com muito maior frequência, a do conjunto habitacional periférico, monótono e pouco integrado aos tecidos urbanos da cidade tradicional. Estereótipo empobrecido do padrão urbanístico moderno - prédio isolado envolto em generosos e indefinidos espaços livres vegetados -, os conjuntos habitacionais de edifícios multifamiliares e sem elevador possuem espaços livres em menor quantidade e qualidade que seus precursores modernos. Boa parte dos espaços livres se reduz a espaços para automóveis - circulação e estacionamento - e taludes gramados mal mantidos (p. 243). 
Esse modelo condominial se origina do mercado de alta renda, reproduzindo soluções generalizadas de espaços de convívio intramuros, que limitam a integração entre grupos sociais nos espaços livres do bairro, provocando uma ruptura física e subjetiva no entorno imediato.

O modelo, de forte apelo mercadológico, reproduz, de maneira limitada, um modo de viver já bastante difundido pelos meios de comunicação como moradia de média e alta rendas, com oferta de espaços de convívio "exclusivos" aos moradores do conjunto. O condomínio de prédios é uma prática que une a necessidade de otimização do solo urbano metropolitano a um modelo de mercado que rompe com a prática urbana, privatizando espaços de lazer e regulando normas e condutas de convívio coletivo.

A produção de condomínios de prédios do PMCMV é morfologicamente uniforme, com uma solução básica de enfileiramento de blocos habitacionais nem sempre implantados em conformidade com topografia, e muito menos pensados para melhor insolação ou ventilação das unidades habitacionais. $O$ enfileiramento, muitas vezes, acaba gerando agrupamentos muito extensos, que causam uma ruptura na malha urbana bastante negativa para práticas sociais de bairro.

Deveriam ser consideradas as particularidades topográficas, não só pensando na redução de cortes e aterros para implantação de edifícios, mas também buscando, nas adequações do terreno, a criação de espaços livres interessantes para as práticas coletivas, e não resíduos da movimentação de terra. Além disso, distanciamentos e posicionamentos em relação ao sol deveriam ser exigidos pelas legislações, considerando as particularidades de cada região do país.

Impressiona, em ambos os modelos de ocupação para a faixa 1, a grande produção habitacional com valores urbanísticos e construtivos bastante limitados, com unidades habitacionais que não permitem o convívio familiar, devido à sua reduzida dimensão e má distribuição espacial, além dos espaços livres que, tampouco, oferecem locais para o convívio familiar e coletivo, não criando condições de desenvolvimento de civilidade.

Talvez isso ocorra por pouco conhecimento das empresas em relação às boas práticas e bons elementos arquitetônicos e urbanísticos, talvez por desprezo a eles, associando-se à pouca exigência dos órgãos oficiais e à lógica de produção baseada na lucratividade, incentivadas pelo modo de fazer habitação social já absorvido como padrão a ser seguido.

Boas soluções urbanísticas não são obrigatoriamente mais onerosas, e poderiam ser feitas a partir de maiores exigências e direcionamentos da política ou do órgão financiador, evitando a reprodução de um modelo de qualidade urbana questionável.

A busca deveria ser por uma solução urbanística de criação de bairro, harmonizando os espaços privados das unidades habitacionais com espaços coletivos e com infraestrutura urbana de convívio urbano, como comércio, serviços e outros atendimentos ao cotidiano da cidade, planejados tanto para o deslocamento lento de pedestres e bicicletas, quanto para os deslocamentos rápidos, privilegiando-se o transporte público. Essas soluções de desenho urbano, a longo prazo, são muito mais econômicas do que espaços não planejados de habitação sem cidade. 

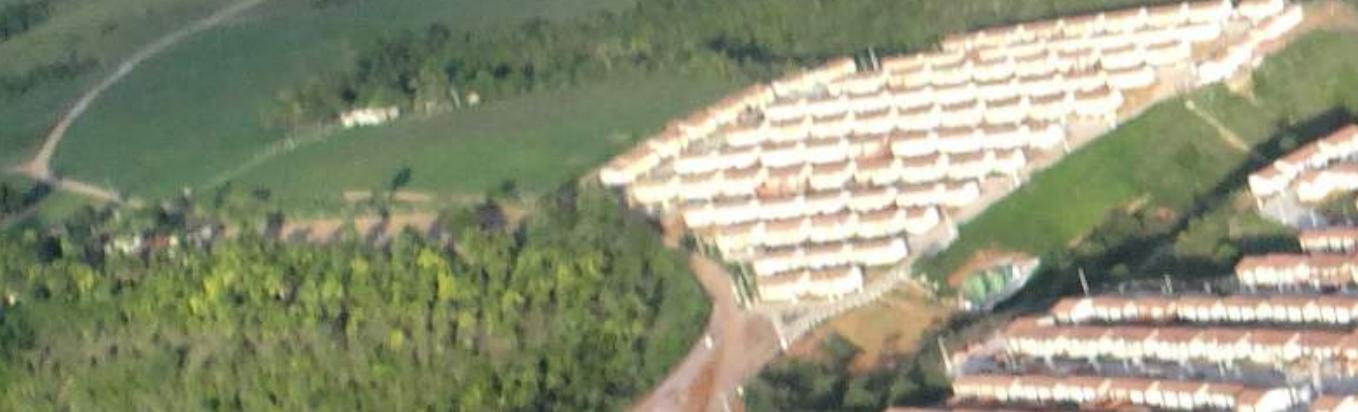

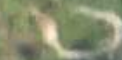

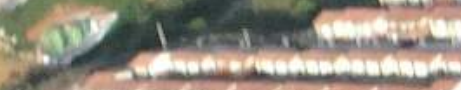

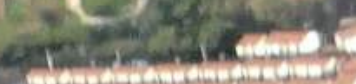
(1)

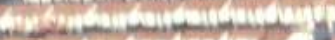

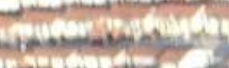
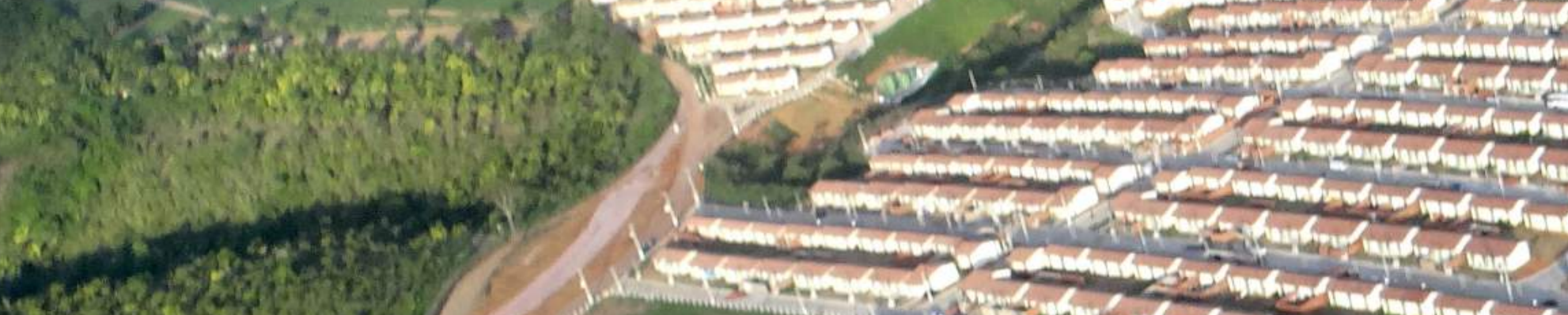

$y^{2}$

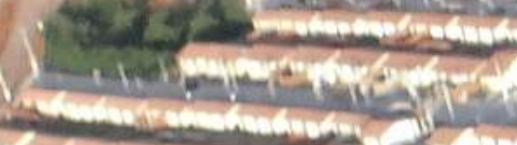

1. Wh

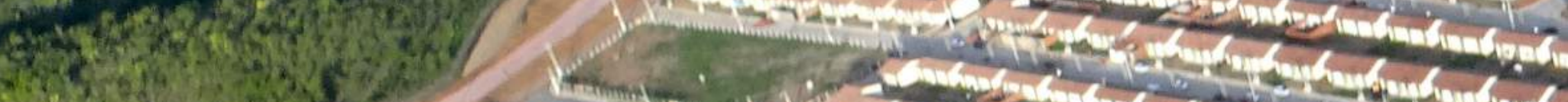

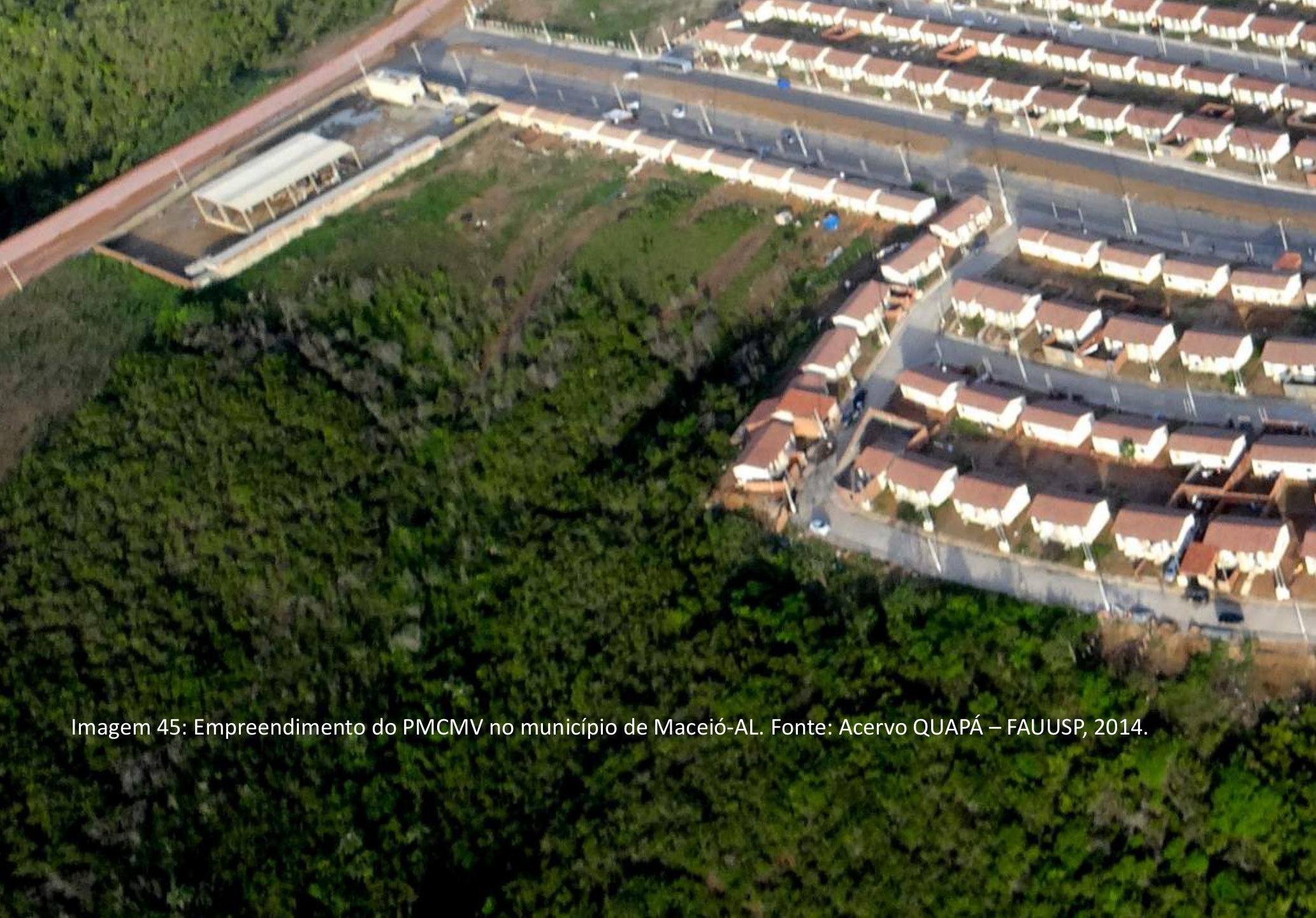




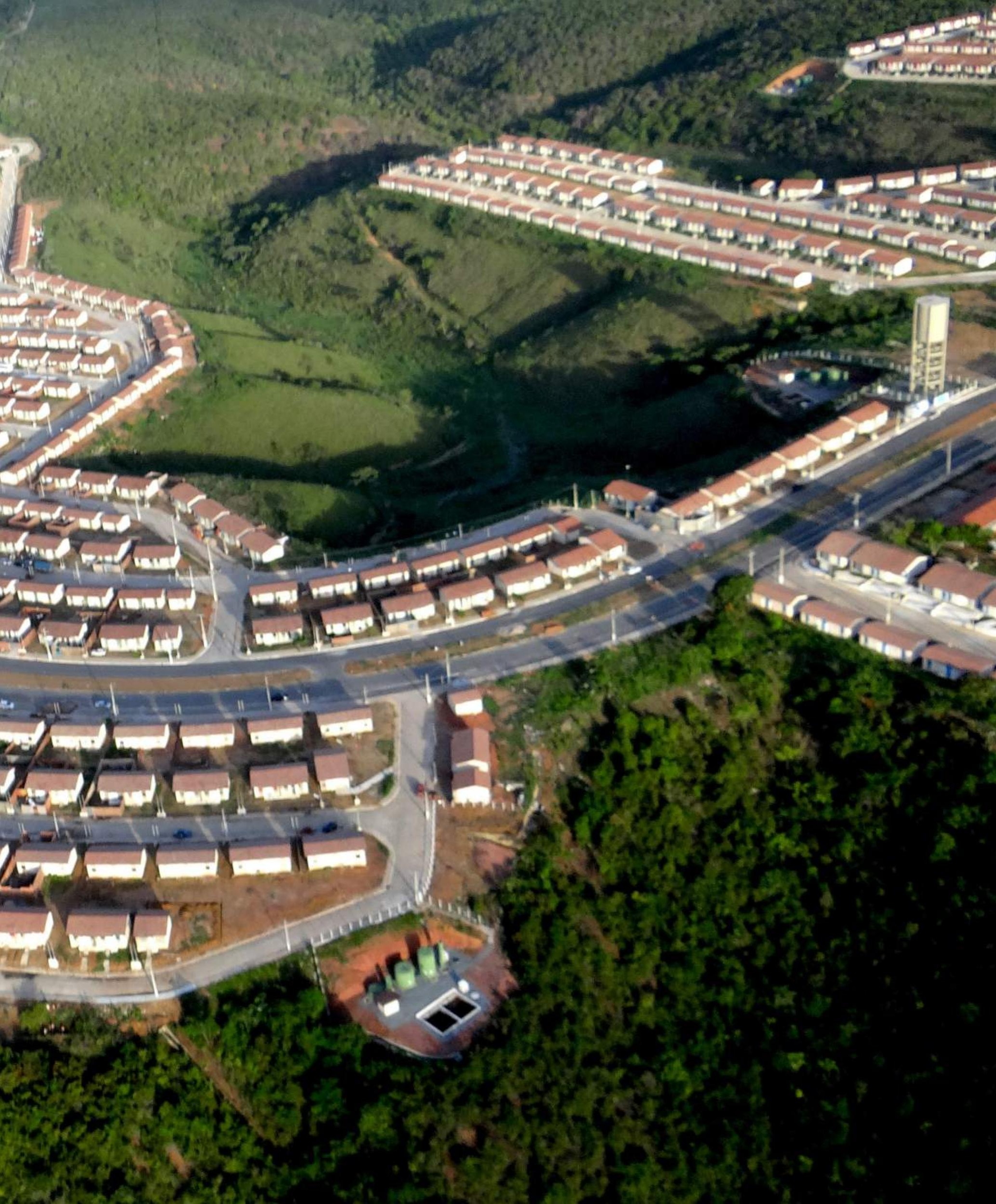



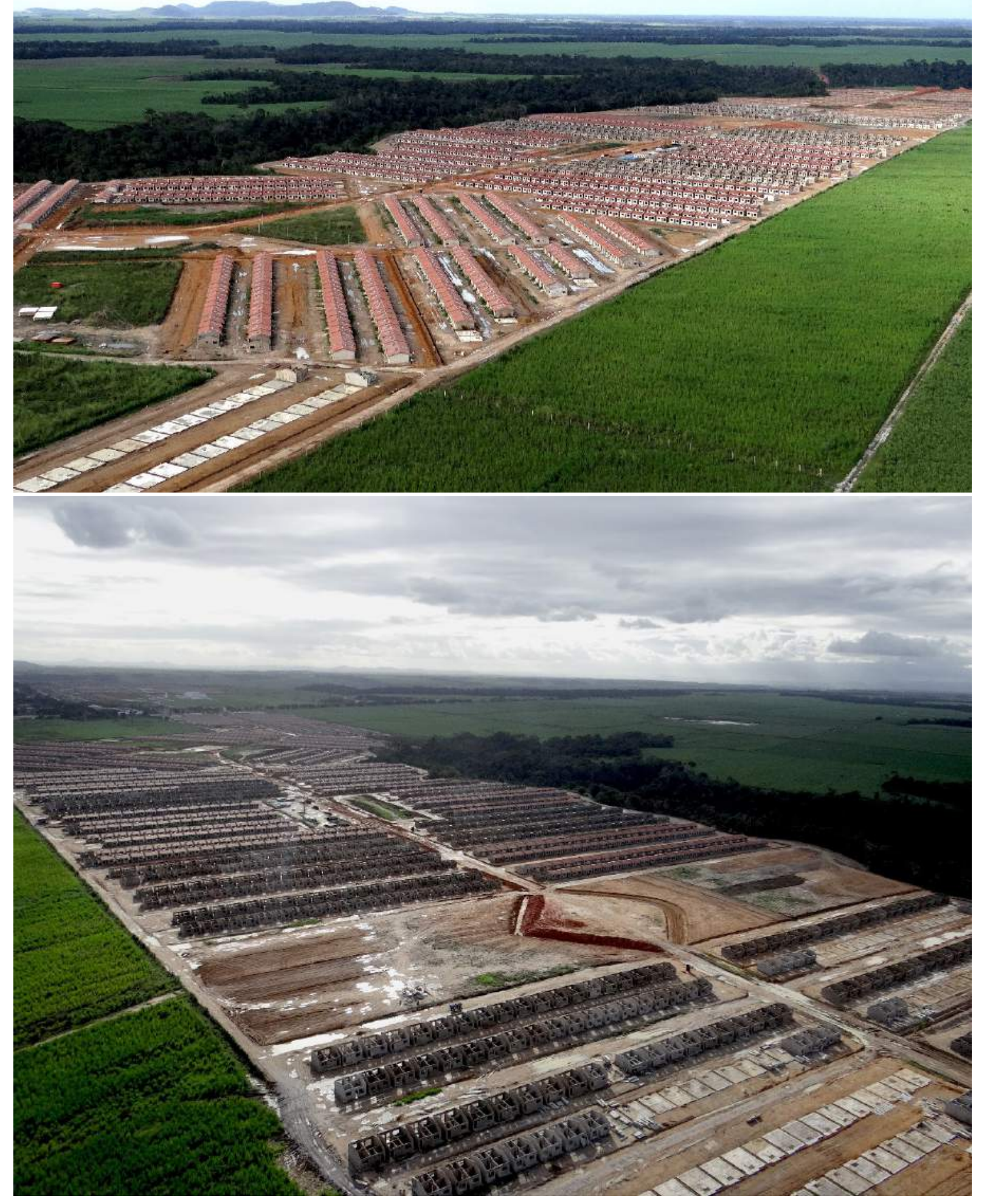

Imagens 46 e 47: Empreendimentos do PMCMV no município de Maceió-AL. Fonte: Acervo QUAPÁ FAUUSP, 2014. 


\section{Particularidades do PMCMV}

Para atender a famílias de diferentes faixas de renda, assim como aos municípios dentro de suas particularidades de porte, além das áreas rurais, o PMCMV foi estruturado em diferentes modalidades:

- PMCMV Empresas;

- PMCMV Entidades;

- PMCMV Oferta Pública45;

- PMCMV Rural.

Desde seu lançamento, o programa já teve três fases, que diferem entre si por algumas modificações. A primeira fase foi de 2009 a 2010, a segunda, de 2011 a 2016 e a terceira foi lançada e paralisada em 2016.

O Programa teve grande abrangência econômica, atuando nas faixas de zero até dez salários mínimos ${ }^{46}$, em três faixas de renda:

- Faixa 1: voltada para a produção habitacional para famílias com rendimento entre zero e três salários mínimos (mas na segunda fase do programa teve o valor de renda desassociado do salário mínimo e fixado a $\mathrm{R} \$ 1.600,00$ mensais);

- Faixa 2: para as famílias com rendimento de três a seis salários mínimos (na segunda fase, com renda mensal fixada de $\mathrm{R} \$ 1.600,00$ a $\mathrm{R} \$ 3.275,00)$;

- Faixa 3: para as famílias de seis a dez salários mínimos, de $\mathrm{R} \$ 3.275,00$ a $\mathrm{R} \$ 5.000,00$.

Da primeira e segunda fases do Programa, ocorreram alterações tanto em relação ao limite de renda dos beneficiados como quanto a alterações no valor do financiamento. Essas alterações de valores das faixas de renda das famílias e de valor médio das moradias foi uma reivindicação das construtoras, além de se configurar como uma estratégia do Programa para alocar maiores investimentos para a faixa 1, já que havia predomínio de empreendimentos na faixa 2 e 3, principalmente nas regiões metropolitanas.

45 O PMCMV Oferta Pública de Recursos atuava em municípios com menos de 50 mil habitantes, porém essa modalidade foi suspensa devido a denúncias de irregularidade dos bancos. Essa parcela da população passou a ser atendida, então, pelo PMCMV Empresas Faixa 1 para municípios com menos de 50 mil habitantes, com atuação da Caixa Econômica Federal e Banco do Brasil, com recursos FAR.

46 O Salário Mínimo correspondia a:

2009 - R\$465,00 (200 USD, segundo cotação de 02/01/2009);

2010 - R\$510,00 (296 USD, segundo cotação de 04/01/2010);

2011 - R\$540,00 - R\$545,00 (327 USD e 328 USD, segundo cotação de 03/01/2011 e 01/03/2011, respectivamente);

2012 - R\$622,00 (333 USD, segundo cotação de 02/01/2012);

2013 - R\$678,00 (332 USD), segundo cotação de 02/01/2013);

2014 - R\$724,00 (302 USD de acordo com cotação de 02/01/2014);

2015 - R\$788,00 (293 USD de acordo com cotação de 02/01/2015);

2016 - R\$880,00 (218 USD, de acordo com cotação de 04/01/2016). 
Durante a segunda fase, o Programa apresentou algumas particularidades para a faixa 1, como em relação à demanda dos municípios, à necessidade de cadastro das famílias e ao uso de investimentos públicos a fundo perdido, oriundos do Orçamento Geral da União (OGU), alocados do Fundo de Arrendamento Residencial (FAR). Para essas famílias, o subsídio era quase integral, com algum retorno do beneficiário. As modalidades que atendem a essa faixa de renda são: PMCMV Empresas-FAR; PMCMV Entidades-FDS (Fundo de Desenvolvimento Social); Rural Grupo 1 e municípios até 50 mil habitantes.

Já as faixas 2 e 3, durante a segunda fase, recebiam recursos advindos do Fundo de Garantia por Tempo de Serviços (FGTS), com facilidades de acesso ao crédito e taxa de juros reduzida. Para a faixa 2 havia uma porcentagem de subsídio e outra de financiamento, com recursos OGU e FGTS, o que significou que o subsídio público, que atendia à população de mais baixa renda, também atendeu às famílias com renda de até 6 salários mínimos. Já para a faixa 3, o instrumento era o financiamento com recursos do FGTS.

Esse duplo atendimento do subsídio público para duas faixas de renda no programa gerou interferências em uma competição desigual, já que os construtores destinavam os terrenos mais bem localizados para a faixa 2 , deixando os terrenos menos valorizados e áreas urbanas mais periféricas para a faixa 1 (FERREIRA, 2012).

No início do Programa, a faixa 1 não tinha uma proeminência numérica maior. Movimentos sociais apontaram essa questão e lutaram para que houvesse mais investimentos para a faixa 1.

\begin{tabular}{|c|c|c|c|c|}
\hline \multicolumn{5}{|c|}{ PMCMV - fase 2 } \\
\hline Faixa & Renda & Instrumentos & Modalidades & Fonte \\
\hline $\mathbf{1}$ & Até $\mathrm{R} \$ 1.600,00$ & $\begin{array}{c}\text { Subsídio quase integral }+ \\
\text { retorno beneficiário }\end{array}$ & $\begin{array}{c}\text { Empresas/FAR } \\
\text { Entidades/FDS } \\
\text { Municípios até } 50 \text { mil } \\
\text { hab. }\end{array}$ & OGU \\
& Até $\mathrm{R} \$ 3.275,00$ & Subsídio + Financiamento & FGTS & OGU + FGTS \\
\hline $\mathbf{2}$ & R & Rural Grupo 2 & \\
\hline & R\$5.000,00 & Financiamento & FGTS & FGTS \\
\hline
\end{tabular}

Tabela 3: Realizada com dados do Programa Minha Casa Minha Vida, disponíveis em: <http://www.caixa.gov.br/poder-publico/programas-uniao/habitacao/minha-casa-minha-vida>, consultados em mar. 2014. 
Sobre as modalidades atuantes para a Faixa 1 do Programa, encontram-se:

\begin{tabular}{|c|c|c|c|c|c|}
\hline Modalidade & $\begin{array}{l}\text { Fonte dos } \\
\text { Recursos }\end{array}$ & Operação & $\begin{array}{c}\text { Valor da UH } \\
\text { - fase } 2 \\
\end{array}$ & $\begin{array}{c}\text { Parcela paga pelo } \\
\text { beneficiário }\end{array}$ & Particularidades \\
\hline $\begin{array}{l}\text { Empresas/FAR } \\
\text { Municípios } \\
\text { com mais de } \\
50 \text { mil habi- } \\
\text { tantes }\end{array}$ & $\begin{array}{l}\text { Fundo de Ar- } \\
\text { rendamento } \\
\text { Residencial - } \\
\text { FAR }\end{array}$ & $\begin{array}{lr}\text { Caixa } & \text { e } \\
\text { Banco } & \text { do } \\
\text { Brasil } & \end{array}$ & $\begin{array}{l}\mathrm{R} \$ 54.000,00 \\
\text { a } 76.000,00 \\
\text { (valor se al- } \\
\text { tera de acor- } \\
\text { do com a re- } \\
\text { gião) }\end{array}$ & $\begin{array}{l}5 \% \text { da renda men- } \\
\text { sal, com duração } \\
\text { de } 10 \text { anos, com } \\
\text { prestação mínima } \\
\text { de } R \$ 25,00\end{array}$ & $\begin{array}{l}\text { Famílias são indicadas } \\
\text { pela Prefeitura, que de- } \\
\text { vem estar cadastradas } \\
\text { no Cadúnico }{ }^{47} \text {. }\end{array}$ \\
\hline $\begin{array}{l}\text { Empresas/FAR } \\
\text { Municípios até } \\
50 \text { mil habi- } \\
\text { tantes }\end{array}$ & $\begin{array}{l}\text { Fundo de Ar- } \\
\text { rendamento } \\
\text { Residencial - } \\
\text { FAR }\end{array}$ & $\begin{array}{lr}\text { Caixa } & \text { e } \\
\text { Banco } & \text { do } \\
\text { Brasil } & \end{array}$ & $R \$ 35.000,00$ & $\begin{array}{l}5 \% \text { da renda men- } \\
\text { sal, com duração } \\
\text { de } 10 \text { anos, com } \\
\text { prestação mínima } \\
\text { de } R \$ 25,00\end{array}$ & $\begin{array}{l}\text { Famílias são indicadas } \\
\text { pela Prefeitura, que de- } \\
\text { vem estar cadastradas } \\
\text { no Cadúnico. } \\
\text { Obrigatória contrapar- } \\
\text { tida do ente local. }\end{array}$ \\
\hline Entidades/FDS & $\begin{array}{l}\text { Fundo de De- } \\
\text { senvolvimen- } \\
\text { to Social - FDS }\end{array}$ & Caixa & $\begin{array}{l}R \$ 54.000,00 \\
\text { a } 76.000,00 \\
\text { (regionaliza- } \\
\text { do) }\end{array}$ & $\begin{array}{l}5 \% \text { da renda men- } \\
\text { sal, com duração } \\
\text { de } 10 \text { anos, com } \\
\text { prestação mínima } \\
\text { de } R \$ 25,00\end{array}$ & $\begin{array}{l}\text { Entidades são respon- } \\
\text { sáveis pela seleção dos } \\
\text { beneficiários, projeto e } \\
\text { construção. }\end{array}$ \\
\hline Rural Grupo 1 & OGU e FGTS & $\begin{array}{lr}\text { Caixa } & \text { e } \\
\text { Banco } & \text { do } \\
\text { Brasil } & \end{array}$ & $\begin{array}{l}R \$ 28.500,00 \\
\text { (construção) } \\
17.200,00 \\
\text { (reforma) }\end{array}$ & $\begin{array}{l}4 \% \text { do valor da } \\
\text { unidade, em } 4 \\
\text { prestações anuais }\end{array}$ & $\begin{array}{l}\text { Entidades são respon- } \\
\text { sáveis por organizar a } \\
\text { demanda, realizar o } \\
\text { projeto, acompanhar a } \\
\text { construção. }\end{array}$ \\
\hline
\end{tabular}

Tabela 4: realizada com dados do Programa Minha Casa Minha Vida, disponíveis em: <http://www.caixa.gov.br/poder-publico/programas-uniao/habitacao/minha-casa-minha-vida>, consultados em mar. 2014.

A modalidade Empresas foi a que mais teve atuação em todas as fases do programa. O valor da unidade habitacional, no caso empresarial, era fixo, mas com alterações regionais, variando, em 2014, de $\mathrm{R} \$ 54.000$ a $\mathrm{R} \$ 76.000^{48}$. O financiamento da habitação deveria ser pago pelo beneficiário durante 10 anos, com prestações mínimas de $\mathrm{R} \$ 25,00$, que deveriam corresponder a $5 \%$ da renda familiar.

Segundo dados do Ministério das Cidades, até janeiro de 2014 haviam sido contratadas 1.52 milhão de unidades habitacionais na faixa 1. Durante a primeira fase do Programa, em 2009

47 O Cadastro único (Cadúnico) era coordenado pelo Ministério de Desenvolvimento Social e Combate à Fome (MDS), que foi extinto na gestão Temer após reforma ministerial. O MDS se fusionou com o Ministério do Desenvolvimento Agrário, e passou a ser denominado Ministério do Desenvolvimento Social e Agrário. O Cadastro Único identifica e caracteriza as famílias de baixa renda que fazem parte de algum Programa Social do Governo. Esses dados podem ser acessados pelos governos estaduais e municipais.

48 De 22.528 USD a 31.706 USD, considerando a cotação de 1ำ jan. 2014, com o dólar a $\mathrm{R} \$ 2,397$. 
- 2010, 2\% dos contratos corresponderam a unidades habitacionais pelo PMCMV-E, com recursos FDS, e 1\% contratado por meio do Programa Rural. Assim, as duas modalidades que apresentam entidades (MCMV-E e MCMV Rural) representaram apenas 3\% das unidades contratadas em 2009-2010.

A principal mudança ocorrida na terceira fase PMCMV, lançada em março de 2016, foi a proposta da inserção, entre as faixas 1 e 2, de mais uma faixa de financiamento para atingir os beneficiários da faixa 1 com utilização dos recursos do FGTS. Houve também mudança das faixas de renda: a faixa 1 teve limite de renda alterado de $\mathrm{R} \$ 1,6$ mil para $\mathrm{R} \$ 1,8$ mil; a nova faixa 1,5 foi anunciada para famílias com renda de até $R \$ 2.350$; a faixa 2 passou de $R \$ 3.275$ para $R \$ 3,6$ mil e a faixa 3 de $\mathrm{R} \$ 5$ mil para 6,5 mil.

O subsídio dos imóveis também foi alterado na terceira fase: na faixa 1, passou de $\mathrm{R} \$ 76$ mil para $\mathrm{R} \$ 96$ mil, com subsídio de até $\mathrm{R} \$ 86,4$ mil; na faixa 1,5, teve previsão de $\mathrm{R} \$ 135$ mil; na faixa 2 , subiu de $R \$ 190$ mil para $R \$ 225$ mil, com subsídio de até $R \$ 27,5$ mil e na faixa 3 , passou de $\mathrm{R} \$ 190$ mil para $\mathrm{R} \$ 225$ mil, sem subsídio.

\section{O Programa Minha Casa Minha Vida - Entidades (PMCMV-E)}

\section{- Histórico}

As primeiras experiências com projetos de autogestão, antes da criação do Ministério das Cidades e da retomada da temática da autogestão nas políticas nacionais, eram pontuais e restritas aos municípios. Uma primeira tentativa de oficializar as experiências autogestionárias pelo Ministério foi a inclusão da autogestão no Programa de Arrendamento Residencial (PAR) (MINEIRO; RODRIGUES, 2012).

No final de 2003, o Ministério das Cidades apresentou uma melhor alternativa, com a criação do Programa Crédito Solidário (PCS), utilizando o Fundo de Desenvolvimento Social (FDS) e tendo a Caixa Econômica Federal como agente operador e financeiro para gerir a aplicação dos recursos nos programas habitacionais (MINEIRO; RODRIGUES, 2012).

Novamente avanços legais, mas foram poucos os empreendimentos urbanos contratados nesses moldes, pelas dificuldades de documentação e aprovação que inviabilizavam a participação das Entidades, até que o Programa Crédito Solidário, devido à pressão dos movimentos sociais, foi substituído, em 2007, pelo Programa Crédito Solidário 2, que gerou mudanças na forma de financiamento, com novas medidas legais (MINEIRO; RODRIGUES, 2012).

Com a criação, em 2005, do Sistema Nacional de Habitação de Interesse Social (SNHIS), muitos movimentos sociais acreditaram que o Fundo Nacional de Habitação de Interesse Social (FNHIS) centralizaria recursos e programas de habitação e urbanização, porém os recursos do FNHIS foram definidos como destinados a organizações públicas, o que excluiu cooperativas e associações. Somado a isso, o PAC Urbanização foi criado fora do FNHIS, frustrando parte das Entidades. Posteriormente, com a pressão desses movimentos, uma medida provisória autorizou o repasse de recursos do FNHIS diretamente a elas, por meio do Programa Produção Social da Moradia, que atuaria, então, com recursos do FNHIS (MINEIRO; RODRIGUES, 2012)

Pouco tempo depois, entraria em vigor um novo "pacote habitacional", com o Programa Minha Casa Minha Vida. No final de 2008, após diversas atividades de mobilização por parte dos 
movimentos e de negociação com o Presidente da República e com a então ministra da Casa Civil, Dilma Rousseff, surgiu o Programa Minha Casa Minha Vida Entidades (PMCMV-E).

A modalidade "Entidades" (PMCMV-E) foi formatada de maneira similar à modalidade "Empresas", com a diferença de que organizações sem fins lucrativos, devidamente habilitadas pelo Ministério das Cidades, poderiam se responsabilizar pelo empreendimento. A entidade era responsável por diversos aspectos: selecionar as famílias beneficiadas, aprovar o empreendimento na instituição financeira; realizar a construção do empreendimento e mesmo atuar com trabalhos sociais.

A modalidade surgiu, dessa forma, por grande pressão dos movimentos populares, resultado da atuação de projetos de autogestão que vinham agindo desde os anos 1980. A força dos movimentos populares brasileiros tem sua importância, assim como a participação popular, mesmo que pontual em alguns programas e projetos sociais, como comentado no capítulo 2. Esses aspectos, somados aos instrumentos legais de Direito à Cidade, são exemplares, em comparação com outros países da América Latina, como o Chile, que não apresenta instrumentos nesse sentido, afora uma tímida participação social.

O PMCMV-E trouxe alguma esperança de melhorias nos empreendimentos para a população, por ter uma base alternativa à lógica empresarial, já que, ao menos em teoria, deveria atuar por maiores benefícios às famílias e com menor lucratividade. Porém, o PMCMV-E foi suspenso logo no início do governo Temer, em 2016.

\section{- Atuação}

No que tange à aprovação de projetos e liberação de recursos, o PMCMV-E seguiu os mesmos passos do PMCMV Empresas. Havia exigência de documentação jurídica muito grande, numa dificuldade técnica que intrincava a atuação de entidades formadas por grupos populares.

Além das complexidades jurídicas, existia também a dificuldade com o custo do solo urbano: como no PMCMV, de um modo geral, o valor do terreno está considerado no valor total da unidade a ser financiada, não há grande possibilidade de viabilizar um empreendimento se este não estiver localizado em áreas mais baratas. Com isso, as empresas atuantes na faixa 1 e as entidades tendem a disputar terrenos disponíveis, quase sempre em áreas periféricas.

É muito difícil adquirir um terreno dentro dos moldes do Programa, já que a exigência é de que eles estejam regularizados, tanto no âmbito da propriedade, quanto do parcelamento e do projeto a ser executado. Com isso, o tempo médio de realização do empreendimento pelas entidades aumenta, pois perde-se muito tempo com a busca do terreno e com sua regularização para ser enquadrado nas regras do Programa, o que, em muitos casos, gera processos que podem durar mais de um ano, chegando até a cinco anos (MINEIRO; RODRIGUES, 2012).

No entanto, se, por um lado, a maior exigência do programa em relação à regularização dos terrenos origina maiores dificuldades tanto para as empresas quanto para as entidades, por outro lado, isso permite que a família tenha a escritura do imóvel no final do processo.

Focando-se a análise dos empreendimentos do PMCMV-E para a Região Metropolitana de São Paulo, o que se verificou, em primeiro lugar, foi a dificuldade dos movimentos populares em encontrar terrenos bem localizados para a execução de empreendimentos. Há uma clara disputa por terrenos na região metropolitana, e as construtoras e incorporadoras saem ganhan- 
do na busca e na aquisição de áreas para o desenvolvimento de empreendimentos.

Essa disputa de terra entre entidades e construtoras poderia ser aliviada se houvesse políticas municipais efetivamente atuantes na reserva de terras urbanizadas para habitação social. Como não há, de fato, esse planejamento, as áreas passam a ser disputadas, com maiores vantagens para as construtoras, que dispõem de recursos para aquisição rápida de terrenos.

Apesar das dificuldades, o avanço do PMCMV-E se deu pela incorporação de grupos autogestionários como uma das modalidades dentro da política nacional de habitação, de maneira que as Entidades Organizadoras têm um papel no processo. Assim, a principal diferença em relação ao PMCMV está na valorização da autogestão e da participação (TATAGIBA et al., 2013).

\section{- Características}

Somente as famílias residentes em áreas de risco ou insalubres ou que estivessem desabrigadas podiam ser assistidas pelo PMCMV-E. Outra prioridade do programa era atender às famílias com mulheres responsáveis pela unidade familiar e aquelas com pessoas com deficiência e, posteriormente, as populações oriundas de comunidades tradicionais.

Os beneficiados pelo programa deveriam cumprir algumas premissas, dentre elas: não serem titulares de financiamento imobiliário ativo em qualquer lugar do país; não terem propriedades em qualquer lugar do país; não terem débito junto à Receita Federal.

O programa também previu que se deveriam reservar, no mínimo, 3\% das unidades habitacionais para atendimento a idosos, porcentagem que poderia ser aumentada com exigências de legislações locais.

Em relação às exigências nas contratações para Pessoa Física e Pessoa Jurídica, estavam:

\begin{tabular}{|ll|}
\hline Pessoa Física & Pessoa Jurídica \\
1 - Aquisição de terreno e construção & 1 - Construção em terreno de sua propriedade \\
2 - Construção em terreno próprio ou de ter- & 2 - Aquisição de terreno, pagamento de assistência \\
ceiros & técnica e despesas com legalização \\
3 - Aquisição de imóvel novo ou para requalifi- & 3 - Aquisição de terreno e construção \\
cação ou constituintes de patrimônio histórico & 4 - Pagamento de assistência técnica e despesas \\
& com legalização em terrenos transferidos e em pro- \\
& cesso de transferência pelo poder público ou de \\
propriedade da entidade organizadora & 5 - Construção das unidades habitacionais em ter- \\
& renos de que tratam de alíneas específicas. \\
\hline
\end{tabular}

Tabela 5: realizada com dados do Programa Minha Casa Minha Vida, disponíveis em: <http://www.caixa.gov.br/poder-publico/programas-uniao/habitacao/minha-casa-minha-vida>, consultados em mar. 2014. 
Em relação ao projeto, este poderia apresentar unidades residenciais contíguas urbanas, formando um conjunto habitacional (tipo "concentrado") ou unidades residenciais isoladas e dispersas em área urbana (tipo "pulverizado"), sendo que este último não poderia ser realizado por Pessoa Jurídica. Além disso, os projetos deveriam obedecer às especificações mínimas do Ministério das Cidades.

Também deveria ser respeitado o limite de quantidade de unidades habitacionais por projeto, que atendeu às seguintes especificações na segunda fase do Programa:

\begin{tabular}{|ll|l|}
\hline \multicolumn{2}{|c|}{ Contratação por pessoas físicas } \\
Município com: & $\begin{array}{l}\text { Número de UH } \\
\text { Concentradas }\end{array}$ & $\begin{array}{l}\text { Número de UH } \\
\text { Pulverizadas }\end{array}$ \\
População até 20.000 habitantes & 100 & 25 \\
População entre 20.001 e 50.000 habitantes & 150 & 50 \\
$\begin{array}{l}\text { População superior a 50.000 habitantes ou cidades } \\
\text { componentes de RM's das Capitais }\end{array}$ & 500 \\
\hline
\end{tabular}

Tabela 6: realizada com dados da segunda fase do Programa Minha Casa Minha Vida, disponíveis em: <http://www.caixa.gov.br/poder-publico/programas-uniao/habitacao/minha-casa-minha-vida>, consultados em mar. 2014.

Observação: Esses limites poderiam ser ampliados em até $50 \%$ da quantidade de UH, excepcionalmente e mediante autorização.

\begin{tabular}{|c|c|}
\hline \multicolumn{2}{|l|}{ Contratação por pessoa jurídica (entidade organizadora) } \\
\hline Município com: & $\begin{array}{l}\text { Número de UH } \\
\text { Concentradas }\end{array}$ \\
\hline Até 20.000 habitantes & 150 \\
\hline Acima de 20.001 e até 50.000 habitantes & 250 \\
\hline $\begin{array}{l}\text { Acima de } 50.0001 \text { habitantes, capitais ou municípios integrantes de RM's } \\
\text { das capitais }\end{array}$ & 500 \\
\hline
\end{tabular}

Tabela 7: realizada com dados da segunda fase do Programa Minha Casa Minha Vida, disponíveis em: <http://www.caixa.gov.br/poder-publico/programas-uniao/habitacao/minha-casa-minha-vida>, consultados em mar. 2014.

As Unidades Comerciais e Equipamentos Comunitários são mencionadas no manual do PMCMV-Entidades, e também na lei 12.424/2011. Admitia-se a produção de unidades destinadas à atividade comercial no empreendimento, ressalvando-se que o uso comercial deveria ser revertido em prol do condomínio, vedando-se a concessão não onerosa.

Porém, empreendimentos com comércio nos moldes da lei 12.424/2011 não foram concre- 
tizados devido a dois fatores: falta de regulamentação e dependência de respaldo jurídico para implementação (por conta da lei de condomínio, que não permite que estes tenham fins lucrativos).

Era permitido, até 2016, haver equipamentos comunitários, mas eles deveriam estar vinculados ao empreendimento e estar dentro dos valores máximos da operação, definido por UF.

Destaca-se que, em alguns casos, admitia-se a ausência de pavimentação, como em municípios com população inferior a 50.000 habitantes fora de Regiões Metropolitanas, retirando-se o custo relativo à pavimentação por unidade habitacional. Em unidades habitacionais dispersas, chamadas pelo PMCMV-E de "pulverizadas", a pavimentação também poderia ser excluída.

Em relação ao custo do terreno, quando a contratação ocorria diretamente com a entidade organizadora, ele deveria se limitar a $15 \%$ do Valor da Operação. Já o projeto (considerando todos os levantamentos, sondagens, licenciamentos e outros itens necessários), assistência técnica e administração da obra ficavam limitados a $8 \%$ do Valor do Investimento, com o custo do projeto variando de 1,5 a $3 \%$, de acordo com o número de unidades habitacionais, sendo que o maior valor estava relacionado a um número maior de unidades habitacionais (limite de $1,5 \%$ do valor de operação para projetos com até 100 unidades habitacionais, e limite de 3\% do valor de operação para projetos com mais de 200 unidades habitacionais).

\begin{tabular}{|ll|l|}
\hline Localidade & \multicolumn{2}{l|}{$\begin{array}{l}\text { Valor de Operação - Recursos FDs } \\
\text { Apartamento }\end{array}$} \\
$\begin{array}{lll}\text { Municípios integrantes das regiões metropolitanas da Capital, } \\
\text { de Campinas-SP e Baixada Santista-SP }\end{array}$ & $76.000,00$ & $76.000,00$ \\
Demais municípios com mais de 50 mil habitantes & $70.000,00$ & $70.000,00$ \\
Municípios entre 20 e 50 mil habitantes & $60.000,00$ & $60.000,00$ \\
Municípios com população até 20 mil habitantes & $49.000,00$ & $49.000,00$ \\
\hline
\end{tabular}

Tabela 8: Valor de Operação para o Estado de São Paulo para a segunda fase do PMCMV-E. Realizada com dados do Programa Minha Casa Minha Vida, disponíveis em: <http://www.caixa.gov.br/poder-publico/programas-uniao/habitacao/minha-casa-minha-vida>, consultados em mar. 2014.

A entidade organizadora foi o grande diferencial do programa, pois tinha diversas atribuições no processo, tanto no desenvolvimento quanto na execução. A entidade apresentava à Caixa a proposta/projeto de intervenção habitacional, orientava o cadastro das famílias no Cadúnico, selecionava as famílias associadas, auxiliava na elaboração da documentação dos associados, assinava Termo de Cooperação e Parceria com a Caixa e demais contratos de financiamento, fiscalizava a obra, apresentava a documentação para a liberação do recurso e providenciava a legalização do empreendimento.

Assim, a entidade tanto atuava no projeto e no repasse dos recursos para a execução do projeto, quanto auxiliava e incentivava as famílias a participarem do processo, além de intervir na organização do movimento de luta pela moradia.

Com isso, a política elaborada incentivou o fortalecimento dos movimentos sociais enquanto entidades organizadoras e também contribuiu, por meio do envolvimento da população, com um maior desenvolvimento de noções de cidadania e de pertencimento ao conjunto habitacional criado. 


\section{O Programa Minha Casa Minha Vida na RMSP}

A concentração de habitação social nas mesmas regiões da cidade é fruto de diversos processos. Por um lado, há a maneira história de se produzir cidade, com a manutenção das diferenças socioespaciais na relação do acesso à terra. Por outro, estão as diversas ações dos movimentos sociais e as experiências de administração pública democrática que buscaram ora atuar na contralógica, ora apaziguar o que o processo havia gerado.

Soma-se à manutenção, a dualidade de alguns instrumentos urbanos gerados no período de redemocratização, como as ZEIS, que tanto atuam positivamente, lutando contra o preço diferencial do solo urbano e permitindo que existam habitações de interesse social em áreas mais centrais, quanto acabam por estimular a manutenção da concentração socioeconômica, quando não conseguem ir contra a lógica imobiliária de custo do solo urbano. Essa dualidade, dependente de interesses de diversos agentes e aplicações de instrumentos urbanísticos, tem resultado, até o período atual, na produção de habitação social principalmente em franjas de expansão urbana, ou seja, em locais onde a terra é mais barata.

No entanto, essa situação não pode ser generalizada, pois existem casos em que foram viabilizados empreendimentos sociais em regiões urbanas centrais. Muitas vezes, essas exceções são fruto de administrações municipais mais engajadas com as lutas dos movimentos sociais.

Contudo, embora existam tais exceções, a regra com o PMCMV é a continuidade da localização de empreendimentos de habitação social em regiões periféricas, como pode ser verificado nos municípios da Região Metropolitana de São Paulo. Para comprovar esse fato, realizou-se um mapeamento dos empreendimentos do PMCMV faixa 1 para a RMSP, contabilizando tanto empreendimentos que já estavam construídos, quanto outros em processo de construção ou em vias de iniciar o processo, desde que devidamente aprovados.

Foram coletados dados de empreendimentos aprovados para a faixa 1 desde o lançamento do PMCMV até abril de 2014, em todos os municípios da Região Metropolitana de São Paulo. No levantamento, foram encontrados 168 empreendimentos aprovados na RMSP, divididos em 108 na modalidade Empresa, 26 com recursos FAR ${ }^{49}$, e 34 na modalidade Entidades (figura 48).

Do total aprovado, dez empreendimentos não puderam ser localizados, devido à ausência de informações ${ }^{50}$.

Na RMSP, foram aprovadas 43.811 unidades habitacionais para a faixa 1, correspondendo a 30.261 unidades na modalidade Empresas, 4.710 unidades com recursos FAR e 8.840 unidades na modalidade Entidades. Do total, cerca de 7.500 unidades já haviam sido entregues até abril de 2014.

49 As contratações chamadas "FAR - Urbanização" (Fundo de Arrendamento Residencial) pelo Ministério das Cidades são aquelas em que as unidades habitacionais, destinadas ao reassentamento de famílias em operações do PAC, foram construídas nos moldes do PMCMV.

50 Dos empreendimentos não localizados, um é em Embu das Artes, um em Francisco Morato, dois em Guarulhos, um em Mairiporã, um em Mauá, dois são em Santo André, um em São Bernardo do Campo e um em São Paulo. Essa dificuldade de localização ocorreu devido a diversos fatores, como desatualização da imagem satélite Google Earth em alguns trechos urbanos, a localização em ruas e estradas sem definição numérica ou mesmo endereços ainda inexistentes no Google, por serem ruas criadas especificamente para o empreendimento. 



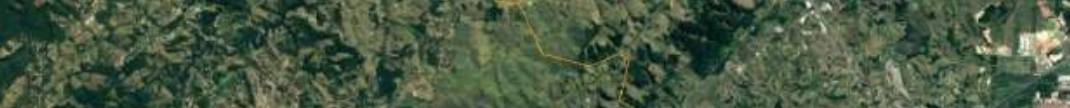


O mapeamento dos empreendimentos mostrou muitas concentrações em franjas urbanas, seja em estradas, seja em limite com áreas rurais, em áreas muitas vezes carentes de equipamentos de saúde, educação e serviços.

As administrações municipais demonstram certa dificuldade em regular e controlar os processos de expansão urbana, articulando interesses e pressões para beneficiar as famílias e as ações imobiliárias. Em geral, a aprovação dos empreendimentos acaba por facilitar a ação do empreendedor. A localização fica atrelada ao custo da terra e, caso o poder público não doe terrenos bem localizados, estes serão relegados a localidades com custo de solo menor. Porém, somente o valor do terreno não é justificativa para a localização periférica, pois, quando se aumenta o valor do financiamento, a localização continua a ser a mesma, já que a prática especulativa empresarial é de estocar terras baratas para a produção em grande escala.

Foram localizados apenas três empreendimentos de casas térreas: um em Cajamar, um em Itaquaquecetuba e um em Suzano. Os empreendimentos mapeados demonstram principalmente a produção de condomínios de prédios; dentre eles, a maioria segue o modelo de edificação com térreo e mais quatro pavimentos, evitando-se o uso do elevador, utilizando com frequência o terreno acidentado para fazer o acesso ao segundo ou terceiro andar do edifício, construindo, assim, mais pavimentos (figura 49). Um condomínio de torre, exceção à regra, foi encontrado em Cidade Tiradentes (Conjunto Habitacional Florestan Fernandes), na categoria Entidades, com uso de elevador.

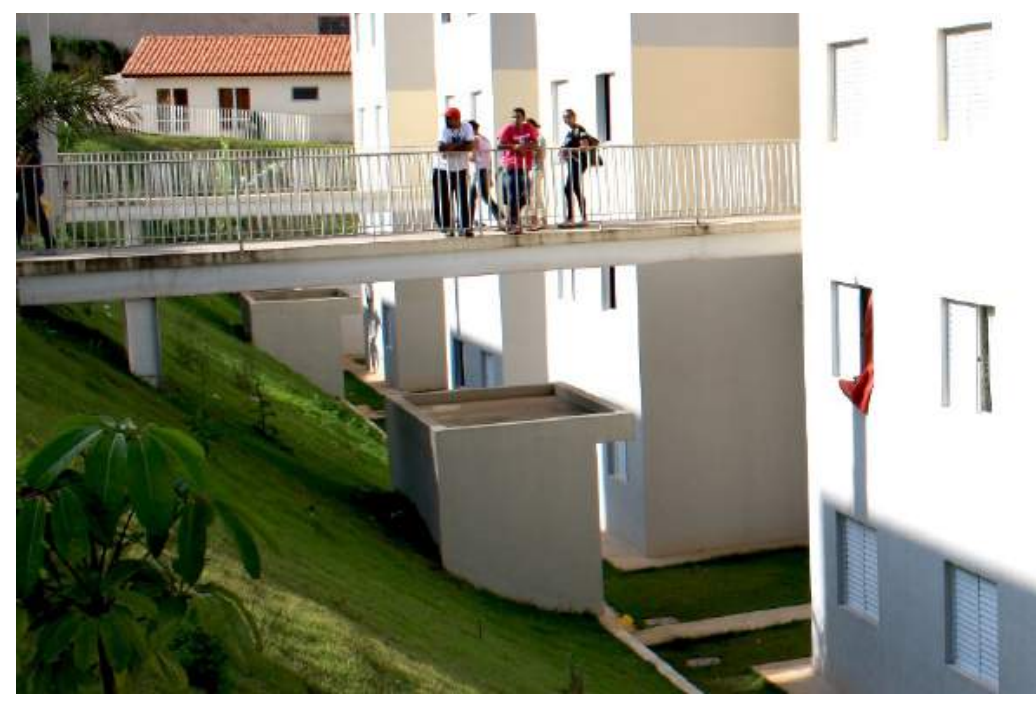

Figura 49: Conjunto Habitacional São Marcos Baviera, empreendimento da construtora ESECON em Embu das Artes. Acesso no segundo pavimento do edifício permitiu construção de mais pavimentos sem o uso do elevador. Fotografia da autora, abr. 2014.

Em relação ao porte, o menor empreendimento encontrado é composto por 32 unidades habitacionais em São Paulo. Já o maior tem 1.500 unidades habitacionais, localizado em GuaruIhos. Também foram encontrados diversos empreendimentos que se fragmentaram em condomínios vizinhos, principalmente derivados da primeira fase do programa, que restringia 0 porte dos empreendimentos.

A Cury Construtora é responsável por alguns empreendimentos de grandes dimensões, como um de 1.240 unidades em Mogi das Cruzes, com cinco condomínios residenciais de nomes bastante genéricos e subjetivamente perversos, devido à impessoalidade: Triângulo, com 280 apartamentos; Quadrado, com 240 apartamentos; Bambu I, II e III, com 200, 280 e 240, res- 
pectivamente, todos com $43.80 \mathrm{~m}^{2(51)}$. Outro empreendimento da Cury, com muitas unidades habitacionais, é o Condomínio Residencial Canaã, em Mairiporã, com 1.100 unidades habitacionais, divididas em 4 condomínios, em um total de 55 prédios com 20 unidades habitacionais cada.

A construtora EMCCAMP também realizou empreendimentos de grande porte na RMSP, como o Conjunto Habitacional América do Sul, com 1.118 unidades habitacionais, no bairro do Grajaú, em São Paulo.

A solução em condomínios de prédios, que já ocorria no Brasil desde o BNH, continua a se repetir com o PMCMV, resultando em uma paisagem homogênea de edifícios similares, abrigando uma monofuncionalidade que faz com que áreas de comércio surjam espontaneamente, já que não são planejadas em um contexto de bairro. Em conjuntos habitacionais com muitas unidades habitacionais, a monofuncionalidade planejada se contrapõe ao cotidiano vivo dos espaços urbanos heterogêneos, que surgem para aliviar o cotidiano frio dos espaços planejados somente para moradia.

Os condomínios de prédios voltam o convívio para o interior do espaço murado e condominial, limitando o cotidiano da rua pública muitas vezes a práticas diárias de deslocamento. Com isso, surge, nas vias internas dos condomínios, a prática social que antes ocorria no espaço externo aos muros, com jovens, crianças e automóveis disputando a apropriação do espaço da via condominial, em uma apropriação limitada pelo uso de um grupo social reduzido, ou seja, em um uso (des)praticado (figura 50).

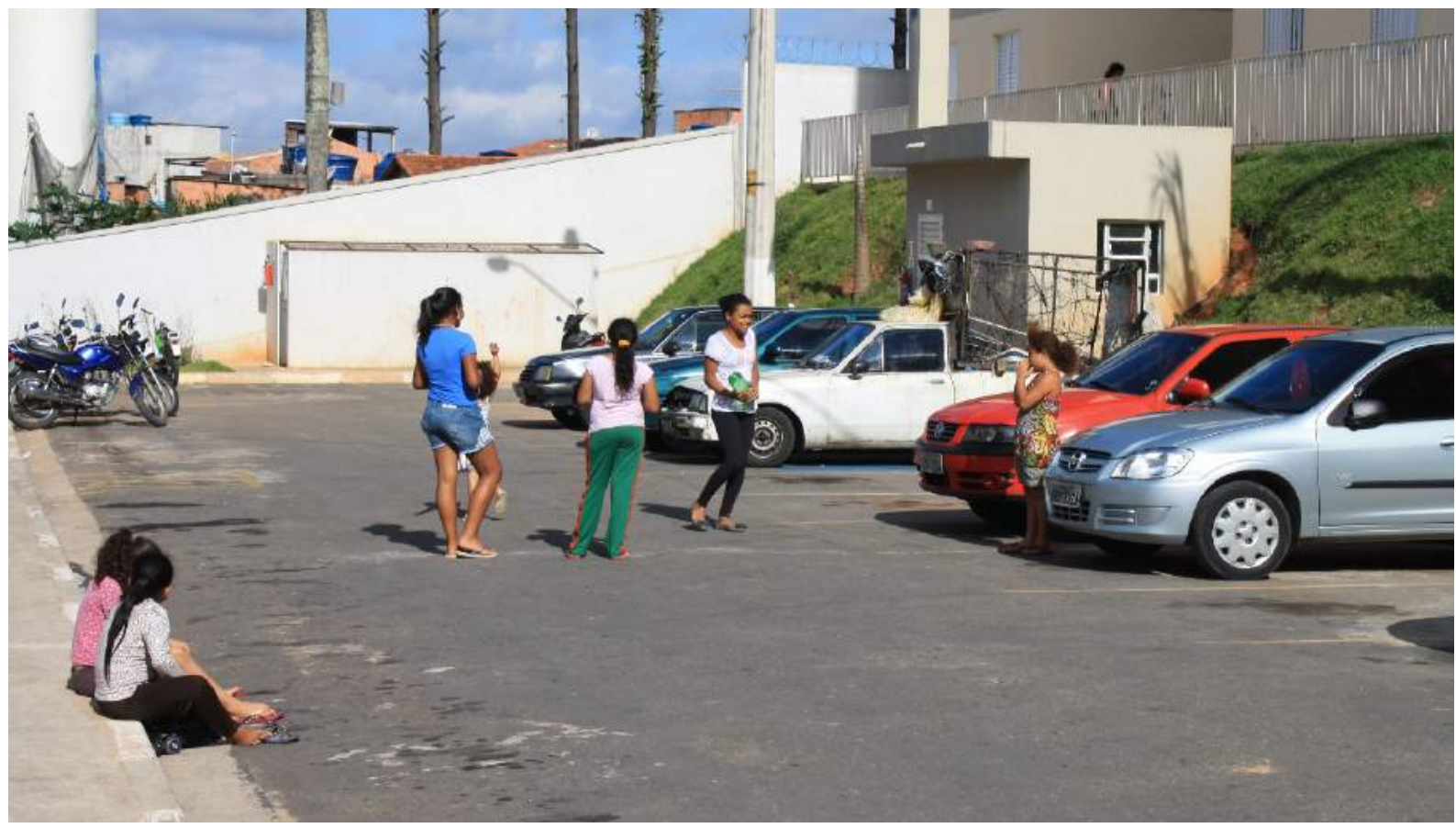

Figura 50: Via condominial do Conjunto Habitacional São Marcos Baviera em Embu das Artes. Fotografia autora, abr. 2014.

51 Segundo notícia publicada na página oficial da Prefeitura de Mogi das Cruzes (Alckmin anuncia 1.240 moradias para Mogi das Cruzes durante solenidade realizada em Poá). 19 jan. 2013. Disponível em: < http://www.mogidascruzes.sp.gov.br/comunicacao/noticia.php?id=5090>. Acessado em 09 out. 2016. 
A apropriação dos espaços coletivos condominiais nem sempre ocorre a favor de todos os moradores, podendo ocorrer mais vezes associadas a grupos ou a ações individuais, devido ao desinteresse pelas áreas livres dos conjuntos, impostas ou pouco planejadas, que dificultam a apropriação coletiva ${ }^{52}$.

O PMCMV, na região metropolitana, apresenta tanto grandes construtoras atuantes na produção, como a Cury, como construtoras menores. Essa atuação é bastante particular para cada município.

Em Embu das Artes, por exemplo, há predomínio da ESECON Construtora e Incorporadora, responsável por 10 dos 12 empreendimentos aprovados até 2014 para a faixa 1. Muitos desses empreendimentos possuem poucas unidades habitacionais, como é o caso do Jardim Castilho 1, 2 e 3, com 28, 20 e 10 unidades respectivamente, e do Pombas Botucatu 1, 2 e 3, com 40, 20 e 30 unidades habitacionais. Também existem empreendimentos maiores, como o Parque das Chácaras I, III e IV, com 112 unidades habitacionais cada, e o São Marcos Baviera, com 224 unidades.

A diminuição de tamanho dos conjuntos possibilita uma relação mais interessante entre os moradores e o entorno. São menos famílias, que partilham áreas comuns também menores, mas com maior aproveitamento dos espaços, e que trazem uma situação mais intimista de convívio diário coletivo, ainda que limitado ao grupo social, sem contato com o convívio público cotidiano. Externamente, a relação ainda é a mesma, com muros cercados em um entorno urbano de muitas carências e conflitos sociais. Essa relação de cotidiano intramuros, de práticas sociais limitadas pelo modelo urbano e por aspectos subjetivos das questões sociais, de (des)prática do território, será apresentada no capítulo 6, com dois estudos de caso.

\section{Dificuldades de inserção de um grupo social em um modelo condominial im- posto}

Em 2011, o Tribunal de Contas da União (TCU) realizou auditoria, aprovada pelo Acórdão 2431/2012-Plenário, para avaliar a parte do PMCMV que é operacionalizada por intermédio do Fundo de Arrendamento Residencial. A auditoria avaliou: a cobertura do atendimento do programa, a qualidade das construções, o atendimento às especificações, a disponibilidade de infraestrutura no entorno dos empreendimentos e o desenvolvimento do Trabalho Técnico Social (TTS) com os beneficiários (BRASIL, 2014).

Em relação à cobertura do atendimento do Programa, a auditoria observou a existência de unidades da Federação com baixos índices de contratação, embora com considerável participação no déficit habitacional brasileiro.

Já em relação à qualidade dos empreendimentos, foram observadas as produções de conjuntos habitacionais em zonas urbanas não consolidadas, com entorno desprovido de assistência básica de ensino, saúde, lazer e serviços, (apesar de o Programa definir critérios de priorização de terrenos com infraestrutura urbana, combatendo a retenção especulativa de solo urbano), devido à dificuldade de lidar no jogo de interesses políticos, eleitorais e municipais que deixam

52 Esse fato faz com que ocorram, nos condomínios de prédios, diversas depredações, ou mesmo invasões das áreas livres por particulares, principalmente nas unidades térreas, diferentemente do que ocorre no Chile, que tem invasões em altura, com as construções de palafitas, que estendem o apertado interior da unidade habitacional para cima das áreas coletivas. 
o planejamento urbano, via de regra, como uma regulamentação urbanística de pouco efeito prático.

Também foram observadas patologias construtivas relacionadas às fases de concepção e à execução de obras, a maioria decorrentes de vícios e defeitos construtivos, como inadequações no dimensionamento, indisponibilidade de equipamentos de lazer e deficiências nas ruas, nas calçadas, nos sistemas de esgoto sanitário, pluvial e na drenagem urbana.

A localização periférica de novos empreendimentos habitacionais sociais não consegue ser evitada. No entanto, permitir que empreendimentos periféricos e sem cidade sejam produzidos é estimular a segregação social, além de estimular o círculo de estímulo ao mercado imobiliário, de valorização do solo urbano e consequente expulsão de famílias de menor renda que, por sua vez, passam a estimular a produção habitacional pelo mercado informal (figura 51).

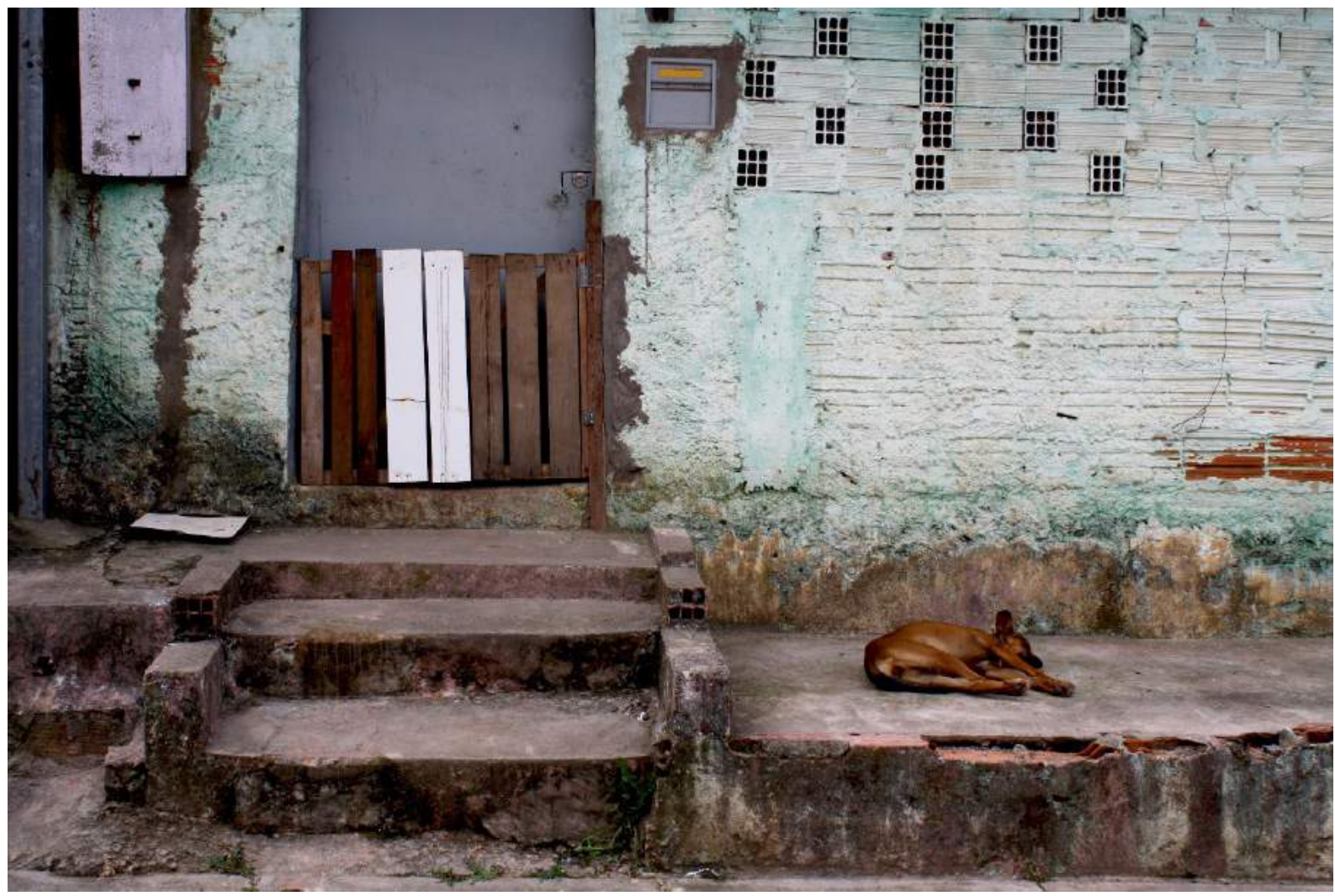

Figura 51: Entorno de empreendimentos do PMCMV em Embu das Artes, de habitação informal. Fotografia da autora, abr. 2014.

Sobre o desenvolvimento do TTS (Trabalho Técnico Social), a auditoria constatou a ausência ou a descontinuidade das ações educativas nas fases de pré e pós-ocupação. Na fase prévia, verificou-se dificuldade de seleção dos beneficiários pelo poder público e de elaboração de projeto de TTS. Na etapa de pós-ocupação, constatou-se carência de articulações e de parcerias entre os órgãos governamentais e dificuldade no apoio à gestão condominial.

O relatório do TCU, apesar de pecar pela generalização do fenômeno devido a apresentar poucos estudos de caso, mostra os problemas técnicos da edificação e dificuldades da vida 
em condomínio. Como são todos empreendimentos recém-construídos, a análise não mostra os possíveis problemas que a inserção de um grupo social em um modelo arquitetônico condominial imposto pode gerar, como depredações, dificuldade nos custos condominiais, falta de identificação dos moradores com o modelo arquitetônico e urbanístico, violência urbana, abandono das unidades adquiridas, dentre outros.

As soluções propostas pela auditoria para a administração condominial são superficiais, com a sugestão de custeio de atividades destinadas ao apoio técnico e capacitação de síndicos, bem como a contratação de administradoras condominiais por determinado período de tempo, o que agrava a dificuldade que as famílias demonstram de custear a manutenção do condomínio. Não é somente uma questão administrativa de gestão condominial, é a escassez de recursos, agravada pela falta de identificação com o cotidiano em condomínio.

Sobre o porte do empreendimento, quanto maior o número de unidades a serem administradas, maior será a dificuldade em gerar sentido de pertencimento e participação, além da maior dificuldade administrativa. E as diferentes fases do PMCMV têm permitido empreendimentos com cada vez mais unidades, como ocorreu no Residencial Portal Flora, em Guarulhos, entregue em 2016 (figuras 52 e 53) ${ }^{53}$.

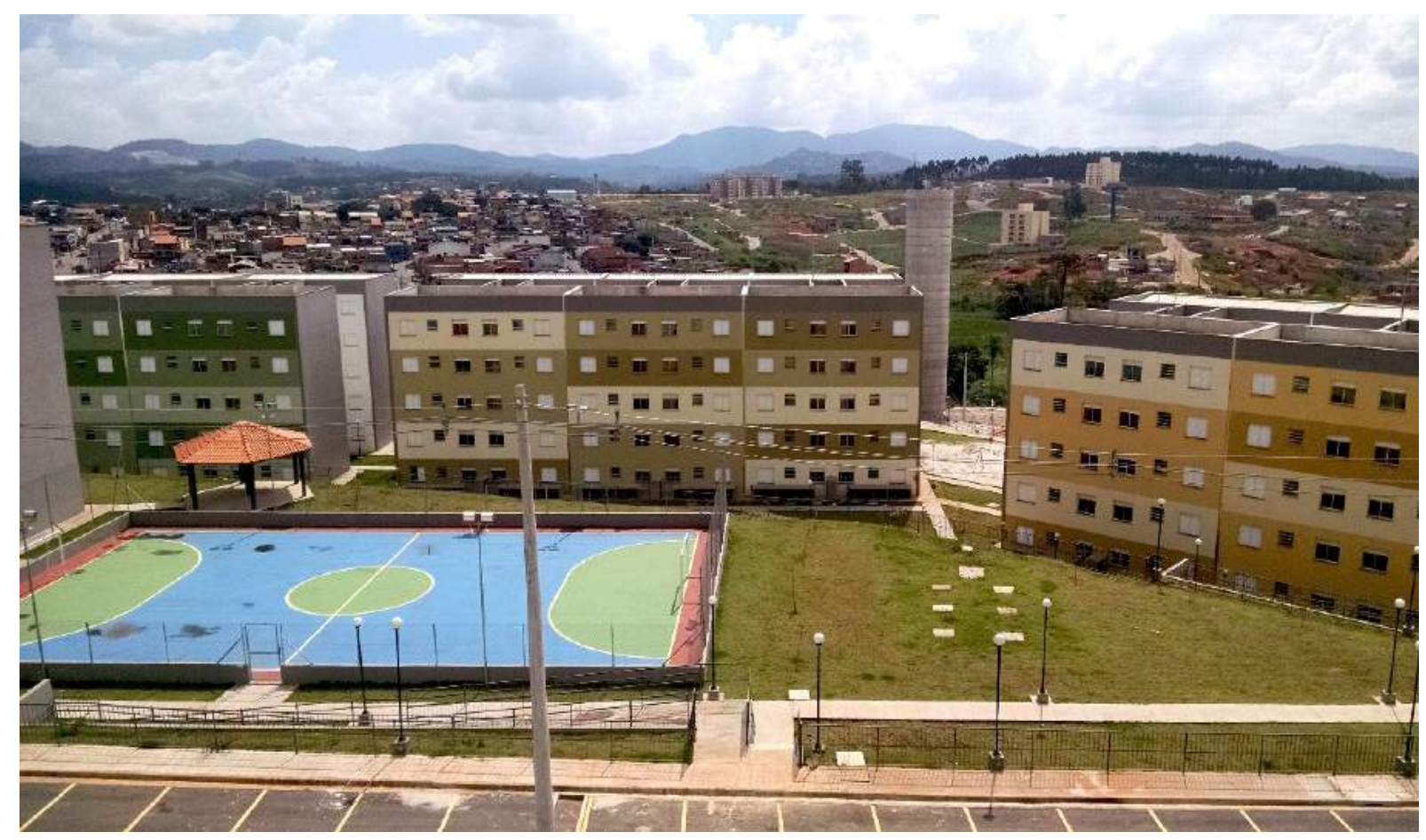

53 O Residencial Portal Flora, da construtora Qualyfast, tem as 1.500 unidades habitacionais de $48,62 \mathrm{~m}^{2}$ divididas em 25 blocos de 4 pavimentos, por sua vez divididos em 4 empreendimentos, os Residenciais Flamboyant, Ypê, Acácia e Araucária. Cada residencial tem seu fechamento, portaria, acesso para veículos e áreas comuns independentes, havendo acesso para pedestres entre os residenciais. Nas áreas comuns de cada condomínio estão: parque infantil, quadra esportiva, salão de festas, quiosque para redes e equipamentos de ginástica, um recente modismo que se prolifera em diversos espaços livres públicos em todo Brasil, em uma organização bastante influenciada pelos "condomínio-clubes" de alta renda. 


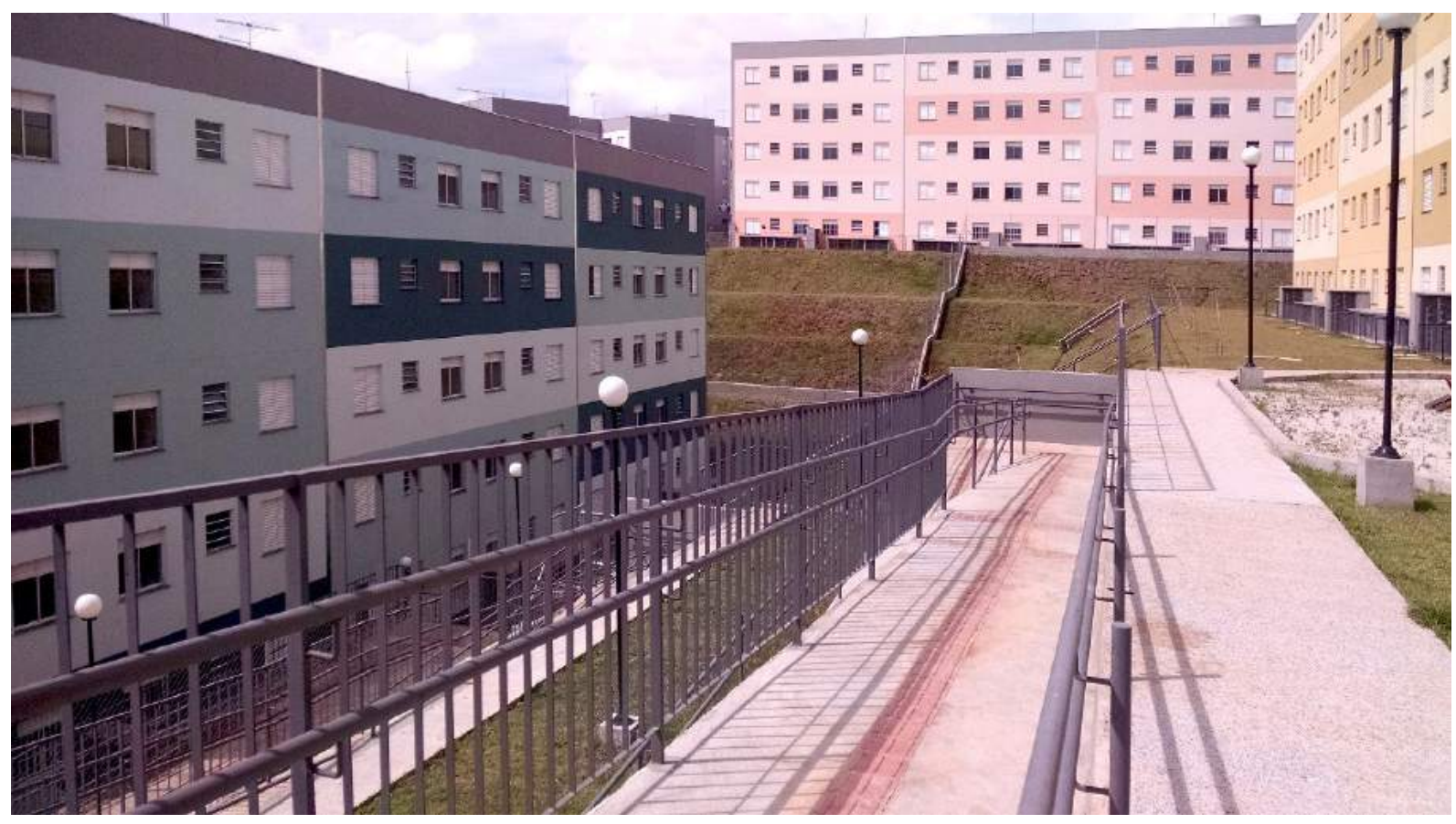

Figuras 52 e 53: Residencial Portal Flora antes de ser entregue aos moradores. Fotografia da autora, de 16 abr. 2015.

Pode-se dizer que o PMCMV faixa 1 apresenta três escalas de questões a serem melhoradas: a inserção urbana dos empreendimentos produzidos; a qualidade urbanística e arquitetônica do conjunto, e não somente das unidades; os espaços livres coletivos, pouco ou nada pensados até o presente momento, que pouco estimulam a socialização da comunidade. As exigências do programa, assim, precisam evoluir e não se conter apenas à unidade habitacional em si, exigindo relações entre as áreas livres de edificação e o conjunto habitacional construído.

O PMCMV deveria ser reformulado com objetivo de enfatizar o bairro, e não mais a produção habitacional para suprir uma simples carência quantitativa. Da maneira como a política foi desenhada, não houve sequer a possibilidade real de haver áreas de comércio dentro dos empreendimentos, o que estimula um modelo urbano extremamente homogêneo. Também não houve exigência de entrega simultânea das unidades habitacionais (por parte dos empreendedores) e dos equipamentos públicos (por parte do poder local). Além disso, não havia normas nem diretrizes para as áreas de convívio social. Mais do que uma casa, as famílias precisam de “direito à cidade" (LEFEBVRE, 2001), de “direito à paisagem” (QUEIROGA, 2012).

Faz-se necessário tanto haver maiores exigências quanto fornecer maiores subsídios para que a produção de habitação social contenha espaços mais adequados às práticas sociais. Considerando que a iniciativa privada sempre vai buscar viabilizar um empreendimento com a maior margem de lucro possível e quase sempre se restringirá a atender aos padrões mínimos exigidos, há que se estipular um novo padrão mínimo, que realmente se pretenda alcançar, o que significa também alterar a orientação de produção de empreendimentos em modelo de grandes condomínios. 
Uma dificuldade que o PMCMV apresenta é em relação às responsabilidades municipais: a atuação municipal influi diretamente na qualidade urbanística do empreendimento realizado (Planos Diretores, cadastros de famílias, infraestrutura para expansão urbana, exigências legais e ambientais, além do TTS, pouco colocado em prática). São estratégias que, na lei, são quase poéticas, e na prática, débeis.

A tentação política dos municípios em atender o programa nacional foi também uma estratégia política eleitoral, "dando" unidades habitacionais para famílias que até então não conseguiam acessar o mercado imobiliário formal. Somado ao interesse político, se associou a benevolência do poder público frente a iniciativa privada, com a realização de empreendimentos em áreas pouco adequadas. Infelizmente, o desejo de atender as famílias não passou pelo crivo qualitativo de produção de habitat.

Inovações na política envolvem uma grande dificuldade: articular o programa às políticas urbana e fundiária. Porém, ações menores podem auxiliar a produzir resultados mais interessantes, tais como acrescentar, no Programa, mais adequação às particularidades de cada região; exigir padrões mínimos mais adequados ao perfil das famílias brasileiras, o que inclusive deve ser regionalizado, e exigir maior atenção às áreas de convivência.

São diversos os instrumentos legais brasileiros bem estruturados, mas que não conseguem ser aplicados, e a tentativa de cumprir meta produtiva influi negativamente na qualidade urbanística dos empreendimentos habitacionais.

São vários os aspectos que precisam ser aprimorados na política do PMCMV. A boa localização e a inserção urbana precisam ser levadas em consideração para a aprovação de um empreendimento, assim como a qualidade arquitetônica, urbanística e paisagística, e esses padrões de qualidade precisam ser apresentados pelo Ministério das Cidades como critérios de elegibilidade de empreendimentos a serem aprovados no Programa.

(...) Seguem esse padrão medíocre a maioria dos empreendimentos aprovados no país pelo Programa Minha Casa Minha Vida (PMCMV), ou, em São Paulo, a maior parte da produção promovida pela Companhia de Desenvolvimento Habitacional e Urbano (CDHU) do Governo do Estado de São Paulo. Em pleno século XXI, as principais ações na área da habitação de interesse social reproduzem padrões dos anos 1960 já exaustivamente criticados. Até quando a desculpa da rapidez e ganho de escala poderá ser dada para que se aceitem péssimos programas e projetos, como se, para pobres, só se pudesse falar em quantidade, não em qualidade? (QUEIROGA, 2012, p. 244).

Um dos erros mais graves do PMCMV é o foco de produzir habitação e não habitat. Uma solução que se considera plausível é a mudança do modelo de condomínio, que não se adapta para habitação social, nem para o modelo de produção em grandes proporções numéricas.

As normativas e o financiamento do Programa deveriam alterar a "imposição" do modelo condominial, permitindo que outras alternativas e modelos urbanos sejam criados, como o planejamento de bairro, com espaços de convívio públicos, e não limitados ao condomínio. Embora inseridas em ambientes urbanos com problemas sociais severos, que fazem com que as práticas sociais cotidianas, devido ao medo do convívio coletivo livre urbano, interiorizem-se em espaços fechados e controlados, as habitações sociais não podem ser fechadas ao convívio público, pois isso estimula o esquecimento da realidade urbana extramuros, criando um microcosmo fictício de convívio e cotidiano. 
Continuar a produção de unidades habitacionais sem equacionar uma política de bairro, que acrescente componentes de melhoria urbana, com participação popular e acompanhamento de assistentes sociais, não trará benefício à população. Com o foco na produção de um bairro, e não somente de habitação resolvida em um modelo condominial, há maiores possibilidades de práticas sociais completas, de ações cotidianas de resistência crítica à apatia, de superação do dia a dia, pela importância dos espaços livres de uso público para a vivacidade urbana.

\section{Mudanças no cenário político brasileiro após o impeachment da presidenta Dilma Rousseff}

Em dezembro de 2015, foi anunciada a abertura de processo de impeachment da presidenta Dilma Rousseff. O processo foi instaurado por uma acusação de crime de responsabilidade pelo uso de "pedaladas fiscais", que consistem em estratégias de gestão orçamentária que atrasam o repasse do Tesouro a bancos públicos.

O pedido de impeachment contra Dilma foi bastante contraditório, com a argumentação dos aliados de que não houve ilegalidade ou má-fé, e que as "pedaladas" não configuram empréstimos, e sim prestações de serviços que foram regularizadas com orientações do TCU. 0 processo foi associado a um "golpe parlamentar", promovido pela oposição.

Em 31 de agosto de 2016, o Senado aprovou o impeachment da presidenta, sob acusação de crimes de responsabilidade fiscal. Com isso, assume o governo o vice-presidente Michel Temer.

Ruas em todo o Brasil foram ocupadas por manifestações contrárias ao impeachment, em um grito de "golpistas não passarão", "fora Temer" e "Diretas Já", duramente reprimidos pela polícia militar.

Enquanto Dilma foi condenada por usar fundos de bancos públicos para equilibrar contas do Estado, o presidente em exercício formou a sua equipe de governo com vários ministros acusados de implicação na operação "Lava Jato", o maior caso de corrupção da história do país, que investiga a corrupção na Petrobrás. Relevante o fato de não haver nenhuma mulher e nenhum negro na primeira equipe de governo montada por Temer, em uma postura política que não deu espaço a nenhuma minoria. A ausência de mulheres nos ministérios não ocorria desde o governo do general Ernesto Geisel (1974-1979). Por conta da repercussão negativa do governo retrógrado e machista do presidente Temer, ele convidou para assumir o posto de Advogada Geral da União, em setembro de 2016, a primeira mulher a integrar a sua equipe.

O Brasil encerra o ano de 2016 com a economia em recessão, a política movimentada por escândalos de corrupção, um novo governo conservador e neoliberal, uma imprensa controladora, repressão policial violenta e população decepcionada e dividida. A nação tem, em seus grupos sociais, cisões marcadas pela divergência da opinião política, que divide a esquerda da direita, o vermelho do azul, o Partido dos Trabalhadores do Partido da Social Democracia Brasileira, em ações irracionais de disputa ideológica. 
Temer, esperança da comunidade empresarial e da elite econômica, em 2016, inicia seu governo com a extinção de pastas sociais, como Mulheres, Direitos Humanos, Igualdade Racial e Desenvolvimento Agrário, e desmembramento de ministérios, como o Ministério do Trabalho, concentrando suas atribuições em outros ministérios, justificando-se por meio da redução de gastos, embora isso signifique mais uma redução simbólica de poder social que algumas pastas tinham. Assim, muitos dos direitos adquiridos com muita luta nos anos de retorno à democracia foram, de repente, suprimidos.

Essa contextualização política se faz necessária pelas mudanças que ocorreram e ocorrerão na política habitacional do país durante o Governo Temer. Uma primeira ação foi a reavaliação dos contratos do PMCMV, com a suspensão de novas contratações e de toda a terceira etapa do Programa, que havia sido anunciada por Dilma Rousseff em 2014. O PMCMV, no Governo Temer, passará por processo de "aprimoramento" e, no final de 2016, ainda estava pouco claro o que tais alterações significariam.

Alegando restrições orçamentárias, o primeiro braço do programa bloqueado foi o Programa Minha Casa Minha Vida - Entidades, embora essa modalidade, juntamente com o PMCMV Rural, tenha representado apenas 3\% das unidades contratadas no período de 2009 a 2010, como já foi comentado.

Cortaram-se também os subsídios concedidos às famílias da faixa 1 e 2 de todo o Programa, eliminando-se o uso dos recursos do FGTS. Ao final de 2016, ainda não é possível afirmar qual o futuro do Programa Minha Casa Minha Vida após o conturbado contexto político e econômico, mas o corte nas faixas 1 e 2 e no programa Entidades, juntamente com a extinção de pastas sociais, trará impactos bastante negativos para os grupos sociais de menor renda, acentuando ainda mais as diferenças socioeconômicas e culturais do país. 
Capítulo 5: "Modus operandi" de grandes concentrações de habitação social no Chile e no Brasil

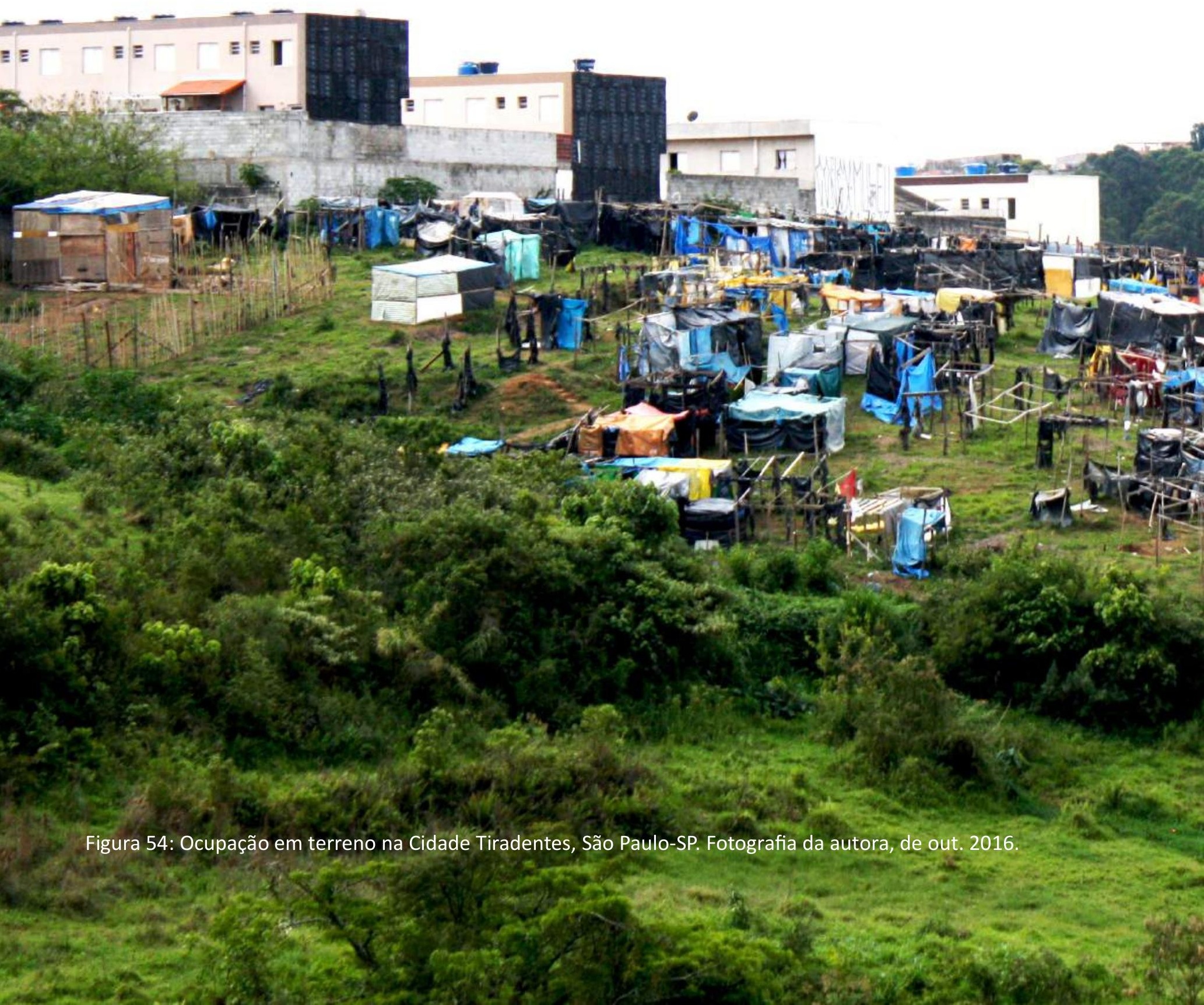


Guerrilheira camuflada num campo de palavras

Estraçalha covarde, canalha que não vive o que fala

Contradiz seus pretextos, são apenas segredos

Não é o primeiro nem o último desfecho desse enredo

(...)

Trecho de "Agressora", música de A's Trinca, grupo feminino de rap que surgiu na Cidade Tiradentes.

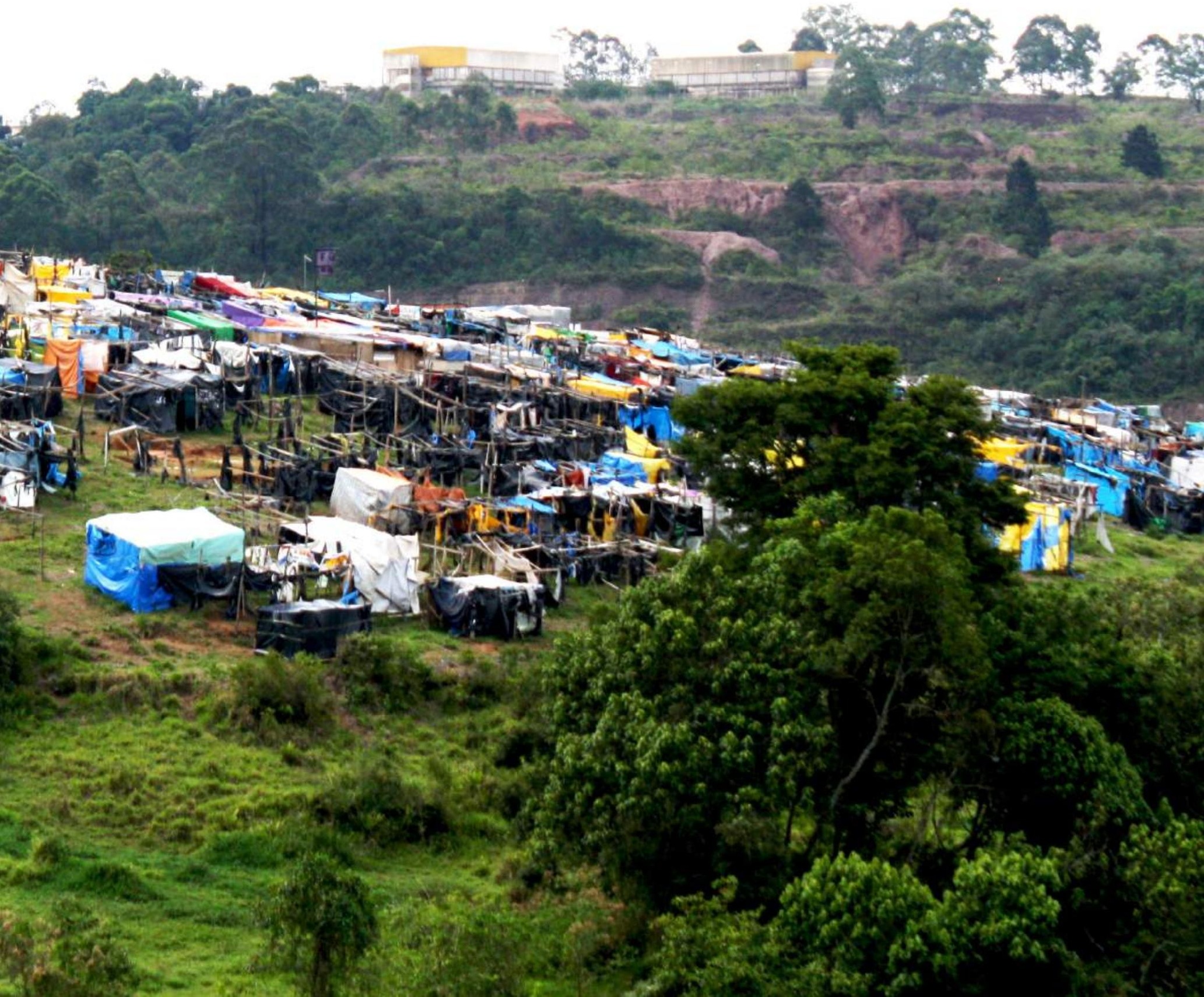


No Brasil e no Chile, diversos momentos das políticas habitacionais caracterizaram um modo de produzir habitação social em vastas extensões do território em um modelo monofuncional e condominial, aqui chamado de modus operandi de produção em larga escala. Essa característica, adotada em muitos outros países, foi uma solução da utopia moderna para enfrentar o déficit habitacional e acabou por estampar o modelo de produção pública de conjuntos habitacionais.

Essa solução urbana representa a pura ineficácia da imposição de um modelo projetual: fisicamente, caracteriza-se pela grande dimensão ocupada para a produção de edifícios habitacionais de morfologia semelhante, somada à concentração de famílias de mesmo perfil econômico, reunindo também questões sociais que não se resolvem simplesmente com a entrega da moradia. Os grandes conjuntos habitacionais, em geral construídos antes da chegada da infraestrutura urbana no local, acentuam os problemas sociais e o receio no uso dos espaços livres, além de estimular a persistência da inclusão periférica.

Demolições massivas de condomínios modernistas têm acontecido em diversos países, mesmo na França, berço do modelo (SOUZA, 2014). No Brasil e no Chile, infelizmente, a realidade ainda é produzi-los nos mesmo moldes.

Para representar esse modus operandi, serão apresentados os casos de Bajos de Mena, no extremo sul de Santiago, e Cidade Tiradentes, no extremo leste de São Paulo. Ambos representam processos de urbanização em antigas glebas agrícolas, como fazendas e chácaras, principalmente a partir dos anos 1980, e estão distantes dos respectivos centros em cerca de $30 \mathrm{~km}$ de percurso pelas vias urbanas. Em São Paulo, a expansão de habitação social na Zona Leste representou a face da experiência de implantação do modelo modernista empobrecido (sem pilotis e tetos-jardim, nem vias expressas, tampouco amplas áreas verdes ou adequados equipamentos sociais), para população de baixa renda. Em Santiago, Bajos de Mena é hoje o maior exemplo do problema dos con techo de Santiago, com inúmeras estratégias do governo para tentar solucionar os problemas sociais, urbanos e arquitetônicos que surgiram devido a essa produção.

Ambos os casos constituem objetos de estudo já bastante analisados pelo meio acadêmico, com trabalhos que questionam qualidade habitacional, ausência de cidade, questões sociais, políticas e econômicas, entre outros. Aqui, serão ressaltados os pro- 
blemas que esse modelo produtivo - que continua a ser utilizado pelas políticas públicas de produção de habitação social - têm trazido para o cotidiano dos moradores. Os impactos criados vão além da segregação física e social, com influência na subjetividade, (des)prática do território, receio em usar os espaços coletivos, diferenciação do outro e, finalmente, busca de alteração do habitus imposto e mudança social por meio das práticas sociais.

O habitus, para Bourdieu (1989), é tanto um sistema de esquemas de produção de práticas quanto um sistema de percepção e apreciação delas e, em ambas as dimensões, expressa a posição social em que foi elaborado. O habitus produz práticas e representações a partir de condições sociais.

O lado da sociedade que não é observado, a sua face invisível, chamado por Milton Santos de "espaços opacos" (SANTOS, 1994), se contrapõe às áreas luminosas, marcadas pelo controle, historicamente construídas e que abrigam elevada densidade simbólica.

A reflexão proposta é sobre a dualidade do habitus e dos espaços opacos miltonianos, processo em que o sujeito tem a possibilidade de lutar e alterar as condutas individuais e coletivas impostas no cotidiano alienado. Porém, essa resistência do cotidiano só ocorre quando há a superação subjetiva, ou seja, através da experiência da alteridade, quando se compreende a conquista individual junto e através do coletivo, a partir do olhar ao outro.

Essa superação é carregada de conflitos, muitos deles marcados pelo contexto histórico em que se inserem, e da imposição visível e invisível que orienta as condutas sociais. Em um contexto dramático de criação de bairros para pobres, louvado pelo estímulo individualista de acesso à casa própria e salientado pela imposição de comportamento controlado pelo modelo condominial, a difícil superação depende das práticas sociais, que procuram inverter os códigos excludentes, segregacionistas e o habitus imposto. 


\section{- Bajos de Mena}

Os vencedores construíram seus castelos sobre as ruínas.

Os outros empilharam seus tetos com os restos.

(Mathias Schelp, Pequenos Contos Preguiçosos)

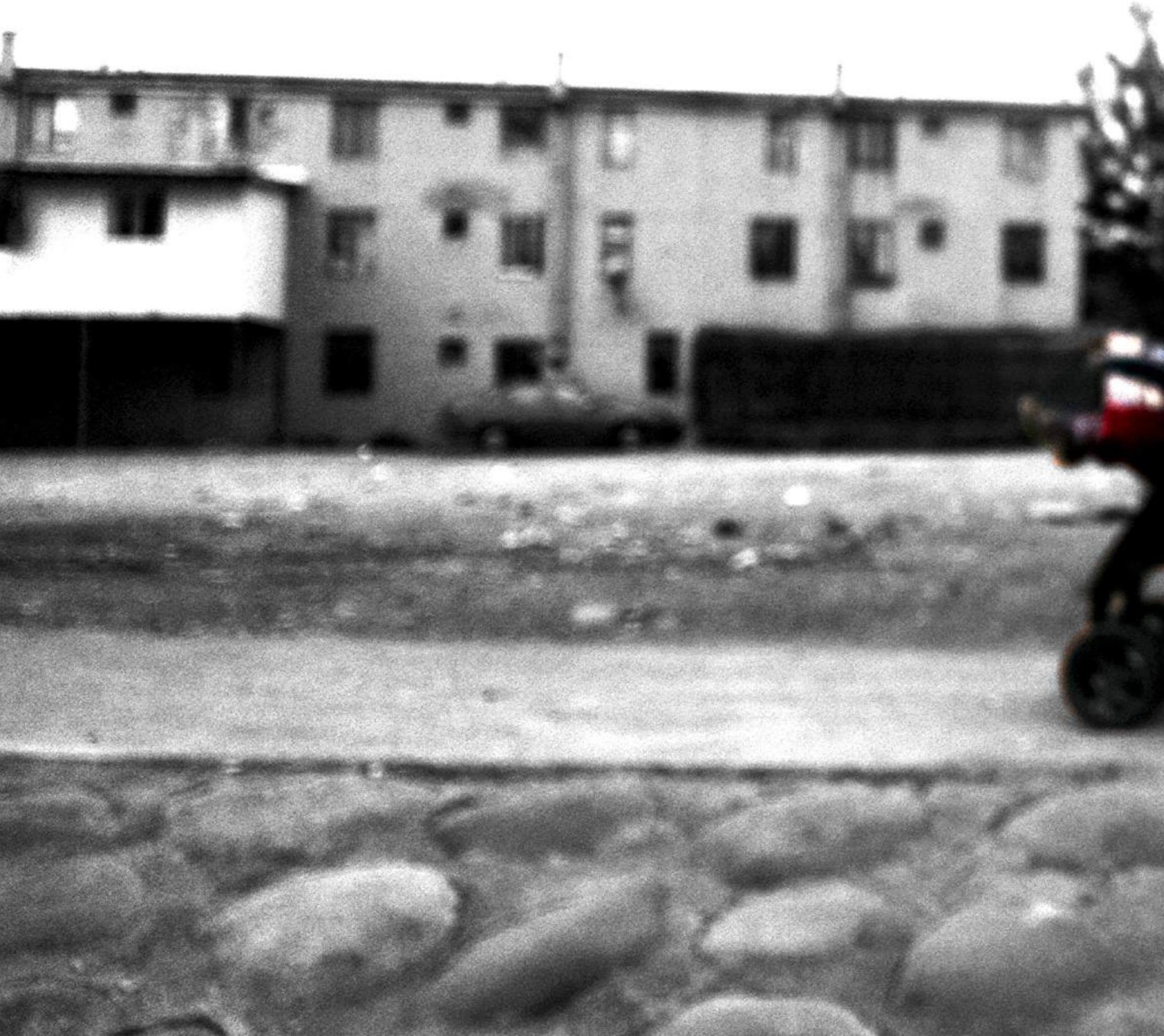




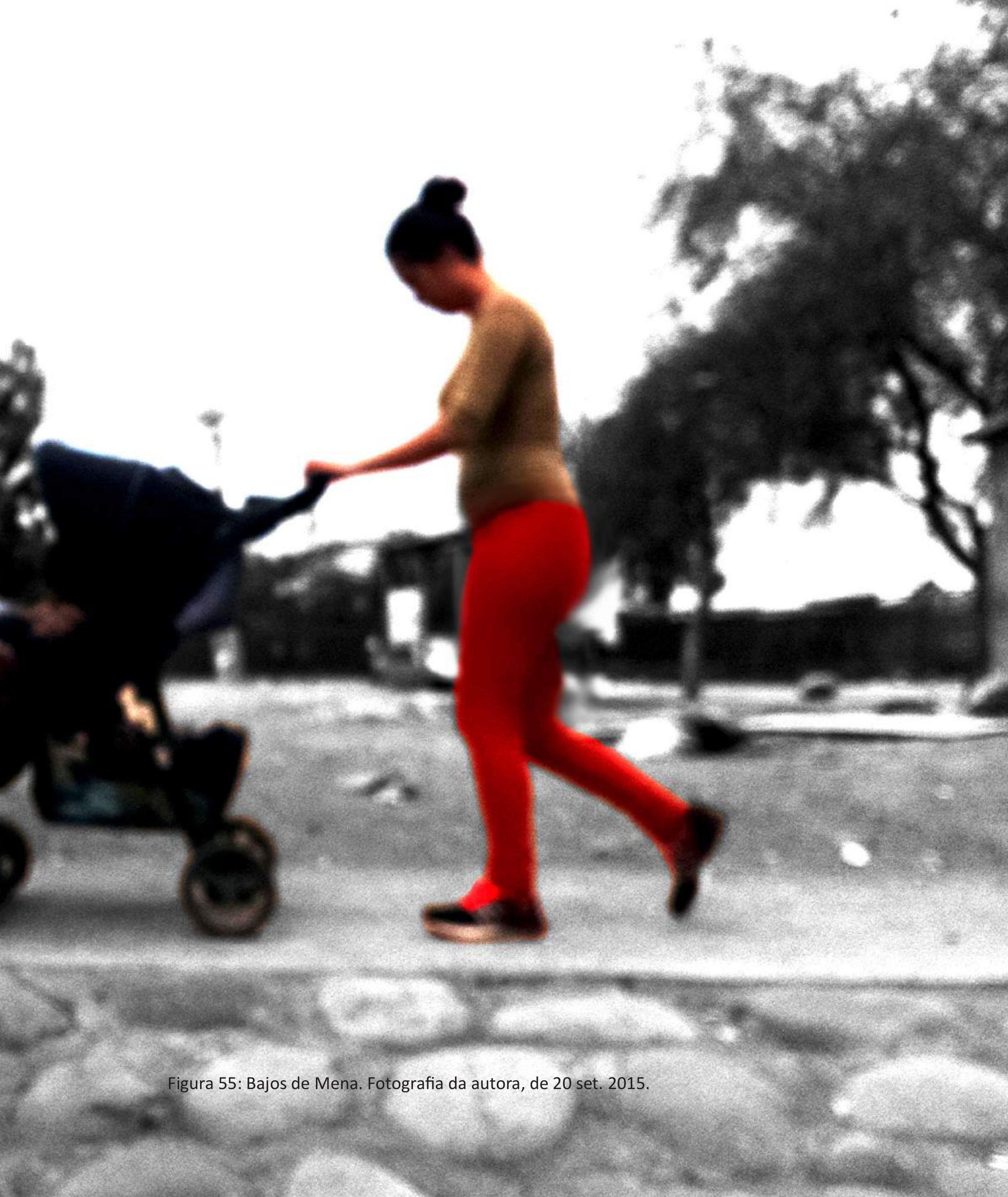


Como já demonstrado, a produção habitacional chilena, desde o período militar, tem concentrado conjuntos habitacionais sociais em comunas periféricas, formando grandes aglomerados de paisagem urbana onde predominam os condomínios de prédios, com população de perfil socioeconômico similar. Tal produção estimulou o surgimento de problemas sociais, econômicos e políticos, que se manifestam por meio da delinquência, tráfico de drogas, deserção escolar, violência familiar, entre outros aspectos de marginalidade física e social.

Dessa forma, enclaves de marginalidade e descaso são criados física e subjetivamente através do modus operandi de produção habitacional social. A concentração de renda, incitada pela subjetividade da inclusão periférica social e econômica, estimula o esquecimento social e físico dos outros, que se mantêm "perifericamente incluídos", ou seja, integrando a estrutura urbana, sendo parte representativa do sistema econômico, mas estando na periferia física e sistêmica.

Los barrios pobres, en definitiva, no parecen un producto generado desde "fuera" de la ciudad. Tampoco serían exclusivamente el refugio de los rechazados por el sistema económico. Son parte integrante de la estructura urbana. (SABATINI, 1981, p. 61)

São vários os casos de concentrações de conjuntos habitacionais sociais periféricos na Região Metropolitana de Santiago, sendo, há anos, tema de debate público que busca alternativas para solucionar o problema social e urbano gerado.

Bajos de Mena é um exemplo desse tipo de construção social, com uma população de mais de 120.000 habitantes e de mais de 13.000 apartamentos ${ }^{54}$ em condomínios de prédios, entre outras unidades residenciais (tabela 9; figura 60). Essas unidades habitacionais, produzidas entre os anos de 1983 e 2014, estão distribuídas em vilas, algumas abrigando edifícios em sistema de copropriedade e outras, habitações unifamiliares.

Bajos de Mena está localizado no extremo sul da Região Metropolitana de Santiago, na comuna de Puente Alto (figura 56). Essa comuna teve seu desenvolvimento urbano estimulado pela ferrovia (figura 57) e pelo consequente surgimento de algumas indústrias importantes, como a Compañia Manufacturera de Papeles y Cartones (CMPC) e a Fábrica de Tejidos Victoria, entre os anos 1900 e 1920.

54 Segundo dados do Ministerio de Vivienda y urbanismo do Chile (Ministro Pérez informa plan de intervención por \$44 mil millones en sector Bajos de Mena de Puente Alto), publicado em 7 jun. 2002. Disponível em: <http://www.minvu.cl/opensite_det_20120607153314. aspx>. Acessado em set. 2015 


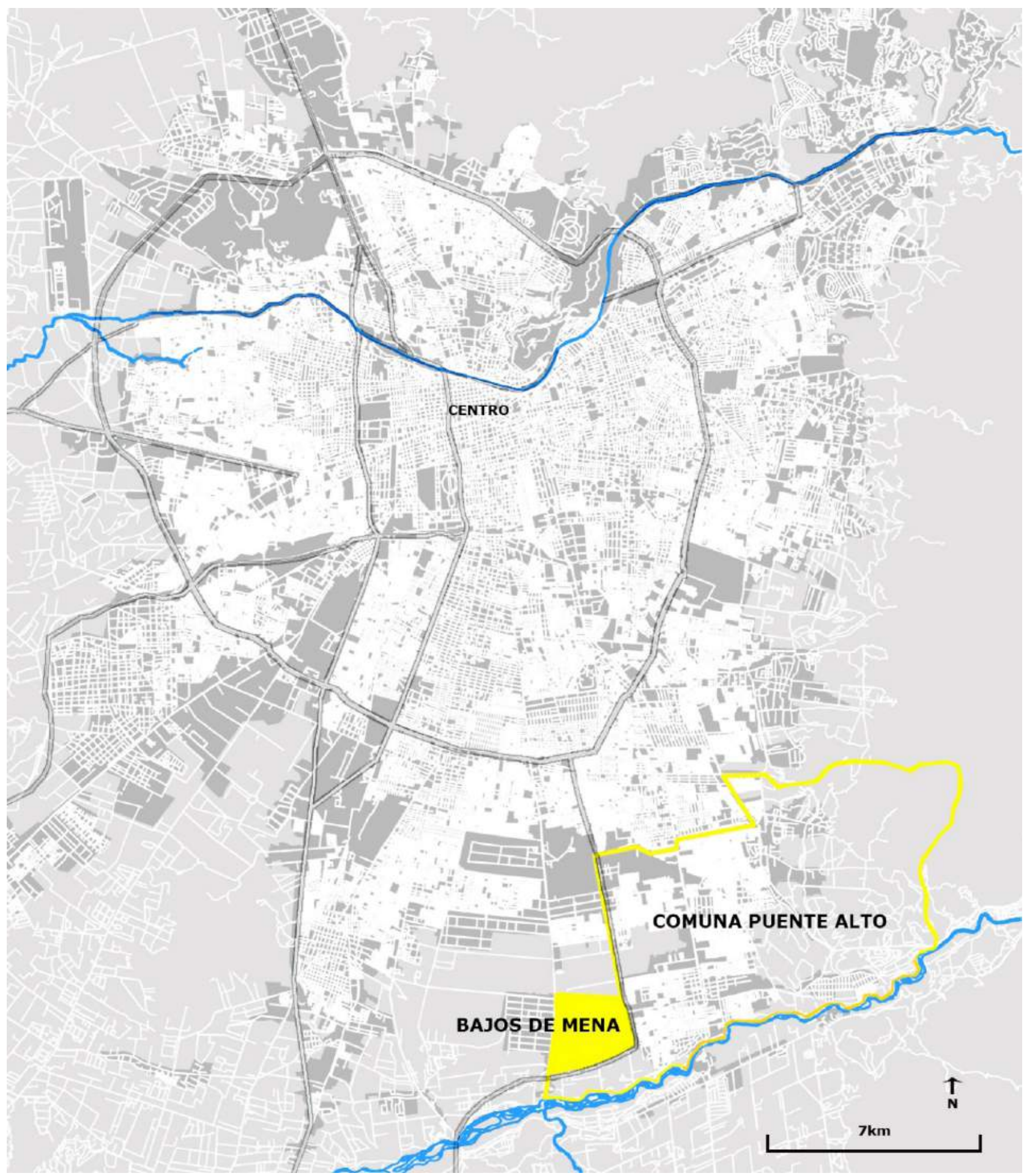

Figura 56: Localização de Bajos de Mena, na Comuna de Puente Alto. Fonte: elaborado pela autora, sob base OCUC - Observatorio de Ciudades (2003) ${ }^{55}$ e Google Earth (2015).

55 Disponível em: <http://ocuc.cl/>. Acessado em 4 dez. 2016. 
Com a chegada de grandes indústrias à zona sul de Santiago, houve a necessidade de trazer os trabalhadores para mais perto do local de trabalho (figuras 57 e 59). Foram as próprias indústrias que começaram a construir habitações nessa região, como foi o caso da CMPC, que fez um bairro habitacional, dividido por setores, para abrigar os seus funcionários (figura 58).
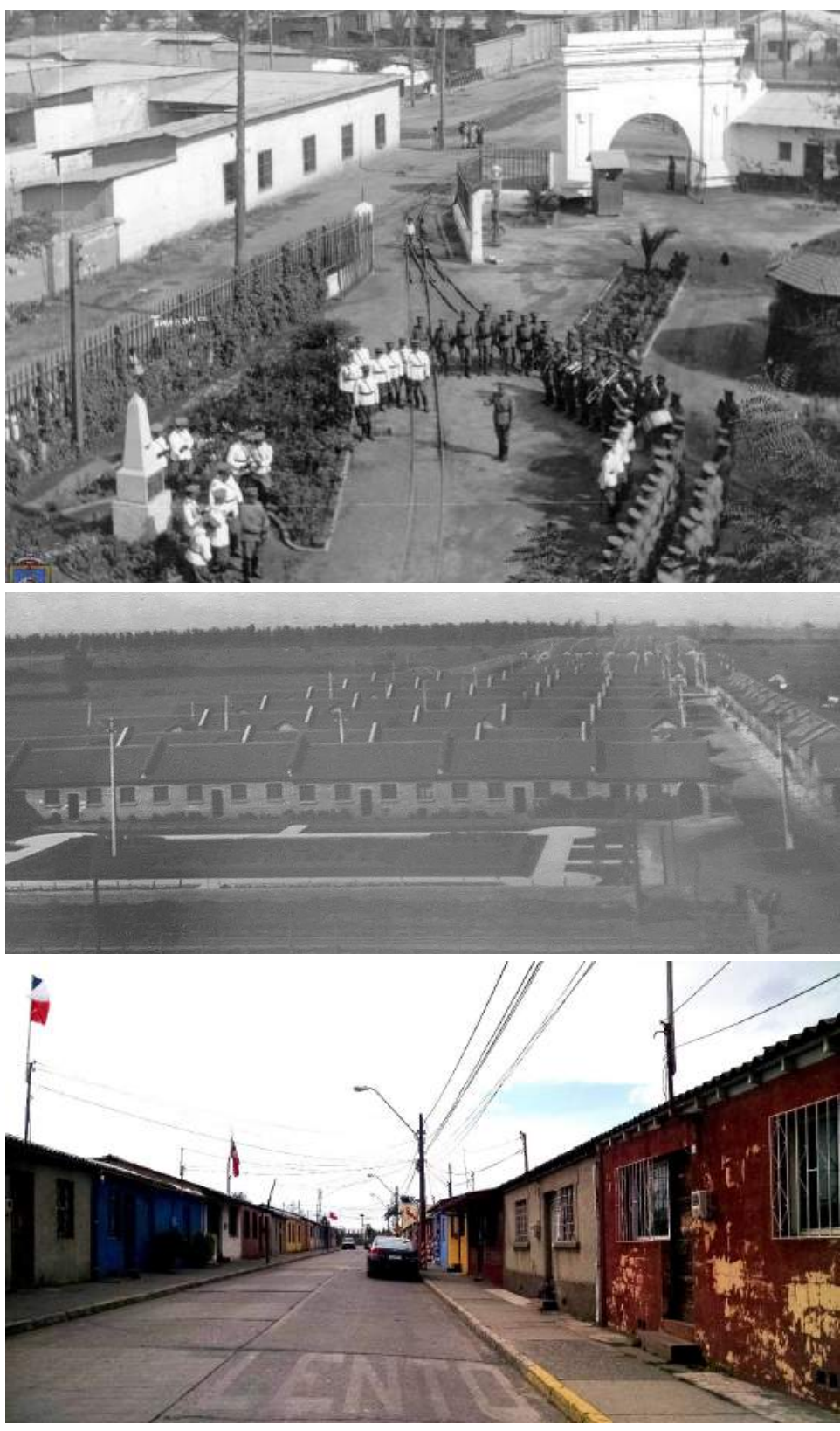

Figura 57: Fotografia do Regimento de Ferrocarril de Puente Alto. Fonte: <www.patrimoniopuentealto.cl>. Acesso em 14 set. 2015.

Figura 58: Fotografia da construção da "Población Papelera" nos anos 1930, projeto habitacional desenvolvido pela Compañia Manufacturera de Papeles y Cartones (CMPC) para seus trabalhadores. Fonte: <www.patrimoniopuentealto.cl>. Acesso em 14 set. 2015.

Figura 59: Fotografia das habitações construídas pelas indústrias em Bajos de Mena. Fotografia da autora, 20 set. 2015.

Nesse período de formação do território, os terrenos da comuna pertenciam a poucos proprietários, como no caso dos terrenos do Senhor Manuel Mena, que deu origem a Bajos de Mena (DELGADO VALVERDE, 2013).

Fisicamente, Bajos de Mena se constitui em um polígono de 600 hectares (DELGADO VALVERDE, 2013) limitado ao norte pelo Canal de Mena, ao sul pela autopista Acceso Sur, a leste pelo Cerro Las Cabras e a oeste pela Avenida Santa Rosa. Em termos de continuidade do tecido urbano, o setor é desconectado mesmo da própria comuna em que se localiza. 
A tabela 9, a seguir, especifica os condomínios de prédios de Bajos de Mena construídos até 2002:

\begin{tabular}{|c|c|c|c|c|}
\hline LOTEO & $\mathrm{N}^{\circ}$ HABITACOES & HABITANTES & SUPERFÍCIE HA & ANO \\
\hline CASAS DE SAN GUILLERMO & 495 & 1980 & 6,44 & 2002 \\
\hline CASAS DE SAN GUILLERMO ॥ & 831 & 3324 & 12,46 & 2002 \\
\hline CASAS DE SAN GUILLERMO & 64 & 256 & 2,19 & 2002 \\
\hline CERRO MORADO & 168 & 672 & 1,92 & 1995 \\
\hline CHILOE ZONA I & 589 & 2356 & 6,47 & 1986 \\
\hline CHILOE ZONA II & 449 & 1796 & 6,15 & 1986 \\
\hline EL CALEUCHE & 1200 & 4800 & 13,6 & 1994 \\
\hline EL MARISCAL & 400 & 1600 & 6,96 & 1983 \\
\hline FRANCISCO COLOANE & 1188 & 4752 & 9,48 & 1996 \\
\hline JUANITA ORIENTE & 1054 & 4216 & 9,94 & 1997 \\
\hline JUANITA ORIENTE II & 144 & 576 & 2,22 & 1997 \\
\hline MAMIÑA 7 & 496 & 1984 & 4,38 & 1995 \\
\hline MAMIÑA 8 & 466 & 1864 & 3,92 & 1995 \\
\hline MARTA BRUNET & 1256 & 5024 & 11,15 & 1997 \\
\hline PEDRO LIRA & 1530 & 6120 & 13,56 & 1997 \\
\hline QUITALMAHUE & 174 & 696 & 1,41 & 1999 \\
\hline SAN MIGUEL I & 599 & 2396 & 6,21 & 1994 \\
\hline SAN MIGUEL II & 199 & 796 & 2,24 & 1994 \\
\hline SAN MIGUEL III & 452 & 1808 & 4,76 & 1994 \\
\hline SAN MIGUEL IV & 492 & 1968 & 4,04 & 1995 \\
\hline SAN MIGUEL V E VI & 491 & 1964 & 4,36 & 1996 \\
\hline SARGENTO MENADIER & 380 & 1520 & 4,68 & 2002 \\
\hline SARGENTO MENADIER II LOTE 2A & 299 & 1196 & 3,44 & 2002 \\
\hline SARGENTO MENADIER II LOTE 2B & 100 & 400 & 1,47 & 2002 \\
\hline SARGENTO MENADIER III LOTE 2 & 299 & 1196 & 3,84 & 2002 \\
\hline SARGENTO MENADIER IV LOTE 2C & 283 & 1132 & 3,16 & 2002 \\
\hline VOLCAN SAN JOSE I & 598 & 2392 & 3,84 & 1995 \\
\hline VOLCAN SAN JOSE II & 1708 & 6832 & 13,02 & 1995 \\
\hline VOLCAN SAN JOSE III & 1257 & 5028 & 11,01 & 1995 \\
\hline
\end{tabular}

Tabela 9: Condomínios de prédios em Bajos de Mena, na Comuna de Puente Alto, Santiago do Chile. Fonte: DELGADO VALVERDE, 2013, sob dados do Servicio Regional de Vivienda y Urbanización Región Metropolitana. 


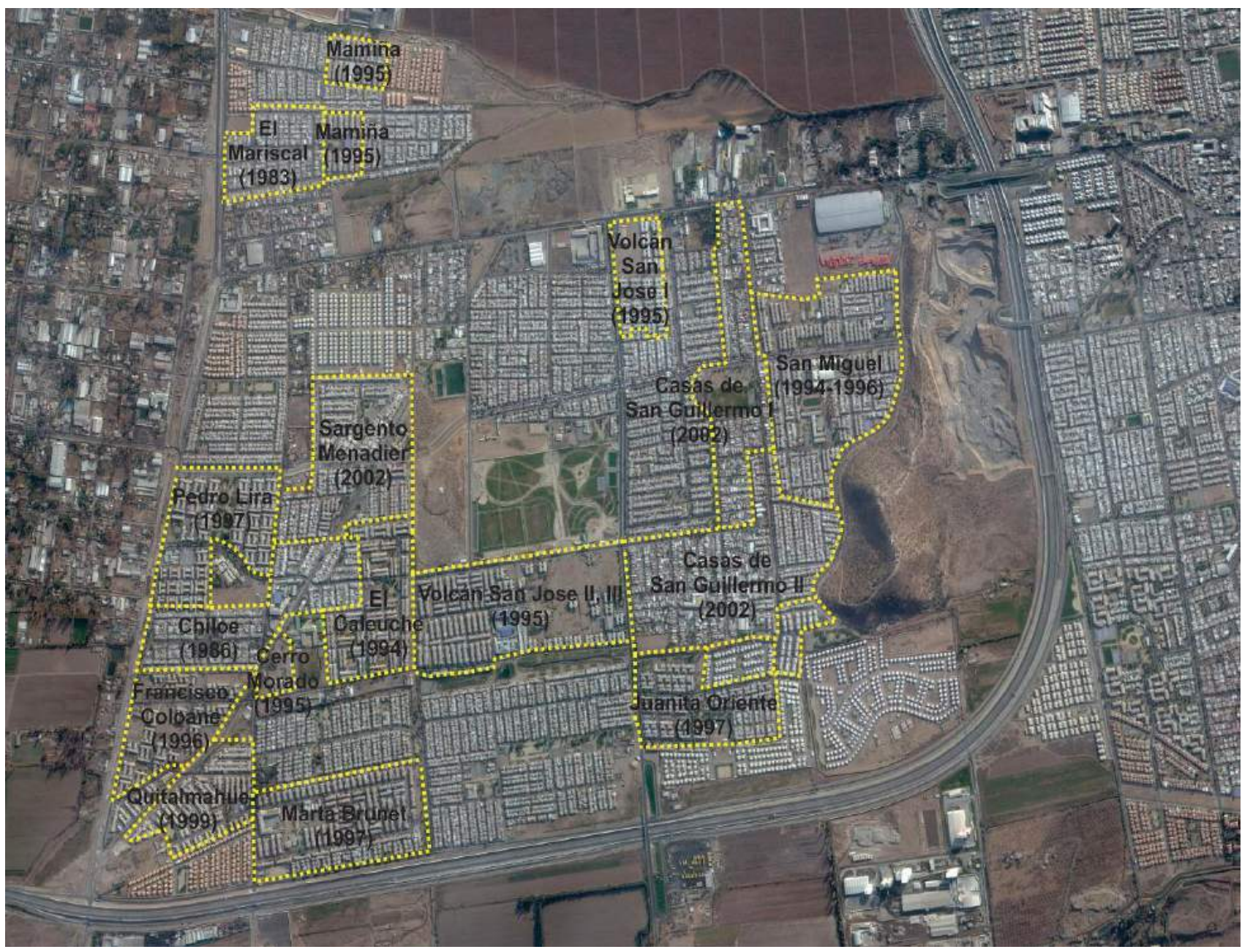

Figura 60: Localização dos condomínios de prédios em Bajos de Mena dos anos 1980 a 2002 e seu respectivo ano de construção. Fonte: elaborado pela autora, sob base Google Earth (2015).

Bajos de Mena é um território de grandes dimensões, em uma escala totalmente distinta dos outros casos chilenos apresentados nesta tese. O setor apresenta uma concentração de habitações sociais cujos espaços livres denunciam o descaso cotidiano e insegurança.

Como é um setor que urge por soluções, são diversos os programas governamentais criados para nele intervir, principalmente a partir de 2006, como por exemplo o Programa Quiero Mi Barrio, iniciado durante o primeiro mandato de Bachelet, sendo a maior área de intervenção do Programa.

Para articular as ações desses diversos programas dentro do setor, o governo propôs um plano maestro de intervenção, o Plan Integral Bajos de Mena (figura 62), um projeto ambicioso que atua em diversos eixos estratégicos: habitação, bairro, educação, infraestrutura, saúde, meio ambiente, desenvolvimento econômico local, cultura, esporte, recreação e infância, com um custo de mais de 150.000.000.000 pesos chilenos, equivalentes a 242.420.325 USD ${ }^{56}$ e prazo de execução de 2015 a $2022^{57}$.

56 Segundo conversão realizada em 02 março de 2015, com 1 dólar equivalendo a 618,76 pesos chilenos.

57 Disponível em: <http://www.planintegralbajosdemena.cl/>. Acessado em dez. 2016. 


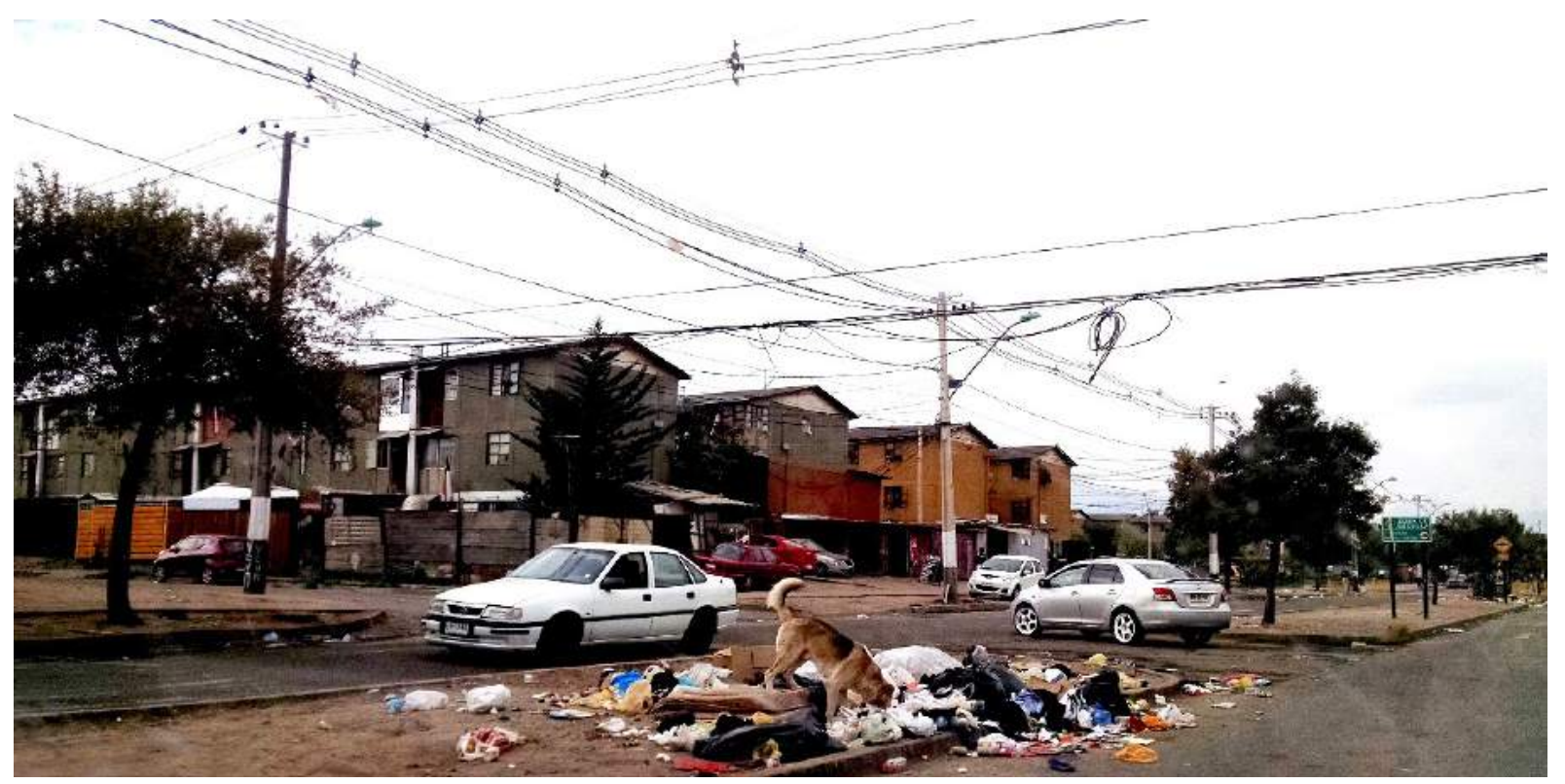

Figura 61: Avenida de Bajos de Mena. Fotografia da autora, 20 set.2015.

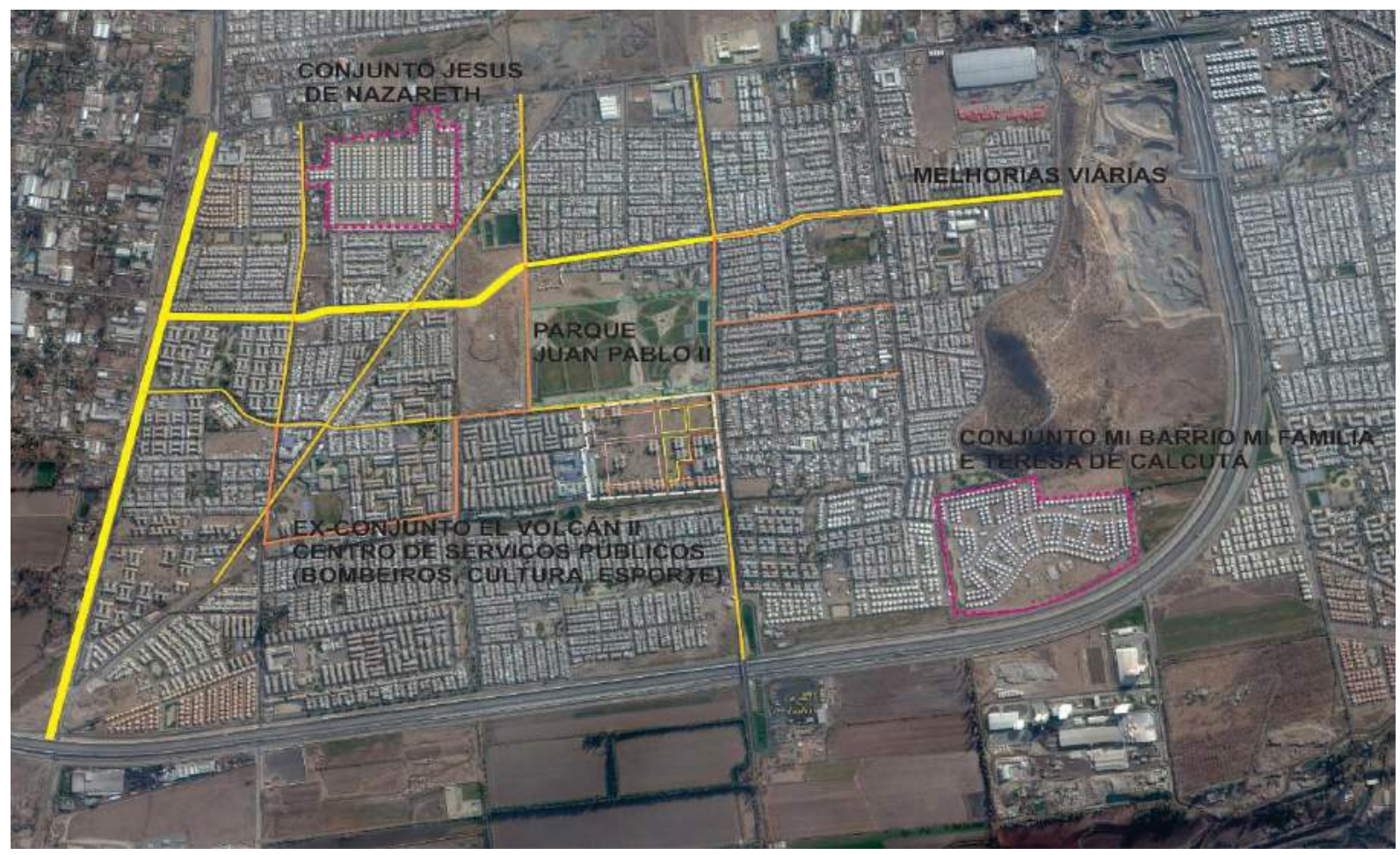

Figura 62: Algumas das estratégias do Plan Integral Bajos de Mena. Demolições, novos conjuntos habitacionais, parque urbano, intervenções viárias, criação de centros de serviços públicos, além de equipamentos de educação e saúde. Fonte: elaboração da autora, com base em informações do Plan Integral Bajos de Mena ${ }^{58}$.

58 Disponível em: <http://www.planintegralbajosdemena.cl/>. Acessado em dez. 2016. 
Embora a intenção do governo se destaque, também chama a atenção qual a real necessidade dos moradores e quais suas reais demandas. Em manifestações dos moradores em 2014, cartazes com os dizeres "no queremos mejoras, queremos irnos de aqui" eram visíveis nas ruas e conjuntos habitacionais (GUTIERREZ, 2014 e 2015).

No sentido de atender à demanda dos moradores de sair de Bajos de Mena, foi criado, durante o governo Piñera, o Programa Condominios Sociales Segunda Oportunidad. Inicialmente, esse Programa foi implementado em três condomínios habitacionais de Santiago, dois na comuna de Puente Alto (Francisco Coloane e Cerro Morado) e um em Quilicura, em 2012.

O Programa consistiu em oferecer um subsídio a famílias de setores sociais estigmatizados para que elas pudessem se deslocar para setores mais bem estruturados da cidade. O objetivo era diminuir a densidade dos conjuntos com a demolição total ou parcial de alguns edifícios, dando a "segunda oportunidade" às famílias de comprar uma habitação em outro local. O subsídio, de 700 UF $^{59}$, só era repassado caso 90\% dos moradores do edifício de cada copropriedade aderissem ao programa voluntariamente, sendo que o $10 \%$ não aderente era sujeito a permuta ou mesmo expropriação (SOLANGE, 2014).

Porém, o subsídio só foi suficiente para deslocar as famílias a outros setores periféricos, além de estimular os proprietários a venderem suas casas, gerando mais especulação e, consequentemente, mantendo o sentimento de ser perifericamente incluído. Segundo entrevista, realizada por Solange (2014):

Con las 700 UF del subsidio no alcanza para comprar una casa buena, menos aspirar a mejorar el barrio o cambiar la comuna. La mayoría se deslumbró con la plata, fueron muy ingenuos y adhirieron a ojos cerrados, pensando que iban a encontrar casa rápido. Pero la realidad es muy distinta. No alcanza la plata y los vendedores subieron los precios de venta de todas las casas aquí en Bajos de Mena. La mayoría de estas casas no cuesta más de 14 millones, pero como los vendedores sabían que el Estado pagaba 17 millones, las subieron a ese precio (...). (Entrevista A7, p. 97)

Assim, o Programa atuou com liberação de solo para especulação imobiliária, usando como solução habitacional a demolição dos imóveis e a entrega de subsídio, sem considerar os impactos urbanos, sociais e econômicos que esses deslocamentos e demolições podem causar tanto nas populações que se deslocam, quanto naquelas que permanecem.

Além disso, houve a ruptura das redes sociais, já debilitadas, que se fragilizaram ainda mais com o deslocamento aleatório de famílias para locais desconhecidos, onde havia poucos vínculos sociais, seja de pertencimento, seja de identidade. Após o deslocamento, não havia satisfação com a habitação ou com seu entorno, somente compatibilidade com o custo.

Segundo entrevistas realizadas por Solange (2014) com moradores de Francisco Coloane que aderiram ao programa, o principal motivo de adesão foi a falta de identificação com a tipologia de edifício habitacional, sendo que os motivos de descontentamento incluíam: alta densidade populacional, falta de possibilidade de ampliação da unidade habitacional, escassa privacidade e necessidade de pátios privados, ventilação e iluminação insuficientes (também ocasionadas pelas ampliações irregulares de vizinhos), falta de higiene e salubridade e dificuldade com

59 A Unidade de Fomento (UF) de 1 de fevereiro de 2012 equivalia a 22.412,68 pesos chilenos. Com o dólar da mesma data a 488,75 pesos chilenos, os 700 UF equivaliam a 32.100 dólares. 
a vida em copropriedade, ou seja, em condomínio.

As entrevistas demonstraram a preferência geral das famílias por trocar sua habitação em condomínio de prédios de Bajos de Mena por uma casa com jardins na frente e fundos do lote. Em relação à preferência de localização, as famílias buscavam duas situações: ou encontrar uma nova habitação em localidade próxima e conhecida, ou retornar ao habitat de origem, desde que ainda existissem ali redes sociais (SOLANGE, 2014):

Busqué casa nueva y aislada sin muros compartidos, porque no quiero escuchar la vida de mis vecinos, ya tuve suficiente en Coloane. Lo malo es que todas las villas nuevas que fui a ver eran casas pareadas, lindas igual, pero estaban muy caras y con las 700 UF del subsidio no alcancé. Yo no podía pedir un crédito, porque no tengo un contrato (...) Igual encontré una casa nueva pero estaba en (la comuna de) Pirque, no me quería ir tan lejos. Al final compré una casa sola antigua y con patio aquí cerca, fuera de Bajos de Mena, porque aquí solo hay casas en carro o pareadas y está más caras (Entrevista A8, p. 92)

Verifica-se, nos relatos coletados por Solange (2014), o paradoxo em relação à violência urbana: esta existe sempre no território vizinho, não no território cotidiano. Portanto, há uma grande relatividade na sensação de segurança, como comprova a entrevista A7:

Prefiero casa en Bajos de Mena, después de 16 años viviendo aquí, conocemos bien el territorio y a los vecinos, sabemos dónde es peligroso: (las Villas) El Volcán, Pedro Lira y El Caleuche, pero aquí es tranquilo. Sabemos dónde tomar micro o colectivo ¿A dónde me voy a ir? Además no voy a sacar mis hijos del colegio porque es bueno y barato, imposible encontrar algo así, en otro sector caras. (p. 94)

As entrevistas com os moradores que não aderiram ao programa mostraram, entre os motivos de não adesão, principalmente o vínculo ou a dependência entre famílias e redes de vizinhos no território. Também aparece no discurso a valorização de Bajos de Mena e a recusa em responder a interesses políticos e econômicos de liberar mais solo urbano (SOLANGE, 2014).

Os moradores não tiveram auxílio do Programa para escolher uma casa mais adequada ao seu cotidiano, e o deslocamento para novas unidades habitacionais ficou limitado pelo pouco conhecimento dos moradores, agravado pela falta de assessoria técnica e por poucos recursos financeiros.

Segundo Flores (2006, apud SOLANGE, 2014), as famílias resistem às mudanças de localização pelo receio frente ao desconhecido, o que faz com que tendam a permanecer em um mesmo território, por já terem familiaridade e conhecimento do ambiente, mantendo características similares com as que já estão acostumadas.

O dilema dos moradores em sair, mas, ao mesmo tempo, ficar no território de Bajos de Mena causou conflitos entre vizinhos, que se agravaram com o processo de demolição dos edifícios, marcado pela resistência dos que não queriam sair das unidades.

Os destroços, juntamente com a presença de edifícios em processo de demolição ainda com moradores resistentes, são de uma paisagem que lembra os conflitos bélicos de Gaza: pessoas vivendo no meio de escombros, de lixo, do esgoto a céu aberto e mais todo tipo de contaminação ambiental e visual, além do impacto psicológico do cotidiano nesses espaços (figuras 63 e 64). 


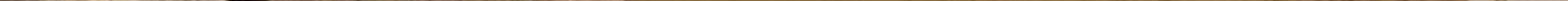




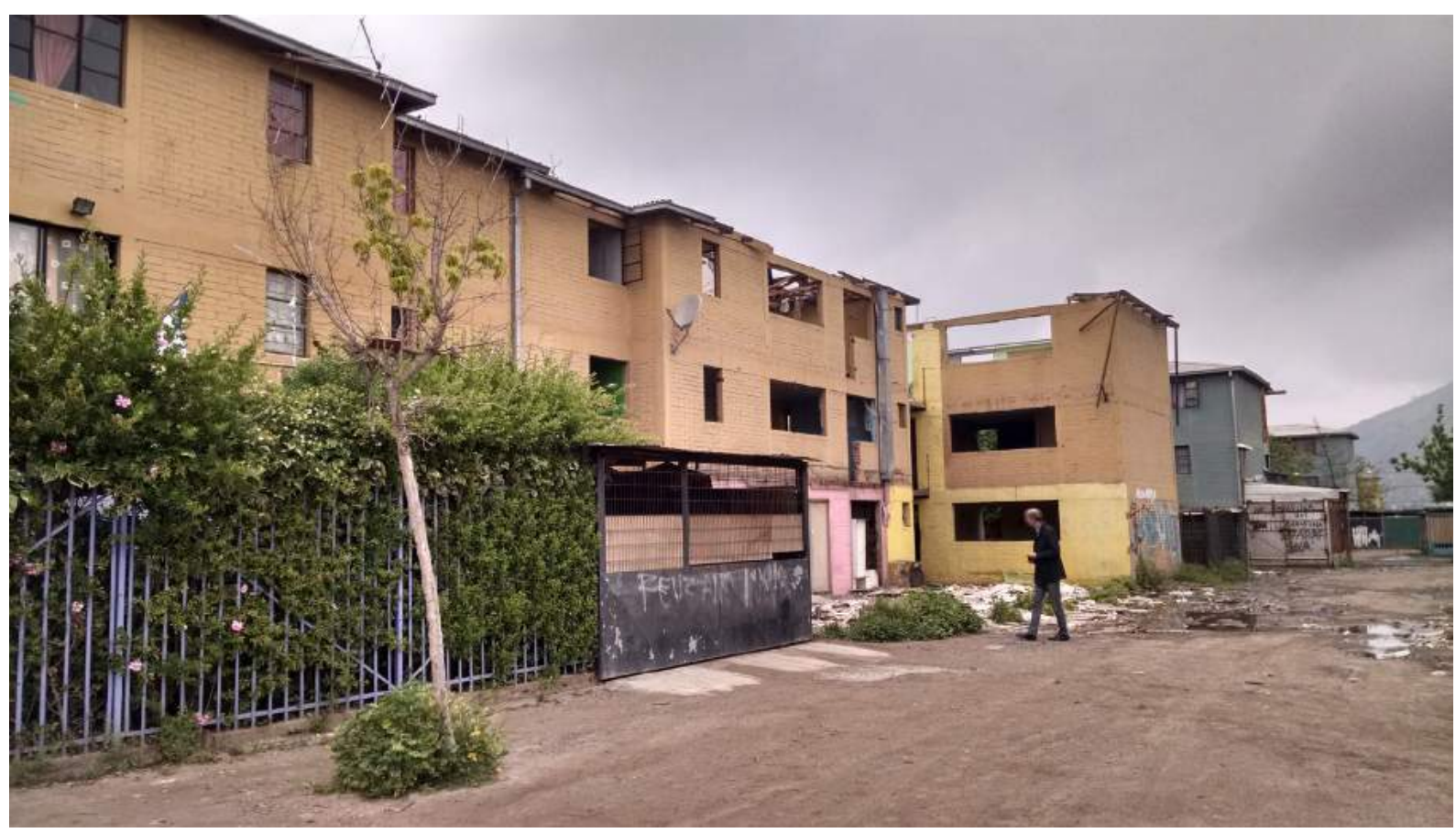

Figuras 63 e 64: Um dos edifícios habitacionais do Conjunto Habitacional Francisco Coloane em processo de demolição. A presença de famílias resistentes causou uma pausa no processo de demolição, e aqueles que ainda permanecem no local vivem em meio aos escombros. Fotografias da autora, out. 2015.

Em entrevista ao Jornal La Tercera, de 17 de agosto de $2014^{60}$, o ex-subsecretario de Vivienda Francisco Irarrazával justificou a demolição mesmo com famílias relutantes: "No podíamos esperar a que todos se pusieran de acuerdo para salir, porque de lo contrario no habríamos sacado a las personas nunca. Los que querían irse nos exigían hacer algo". Na mesma reportagem, é possível identificar o individualismo dos vizinhos no processo de aquisição do subsídio do programa, com o testemunho de uma beneficiada, Viviana Fuentes, afirmando o seu logro pessoal, e comentando sobre as famílias que ainda vivem nos escombros: "es indigno que vivan así pero ellos tomaron la opción de no aceptar el subsidio" (GONZÁLEZ, 2014).

O grande uso de subsídios na política social e habitacional chilena é, também, exemplo de ações que focam o indivíduo e não o grupo social. Embora a focalização seja importante, não se deve perder de vista a necessidade do coletivo.

(...) El 9 de septiembre a las 7 AM demolieron la mitad del block. No lo demolieron completo solo porque estaba yo. Como no habíamos salido del departamento, detuvieron a mi marido y a mi hijo, hasta que la retroexcavadora terminó de botar la mitad del block. Ni siquiera traían una orden de desalojo y a mi hija a mi nos encerraron aquí. Usted no imagina como se movía el block y se caían las cosas mientras la máquina demolía, parecía terremoto. A las 10 de la mañana una vecina llamó a la prensa, pero ya había terminado la retroexcavadora (...) Al final de todos los que decían que eran resistentes, yo fui la única que realmente resistió, porque todos terminaron cediendo, a mí me van a expropiar y pagar 12 millones y medio, en vez de los 17 que recibieron todos. (SOLANGE, Entrevista R4, 2014, p. 99)

60 Disponível em: <http://www.latercera.com/noticia/sobrevivir-entre-los-escombros/>. Acessado em 5 dez. 2016. 
Dessa forma, a atuação do Programa Segunda Oportunidad gerou um território ainda mais estigmatizado, cujos impactos sociais têm custos que não são numéricos, pois a manutenção subjetiva da condição social e econômica fez com que as famílias se mantivessem no mesmo território, que queriam e querem, elas mesmas, esquecer.

O estigma é, subjetivamente, resultante de mecanismos de produção que, embora variáveis em objetivos políticos e finalidades, buscam o controle sobre grupos como garantia de poder (NAKANO, 2002). O estigma, então, provém de fora, mas é também alimentado pelos próprios moradores, o que se soma também a um elemento de vitimização, segundo o qual o grupo social se coloca como minoria, como excluídos. Nas práticas sociais, verificam-se os enfrentamentos ou a aceitação dos discursos dominantes, e a interação social ocorre entremeada de sentidos do papel social do sujeito. Esse papel, regido por regras e normas de conduta, é uma representação social do habitus, de um discurso oficial.

Bourdieu (2001) também define o habitus de classe, produto de condicionantes ou condicionamentos intrínsecos a uma classe social, ou seja, de indivíduos dotados de um mesmo habitus como sistema de disposições comuns, sendo reflexo e expressão das estruturas interiorizadas e dos sistemas subjetivos de uma classe ou grupo social.

Ribeiro $\left(2013^{61}\right)$ comenta sobre a alienação do território, que atinge especialmente as classes médias e altas, e se relaciona com a influência do economicismo e do pragmatismo para a inclusão periférica na experiência urbana. A alienação territorial pode assumir a forma de projetos de renovação urbana que acentuam a segregação, originando um território alienado, que acentua estruturas espaciais com ambientes socialmente exclusivos e impede conquistas sociais.

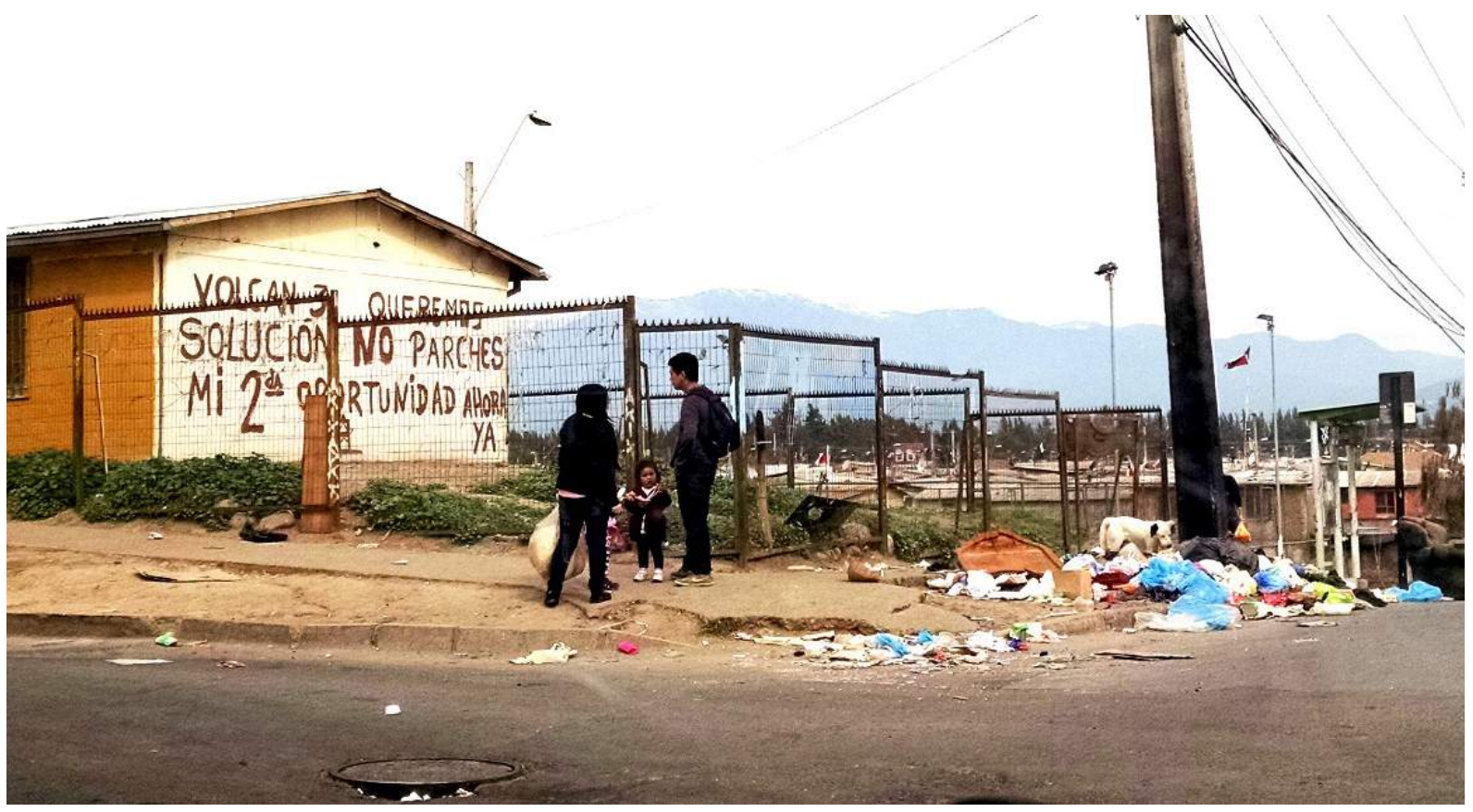

Figura 65: Pichação em parede de casa: “Volcao 3, queremos solução, não remendos. Minha 2a oportunidade agora" Fotografia da autora, 20 set. 2015.

61 Outros territórios, outros mapas. Vol. 5, p. 201-212. 
No início de 2014, foi inaugurado o Parque Juan Pablo II (La Cañamera), ocupando um terreno que antes era um depósito de lixo, desabilitado em 1978. Em 1985, parte desse depósito desabilitado foi comprado pelo MINVU para a construção de habitações sociais para famílias que foram posteriormente indenizadas pelos danos à saúde causados pelos gases tóxicos que o antigo depósito emanava. Outra parte ficou desocupada e foi informalmente utilizada pela população para descarte ilegal de lixo (GAETE, 2013; BRICEÑO, 2013).

Em 2013, 158 famílias da Villa San Guillermo II foram indenizadas, por danos psicológicos e de saúde, pela proximidade com o antigo depósito de lixo, caso que passou a chamar a atenção depois que, em 2003, houve uma explosão na rua devido à acumulação de gases tóxicos. Embora agora exista um parque no antigo terreno do depósito, construído isolando o solo e com chaminés para que os gases tóxicos saiam do solo, o estigma de viver ao lado de um depósito de lixo ainda será sentido pelos moradores por muitos anos (VALENCIA, 2013).

O Parque, que inicialmente seria chamado de La Cañamera, nome do depósito de lixo, teve seu nome modificado para Juan Pablo II, em homenagem a uma estátua do Papa Juan Pablo II doada pela Universidade San Sebastián ${ }^{62}$, que deveria ter sido instalada em frente à Faculdade de Direito da Universidad de Chile no bairro central Bellavista, mas que, por suas grandes dimensões, não pôde ser ali instalada (GAETE, 2013).

A estátua foi, então, deslocada para Bajos de Mena, em uma imposição estética e religiosa que impacta tanto de modo visível como invisível, em uma postura que parece considerar que onde vivem os outros é a terra de ninguém, para onde podem ser levadas sobras ou elementos urbanos que não puderam ser instalados em outros lugares.

O Parque surgiu juntamente com o Programa do Legado Bicentenario, que construiu diversos parques nas comunas periféricas de Santiago, beneficiando vários setores de habitação social e demonstrando os esforços do governo em sanar as dívidas governamentais com setores carentes, com o intuito de resolver os problemas deixados pelos anos de produção puramente habitacional e periférica.

A estratégia da construção de parques é crucial para alterar um setor estigmatizado, pois proporciona espaços que melhoram a qualidade de vida dos moradores e amplificam as possibilidades de convívio em áreas livres. Entretanto, a estratégia deveria considerar a participação da população para a definição das áreas de convívio do parque, bem como dos elementos urbanos ali presentes.

Os custos desses esforços governamentais são altos: somente o parque Juan Pablo II teve um custo de $\$ 2.617 .172 .000$ pesos chilenos ${ }^{63}$, equivalentes a USD 4.707.228 ${ }^{64}$.

A reconversão de terrenos que já foram depósito de lixo em parques é uma tendência do pai-

62 CHILE. Ministério del Interior y Seguridad Pública, Intendencia Región Metropolitana. Intendente Metropolitana y Ministra de Vivienda participan en inauguración de Parque Juan Pablo II en Puente Alto. 28 may 2014. Disponível em: <http://www.intendenciametropolitana.gov.cl/n5997_2805-2014.html>. Acessado em 14 set. 2015.

63 Segundo dados do Ministério del Interior y Seguridad Pública (Intendencia Región Metropolitana). Disponível em: <http://www.intendenciametropolitana.gov.cl/n5997_28-05-2014.html>. Acessado em 14 set. 2015.

64 Conversão realizada a partir de cotação do dólar em 28 de maio de 2014, de 555,99 pesos por 1 USD. Fonte: Servicios de Impuestos Internos. Disponível em: < http://www.sii.cl/pagina/valores/ dolar/dolar2014.htm>. Acessado em 13 dez. 2016. 
sagismo dos anos 1990 e 2000. Em São Paulo podem ser citados os projetos do Parque Villa Lobos e da Praça Victor Civita, os quais, porém, não estão localizados em bairros com população de baixos recursos, e sim em regiões de classe média e alta.

As construções em terrenos próximos ao antigo depósito de lixo são só um dos paradigmas que exemplificam os anos de descaso com as construções de habitação social em Bajos de Mena. Outro fato que alcançou os meios de comunicação e que também originou procedimento indenizatório ficou conhecido como o das "Casas Copeva" ou "Casas de Nylon", construções da Villa Volcán San José II realizadas pela empresa Copeva.

Essas construções tiveram falhas na construção que geraram impressionantes infiltrações de água durante as chuvas no inverno de 1997 (figura 66), poucos meses antes de serem entregues aos moradores, o que fez com que os edifícios habitacionais precisassem ser cobertos com uma lona plástica. Na ocasião, 605 famílias foram afetadas (VALENCIA, 2013).

Através do Programa de Recuperación de Barrios, optou-se pela demolição desse conjunto, mesmo após muito investimento público com a reforma das casas (MARTORELL, 2006). A primeira fase da demolição se iniciou em agosto de 2006 (HIDALGO; ZUNINO; ALVAREZ, 2007), com os moradores sendo relocados para outras habitações, e a sua segunda fase de demolição teve início em dezembro de 2014 (figuras 67 e 68).

Sobre as "Casas Copeva", Martorell (2006) afirma: "Se trataba de casas construidas de acuerdo al programa de Viviendas Básicas, tipología C, en copropiedad con 24 departamentos por bloque, de aproximadamente 40 metros cuadrados en tres pisos y que fueron levantadas, algunas por mandato de Serviu y otras por empresas privadas, con subsidio del Estado, entre 1994 y 1995." 65

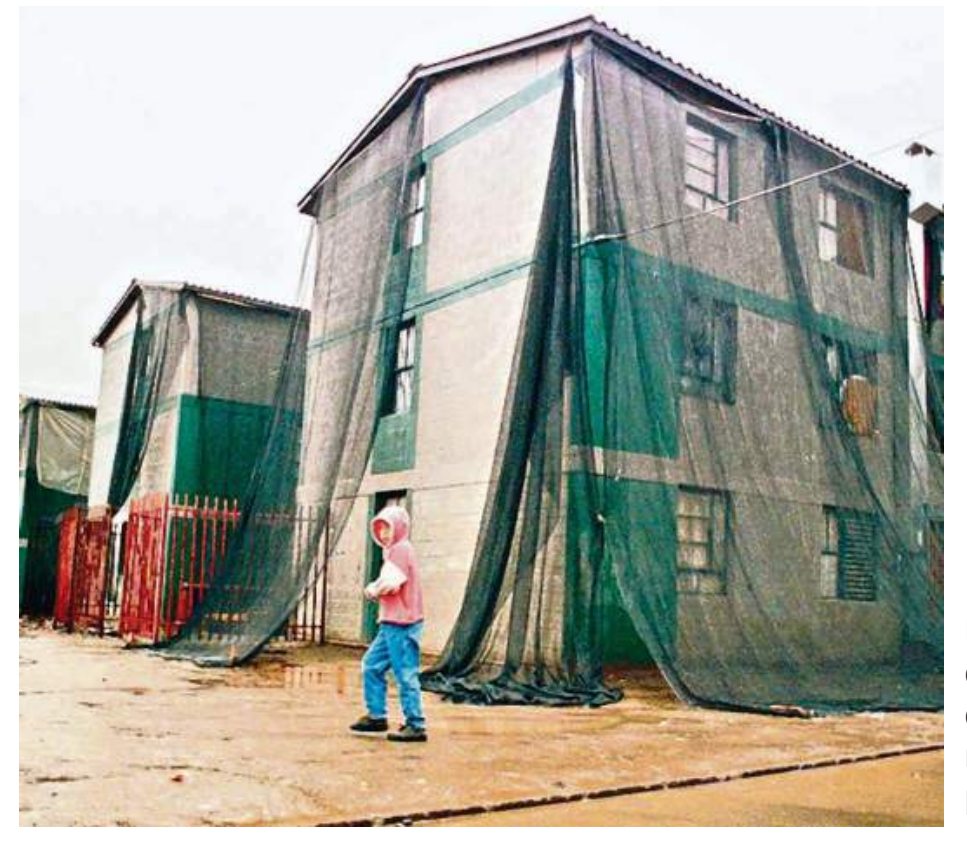

Figura 66: "Casas Copeva": má construção provocou infiltração de água durante chuvas do ano de 1997. Solução temporária foi cobrir as casas com uma lona plástica. Fonte: Diario La Tercera. ${ }^{66}$

65 Disponível em: < http://www.elperiodista.cl/newtenberg/1881/article-75337.html>. Acessado em 14 set. 2015.

66 Disponível em: <http://diario.latercera.com/2012/10/25/01/contenido/pais/31-121361-9suprema-ordena-reparar-con--1734-millones-a-592-familias-por-casas-copeva-de-p.shtml>. Acessado em 14 set. 2015 . 


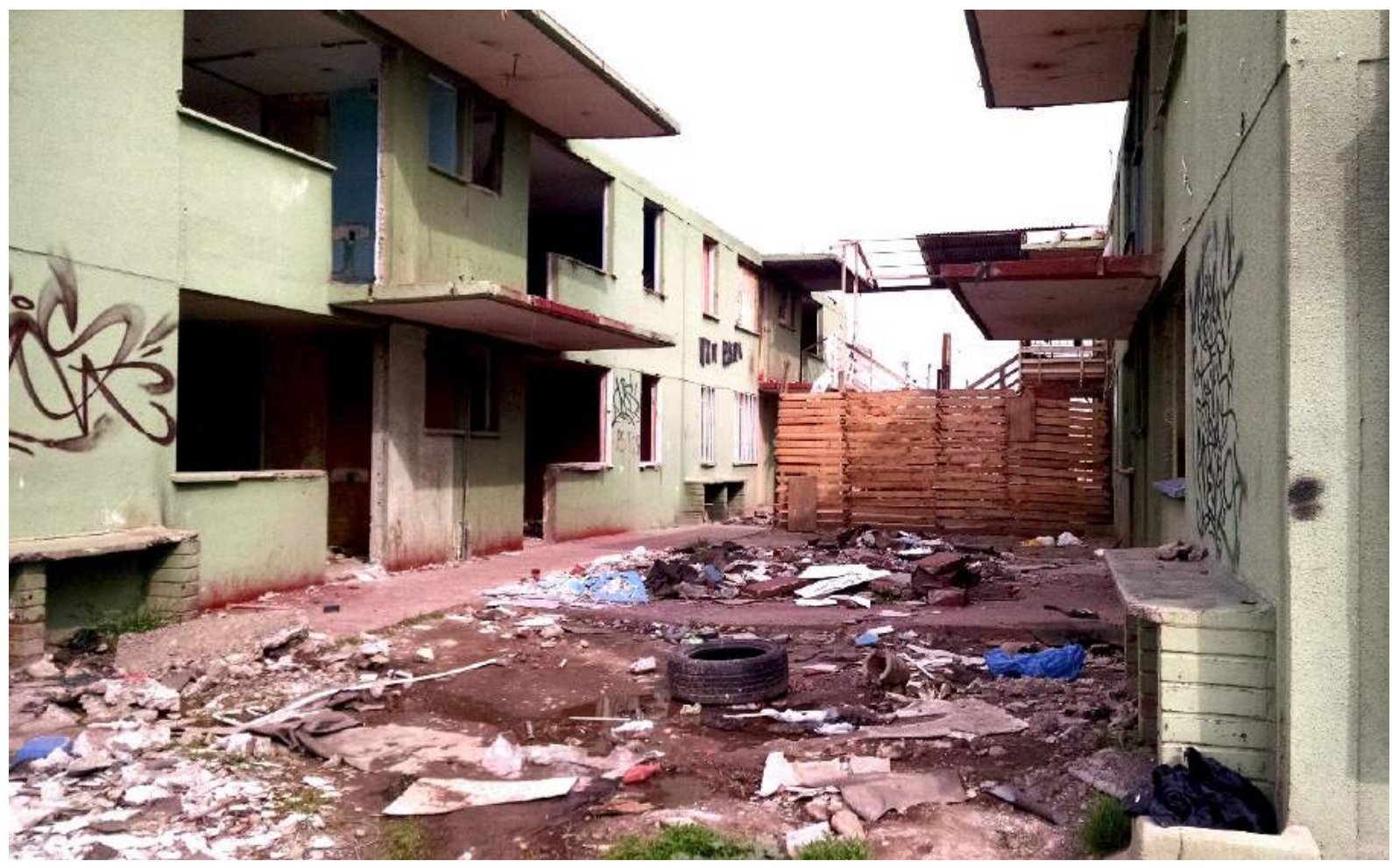

Figura 67: Escombros da Villa El Volcán II, ainda em processo de demolição, em setembro de 2015. Depósito de lixo e ocupações irregulares. Fotografia da autora, 20 set. 2015.

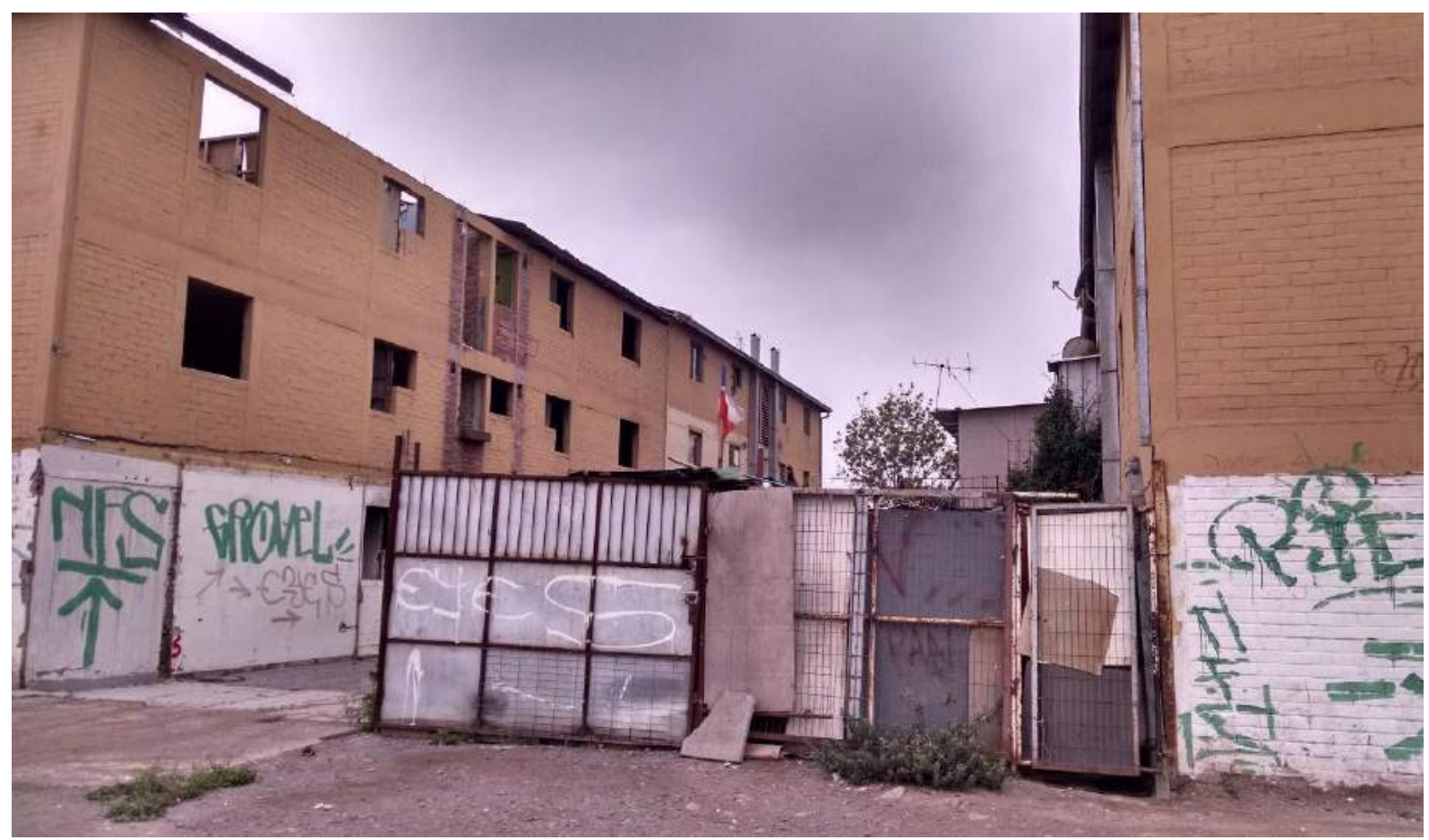

Figura 68: A ocupação irregular nos escombros do Conjunto Francisco Coloane. Fotografia da autora, 28 out. 2015. 


Além das demolições da Villa El Volcán II outros conjuntos habitacionais de Bajos de Mena poderão ser demolidos nos próximos anos. Em contrapartida, novos conjuntos habitacionais estão sendo construídos no mesmo setor, como é o caso de Jesús de Nazareth, Mi Barrio, Mi Família e Teresa de Calcuta, abrigando as famílias inseridas no Programa Segunda Oportunidad e moradores dos conjuntos demolidos.

Alguns apartamentos de Villa Teresa de Calcuta começaram a ser entregues em setembro de 2015, na ocasião com uma cerimônia de entrega das chaves para 200 famílias.

A principal crítica dos moradores dos condomínios de prédios de Bajos de Mena diz respeito ao reduzido espaço privado da residência, que tem, em média, de 40 a $45 \mathrm{~m}^{2}$. Esperar-se-ia, portanto, que além de um melhor desenho urbano, os novos conjuntos habitacionais apresentassem dimensão interna mais adequada às famílias. Nesse aspecto, houve uma melhora singela: as habitações da Villa Teresa de Calcuta apresentam $44,43 \mathrm{~m}^{2}$ distribuídos entre dois dormitórios, sala de estar, banheiro e cozinha, com uma área de ampliação projetada de $10,66 \mathrm{~m}^{2}$. Dentre as áreas comuns, estão sede comunitária e áreas de jogos infantis (figuras 70 e 71 ).

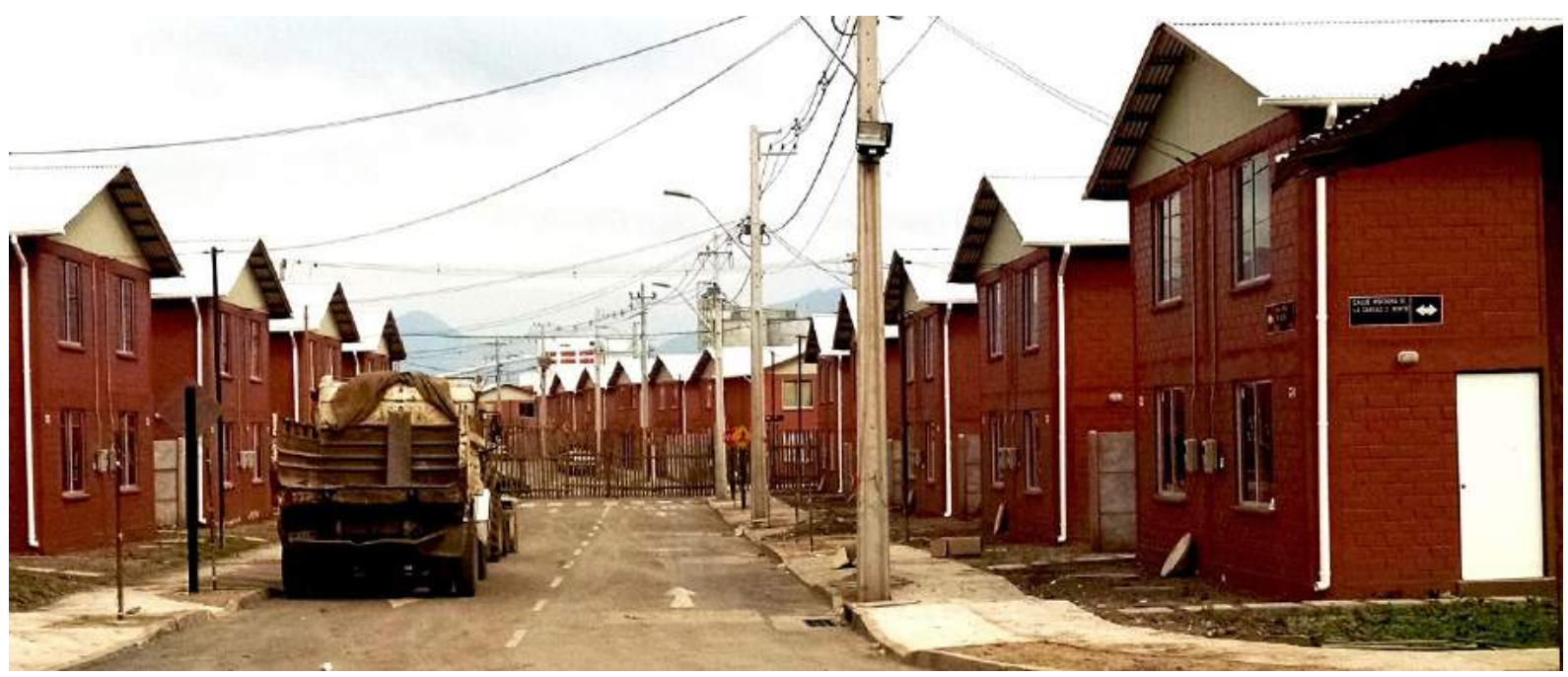

Figura 70: Recém entregue conjunto habitacional Villa Teresa de Calcuta em Bajos de Mena, em modelo de condomínio. Fotografia da autora, 20 set. 2015.

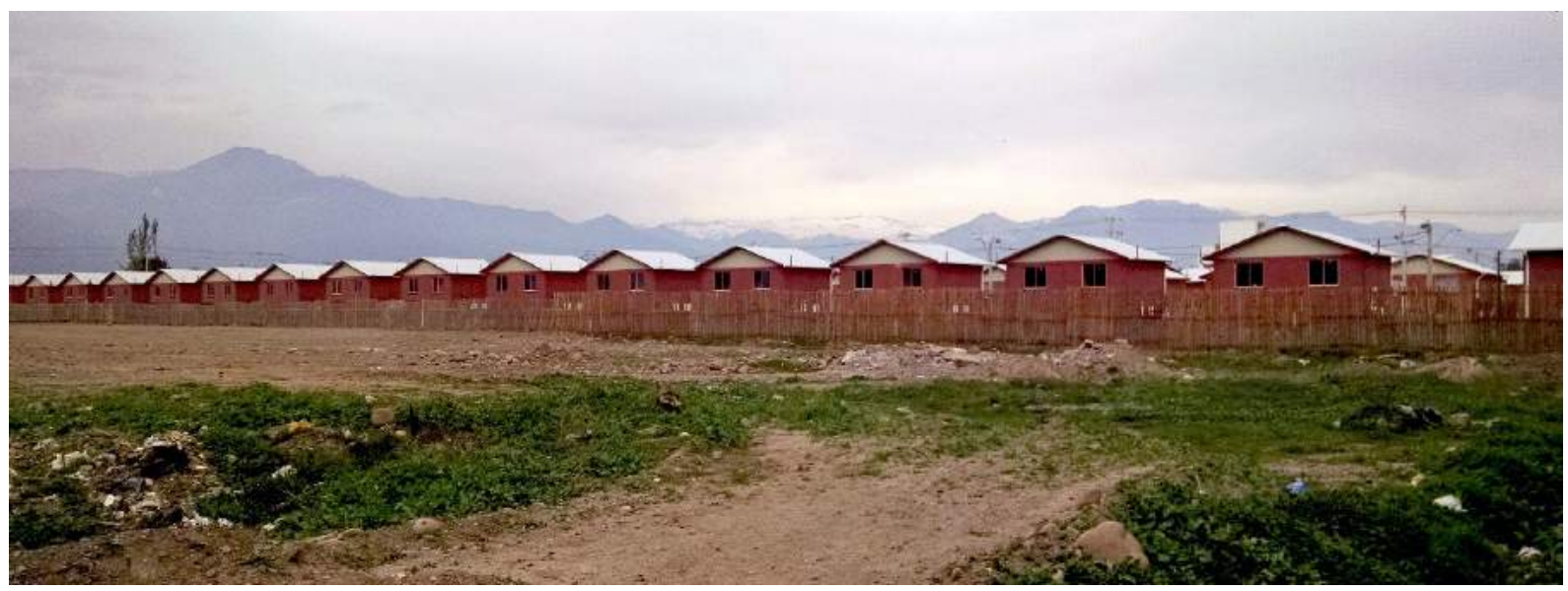

Figura 71: Recém entregue conjunto habitacional Villa Teresa de Calcuta em Bajos de Mena. Fotografia da autora, 20 set. 2015. 
O Conjunto Jesús de Nazareth em Bajos de Mena (figura 72) segue o mesmo modus operandi, mas com habitações um pouco maiores. As primeiras unidades, com $55,6 \mathrm{~m}^{2}$ e três dormitórios, foram entregues, em junho de 2015, para famílias da antiga Población El Voncán San José II e da Villa Santa Elvira.

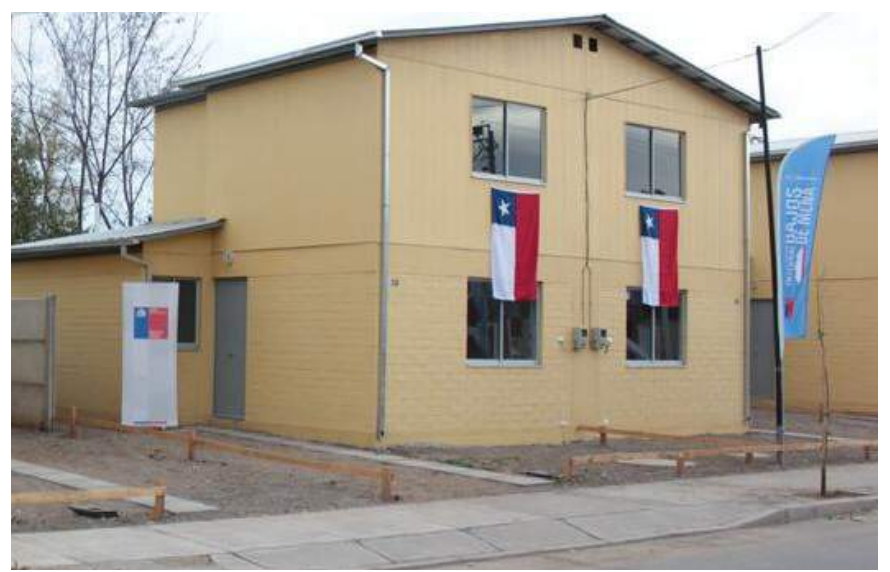

Figura 72: Mais do mesmo. O recém entregue conjunto habitacional Jesús de Nazareth em Bajos de Mena. Fonte: Plan Integral Bajos de Mena. ${ }^{67}$

Os novos conjuntos habitacionais em Bajos de Mena não cumprem vários dos critérios qualitativos elaborados no capítulo 1: não houve participação cidadã ou consideração das redes sociais, a inserção urbana permanece questionável, não há diversidade morfológica ou funcional, não há visibilidade na relação entre o conjunto habitacional e o restante do setor. É mais do mesmo, uma construção de qualidade urbana questionável que não contribui para a criação do habitat, somente acentua a dimensão subjetiva do descaso com o outro.

Nos entornos das vilas de casas unifamiliares no setor de Bajos de Mena, existem muitos espaços de convívio social, como praças de bairro. Já no entorno de alguns conjuntos habitacionais de prédios, existem espaços de jogos para crianças e algumas quadras esportivas. Muitos desses espaços estavam deteriorados durante as visitas do ano de 2015 (figuras 73, 74 e 75), e muitos eram usados como depósito de lixo.

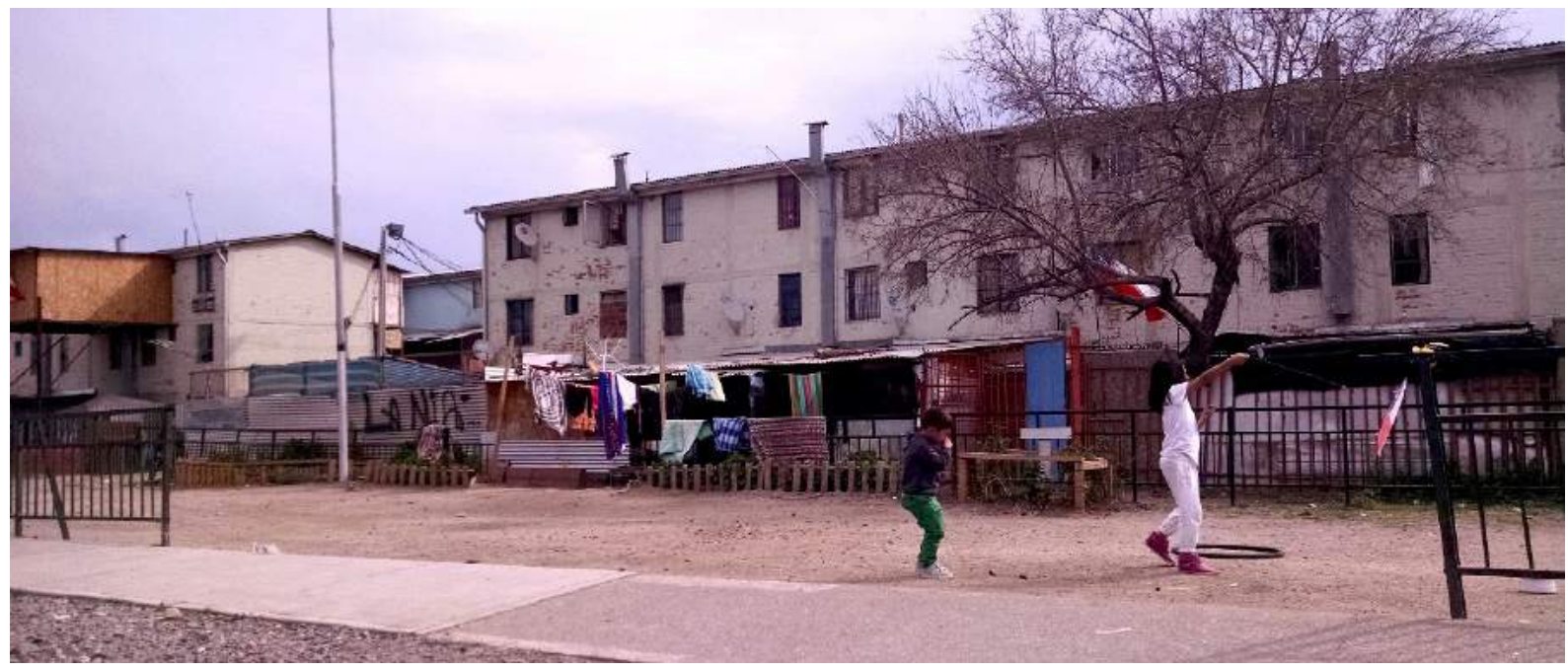

Figura 73: Área pública de convívio social em conjunto habitacional social localizado em Bajos de Mena. Ao fundo, notam-se ocupações irregulares no espaço de copropriedade de um dos conjuntos habitacionais. Fotografia da autora, 20 set. 2015.

67 Disponível em: <http://www.planintegralbajosdemena.cl/serviu-entrega-216-viviendas-del-nuevo-conjunto-jesus-de-nazareth-en-bajos-de-mena/>. Acessado em 10 set. 2015. 

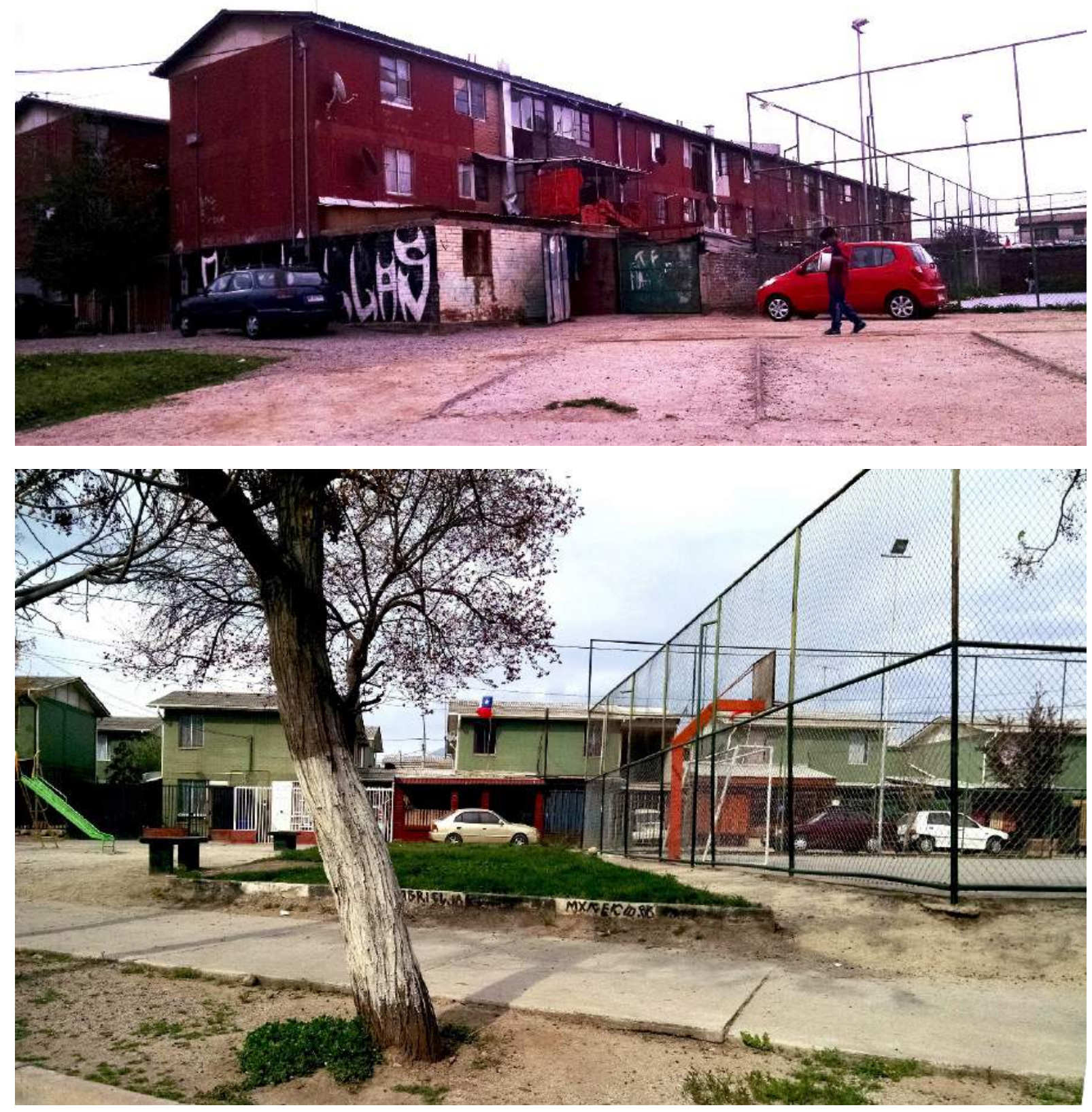

Figuras 74 e 75: Praças de bairro entre as residências unifamiliares e espaços esportivos no entorno dos conjuntos habitacionais verticais: deterioração e pouco uso cotidiano. Fotografias da autora, 20 set. 2015.

Em alguns trechos do setor de Bajos de Mena existem calçadas com melhor dimensionamento em comparação ao restante do setor, com recuo considerável das construções dos condomínios de prédios. Embora sejam minoria, esses espaços trazem maior qualidade ao seu entorno, e tem potencial para serem usados como espaços de convívio coletivo ao ar livre (figuras 76 e 77$)$. 

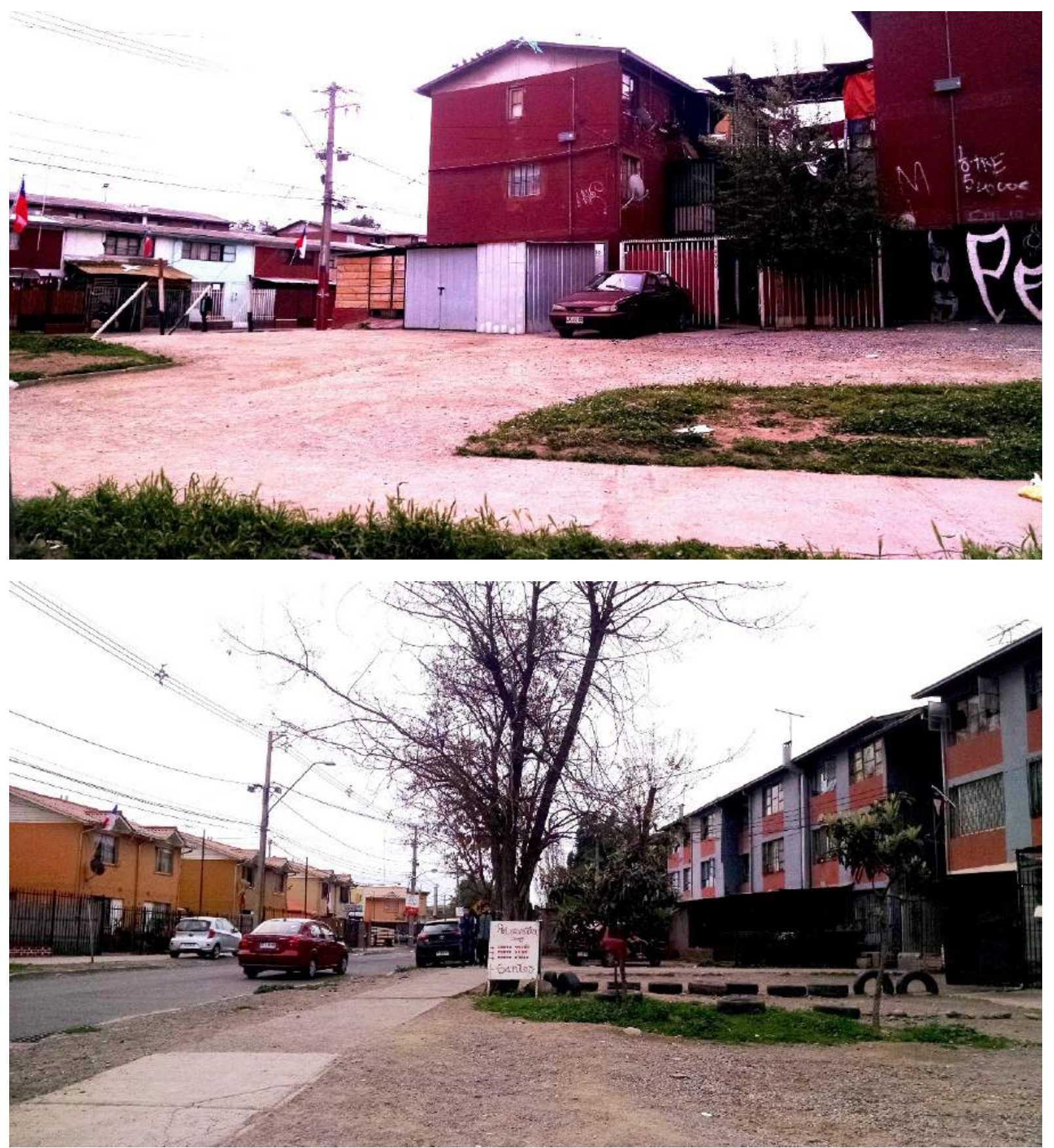

Figuras 76 e 77: Calçadas amplas e edifícios recuados em relação ao leito carroçável: esses espaços livres têm grande potencial para o convívio social. Fotografias da autora, 20 set. 2015.

A presença de lixo e vandalização nos espaços livres de uso comum demonstram a falta de apropriação pelos moradores. Fotos realizadas durante as Festas Pátrias de 2015, momento em que o uso dos espaços livres poderia estar potencializado, demonstraram o pouco uso desses espaços mesmo em momento de festa tradicional chilena, quando manifestações e ocupações dos espaços livres são frequentes. Também foi possível observar o uso de espaços livres não projetados para o uso coletivo, como em um dos terrenos nos quais se demoliram habitações do Volcão I e onde alguns empinavam pipa (figura 78). 


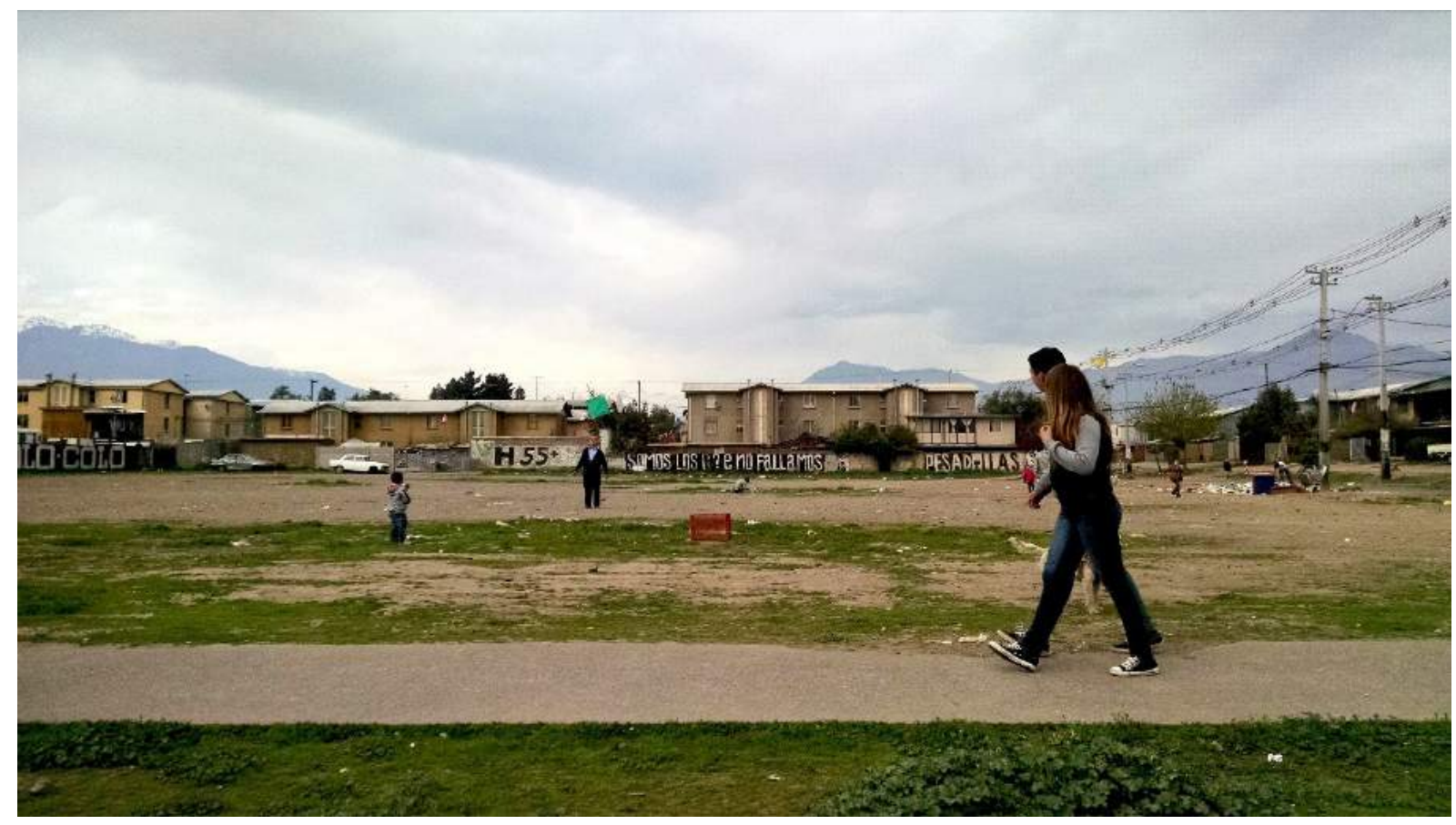

Figura 78: Terreno que antes era ocupado por conjuntos habitacionais é apropriado pelos vizinhos tanto para práticas de convívio social, como para descarte irregular de lixo doméstico. Fotografia da autora, 20 set. 2015 .

O pouco uso dos espaços coletivos mesmo em datas festivas indica que as práticas sociais devem ocorrer no interior das habitações, o que enfatiza a importância do lar no cotidiano das famílias. A força subjetiva do interior da moradia se inicia no próprio processo de aquisição da casa própria, já que as famílias lutaram individualmente pelo seu teto, muitas vezes desvinculadas do espaço social onde se inserem, apenas buscando por um imóvel próprio, o que tem muita importância para elas. Tal fato estimula, invisivelmente, o distanciamento dos espaços fora do limite da vida privada.

A falta de uso dos espaços livres públicos é justificada por discursos de falta de interesse e insegurança, por um estranhamento aos espaços projetados e medo do convívio coletivo. $\mathrm{O}$ espaço seguro e familiar é o interior da habitação, e o espaço exterior é ameaçador e temido, apropriado pelo tráfico de drogas, pela delinquência e pela violência. Os muros da habitação marcam uma fronteira material, social e subjetiva (BESOAIN, 2012).

Há medo constante do outro, configurando o imaginário da percepção de insegurança, que direciona as práticas sociais para o interior das habitações, enclausurando famílias pelo receio do que pode acontecer no espaço externo à residência. Esse medo se traduz também nos diversos fechamentos a mais nos condomínios, com grades nas escadarias que segregam acessos, demostrando de forma concreta o pavor de uma violência já interiorizada no cotidiano (figura 79).

A mudança brusca de realidade dos moradores dos conjuntos habitacionais sociais, desloca- 
dos de um trecho urbano para outro desconhecido em busca da casa própria, em princípio é vista de maneira positiva: a aquisição de um imóvel, herança aos filhos para melhores condições de vida futura, é vista positivamente apesar do endividamento, da localização periférica, da falta de infraestrutura ou de equipamentos.

Essa visão otimista, no entanto, vai aos poucos desaparecendo, quando a dificuldade com a nova maneira de viver, a localização e os trajetos diários desgastantes, a diminuição da união entre moradores e a falta de assistência do Estado passam a fazer parte do dia a dia. A sensação posterior é de apatia e de negativismo, de abandono da luta por melhores condições de habitat.

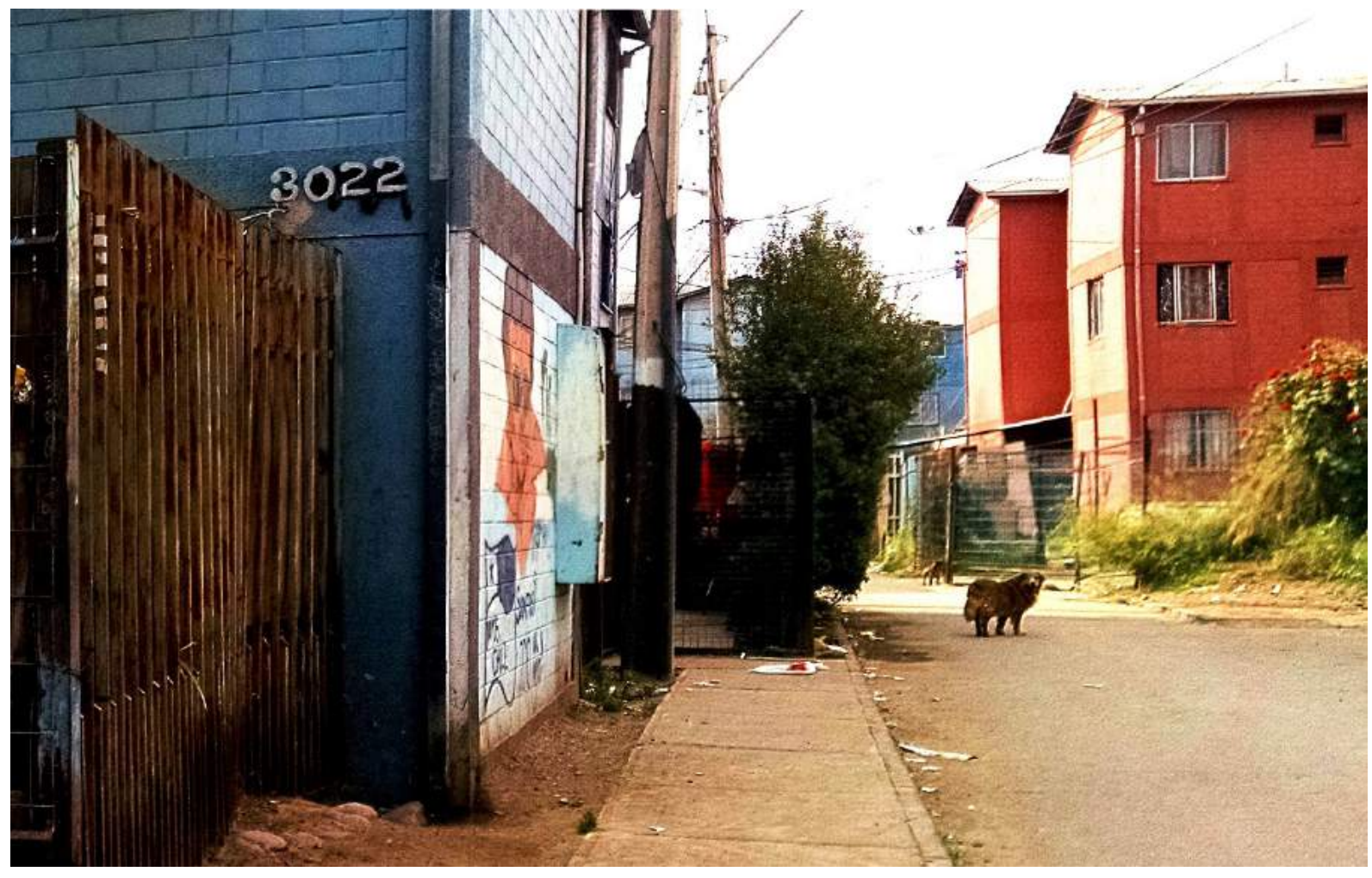

Figura 79: Área livre tradicional de Bajos de Mena. Calçadas estreitas, ausência de usuários e desconfiança do espaço de uso coletivo. Fotografia da autora, 20 set. 2015.

Durante visita realizada no feriado das Festas Pátrias de 2015, um dos usos do espaço livre público do setor despertou atenção: um grupo social religioso passeava pelas ruas, entre condomínios de prédios, passando mensagens religiosas com amplificação sonora (figura 80). Essas pregações, frequentes em praças centrais brasileiras, são também parte do cotidiano chileno, com cortejos que se movimentam pelo espaço público. Em Bajos de Mena assumiam nova condição, com a pregação ambulante que invadia sonoramente o ambiente privado, em busca de mais adeptos à causa religiosa: talvez uma adaptação da pregação tradicional ao cotidiano privatizado e interiorizado dos moradores dos conjuntos habitacionais sociais. 
As práticas religiosas têm muita importância em grupos sociais fragilizados. Mas mais do que propor a superação, a leitura do evangelho orienta à aceitação da condição humana em que se encontram, e deve ser observada com cautela e dentro do seu contexto socioeconômico e cultural.

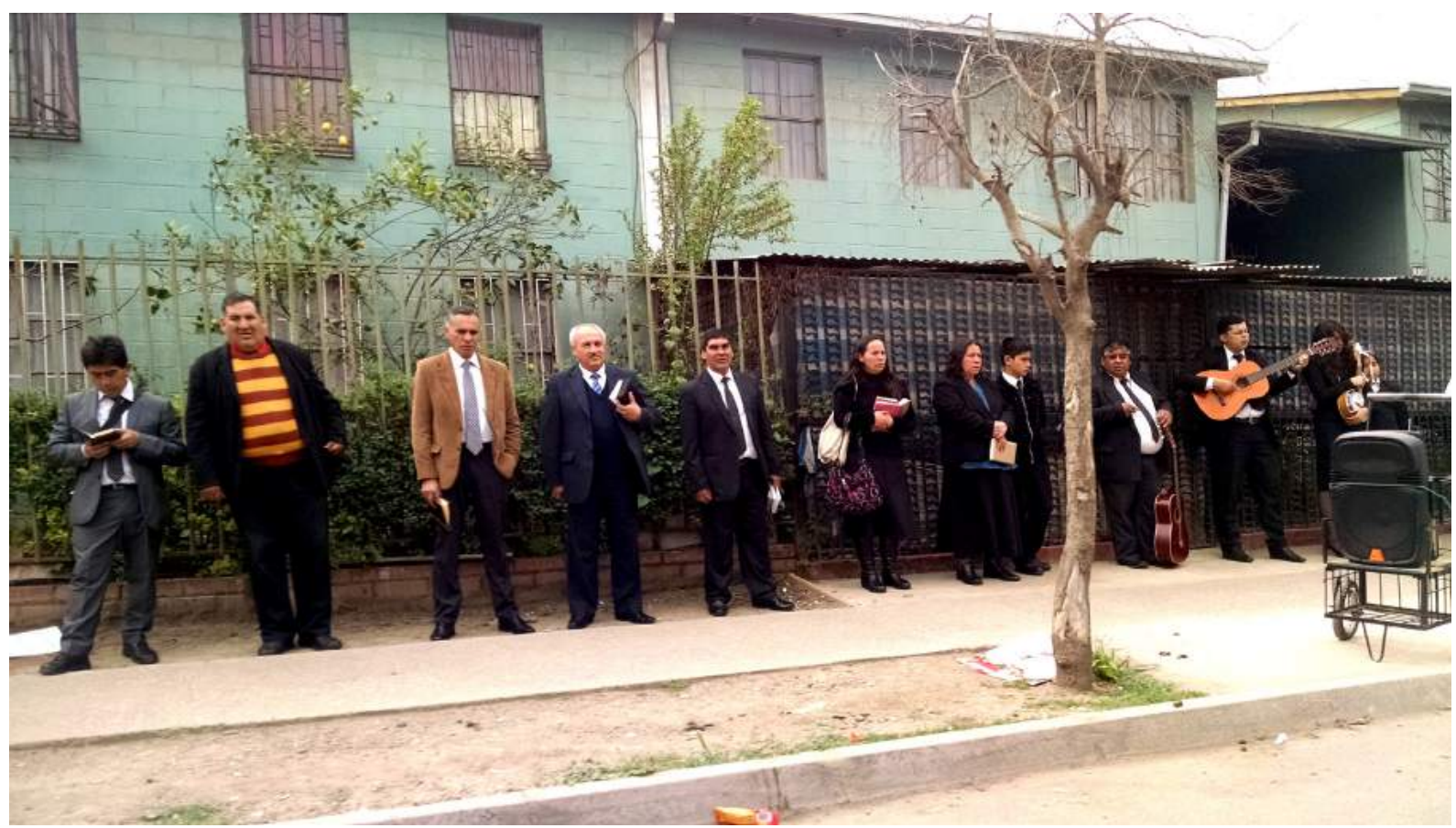

Figura 80: Pregação ambulante com amplificadores invade o cotidiano internalizado dos moradores dos conjuntos habitacionais sociais. Fotografia da autora, 20 set. 2015.

A impressão que o Plano Integral de Bajos de Mena transmite é uma tentativa desesperada do governo de investir em soluções para um problema gerado pela própria política habitacional. O investimento no território é altíssimo, mas será realmente efetivo? Novamente é uma imposição de uma maneira de viver em um trecho urbano, sem participação popular nas escolhas, o que dificultará a apropriação pelos moradores dos espaços projetados.

Mesmo o projeto das áreas de convívio social realizadas a partir dos anos 1980 parece ter surgido de uma imposição externa, de um modo de conviver e de se relacionar que os moradores daquele território não compartilham. O abandono dessas áreas formalmente projetadas e a apropriação de espaços não projetados é exemplo desse fato, pois a identificação dos moradores não se dá pelas áreas impostas.

O próprio parque Juan Pablo II é de uma imposição exacerbada, visível pela estátua religiosa de $13,5 \mathrm{~m}$ de altura que foi implantada sem consulta aos moradores. A consequente falta de uso dos espaços de convívio do parque e a necessidade de policiamento para que não haja depredações é resultado do processo imperativo das ações políticas nesse setor. As imposições do Plano continuam, com a criação de novos equipamentos, necessários, mas com projeto 
elaborado sem participação e com arquitetura elitista, similar a construções que se encontrariam nas comunas de alta renda de Santiago, o que cria um universo fictício que não faz parte do cotidiano do setor.

A atuação do Programa Segunda Oportunidad em Bajos de Mena demonstra a dimensão do problema social gerado nesse território: oferecer um subsídio para que as famílias possam ter uma "segunda oportunidade", deslocando-se para um território melhor, é assumir o erro público de criação de um trecho urbano estigmatizado, na tentativa de resolvê-lo da maneira mais fácil possível: esquecendo-o. Porém, o esquecimento social traz impactos ao sujeito que não podem ser resolvidos com novos subsídios.

A problemática originada pelo modus operandi que cria concentrações de habitação social é particularmente dramática em Bajos de Mena. Foram diversas as propostas que surgiram para transformá-lo, assim como em outros setores similares, como demolições, construções de parques e serviços públicos. Porém, acreditar que uma política de infraestrutura e serviços é suficiente para a superação das adversidades é ilusório.

Nenhuma ação política em Bajos de Mena conseguirá atuar na esfera subjetiva da inclusão periférica. Entre o Plano Integral e o Programa Segunda Oportunidad, aparece o dilema governamental de não saber o que fazer para resolver o problema criado: demolir, realocar ou criar novas habitações e novos equipamentos? Como resolver Bajos de Mena?

Os melhoramentos propostos pelo Plano Integral impõem uma urbanidade que não necessariamente será de interesse dos moradores do setor. É também uma maneira de manter a segregação, melhorando um local fadado ao fracasso para que as pessoas não saiam dali. Desde os anos 1920, Bajos de Mena tem questões principalmente sociais pelo deslocamento de famílias para, mais do que um setor segregado, uma realidade que não conseguirão esquecer ou superar.

Bajos de Mena é um território de difícil solução, e é o maior exemplo do que uma política habitacional social impositiva, segregatória, e sem participação, pode causar. Um caso típico dos "pobres com teto" (RODRIGUEZ; SUGRANYES, 2005), em que as demandas dos moradores já não são mais estimuladas pelo sonho da casa própria, mas sim pela realidade da casa imprópria à vida. 


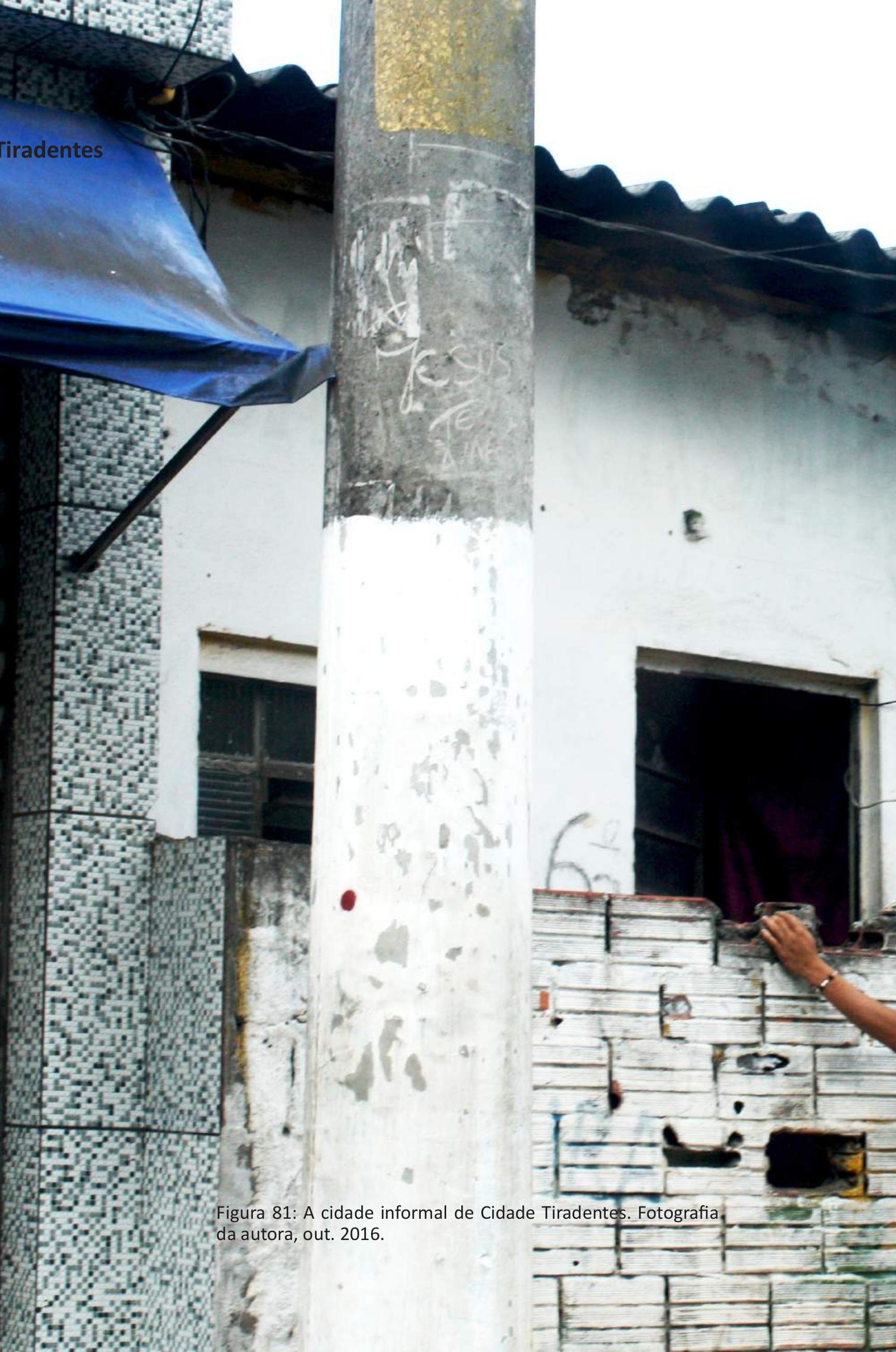


Nasceu de um não...Unidade concretada. Sociedade desconexa. Ocupação.

(Mathias Schelp, Pequenos Contos Preguiçosos)

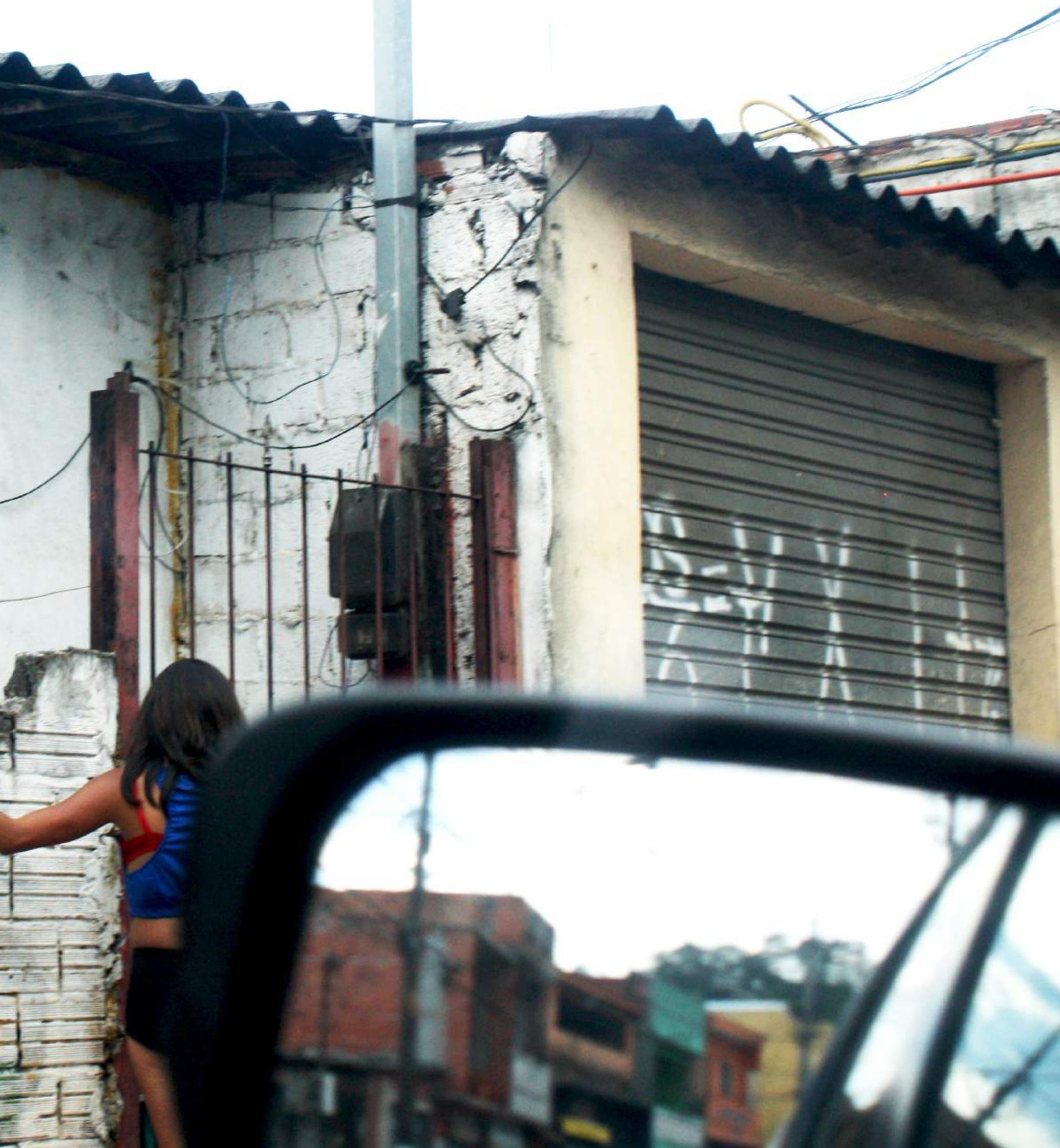


O distrito de Cidade Tiradentes, localizado no extremo leste de São Paulo, na divisa com o município de Ferraz de Vasconcelos (figura 82), é composto por diversos bairros, divididos em setores nomeados pelas letras do alfabeto e por números, em uma classificação impessoal e pouco identitária.

Tem sua história associada ao fim do Sistema Financeiro de Habitação e ao posterior gerenciamento da política habitacional a partir de órgãos municipais. No caso de São Paulo, esse gerenciamento passou a ser feito pela COHAB (Companhia Metropolitana de Habitação de São Paulo), criada em 1965 e responsável pela execução do Plano Nacional de Habitação lançado em 1964 pelo regime militar, atuando no município de São Paulo até o período atual. Juntamente com a COHAB-SP, também atuaram na RMSP diferentes órgãos de âmbito estadual e nacional, como a Companhia de Desenvolvimento Habitacional e Urbano do Estado de São Paulo (CDHU), e o recente Programa Minha Casa Minha Vida.

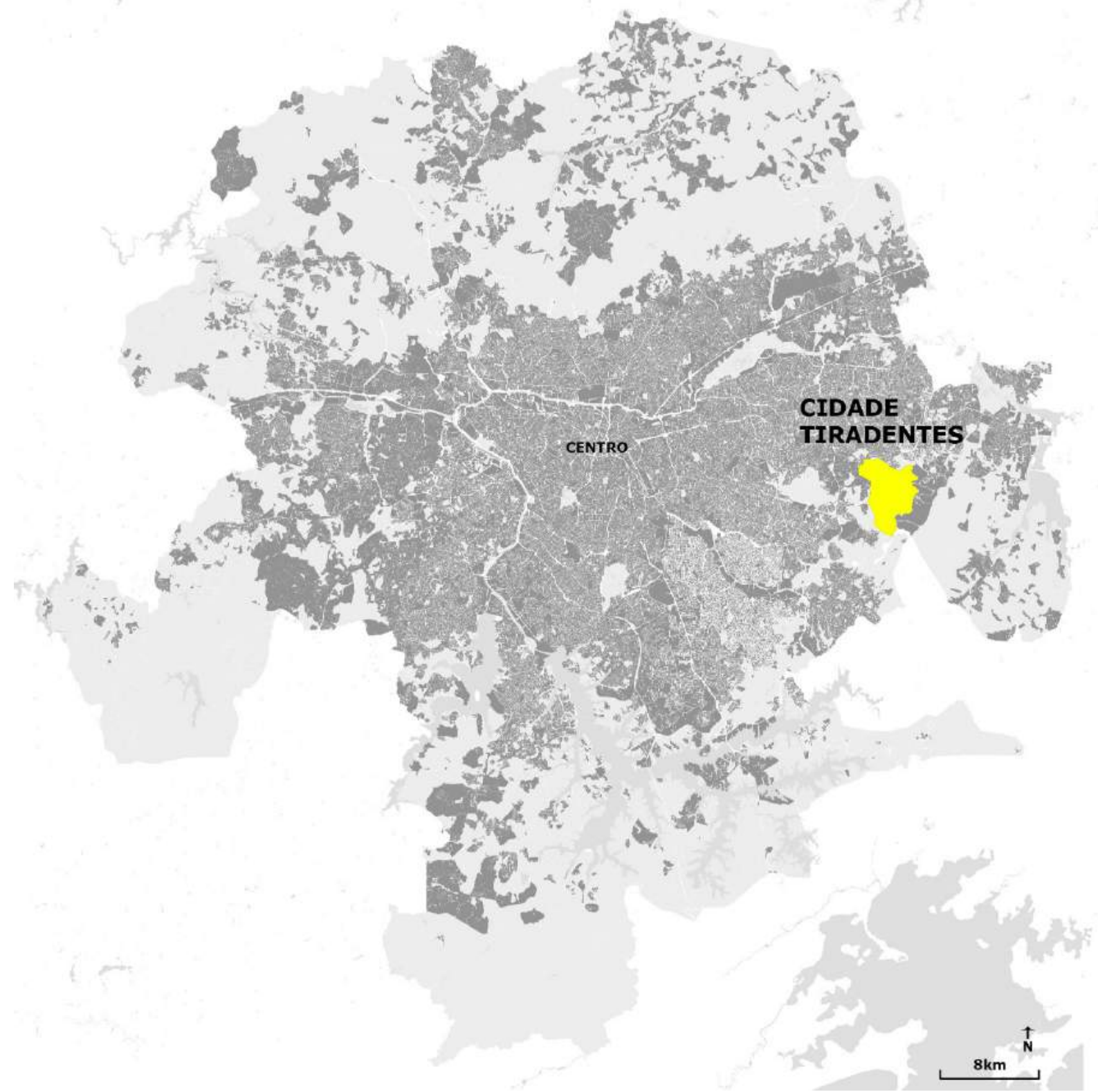

Figura 82: Localização de Cidade Tiradentes, no município de São Paulo-SP. Fonte: elaboração da autora, sob base QUAPÁ (2016). 
A COHAB-SP construiu na Cidade Tiradentes muitos edifícios habitacionais, já que, durante os anos 1970 e 1980, ofertou-se um grande estoque de terras para construção de conjuntos habitacionais, a maior parte na Zona Leste do município (LAVOS, 2009). Essas terras baratas eram antigas terras agrícolas e extrativistas, que começaram a ser adquiridas pelo poder público para a construção de moradias populares. Foi a partir da aquisição de uma gleba conhecida como Fazenda Santa Etelvina, no final da década de 1970, que começou o processo de construção na Cidade Tiradentes.

Essa construção de Cidade Tiradentes se relaciona com o bairro Itaquera, também em São Paulo, que precedeu o modelo de ocupação da zona leste do município, no final dos anos 1970. Itaquera se formou em áreas da antiga Fazenda Caaguaçu, no entorno da antiga Estrada de Ferro Central do Brasil, construída em 1875. No período anterior a 1900, tanto Itaquera quanto a futura Cidade Tiradentes abrigavam cotidiano ligado à agricultura de subsistência e vida rural de imigrantes, principalmente italianos, além de japoneses (SOUZA, 2014).

Foi a partir dos anos 1970 que a zona leste passou a ser conhecida pela construção de conjuntos habitacionais que representaram a produção de habitação social desde a ditadura militar, estimulada pelo incremento populacional e pela industrialização que atraía mais migrantes, alterando a paisagem física e social do lugar. Essa mudança exemplifica o período de emergência da periferia enquanto local de moradia de classes menos favorecidas, relação que se modificará a partir dos anos 1990, no processo que Caldeira (2000) identificou como o novo padrão de segregação urbana periférica, dos enclaves fortificados de moradia de alta renda.

O conjunto Prestes Maia, inaugurado em 1975 e o primeiro construído na zona leste, foi também o primeiro realizado pela COHAB-SP naquela região, em um cenário de paisagem rural e de povoado pacato, ligado à estação ferroviária (SOUZA, 2014). Ao lado desse conjunto, em área desocupada do loteamento, desenvolveu-se, nos anos 1980, o loteamento irregular Vila das Hortênsias, em um modelo morfológico que caracterizará Cidade Tiradentes: nas áreas livres que entremeiam os conjuntos habitacionais surgiram ocupações irregulares, favelas e comércio espontâneo.

Naquela época também surgiram movimentos de natureza reivindicativa, que foram representativos principalmente quando o poder municipal foi gestado por partidos de esquerda, como durante a gestão de Luiza Erundina (1988-1992).

Cidade Tiradentes se organizou por setores. Os conjuntos habitacionais se localizavam ao longo de ruas sem saída, ramificadas desde o sistema viário principal. As vias foram batizadas em homenagem a categorias profissionais, como metalúrgicos, marceneiros, ferroviários.

Embora tenha surgido no período de abertura democrática, sua arquitetura é representativa dos últimos grandes financiamentos do $\mathrm{BNH}$, com construções de inspiração quase fordista (figuras 83, 84, 85 e 86), recebendo populações de migrantes e ex-moradores de favelas, deslocados pelas diversas ações de remoção e obras viárias dos anos 1980 e 2000.

Muitas dessas ações foram transferências de interesse especulativo, as chamadas "limpezas urbanas", como as remoções de favelas de áreas de operação urbana, como a "nova" Faria Lima e a abertura da Avenida Águas Espraiadas, que deslocou diversas famílias para os conjuntos habitacionais Barro Branco e Santa Etelvina (SOUZA, 2014). 

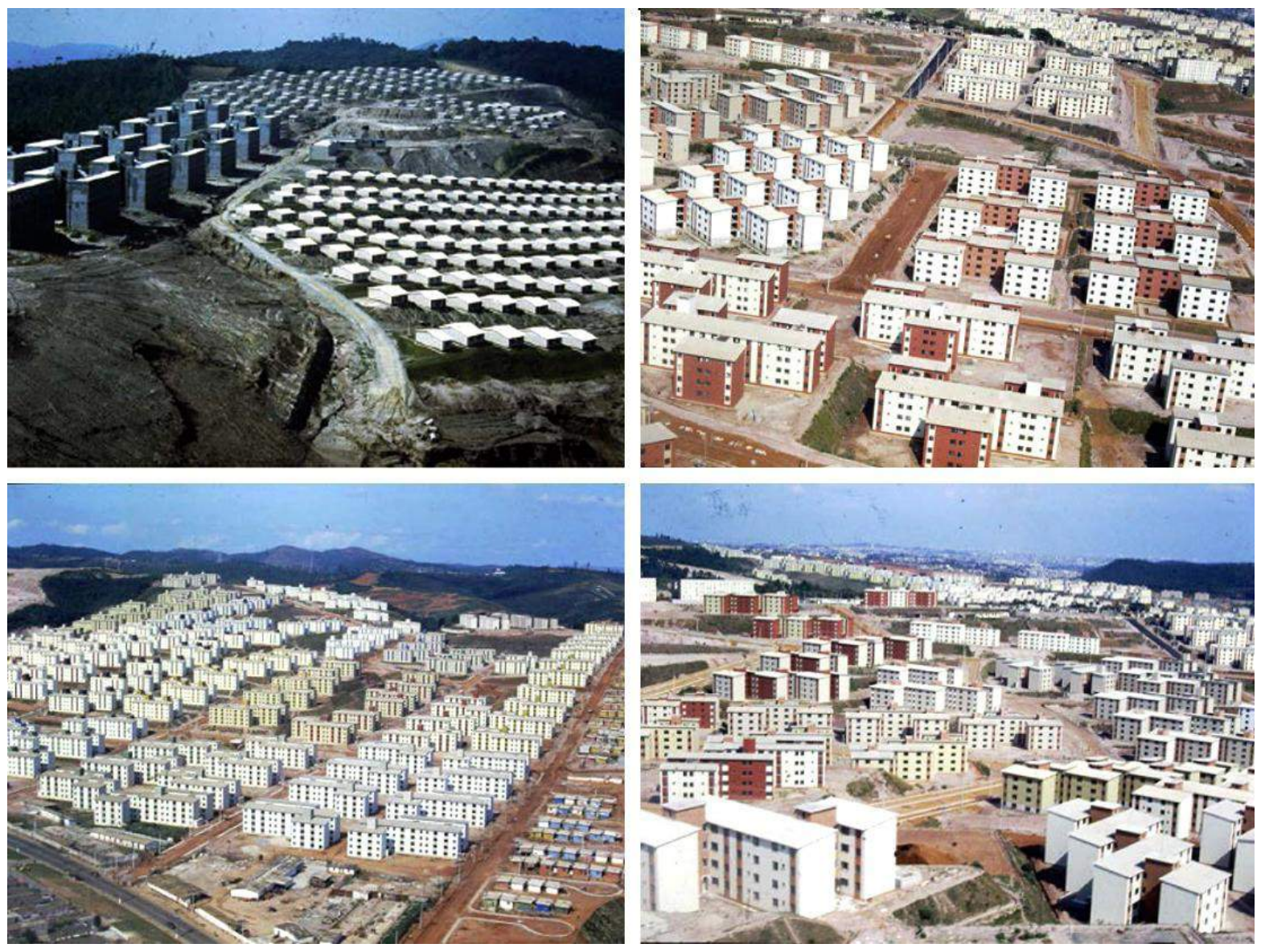

Figuras 83, 84, 85 e 86: Construção dos conjuntos habitacionais na Cidade Tiradentes. Fonte: CDTED COHAB-SP, apud SOUZA, 2014.

O modelo de construção típico da COHAB é o de bloco de apartamentos, administrado como condomínio, com planta construída em forma de "H". São, geralmente, compostos por 4 a 5 pavimentos, para evitar a necessidade de utilizar elevadores, com apartamentos em todos os andares, inclusive no térreo. As áreas comuns abrigam pequenas construções, como abrigos de gás, centrais de medição, caixas d'água e lixeiras, e áreas livres que foram, aos poucos, sendo ocupadas pelos moradores como estacionamento de veículos.

A concentração de habitação social na Cidade Tiradentes tomou conta dos jornais locais nos anos 1980 e 1990, com críticas à ausência de transporte e segurança, além da baixa qualidade da habitação. Em reportagem de Paulo Ferraz de $1994^{68}$, destaca-se a operação policial para tentar desmontar o primeiro QG do Comando Vermelho em São Paulo, identificando o início da formação de "olheiros" em prédios nos pontos topográficos mais altos da Cidade Tiradentes. Segundo o coronel do Comando de Policiamento Metropolitano, citado na repor-

68 FERRAZ, Paulo. CV monta rede de informações na zona leste. Folha de São Paulo, 15 de março de 1994, p. 3-4. Disponível em: < http://acervo.folha.uol.com.br/fsp/1994/03/15/264/>. Visualizado em 6 dez. 2016. 
tagem, o distrito foi escolhido pelo Comando Vermelho por ser similar à Baixada Fluminense, pois concentrava população de baixa renda, era distante do centro da cidade, tinha vários locais propícios para esconderijo e apenas uma via principal de acesso, o que facilitava o controle do tráfico.

Durante os anos 1990 e 2000, foram diversos os conjuntos habitacionais construídos no Distrito, que passou de 95.926 habitantes, em 1991 (HIRAO, 2008) para 211.501 em 2010, com uma densidade demográfica de $14.100 \mathrm{hab} / \mathrm{km}^{2(69)}$. Atualmente, abriga um grande complexo de conjuntos habitacionais, com um total de 60.710 domicílios, dentre os quais 28.910 são residências, 224 são casas de vila ou condomínio, 31.366 são apartamentos e 210 são cortiços, casas de cômodos ou "cabeça de porco"70 (IBGE, 2010).

Em sua tese, Slomiansky (2002) analisa os 55 conjuntos habitacionais construídos pela COHAB-SP entre 1965 e início do ano 2000 na RMSP. Desses 55 conjuntos, 67,9\% foram construídos na Região Leste, com 28 conjuntos habitacionais, dentre os quais onze ocupam glebas de superfície superior a $500 \mathrm{mil} \mathrm{m}^{2}$. A autora critica os critérios arquitetônicos e urbanísticos na definição dos projetos e observa como essas soluções afetam os conjuntos, estimulando o desenvolvimento de padrões de ocupação indesejados. Tal fato a leva a questionar as práticas projetuais e os mecanismos de controle urbano.

Slomiansky tem em sua escrita marcas da vivência como estudante militante na Argentina durante a ditadura militar, o que a aproxima ainda mais deste trabalho. A autora também partilha da mesma crítica sobre o padrão construtivo dos empreendimentos habitacionais e a perversidade que a inclusão periférica ocasiona visível e invisivelmente, apostando também nos programas de requalificação das periferias a partir da participação comunitária. $\mathrm{E}$ afirma, na mesma linha de raciocínio desenvolvido nesta tese, que "para compreender, é preciso chegar perto" (SLOMIANSKY, 2002, p. 197).

Os empreendimentos da COHAB em Cidade Tiradentes têm bastante variação de porte, com o conjunto loteado com distribuição de áreas verdes, áreas institucionais, áreas de habitação "formal" - que concentram os edifícios $\mathrm{H}$, ou residências projetadas - e áreas remanescentes, estas em alta proporção em muitos dos conjuntos, e que foram ocupadas por habitações irregulares, ou "informais", a partir dos anos 1990. Atualmente, essas áreas remanescentes vêm sendo utilizadas para a construção de empreendimentos do Programa Minha Casa Minha Vida (figura 87).

69 Dados disponíveis no site da Secretaria Municipal de Coordenação das Subprefeituras da cidade de São Paulo (Dados demográficos dos distritos pertencentes às Subprefeituras): <http:// www.prefeitura.sp.gov.br/cidade/secretarias/subprefeituras/subprefeituras/dados_demograficos/ index.php?p=12758>. Acessado em 25 set. 2016.

70 Os cortiços, "cabeças de porco" ou casas de cômodos são habitações que o IBGE considera em uma mesma categoria, sendo a unidade de moradia multifamiliar, ou seja, com várias famílias diferentes, tendo como característica o uso comum de um mesmo ambiente para diversas funções, como dormir e cozinhar, o uso comum de instalações hidráulica e sanitária e vários domicílios dividindo um mesmo lote urbano ou edificação. 
Os primeiros anos dos moradores na Cidade Tiradentes foram destinados à adaptação a uma realidade completamente diferente da que estavam acostumados. A distância entre o local de trabalho e a antiga moradia, o comércio insuficiente e precário, a infraestrutura urbana ausente ou insuficiente, o excesso de espaço livre em contradição com a falta de espaços livres para as práticas cotidianas, as enchentes e deslizamentos de terra periódicos ${ }^{71}$, a crise econômica do país e, finalmente, o isolamento urbano e social fizeram de Cidade Tiradentes a face da outra cidade, a cidade dos outros.

A Cidade Tiradentes dos anos 1980 gerou um olhar preconceituoso até mesmo por parte dos próprios moradores, talvez por não acreditarem num lugar que não oferecia grandes possibilidades de superação do dia a dia. No entanto, essa realidade foi se alterando, com a chegada, finalmente, da cidade na Cidade: asfalto, iluminação, equipamentos urbanos, transporte, comércio. Essa mudança, lenta, é fruto da discrepância do tempo da construção civil empresarial com o tempo da construção pública, o que continua ocorrendo até o período atual, com a entrega de habitações muito antes da chegada do urbano.

As melhorias tardias, hoje, fazem parte do cotidiano, mas a imagem e representação da Cidade Tiradentes fria dos anos 1980 é parte do imaginário coletivo, assim como o talvez estigma de ser e viver a periferia leste paulistana.

Atualmente, Itaquera já é um setor estruturante da Zona Leste, abrigando diversos equipamentos urbanos importantes, como Escolas Técnicas e Faculdades de Tecnologia construídas pelo Governo do Estado, além do estádio de um importante time de futebol, o Sport Club Corinthians Paulista, construído em um terreno que já pertenceu à COHAB (SOUZA, 2014) e que tem abrigado diversos eventos nacionais e internacionais.

A relação das periferias brasileiras com o futebol é intensa (figura 88). Os primeiros clubes de futebol nascem em espaços livres e organizam a rede de sociabilidade, bem como as relações de poder entre os grupos sociais, que disputam não só o campo de futebol, mas o campo simbólico da posição de controle e pertencimento a um grupo social.

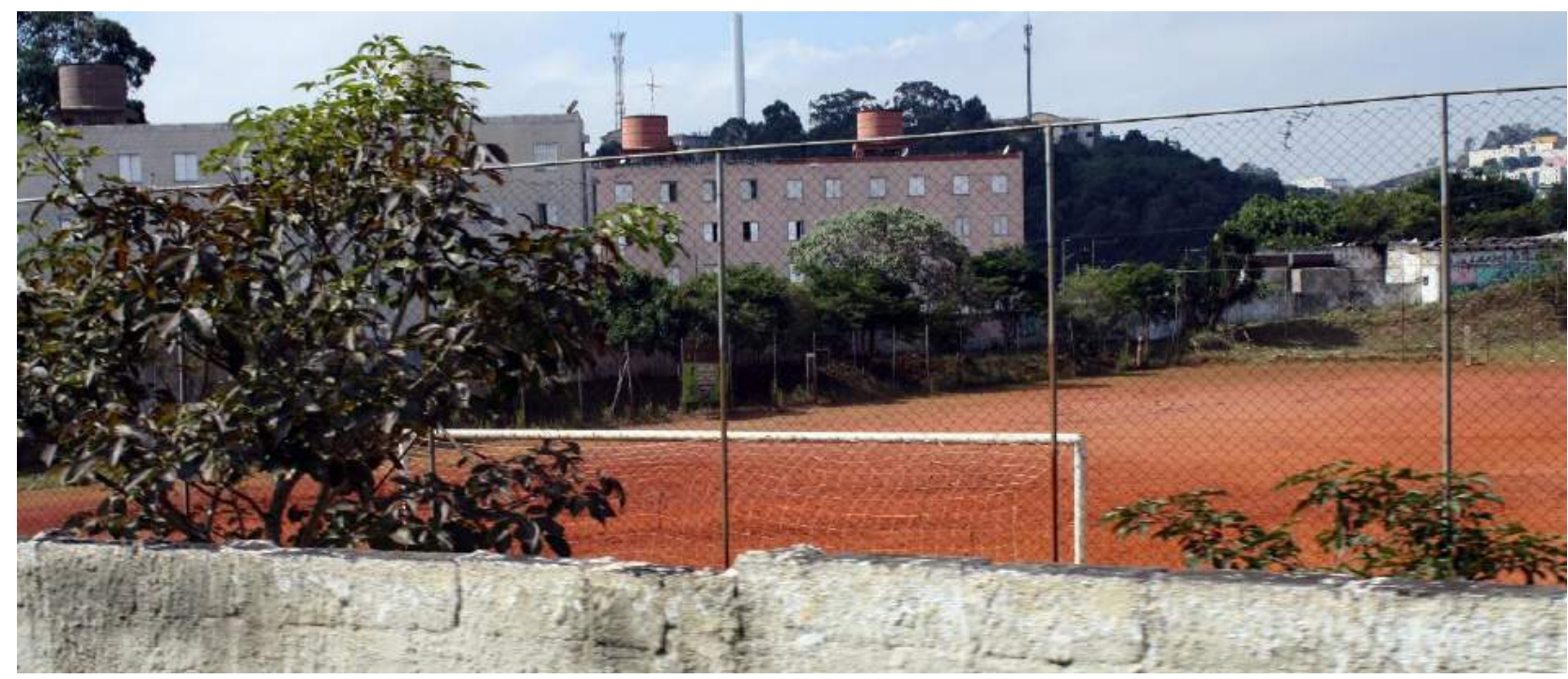

Figura 88: Espaço livre usado como campo de futebol em Cidade Tiradentes. Fotografia da autora, maio 2016.

71 Sobre as enchentes periódicas, M. R. Silva (2008) destaca o interessante apelido de um dos principais cruzamentos de vias na Cidade Tiradentes: "Tobogã", como é chamada a convergência da Estrada do Iguatemi com o vale do Rio Aricanduva, em direta relação com as inundações constantes no local em períodos de chuva. 
Demolições de habitações também ocorreram em São Paulo. Durante os anos 1980-1990, algumas casas e apartamentos foram condenados e demolidos, por terem sido construídos com técnicas da construção civil que geraram risco à segurança dos moradores. Foi o caso das construções experimentais feitas pela Construtora Coan, que utilizou uma técnica mista com $40 \%$ de cimento e $60 \%$ de gesso, o concreto plástico-químico, cujas paredes se desfaziam com a ação da água das chuvas (figuras 89, 90, 91 e 92). ${ }^{72}$
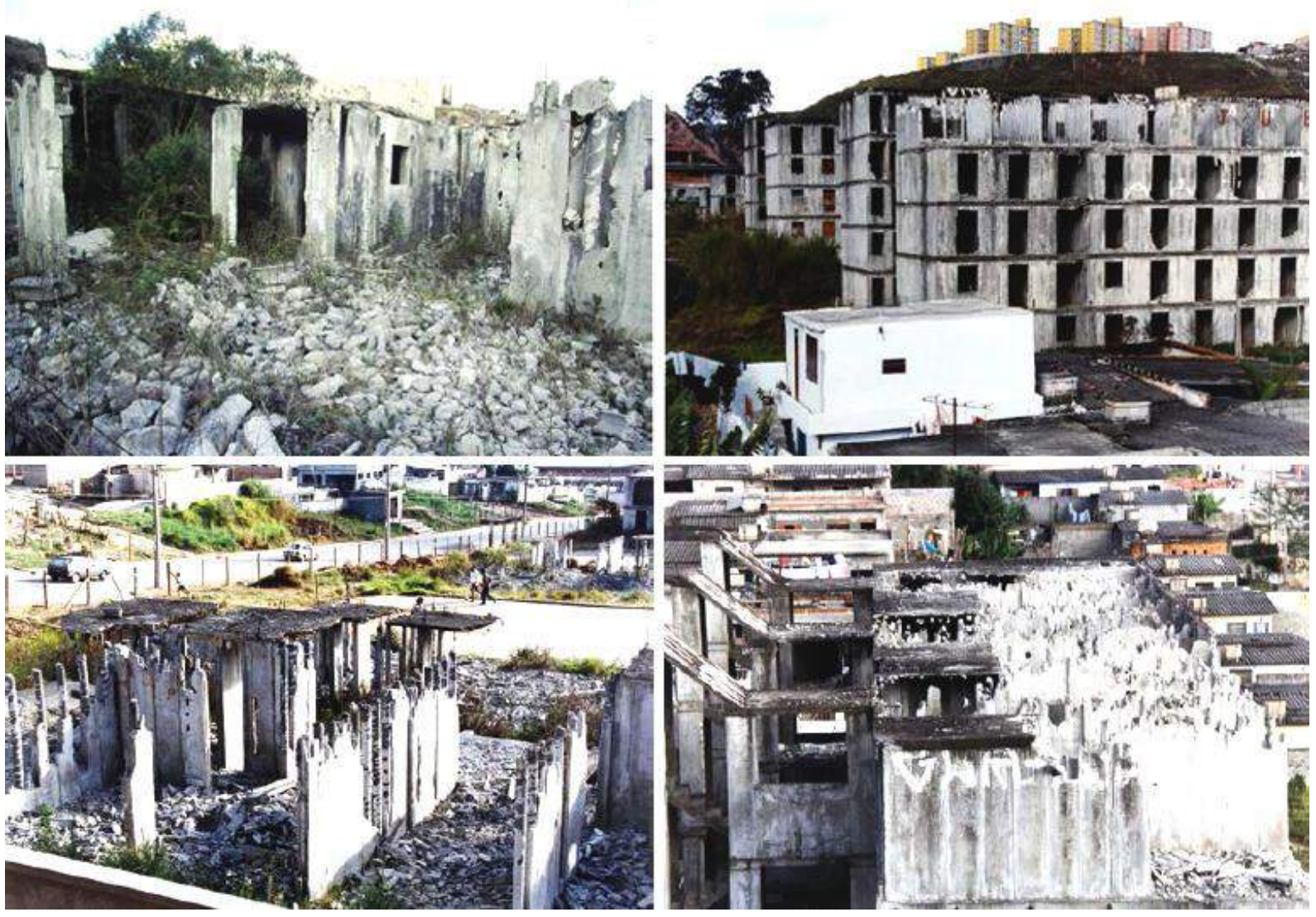

Figuras 89, 90, 91 e 92: Construção deteriorada da Construtora Coan em Cidade Tiradentes. A utilização de uma nova técnica, com incorporação do gesso com o cimento, fez com que a estrutura entrasse em decomposição pela ação das chuvas. Fonte: CDTED COHAB-SP, apud SOUZA, 2014).

Similar aos processos de demolição de Santiago, o caso Coan teve a desocupação das moradias em risco e posterior ocupação irregular, o que acentuou a dificuldade de demolição e os problemas de segurança pública, já que muitas habitações condenadas eram utilizadas para atividades ilícitas (SOUZA, 2014).

No total, foram demolidas 900 casas da Construtora Coan no município de Itapevi, 360 apartamentos no município de Carapicuíba, 240 apartamentos no Conjunto Habitacional Castro Alves e 300 apartamentos no Conjunto Habitacional Santa Etelvina, ambos em Cidade Tira-

72 Segundo matéria publicada no jornal Folha de São Paulo de 30 abr. 1991, caderno Cotidiano p.5. Disponível em: <http://acervo.folha.uol.com.br/fsp/1991/04/30/15>. Visualizado em 2 dez. 2016. 
dentes (SOUZA, 2014).

No caso de Carapicuíba, em 1991, foram dez edifícios implodidos do Conjunto Habitacional Castelo Branco, um deles implodido anteriormente como teste preliminar e os nove restantes demolidos com implosão simultânea. O conjunto havia sido construído apenas nove anos antes da implosão, a um custo de US\$25 milhões. Os moradores, que deixaram os apartamentos em 1987, receberam novos apartamentos somente anos depois ${ }^{73}$.

O fiasco da construção desses edifícios se somou ao insucesso da própria demolição em Carapicuíba: após o acionamento dos explosivos, a estrutura foi apenas parcialmente demolida, pois houve resistência da estrutura, deixando em pé sete dos nove edifícios implodidos ${ }^{74}$. 0 fracasso iniciou o questionamento sobre a real necessidade do arrasamento do conjunto, e acarretou uma chacota midiática, de cunho amplamente político, em relação ao processo: "implode mais não cai", estampavam os noticiários. O processo, carregado da simbologia de eliminar modelos COHAB, não se repetiu nessas proporções até o período atual.

A participação popular na construção de habitações sociais na Cidade Tiradentes ocorreu em alguns momentos. Como comentado, durante o governo da prefeita Luiza Erundina (19891992), grupos associados lutavam por melhores propostas para os seus locais de moradia, e foram muitos os mutirões de construção de habitação no Distrito, com participação social e organização pelos movimentos de luta e resistência.

As propostas do governo Erundina para Cidade Tiradentes foram criadas com participação dos movimentos autogestionários e das práticas de construção com mutirão. Também houve propostas para Praças de Equipamentos Sociais - PES, sob o comando de Marilena Chauí e Paulo Freire (SOUZA, 2014), propostas pelo Departamento de Edificações (EDIF) juntamente com as Secretarias de Cultura e de Educação. Essa proposta, de 1989, consistiu em reunir vários equipamentos educacionais, culturais, de saúde e de lazer, adicionados à participação da comunidade na transformação do espaço, mas o projeto não foi concretizado, sendo retomado parcialmente e como outra proposta apenas em 2001, na gestão de Marta Suplicy, com a criação dos Centros de Educação Unificado - CEUs.

Dentre os exemplos de construção por mutirão, estão o Conjunto Habitacional Paulo Freire (figura 93) e o conjunto vizinho Unidos Venceremos.

No caso do Paulo Freire, feito com a assessoria técnica do USINA CTAH e de um grupo de moradia do Movimento dos Trabalhadores Sem Terra Leste 1 (MST Leste 1), vinculados à União dos Movimentos de Moradia (UMM), as primeiras conversas e negociações com a prefeitura ocorreram nos anos 1990, e o projeto foi construído entre os anos 2003 e 2010.

O Conjunto Paulo Freire foi uma exceção à regra no quesito tecnologia construtiva - com emprego de estrutura metálica - maior dimensão dos apartamentos e participação popular na construção e decisões de escolha de materiais, mas só difere visualmente dos outros conjuntos habitacionais da Cidade Tiradentes pela tecnologia construtiva. Ainda se insere como um condomínio fechado em um bairro com grandes problemas sociais, contribuindo para o

73 Idem, ibidem.

74 Segundo matéria publicada na Folha de São Paulo (10 maio 1999). Disponível em: <http:// acervo.folha.uol.com.br/fsp/1991/05/01/15/>. Visualizado em 6 dez. 2016. 
emaranhado de contradições sociais e da (des)prática presente nas práticas sociais cotidianas. Sobre o Conjunto Paulo Freire, Souza (2014) comenta:

Do ponto de vista da construção, há uma apropriação metafórica da tecnologia, ligada à tentativa de libertar as técnicas e materiais do domínio econômicos inerentes à lógica do mercado e com isso alcançar outro tipo de expressão arquitetônica e espacial. A opção pela estrutura metálica responderia à urgência no atendimento das necessidades habitacionais dos participantes, numa perspectiva que revelou-se por demais otimista, mas também a um 'sentido simbólico' (...) Procurava-se com isso tomar posse das tecnologias desenvolvidas pelo capital em benefício dos trabalhadores. (p. 361)

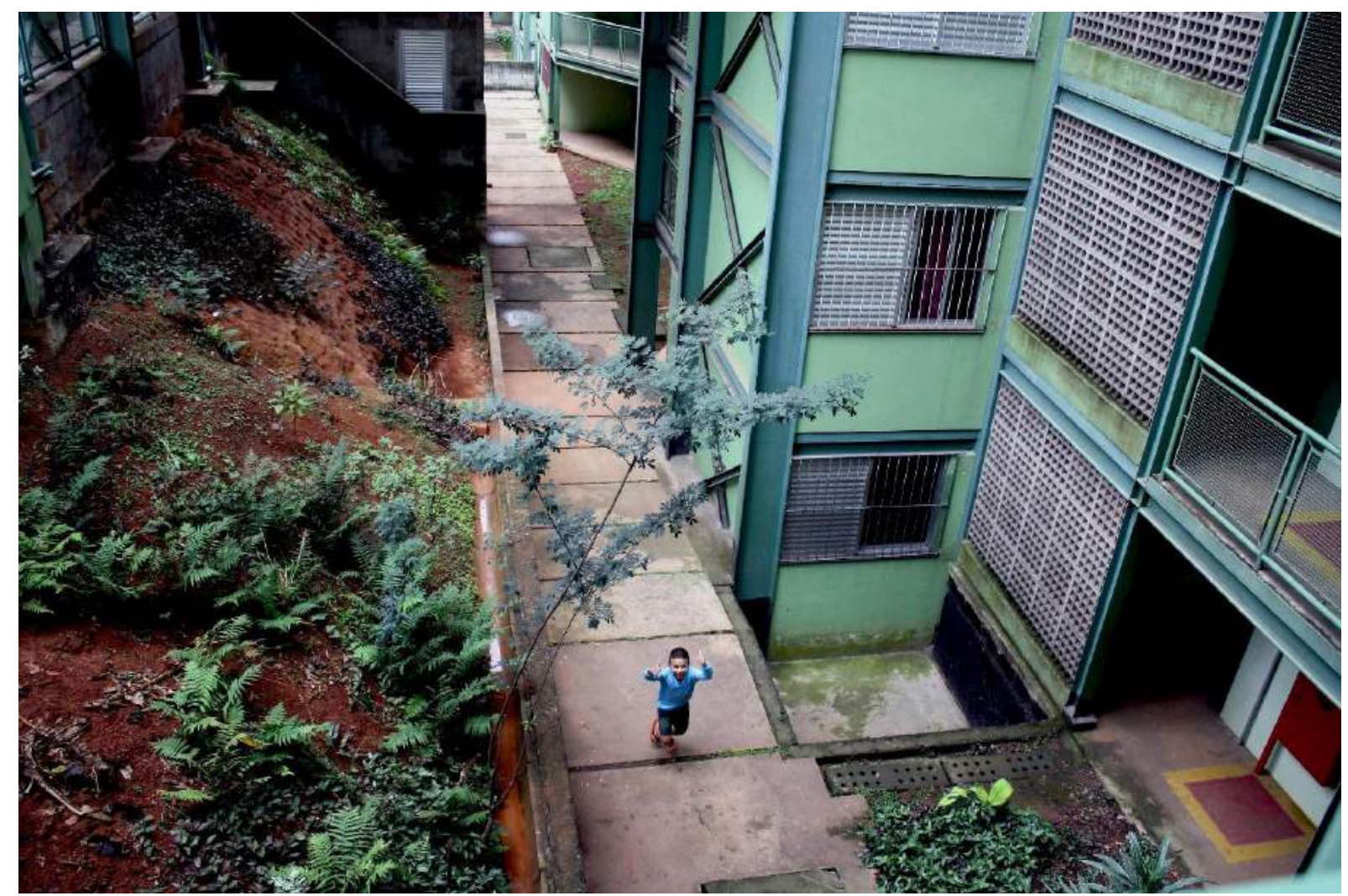

Figura 93: Conjunto Habitacional Paulo Freire. Fotografia da autora, maio 2016.

Nos governos de Paulo Maluf (1993-1996) e Celso Pitta (1997-2000), houve resistência à continuidade das ações de Erundina, redirecionando os projetos de habitação social à construção de pequenos conjuntos habitacionais em áreas de favela, denominados Cingapura, os quais viraram estampa e logomarca das gestões desses prefeitos. Segundo Lavos (2009) e Ferraz (1994), foi também nesse período que o tráfico se organizou e ordenou as práticas sociais no distrito de Cidade Tiradentes.

Aos poucos foram sendo construídas escolas e postos de saúde, e foi aumentando o acesso por meio de novas linhas de ônibus. Durante as gestões de Marta Suplicy (2001-2005) e Serra-Kassab (2005-2008), foram construídos e inaugurados um Hospital Municipal, uma Escola Técnica e dois Centros de Ensino Unificados. 
Nos primeiros anos, Cidade Tiradentes poderia ser considerada como uma cidade dormitório: o bairro todo era um amontoado de embriões e edifícios de apartamentos pequenos. Os moradores chegavam de todas as partes da cidade, vindos de condições de habitação ou situações familiares mais precárias, e entravam nos apartamentos e nos embriões em busca, invariavelmente, do sonho da casa própria. O sonho confrontava-se com a dura realidade dos ônibus e trens lotados nas duas únicas linhas de ônibus existentes (...). Considerada área rural pela administração municipal, comércio inexistente, serviços públicos de educação e saúde insuficientes, a escolha pela Cidade Tiradentes revelava a falta mesmo de alternativas destas famílias (...) (LAVOS, 2009, p. 67)

Os CEUs foram responsáveis por alterar física e socialmente diversos bairros com carências sociais e culturais de São Paulo. Concentrando diversas atividades culturais e educativas, os CEUs inseriram novas possibilidades para a convivência comunitária, desenvolvimento da cidadania e crescimento profissional em muitos bairros de urbanização precária. Contêm bibliotecas, salas de aula, escolas técnicas, teatros, equipamentos esportivos e de saúde, entre outros equipamentos particularizados para cada situação em que se encontram, mas com uma arquitetura sempre similar, que estampa o modelo CEU com uso do concreto e ocupação de grandes glebas, em um regime de administração que, novamente, remete ao condomínio.

Sem desmerecer a grande importância dos CEUs para as comunidades, o seu modelo arquitetônico é de um equipamento fechado para o seu entorno com muros, o que chama o usuário para o seu espaço interno, sob um regimento de comportamento e aprendizado normatizado. Assemelha-se a entrar em um ambiente totalmente distinto do dia a dia comum, em uma possibilidade cotidiana que mais se parece com um universo paralelo fictício do que com a realidade concreta.

Da origem ao período atual foram muitas mudanças: de alguns de edifícios habitacionais em meio a plantações de eucaliptos, sem infraestrutura, para uma concentração de edifícios habitacionais já em um trecho de cidade, com infraestrutura, comércio e serviços, embora ainda com bastante necessidade de melhoria nessas áreas. As mudanças ocorreram devido a reivindicações dos movimentos e associações de moradores, cujos líderes dos movimentos, muitos ligados a partidos políticos de esquerda, cresciam nas regiões periféricas. Também foram influentes os líderes de grupos religiosos, pressionando para melhores condições na Cidade Tiradentes.

O fechamento por muros, seja o dos condomínios habitacionais, seja pelos equipamentos, é também uma forma de segregação, que segrega alterando o cotidiano dos grupos sociais e (des)praticando o espaço, pela limitação que as práticas sociais acabam tendo em um espaço socialmente conduzido e com apropriações reduzidas a determinados usuários.

Os edifícios construídos pela COHAB-SP, de orientação modernista ou, como coloca Lavos (2009), de rebaixamento da estética modernista, foram construídos por empresas de construção civil nos terrenos adquiridos pela Companhia. O projeto, bem como o planejamento urbano, foi de responsabilidade da COHAB-SP, sem participação dos moradores, que recebiam uma unidade após sorteio.

Sem possibilidade de adquirir unidades comerciais nos condomínios da COHAB, definidos como estritamente residenciais, aos poucos os moradores foram implementando pequenos anexos aos edifícios para o desenvolvimento de atividades de comércio e também para uso como garagens (figuras 94 e 95). 

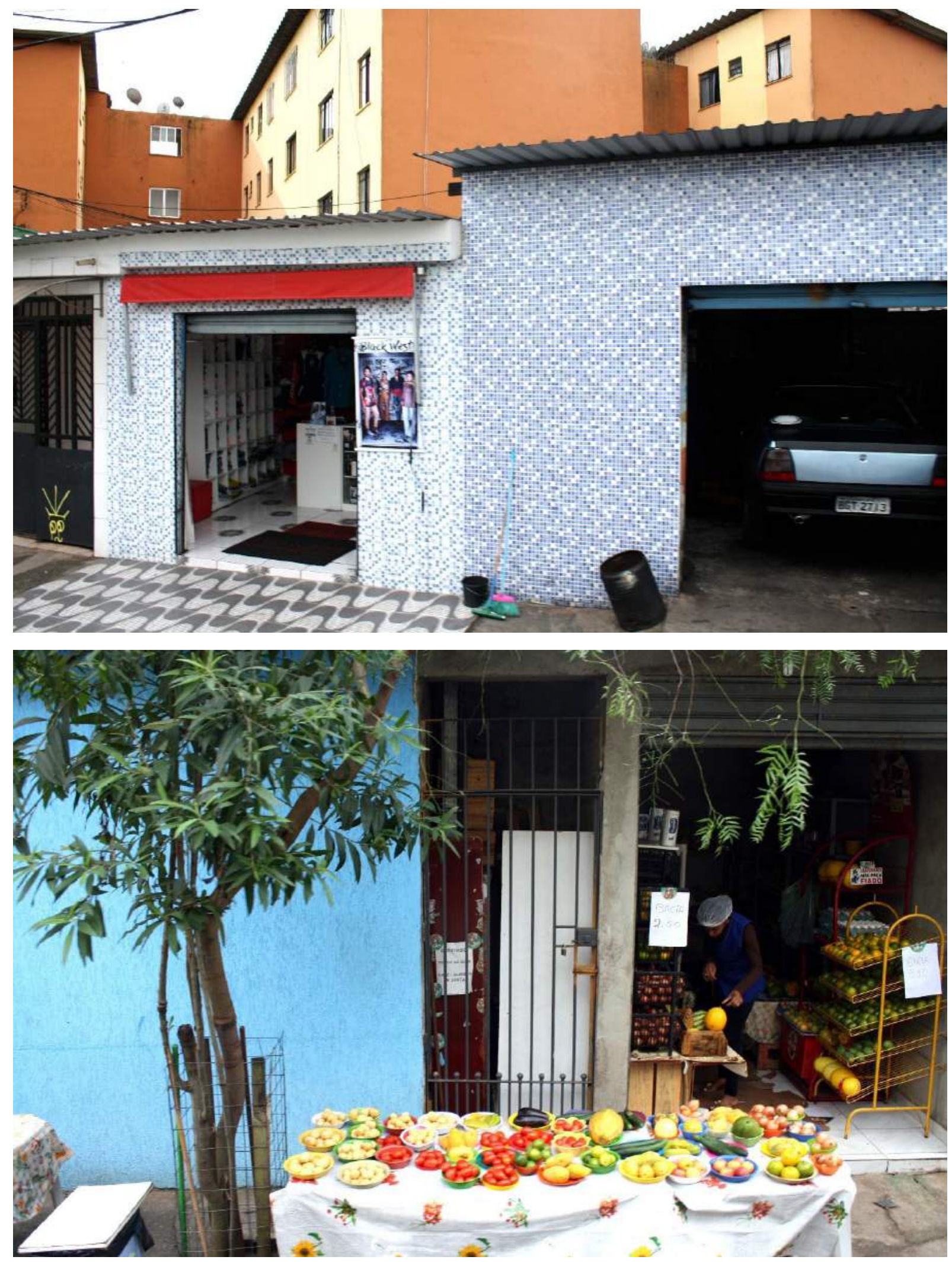

Figuras 94 e 95: Garagens e comércio em Conjuntos Habitacionais de Cidade Tiradentes. Fotografias da autora, maio 2016. 
Para a COHAB-SP, as garagens inexistem. Não há plantas, não há registros de propriedade. Mas elas são amplamente construídas, utilizadas e comercializadas. Nelas são realizadas atividades comerciais, que tampouco poderiam acontecer no espaço da COHAB-SP. A despeito de não existirem no papel, elas são usadas para guardar os carros, ou para atividades comerciais, e negociadas pelos moradores coo imóveis. São feitos contratos de compra e venda sem nenhum documento ou planta. A regulação destes espaços é inteiramente realizada dentro do espaço coletivo como extensão do espaço privado, mas fora da legislação pertinente. É uma apropriação dos moradores, que se auto-organizam em torno de algo que passa a ter valor para eles (...) (LAVOS, 2009, p. 150)

Além dos diversos conjuntos habitacionais, há também loteamentos habitacionais irregulares e algumas favelas (em 2015, a SEHAB/HABISP ${ }^{75}$ contabilizou 14 favelas em Cidade Tiradentes), que foram sendo construídas em áreas privadas, como em áreas residuais entre alguns condomínios habitacionais.

As entradas e acessos aos edifícios, e mesmo alguns conjuntos, foram muradas pelos moradores para controlar as áreas condominiais da cidade formal, dividindo ainda mais as "duas Cidades Tiradentes": a produzida pelo poder público e a produzida pela própria população (figura 96 e 97).

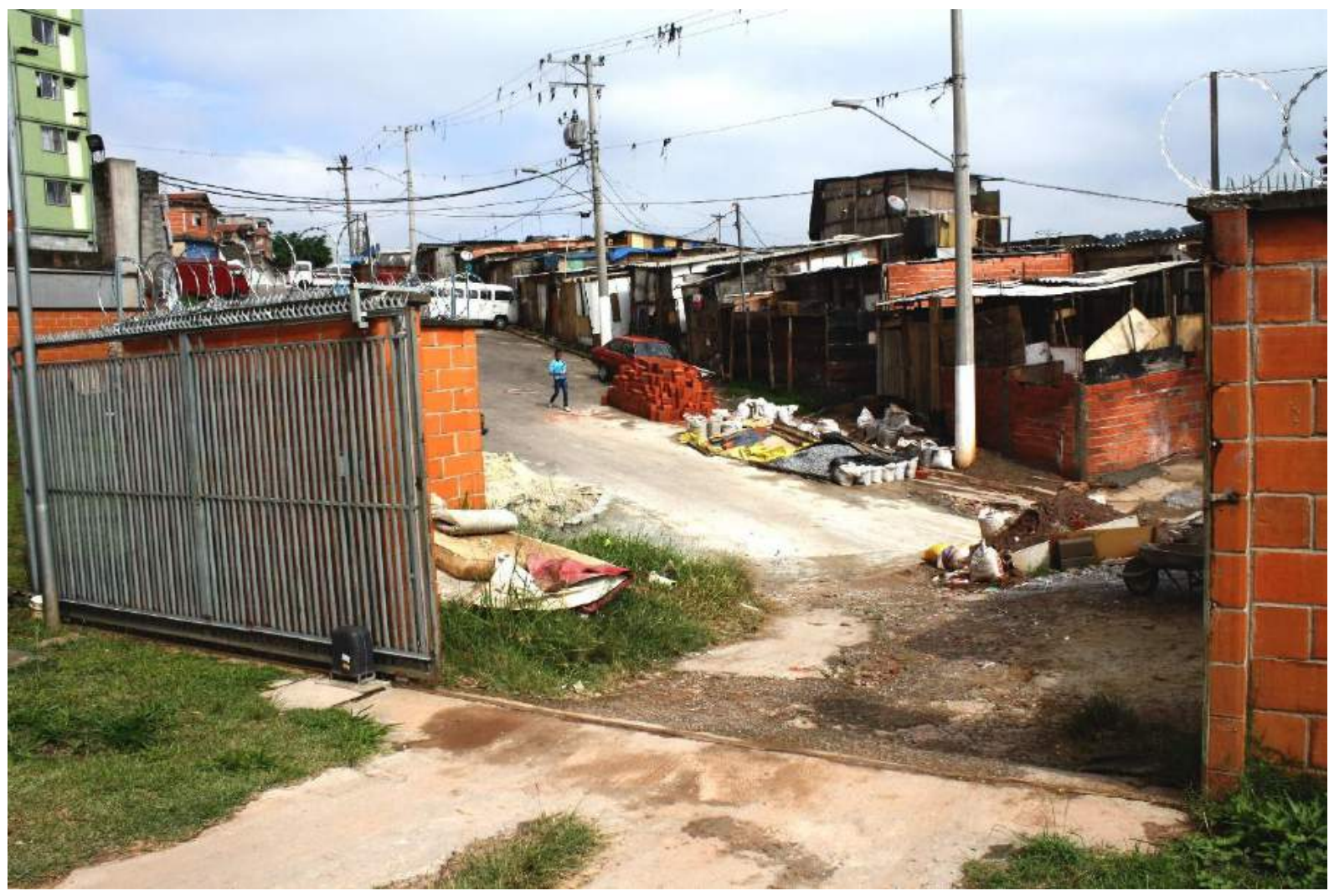

Figura 96: O Conjunto Habitacional Unidos Venceremos e seu entorno. O fora e o dentro do Condomínio Habitacional. Diferenciação em relação ao outro e alteridade no cotidiano. Fotografia da autora, maio 2016.

75 SEHAB/HABISP. Listagem de Favelas do Município de São Paulo. 2015. Disponível em: <http:// infocidade.prefeitura.sp.gov.br/htmls/9_distribuicao_das_favelas_2015_516.html>. Acessado em 25 set. 2016. 


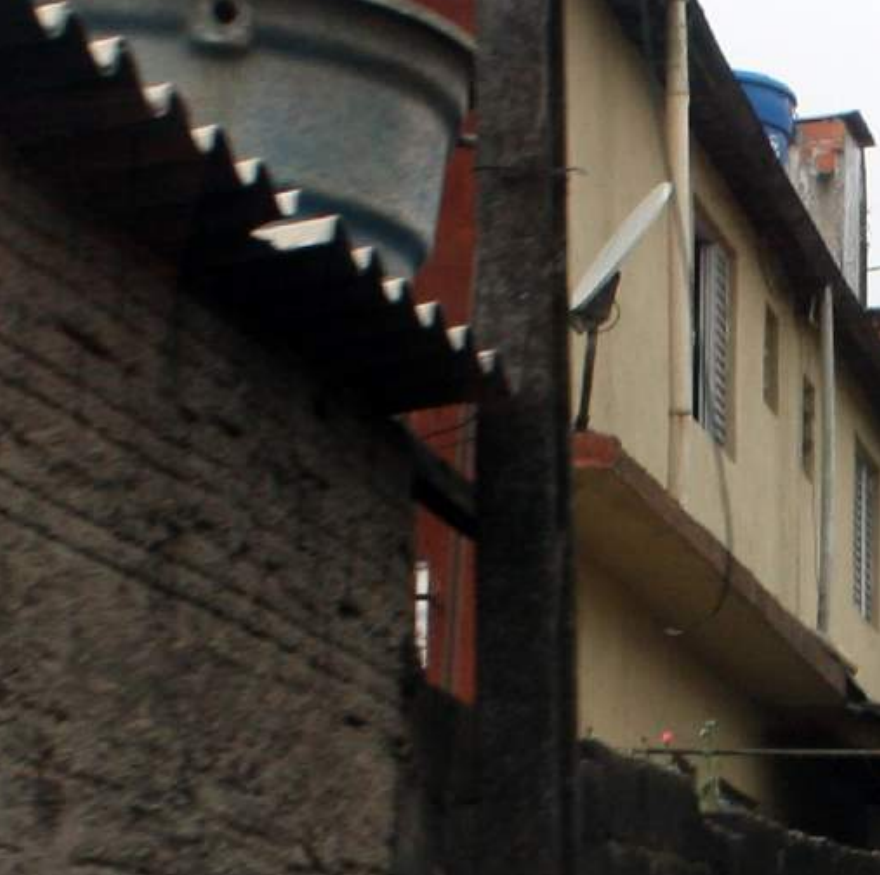




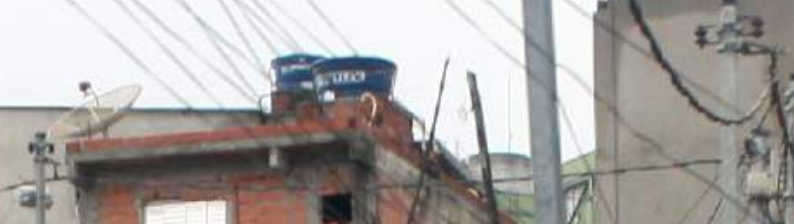

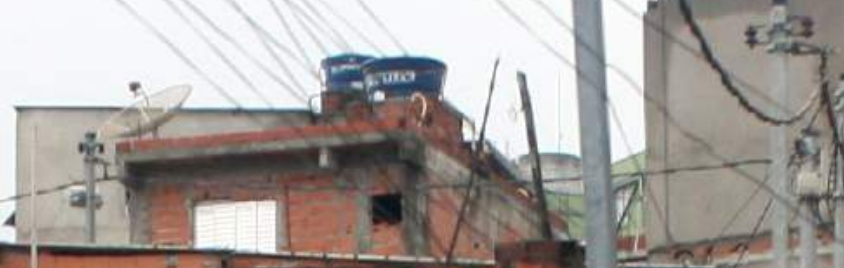

2

t)

$1=$

$\frac{7}{4}$

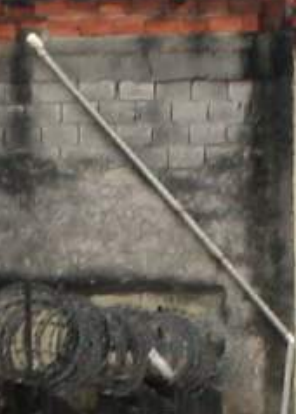

set?

9

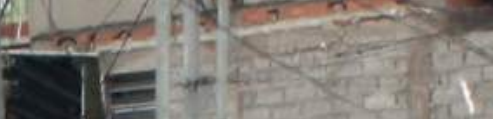

- $\sqrt{\text {. }}$
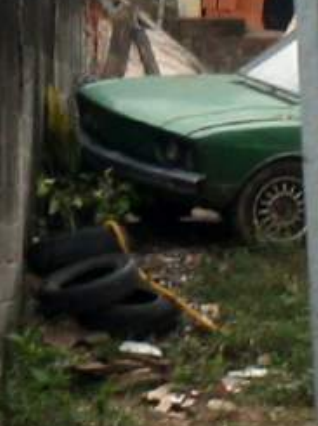

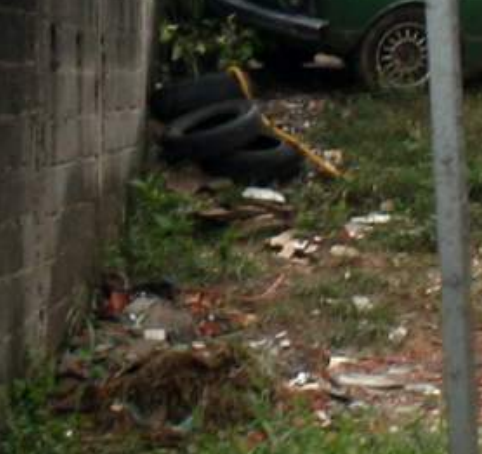

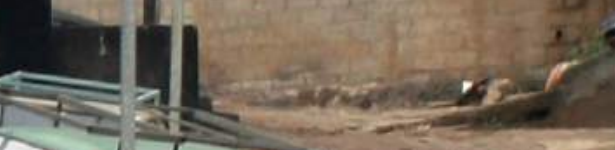
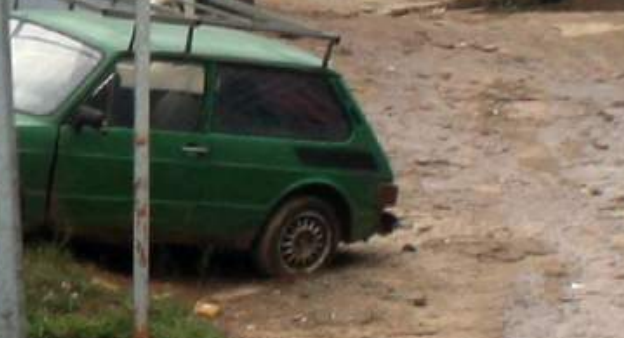

$\frac{1}{1+1}+\frac{1}{4}$

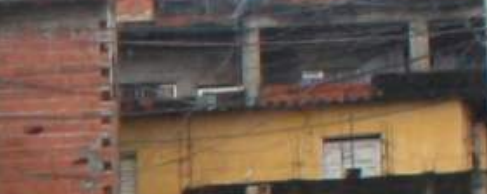

17.

1

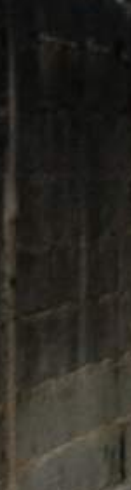
$=\infty$

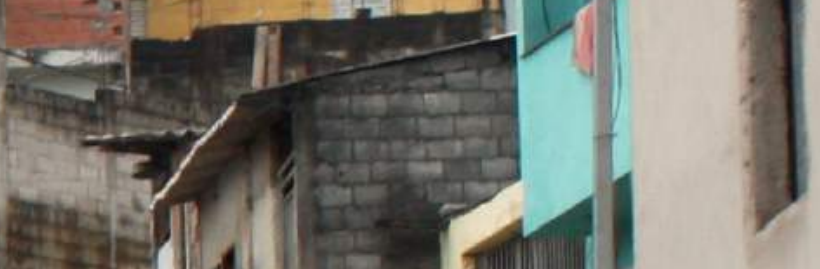

Q6.

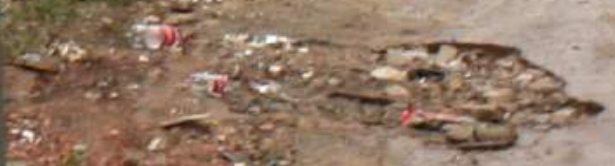

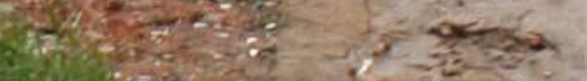

$$
\begin{aligned}
& 3=\operatorname{lig}^{2}-3
\end{aligned}
$$

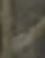

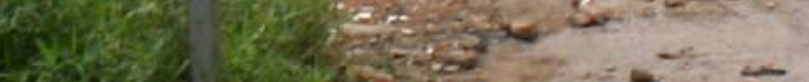
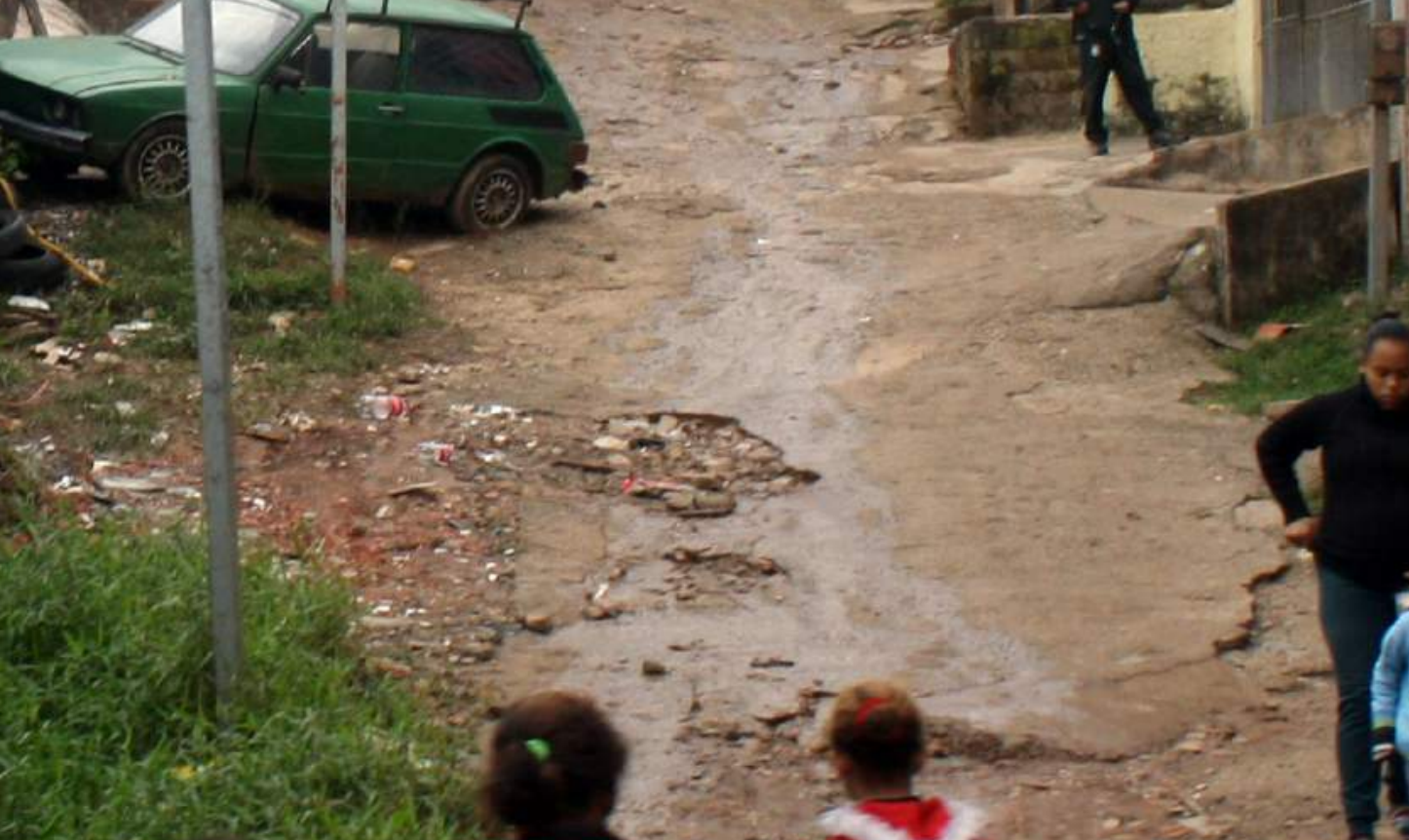

3
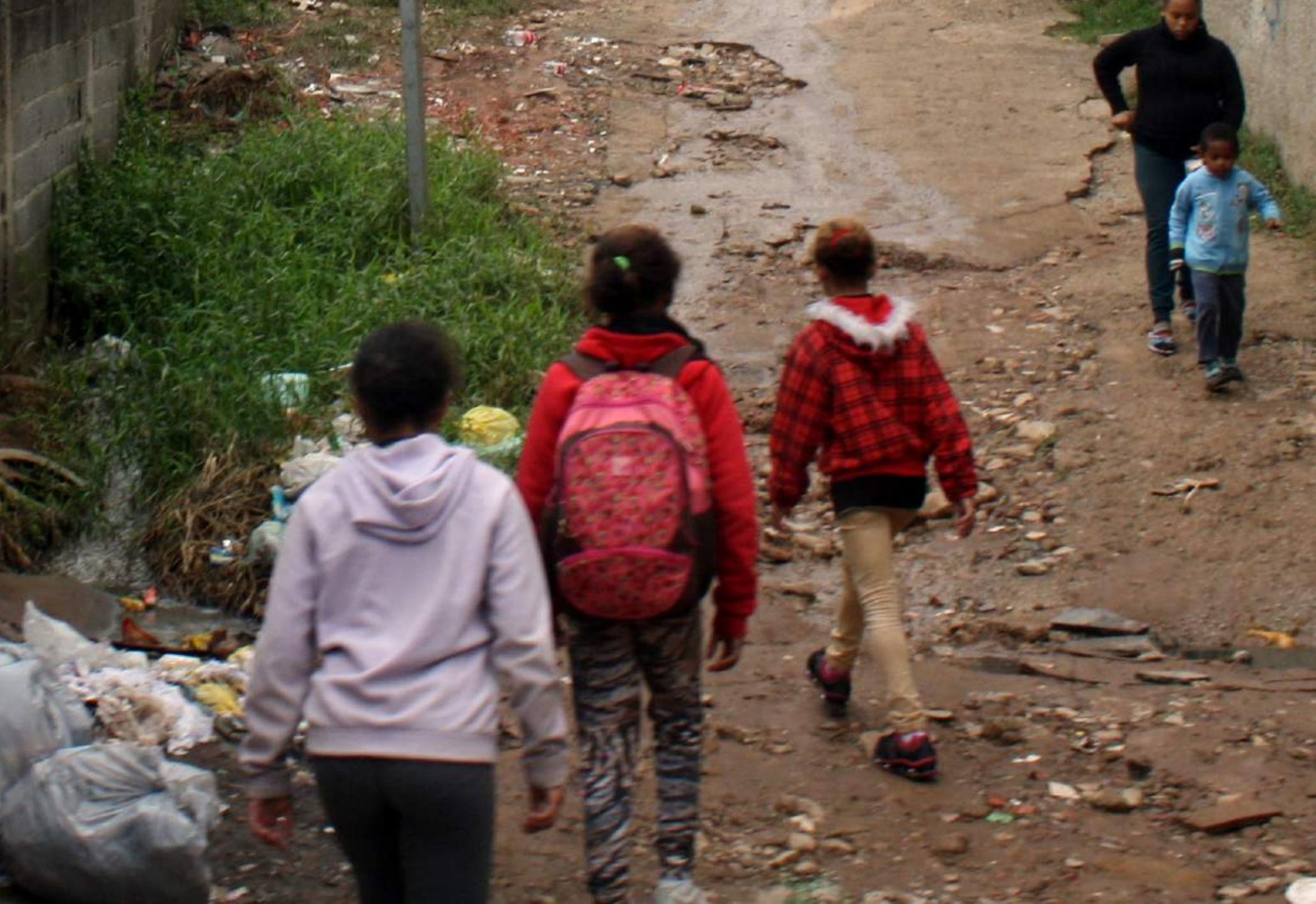
Materializado na concepção de condomínio, os edifícios habitacionais construídos em Cidade Tiradentes têm no cotidiano a gestão dos espaços coletivos. Essa gestão pressupõe providências administrativas, com a eleição de um síndico, elaboração de regras em um estatuto, organização para rateio dos custos de manutenção das áreas comuns, bem como consumo de água e luz, entre outras eventualidades. Essa solução condominial orienta ações que reduzem a espontaneidade da prática social.

M. R. Silva (2008) coletou depoimentos de diversos frequentadores de Cidade Tiradentes, como o de Zilda Borges, coordenadora pedagógica de uma escola local, a EMEF Olinda Menezes Serra Vidal. A entrevistada demonstra dificuldade de lidar com regras do prédio impostas pelo síndico para as crianças brincarem nas áreas condominiais, que se transforma de espaço de brincar para espaço de estacionar veículos particulares.

Essa imposição de regras dificulta a espontaneidade do cotidiano juvenil, de uso do espaço externo à moradia para encontro e brincadeiras. Essa dificuldade, uma quase ausência de possibilidade, leva as atividades infantis para o interior de equipamentos públicos, como o pátio de escolas, os espaços dos CEUs e mesmo igrejas, que têm construído áreas esportivas para atrair jovens e possibilitar o encontro de similares, novamente orientado com regras e normativas, desta vez com o objetivo de ampliar o número de fiéis.

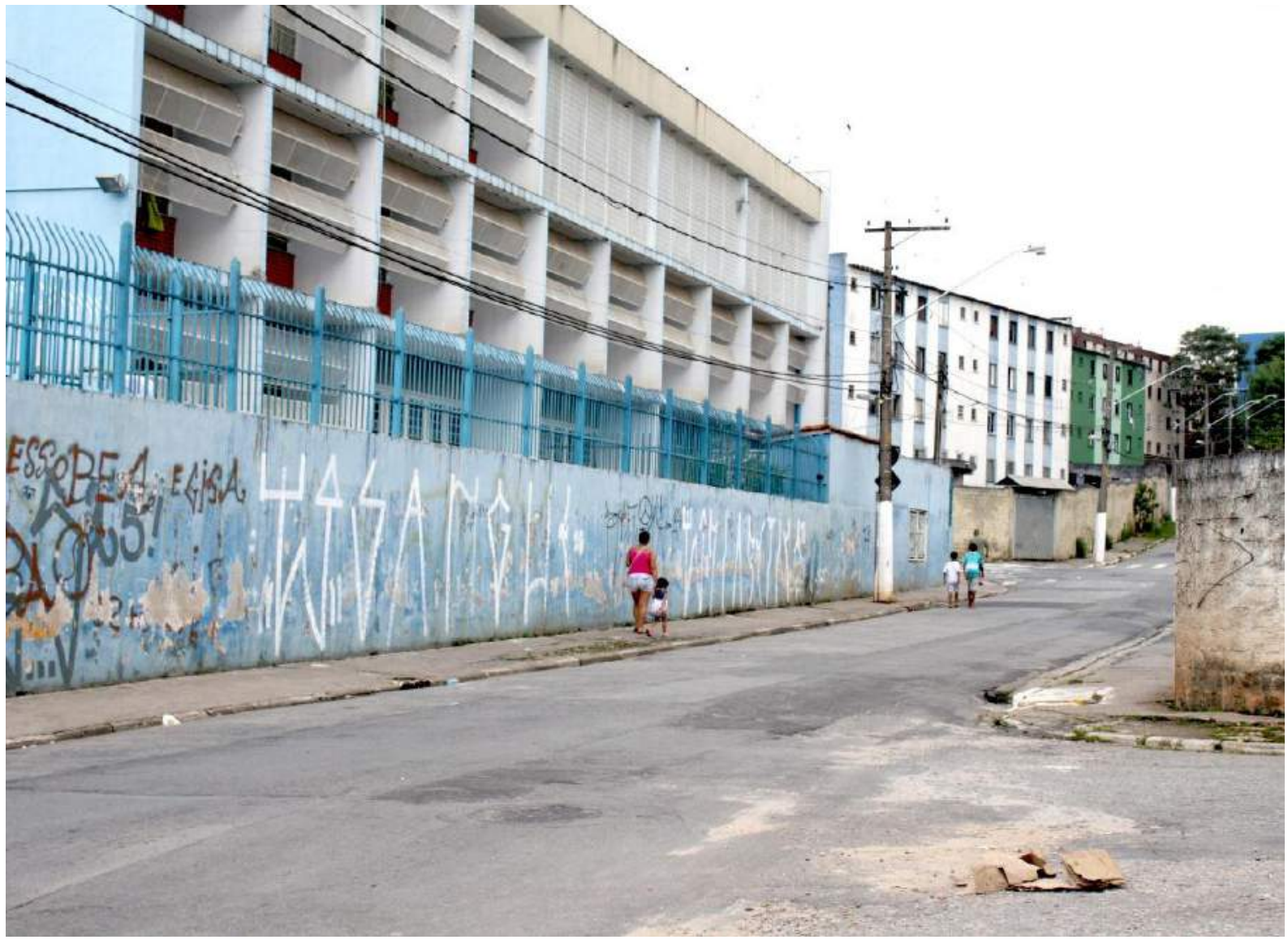

Figura 98: Rua da Escola Municipal de Ensino Fundamental - EMEF Elias Shammass, no Conjunto Sítio Conceição, Cidade Tiradentes. Fotografia da autora, out. 2016. 
Cidade Tiradentes não difere de outras áreas de São Paulo em relação aos espaços livres e a forma urbana: as calçadas são estreitas, há ausência de praças e parques, os lotes têm tamanhos que induzem sua quase total ocupação, os edifícios habitacionais negam o seu entorno com fechamentos rígidos e são entremeados por ocupações irregulares, em geral construídas em terrenos pouco adequados para urbanização e/ou áreas de preservação ambiental (figura 99). Por outro lado, a maior qualificação do espaço ao longo de décadas trouxe maior heterogeneidade, maiores investimentos, inclusive maior mescla social e econômica, com mais classe média habitando o distrito e maiores investimentos imobiliários.

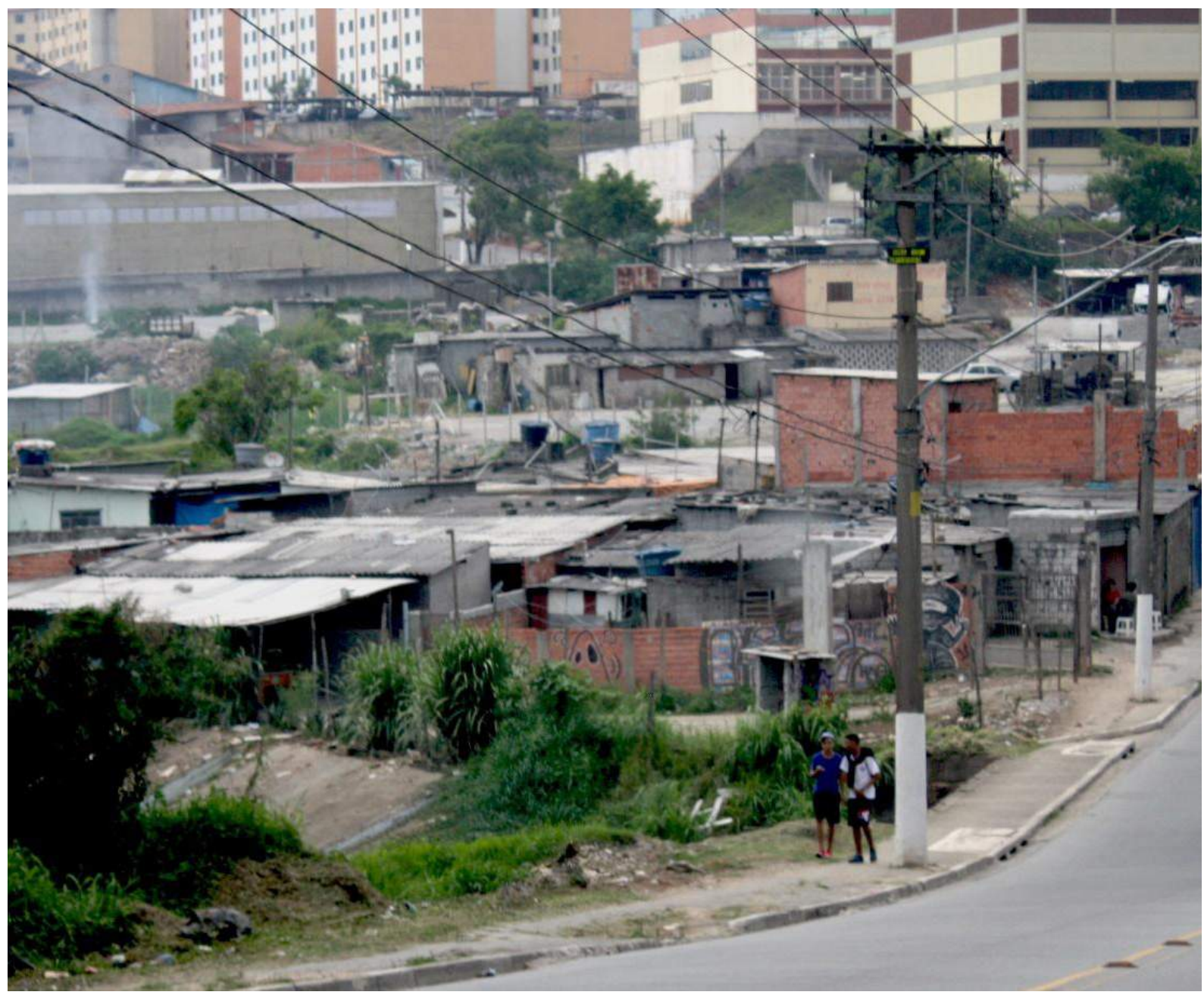

Figura 99: Cenário típico de Cidade Tiradentes. Fotografia da autora, out. 2016.

Para os 211.501 habitantes, havia 4.540 empregos formais, exclusive Administração Pública, em 2010. Desses empregos, 2.369 exigiam Ensino Médio completo, e 1.386 ofereciam faixa de rendimento de 1,51 a 2 Salários Mínimos ${ }^{76}$.

76 Segundo a Relação Anual de Informações Sociais, do Ministério do Trabalho e Emprego. Disponível em: <http://infocidade.prefeitura.sp.gov.br/index.php?cat=18\&titulo=Trabalho>. Acessado em 25 set. 2016. 
Cidade Tiradentes não aparenta ser um distrito violento quando se observam informações censitárias. Dados da Secretaria de Estado da Segurança Pública de São Paulo, organizados pelo jornal Estadão77, mostram que, no ano de 2015, foram registrados 86 furtos, 1 homicídio, 29 lesões corporais, 4 estupros e 1 latrocínio. Em relação ao tráfico de drogas, somente 5 casos foram registrados pelo Distrito Policial. Porém, dados do Mapa de Garantia dos Direitos Humanos de 2004, organizados por Hirao (2008), mostram vulnerabilidade de jovens do sexo masculino, de 15 a 29 anos, para homicídios, e vulnerabilidade de mulheres para gravidez, com uma alta taxa de gestações de jovens menores de 17 anos.

Os poucos registros de dados criminais são também justificados porque há uma hegemonia do Comando Vermelho na organização criminosa na Cidade Tiradentes. Até a conquista do território pelo grupo, ocorreram diversos embates entre traficantes, que diminuíram atualmente. Essa diminuição do confronto trouxe maior sensação de segurança para os moradores, ao mesmo tempo em que se instaurou um código de conduta invisível, também legitimado por acordos entre os traficantes, moradores e policiais.

Segundo Hirao (2008), o jovem é o grande protagonista na Cidade Tiradentes. A maioria cresceu no distrito e passa grande parte do seu cotidiano no local. A autora diferenciou, dentro do grupo dos jovens da região, aqueles que desejam se mudar do local e aqueles que desejam mudar o local. Para a mudança, os jovens se apoiam em redes de sociabilidade e têm expectativas de melhorar os espaços cotidianos das práticas sociais, com incremento dos equipamentos de lazer. A autora também identificou a estrutura familiar centrada na figura da mulher, responsável pelo serviço doméstico, e o cotidiano organizado no espaço privado e institucionalizado.

Enquanto os jovens vivenciam o cotidiano do distrito, os pais estabelecem movimentos pendulares em função de trabalho e acesso a serviços. Há, então, uma dualidade deslocamento X permanência:

(...) Temos, de um lado, um extenso grupo de adultos cujo deslocamento pendular lhes garante trabalho, renda, suficiência financeira; de outro, um extenso grupo de jovens cujo tempo disponível não é suficientemente conhecido nem socialmente legitimado, porém que vive e permanece na Cidade Tiradentes (HIRAO, 2008, p. 65).

A identificação de grupos de jovens com o distrito é imbuída de significado da luta de um grupo social para enfrentar adversidades, noções essas que aparecem nas manifestações culturais, como música e arte urbana. Os movimentos do hip hop e do rap têm grande importância para os jovens da Cidade Tiradentes, revelando os traços específicos das reivindicações através de rimas de tom crítico e político que denunciam a intolerância racial, afirmando a identidade negra e os direitos das minorias. Também se somaram aos movimentos musicais outros tipos de produções culturais que articulam cidadania e protestos, como os grafites (figura 100), resultando em uma produção de arte urbana que ocupa os espaços públicos e os transforma (CALDEIRA, apud ABARCA, 2016). Esses movimentos culturais são identificados por jovens de diversas regiões da metrópole.

77 Segundo infográfico Criminalidade bairro a bairro. 2014. Disponível em: <http://infograficos. estadao.com.br/cidades/criminalidade-bairro-a-bairro/>. Acessado em 7 maio 2015. 


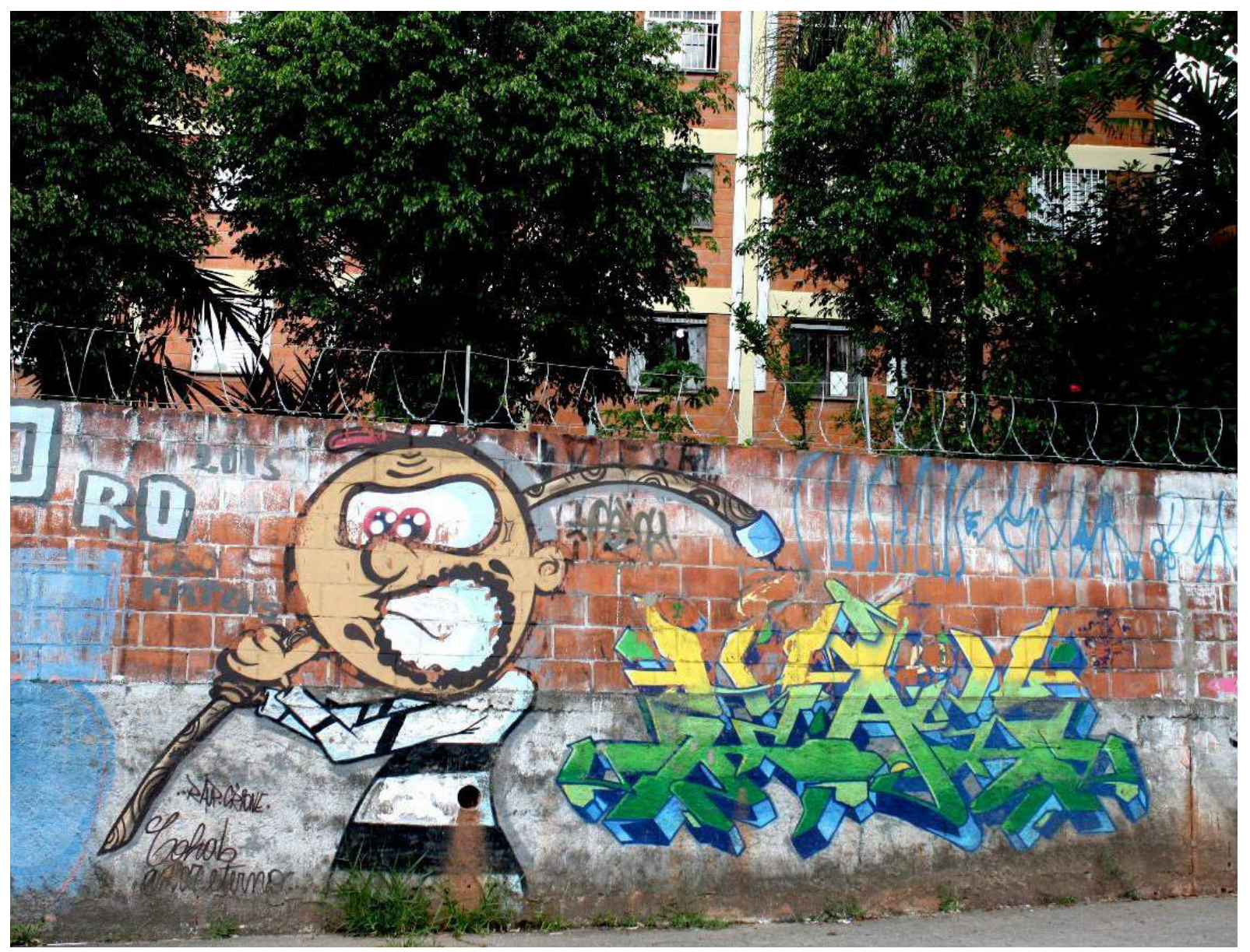

Figura 100: Grafite em Cidade Tiradentes. Fotografia da autora, out. 2016.

A circulação urbana dos jovens em busca de lazer para além do distrito foi identificada por Hirao (2008) como uma busca por equipamentos que eles não encontram na Cidade Tiradentes, o que os leva a deslocarem-se para shopping centers (como o Aricanduva), parques (como o Parque do Carmo) e equipamentos urbanos, como as unidades do Serviço Social do Comércio (como o SESC Itaquera).

No entanto, de modo geral, a circulação dos jovens ocorre dentro do distrito, por receio em relação ao uso do espaço da rua: “(...) o discurso aponta para uma rua marginalizadora, onde estão as más companhias, onde surge o convite ao crime, onde as cabeças estão vazias. A cabeça vazia, ou o ócio, dá lugar a pensamentos ruins e a atividades ilícitas" (HIRAO, 2008, p. 75).

Por outro lado, no discurso dos jovens, Hirao (2008) identificou a vontade de utilizar o espaço das ruas para as práticas sociais, contraposto ao receio dos pais e sua imposição para que o uso não seja frequente. As práticas cotidianas ocorrem principalmente em espaços internos (residenciais, religiosos, institucionais, condominiais); em alguns casos são mais tensas e conturbadas, com conflitos decorrentes de formas de apropriação do espaço e das normativas impostas. 
Também sobre o uso dos espaços públicos para lazer, Hirao (2008) identificou distinções de gênero: predominam nas ruas jovens do sexo masculino, enquanto que jovens do sexo feminino permanecem mais no espaço doméstico ou em outros locais fechados. Como motivo pela falta de uso dos espaços públicos por meninas e moças, está o medo de serem vítimas de violência sexual e a sujeição a processos de controle social, como o cumprimento de ordens dos pais, de membros da igreja ou do próprio tráfico de drogas. O cotidiano da rua, então, passa a ser associado a atividades de caráter transgressor.

Existe uma identidade entre os moradores da Tiradentes com o distrito que revela duas situações distintas: a que congrega e a que discrimina. A primeira é aquela construída ao longo de 24 anos, que compartilha a esperança, os projetos, as descobertas, as dificuldades, as conquistas e a discriminação. Ela é a responsável pelo sentimento de segurança e de comunidade. A outra é aquela de quem vê de fora. Há um olhar homogeneizante e estigmatizador resultante das informações que são difundidas pela grande mídia, a maioria delas verdadeiras, porém rechaçadas com uma dose de sensacionalismo que ignora a vida comunitária, a produção cultural e a organização social, por exemplo. O estigma criado, se por um lado é duramente combatido pelos moradores, por outro penetra discretamente nos discursos dos mesmos. (HIRAO, 2008, p. 105).

Muito já se tem documentado sobre o processo de construção na Cidade Tiradentes e a grande produção da COHAB-SP até os anos 2000. Mas qual o impacto do Programa Minha Casa Minha Vida no território? Há uma continuidade de produção nesse setor? Há uma manutenção do modelo de produção condominial para habitação social?

No mapeamento dos empreendimentos do PMCMV contratados até abril de 2014 para a RMSP, foram encontrados 11 empreendimentos em Cidade Tiradentes. Do total, 5 são da construtora Simétrica, do Engenheiro Sérgio Tiaki Watanabe, que já foi presidente do Sindicato da Indústria da Construção Civil do Estado de São Paulo durante alguns mandatos.

Dos empreendimentos da construtora Simétrica, todos estão em terrenos que eram da COHAB: O Condomínio Residencial Mirassol encontra-se em terreno do Conjunto Habitacional Castro Alves; o Condomínio Residencial Pirassununga, no Conjunto Habitacional Sítio Conceição; o Condomínio Residencial Leme, no Conjunto Habitacional Barro Branco; os Conjuntos Habitacionais Mongaguá e Guarujá, no Conjunto Habitacional Santa Etelvina II-B.

Dos empreendimentos, o Mirassol tem 260 unidades contratadas; o Pirassununga, 200; o Leme, 60; o Mongaguá, 40 e o Guarujá, 32.

Alguns desses empreendimentos passaram por diferentes etapas até chegar ao Programa Minha Casa Minha Vida. O Condomínio Residencial Pirassununga, por exemplo, começou como processo de mutirão, mas, por dificuldades em finalizar o empreendimento, foi passado para a Caixa Econômica Federal, que por sua vez fez a licitação para a sua finalização pela modalidade empresarial do PMCMV. Enquanto os procedimentos burocráticos eram realizados, o empreendimento foi invadido duas vezes, sendo saqueado e depredado (figuras 101 e 102), o que exigiu da Caixa a instalação de segurança 24h até que a documentação fosse finalizada para a obra ser retomada. 

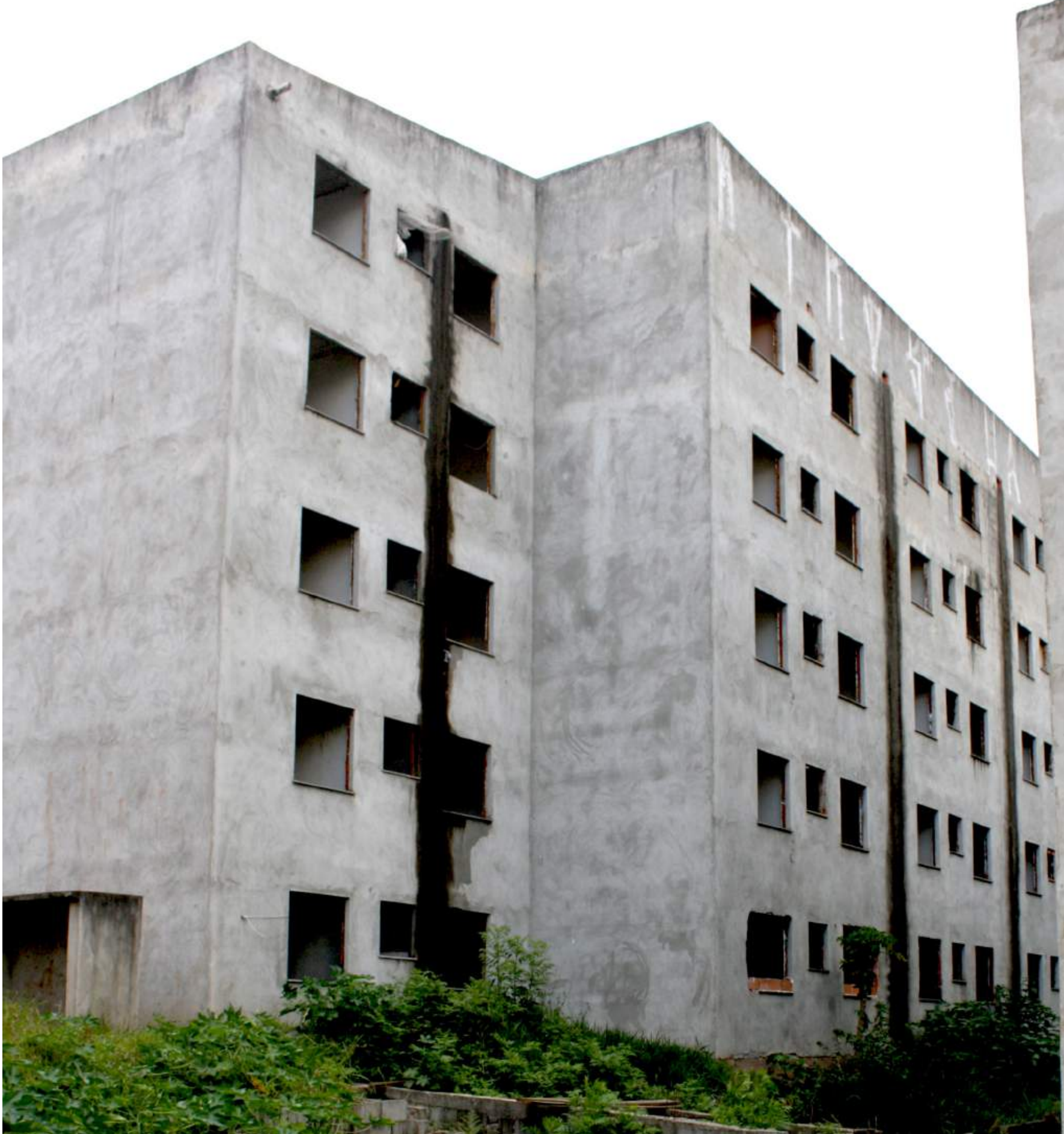

(1)

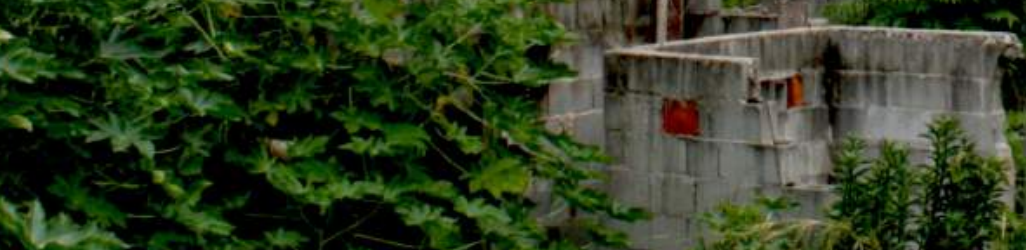

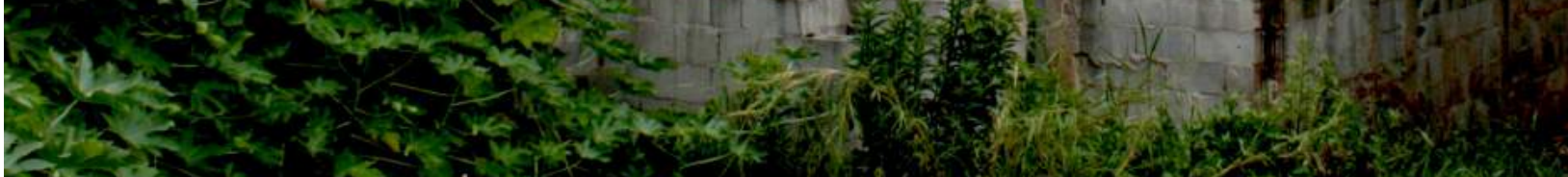

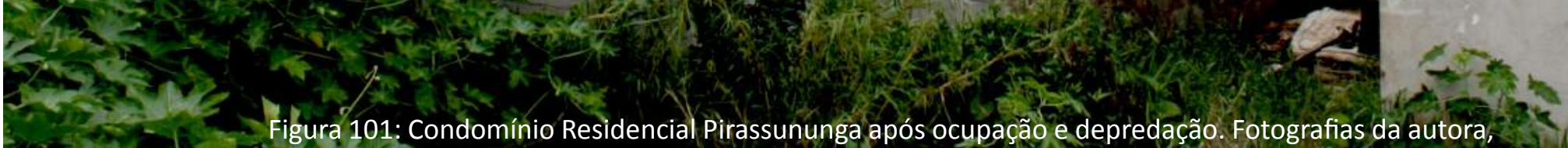
(2) 

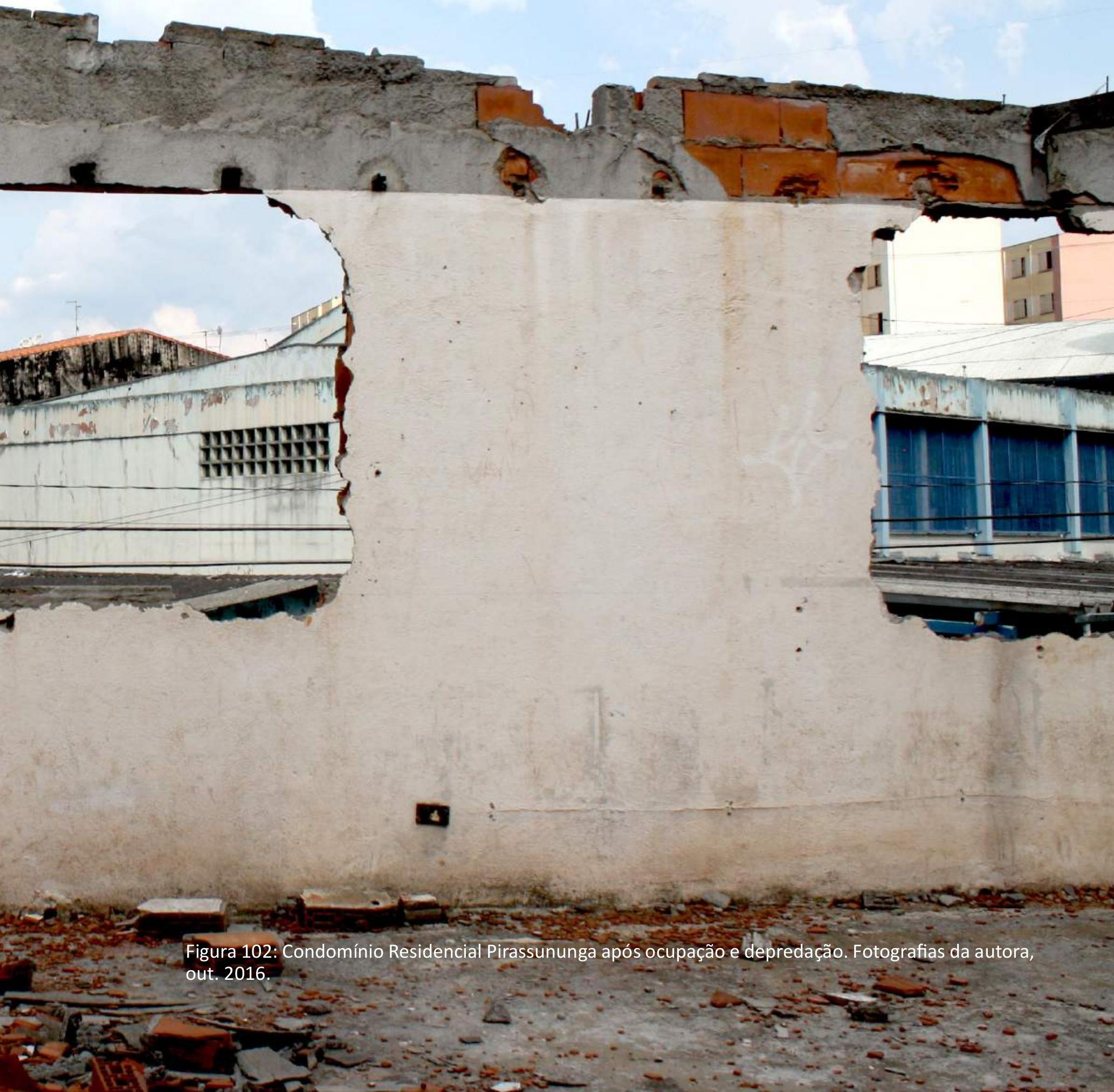
Os outros empreendimentos em Cidade Tiradentes são na modalidade Entidades: 0 Cidade Tiradentes I, II, III e IV; o Florestan Fernandes e o José Maria Amaral, que representam, na verdade, dois grandes empreendimentos desmembrados. A tabela 10, a seguir, elenca os empreendimentos realizados pelo PMCMV em Cidade Tiradentes, aprovados até abril de 2014.

\begin{tabular}{|c|c|c|c|c|c|c|}
\hline $\begin{array}{c}\text { NOME DO } \\
\text { EMPREENDIMENTO }\end{array}$ & $\begin{array}{l}\text { NOME DA } \\
\text { CONSTRUTORA/ } \\
\text { INSTITUIÇÃO }\end{array}$ & MODALIDADE & $\begin{array}{c}\text { UNIDADES } \\
\text { CONTRATADAS }\end{array}$ & $\begin{array}{c}\text { DATA DA } \\
\text { CONTRATAÇÃO }\end{array}$ & ENDEREÇO & $\begin{array}{c}\text { UNIDADES } \\
\text { ENTREGUES } \\
\text { ATÉ NOV. } \\
2016 \\
\end{array}$ \\
\hline $\begin{array}{l}\text { CONDOMÍNIO RESI- } \\
\text { DENCIAL MIRASSOL }\end{array}$ & SIMETRICA & Empresas & 260 & 01/10/2010 & $\begin{array}{l}\text { R. CORAÇÃO DE } \\
\text { MAÇÃ LOTES } 4 \text { A } \\
9 \text { QD } 32\end{array}$ & 260 \\
\hline $\begin{array}{l}\text { CONDOMINIO RE- } \\
\text { SIDENCIAL PIRAS- } \\
\text { SUNUNGA }\end{array}$ & SIMETRICA & Empresas & 200 & $25 / 05 / 2012$ & $\begin{array}{l}\text { R.CONJUNTO SI- } \\
\text { TIO CONCEIÇÃO } \\
\text { X R.PEQUENO } \\
\text { ROMANCE } \\
\end{array}$ & 0 \\
\hline $\begin{array}{l}\text { CONDOMÍNIO RESI- } \\
\text { DENCIAL LEME }\end{array}$ & SIMETRICA & Empresas & 60 & $14 / 12 / 2010$ & $\begin{array}{l}\text { R.ALFONSO AS- } \\
\text { TURARO, S/N X } \\
\text { R.RICARDO DA } \\
\text { COSTA LT } 41 \text { QD } \\
46\end{array}$ & 60 \\
\hline $\begin{array}{c}\text { CONDOMÍNIO RESI- } \\
\text { DENCIAL MONGA- } \\
\text { GUA }\end{array}$ & SIMETRICA & Empresas & 40 & $14 / 12 / 2010$ & $\begin{array}{c}\text { R.ARROIO } \\
\text { TRIUNFO X } \\
\text { R.MARCIO BECK } \\
\text { MACHADO S/N }\end{array}$ & 40 \\
\hline $\begin{array}{l}\text { CONDOMINIO RESI- } \\
\text { DENCIAL GUARUJA }\end{array}$ & SIMETRICA & Empresas & 32 & $14 / 12 / 2010$ & $\begin{array}{l}\text { RUA ARROIO } \\
\text { CAMPO BOM } \\
\text { S/N }\end{array}$ & 32 \\
\hline $\begin{array}{c}\text { CID.TIRADENTES I, } \\
\text { CHIS }\end{array}$ & $\begin{array}{l}\text { Movimentos } \\
\text { diversos }\end{array}$ & Entidades & 216 & 04/05/2012 & $\begin{array}{l}\text { ESTRADA CA- } \\
\text { CHOEIRA PAULO } \\
\text { AFONSO, S/N } \\
\end{array}$ & 0 \\
\hline $\begin{array}{c}\text { CID.TIRADENTES II, } \\
\text { CHIS }\end{array}$ & $\begin{array}{l}\text { Movimentos } \\
\text { diversos }^{\mathrm{a}}\end{array}$ & Entidades & 222 & 04/05/2012 & $\begin{array}{l}\text { ESTRADA CA- } \\
\text { CHOEIRA PAULO } \\
\text { AFONSO, S/N } \\
\end{array}$ & 0 \\
\hline $\begin{array}{c}\text { CID.TIRADENTES III, } \\
\text { CHIS }\end{array}$ & $\begin{array}{l}\text { Movimentos } \\
\text { diversos }{ }^{a}\end{array}$ & Entidades & 228 & 04/05/2012 & $\begin{array}{l}\text { ESTRADA CA- } \\
\text { CHOEIRA PAULO } \\
\text { AFONSO, S/N } \\
\end{array}$ & 0 \\
\hline $\begin{array}{c}\text { CID.TIRADENTES IV, } \\
\text { CHIS }\end{array}$ & $\begin{array}{l}\text { Movimentos } \\
\text { diversos }\end{array}$ & Entidades & 228 & 04/05/2012 & $\begin{array}{l}\text { ESTRADA CA- } \\
\text { CHOEIRA PAULO } \\
\text { AFONSO S/N } \\
\end{array}$ & 0 \\
\hline $\begin{array}{l}\text { FLORESTAN FER- } \\
\text { NANDES }\end{array}$ & $\begin{array}{l}\text { MOVIMENTO } \\
\text { SEM TERRA } \\
\text { LESTE } \\
\end{array}$ & Entidades & 198 & $27 / 04 / 2010$ & $\begin{array}{l}\text { RUA MAR DE } \\
\text { BAFFIM S/N }\end{array}$ & 0 \\
\hline $\begin{array}{l}\text { JOSÉ MARIA AMA- } \\
\text { RAL }\end{array}$ & $\begin{array}{l}\text { MOVIMENTO } \\
\text { SEM TERRA } \\
\text { LESTE }\end{array}$ & Entidades & 198 & $27 / 04 / 2010$ & $\begin{array}{l}\text { RUA MAR DE } \\
\text { BAFFIM S/N }\end{array}$ & 0 \\
\hline
\end{tabular}

Tabela 10 - Empreendimentos do PMCMV em Cidade Tiradentes

a - Movimento de Moradia dos Encortiçados, Sem Teto, Catadores de Papelão da Região Central de São Paulo (MMC); Movimento pelo Direito a Moradia (MDM); Associação dos Mutuários e Moradores da COHAB I (AMMO). 
O Florestan Fernandes e o José Maria Amaral são empreendimentos desmembrados em dois condomínios do Movimento Sem Terra Leste em parceria com a Ambiente Arquitetura Assessoria Técnica, que surgiu com o governo Erundina, atuando com participação, fortalecimento dos movimentos sociais e construção com autogestão e mutirante.

O empreendimento é uma obra com autogestão, em que os moradores são responsáveis por algumas atividades, desde a participação em reuniões do grupo juntamente à assessoria técnica até escalas de trabalho durante a obra. Os processos de participação permitem que o grupo social aspire por maiores lutas que não só a habitacional, organizando as famílias em um processo de empoderamento, que é a base para maiores mudanças sociais. Há também a crença, originada na fragilidade social, de que o processo de mutirão e movimento social são possibilidades de mudança da realidade cotidiana.

São 396 apartamentos de 58m² (figuras 103 e 104), com dois dormitórios, sala com varanda, cozinha e banheiro, distribuídos em torres de 15 andares, um dos poucos com elevador na Cidade Tiradentes, o que exige uma outra sensibilidade dos envolvidos: como fazer com que o empreendimento não seja visto como um edifício elitista, diferente dos outros? Como inserir essas famílias dentro do contexto de reconhecimento frente ao diferente? Como garantir a gestão dos custos condominiais, acrescidos da manutenção dos elevadores?

Em visita à obra, juntamente com arquitetos da Assessoria Técnica, foi possível observar que, em empreendimentos com processo de mutirão, não se trata somente de construir habitação, mas de politizar e empoderar o grupo social, em um processo complexo que busca a mobilização social para maiores lutas, que não só a habitacional (figura 105).

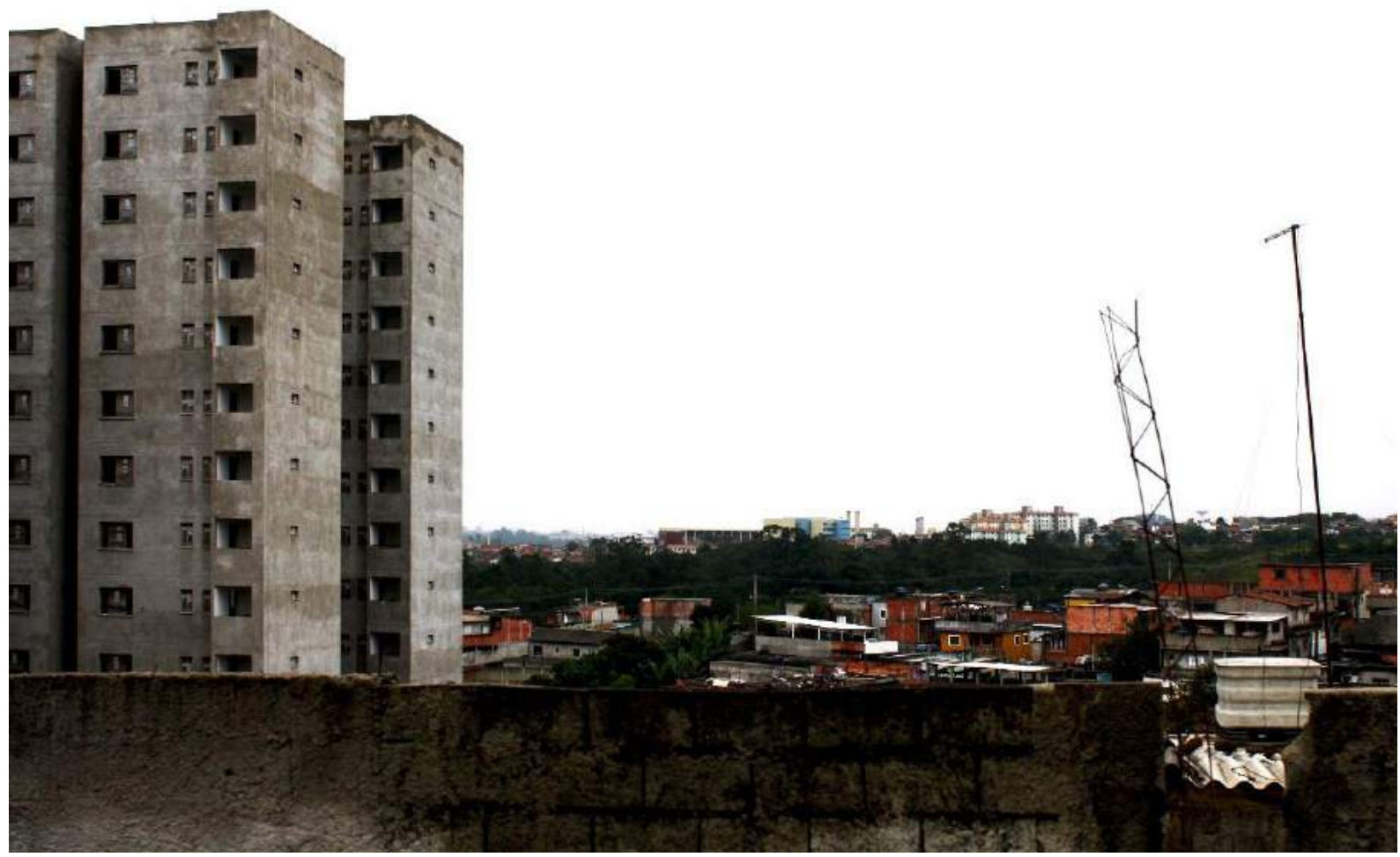

Figura 103: Conjunto Habitacional Florestan Fernandes em obra. Fotografia da autora, de maio de 2016. 


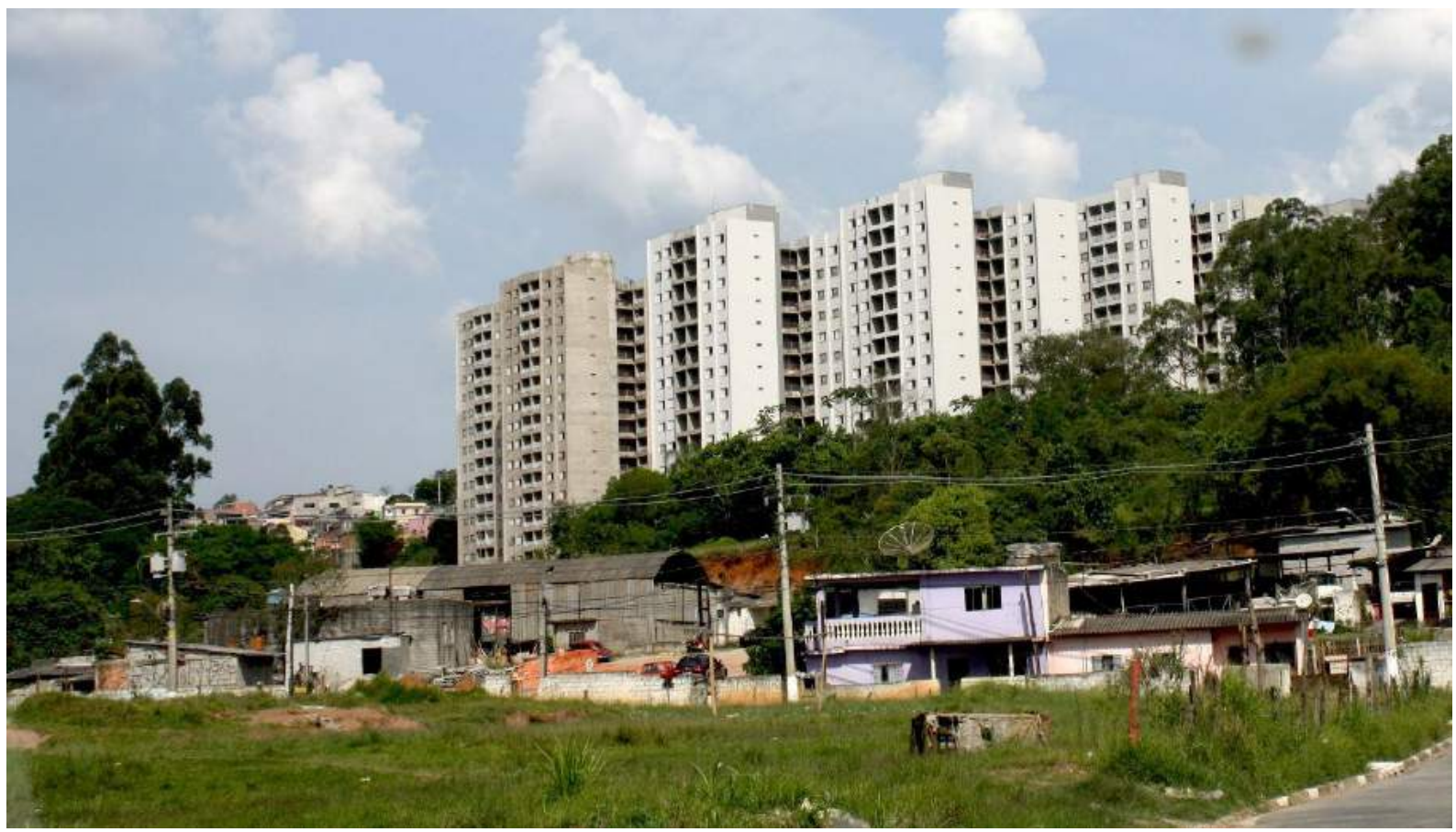

Figura 104: Conjunto Habitacional Florestan Fernandes em obra. A altura dos edifícios, acentuada pela topografia, pode causar estranhamento pelos outros moradores. Fotografia da autora, de out. 2016.

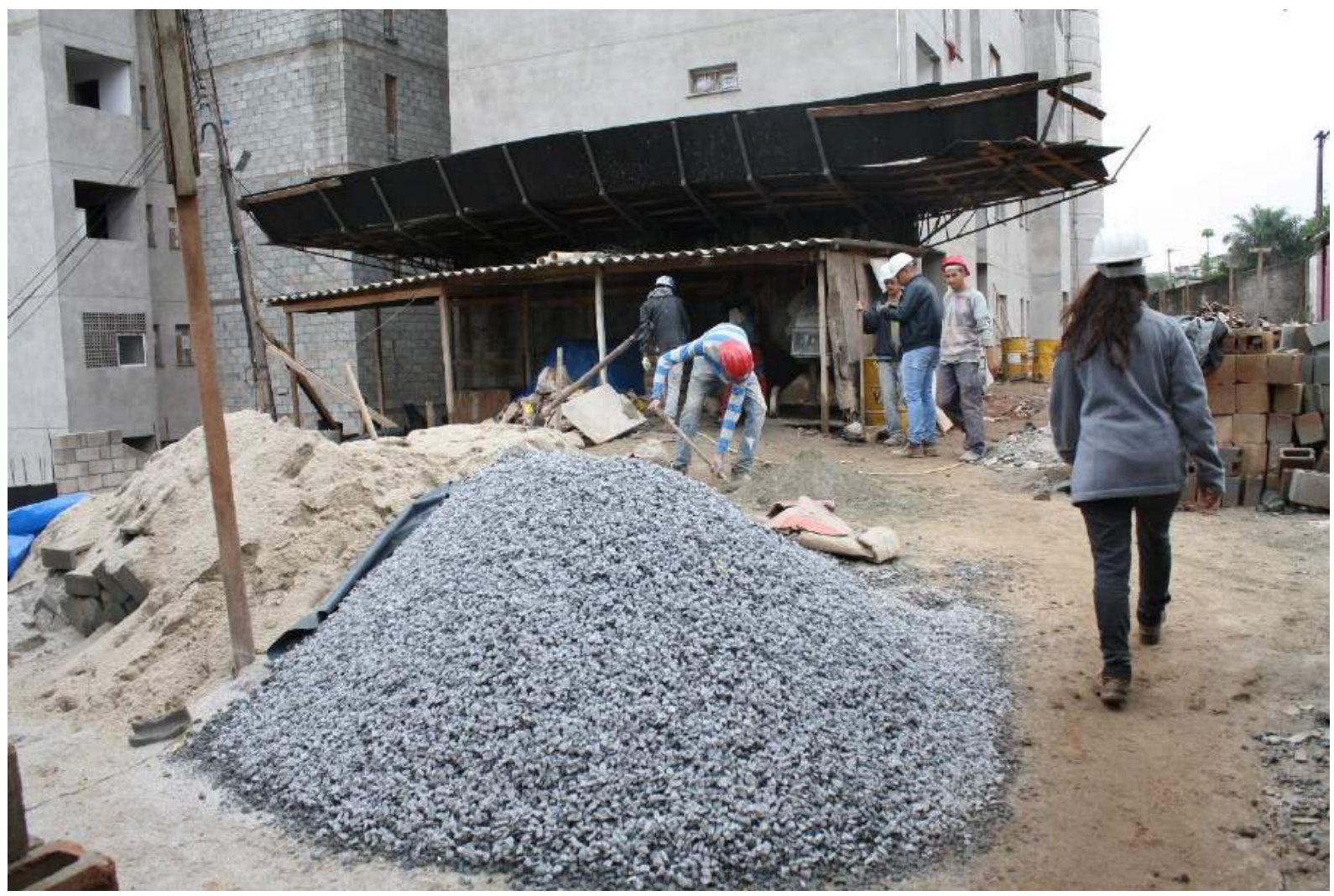

Figura 105: Conjunto Habitacional Florestan Fernandes e José Maria Amaral em obra com mutirão. Fotografia da autora, maio 2016. 
Nesse empreendimento foi observada dificuldade de envolvimento dos mais jovens. No geral, a luta feminina é muito grande, com desejo de deixar um legado familiar aos fiIhos. Já a falta de participação dos jovens não tem motivo claro. Seria a falta de espaços de convivência? Seria a dificuldade econômica? Seria a inserção urbana do empreendimento, muitas vezes distante das residências de origem? Provavelmente se trata de um complexo de fatores, passíveis de serem investigados por uma pesquisa qualitativa e imersão de campo, que foge ao escopo desta tese. Por outro lado, observa-se na juventude uma oportunidade de engajamento nas mudanças sociais, que precisa ser estimulada.

Outras questões identificadas foram: a concentração de tarefas, dificultada pela ausência de capacitação em diversas frentes de trabalho; as despesas das famílias, aumentadas pela diminuição de horas de trabalho nos empregos formais; a necessidade de contrapartida das famílias e a falta de reconhecimento, dentro da comunidade, da importância do processo.

No geral, nos empreendimentos com participação social, pode ser identificada a determinação de mudança da realidade, com o fortalecimento dos moradores por meio da luta contínua e politizada dos movimentos, que geram experiência comunitária, promoção e emancipação, o que pode, ou não, ser mantido após a conclusão das obras. A subjetividade do processo de aquisição da casa própria pode levar, mesmo nos processos mais participativos, a uma posterior desmobilização do grupo social e ao enfraquecimento de sua ação política, após saciada a necessidade individual de moradia.

No cenário político recente brasileiro, de corte de recursos para o PMCMV-E, surge a necessidade de se analisarem quais as alternativas para os movimentos sociais, buscando recursos em outras fontes. Os aportes federais expressivos dos primeiros anos do PMCMV fizeram com que ações menores dentro dos municípios fossem deixadas de lado, mas elas podem ser retomadas. As interrupções e descontinuidades políticas em programas e recursos sempre ocorrem, e alternativas para pensar novas fontes para financiar projetos sociais são sempre necessárias. 


\section{Capítulo 6: Cotidiano intramuros}

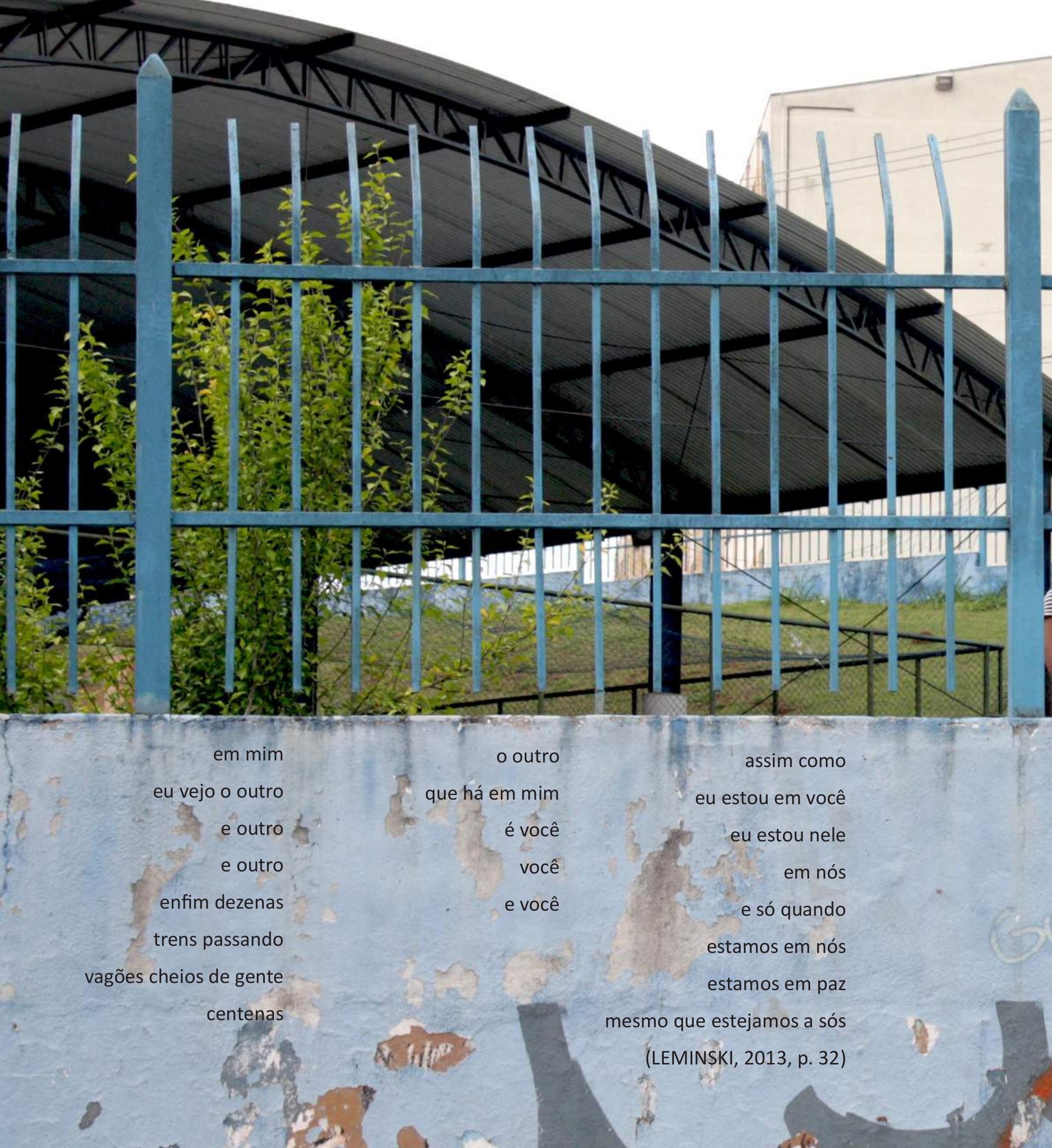


Este capítulo expõe a limitação da prática social no cotidiano intramuros de conjuntos de habitação social, estruturada pela morfologia de condomínio de prédios, que orienta a prática para as áreas dentro do empreendimento, reduzindo o convívio - e o conflito - cotidiano aos próprios vizinhos.

O território (des)praticado, cujas práticas sociais não se realizam de forma completa por limitações diversas, é resultado do contexto histórico de produção do espaço urbano, com relação direta com questões sociais, culturais, econômicas e ideológicas que caracterizam uma determinada ordem social.

Situações físicas e subjetivas orientam as práticas sociais - conscientes ou não - no espaço livre. O pouco uso e o estranhamento frente aos espaços de convívio coletivo em habitação social são faces da limitação da (des)prática, com as condutas individuais predominando em detrimento das coletivas, cujos processos conflituosos estão marcados no território e na sociedade.

Como já comentado em capítulos anteriores, o modelo condominial em habitação social no Brasil e no Chile se intensifica a partir da ditadura militar, principalmente em Regiões Metropolitanas, não só pela limitação de terreno disponível, mas também influenciado pelo "modus operandi" de produção de condomínios de prédios. É assim desde o período do BNH brasileiro e do CORVI chileno, mantendo-se até o período atual, com singelas experiências chilenas mais recentes que buscam alterar essa lógica, como será mostrado no capítulo 7.

O modelo condominial, morfologicamente, exclui o que está fora dos muros, e os que vivem fora estão sem lugar, sem destino (DUNKER, 2015). O condomínio concentra as convivências no espaço intramuros em um espaço concebido e vivido como falso universo protegido, que abriga uma liberdade fictícia.

Em condomínios de habitação social, muitas vezes soma-se ao controle dos muros a autoridade impessoal do tráfico de drogas ou de outras práticas do crime organizado, que orientam ações e questionam ordens condominiais, personificando uma autoridade constituída pela imposição do medo, que exige submissão e manipula exceções a regras, tanto no intramuros quanto no urbano extramuros.

Os condomínios fechados, principalmente de alta renda, são associados pela mídia dominante a uma imagem de felicidade, bastante irônica, em uma ilusão da realidade urbana. A artificialização dos condomínios fechados de alta renda, vazios de conteúdo urbano, é derivada de formas de vida planejada e controlada de cidades utópicas, com regulamentos, protocolos e promessa de reconstrução de uma experiência ou modo de vida perdido (DUNKER, 2015).

Essa artificialização da realidade urbana baseada em um protótipo condominial de alta renda, de imagética bastante difundida e comercializada, é também modelo morfológico para as habitações sociais, estimulado por diversos motivos, entre eles:

- A redução de custos públicos, direcionando para a iniciativa privada a criação de áreas de convívio dentro do empreendimento habitacional;

- A falsa crença dos gestores, bancos financiadores e demais técnicos de que esse é o melhor modelo morfológico para o convívio coletivo;

- O "modus operandi" de produção, seguindo uma prática já estabelecida há anos, reproduzindo construções como estampas similares, a baixo custo de construção e mínimo raciocínio criativo.

O fato é que a habitação social em formato de condomínio tem se firmado como política habitacional, e cada vez mais tem buscado, no fechamento murado e no convívio reduzido, o manejo das diferenças socioespaciais que não se conseguem solucionar e o abrandamento da falta de urbanidade dos locais em que se inserem. 
Para exemplificar a dificuldade da prática social condominial que resulta na (des)prática, escolheu-se como estudo de caso os empreendimentos Condomínio Residencial Parque Estela e Condomínio Residencial Pimentas I, localizados em Guarulhos, na RMS.

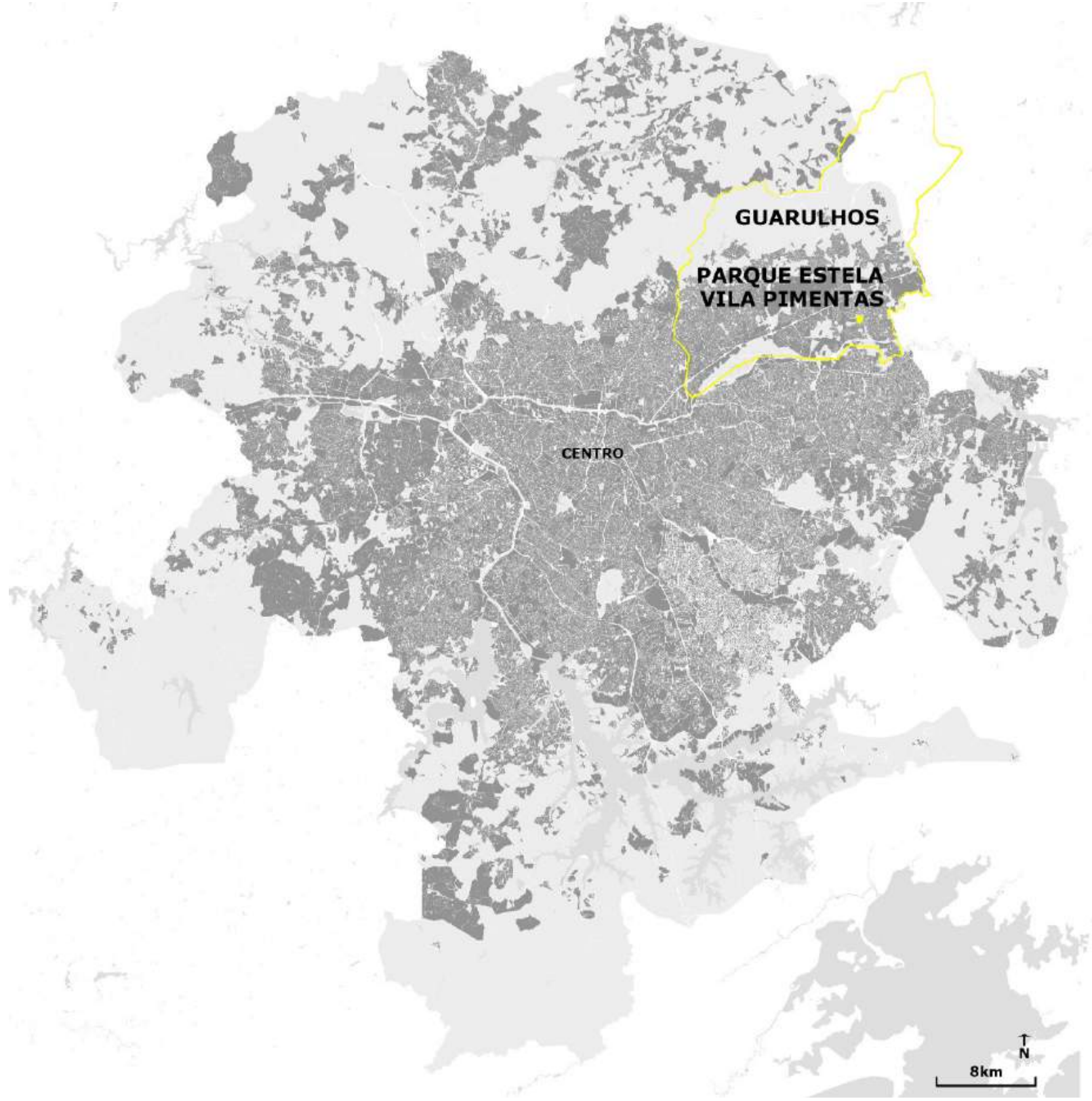

Figura 107: Localização dos Condomínios Residenciais Parque Estela e Vila Pimentas I, em Guarulhos, Região Metropolitana de São Paulo. Fonte: Elaboração da autora (2016), sob base arquivo QUAPÁ78.

Vizinhos, os empreendimentos, ambos do Programa Minha Casa Minha Vida, estão em um setor que tem recebido diversos condomínios de prédios de habitação de interesse social, e foram os primeiros a serem entregues aos moradores. Pelo menos mais cinco empreendimentos habitacionais serão entregues em seguida (2017): o Pimentas II e o São Judas I, II, III e IV, somando mais de 1.500 unidades habitacionais, todos localizados na mesma rua dos empreendimentos estudados, em um labirinto insensato de muros (DUNKER, 2015) e calçadas pouco - ou nada - existentes.

78 Mapeamento georeferenciado realizado pelo Laboratório QUAPÁ da Faculdade de Arquitetura e Urbanismo da Universidade de São Paulo, que desenvolve estudos sobre a paisagem das cidades brasileiras. A autora é pesquisadora do laboratório. 


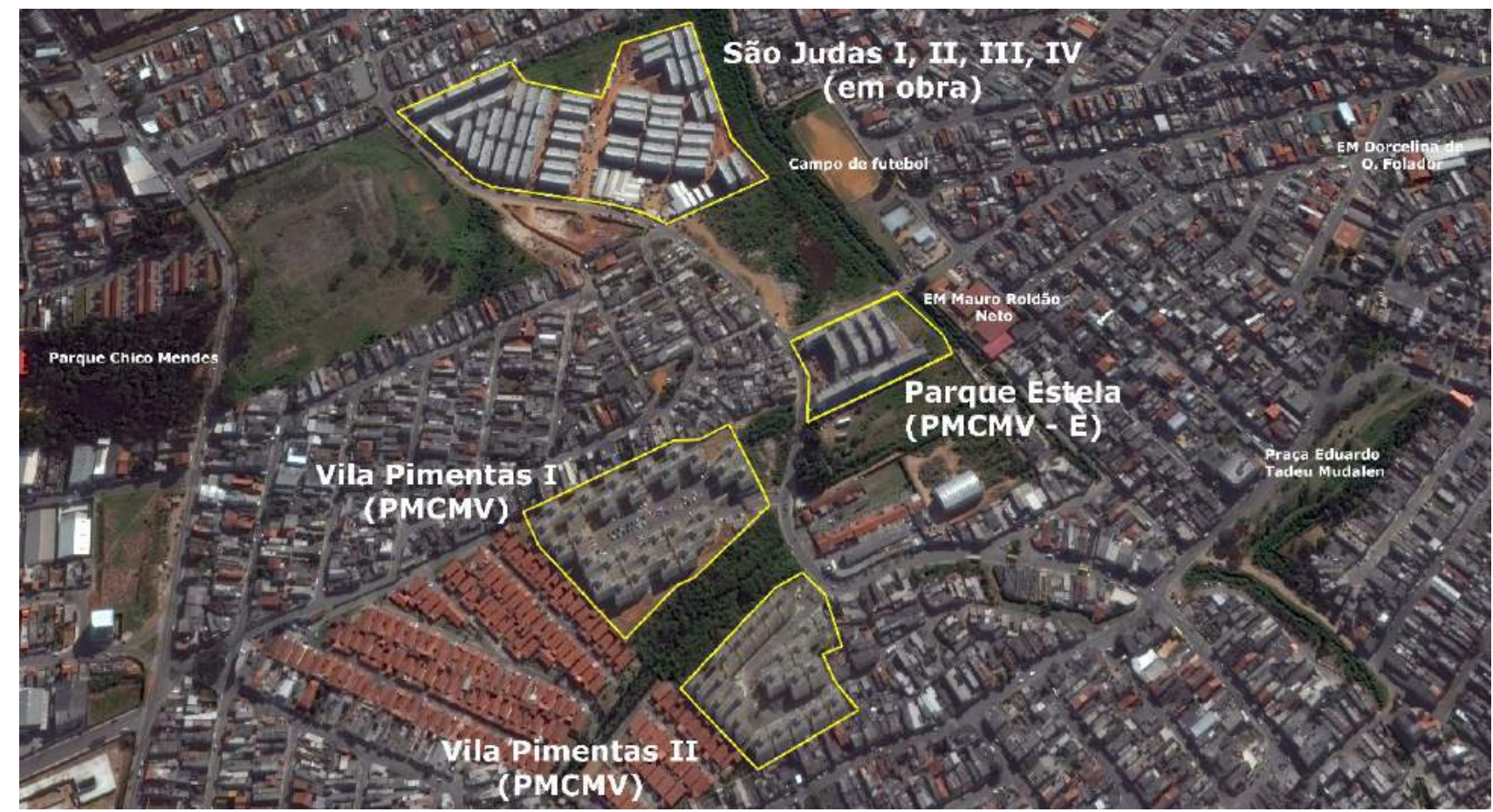

Figura 108: Localização dos empreendimentos Parque Estela, Vila Pimentas I e II, São Judas I, II, III e IV. Fonte: Elaboração da autora, sob base Google Earth.

Os empreendimentos se localizam na Rua Mucugeo (figura 109), no bairro dos Pimentas, em Guarulhos (figuras 107 e 108), em uma área considerada pelo município como de crescimento urbano. Reconhece-se esse crescimento, apesar de ser, atualmente, limitado a conjuntos habitacionais. Ainda falta urbanidade, embora no entorno existam escolas, creches e um CEU, entre outros equipamentos, o que, inicialmente, parecia benéfico, mas se demonstrou insuficiente, pela maioria dos equipamentos já estarem saturados pela demanda do entorno.

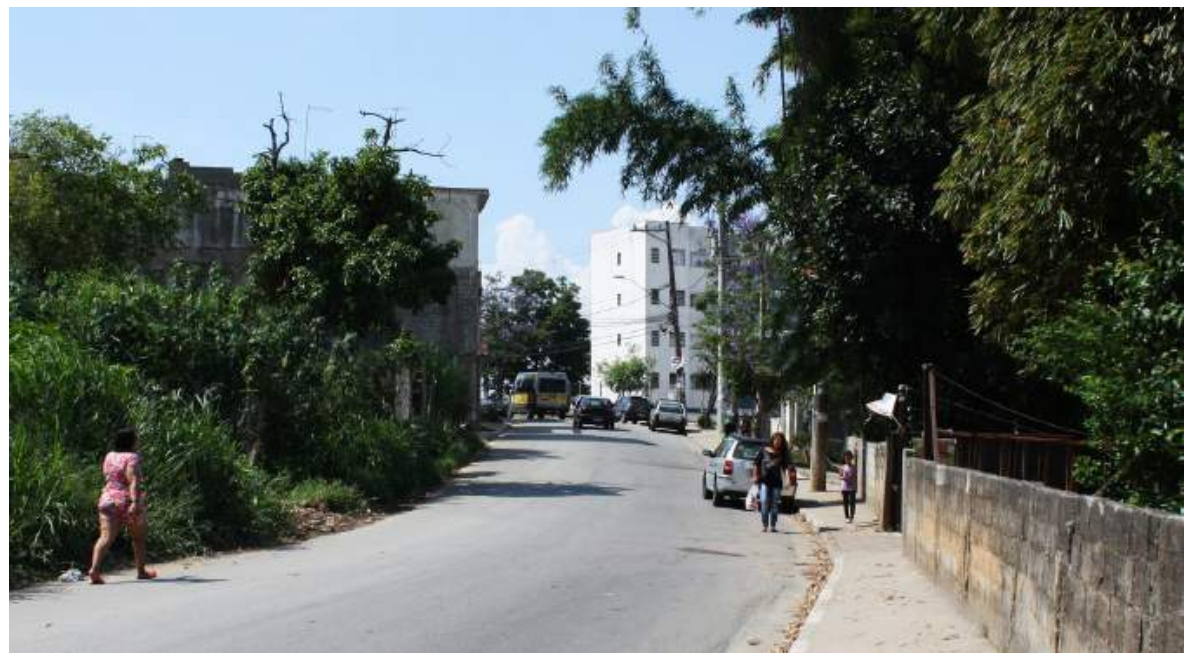

Figura 109: Rua Mucugeo, em frente ao Condomínio Residencial Vila Pimentas I, e seu espaço nada planejado para o pedestre. Fonte: Fotografia da autora (2016).

Como já comentado, o município deveria se responsabilizar por uma política urbana que viabilizasse terras para a população de menores recursos. É uma questão política histórica, que não se soluciona. Mesmo no momento em que foram dados muitos subsídios para habitação, como o que ocorreu com o Programa Minha Casa Minha Vida, acabaram-se repetindo padrões de segregação urbana da época da ditadura militar. 
O Programa Minha Casa Minha Vida praticamente impõe a implantação de um modelo condominial, e essa configuração de cidade está se consolidando pelo país, principalmente em regiões metropolitanas.

Porém, o modelo condominial não se adapta, via de regra, ao cotidiano das famílias que recebem uma habitação social. Como já foi comentado no capítulo anterior, seria mais interessante que os espaços coletivos nesses locais fossem públicos, externos aos limites da habitação, como será mostrado com maior rigor no capítulo 7. Isso reduz os custos condominiais, mas exige uma contrapartida municipal, que nem sempre corresponde às intenções, possibilidades de gestão e manutenção pelo poder público.

Com os arranjos institucionais da política urbana e habitacional brasileira, comentados nos capítulos 2 e 4, os governos locais assumiram-se como protagonistas, inclusive no que tange à responsabilidade de captar e gerir recursos disponíveis para os programas existentes, criando instrumentos específicos para a produção habitacional municipal. Nesse contexto, Guarulhos criou, juntamente com ações participativas, o Plano Local de Habitação de Interesse Social (PLHIS de Guarulhos), consolidando objetivos do Estatuto da Cidade e do Plano Diretor.

Os princípios que gerem a PLHIS de Guarulhos são gerais, assim como os definidos pela Política Nacional de Habitação de 2004, buscando, por meio de mecanismos locais, garantir o direito universal à moradia, a função social da propriedade urbana, a implementação de uma política municipal de habitação de forma articulada, a gestão democrática e participativa e as articulações de ações com demais políticas urbanas, como sociais e ambientais.

O diagnóstico do PLHIS de Guarulhos identifica algumas características próprias da inserção do município na RMSP, destacando dinâmicas e decisões regionais que impactaram no desenvolvimento do território municipal desde a expansão da metrópole paulistana nos anos 1950, dentre as quais a construção de vias de ligação importantes, como a Rodovia Presidente Dutra, na década de 1950, do Aeroporto Internacional de Guarulhos/Cumbica (GRU), em 1980 e 1990, e recente trecho do Rodoanel, ainda em obras em 2016.

Também segundo o PLHIS, os empreendimentos habitacionais realizados com recursos do Governo Federal nos últimos 50 anos produziram cerca de 7.500 unidades habitacionais no município para famílias de baixa renda, a partir de diversos programas, como BNH e INOCOOP ${ }^{79}$ em 1960 e 1980, e os recentes Programas Federais, como Habitar Brasil, Programa Morar Melhor, Programa de Arrendamento Residencial, Programa Minha Casa Minha Vida, entre outros.

A participação popular na gestão pública ocorre em algumas instâncias, como nos Conselhos (de Habitação, de Desenvolvimento Urbano, e Gestor de Zona Especial de Interesse Social) e no Orçamento Participativo. Em relação à produção de novas habitações sociais, a participação de movimentos de moradia ocorreu com aval dos Governos Estaduais e Municipais principalmente a partir do final da década de 1990 e início de 2000, como comentado no capítulo 3, e recentemente ocorreu com estímulo do Governo Federal com a modalidade Entidades do Programa Minha Casa Minha Vida, que é o caso do Condomínio Residencial Parque Estela.

79 O Instituto de Orientação às Cooperativas Habitacionais de São Paulo (INOCOOP-SP) foi criado em 1966, dentro de proposta de criação de Cooperativas Habitacionais por um programa implementado no período BNH. O INOCOOP-SP continua a sua atuação até o período atual, prestando assessoria às Cooperativas Habitacionais e mesmo construindo empreendimentos próprios com recursos de agentes financeiros, como a Caixa Econômica Federal. 

O Parque Estela foi idealizado junto ao Movimento Nacional de Luta pela Moradia, um movimento com bastante atuação na Região Metropolitana de São Paulo, e à Entidade PEABIRU Trabalhos Comunitários e Ambientais, ONG de assessoria técnica sediada em São Paulo-SP e originada dos movimentos de moradia e mutirões dos anos 1990, relacionada aos movimentos e à luta pela moradia desde então.

No caso do Parque Estela, os movimentos por moradia começaram a se organizar em 2004 e 2005, e procuraram a PEABIRU em dois momentos diferentes: primeiro, durante a busca por um terreno para a construção de um empreendimento habitacional e, depois, para a elaboração do projeto e aprovações em diferentes instâncias exigidas pelo PMCMV-E. A Entidade PEABIRU, dessa forma, assessorou o grupo social desde o aspecto burocrático para a entrada no programa até a definição do projeto arquitetônico.

O primeiro terreno que o movimento buscou adquirir para a construção do projeto foi perdido para a iniciativa privada, pela limitação econômica do grupo social em comprar glebas, que acabam sendo adquiridas com maior rapidez por construtoras atuantes no PMCMV empresarial. O Condomínio Residencial Parque Estela só foi viabilizado no terceiro terreno que o movimento encontrou, cuja aquisição só foi possível por intermédio de uma parceria realizada com uma construtora, a Noroeste, que comprou o terreno para o movimento de moradia.

Essa empresa não foi encarregada de realizar a obra, e uma próxima empresa, a Lemma Assessoria e Construtora LTDA, foi selecionada para realizar a construção. Porém, a Lemma não conseguiu cumprir o acordado, parando a obra nos momentos iniciais de adequação topográfica do terreno. Uma nova contratação foi, naquele momento, realizada, e a QUALIFAST Construtora LTDA assumiu a obra, reiniciando a construção em meados de 2011 e entregando o empreendimento ao grupo social em 2013 (figura 111). Paralelamente ao andamento da obra, iniciaram-se os trabalhos sociais com as famílias e a equipe da PEABIRU.

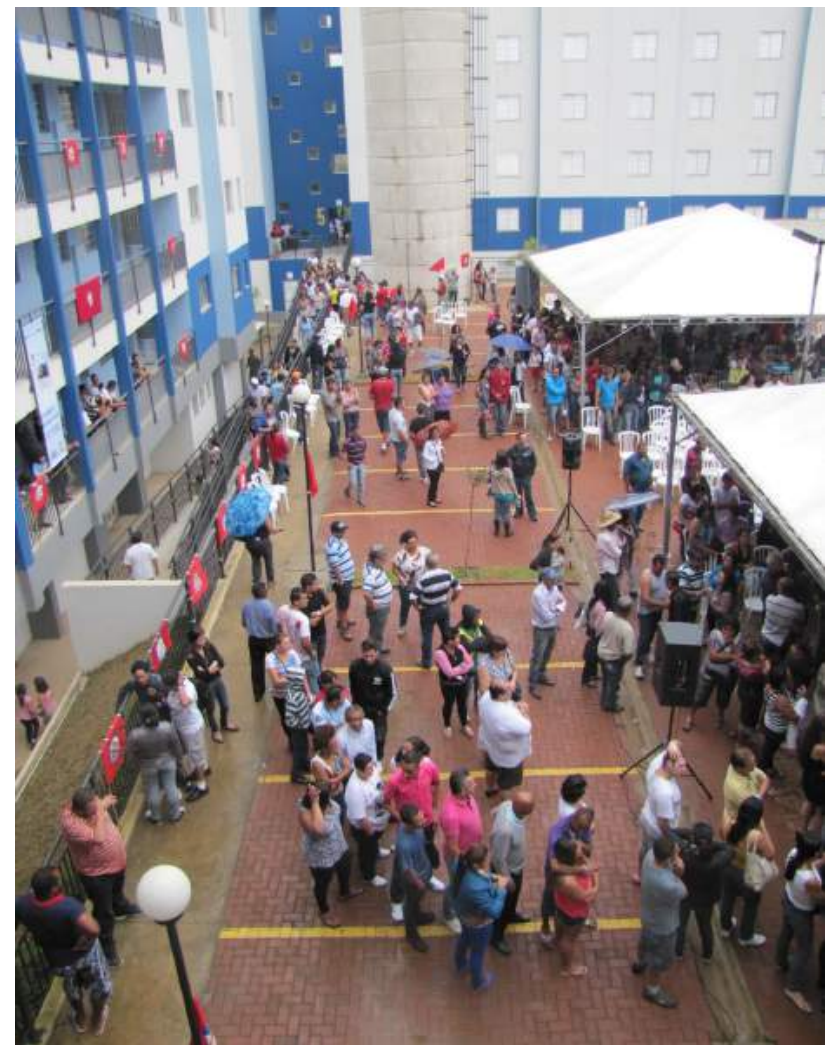

Figura 111: Cerimônia de entrega das chaves. Fonte: acervo PEABIRU (2013). 
No PMCMV-E, a Caixa Econômica Federal paga antecipadamente por etapas cumpridas durante a obra. Assim, essas rupturas com construtoras que não finalizaram a obra não prejudicaram o andamento financeiro do empreendimento.

O projeto demorou mais de dois anos para ser aprovado, pois apresenta, em seu terreno, uma Área de Preservação Permanente de aproximadamente $2.000 \mathrm{~m}^{2}$, em uma faixa de 30 metros paralela ao córrego do Moinho Velho, o que exigiu aprovação específica na CETESB, órgão estadual de saneamento. Entre aquisição do terreno e aprovação, passaram-se aproximadamente cinco anos e, durante esse período, não houve interação ou participação da Entidade com as famílias, que já estavam selecionadas e organizadas pelo movimento de moradia.

O Condomínio Residencial Parque Estela é formado por seis edifícios habitacionais dentro de um mesmo condomínio, sendo que cinco dos edifícios são compostos por cinco pavimentos e um por seis pavimentos, em um total de 218 apartamentos de $41,35 \mathrm{~m}^{2}$.

O projeto em si foi desenvolvido pela equipe PEABIRU sem a participação do grupo social, pois o processo de criação depende de aprovações na Caixa Econômica Federal e de exigências básicas do PMCMV-E, o que não permite muitas alterações na unidade habitacional nem no modelo condominial, além de exigir maior agilidade para o desenvolvimento do projeto e aprovação, o que acaba resultando em uma solução morfológica bastante padronizada de condomínio de prédios.

O único diferencial morfológico dos edifícios do Parque Estela é o corredor de acesso às habitações, livre, que cria uma sensação de varanda ao conjunto, e possibilita um espaço que poderia ser utilizado para o convívio direto entre vizinhos, mas que, por normas de segurança contra incêndio, não podem ser ocupados, por exemplo, com mobiliário, ou outros elementos que bloqueiem uma possível rota de saída em situação emergencial.

Devido à rigidez do processo de aprovação, que limita o modelo arquitetônico, a possibilidade de participação popular se reduziu à definição das áreas comuns condominiais. Estas, no Parque Estela, são formadas pelo estacionamento de veículos e por outras áreas livres residuais projetadas para convívio do grupo.

Para a definição do que haveria em cada espaço comum condominial, a Entidade promoveu algumas oficinas para as famílias (figuras 112, 113, 114 e 115), durante as quais foram discutidos o programa das áreas comuns, a adequação das demandas à realidade, os custos condominiais, a inserção urbana do conjunto habitacional e as caraterísticas do bairro, destacando-se os espaços livres e equipamentos urbanos que poderiam ser usados pelos moradores.

Essa discussão sobre os equipamentos presentes no entorno do Parque Estela auxiliou a definição das áreas comuns do empreendimento, reduzindo a necessidade de alguns espaços solicitados pelos moradores, como um campo de futebol intramuros, desnecessário pela existência de um campo de futebol no terreno vizinho. Após as oficinas participativas de definição dos espaços de uso comum condominial, outras reuniões foram realizadas, mostrando-se a proposta da Entidade para o projeto desses espaços.

Assim, apesar da configuração da implantação dos edifícios já estar definida no momento da participação do grupo social, a definição dos usos surgiu com as oficinas participativas. Porém, a participação limitou-se a algumas famílias mais envolvidas. O processo participativo envolve um trabalho social de reconhecimento do território, solução de conflitos, entre outras iniciativas de construção de vínculo com o projeto e com os moradores, que não era de interesse de todos. A maioria acabou se envolvendo minimamente, estando apenas engajados individualmente na aquisição de casa própria, enquanto alguns se envolveram de modo efetivo, reconhecendo a importância do trabalho participativo. 


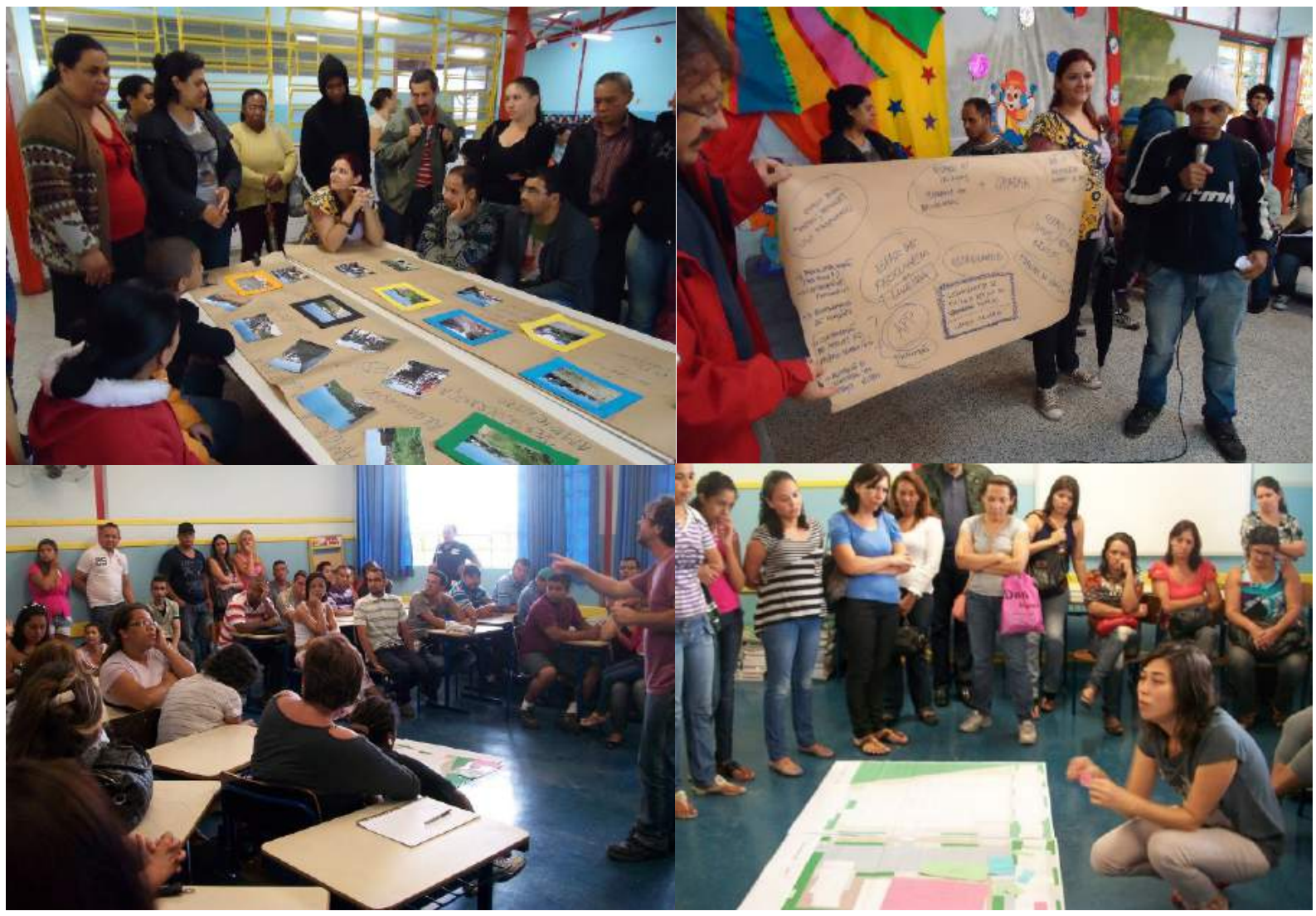

Figuras 112, 113, 114 e 115: Oficinas participativas para a definição das áreas comuns condominiais. Fonte: Acervo Peabiru (2012).

As demandas e sugestões dos moradores nas oficinas fizeram, por exemplo, com que se construísse uma churrasqueira próxima à área de preservação permanente, em uma situação similar ao Parque do Carmo, muito frequentado por eles, onde há churrasqueira próxima à vegetação. No entanto, apesar da demanda ter surgido do grupo, ou melhor, dos poucos moradores que realmente participavam das oficinas, a churrasqueira era, após a entrega do empreendimento e até o momento de trabalho de campo desta pesquisa, um dos espaços de menor apropriação dentro do condomínio.

Próximo à portaria principal do empreendimento, foram instalados bancos e mesas, também por demanda dos moradores, que costumam observar o movimento da rua. Esse mobiliário também permite o uso para jogos de xadrez, mobiliário urbano bastante implantado em praças de bairro nos anos 1980 e 1990, mas cujo interesse precisaria ser reavaliado para aquele grupo social, sem reproduzir um modelo estereotipado e, possivelmente, ultrapassado ou inadequado.

Há também um centro comunitário, formado por um salão de festas e uma área coberta, para atividades que possam se desenvolver em dias de chuva, localizado no térreo de um dos edificios habitacionais. Os outros pavimentos térreos são ocupados por vagas de estacionamento e algumas unidades habitacionais térreas.

O parque infantil foi projetado em um patamar intermediário (figura 116), onde não há acesso de veículos, para proporcionar maior segurança para os usuários. Próximo a ele, junto às rampas de acesso ao patamar inferior onde se localiza a churrasqueira, foi instalado um escorregador, apropriado por crianças e jovens (figura 117). 

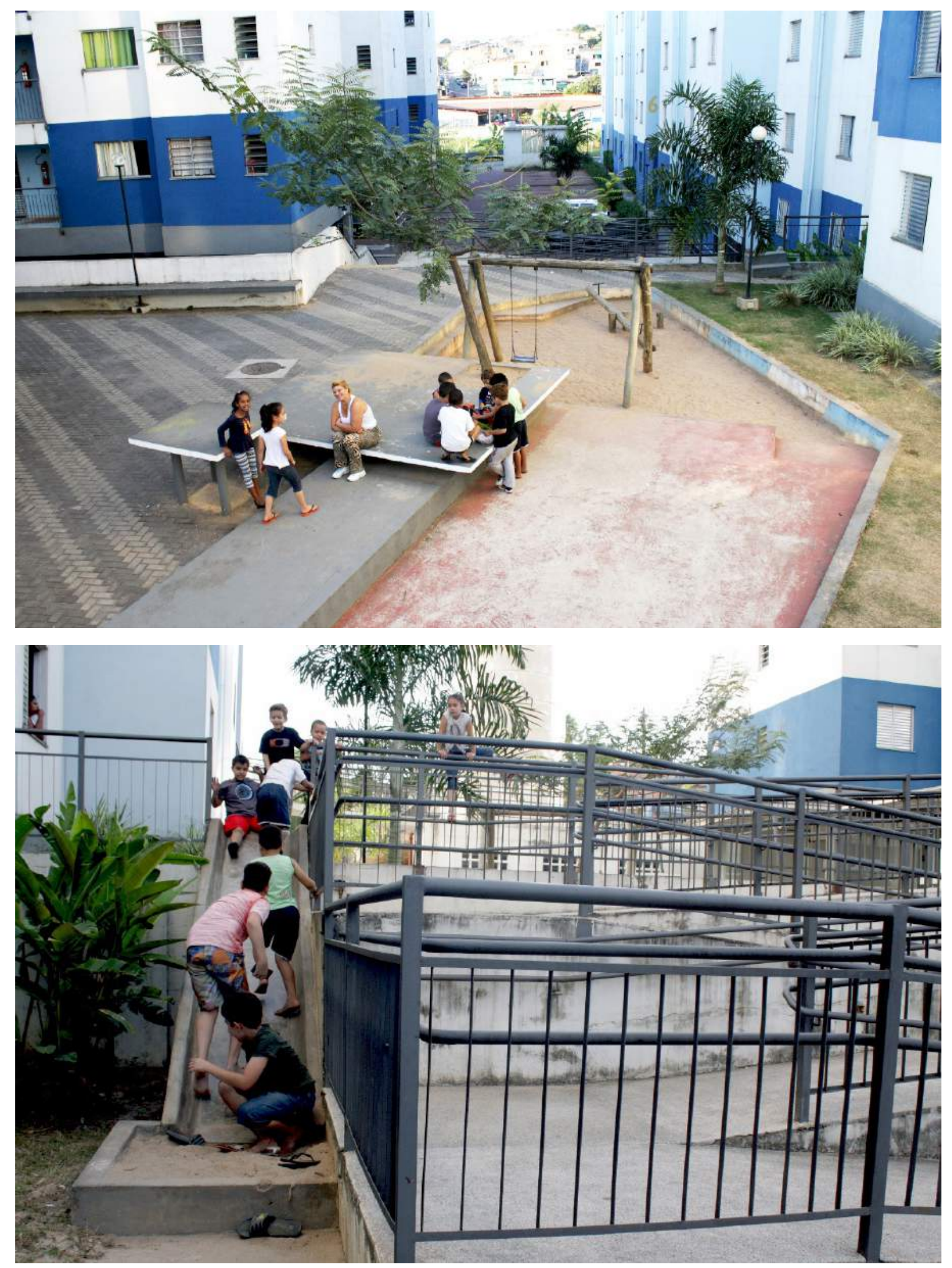

Figuras 116 e 117: Parque infantil. Fonte: fotografia da autora (2016). 
Também surgiu nas oficinas com os moradores a proposta de se realizarem trilhas na APP, que foram projetadas e aprovadas na CETESB. Foi feito um mutirão para plantio de espécies por meio do qual foram plantadas 80 árvores nativas como compensação ambiental. Apesar do empenho da Entidade e do grupo social, o uso da APP é limitado pela legislação ambiental, o que faz com que a área seja vista, por alguns moradores, mais como um problema (devido ao custo de manutenção da vegetação, à pouca possibilidade de uso e ao compromisso de preservação da área perante a CETESB, com risco de sanções legais em caso de descumprimento do compromisso) do que como um elemento qualificador de suas áreas livres.

A entrada dos membros das famílias em creches e escolas do entorno buscou ser equacionada durante a obra, mas só passou a ser um conflito real com a mudança das famílias e a necessidade de adequação ao novo contexto urbano, já que não havia vagas para todos no momento imediato à chegada das famílias.

Havia uma grande demanda dos moradores por vagas de estacionamento. Durante o processo participativo, a equipe do PEABIRU fez um levantamento de quantas famílias tinham veículos, e constatou-se que o número era reduzido. Porém, todas elas tinham desejo de ter um veículo particular, como uma próxima conquista após a casa própria.

A proporção de vagas para veículos por unidade habitacional, de uma a cada dois apartamentos, por regra do Programa e do Agente Financiador, não foi bem aceita pelos moradores, pois mesmo os que não tinham veículo particular desejavam uma vaga para cada apartamento, o que não foi possível. Essa divisão de vaga por moradores causava receio ao grupo social, por medo de conflito entre vizinhos.

Há limitações no processo participativo do PMCMV-E, mas o que o diferencia do PMCMV empresarial é o reconhecimento dos moradores em seu grupo social e a consequente criação de laços durante o processo de aquisição da casa própria, numa união que auxilia a identificar as particularidades do outro. Dessa maneira, a participação é uma ferramenta de construção de vínculo entre as pessoas e o território.

As famílias têm sempre um repertório e alguns interesses para os espaços comuns da sua moradia. Assim, a função da equipe de profissionais da Entidade é mediar e orientar os moradores nas escolhas para esses espaços. O Entidades, quando ignora o pensamento produtivo imobiliário e estimula o grupo social a refletir sobre a sua moradia, possibilita maior apropriação dos espaços livres.

Além disso, a discussão sobre o espaço livre é mais frutífera, em termos de construção de cidadania, do que a discussão sobre a unidade habitacional, o espaço privado. No projeto dos espaços coletivos, encontra-se a possibilidade de construção de vínculos sociais, mesmo que limitados ao grupo social e a um território (des)praticado. 

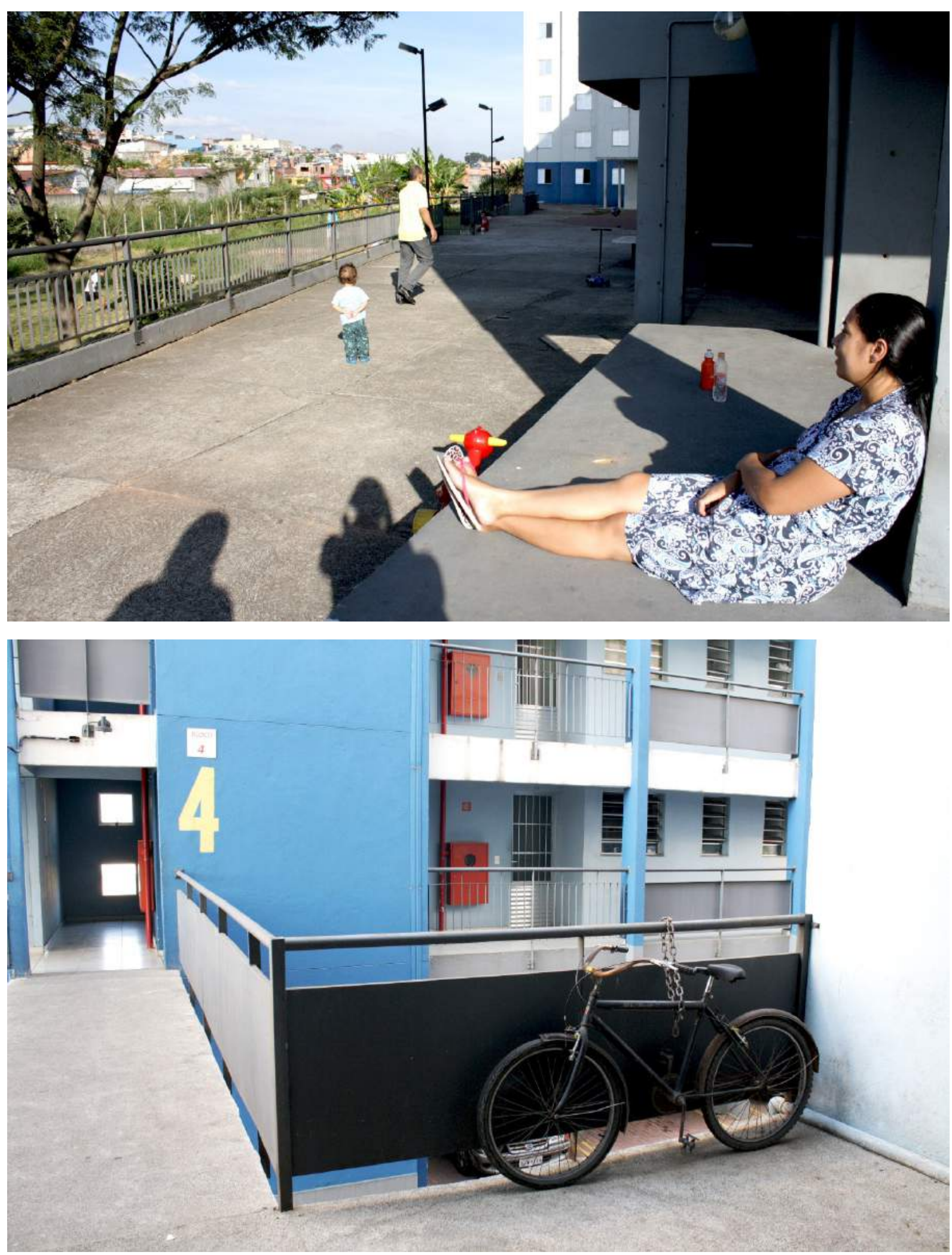

Figura 118 e 119: áreas livres do empreendimento e corredor de acesso aos blocos. Fonte: Fotografias da autora (2016). 
Porém, a participação, quando ocorre apenas em um empreendimento em um setor urbano com muitos conflitos sociais, como ocorreu nesse trecho de Guarulhos, acaba também segregando ainda mais o grupo social envolvido no processo participativo, visto como "diferente" pelos moradores dos outros empreendimentos, que não passaram pelo mesmo processo.

Do mesmo modo, os moradores do Parque Estela observam com estranhamento outros espaços condominiais e urbanos vizinhos, muitas vezes reduzindo a experiência desses outros moradores a situações menos interessantes do que a que eles próprios vivenciaram, em uma separação inconsciente, típica do mal-estar condominial.

Na participação e discussão dos espaços coletivos já se orientam noções de gestão dos espaços e da vida coletiva em condomínio, buscando-se amenizar os conflitos intramuros. A maioria dos moradores do Parque Estela nunca havia morado em condomínio e é nos espaços coletivos que surgem os principais problemas do convívio, cuja solução exige um exercício cotidiano, de reconhecimento de um espaço que é de todos, que recebe as diferenças.

Andreia ${ }^{80}$, líder comunitária do Parque Estela, em conversa com a autora, relatou alguns dos conflitos que surgiram: discussões entre vizinhos, depredações e resistência às normas estabelecidas. A moradora também reclamou da crítica de outros à sua postura de gestora dos espaços.

Mais do que síndicos, os líderes comunitários interagem com os grupos sociais e estabelecem as normas de convívio, definindo regras e, por conta disso, exercendo o poder e mesmo o controle social. Isso pode gerar mal-estar pela perda de liberdade que os regulamentos em espaços já excessivamente planejados trazem. Apesar do controle, encontros e desencontros cotidianos ocorrem nos espaços intramuros e, eventualmente, podem ser remediados com novas sanções e proibições condominiais. Dunker (2015) comenta acerca da neurose em se estabelecer normas excessivas em espaços intramuros, em uma compulsão legislativa que pode controlar as práticas sociais e diminuir os encontros cotidianos.

De um modo geral, como há uma vida coletiva que se constrói cotidianamente e que se altera com o tempo, é cedo para chegar a conclusões definitivas sobre a (des)prática condominial no Parque Estela e a interferência de um projeto participativo nas práticas cotidianas, mas já é possível reconhecer as qualidades e as deficiências do empreendimento, do seu entorno e do modelo condominial.

Não é a participação que vai remediar todos os conflitos possíveis. Os espaços comuns projetados, mesmo que decididos juntamente com as famílias, poderão não ser utilizados exatamente como planejado, pois as situações se modificam, novos usuários que

80 Os nomes dos moradores que colaboraram com a tese foram alterados para nomes fictícios, de modo a preservar as suas identidades. 
não estavam envolvidos no trabalho social são inseridos. Há também a dificuldade do próprio planejamento em pensar o cotidiano do outro sem imposições, agravada pela complexidade de se mediar sonhos, interesses, ordens dominantes e conhecimento técnico, realizando um espaço que permita mudanças de uso, sem controlar demasiadamente o espaço percebido.

A longo prazo, poderá haver ainda mais mudanças nas práticas sociais, com alterações no uso dos espaços, dependentes de administração, manutenção, gestão, interesse e possibilidades dos moradores em gerenciar os conflitos nos espaços comuns.

Há um certo dilema, quando se trabalha com espaços condominiais em habitação social, criado pelo custo de manutenção. Excesso de jardins traz custo, assim como equipamentos, por exemplo.

A assessoria técnica PEABIRU realizou algumas simulações de custo e apresentou-as aos moradores, durante o trabalho social, com cenários possíveis, como o uso de uma ou duas portarias $24 \mathrm{~h}$, ou um jardineiro e um funcionário para faxina, entre outros aspectos. Por mais cautelosa que a assessoria seja, esses conflitos costumam surgir de várias formas, dependendo de períodos econômicos e mudanças dentro das próprias famílias sendo, muitas vezes, amenizados pela própria gestão condominial.

Há uma ilusão da mudança para a casa própria como solução de muitas angústias, pelo pouco conhecimento em relação aos custos rotineiros e às limitações do modelo condominial. No geral, as famílias acreditam que, distribuindo todos os custos entre todos os vizinhos, é possível ter espaços como aqueles midiatizados para classes de mais alta renda. Porém, a administração condominial em habitação social envolve uma complexidade típica do grupo social, já que ainda há, dentro das famílias de faixa 1 , diferenças de renda bastante expressivas.

Também pertencem ao imaginário coletivo o receio do outro, o que leva à sua exclusão, com a separação não só do grupo em relação ao entorno urbano, mas dentro do próprio condomínio, o que pode ocorrer ao se estigmatizarem moradores que tenham passado por situações conflitivas, como os moradores envolvidos com práticas ilícitas ou desempregados.

Essa cisão dentro do próprio grupo social tende a se repetir com os moradores do lado de lá do muro, cujo cotidiano é visto com curiosidade. Eles podem ser categorizados em situação pior ou melhor do que a vivenciada no intramuros particular de cada grupo, como é o caso dos moradores do Condomínio Residencial Vila Pimentas I. 


\section{- Condomínio Residencial Vila Pimentas I - Guarulhos (PMCMV)}

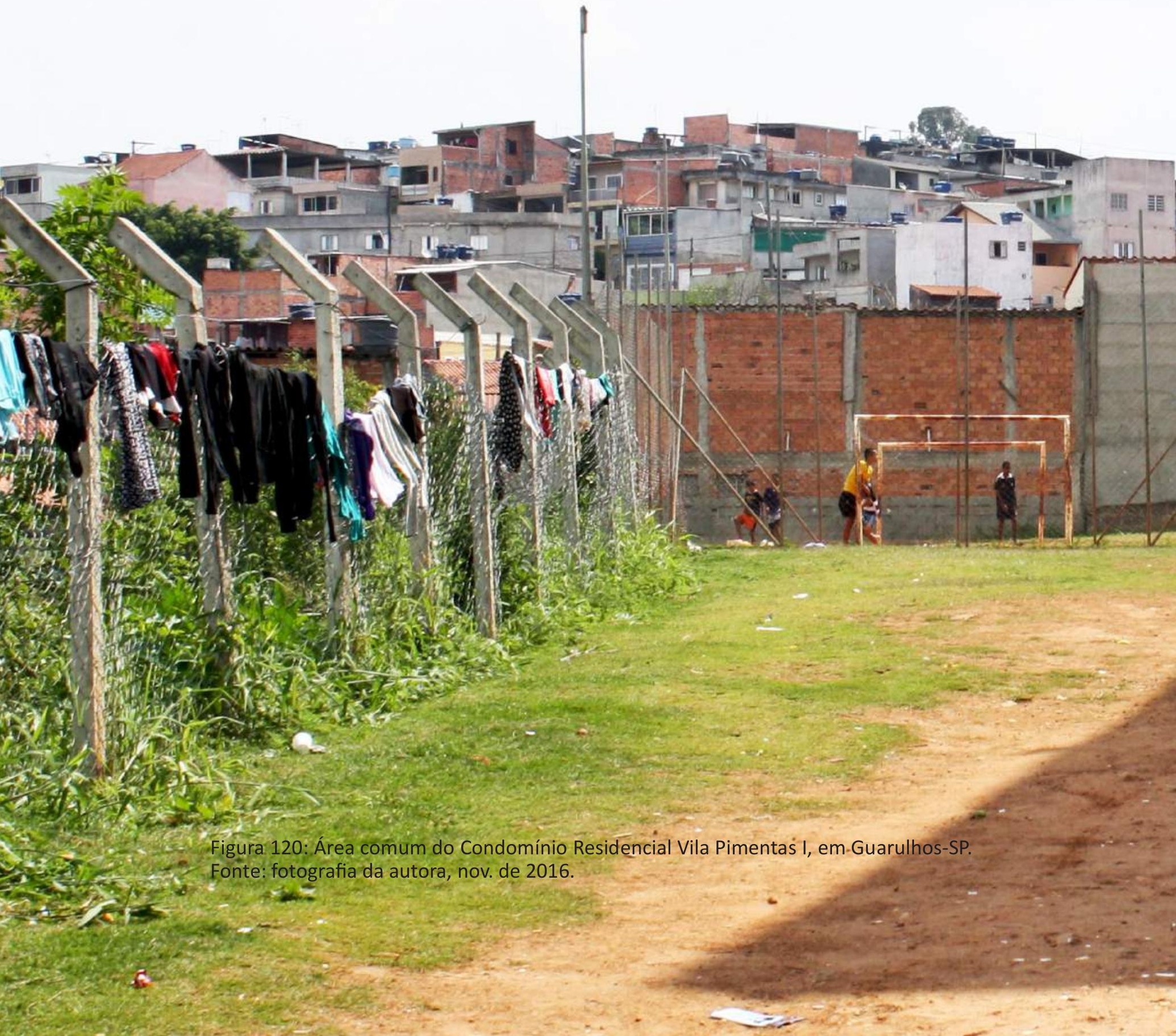


serectio

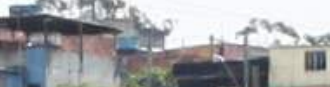

Inebonis.

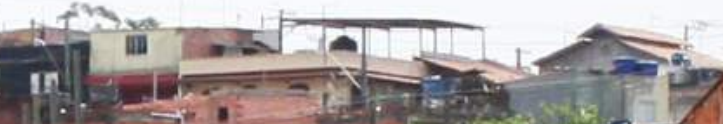
as: $2 x+4=0$
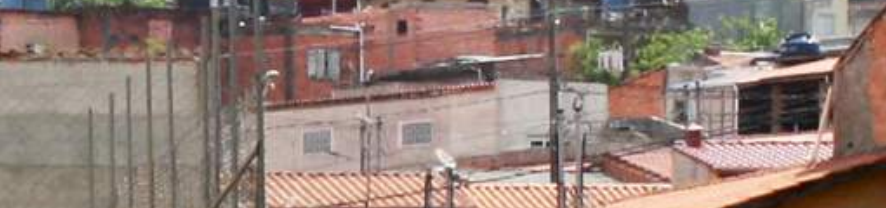
O Condomínio Residencial Vila Pimentas I e II foi projetado pela Dib Construtora e Incorporadora, que não finalizou a obra, passando-a, por uma nova licitação, para a responsabilidade da Construtora Camargo Rodrigues Ltda (CCRL), que assumiu o final da construção dos empreendimentos.

As famílias que receberam apartamentos do Vila Pimentas I moravam em algumas favelas de Guarulhos, principalmente na favela Vila Flora, no bairro Itapegica, mas também nas comunidades Brasileira e São Judas. O Condomínio Residencial Vila Pimentas I, com 580 unidades habitacionais, reuniu, dessa forma, moradores de três diferentes grupos sociais e regiões de Guarulhos, em um eminente conflito estabelecido pela combinação de grupos sociais com histórias e particularidades distintas.

Quando o Pimentas I foi entregue, em dezembro de 2015, o Pimentas II, empreendimento com 420 unidades habitacionais, foi invadido, em uma ocupação organizada pela Associação de Deficientes e Idosos e Lar para Todos (CRUZ, 2016). Os invasores foram retirados por meio de reintegração de posse, a pedido da Caixa Econômica Federal, mas o empreendimento acabou sendo vandalizado, o que exigiu nova liberação de recursos para sua finalização. Em novembro de 2016, a obra do Pimentas II ainda permanecia parada, aguardando liberação dos recursos pela Caixa Econômica Federal.

Antes da aquisição de uma unidade habitacional condominial, os moradores da favela Vila Flora, mais conhecida como Itapegica, sofreram com diversos problemas, como incêndios e contaminação do solo no terreno onde a favela se localizava, sendo removidos do seu espaço e deslocados para aluguel social até a aquisição de casa própria pelo Programa Minha Casa Minha Vida faixa 1. Um dos incêndios na Vila Flora ocorreu em 1995, destruindo cerca de 200 barracos, em uma área de aproximadamente 5.000 metros quadrados, deixando, na época, cerca de 500 pessoas desabrigadas ${ }^{81}$

Rosângela ${ }^{82}$, que passou nove anos representando a comunidade da Vila Flora nos movimentos de moradia, em conversa com a autora, comenta que os edifícios habitacionais destinados às famílias do Itapegica deveriam ter sido construídos no mesmo local onde ficava a favela, mas a contaminação do solo impediu que isso ocorresse. O município pretende recuperar o terreno onde estava a favela, descontaminando o solo para a construção de um parque, ainda sem data prevista para ser realizado.

Os moradores, naquele momento, precisaram decidir entre o empreendimento Vila Pimentas I, que já estava em obras, e um outro terreno no Jardim Adriana, que ainda não tinha projeto nem obras em andamento.

Uma comissão, formada por apenas seis moradores do Itapegica (de um total de 482 dentre uma comunidade pouco mobilizada) fez uma campanha, que conseguiu convencer as famílias das vantagens de mudar para o Vila Pimentas I, pois o empreendimento já estava para ser finalizado, o que significaria pouco tempo de aluguel social até receber a casa própria.

Rosângela conta que, no início, a mudança foi positiva, o que é resultado do primeiro momento de aquisição da casa própria, em que se concretiza o sonho individual de moradia. Porém, pouco tempo depois, começaram os problemas, derivados da mistura de grupos so-

81 Segundo matéria publicada na Folha de S. Paulo em 23 maio 1995 (Fogo destrói 200 casas me favela de Guarulhos). Disponível em: <http://www1.folha.uol.com.br/fsp/1995/5/23/cotidiano/22. html>. Acesso 12 dez. 2016.

82 Nome fictício. 
ciais diferentes e de problemas sociais já existentes na favela, que passaram a se agravar pelas regulamentações do modelo condominial: música alta e modo de agir do baile funk, tráfico de drogas, conflitos e desgastes entre os moradores.

Quando se iniciou a constituição do condomínio, envolvendo rateio dos custos, o atrito entre os membros da comunidade já estava instaurado, tanto na vizinhança quanto dentro dos lares, com situações de violência doméstica e discussões familiares causadas pelo diferente interesse de membros da família pela mudança para o novo empreendimento.

No geral, Rosângela relata o maior envolvimento das mulheres na mudança, pois o ambiente na comunidade Vila Flora era muito insalubre, com contaminação ambiental causada pela falta de saneamento básico, o que gerava infestações de insetos e roedores, agravadas quando havia enchentes e incêndios. As mulheres não queriam mais aquele tipo de ambiente para criarem seus filhos.

Apesar das dificuldades na favela, Rosângela comenta que ainda existem muitos moradores que prefeririam ter continuado lá a ter-se mudado para o condomínio. Essa preferência de alguns membros do grupo social ocorre porque na favela não havia organização, contas para pagar e, principalmente, não havia regras. Assim, muitos moradores não se adequaram à vida em condomínio e sentem nostalgia da vida na favela. Por outro lado, não há, ainda, reclamações em relação ao tamanho da habitação na nova moradia.

A teoria do mal-estar condominial desenvolvida por Dunker (2015) se verifica no cotidiano do condomínio Vila Pimentas, à medida em que ocorre desobediência das normas e condutas, gerando hostilidades entre vizinhos e "déficit de felicidade", a partir da imagem que foi emocionalmente vendida pelo modelo condominial.

O Pimentas I é formado por 29 blocos, cada um deles com um líder comunitário, além do síndico e do subsíndico condominial. Nas áreas comuns do condomínio, estão diversos espaços livres remanescentes e pouco qualificados (figura 122), somados às áreas reservadas para estacionamento. Um balanço de madeira e uma quadra esportiva são os únicos elementos de convívio construídos nos espaços livres (figura 121), mas algumas apropriações podem ser vistas, como pequenos jardins criados em pneus pintados e espécies vegetais plantadas pelos próprios moradores, próximas aos seus blocos, ainda que sem interferência do outro.

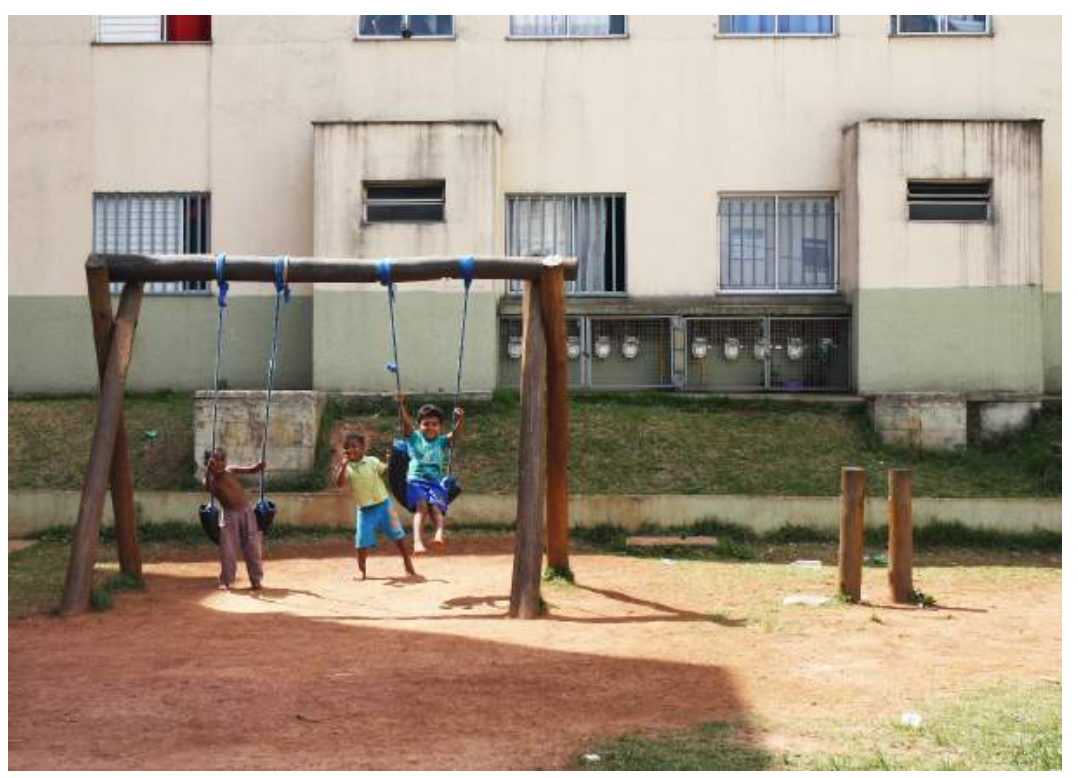

Figura 121: O espaço projetado. Espaços livres projetados no Condomínio habitacional Vila Pimentas I. Fonte: fotografia da autora (2016). 







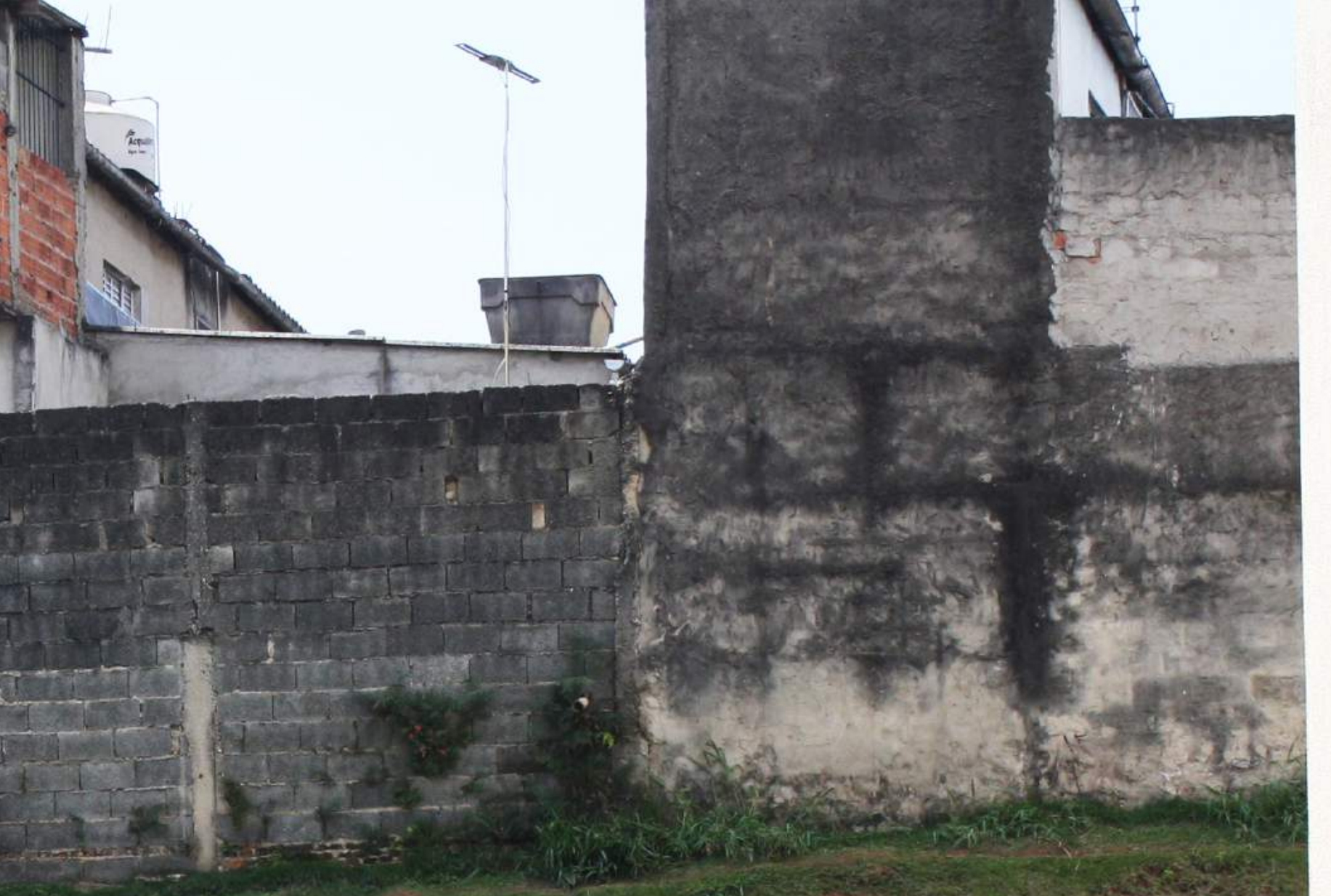

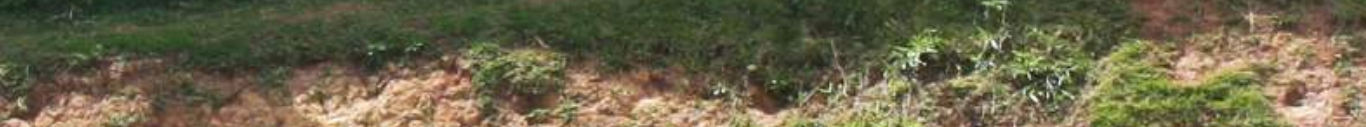

2013

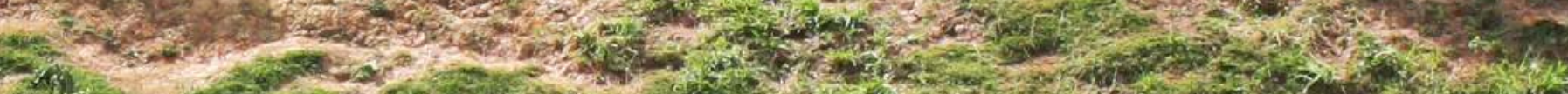
All.

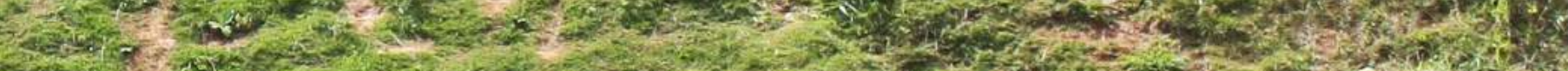

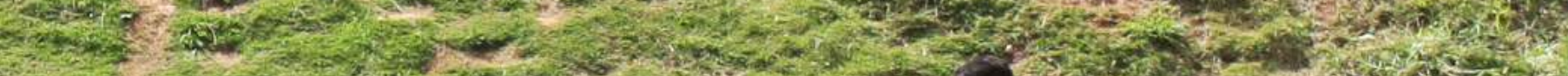
4.

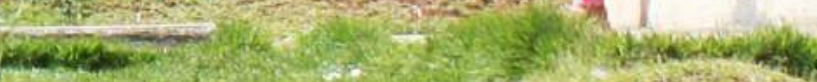
$(-1+3)-30$ 
Os conflitos são agravados pela presença do tráfico de drogas dentro do condomínio. Um dos blocos mais afastados, com posição privilegiada para controlar toda a área livre do empreendimento, se encontra sob domínio de traficantes, que controlam os demais moradores por meio do medo e da coação, o que, infelizmente, limitou esta pesquisa de campo.

Em conversa com a autora, Luigi ${ }^{83}$, morador do Pimentas I, relata que muitos conflitos em relação ao uso do espaço livre ocorrem no estacionamento, já que crianças e jovens, com pouco espaço livre no condomínio para brincar, acabam usando o espaço das vagas de veículos, causando desconforto entre os proprietários, que têm receio de danos ao seu bem material e de atropelamentos.

Luigi também destaca que ele é um dos responsáveis pelo controle da guarita do empreendimento, e ressalta, com orgulho, que não deixa nenhuma criança sair. Em um misto de controle e limitação, resta às crianças passar o cotidiano em espaços fechados, entre o espaço da escola, o transporte coletivo de ida e volta para casa, o espaço privado da moradia e as áreas livres condominiais.

Já os jovens têm maior mobilidade urbana. Luigi comenta que eles têm permissão para sair do empreendimento, costumando jogar bola no campo de futebol no terreno ao lado do Parque Estela, local que é também controlado pelo tráfico de drogas, o que os obriga a seguir regras e normas instituídas pelos líderes do tráfico.

A única quadra esportiva intramuros do condomínio é disputada por diferentes faixas etárias, sendo dominada pelos mais jovens e pelos líderes do grupo social. Resta aos outros moradores o uso das áreas residuais, apropriadas para diversas atividades, principalmente de práticas lúdico-esportivas.

O futebol permanece sendo o principal esporte praticado (figura 123). Em visita de campo ao Pimentas I, moradores estavam jogando na quadra, em área livre próxima a ela e mesmo dentro da sede comunitária, em uma exacerbação da necessidade de mais espaços para práticas esportivas.

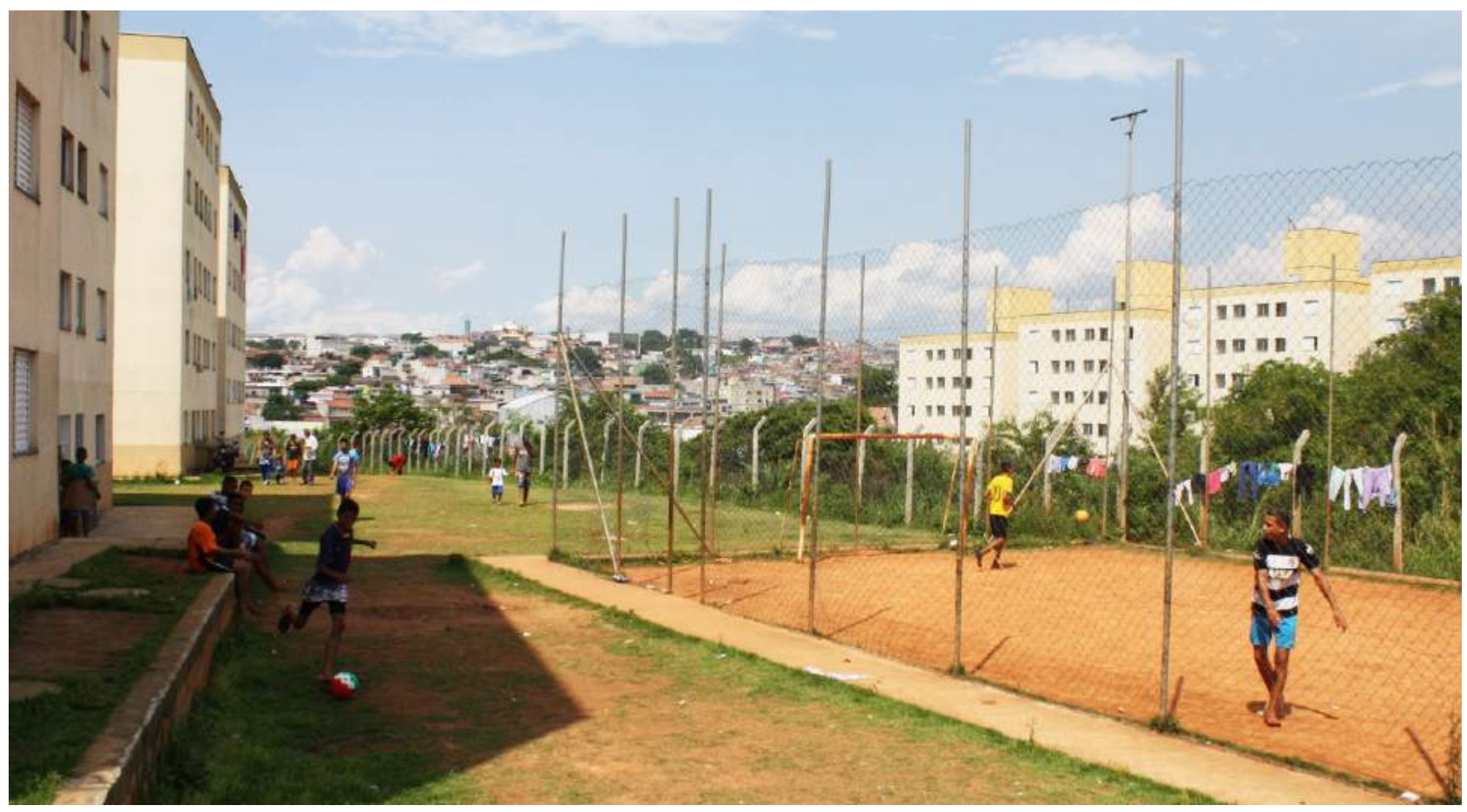

Figura 123: Crianças e jovens jogam bola na única quadra esportiva. Fonte: fotografia da autora (2016). 


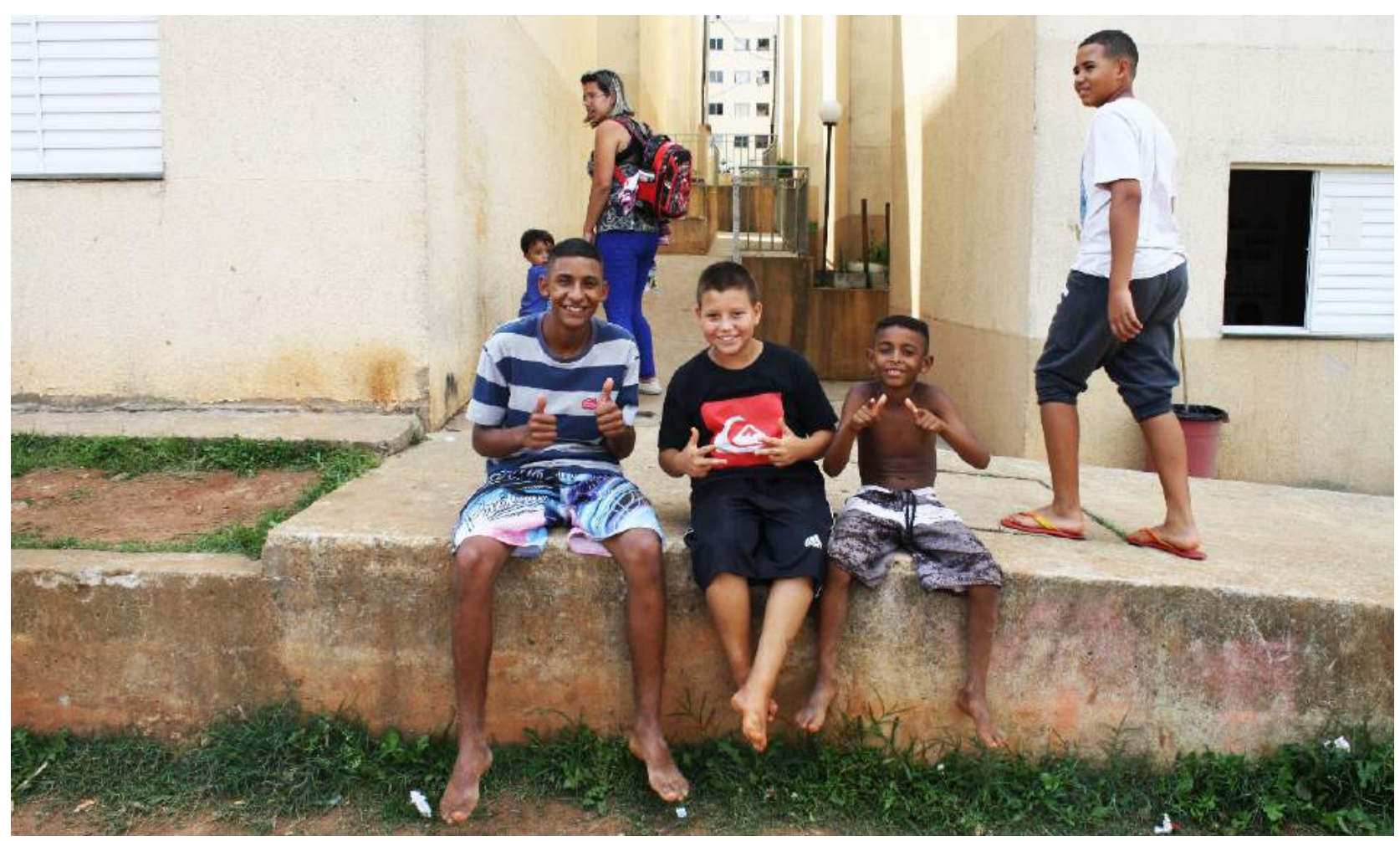

Figuras 124: Crianças e jovens ocupam os espaços livres e observam as partidas de futebol. Fonte: fotografia da autora (2016).

Rosângela relata que gostaria de ver outros equipamentos nas áreas condominiais e constata que há muito espaço livre disponível para eles. A moradora comenta que poderiam ser instalados equipamentos de ginástica, que ela observa em outros empreendimentos. Essa observação, que revela indiretamente a impressão da moradora de que em outros empreendimentos se vive melhor, pois há espaços melhores, é novamente derivada do mal-estar condominial, do isolamento de grupos sociais, da inveja e do desejo em se ter o que é divulgado por veículos de comunicação.

Dunker (2015) comenta a relação do sofrimento interpassivo provocado e organizado pela relação intra/extramuros, pois a vida do outro parece ser sempre mais interessante, enquanto que, do lado de dentro do muro, há somente solidão e banalidade. O mesmo ocorre na visão do outro que, fora do muro, percebe uma satisfação intramuros, que não é real.

A moradora também relata que muitos moradores não trabalham, principalmente homens. São muitos os moradores desempregados no condomínio, mas todas as crianças estão matriculadas em escolas e creches, visto que já estavam todas matriculadas pela prefeitura quando as famílias foram deslocadas do aluguel social para o Vila Pimentas I.

Quando a escola se localiza a mais de 1,5 km de distância, a prefeitura fornece o transporte. Porém, muitas crianças matriculadas em escolas próximas acabam retornando ao condomínio em vans de transporte particular, pela necessidade de adequar a saída da escola com os horários dos pais, pelo entorno pouco amigável e pela pouca frequência de transporte público nos trajetos específicos. Essa situação é vista por alguns moradores com maus olhos, estigmatizando alguns vizinhos que contratam o transporte particular como "vagabundos" ou "preguiçosos". 
Rosângela tem um comércio em um terreno em frente ao Vila Pimentas I, ao lado do Parque Estela. Quando as famílias estavam se organizando para a mudança para o condomínio, Rosângela já tinha assumido o comércio, um misto de restaurante, bar e mercearia. Outros moradores exploram um estacionamento no mesmo terreno, para auxiliar na renda, com ambição de fazer um lava-rápido no local.

A moradora conta que esperava maior movimentação no seu ponto comercial, considerando o número de moradores do entorno. Quando ela abriu o comércio, pensava que a maioria do seu público seria formado pela própria comunidade Vila Flora, mas ela tem mais clientes do Parque Estela e do entorno do bairro. Alguns moradores, majoritariamente do sexo masculino, têm o hábito de ir ao comércio "tomar uma pinga", enquanto outros frequentam o bar para jogar nas máquinas eletrônicas ou para fazer refeições. Rosângela trabalha até as 21 horas diariamente e, após esse horário, tem um vigilante noturno que a ajuda, para garantir que não haja invasão e ocupação do "seu" espaço.

Ali também se organizam algumas festas da comunidade, com música ao vivo. Estas, que começam no anoitecer e vão até o amanhecer, reúnem moradores de todo o entorno, inclusive dos condomínios Vila Pimentas I e Parque Estela. Porém, esses eventos têm ocorrido com menor frequência devido à crise econômica de 2015-2016 e ao aumento do desemprego na região.

Ocasionalmente, ocorrem apropriações no espaço externo aos muros, como no comércio de Rosângela e no uso do único brinquedo externo aos condomínios: um balanço nas árvores dentro do lote comercial, onde brincam crianças do bairro (figura 125). Nesses momentos, interrompe-se o sentimento de receio que as áreas externas parecem provocar nos moradores.

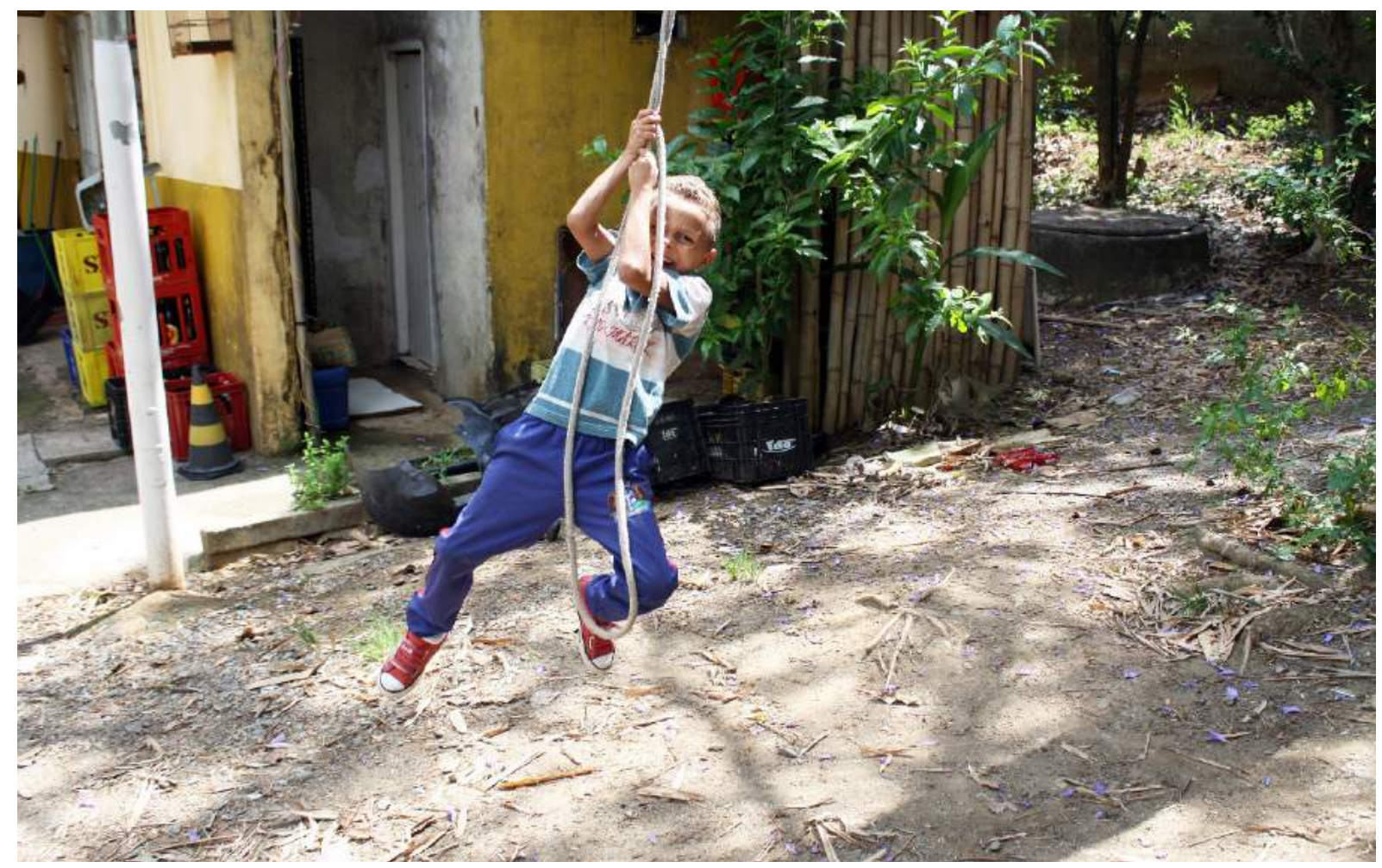

Figura 125: brinquedos improvisados junto ao comércio de Rosângela. Fonte: fotografia da autora (2016). 
Os serviços relativos ao Trabalho Técnico Social junto às famílias do Conjunto Habitacional Vila Pimentas I se encontravam licitados e em fase de contratação no final de 2016, providência sob responsabilidade da Secretaria de Governo, da Secretaria de Finanças e da Coordenadoria de Licitação. Desde a entrega do conjunto habitacional até o momento de finalização do trabalho de campo desta pesquisa, os técnicos da Secretaria de Habitação de Guarulhos estavam assistindo as famílias em plantões sociais semanais, realizando algumas atividades, como atualização dos perfis socioeconômicos, mediação de conflitos entre vizinhos, orientações em relação à manutenção e gestão do condomínio, buscando solucionar demais queixas dos moradores.

Os moradores do Parque Estela e do Vila Pimentas I observam com atenção a obra do Governo do Estado no terreno próximo da rua Mucugeo: o Residencial São Judas I, II, III e IV, da Construtora e Incorporadora Faleiros (figura 126), que prevê a construção de 1.042 Unidades de Interesse Social ${ }^{84}$.

Rosângela vê positivamente a chegada de novos moradores, pois isso pode fortalecer o seu comércio. Aliás, o empreendimento da construtora Faleiros já trouxe benefícios para ela, que atendeu a construtora fazendo mais de 300 marmitas diárias para os funcionários da obra durante o final de 2014 e início de 2015. Toda a família da moradora acordava às 5 horas para fazer a comida das marmitas, contando ainda com ajuda de outras pessoas da comunidade. Naquela época, o empreendimento Vila Pimentas I não havia sido entregue aos moradores, e a família de Rosângela passou a morar no comércio para poder atender à demanda da construtora. Apesar da dificuldade, Rosângela tem boas lembranças daquele momento, que lhe trouxe maior retorno econômico.

Por outro lado, Andreia ${ }^{85}$, moradora do Parque Estela, vê com receio o novo empreendimento, pois teme que os equipamentos públicos e urbanos não comportem tantos usuários. Nesse sentido, a moradora tem razão, pois não adianta haver proximidade com equipamentos públicos, como escolas, postos de saúde, se eles não estiverem capacitados para atender à nova demanda de moradores. Os equipamentos, nas regiões que concentram empreendimentos de habitação social, muitas vezes se encontram saturados, sem vagas. Essa é uma competência municipal, e o Ministério das Cidades poderia criar restrições para que os municípios apresentem sua contrapartida de obrigações aos novos empreendimentos. No entanto, criar parâmetros significa restringir a produção, o que não fez parte da iniciativa que o programa habitacional buscou alavancar.

84 O investimento total do empreendimento, cuja obra se iniciou em outubro de 2014, foi de $R \$ 87.758 .742,26$ (35.674.285,47 USD), onde $R \$ 79.192 .000,00$ (32.191.869,92 USD) foram provenientes do Governo Federal e R\$8.566.742,26 (3.482.415,55 USD) da Casa Paulista, com a Caixa Econômica Federal como agente participante. Valores em dólares segundo conversão realizada em 1 outubro de 2014, com 1 dólar dos EUA/USD equivalendo a 2,46 reais.

85 Nome fictício. 


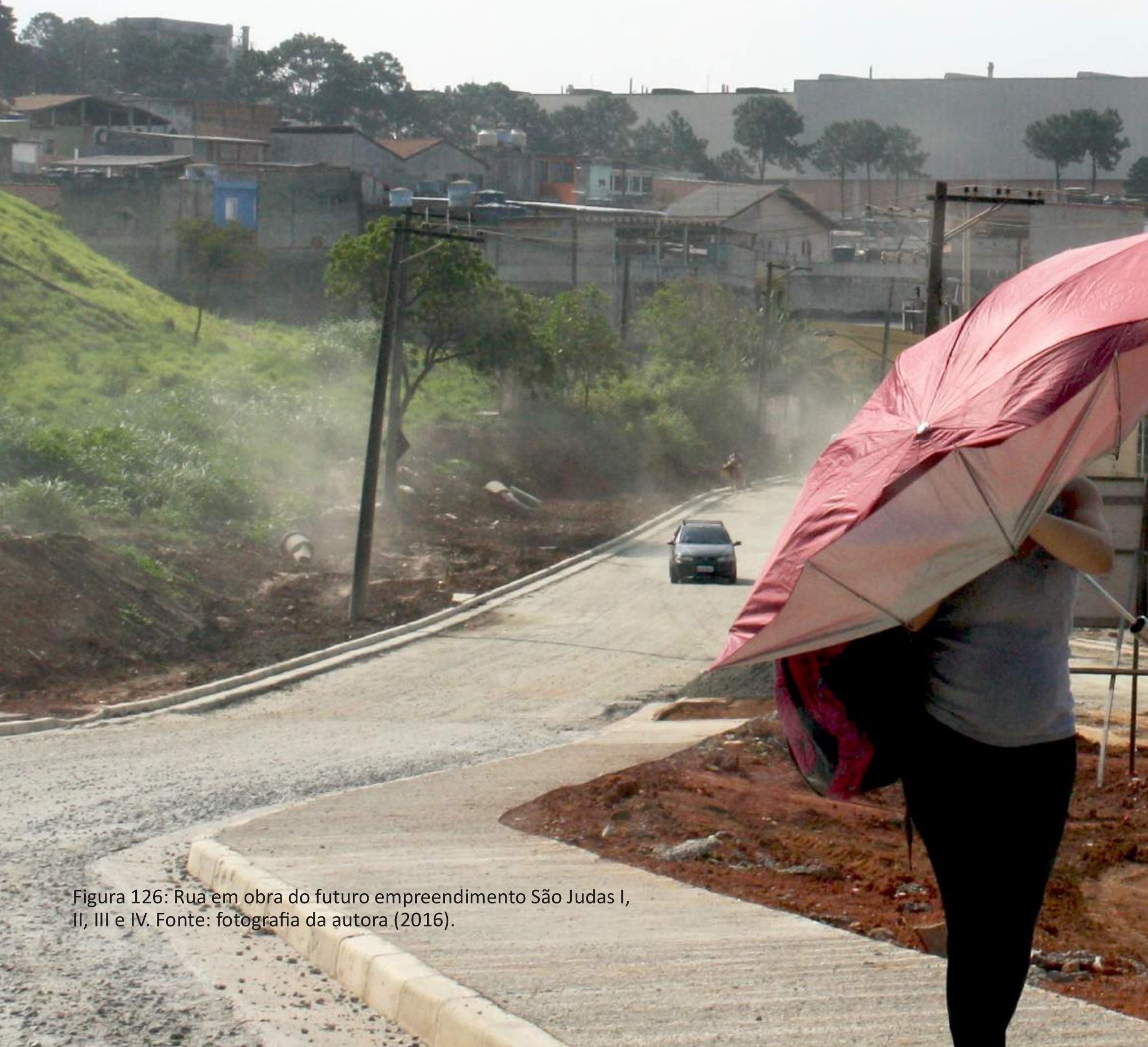




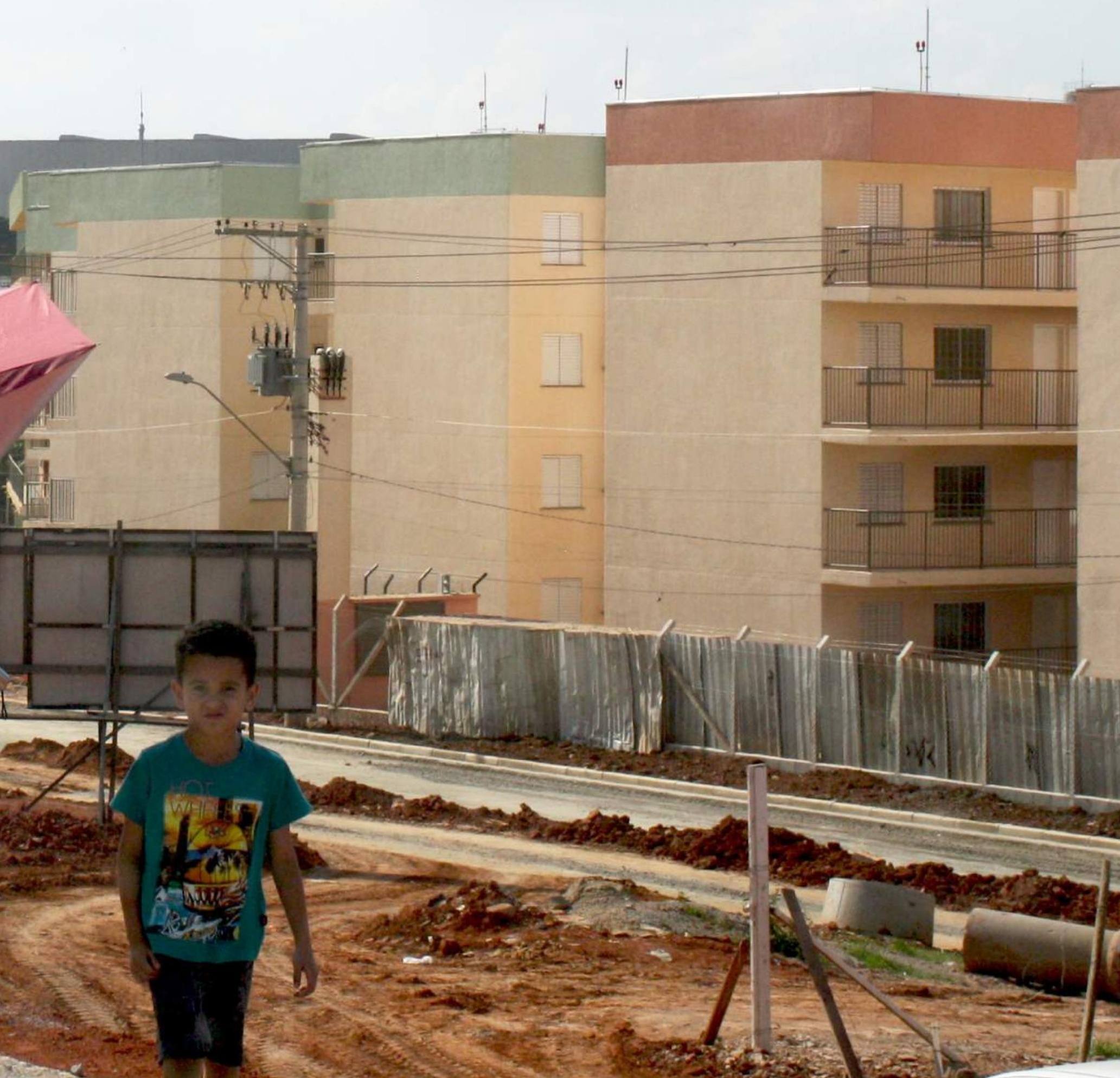


Muitos municípios menores não têm infraestrutura para gerir as obrigações e contrapartidas que poderiam ser feitas, como a produção de equipamentos. Assim, um modelo para apoiar institucionalmente municípios sem recursos precisaria ser traçado. No fundo, é uma discussão de regulação de atuação do Estado e do mercado.

O modelo condominial, quando em habitação social, é complexo, e envolve muito trabalho social para que as famílias se adaptem ao modelo de partilha de espaços e custos comuns. Há de se ter ainda mais atenção aos empreendimentos de grandes dimensões, com vários edifícios partilhando um mesmo condomínio, ou residências unifamiliares carimbadas ad nauseam em áreas de expansão urbana, como já comentado.

A imposição de modelo arquitetônico, urbano e gestacional não traz bons resultados para práticas sociais, o que é agravado pela mudança para uma unidade habitacional muitas vezes menor do que aquelas em que se vivia anteriormente, além do fato de haver novos vizinhos desconhecidos, gastos mensais não planejados e espaços coletivos que não representam as necessidades dos moradores. Em situações como essa, não há possibilidades de que tal modelo funcione de maneira respeitosa aos usuários finais.

Em relação às áreas comuns condominiais, também há poucas possibilidades de estas se adaptarem ao cotidiano das famílias. Equipamentos de ginástica, churrasqueiras, redários e quiosques, estimulados por modismos paisagísticos e imobiliários, são a pura transposição equivocada do modelo habitacional de classe média e alta para a habitação social. Em um primeiro momento, essas áreas são vistas de maneira positiva pelas famílias, já que há o desejo por espaços que são observados na divulgação de empreendimentos de classes mais altas. Porém, posteriormente, o custo e dificuldade de manutenção, além da falta de identificação com os espaços, faz com que eles tendam a se deteriorar, restando apenas áreas livres abandonadas.

De um modo geral, verifica-se receio no uso do espaço externo aos muros, situação sentida pela própria pesquisadora, que sempre foi convidada pelos moradores a estacionar o veículo particular dentro do empreendimento, no caso do Pimentas, ou nas vagas para visitante em frente à portaria, no caso do Parque Estela, em um movimento misto de demonstração de posse de uma vaga de visitante - típica de empreendimentos condominiais de renda mais elevada - e também de estranhamento em relação ao outro, justificado com a sensação de segurança intramuros, frente ao desconhecido urbano do lado de fora.

A pesquisadora também sempre foi acompanhada pelos moradores durante as visitas de campo, mesmo que fosse só para atravessar a rua para chegar ao outro empreendimento. Os moradores, mais do que atenciosos com a presença externa de técnicos, temem alguns atritos com líderes do tráfico, em uma situação de conflito pouco visível para uma pessoa externa ao cotidiano do local, que desconheça os pontos de controle e domínio do tráfico, bastante conhecidos pelos moradores, tanto dentro das áreas condominiais quanto em trechos urbanos.

Essa relação de medo e controle é cotidiana e muito mais complexa do que a simples subjetividade existente no aspecto psicanalítico da vida em condomínio, que ocorre em condomínios de diferentes classes sociais. Em habitação social, quando se reúnem grupos sociais de diferentes origens, geralmente com muitos conflitos entre liderança e poder, a complexidade e a estruturação das relações é muito mais orientada por mecanismos de dominação, como colocou Bourdieu (1989), e pela dependência das condutas individuais e coletivas dentro do sistema de relações que estrutura o habitus.

Bourdieu, Inda e Beneitez (2001) comentam que a vida social acontece tanto dentro de con256 
dições produzidas, como formas morfológicas e modelos administrativos preestabelecidos, quanto em condições não produzidas, nas quais agem as forças de produção e reprodução. A própria conduta dos líderes do tráfico, no modo de se vestir, de se comunicar e na postura impositiva, são habitus estruturadores de uma ação social baseada na coerção e no medo, em uma estrutura de reprodução da dominação que estimula também a reprodução de problemas sociais.

Cada condomínio cria o seu protótipo de cidade, com áreas comuns intramuros que representam um almejo tanto individual quanto coletivo de se diferenciar dos outros. Moradores do Parque Estela ressaltam a diferenciação do seu espaço em relação ao do Pimentas, desorganizado e pouco planejado, em uma sensação de diferença e de satisfação inconsciente de inveja dos outros.

Dunker (2015) comenta que, nos condomínios, as diferenças são resolvidas por meio de um sutil código de convívio, em uma invenção de vida comum sem que haja uma verdadeira comunidade, ou seja, trata-se de uma vida cotidiana (des)praticada, inventada, controlada e idealizada, restrita a um mesmo grupo social. O condomínio, para Dunker (2015), representa uma nova política de manejo das diferenças e conflitos e do antagonismo social, exigindo uma figura de liderança que proponha o ideal de convívio para gerenciar conflitos e tornar possível o cotidiano, o que pode se verificar com a presença de líderes comunitários mais ativos nas normatizações condominiais, como ocorre no caso do Parque Estela.

O conflito administrado intramuros, para o psicanalista, é um mal-estar suprimido, intermediado por fantasias e sintomas. Quando um sintoma, como um uso imprevisto dos espaços coletivos, surge e passa a ser fonte de angústia, isso gera uma nova solução fantasiosa, o que pode ser exemplificado com as remediações de conflitos em condomínios de habitação social, com as normatizações do uso dos espaços coletivos para solucionar problemas causados por usos distintos dos espaços, como ocorre na apropriação do espaço livre do estacionamento no Villa Pimentas I, remediando-se o conflito com os moradores que possuem veículos particulares.

O condomínio é uma espécie de unidade autônoma urbana, uma nova comunidade, que substitui e supre a ausência de urbanidade dos entornos de habitação de interesse social. Porém, principalmente em habitação social, o condomínio é regido por regras e exceções a elas, que levam a perdas de experiência social pelo isolamento dos indivíduos e pela (des)prática imposta pelos conflitos solucionados. Essas exceções são orientações submetidas por autoridades que manipulam regras e isenções a elas, direcionando as práticas sociais, que é o que ocorre com a figura do síndico, do líder comunitário, e mesmo dos moradores associados ao tráfico de drogas e ao crime organizado, dentre outras formas de controle e poder. A separação e a (des)prática regulamentada e marcada por exceções se traduz em um isolamento pessoal, baseado em sentimentos de estranheza e hostilidade para com o outro.

O condomínio habitacional social representa o que Milton Santos (2001) colocou como pobreza "incluída", que se produz e se mantém em um mesmo lugar, contendo o ressentimento social em um ambiente controlado. Na situação intramuros, o cotidiano (des)praticado é também estigmatizado pela personificação de atitudes. Tanto os líderes do tráfico, como a vizinha líder comunitária, representam posições relacionadas às regras sociais, definidas e sustentadas por eles mesmos e também por outros moradores e usuários do espaço, em um jogo de representação baseado em domínio e controle normativo. 
Capítulo 7: Cotidiano de bairro

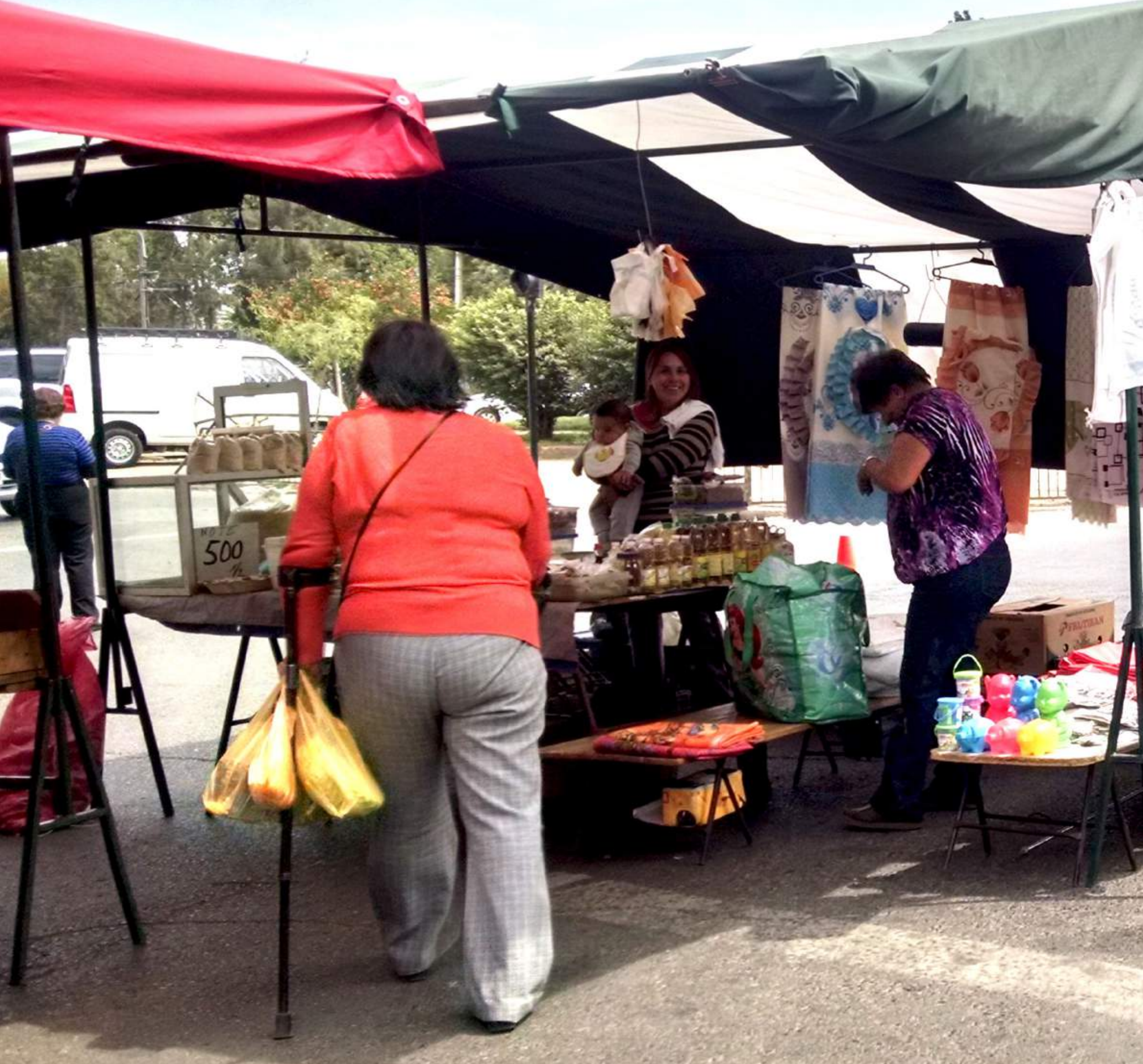

Figura 127: Feira livre em Cerro Navia, Santiago. Fotografia da autora, de nov. 2015. 





Os anos de problemas com as experiências chilenas de produção habitacional social pautada por objetivos quantitativos estimularam a criação de rearranjos políticos dentro dos programas habitacionais, além de iniciativas para buscar amenizar casos mais dramáticos que surgiram nessa trajetória, inclusive articulando programas para atuar conjuntamente em um mesmo território. Dentro das iniciativas destacadas por esta pesquisa, além do caso de Bajos de Mena (já abordado no capítulo 5), estão situações pontuais realizadas em algumas comunas da região metropolitana, como ocorreu com a criação do Lomas del Prado e a ação na población Santa Adriana, ambas intervenções urbanas com dinâmica de bairro.

O Las Viñitas/Lomas del Prado foi uma intervenção com ações integradas do Programa Quiero Mi Barrio (PQMB) e recursos do Fondo Solidario de Vivienda (FSV), e que resultou na demolição, em 2012, do conjunto habitacional Las Viñitas, construído em 1985, e na construção do bairro Lomas del Prado, também em 2012, ambos na comuna Cerro Navia.

Já o caso de Santa Adriana, na Comuna Lo Espejo, foi escolhido como uma das intervenções principais do Programa Quiero Mi Barrio logo na sua criação, realizando trabalhos urbanos, sociais e culturais com foco nas práticas sociais, de setembro de 2006 ao final de 2014.

Neste capítulo, será apresentada, primeiramente, uma contextualização sobre os programas públicos atuantes nos estudos de caso.

\section{Os Programas Quiero Mi Barrio (PQMB) e Fondo Solidario}

O PQMB foi idealizado para agir além dos programas habitacionais: com foco em propostas de desenvolvimento de bairro e cidadania, atua, principalmente, na recuperação de espaços públicos deteriorados em comunas periféricas para melhorar as condições do entorno e fortalecer as relações sociais.

É um programa de ação socioespacial com foco nas práticas sociais, que aposta no potencial dos espaços livres para integrar socialmente bairros e revigorar o convívio social cotidiano. Busca atuar a partir da noção de que o estado físico de um bairro influi substancialmente para a estigmatização do território e para a concentração de fatores de vulnerabilidade social, que incluem contextos de pobreza, marginalização, desemprego, baixos níveis educacionais, deterioração, precariedade dos espaços de convívio social, insegurança, violência, delinquência e, consequentemente, inclusão periférica e estigmatização social (SEREMI, 2008).

Assim, o PQMB atua em setores urbanos chilenos com problemas de deterioração urbana e vulnerabilidade social. O prazo médio de atuação é de, aproximadamente, dois a três anos, dependendo da complexidade do local, pois cada caso tem a sua particularidade, que é reconhecida pelos profissionais atuantes no Programa. Com equipe multidisciplinar, a intervenção tem possibilidade de ser diária e direta com a comunidade desde o início da atuação, com a elaboração do diagnóstico e do plano de ação com participação de vizinhos e equipes técnicas.

Nesse sentido, os resultados são dependentes do equilíbrio entre a definição dos campos de atuação, o tempo de operação junto à população e a conscientização dos participantes sobre a continuidade autônoma das mudanças, de maneira que é necessário encorajar, não somente a participação cidadã, mas principalmente o sentimento comunitário de corresponsabilidade, chave para a continuidade das ações após o término da intervenção (SEREMI, 2008).

Como estratégia para alcançar essa conscientização, o programa cria uma série de instâncias locais: um conselho de vizinhos (Consejo Vecinal de Desarrollo - CVD), instância legal que 
representa o grupo social; uma equipe interdisciplinar da Secretaria Regional Ministerial (SEREMI) Metropolitana de Vivienda y Urbanismo, com possibilidade de definir uma equipe específica de acompanhamento diário para o bairro para os casos de maior vulnerabilidade; uma Mesa Técnica Comunal, instância de trabalho e coordenação das ações pelos profissionais do SEREMI que pode ter participação do CVD, e uma Mesa Técnica Regional, em que profissionais do SERVIU, SEREMI e Equipe Regional revisam tecnicamente e aprovam (ou não) os projetos.

Todas essas instâncias são responsáveis pela definição de um Projeto Integral de Recuperação do Bairro, que abarca um Plan de Gestión de Obras (PGO), um Plan de Gestión Social (PGS) e um Plan de Gestión de los Recursos Complementarios (PGRC).

As ações do PQMB ocorrem, dessa forma, tanto na escala visível do urbano quanto na escala invisível das redes e práticas sociais. Para a atuação na dimensão social, são realizadas atividades diversas para estimular a reunião e a cidadania, por meio de atividades recreativas, de esporte, de saúde, de trabalho e de educação (SEREMI, 2008). Já na atuação urbana está a recuperação das áreas públicas, como de circulação e convívio social, construção de equipamentos e também melhor definição legal, normativa e identitária das áreas habitacionais.

O Programa teve início no ano de 2006 com 200 bairros selecionados em todo o país, dentre eles, 86 na Região Metropolitana (SEREMI, 2008).

Evidentemente, em uma atuação desse porte, alguns bairros tiveram intervenções menores e mais curtas, enquanto outros passaram por ações mais duradouras e amplas. Dentre os Programas com grande atuação na RMS estão Las Viñitas-Lomas del Prado e a población Santa Adriana, sendo esta última um setor que teve, até o momento atual, a maior intervenção do $P Q M B$, tanto no que tange ao tempo de atuação quanto ao montante de recursos aplicados ${ }^{86}$ e ao porte da intervenção.

O Programa Fondo Solidario de Vivienda (FSV - Decreto Supremo [D.S.] No 174 de 2005) ${ }^{87}$, criado durante o governo de Ricardo Lagos, sofreu alterações nos governos que se seguiram, mas continua atuante em 2016. O funcionamento do FSV acontece por meio da entrega de subsídios tanto para construção ou reformas de habitações sociais quanto para adquirir habitações já construídas. O FSV seleciona os beneficiários cadastrados em uma Ficha de Proteção Social, a qual categoriza as famílias por pontuação de carência, considerando, dentre outros, situação de allegamiento ${ }^{88}$, grande densidade populacional e habitacional, deterioração e precariedade da habitação, carência de água e ou esgoto e participação no Chile Solidario ${ }^{89}$.

Para a aquisição de habitações, as postulações ao programa são feitas de maneira individual; para construção, são coletivas.

86 O investimento do Programa Quiero Mi Barrio no setor foi de 7.000.000.000 de pesos chilenos, equivalentes a aproximadamente 9.930.000 USD segundo conversão de 30 de setembro de 2015, com 1 peso equivalente a 0,00142 dólar.

87 Segundo Decreto Supremo (D.S.) No. 174 de 2005, disponível em: < http://www.minvu. cl/incjs/download.aspx?glb_cod_nodo=20061113165715\&hdd_nom_archivo=DS_174_2005_ ACT_20_03_15_FSV.pdf>. Acessado em 18 dez. 2016.

88 O allegamiento é uma palavra chilena que se refere a mais de uma família compartilhando uma mesma unidade habitacional.

89 Criado em 2002, o Chile Solidario é um componente do Sistema de Protección Social, o qual atende às famílias em situação de vulnerabilidade, atuando de forma descentralizada, com programas próprios e em convênio com outros. 
O projeto de construção de habitações novas no FSV (D.S. N 174 ) era realizado por meio da Entidad de Gestión Inmobiliaria Social (EGIS) ou, no caso das áreas rurais, pelo Prestador de Servicios de Asistencia Tecnica (PSAT). As PSATs já atuavam antes da criação do FSV, mas, com a criação das EGIS, dividiu-se a atuação destas em três ramificações: Programa Fondo Solidario de Vivienda I e II e os PSATs para as famílias que optassem pelo Subsidio Habitacional Rural e Programa de Protección del Patrimonio Familiar (PPPF).

Assim, o Programa Fondo Solidario instituiu, dentro de um novo marco regulatório, a participação das entidades de assistência técnica, que são contratadas pelo Estado, não podendo cobrar honorários adicionais aos postulantes.

Em 2011, alteraram-se alguns aspectos do Programa FSV, mudando-lhe a denominação para Fondo Solidario de Elección de Vivienda, passando a ser gerido pelo Decreto Supremo $\mathrm{N}^{\circ} 49^{90}$. As EGIS foram substituídas por uma nova figura legal, as Entidades Patrocinantes (EP), porém sem alteração nas funções desempenhadas dentro do programa.

Com a mudança do FSV para Fondo Solidário de Elección de Vivienda a partir do D.S. 49 em 2011, altera-se principalmente a estrutura do subsídio (que antes era dividido por subsídio base e subsídio para a aquisição e para a localização da habitação entre outros), e que, após o novo decreto, passa a ser único, incluindo todos os aspectos anteriores e passando a ser regionalizado, ou seja, definido em UF conforme a localização no território ${ }^{91}$.

EGIS, EP e PSAT são nomes diferentes para fundações que têm funções similares: organizam as famílias interessadas em postular por um subsídio, assessoram-nas legalmente e apoiam no desenho dos projetos e na construção, entre outros aspectos, destacando-se a elaboração do Plan de Habilitación Social (PHS), que permite às famílias participarem do processo.

A atuação das EGIS, EPs e PSATs chilenas é correspondente à figura do Entidades brasileiro. Todos atuam assessorando e representando as famílias cadastradas para receber habitações sociais, com responsabilidades que variam de aspectos técnicos, como realização de projetos, contratações de empresas para a realização das obras, vistoria das obras, à organização social.

Uma particularidade, no caso chileno, é que algumas EPs podem ser de direito público, como administrações municipais ou o próprio SERVIU, instituições essas que podem se tornar EPs para facilitar o acesso ao subsídio de algumas famílias, o que se assemelha ao Trabalho Técnico Social brasileiro, de etapa complementar ao PMCMV.

Porém, segundo dados levantados por Paz em 2010, a maioria das EGIS atuantes na Região Metropolitana de Santiago, correspondendo a $87,6 \%$ do total, eram de caráter privado. Dentre elas, algumas são formadas por organizações sem fins lucrativos, como Organizações não Go-

90 Disponível em: <https://www.leychile.cl/Navegar?idNorma=1039424>. Acessado em 18 dez.

2016.

91 O subsídio base passou a ser 330 UF para construção em novos terrenos, 500 UF para construção em terreno próprio, 550 UF para construção em "densificação" predial (novos edifícios habitacionais em um conjunto habitacional já existente), 550 UF para construção em pequeno condomínio e 280 UF para aquisição de habitação construída.

Os subsídios complementares foram mantidos praticamente com os mesmos valores. O Subsidio Diferenciado a la Localización se manteve em até 200 UF, mas surpreende a criação do Subsidio de Factibilización, que facilita novamente a criação de habitações sociais em regiões periféricas, enquandrando os projetos que não cumprem os requisitos para o Subsidio Diferenciado a la Localización e oferecendo até 120 UF para projetos de construção em áreas rurais ou de extensão urbana. 
vernamentais (ONGs), e outras por corporações com finalidades lucrativas, como construtoras e empresas de consultorias, dentre outras (PAZ, 2010).

Algumas EGIS/EPs também foram formadas por comitês de vivienda e movimentos de moradores, como o Movimiento de Pobladores en Lucha (MPL) e o Movimiento Pueblo sin Techo (MPST), que se formaram para satisfazer as necessidades sociais e urbanas dessa parcela da população (CASTILLO, 2013).

A figura das EGIS/EPs e do Entidades (PMCMV-E) possibilita a maior participação das famílias no processo de aquisição da casa própria, mas todas enfrentam o mesmo problema de busca de solo urbano para a construção das habitações sob sua coordenação: embora no Chile exista um subsídio específico, complementar, para a compra de terrenos mais bem localizados, não há um mecanismo que regule os terrenos disponíveis para a construção de habitações sociais, como existe na figura dos Planos Diretores brasileiros e as ZEIS.

Apesar da presença das EGIS/EPs demonstrar uma maior aproximação da política chilena com os processos participativos coletivos, os programas e subsídios chilenos operam baseados nas iniciativas particulares e não coletivas, focando o sucesso individual na conquista da casa própria, o que acaba por estimular a vida cotidiana no ambiente privado e não no espaço coletivo. São possibilidades diversas para se obter subsídios, ou mesmo bonificações, para ações individuais.

A preocupação com a participação popular nos programas habitacionais sociais no Chile passa a ser notada nos anos 1990, porém a inserção da participação nos instrumentos legais ainda é bastante tímida no caso chileno, se comparado aos diversos instrumentos brasileiros já criados.

Nos programas chilenos, as famílias procuram o SERVIU, cadastram-se (similarmente ao Cadúnico brasileiro) e, de acordo com sua pontuação, são selecionadas para receber o subsídio do programa. O cadastro não ocorre através das entidades, e o contato destas com as famílias acontece somente a partir do momento de contratação, não atuando, em geral, na organização social de grupos para solicitar a participação nos programas.

O subsídio se alterou nas diferentes frentes de atuação do Fondo Solidario, variando o custo máximo de 750 a 1.000 UF $^{92}$, a depender da comuna onde se localizam. As famílias deveriam apresentar particularidades de valor de poupança, que variou de 10 a 30 UF, além de aportes adicionais que foram criados a partir da segunda fase do programa, como créditos opcionais ${ }^{93}$.

Alguns subsídios adicionais foram criados, como o Subsidio Diferenciado a la Localización, usado para compra de terreno de até 200 UF. No caso de as famílias não o solicitarem, a aquisição do terreno poderia utilizar até $30 \%$ do valor do subsídio original.

São diversos os critérios de elegibilidade para o subsídio de localização, como distâncias a equi92 Como já comentado no capítulo 2, a UF (Unidad de Fomento) é a moeda de câmbio criada em 1968 e utilizada no Chile até o período atual, sendo constantemente ajustada à inflação e ao dólar. Em 01 jan. 2015, a UF correspondia a 24.627,10 pesos (38,97 dólares, considerando a cotação do dólar em 21 mar. 2015, segundo a qual 1 dólar correspondia a 632 pesos). Fonte: Base de Dados Estadísticos - Banco Central de Chile.

93 De um modo geral, o subsídio repassado às famílias, no FSV I (para famílias mais vulneráveis, com pontuação de carência de até 8.500 pontos), foi de 330 a 470 UF para habitações a serem construídas, e de 280 a 420 UF para habitações a serem adquiridas, com poupança familiar comprovada de 10 UF. Já no FSV II (para famílias com carência de até 11.734 pontos), a poupança familiar exigida chega a 30 UF, e tanto a construção quanto a aquisição contam com subsídio entre 280 e 420 UF. No FSV III (habitações na área rural), o valor de subsídio foi o mesmo do FSV II, porém com a poupança familiar cotada em 10 UF. 
pamentos, acesso ao transporte público e prioridade a grupos pequenos, de no máximo 150 famílias, oriundas da mesma comuna ou de comunas vizinhas.

Embora esse subsídio pareça interessante para auxiliar na busca por melhor localização das habitações sociais, na prática ele causa um conflito, pois faltam critérios que definam o que seria uma boa e uma má localização, uma boa e uma má inserção urbana, limitando-se a definir distâncias mínimas a equipamentos e transporte, sem considerar a complexidade do fenômeno da habitação social periférica, que ocorre de maneira diferente em cidades pequenas, médias e em regiões metropolitanas. Tal aspecto poderia ser aprimorado caso se complementassem as exigências, como por exemplo, impedindo que o subsídio fosse destinado a novos conjuntos habitacionais em setores com presença massiva de conjuntos habitacionais sociais, para não estimular o fenômeno das grandes concentrações de habitação social.

Além do Subsidio Diferenciado a la Localización, existem outros subsídios complementares que podem ser solicitados pelo Fondo Solidario ${ }^{94}$. Os grupos vulneráveis participantes do Fondo Solidario também podem requerer subsídio para melhorar a habitação individualmente ou podem solicitar participação no Programa de Protección al Patrimonio Familiar (PPPF), que oferece subsídios adicionais para o melhoramento do entorno da habitação e do equipamento comunitário.

No entanto, esses subsídios adicionais parecem mais beneficiar os interesses particulares do que melhorar a qualidade de vida coletiva, pois, na prática, atuam para complementar o financiamento e promover benefícios individuais ao invés de melhorar o entorno do equipamento.

Além disso, as brechas legais ou as poucas exigências trazem mais benefícios ao mercado imobiliário do que às famílias em vulnerabilidade social. Como exemplo de brechas legais, está a estipulação de que os subsídios possam ser aprovados cumprindo $50 \%$ dos requisitos exigidos (como apenas o tocante à localização); requisitos esses computados em itens como acesso a transporte, permitindo-se receber o subsídio caso se atinja pontuação mínima em cada item (BRAIN; MORA, 2011).

O Fondo Solidario de Vivienda (FSV) trouxe um aspecto legal interessante para os Programas, com a participação de entidades e com a exigência de execução, por elas, de um Plan de Habilitación Social (PHS), com participação da população, para promover atividades diversas que estimulem as redes comunitárias.

Apesar do excesso de subsídios complementares, não há nenhum que incentive o coletivo e as redes sociais, que possa estimular a luta coletiva pelo habitat à frente da luta individualista pela habitação. Também não há exigência na associação de programas habitacionais com programas de bairro, o que faz com que a política do Fondo Solidario atue mais como programa de subsídio à produção imobiliária do que como programa que busque integralmente melhores soluções para as famílias de recursos escassos.

94 Como exemplo dos subsídios complementares que podem ser solicitados pelo F.S., estão: 20 UF destinadas a famílias com membros com necessidades especiais; entre 5 a 70 UF para a construção de equipamentos, saneamento e tratamento de água e para construção em altura, e até 50 UF para projetos que possibilitem maior superfície nas habitações, acrescentando 2 UF por cada 0,5m² que exceda os $37,5 \mathrm{~m}^{2}$ da habitação. Este último é um subsídio de $30 \%$ do subsídio base, que atua em todas as modalidades e que está associado ao subsídio de localização e a projetos de conjuntos habitacionais em condomínios de prédios. Porém, para receber o subsídio, o projeto deve cumprir alguns critérios, como o apartamento ter três dormitórios e metragem a partir de $55 \mathrm{~m}^{2}$. 
Las Viñitas e Lomas del Prado - demolições e novos desenhos urbanos com o Programa Fondo Solidario de Vivienda

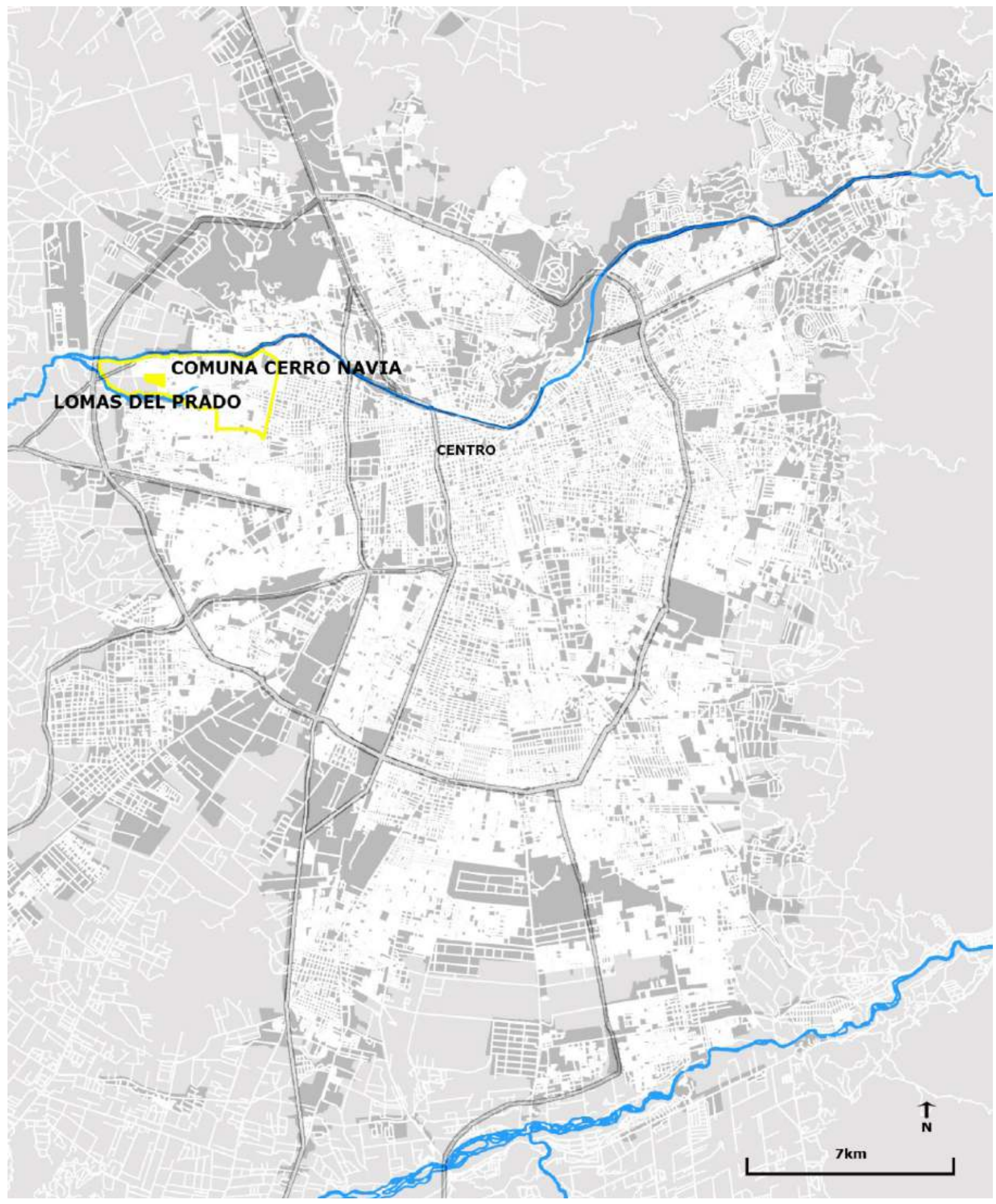

Figura 128: Localização de Lomas del Prado, na Comuna de Puente Alto. Fonte: elaboração da autora, sob base OCUC - Observatorio de Ciudades (2003) e Google Earth (2015). 
Cerro Navia se localiza no setor noroeste da região metropolitana (figura 128), e sua origem remonta à subdivisão de chácaras e à incorporação de setores rurais como bairros da cidade, ocorrida com a expansão de Santiago e o crescimento da antiga comuna Las Barrancas a partir dos anos 1880.

O conjunto habitacional Las Viñitas, localizado em Cerro Navia, foi construído em 1985, durante o Regime Militar, e era composto por três poblaciones: Viñita I, Viñita II e La Hondonada.

Originalmente, Las Viñitas era delimitado pela Av. Mapocho ao norte; pela rua El Parronal à oeste; por um muro, que dividia esse conjunto da población Santa Elvira, à leste, e pela rua La Hondonada ao sul, dividindo a población do "Cañadón de La Hondonada", espaço de solo contaminado em recuperação para abrigar um parque urbano (figura 129).

Las Viñitas surgiu com a política habitacional desenvolvida pelo MINVU nos anos 1980 e no início do Programa Vivienda Basica, em um período de intensa construção habitacional por parte do Estado. Era constituída de 1.029 apartamentos de $35 \mathrm{~m}^{2}$, organizados em 67 blocos de três andares. No primeiro andar, estavam habitações térreas e, no segundo e terceiro, apartamentos duplex.

Las tres poblaciones son construidas durante los años 1984 y 1985, y la recepción final de las obras por la D.O.M de la I.M. de Cerro Navia se realiza con fecha 28 de mayo de 1985 para el caso de las poblaciones Viñita I y II, y el 11 de Julio del mismo año para La Hondonada. Por lo tanto, lo más probable es que los blocks ya hayan estado casi totalmente construidos para el terremoto de 1985. Posterior a esta fecha la mayoría de personas que llegan a ocupar estos departamentos son damnificados del terremoto que han sido erradicados de campamentos con un origen mayoritario en la Comuna de Quinta Normal. (SEREMI, 2008, p. 09)

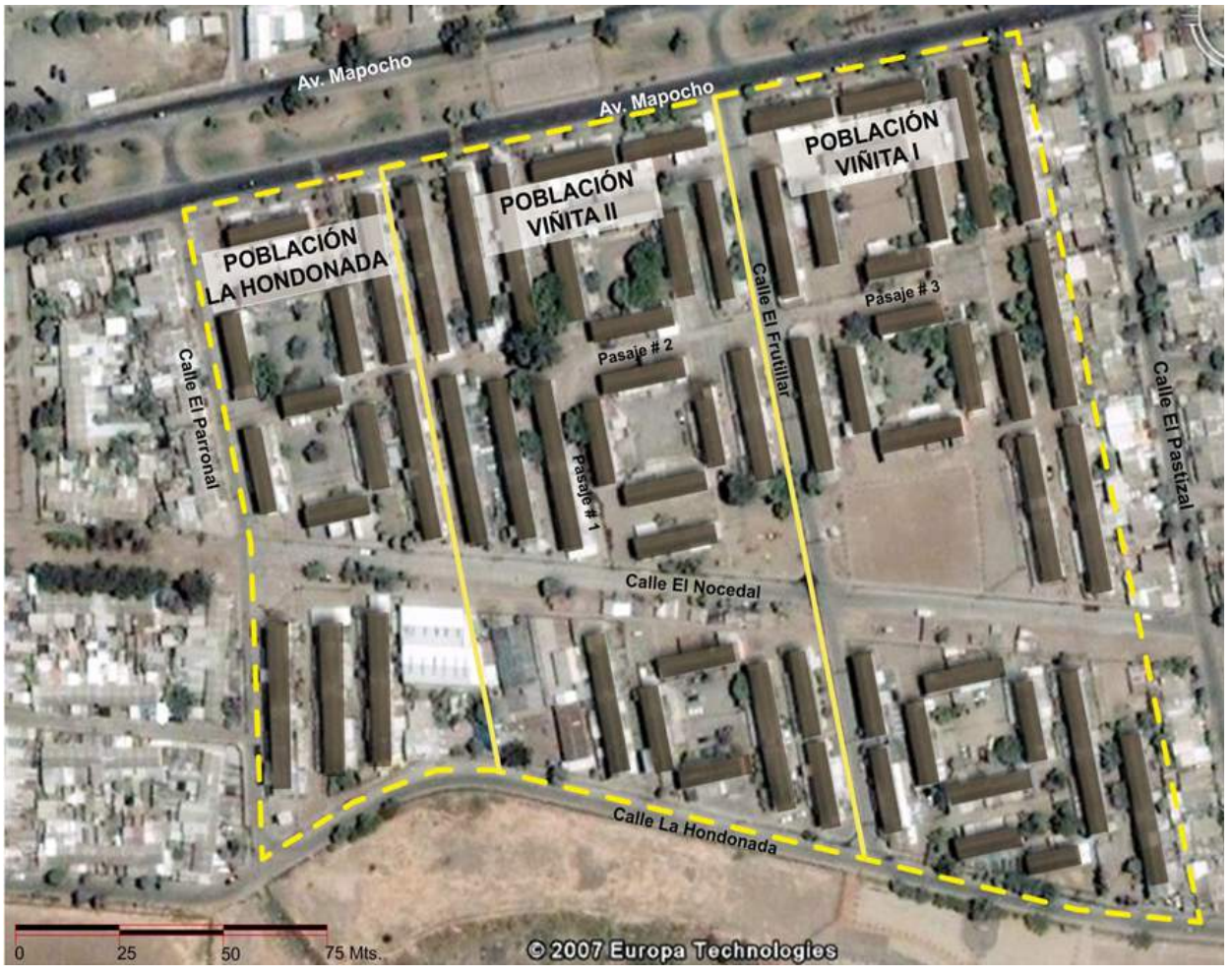

Figura 129: Foto aérea da implantação do conjunto habitacional Las Viñitas. Fonte: material cedido pelo MINVU e Google Earth (2007). 
Segundo o SEREMI (2008), a partir de dados do Censo CASEN de 2006, Las Viñitas abrigava 3.665 habitantes em 1.029 habitações de aproximadamente $36 \mathrm{~m}^{2}$, sendo que $70 \%$ deles correspondiam a proprietários, 20,9\% a arrendatários e 5,6\%, a allegados, com uma população majoritariamente jovem, com maior proporção de crianças e 57\% dos moradores com menos de 30 anos.

Devido à falta de espaço, muitas famílias ampliaram suas habitações, criando problemas estruturais nos edifícios, assim como conflitos pela apropriação individual dos espaços comuns.

Interessante analisar como era constituído o sistema de espaços livres do conjunto habitacional, pois grande parte do solo do conjunto correspondia a copropriedades, onde os vizinhos são proprietários de cada apartamento e coproprietários dos terrenos comuns, o que significa que os terrenos comuns são privados, mas de uso coletivo. Essa característica do uso do solo significa que as áreas livres não podiam ser tratadas como áreas públicas, mas sim como áreas privadas de responsabilidade de todos os proprietários, com a manutenção sendo de responsabilidade dos moradores, o que é equivalente ao sistema condominial brasileiro.

Os três conjuntos habitacionais que conformaram a población se subdividiam em 10 territórios de copropriedades independentes, três na población Viñita I, quatro em Viñita II e três em La Hondonada. Assim, 74,7\% dos terrenos estavam em regime de copropriedade (SEREMI, 2008).

Porém, essas áreas estavam muito mal delimitadas no conjunto habitacional (figura 130), o que causava confusão entre os moradores para custear sua manutenção, contribuindo para seu abandono e consequente deterioração.

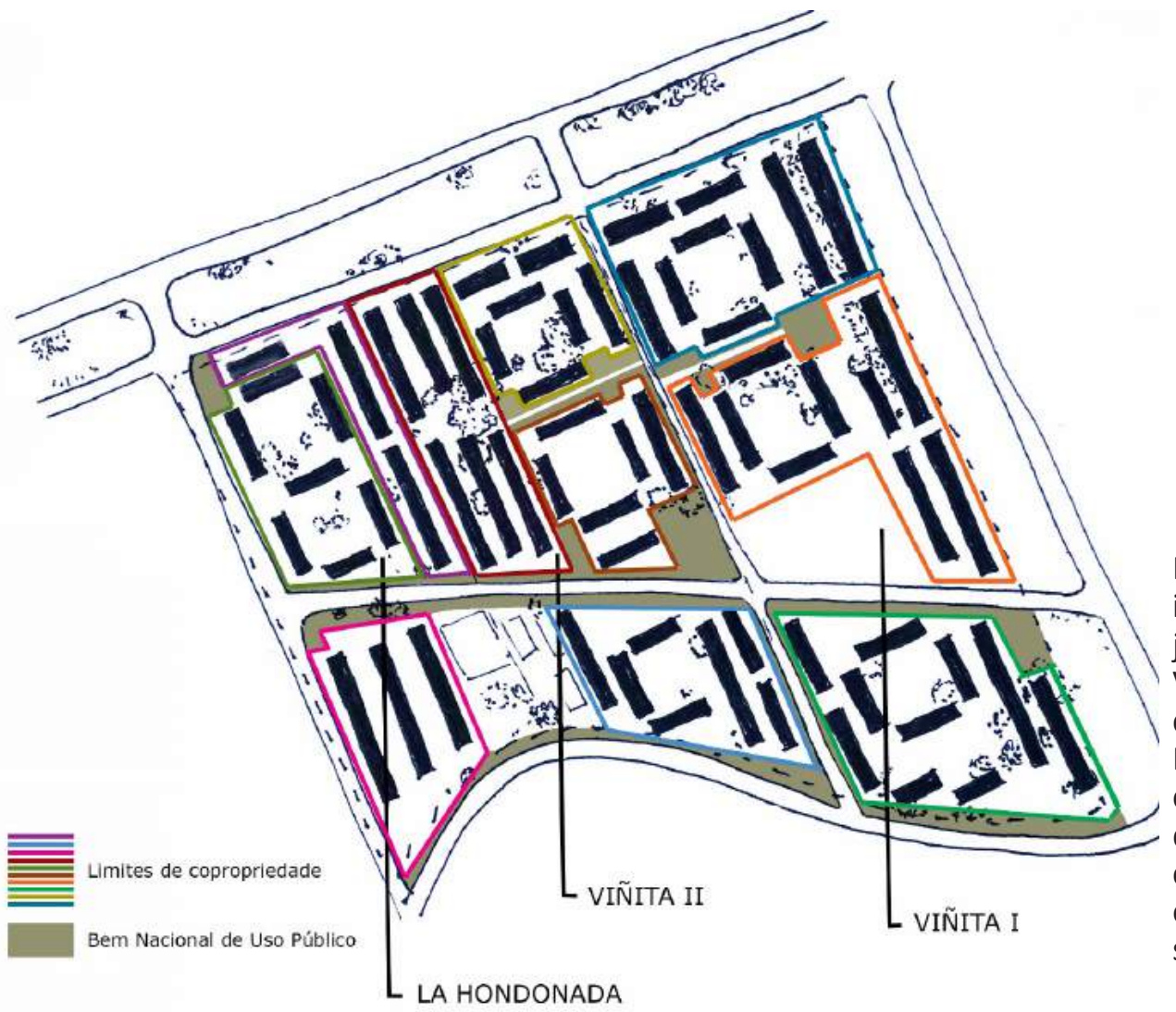

Figura 130: Croqui da implantação do conjunto habitacional Las Viñitas com a delimitação das áreas de Bem Nacional de Uso Público e das confusas áreas de copropriedade de cada conjunto. Fonte: elaboração da autora, sob dados do MINVU. 
Com o passar dos anos, grande parte das áreas livres foram sendo ocupadas, principalmente por ampliações das unidades habitacionais e estacionamento de veículos particulares.

Las Viñitas (e seu regime de copropriedade) foi considerada caso exemplar dos impactos negativos do modelo de produção de habitação social em condomínios. Muitos dos problemas surgidos foram associados a esse regime condominial que, pelas dificuldades de organização coletiva, pouca identificação com as áreas comuns, baixos recursos das famílias para pagamento dos custos condominiais (agravado pelo individualismo na conquista da casa própria) significaram espaços coletivos deteriorados e, principalmente, inúmeras ampliações irregulares nos primeiros e segundos andares (figura 133), além de ocupações particulares das áreas coletivas (figura 131), acentuados pela falta de fiscalização.
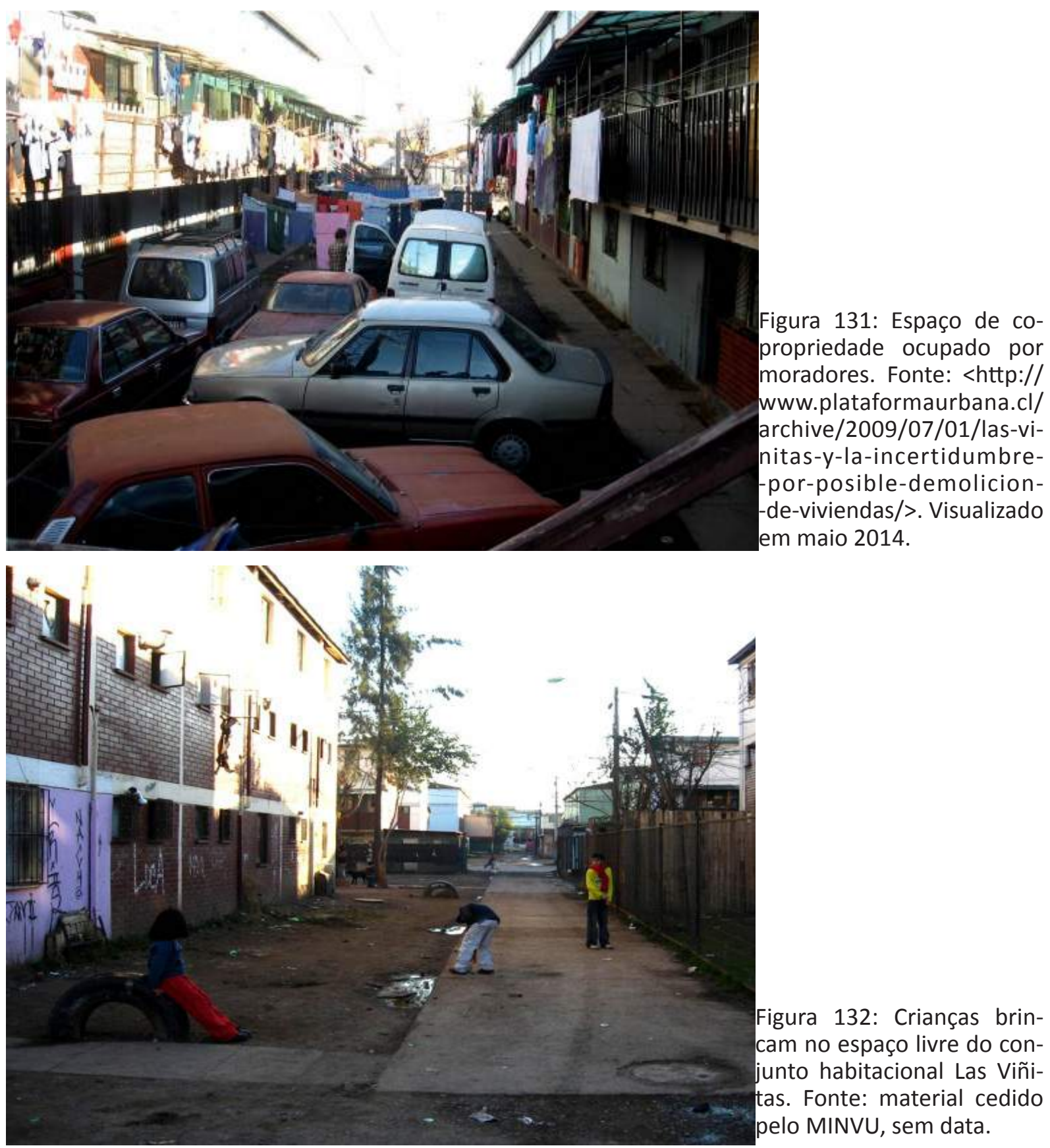

Figura 132: Crianças brincam no espaço livre do conjunto habitacional Las Viñitas. Fonte: material cedido pelo MINVU, sem data. 


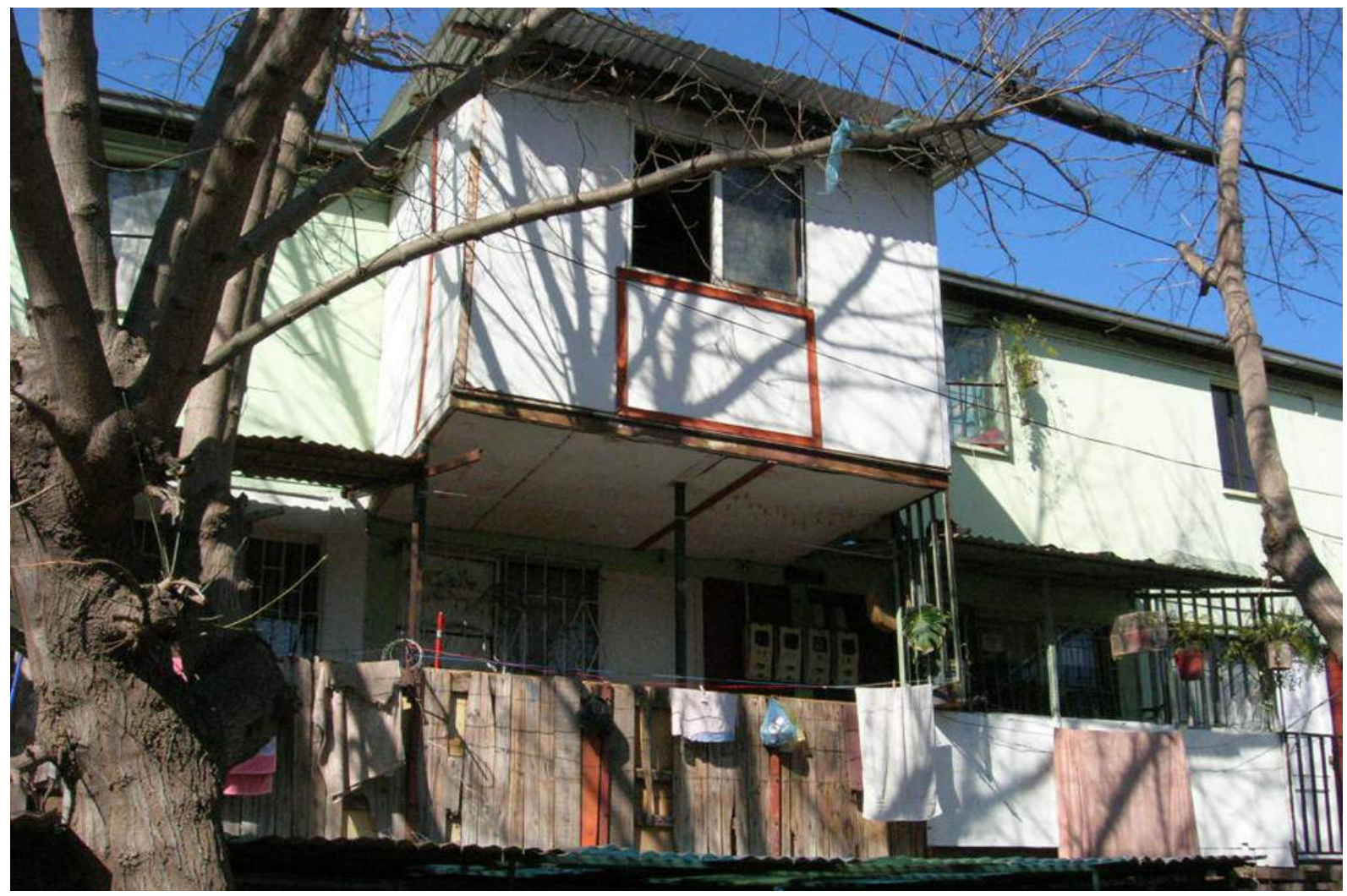

Figura 133: Ampliações no conjunto habitacional Las Viñitas. Fonte: material cedido pelo MINVU, sem data.

O Programa Quiero Mi Barrio começou a atuar em Las Viñitas em 2006, com arquitetos e assistentes sociais buscando soluções para melhorias no cotidiano dos moradores. Dentre as demandas do Programa estava a necessidade de se identificarem possíveis riscos estruturais nos edifícios, além da análise das condições de vida no conjunto em si, considerando a situação física e social.

No início da atuação, depois dos diagnósticos e de diversas reuniões com os vizinhos, verificaram-se que os principais problemas se relacionavam à habitação e aos espaços comuns. Também se verificaram problemas de salubridade e de segurança social.

As questões com as habitações eram causadas pelo reduzido tamanho das unidades, inadequadas para as famílias, e pelas diversas ampliações irregulares realizadas. Os estudos do PQMB demonstraram preocupação com a estrutura dos edifícios, afetada por terremotos e por essas constantes ampliações não planejadas.

Existem controvérsias em relação aos danos estruturais existentes: alguns estudos de 20062007 afirmaram grande risco de colapso, mesmo antes do terremoto de setembro de 2011, enquanto outros salientaram que não havia danos ou riscos à população, e sim interesse político de remover as famílias desse conjunto habitacional e deslocá-las para uma nova área. Esses interesses se devem à proximidade de La Viñitas com a área do futuro Parque La Hondonada, incremento de grande valorização imobiliária para o terreno.

Em um primeiro momento de ação do PQMB, considerou-se a possibilidade de reformar o 
conjunto habitacional. Porém, a partir de um estudo estrutural encomendado à empresa de engenharia DICTUC S.A., concluiu-se, finalmente, que as inúmeras ampliações irregulares afetaram a capacidade estrutural dos edifícios.

A solução inicial encontrada foi demolir todas as ampliações irregulares, que representavam $60 \%$ das superfícies de copropriedade, além de demolir alguns edifícios para melhorar o distanciamento entre as áreas construídas.

Entretanto, a solução adotada foi mais drástica: com mais investimento, decidiu-se demolir $100 \%$ do conjunto e realocar as famílias para um novo local, com uma intervenção urbano-habitacional nova, em um terreno vizinho. Uma intervenção complexa, onerosa para o Estado, para resolver um problema gerado pela própria política habitacional.

Assim, em 2008, o SERVIU Metropolitano adquiriu, por expropriação, para a construção do novo conjunto Lomas del Prado, dois lotes do antigo Fundo Santa Elvira localizados a poucos metros do antigo conjunto Las Viñitas (figura 134).

A intervenção Las Viñitas/Lomas del Prado foi realizada em três fases: fase preparatória, que durou trinta e dois meses; intermediária, de oito meses, e de execução, de três meses, sendo concluída em 2012 com o deslocamento das famílias e demolição de Las Viñitas, realizado em duas etapas com sete meses de diferença entre elas.

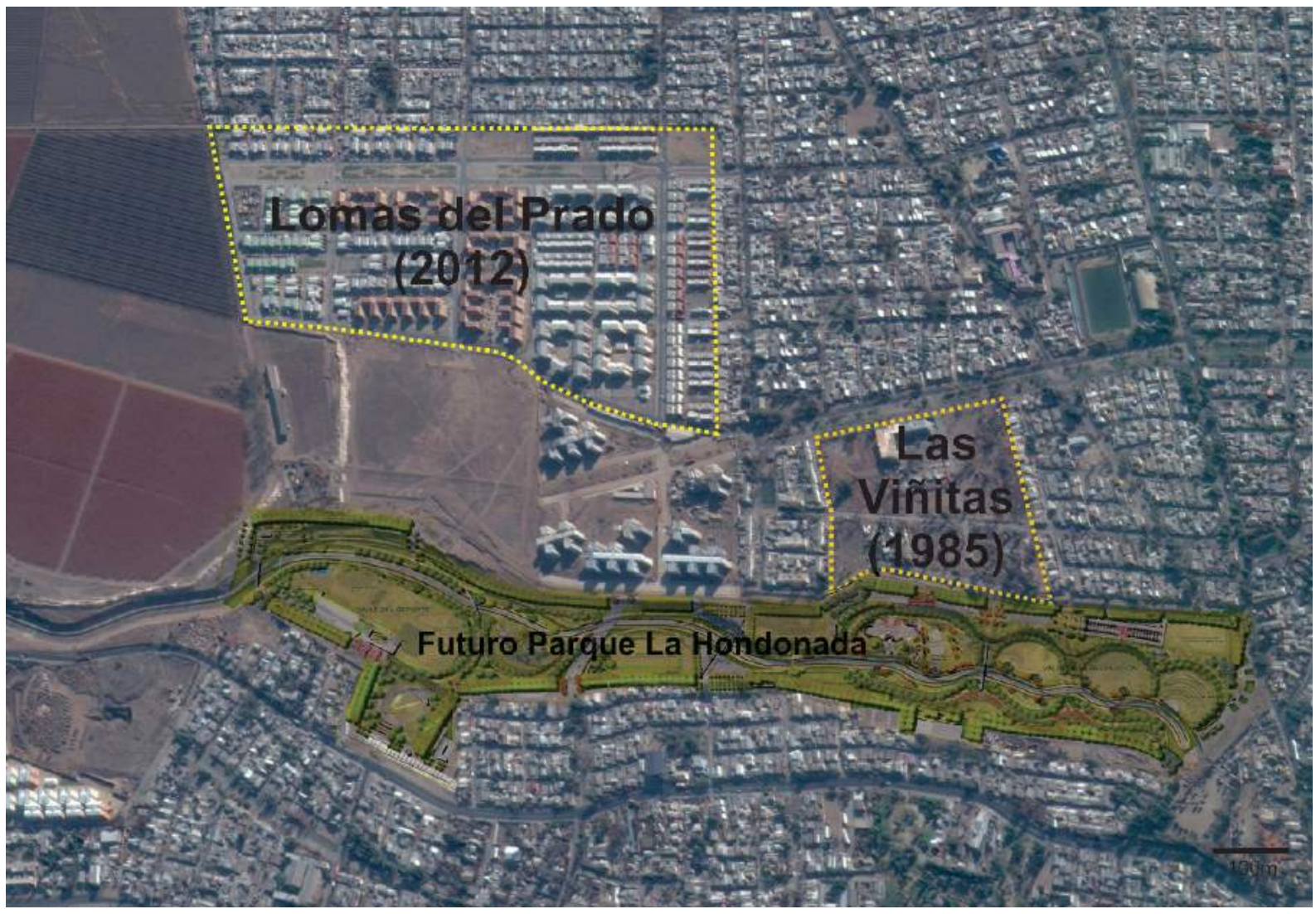

Figura 134: Localização da antiga Población Las Viñitas, do novo bairro Lomas del Prado, e do futuro Parque La Hondonada. Fonte: elaboração da autora, sob base Google Earth (2015). 


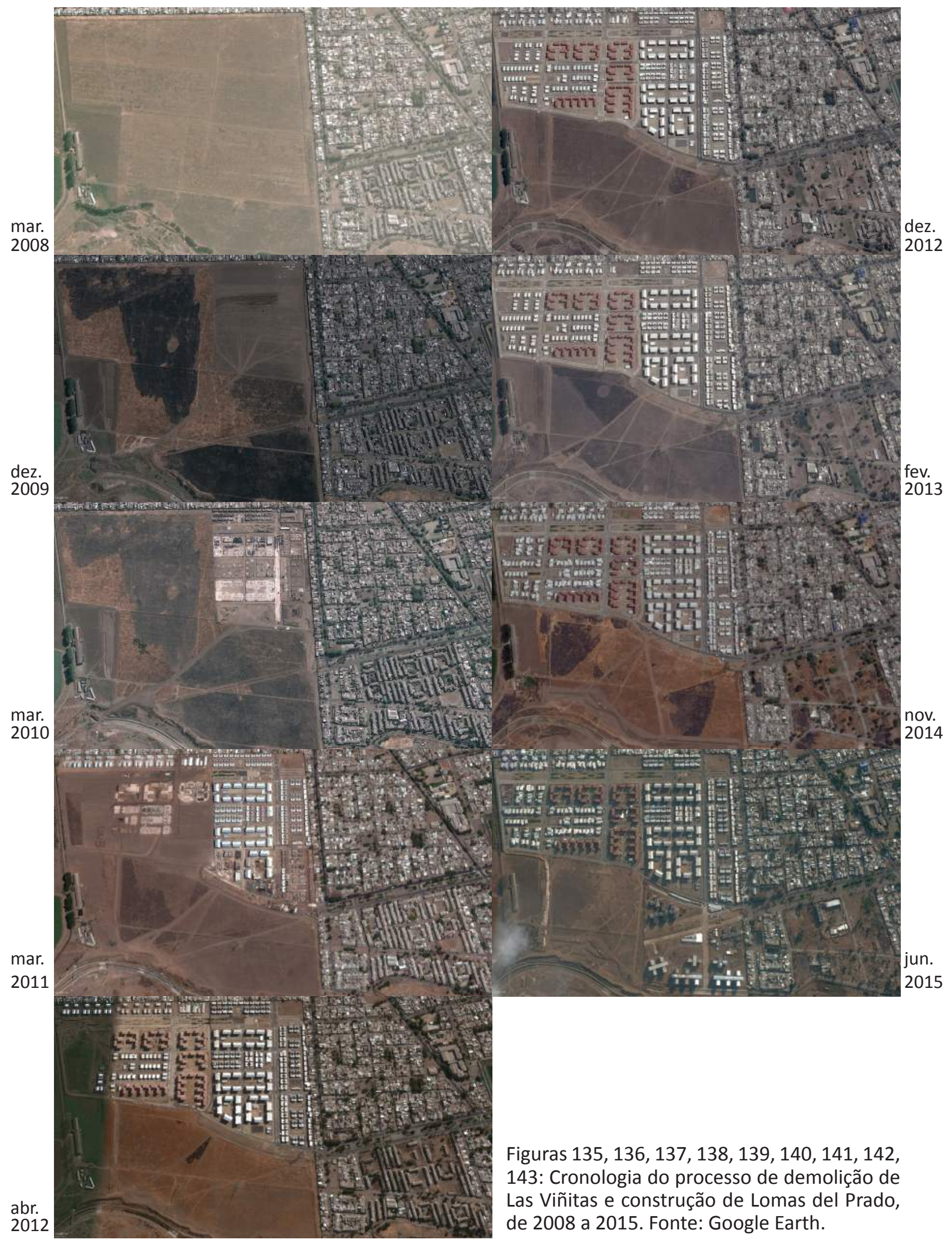


O Conjunto Lomas del Prado foi construído com financiamento do FSV, beneficiado pelas mudanças após o D.S. 49.

Segundo regra do FSV, a entidade é responsável por desenhar o conjunto habitacional e prestar assessoria técnica aos moradores, pois a construção é feita com os subsídios do SERVIU. Porém, no caso de Lomas del Prado, o desenho do bairro foi feito pela equipe do MINVU, enquanto o desenho dos edifícios e das casas foi feito pela Entidade, assim como o Plan de Habilitación Social.

Foram 673 proprietários beneficiados com o programa, dentre eles 116 allegados, 65 arrendatários, 32 moradores em ocupações irregulares, 20 não proprietários nem residentes e mais 16 famílias em situação especial.

A aquisição de unidades habitacionais no novo conjunto Lomas del Prado foi realizada de acordo com a jurisdição dos moradores: os proprietários de unidades em Las Viñitas tiveram prioridade na escolha das unidades residenciais e as adquiriram através de acordo de expropriação ou permuta. Já os moradores que viviam de allegados, que alugavam unidades ou que ocupavam unidades irregularmente puderam adquirir, com subsídio público, uma unidade habitacional nos edifícios novos.

Assim, as unidades residenciais foram destinadas principalmente às famílias que já eram proprietárias de uma unidade em Las Viñitas, enquanto as unidades dos condomínios de prédios foram destinadas aos outros grupos que se candidataram para o subsídio.

O processo de definir quais famílias iriam para as residências e quais para os apartamentos foi complexo, já que a preferência geral dos moradores era pela aquisição de uma unidade residencial.

Como critério, o MINVU definiu que as residências seriam destinadas apenas para os proprietários de Las Viñitas, pois se considerava que eles já tinham pagado uma dívida pela habitação que viria a ser demolida e que, portanto, tinham mais direitos adquiridos que as famílias não proprietárias.

Porém, eram pouco mais de 300 residências, para mais de 400 proprietários nessas condições. A seleção foi feita, portanto, a partir de reuniões e assembleias dos comitês de moradores, com orientação da equipe SERVIU atuante, com cada comitê definindo critérios para distribuir as famílias entre residências e apartamentos. Dentre os critérios estabelecidos, estavam famílias numerosas, famílias com integrantes idosos ou integrantes com alguma deficiência, dentre outros. O processo de seleção também acabou por beneficiar os líderes comunitários, mais participativos nos comitês e defensores dos seus interesses.

O novo conjunto, em comparação ao anterior, ocupa maior superfície, abriga menos unidades habitacionais, apresenta espaços públicos e de copropriedade com boa definição física, espaços coletivos de qualidade e unidades habitacionais mais espaçosas.

Sobre o dimensionamento das unidades, pelo regulamento do FSV, os apartamentos puderam adquirir o subsídio complementar de densificación en altura, que exigiu que os apartamentos tivessem no mínimo $55 \mathrm{~m}^{2}$, divididos em três dormitórios, sala de estar, cozinha, lavanderia e banheiro.

Como no caso das residências não há subsídio complementar nem exigência de três dormitórios, estas foram entregues com dois dormitórios, mas com um projeto aprovado para que a família pudesse realizar, caso desejasse, obras para a ampliação do terceiro dormitório. Em visitas de campo, verificou-se que muitas ampliações foram realizadas nas unidades residenciais, não seguindo, porém, o projeto original de ampliação do programa. 


\begin{tabular}{|l|l|l|}
\hline Característica & Las Viñitas & Lomas del Prado \\
\hline $\begin{array}{l}\text { Superfície que ocupa em } \\
\text { Conjunto }\end{array}$ & 6,2 ha & 11,4 ha \\
\hline Número de habitações & 1029 & 922 \\
\hline Número de famílias & 1334 & 922 \\
\hline Tamanho das habitações & Apartamentos de $36 \mathrm{~m}^{2}$ & $\begin{array}{l}608 \text { apartamentos de } 58 \mathrm{~m}^{2} \text {, distribuídos em } 6 \\
\text { condomínios de copropriedade, e } 314 \text { casas de } \\
52 \mathrm{~m}^{2} \text { ampliáveis para } 72 \mathrm{~m}^{2}\end{array}$ \\
\hline
\end{tabular}

Tabela 11: Características de Las Viñitas e Lomas del Prado. Fonte: SUR Profesionales Consultores (2015). O número de famílias foi resultado de dois cadastros realizados em anos distintos, levando em consideração conflitos em relação a possível inclusão de famílias que não moravam na población.

Devido à complexidade do processo de organização comunitária para manter os bens comuns e as áreas de copropriedade, uma das premissas do Ministério para Lomas del Prado era que, no caso dos apartamentos, os condomínios deveriam ter o mínimo possível de unidades habitacionais, pois, quanto menos vizinhos precisarem se responsabilizar, mais fácil ficará o acordo entre moradores, organizados em grupos menores. Outra premissa foi definir, através da morfologia urbana, quais seriam as áreas públicas, as privadas e as de copropriedade, o que não era claro no antigo conjunto habitacional.

Assim, os edifícios, no novo conjunto, foram posicionados no limite do quarteirão, formando uma área interior mínima de copropriedade, e rodeados de ruas, responsáveis por definir as áreas e limites. Essa conformação e a clareza morfológico-espacial eram grandes preocupações para o novo bairro, para evitar o problema de indefinição das áreas condominiais que ocorreu em Las Viñitas.

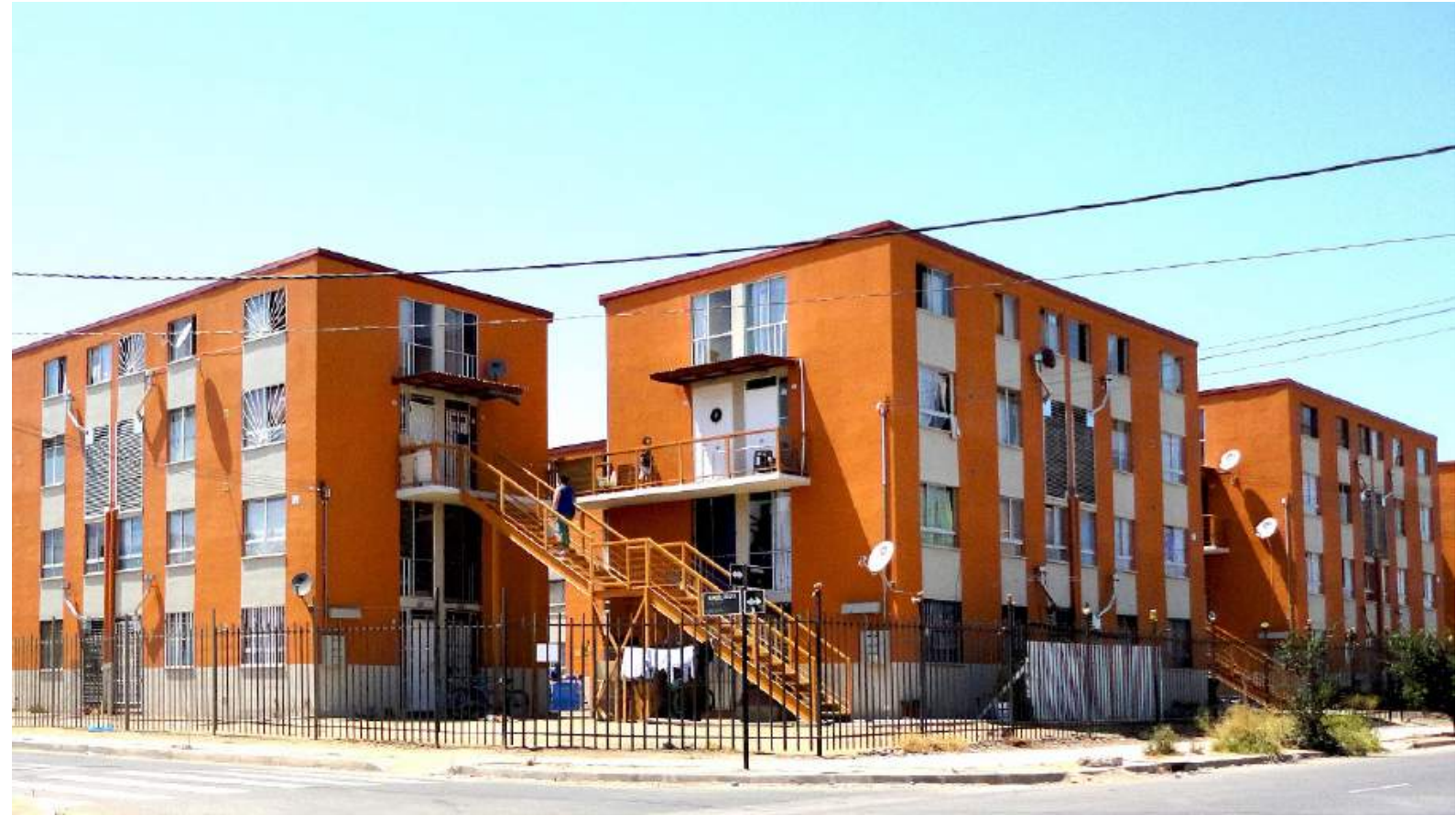

Figura 144: Edifícios habitacionais e áreas condominiais em Lomas del Prado. Fechamento transparente é característica do projeto original de delimitação das áreas de copropriedade condominiais. Fotografias da autora, jan. de 2014. 


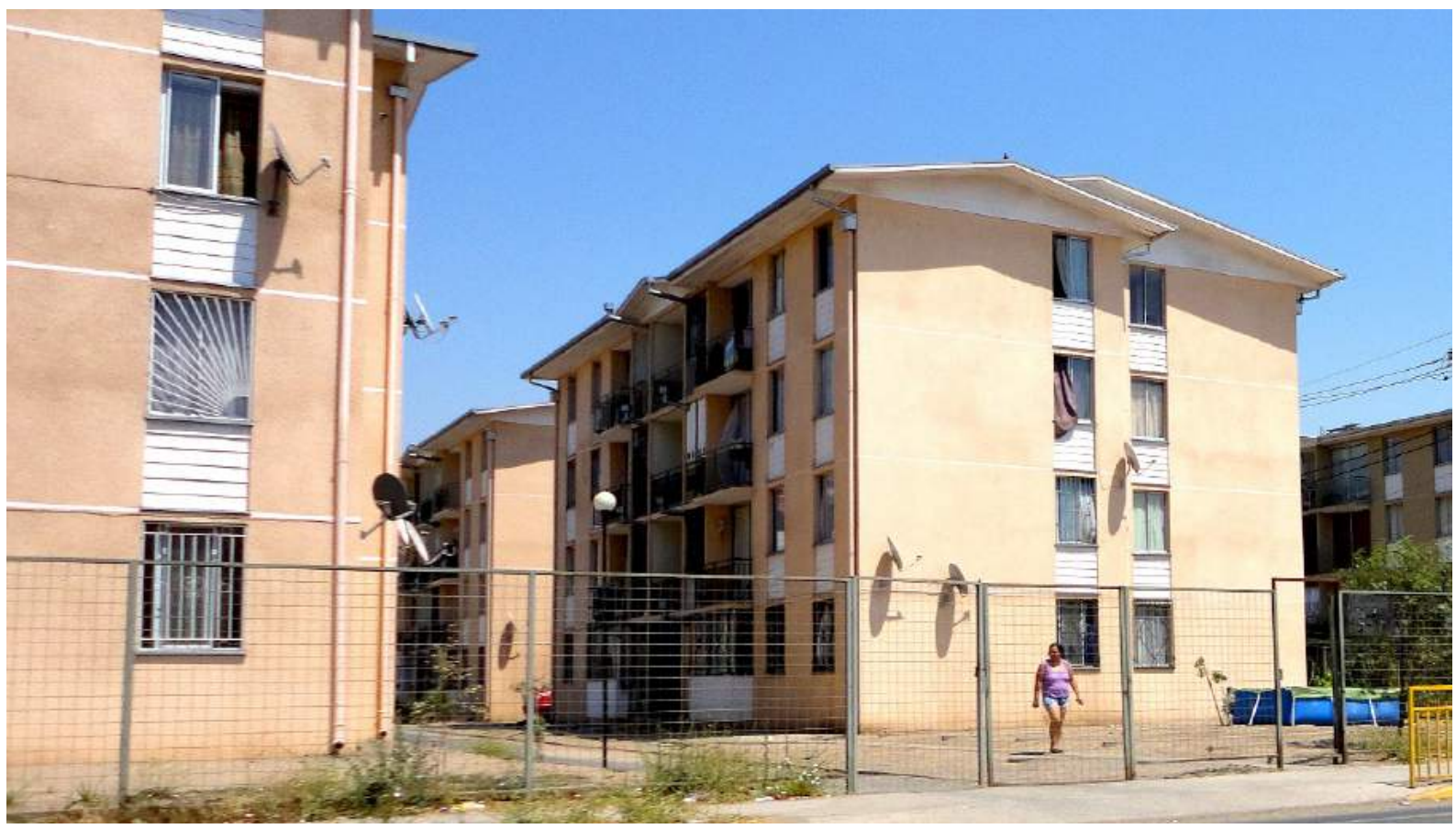

Figura 145: Edifícios habitacionais e áreas condominiais em Lomas del Prado. Transparência permite melhor relação visual do morador com a rua. Fotografias da autora, jan. de 2014.

Assim, dentre os critérios para o desenho urbano do novo bairro, destacam-se:

- Posicionar os edifícios habitacionais de maneira a definir as áreas de copropriedade, as áreas privadas e as áreas públicas;

- Posicionar as unidades residenciais nas bordas do novo setor, dando continuidade ao tecido urbano já existente, local em que já havia unidades residenciais unifamiliares;

- Evitar ruas sem saída e passagens estreitas, adotando uma dimensão mínima de 6 metros de perfil do leito carroçável;

- Construir praças públicas, para criar dinâmica de bairro nas áreas residenciais;

- Definir os equipamentos nos entornos das vias principais;

- Definir uma grande área para os espaços públicos de convívio coletivo.

O novo conjunto Lomas del Prado configura-se com o desenho urbano de um bairro, com unidades residenciais, condomínios de prédios, áreas institucionais ocupadas por uma creche e um anfiteatro de responsabilidade municipal, além de áreas livres públicas para lazer (figuras 146 e 147), equipadas com três quadras poliesportivas, área para jogos infantis, áreas de skate e máquinas para exercícios físicos, sob administração das comunas.

A transparência dos portões de fechamento dos edifícios habitacionais do Conjunto Lomas del Prado (figuras 144 e 145) permite melhor relação visual com a rua, o que causa maior conforto para os usuários do espaço livre e para os moradores do conjunto, contribuindo para criar um sentido de vizinhança. 
Nos espaços condominiais localizam-se: sede comunitária, pátio comum, algumas áreas para jogos infantis, vagas de estacionamento e espaços de manutenção predial, como lixeira e manutenção das bombas de água.

Diferentemente do caso brasileiro, o regulamento do FSV entrega um subsídio para a construção do equipamento, além daquele destinado às unidades habitacionais. Com ele foram construídas também as sedes sociais dos condomínios verticais e uma escola infantil. Quanto a esta última, por escassez de recursos, não pôde ser finalizada pelo programa, sendo acordado que o município teria a responsabilidade de concluir a obra com recursos específicos, implementar o equipamento e definir a gestão do mesmo, o que foi realizado.

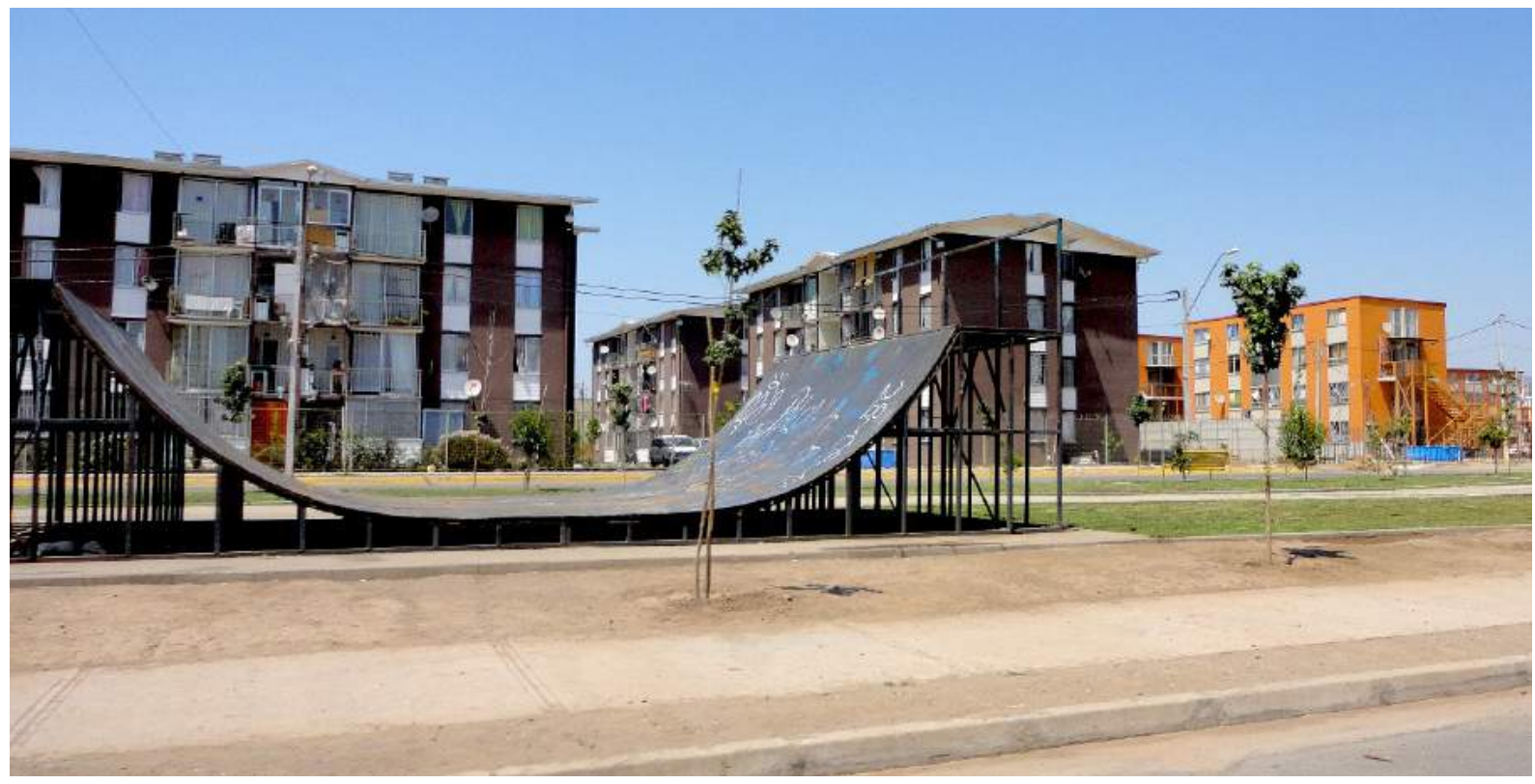

Figura 146: Conjunto Habitacional Lomas del Prado entregue aos moradores. Vista de uma das áreas livres, composta de diversos equipamentos esportivos e de lazer. Fotografia da autora, jan. 2014.

A ausência de áreas destinadas ao comércio estimula o surgimento espontâneo de mercearias e pequenos centros de venda nas próprias residências e nos edifícios habitacionais. Embora o surgimento espontâneo seja positivo, dependente da demanda e da disponibilidade de alguns moradores, essa heterogeneidade de uso do conjunto habitacional poderia ter sido melhor adaptada, direcionando unidades mistas para famílias com interesse em abrir um comércio. Ignorar esse surgimento espontâneo e concentrar os espaços livres em uma avenida principal deixa as outras vias bastante limitadas para o cotidiano dos usuários, podendo estimular apropriações individuais ou até mesmo práticas de atividades ilícitas.

À exceção da avenida principal, definida como a principal área livre de lazer do bairro (figuras 146 e 147), as outras ruas do entorno são estreitas, com calçadas bastante reduzidas. Dessa forma, nas ruas laterais aos acessos dos condomínios de prédios, a situação urbana não é ideal, compondo espaços livres pouco convidativos aos usuários. Devido à falta de manutenção das calçadas e da vegetação, o espaço do pedestre se reduz e a circulação fica limitada (figura 148). Nessas ruas, foi possível verificar o fechamento visual de alguns condomínios, criandose uma relação de maior insegurança para o usuário do espaço público, que atravessa um quarteirão sem contato visual com o interior do condomínio de prédios. 


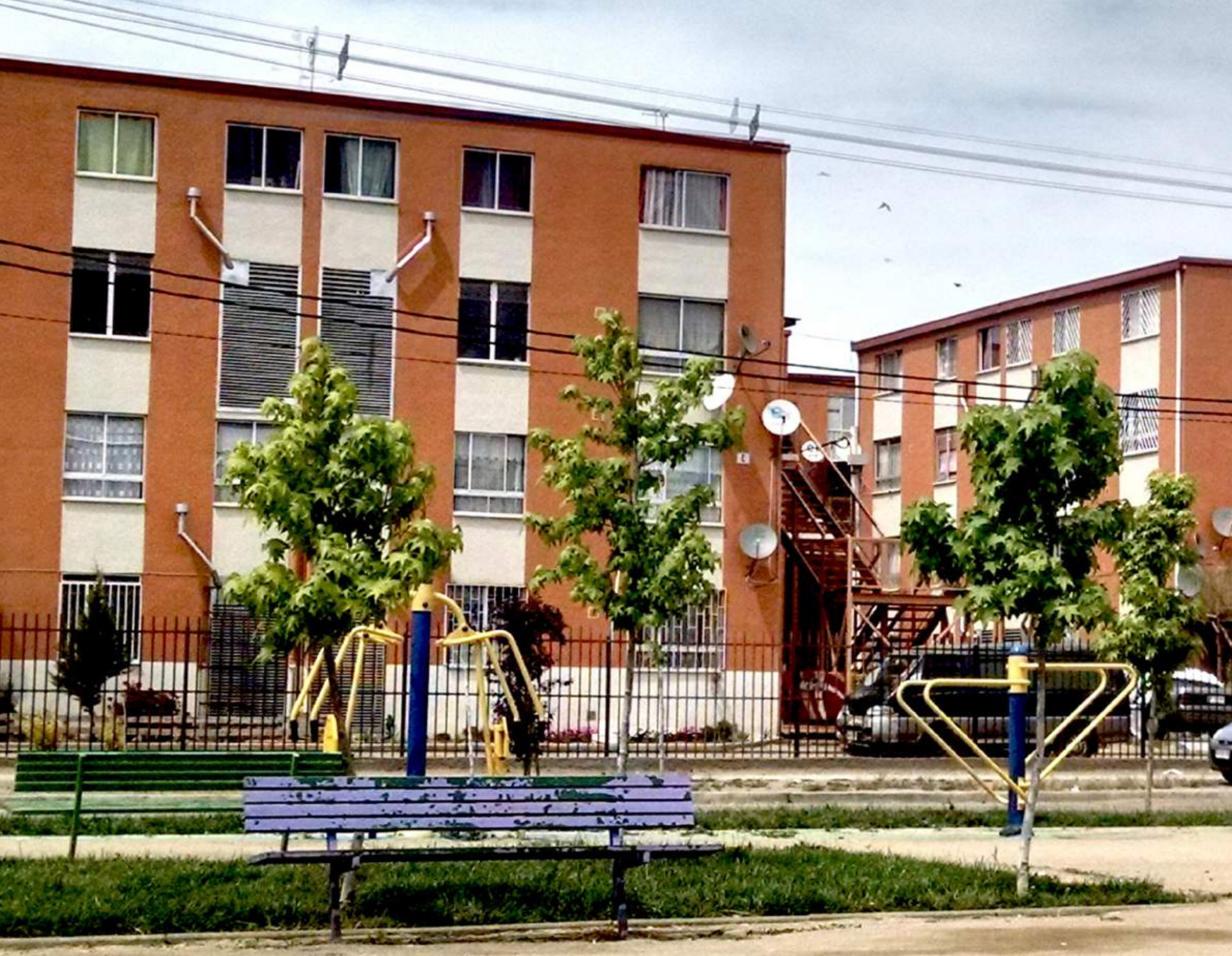


$t$

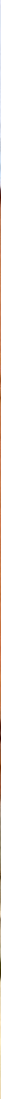

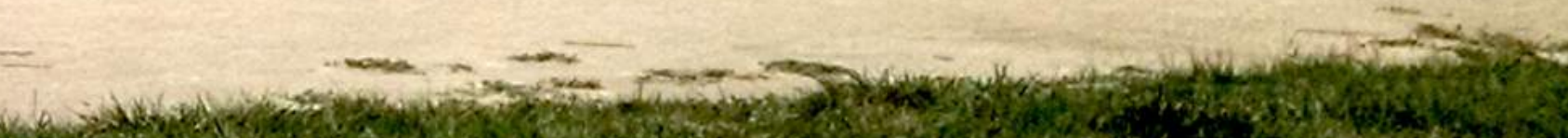

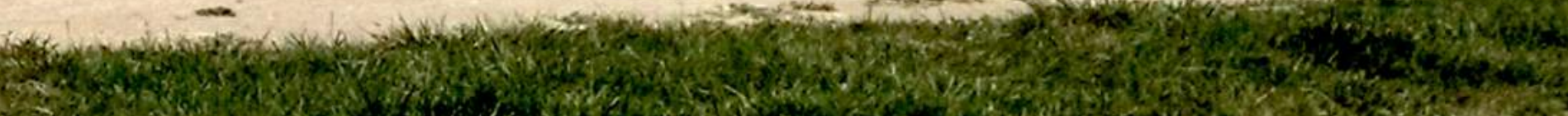

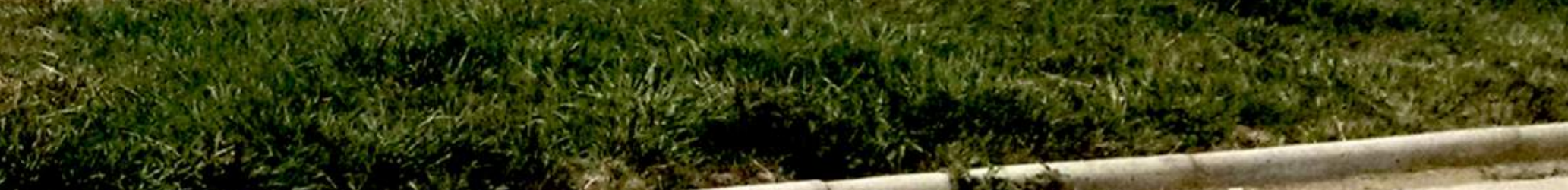

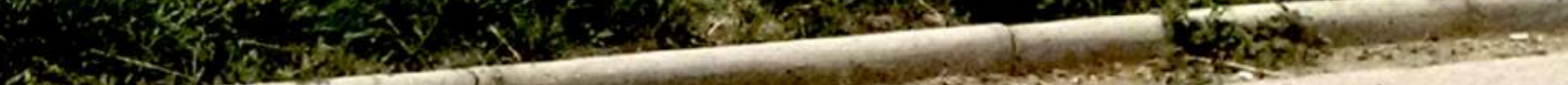


Verificou-se, em visita realizada em novembro de 2015, o uso do terreno das antigas Las Viñitas como depósito de lixo (figura 149). Essa dinâmica urbana individualista, que leva o cidadão a despejar lixo urbano, móveis antigos, e outros elementos domésticos de pouco interesse para os moradores em ruas públicas ocorre em diversas comunas de Santiago, criando micro depósitos de lixo doméstico, que ficam dependentes da ação comunal para limpeza regular. Há dificuldade em se interromper a criação desses depósitos de lixos pelo lento processo de conscientização dos habitantes sobre a prática correta de descarte de lixo doméstico.

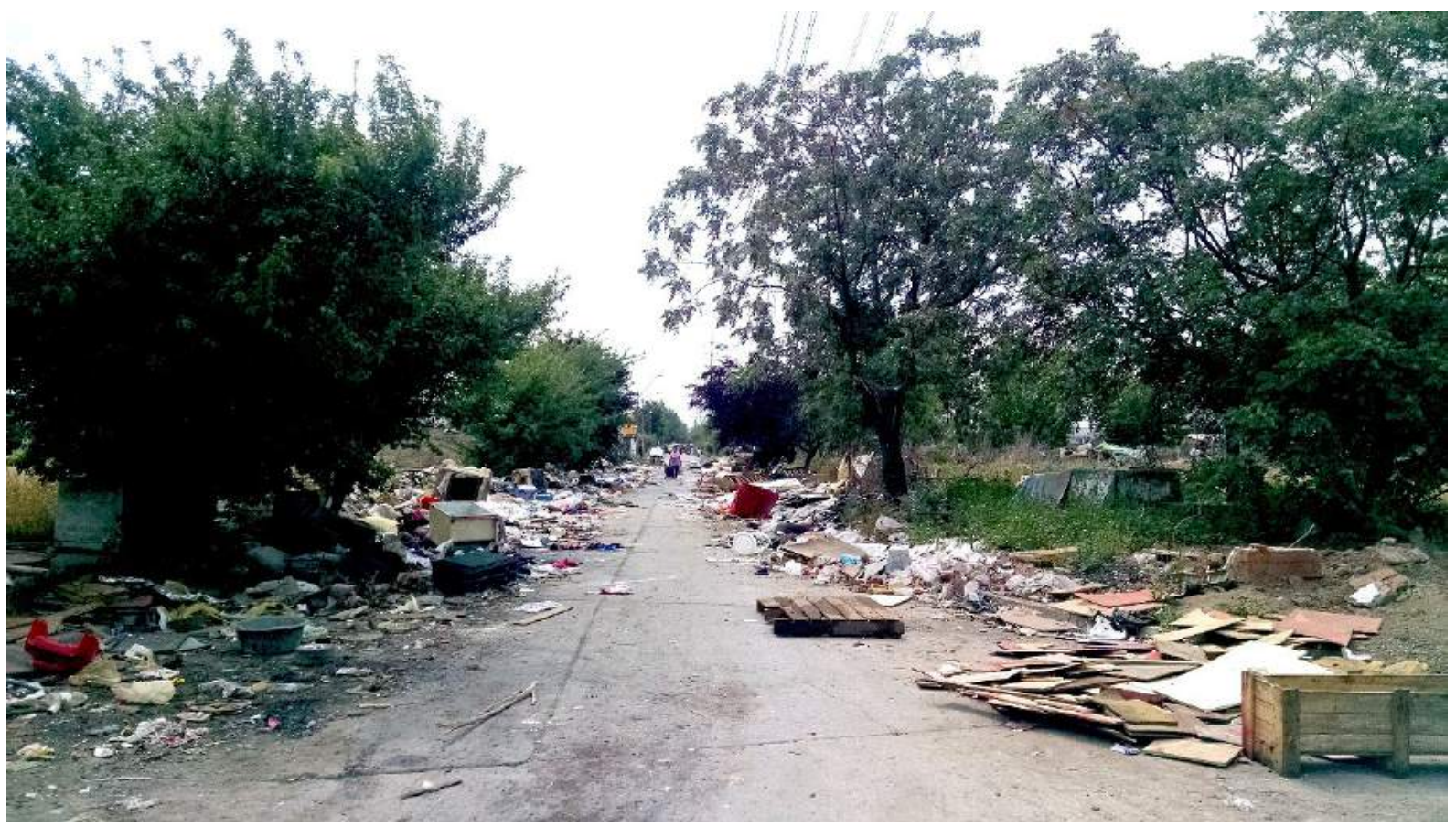

Figura 149: Descarte de lixo em terreno onde existia Las Viñitas. Fotografia da autora, nov. 2015.

A Comuna de Cerro Navia tem tradição das feiras livres, abrigando um dos maiores "mercados de pulgas" da Região Metropolitana de Santiago. A relação dos moradores com o comércio informal é bastante frequente, com várias feiras ocorrendo esporadicamente em algumas ruas da Comuna, com vendas de diversos produtos, como frutas e verduras, laticínios, produtos industrializados e, até mesmo, fármacos.

Nas quadras residenciais de Lomas del Prado foram construídas praças de bairro, algumas equipadas com brinquedos e aparelhos para exercícios, criando-se uma relação visual e morfológica, entre as residências e a praça, que estimula o uso do espaço livre (figura 150).

Em algumas ruas da comuna, como em proximidades do Parque Mapocho Poniente, podem ser verificados recuos consideráveis entre a rua e as unidades residenciais construídas (figura 151), definindo-se um espaço livre amplo, que dialoga com as praças do bairro. Nesses recuos, vários usos e apropriações foram identificados, como no verão de 2014, com ocupação do espaço livre por piscinas de armação. Essa extensão do espaço doméstico para o espaço livre público, que ocorre esporadicamente nos trechos de Cerro Navia com maiores espaços livres disponíveis, pôde ser verificada em Lomas del Prado no espaço coletivo do condomínio (figura 152). 


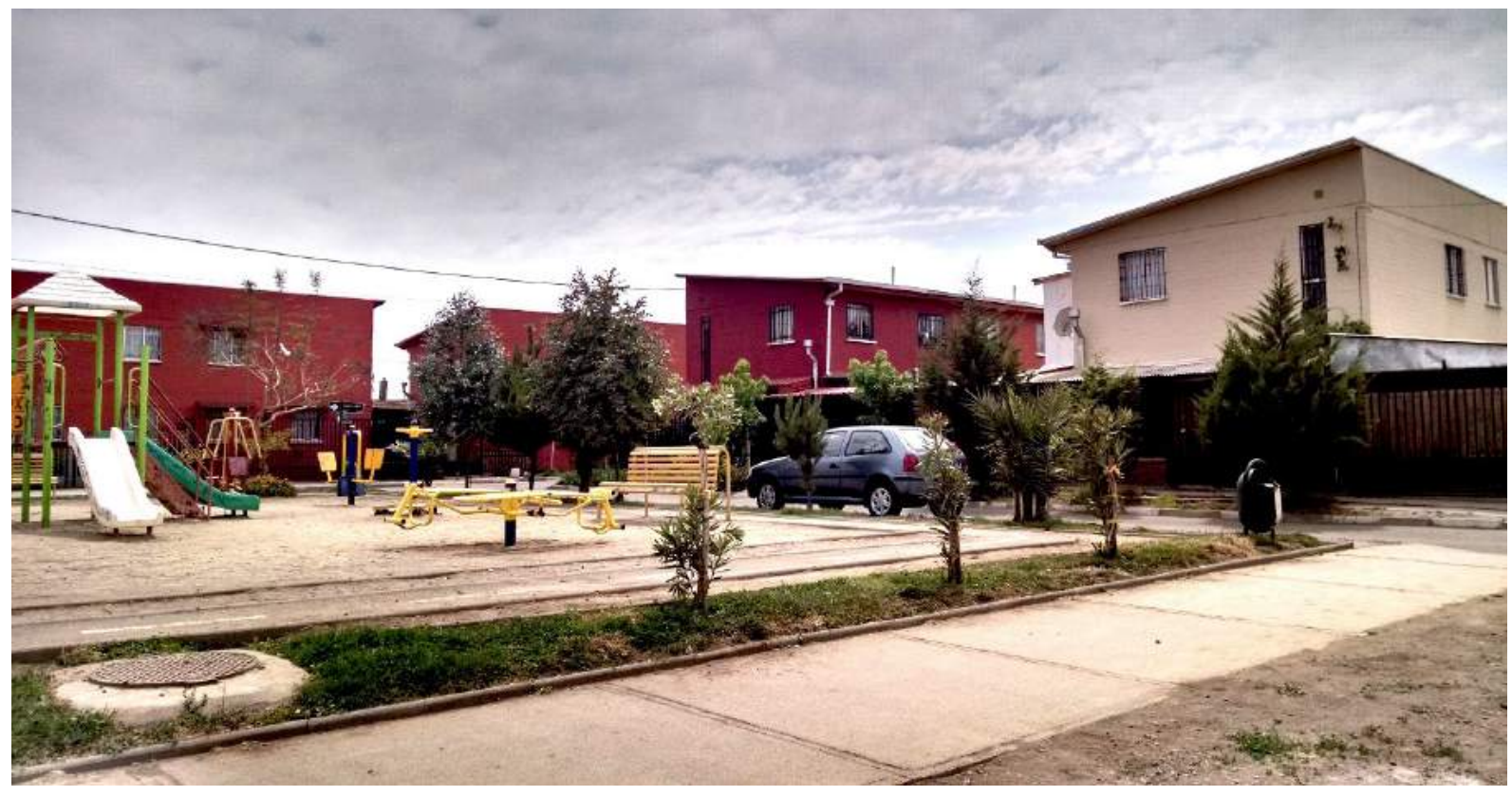

Figura 150: Praças de bairro entre as unidades residenciais em Lomas del Prado. Fotografia da autora, nov. de 2015.

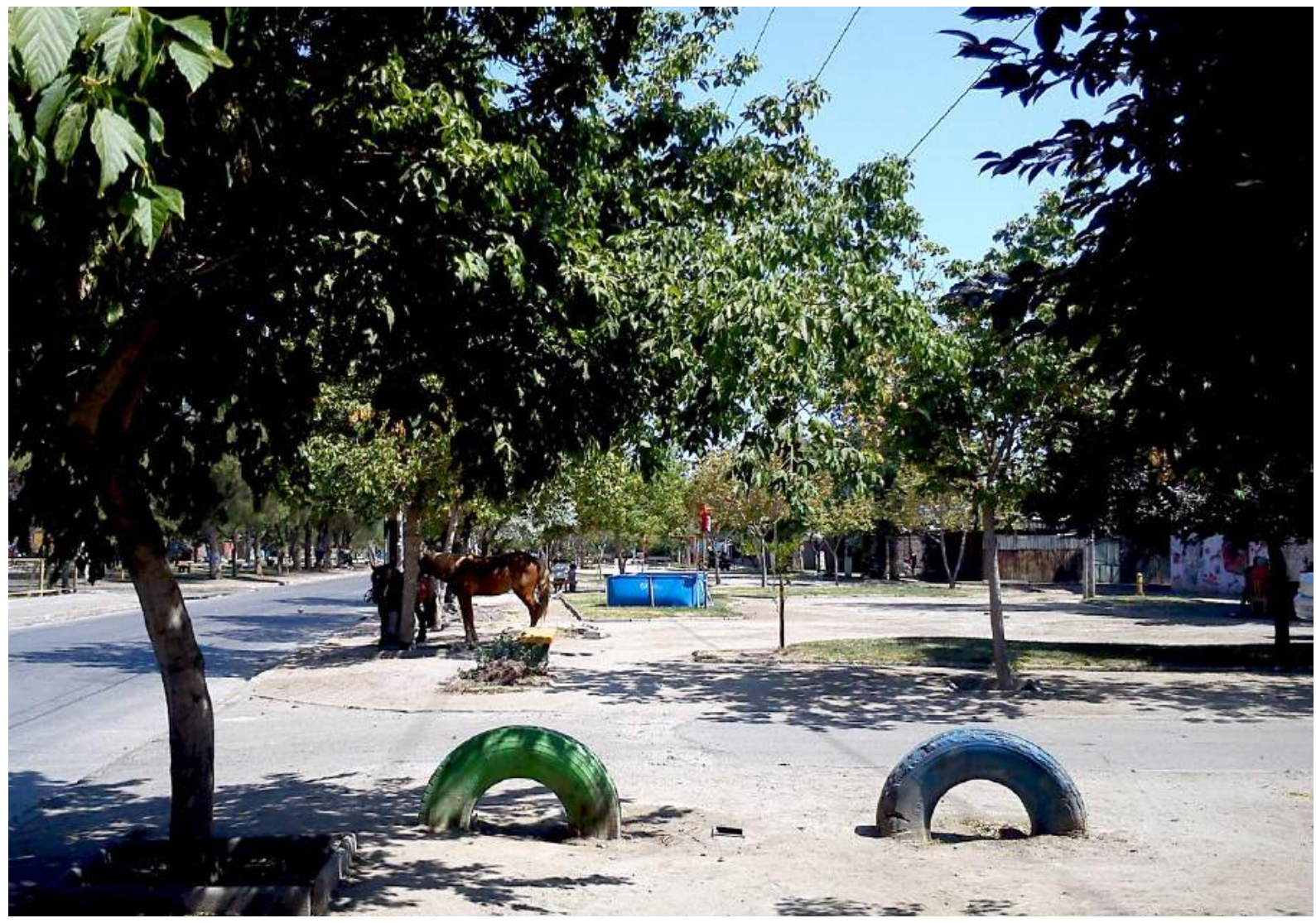

Figura 151: Entorno do Parque Mapocho Poniente, em Cerro Navia. Recuos entre a rua e as unidades habitacionais proporcionam espaço livre generoso, apropriado com piscinas de armação e repouso de animais particulares no verão chileno. Fotografia da autora, jan. de 2014. 


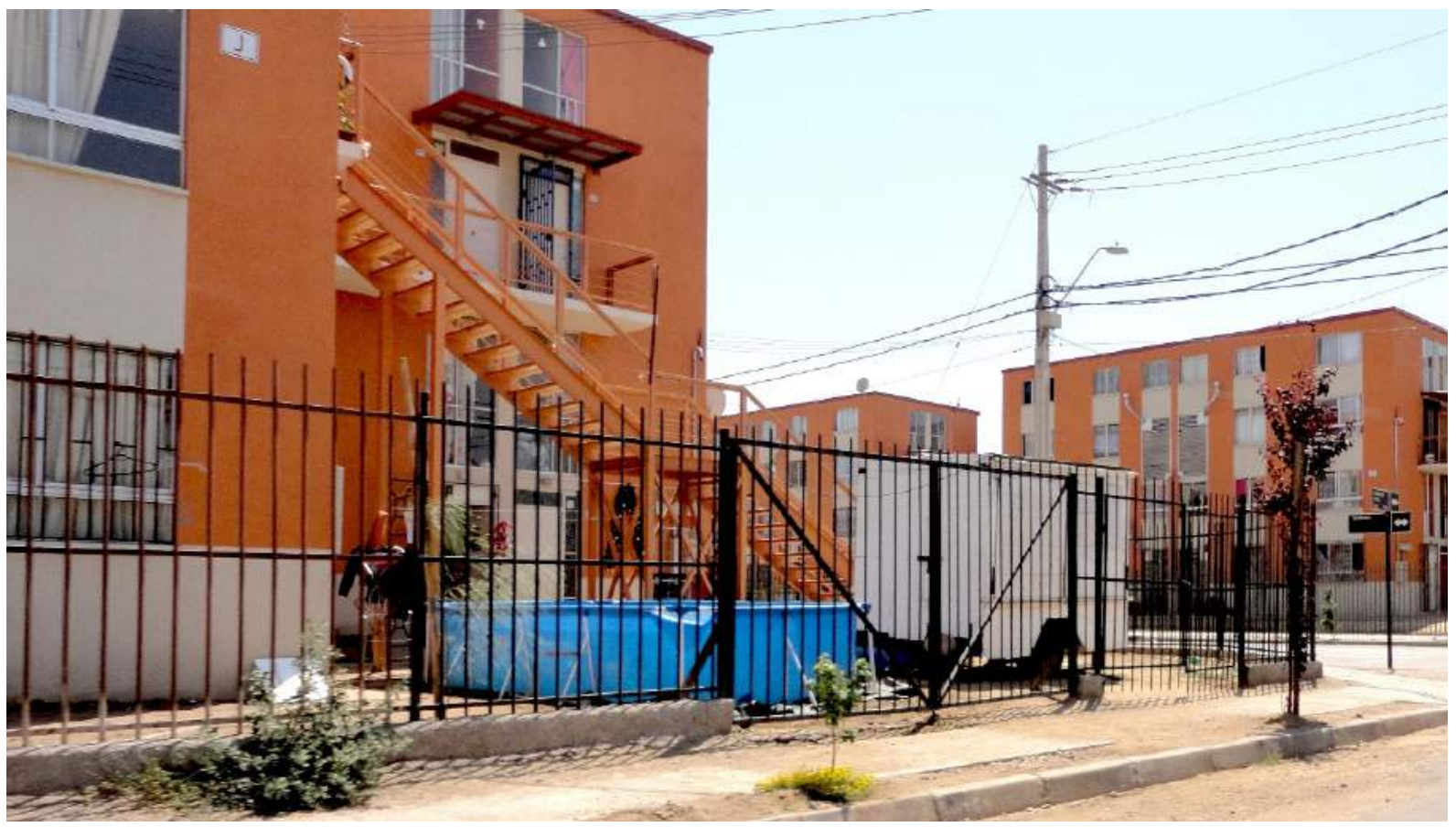

Figura 152: Piscinas de armação nas áreas condominiais de Lomas del Prado, no verão chileno. Fotografia da autora, jan.de 2014.

Através do D.S. 49 de 2011, o SERVIU Metropolitano pode ampliar o alcance do Programa executado em Lomas del Prado até uma etapa posterior à entrega das habitações, com o propósito de fazer estudos de pós-ocupação e consolidar o bairro com ações de organização social e de redes comunitárias.

No Conjunto Lomas del Prado, essa consultoria de pós-ocupação, que se iniciou em março de 2014, dois anos após a mudança das famílias ao novo conjunto, e durou 10 meses, ficou a cargo do escritório SUR Profesionales, sob a denominação Programa de Apoyo al Nuevo Barrio.

O SUR trabalhou diretamente com os moradores, observando diversos aspectos, como o processo de mudança para o novo bairro, os problemas surgidos na nova habitação, a manutenção dos espaços comuns, dentre outros. O planejamento das atividades com a comunidade foi desenvolvido durante o processo, apoiando o intercâmbio entre os vizinhos e a articulação espontânea de redes sociais.

Dentre a problemática apontada, destacam-se problemas com delinquência, violência e segurança:

Los problemas de convivencia en Lomas del Prado era una preocupación para los vecinos y vecinas, ya que existían muchas situaciones de conflicto, que podían escalar en violencia desmedida por falta de comunicación y herramientas comunicacionales para la resolución de los mismos (...) (SUR, 2015, p. 43)

Quanto às dificuldades em relação à infraestrutura, apareceram problemas com as bombas de água nos condomínios, já que, por normativa da empresa sanitária chilena Agua Andina, é 
necessário instalá-las nos condomínios habitacionais. Como, para a melhor utilização dessas bombas, deveria haver um conjunto de ações para habilitar os moradores a entender o seu funcionamento, uma das iniciativas do estudo de pós-ocupação do SUR incluiu capacitar os moradores no uso dessas máquinas.

Sobre as copropriedades, a equipe SUR verificou que:

En términos generales un $47 \%$ de los encuestados manifiesta saber mucho o algo respecto de lo que es una copropiedad, así mismo un $83,4 \%$ de los encuestados manifiesta saber mucho o algo respecto de la diferencia entre bienes comunes y privados, mientras un $78 \%$ conoce mucho o algo de su reglamento de copropiedad. (SUR, 2015, p. 52)

Indo um pouco além de um simples estudo de pós ocupação, o trabalho realizado buscou atuar junto à população a fim de gerar mudanças, por meio de capacitação realizada em oficinas e reuniões, dentre muitos outros eventos comunitários, embora tenham sido realizados em um curto espaço de tempo, o que limita a geração de mudanças. Apesar disso, alguns avanços puderam ser identificados pela equipe do SUR, principalmente no que diz respeito à organização dos líderes comunitários. Porém, outros processos não avançaram, como a questão da segurança, o que se origina da impotência frente à presença do tráfico, além das dificuldades frente à complexidade das práticas sociais em condomínios de habitação social, agravadas pela subjetividade que envolve essas questões.

A criação de Lomas del Prado tem erros e acertos no que tange aos espaços livres. Com participação direta do MINVU, a solução criada poderia ter contado mais com a participação popular na definição dos espaços coletivos, pois o imaginário urbano se mescla aos anseios sociais, identidades e objetivos de vida.

O deslocamento das famílias de Las Viñitas para Lomas del Prado não teve impacto nas redes sociais, pois se manteve a localização urbana e os grupos sociais envolvidos, não se alterando a lógica cotidiana das famílias no que concerne aos deslocamentos para trabalho, escola e acesso a serviços. Pelo contrário, a intervenção em Lomas del Prado também faz parte de uma reestruturação comunal, que envolveu a criação de mais equipamentos para os moradores, como hospitais, creches e centros culturais.

O novo conjunto, dessa forma, rompeu o modus operandi de produção habitacional desconectada entre o desenho do conjunto e o entorno imediato, mantendo um cotidiano urbano bastante similar ao restante do bairro.

Ainda faltam estratégias para a criação de áreas comerciais, flexibilizando o projeto das unidades e dos espaços livres para que possam receber diferentes funções urbanas, além de possibilitarem alterações em momentos diferentes. Como há dificuldade no gerenciamento e na definição dos proprietários para áreas comerciais, a criação impositiva de áreas de comércio no desenho urbano pode não ser uma solução adequada.

A flexibilização, com normatização de áreas mistas e desenhos urbanos propositivos que simulem diferentes situações urbanas, além de assistência técnica pós-ocupação com as famílias, podem auxiliar na heterogeneidade do bairro, aumentando áreas de comércio espontâneo, que têm importância não só para o atendimento das famílias, como também no reforço da 
economia local, familiar e, principalmente para a vida pública. O comércio e o serviço, na escala do bairro, animam a esfera pública geral e a vida dos espaços livres do cotidiano.

Contudo, se por um lado os espaços livres obtiveram algumas conquistas no desenho urbano do novo conjunto, as relações dos moradores com o modelo de habitação condominial permanecem conflituosas. Não há possibilidade, em regiões metropolitanas, de não se construírem edifícios habitacionais, pois há de se considerar a disponibilidade de solo urbano e os custos. A dificuldade com o modelo condominial, no caso de Lomas del Prado, foi aliviada com a diminuição das áreas de convívio intramuros e a transparência dos fechamentos, que estimulam o usuário a se relacionar com o entorno e "externalizam", para fora dos fechamentos condominiais, as práticas coletivas.

Essas situações, obviamente, não ocorrem sem conflitos, pois ainda é preciso administrar as diferenças de interesses entre os moradores dos edifícios, bastante orientadas por interesses individuais, já presentes desde o processo de aquisição da casa própria, e as dificuldades administrativas das áreas condominiais.

Em Lomas del Prado, as calçadas poderiam ter sido dimensionadas com maior generosidade ao pedestre, principalmente nas vias que dividem os condomínios de prédios (figura 148). Soluções mistas de habitação e comércio também poderiam ter sido regulamentadas e direcionadas por desenho urbano, com calçadas mais amplas em alguns trechos do novo bairro.

Considera-se positivo, nos condomínios, o fechamento com grades, as quais permitem maior relação visual entre o público e o privado, gerando uma sensação maior de segurança aos moradores e usuários e proporcionando maior interesse no uso e cuidado dos espaços livres. Porém, em alguns locais já se verificaram a troca pelos moradores das grades por muros, o que altera a relação inicialmente proposta pelo desenho urbano. Essas alterações são também resultantes de uma imposição de desenho que nem sempre representa o que os usuários desejam para seus espaços cotidianos.

Reconhece-se a importância de ações que foquem as práticas sociais em espaços públicos externos aos muros, que convidem os moradores a se socializar além do espaço interiorizado da habitação. Entretanto, o planejamento urbano orienta uma ocupação que, muitas vezes, não se harmoniza com os interesses do grupo social envolvido, e acabam por alterar a produção social do espaço. A diferenciação do espaço concebido para o espaço vivido (LEFEBVRE, 1974), onde as possibilidades de resistência ocorrem pela apropriação dos espaços livres, depende de uma sensibilidade do olhar e do envolvimento do grupo social.

As práticas sociais em Cerro Navia demonstram certa relação com a disponibilidade e a proporção dos espaços livres, não só associadas a espaços planejados para determinadas práticas, mas também ligados à espontaneidade do cotidiano.

A valorização das práticas sociais deve fazer parte do projeto urbano, além da leitura do contexto e da situação social, já que as práticas possibilitam as transformações das condições herdadas, do habitus imposto. Essas práticas devem ser analisadas em seu contexto, que envolve a compreensão do conjunto de forças sociais e ações que orientam o agir. 


\section{Población Santa Adriana, Lo Espejo}

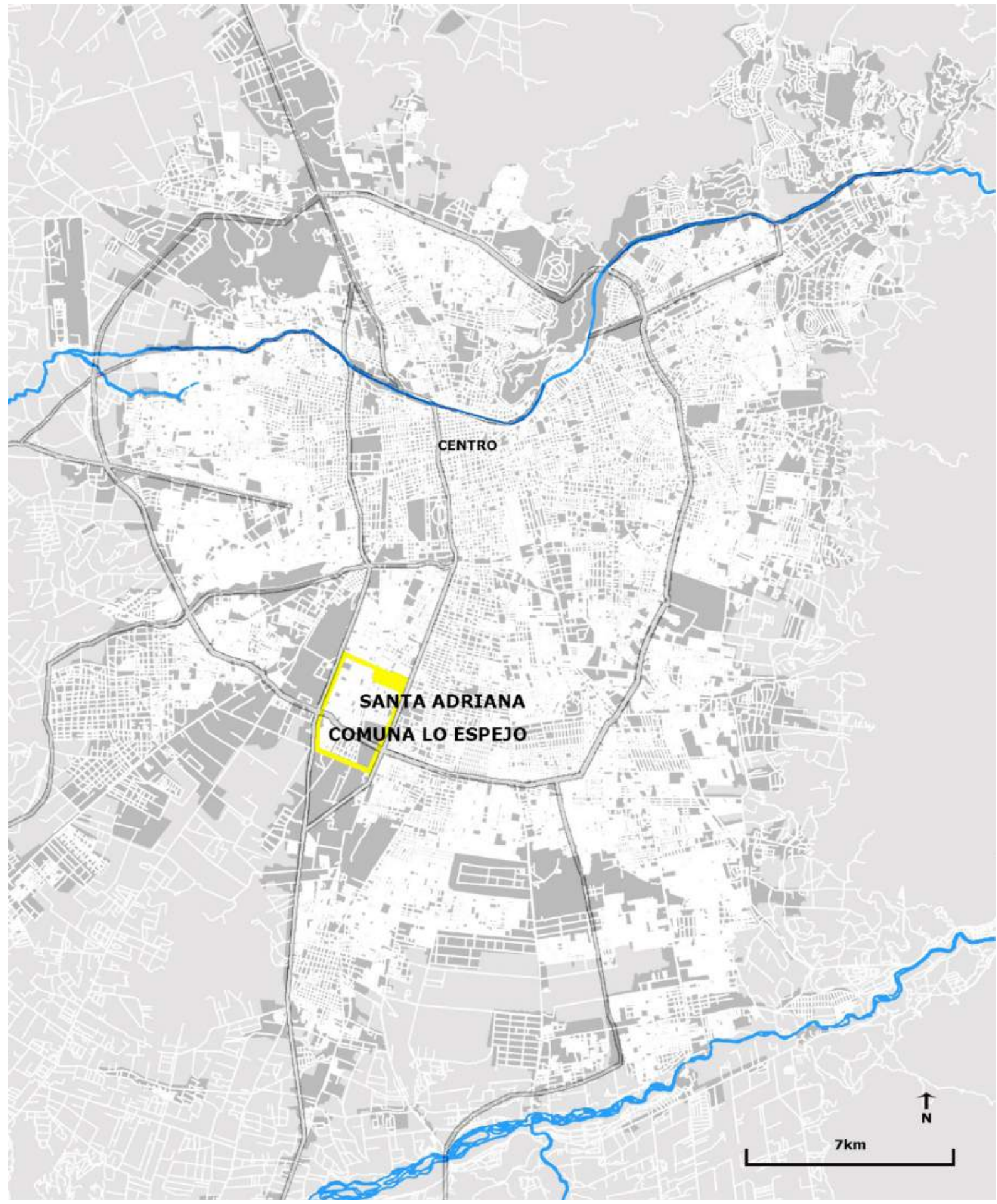

Figura 153: Localização de Santa Adriana na Comuna Lo Espejo. Fonte: elaboração da autora, sob base OCUC - Observatorio de Ciudades (2003) e Google Earth (2015). 
A población Santa Adriana está localizada na comuna de Lo Espejo, em uma área de 58,96 hectares (SEREMI, 2008), limitada pelas Autopista Central, Av. Lo Ovalle, Av. Clotario Blest e calle Lincoln (figura 153). O setor tem boa conexão com o transporte público e acesso razoável a equipamentos urbanos diversos.

Essa población foi formada a partir de ocupações realizadas no final dos anos 1950 e princípio dos anos 1960 na antiga chácara Santa Adriana, tendo, em sua origem, grande relação com movimentos de luta por moradia, já que muitos dos seus dirigentes tinham base de trabalho política (sendo filiados a partidos, como o Comunista e o Socialista) e social (trabalhando com instituições religiosas, como a Igreja Católica) ${ }^{95}$.

Segundo trabalho elaborado pelo Programa Quiero Mi Barrio (PRODEMU, 2004, apud LUNECKE, 2008), documentando a história oral do bairro, no início da formação da población, a vida cotidiana era muito difícil, devido ao pouco acesso a serviços básicos e equipamentos. No entanto, essas dificuldades contribuíram para uma maior organização dos moradores para luta, negociando com as autoridades em busca de melhores condições para o setor. Sobre a mudança das famílias para o local, Yánez (2007) comenta:

Inquilinos y jóvenes sin casa, provenientes de distintas zonas de Santiago, llegaron para quedarse y, los que estaban, ayudaron a transformar lo que antes había sido campo y ahora empezaba a ser parte de la capital, que se extendía más allá de los márgenes originales (p. 13)

Como os moradores do setor eram muito organizados politicamente, durante a ditadura a repressão foi muito intensa, ocorrendo frequentes sequestros, desaparecimentos e mortes de líderes políticos do setor. Com isso, houve a desarticulação dos grupos sociais, pelo temor dos moradores em estarem associados aos movimentos de esquerda.

A ruptura da organização social só foi retomada no final da década de 1970, por meio de atividades clandestinas realizadas no interior das igrejas católicas, que caracterizaram a mobilização social e política dos setores populares chilenos nos anos 1980 (LUNECKE, 2008).

Foi principalmente a partir da ditadura, por medo da repressão militar, que começou a surgir certa desconfiança dos espaços públicos e, consequentemente, as práticas sociais no interior de espaços fechados passaram a fazer parte do cotidiano do bairro. Essa desconfiança, infelizmente, não deixou de existir após a rearticulação social e política, que foi lentamente retomada nos anos de retorno da democracia através de políticas de desenvolvimento comunitário, já que a rede social estava debilitada pela perseguição de dirigentes dos partidos políticos e pela quebra de redes sociais. Também a Igreja Católica, que teve grande importância histórica na organização social da comunidade, após a ditadura passou a centrar suas atividades em temas exclusivamente religiosos (LUNECKE, 2008).

Em Santa Adriana, essa rearticulação ocorreu com o surgimento de uma nova problemática: o tráfico de drogas, que impactou diretamente o setor, não somente pela estigmatização que passou a ter, como também pela diminuição de oportunidades de mobilidade social, agravando o receio do uso dos espaços públicos e a interiorização das práticas sociais. Assim:

95 Segundo o SEREMI (2008), com base em dados CASEN de 2006 (disponível em: <http://observatorio.ministeriodesarrollosocial.gob.cl/layout/doc/casen/publicaciones/2006/Imp_Distrib.pdf>. Acesso 15 dez. 2016), Santa Adriana tem 11.409 habitantes, distribuídos em 2.656 unidades habitacionais com uma média de $43 \mathrm{~m}^{2}$, contando, em média, com cinco moradores por unidade habitacional. Dentre eles, $63,4 \%$ correspondem a proprietários, $11,6 \%$ arrendatários, 16,8\% allegados e 8,3\% se encontram em outra situação/ou relação com a propriedade. Há uma distribuição proporcional entre jovens e adultos, e quase um terço dos moradores vivem no local há mais de 10 anos. 
Pese al pasado organizativo, la historia ha determinado hoy la existencia de una desconfianza generalizada en Santa Adriana, la que se expresa por una parte, en la desconfianza hacia el vecino, las instituciones, el Municipio y el Programa, y por otra, en el temor al uso de los espacios públicos y colectivos, en donde esta desconfianza se traduce también como inseguridad (SEREMI, 2008, p. 38).

O narcotráfico alterou o ambiente do bairro, tornando-o um local controlado física e psicologicamente e integrando o cotidiano da população de uma maneira ambígua, pois, ao mesmo tempo em que se instaura enquanto temor e ameaça, passa a fazer parte da rede social dos moradores do setor. A presença do tráfico gera conflito entre os moradores e estigmatização dentro do próprio grupo social, associando-se os usuários e os traficantes à delinquência:

La sola presencia del narco no constituye directamente un motivo de conflicto. En su doble condición de vecino y delincuente, su presencia, es enjuiciada únicamente frente al incremento del estigma social, la amenaza o frente a la figura de la balacera, no así frente a su presencia y al desarrollo del comercio ilícito. El deambular de los narcos por los pasajes de la población es cotidiano y la sensación de temor de los vecinos, la mayor parte del tiempo, se entremezclan con los saludos y breves conversaciones (UAH, 2004, apud LUNECKE, 2008)

O enfraquecimento da organização social após a ditadura fez com que os sucessos obtidos por meio da luta popular tenham ficado apenas na memória coletiva. Por outro lado, essa memória, ainda viva nos movimentos sociais do setor, foi fator relevante para a escolha de Santa Adriana para receber o Programa Quiero Mi Barrio, que atuou com grande intensidade nas dinâmicas de retomada da história da organização social.

Sobre a morfologia urbana do setor, predominam residências unifamiliares construídas no período de fundação de Santa Adriana, conformando-se por uma maioria de habitações unifamiliares CORVI ${ }^{96}$ construídas entre 1964 e 1965, com adequada proporção e dimensão de espaços livres públicos, como no caso dos recuos entre a rua e as residências (figura 154). As unidades habitacionais residenciais, embora em tamanho reduzido, se inseriam em terrenos amplos, o que possibilitou ampliações sem que o espaço do recuo em relação à rua fosse perdido.

Essa proporção ocorre principalmente nas ruas e avenidas principais, definindo um sistema de espaços livres bem característico do setor e propiciando possibilidades de apropriação no espaço livre bastante favoráveis para as práticas sociais e relações de vizinhança, inclusive para práticas de maior permanência. A morfologia urbana teve seu potencial reconhecido pela equipe do PQMB para reestruturação do espaço livre e recuperação das práticas sociais (figura 154), associado ao contentamento das famílias com o seu bairro e com sua origem na luta dos movimentos sociais.

Também existem ruas e passagens mais estreitas, que se deterioraram e se tornaram locais inóspitos, onde práticas ilícitas passaram a ocorrer, como comercialização de drogas. Tais locais foram reformados pelo PQMB principalmente para se tornarem vias de uso exclusivo do pedestre.

Existe um conjunto de condomínios de prédios no setor, a Villa las Palmeras, construído em 1992 pelo governo de Patricio Aylwin, que consiste em 14 edifícios habitacionais reunindo 2.700 unidades habitacionais (SEREMI, 2008) no formato típico do modelo de habitação social dos anos 1990.

Como é tradicional nesses condomínios chilenos de prédios, foram diversas as ampliações irregulares feitas pelos moradores, para compensar a falta de espaço no interior da habitação (figuras 155 e 156).

96 A CORVI foi uma instituição anterior à criação do MINVU para o provimento de habitação. 


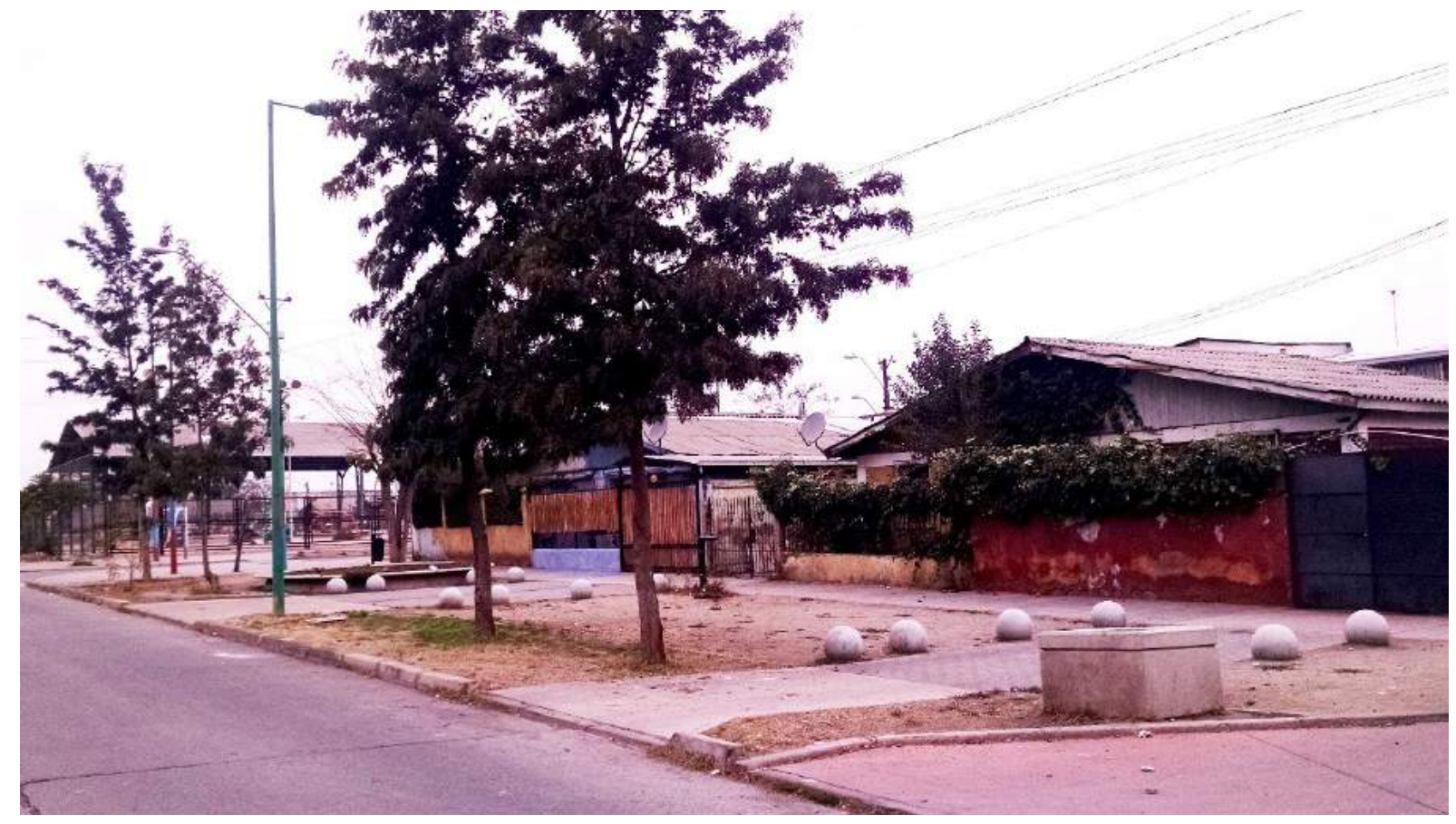

Figura 154: Setor residencial de Santa Adriana já com intervenções do Quiero Mi Barrio. Fotografia da autora, de jul. 2015.

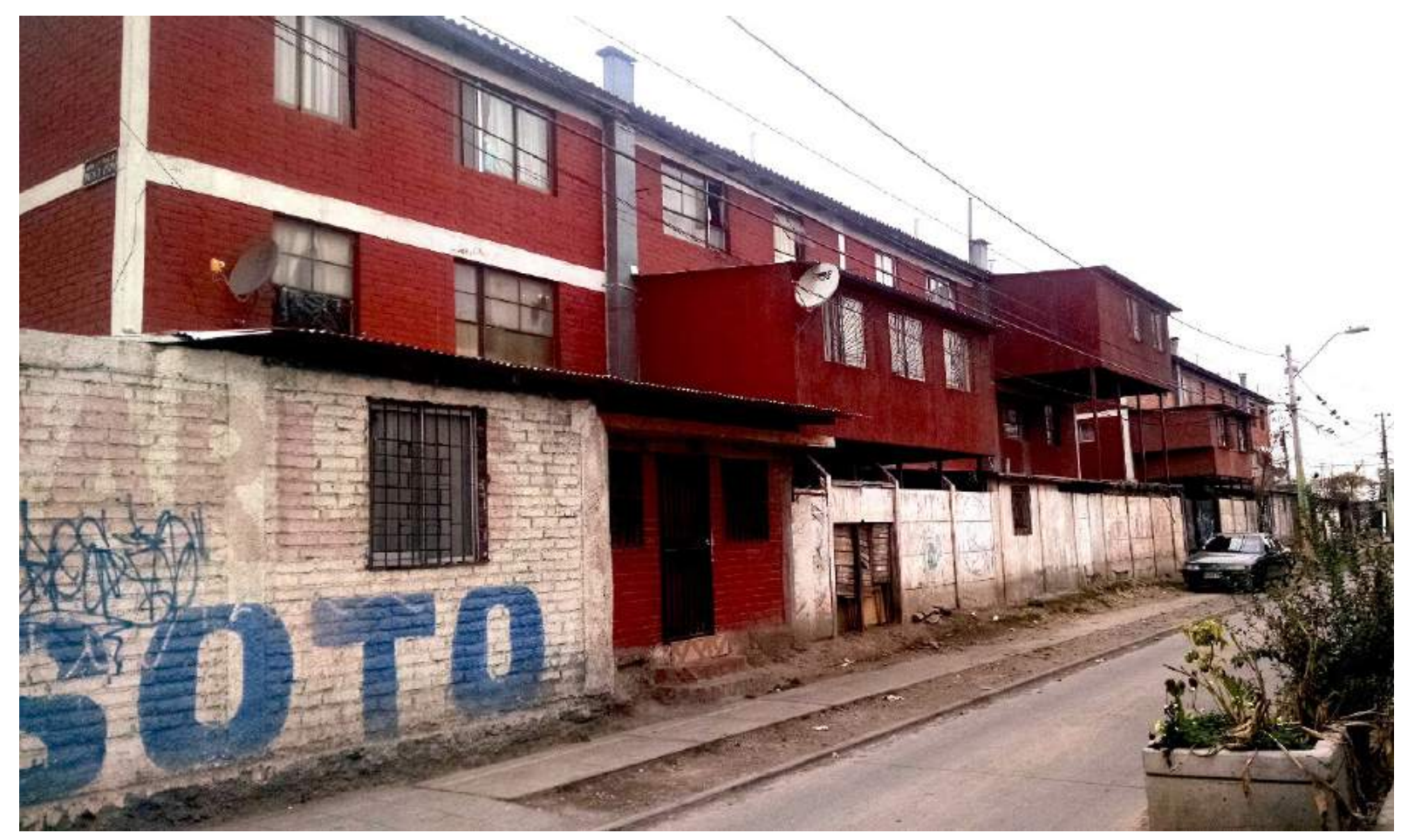

Figura 155: Ampliações irregulares na Villa Las Palmeras em Santa Adriana. Fotografia da autora, jul. 2015. 


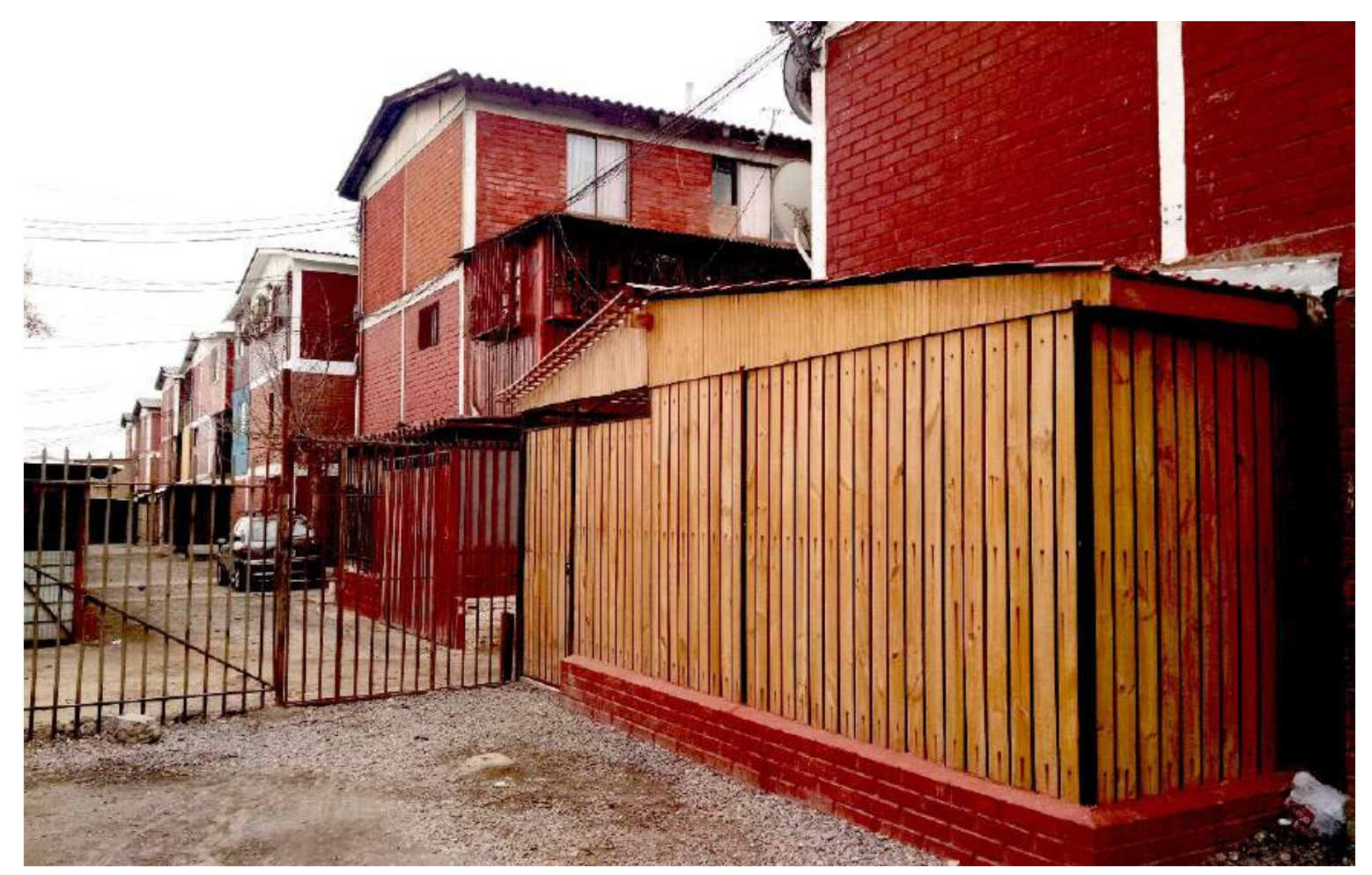

Figura 156: Villa Las Palmeras em Santa Adriana. Fotografia da autora, jul. 2015.

Em levantamento feito pelo SEREMI (2008), a percepção da comunidade em relação à qualidade da habitação individual é satisfatória para as famílias que vivem nas unidades habitacionais residenciais. Já no caso dos moradores dos conjuntos verticais, há grande insatisfação, pois reclamam da falta de beleza do conjunto, da ausência de privacidade, do tamanho insuficiente das unidades habitacionais, da presença de espaços residuais sem uso definido, da falta de higiene nos espaços de uso coletivo, do fechamento e isolamento da Villa das Palmeras em relação ao restante do setor e, finalmente, da imagem negativa da moradia (SEREMI, 2008).

De acordo com o Seremi (2008), "Ios vecinos se sienten parte más de su propio sector que de la totalidad de la población, pues la marcada sectorización del barrio acota los límites de pertenencia, inhibiendo el tránsito y el encuentro de vecinos y vecinas de un sector y otro" (p. 37).

A separação por setores é cotidiana (figura 157), com cada um tendo sua respectiva organização social. A própria diferenciação morfológica também marca a segregação interna do bairro, pois cada setor acaba lutando por seus interesses específicos, não observando as necessidades do restante da población. 


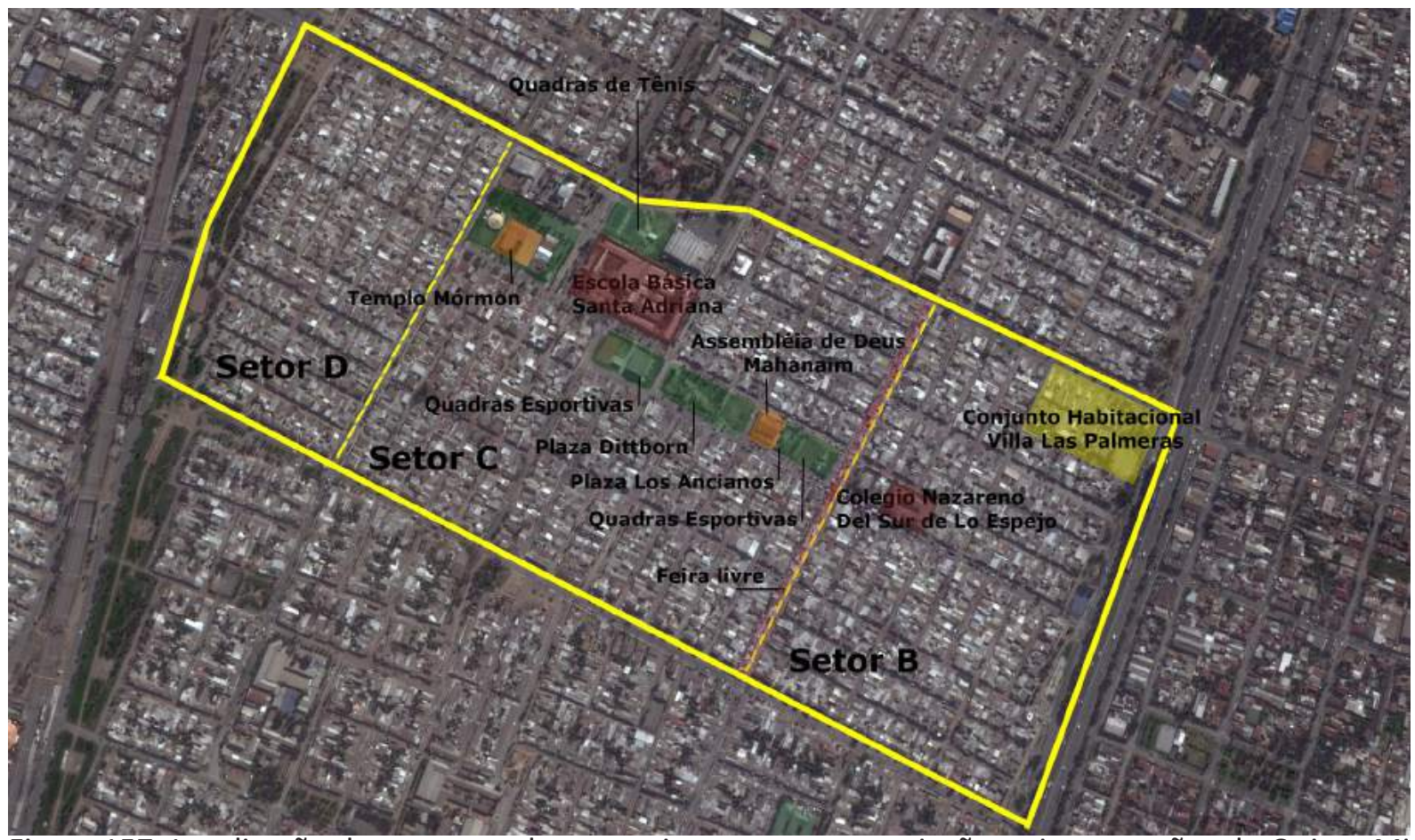

Figura 157: Localização dos setores, alguns equipamentos, apropriações e intervenções do Quiero Mi Barrio. Fonte: elaboração da autora, sob base Google Earth.

O Programa Quiero Mi Barrio selecionou Santa Adriana para intervir a partir de 2006, como já comentado. Porém, esse não é o primeiro programa a agir no local, embora tenha sido o mais extenso e relevante na comunidade até o momento atual: a partir dos anos 2000, devido à luta dos dirigentes do setor por maiores condições de segurança na población, também o programa Barrio Seguro, do Ministerio del Interior, atuou no local (OLATE, 2012).

O diagnóstico do PQMB foi elaborado juntamente com a comunidade, com instâncias participativas nas quais cada setor se organizou para debater os principais pontos positivos, negativos e as necessidades do bairro e dos setores, com foco nos espaços livres e nos equipamentos urbanos. A partir dos diagnósticos, foram elaborados os planos de ação, como o Plan de Gestión de Obras (PGO) e o Plan de Gestión Social (PGS), ambos buscando definir as ações que pudessem auxiliar na organização social e na sensação de pertencimento em relação aos espaços públicos.

Complementarmente, outras instâncias de diagnóstico técnico eram realizadas, com atores municipais, técnicos, políticos e líderes comunitários integrantes do Consejo Vecinal de Desarrollo (CVD), com uma equipe técnica do SEREMI permanente no local não só para gerenciar a obra, mas também para interagir e dialogar com os moradores cotidianamente.

O diagnóstico e as estratégias de ação foram separados por temas, dentre eles:

- Infraestrutura de vias urbanas: identificaram-se o mau estado de conservação e deterioração das vias, o que exigiu melhorias na pavimentação das calçadas e ruas, atenção no desenho dos espaços de convívio, definição de limites de velocidade e trânsito, criação de passeios exclusivamente peatonais e com acessibilidade universal e solução técnica para resolver acúmulos de água de chuva em alguns trechos do bairro;

- Espaços livres: apontaram-se os espaços deteriorados, o déficit de espaços para recreação e 
esporte e o potencial da morfologia urbana para as práticas coletivas oferecido pelos espaços livres generosos. Foram também definidas estratégias de projeto para os espaços associados a equipamentos comerciais, educacionais e comunitários;

- Conflitos ambientais: detectaram-se os depósitos de lixo doméstico em diversos pontos do bairro, geralmente em espaços pouco utilizados, e criaram-se estratégias para conscientização dos moradores;

- Percepção de insegurança e ocorrência de delitos: identificaram-se os locais onde ocorriam delitos e onde os moradores não se sentiam seguros e verificaram-se que estes estavam associados a espaços deteriorados, apropriações individuais, iluminação pública insuficiente, vazios urbanos, ausência de permeabilidade visual nos lotes, presença do tráfico de drogas e conflitos entre traficantes em pontos específicos do bairro;

- Equipamento comunitário: apontou-se a necessidade de reforma das sedes comunitárias e equipamentos públicos, quando existentes, e de criação de equipamentos comunitários e esportivos.

Também no diagnóstico se verificaram os aspectos positivos do bairro, destacando-se:

- Alto nível de satisfação pessoal com a habitação e a morfologia do bairro, com 93,4\% dos moradores entrevistados manifestando estarem muito ou bastante satisfeitos (MAC LEAN, 2012);

- Nível moderado de pertencimento ao bairro, com 51,1\% dos moradores sem interesse em se mudarem para outro setor, ou sem nunca terem pensado em se mudar;

- Estrutura urbana com ruas e calçadas amplas e hierarquia de vias adequada.

O diagnóstico realizado pelo PQMB mostrou não apenas a dimensão física e espacial da infraestrutura urbana deteriorada, mas as fragilidades da estrutura social, como a debilidade da organização social e a violência e os conflitos tanto no interior familiar como no espaço público e no ambiente escolar. Esses aspectos geram vulnerabilidade social, insegurança e desconfiança do outro, fragmentação e estigmatização do setor e, como resultado, estimulam as relações sociais nos espaços fechados e controlados, já que a desconfiança, o temor e a violência dificultam a apropriação dos espaços coletivos, como já comentado.

A insegurança, derivada principalmente da presença do tráfico e consumo de drogas na comuna, foi um dos principais pontos críticos levantados pelo PQMB em Santa Adriana e se materializa na falta de uso dos espaços coletivos por medo dos conflitos que possam ocorrer no exterior da habitação. A sensação de insegurança é ampliada pela visão deteriorada dos espaços livres, frequentemente usados como depósito de lixo, que varia de lixo residencial a escombros e resíduos volumosos. Segundo o SEREMI (2008),

(...) se hace patente el círculo vicioso que se genera entre la no utilización de ciertas áreas y rincones del espacio público - sobre todo de aquellos asociados a muros o espacios de poco control natural - y el depósito de basura en él. De manera evidente, aquellos sitios en los que constantemente existe la presencia de basura y focos de microbasulares se transforman en espacios residuales no utilizados, lo que, dentro de una visión inversa, incentiva la mala práctica de depositar desechos en dichos lugares (p. 40). 
Dados policiais coletados por Lunecke (2008) apontam que, em 2007, as principais bandas de tráfico de drogas estavam instaladas no setor oeste da población. Em relação à percepção de insegurança, um estudo realizado pela Universidad Alberto Hurtado em 2004, citado por Lunecke (2008), verificou que esta não é geral a toda a población, mas sim ao setor específico das cercanias do conjunto habitacional Las Palmeras, onde as ruas, passagens, praças e até mesmo as feiras livres transmitem elementos negativos para a sensação de segurança.

Lunecke (2008) também observou no bairro o pouco uso diário dos espaços livres, com o abandono das práticas coletivas no espaço público e a orientação delas para o interior do lar. Essa situação é típica de comunas com problemas sociais, o que acaba levando à deterioração dos espaços coletivos e sua apropriação por grupos reduzidos.

Por outro lado, identificaram-se, durante visitas de campo da autora em 2015, algumas apropriações esporádicas intensas, como o uso da rua Valparaíso, que divide o setor B e C, para a feira livre da comuna Lo Espejo, uma tradicional "feira persa", com venda de produtos novos e usados a preços negociáveis. Também se verificaram as mesmas pregações religiosas de fiéis no caminho para o culto vistas em Bajos de Mena.

O PQMB em Santa Adriana realizou uma série de intervenções urbanas, dentre elas: meIhoramento de passagens e ruas, remodelação de sedes comunitárias, construção de equipamentos esportivos e de área recreativa e pavimentação. Essas intervenções físicas foram a estratégia mais visível do programa, por meio do qual se experimentaram mudanças espaciais, cujo objetivo era levar moradores e visitantes a alterar sua percepção do bairro (OLATE, 2012).

Assim, foram remodelados espaços públicos de ruas e praças; criados novos equipamentos urbanos, como quadras de tênis e áreas esportivas; construídos novo estabelecimento de educação, um centro comunitário para a Villa Las Palmeras e um centro cívico no setor; reformados outros equipamentos do bairro, como o centro poliesportivo Carlos Dittborn e sedes comunitárias.

As intervenções nas calçadas e passeios permitiram uma melhor relação entre o espaço privado e o espaço público, inclusive com maior visibilidade, através de melhorias de iluminação e de posicionamento da vegetação, que permitem um controle natural do espaço exterior da habitação e possibilitam maior sensação de segurança aos moradores (figuras 158 a 167). Os espaços públicos foram projetados para permitir tanto a circulação quanto a permanência, com acessibilidade universal e clareza nos limites entre cada uso.

Porém, foram utilizados em excesso elementos de mobiliário urbano, como jardineiras e bolas de concreto, que deveriam delimitar o espaço do automóvel, mas que foram utilizados mais como elementos decorativos, com o objetivo de incitar maior identidade local e gerar maior sentido de pertencimento (figura 168). Pela recorrência constante aos elementos, estes acabaram não sendo identificados como parte do bairro pelos moradores, sofrendo algumas depredações pós-ocupação. 


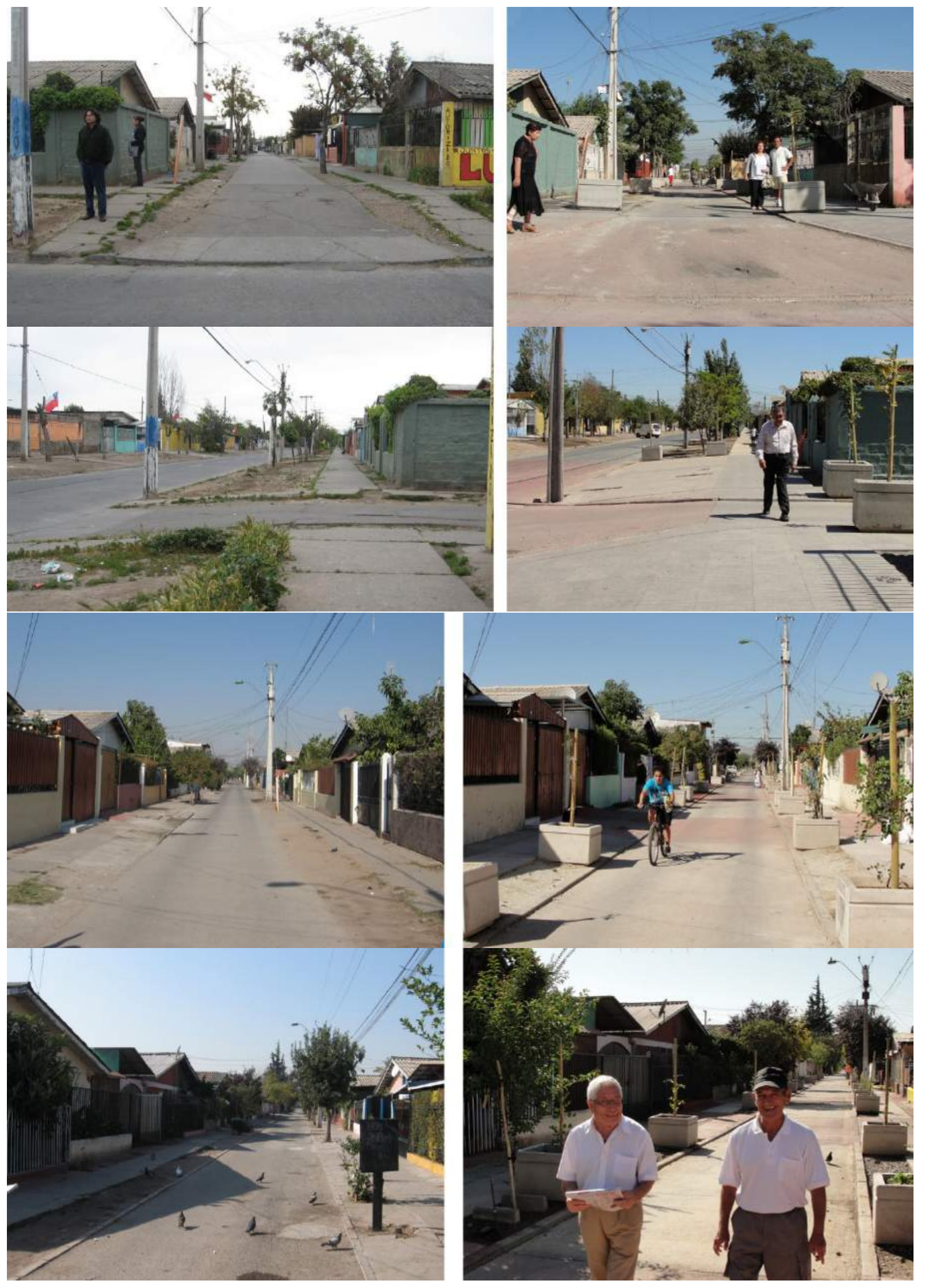



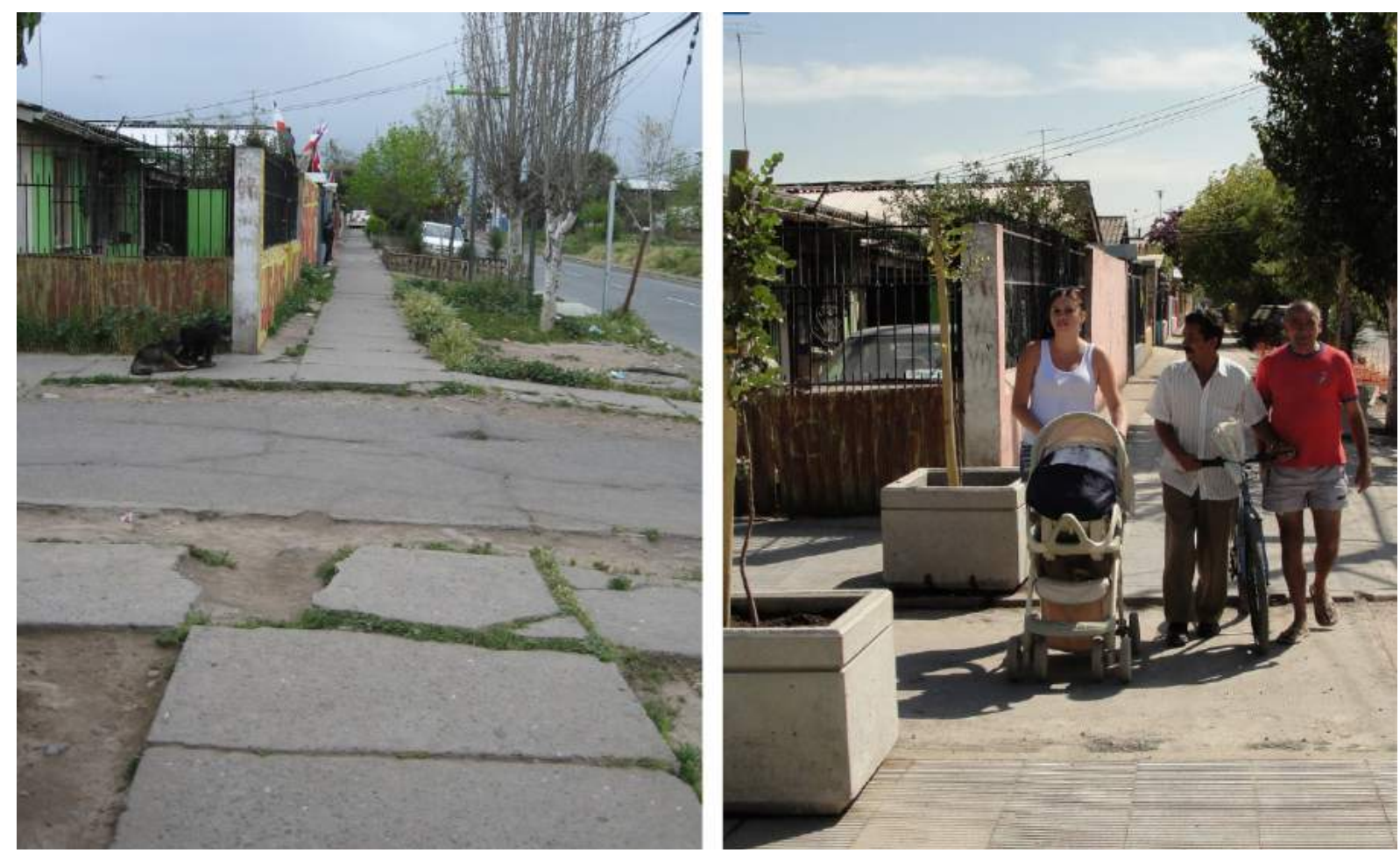

Figuras 158, 159, 160, 161, 162, 163, 164, 165, 166, 167: 0 antes e depois da intervenção urbana do Programa Quiero Mi Barrio em Santa Adriana. Fonte: Quiero Mi Barrio (2010) ${ }^{97}$, editado pela autora.

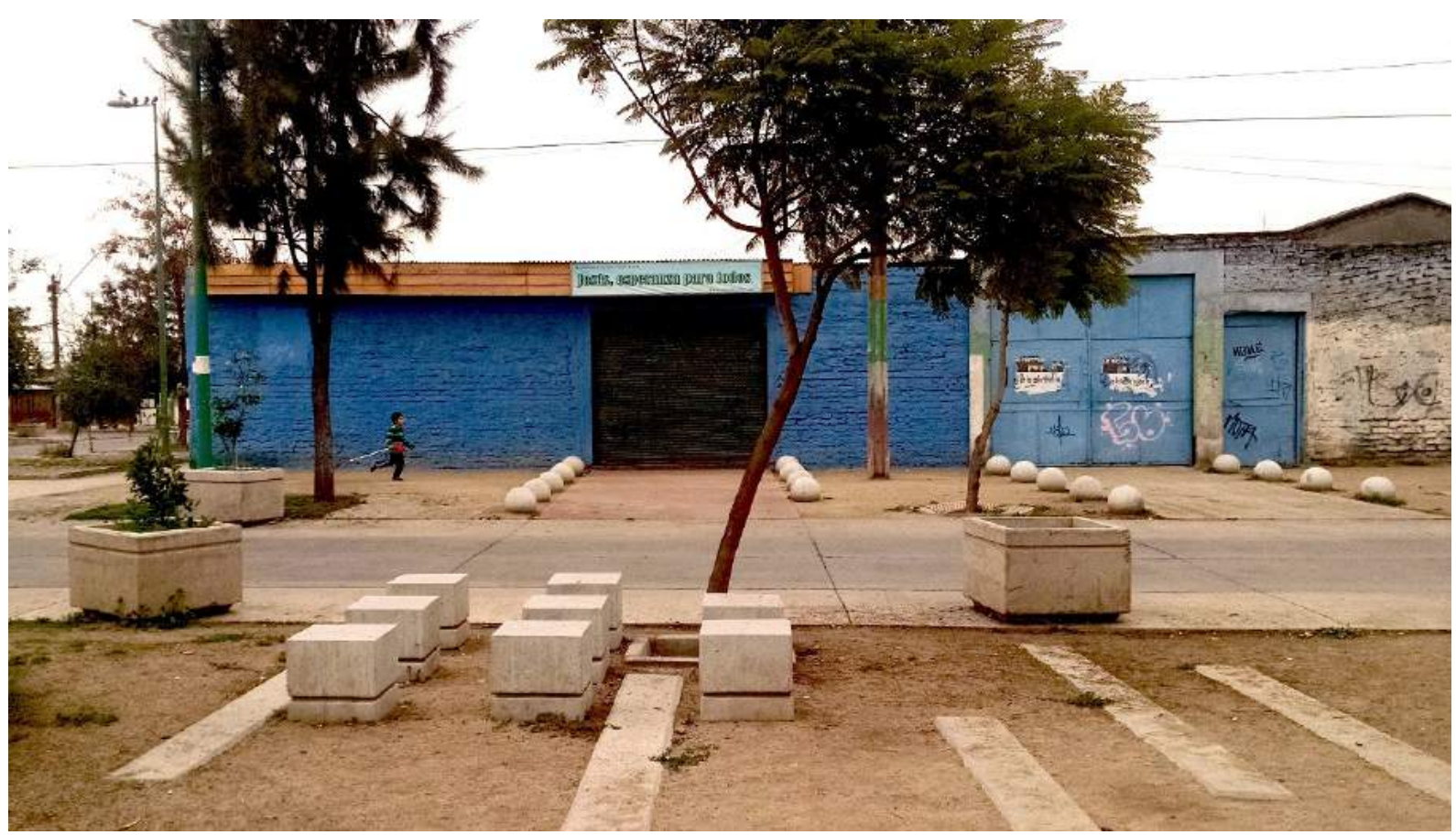

Figura 168: Melhorias físicas nos passeios públicos realizados pelo programa Quiero Mi Barrio em Santa Adriana e o excesso de mobiliário urbano decorativo. Fotografia da autora, jul. 2015.

97 Disponível em: < http://quieromibarriosantaadriana.blogspot.com.br/>. Acessado em dez. 2016. 
No âmbito das iniciativas do Plano de Gestión Social, foram diversas as ações desenvolvidas em torno de eixos estratégicos para a recuperação do bairro, com intervenções baseadas em atividades estabelecidas juntamente com a comunidade para fortalecer a identidade, a história e a cultura do local. Essas ações buscaram favorecer as práticas socioculturais e identidades existentes no bairro e levá-las aos espaços públicos e equipamentos, para promover novos usos e significados (SEREMI, 2008).

Foram realizadas tardes de jogos, dança, música e oficinas diversas, que incluíram construção de brinquedos infantis, pintura do muro da escola Santa Adriana com o artista plástico "Mono" Gonzalez (figuras 169 e 170), construção de instrumentos musicais com materiais recicláveis e conscientização dos moradores sobre o descarte correto de lixo (figuras 171 e 172), além de aulas de yoga, massoterapia e outros temas para adultos e idosos, dentre outras atividades recreativas, todas divulgadas tanto oralmente quanto por meio de boletins e informes físicos e virtuais, em redes sociais e no blog oficial do PQMB em Santa Adriana (figura 173).

Para a realização de todas as intervenções propostas no plano, o SEREMI instalou um escritório no setor, no qual os diversos professionais atuantes se encontravam diariamente durante os anos de intervenção. Ao longo de todo o processo, foram realizadas reuniões semanais com os moradores, que participavam das propostas para o setor.

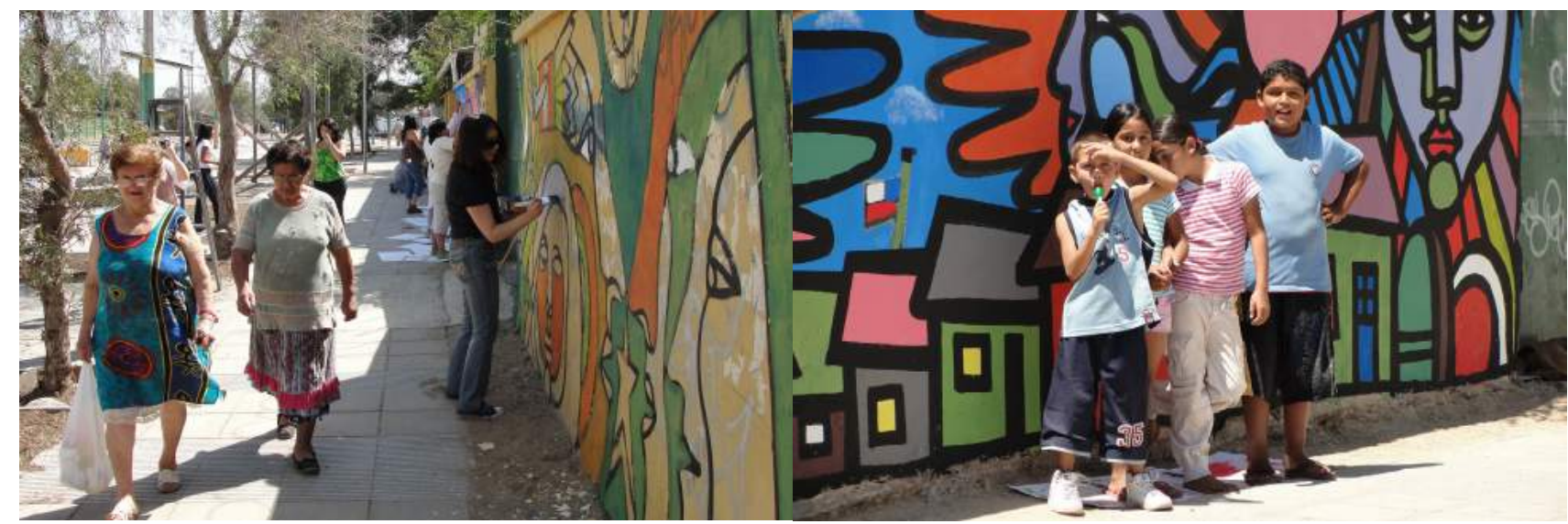

Figuras 169 e 170: Oficina para a pintura do muro da escola Santa Adriana com o artista plástico "Mono" Gonzalez Fonte: Quiero Mi Barrio (2009) ${ }^{98}$.

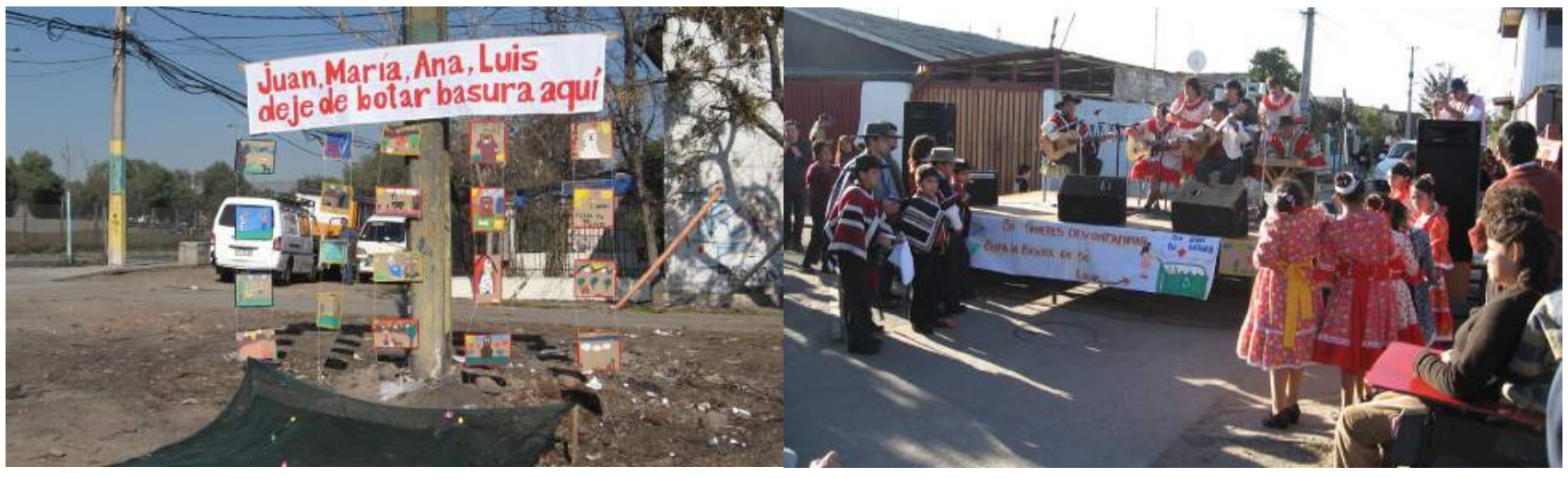

Figuras 171 e 172: Jornada familiar "Santa Adriana Limpia: Acción Ecológica y Cultural" com o objetivo de identificar e intervir nos locais de depósito de lixo para conscientização da comunidade, finalizando a jornada com culinária típica e apresentação de bandas de rock, punk e folclore nacional do setor. Fonte: Quiero Mi Barrio $(2009)^{99}$.

98 Disponível em: < http://quieromibarriosantaadriana.blogspot.com.br/>. Acessado em dez. 2016.

99 Disponível em: < http://quieromibarriosantaadriana.blogspot.com.br/>. Acessado em dez. 2016. 


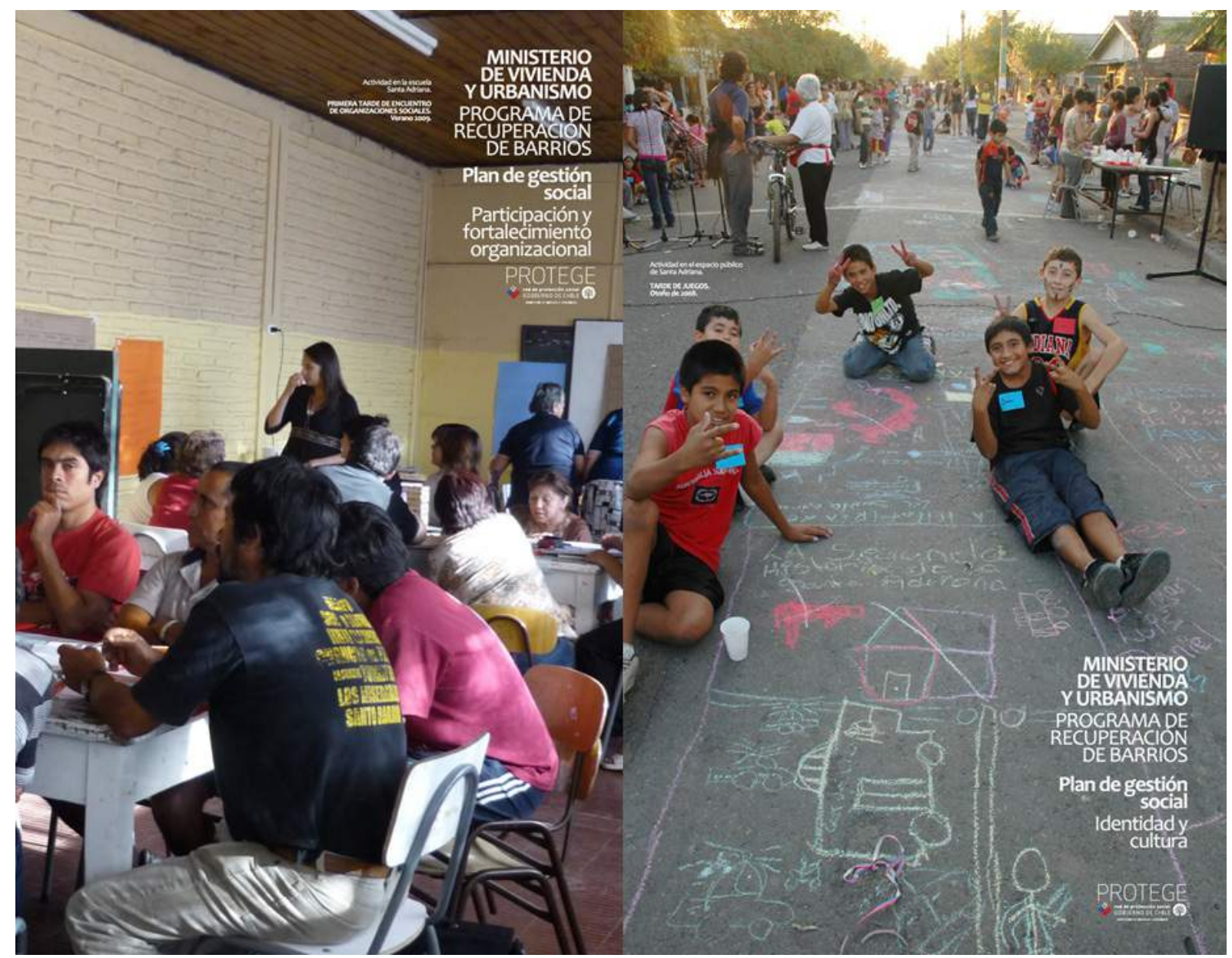

Figura 173: Ações de divulgação do Plan de Gestión Social (PGS) para atividades participativas de fortalecimento organizacional e atividades de identidade e cultura no espaço público. Fonte: Quiero Mi Barrio (2009), editado pela autora ${ }^{100}$.

Segundo entrevistas realizadas por Olate (2012), o PQMB conseguiu alterar a imagem dos moradores sobre o próprio bairro, e muitos se disseram orgulhosos de morar no local. Também houve aumento na sensação de segurança, com 52,6\% das pessoas entrevistadas dizendo se sentirem mais seguras entre 2007 e 2010. O autor acrescenta, ainda, que essa sensação de segurança é provavelmente derivada das melhorias nos espaços públicos:

Si bien las encuestas parecen indicar una mejoría en cuanto a la seguridad, las entrevistas aplicadas a los vecinos entregan aristas que hacen suponer que la mejora percibida no es consecuencia de la disminución de los actos delictivos, sino que más bien se debe a que la percepción de seguridad se ve influenciada positivamente por las mejoras en el espacio público (p. 137).

Entretanto, durante visitas realizadas no setor em 2015, pôde-se verificar que, embora as características físicas da intervenção permanecessem visíveis, alguns espaços e equipamentos estavam deteriorados pela falta de manutenção, por atos de vandalismo e por se tornarem

100 Disponível em: < http://quieromibarriosantaadriana.blogspot.com.br/>. Acessado em dez. 2016. 
depósitos de lixo indevidos. O retorno desses problemas denota uma falta de compromisso da comuna de Lo Espejo na manutenção dos espaços e falta de comprometimento dos moradores em mudar hábitos de vandalismo, o que indica que a dimensão invisível ainda não conseguiu ser resolvida.

Dentre as apropriações em prol de necessidades individuais, identificaram-se algumas demarcações de grupos sociais em espaços livres, como com pinturas em postes e elementos urbanos, o que já se fazia antes da intervenção do Programa. Essas intervenções, com forte carga identitária, apontam os territórios apropriados por grupos sociais, em geral associados a torcedores de times de futebol, que desejam se fazer notar no espaço, apropriando-se subjetivamente, com caráter de posse, de um determinado espaço (figuras 174 e 175).

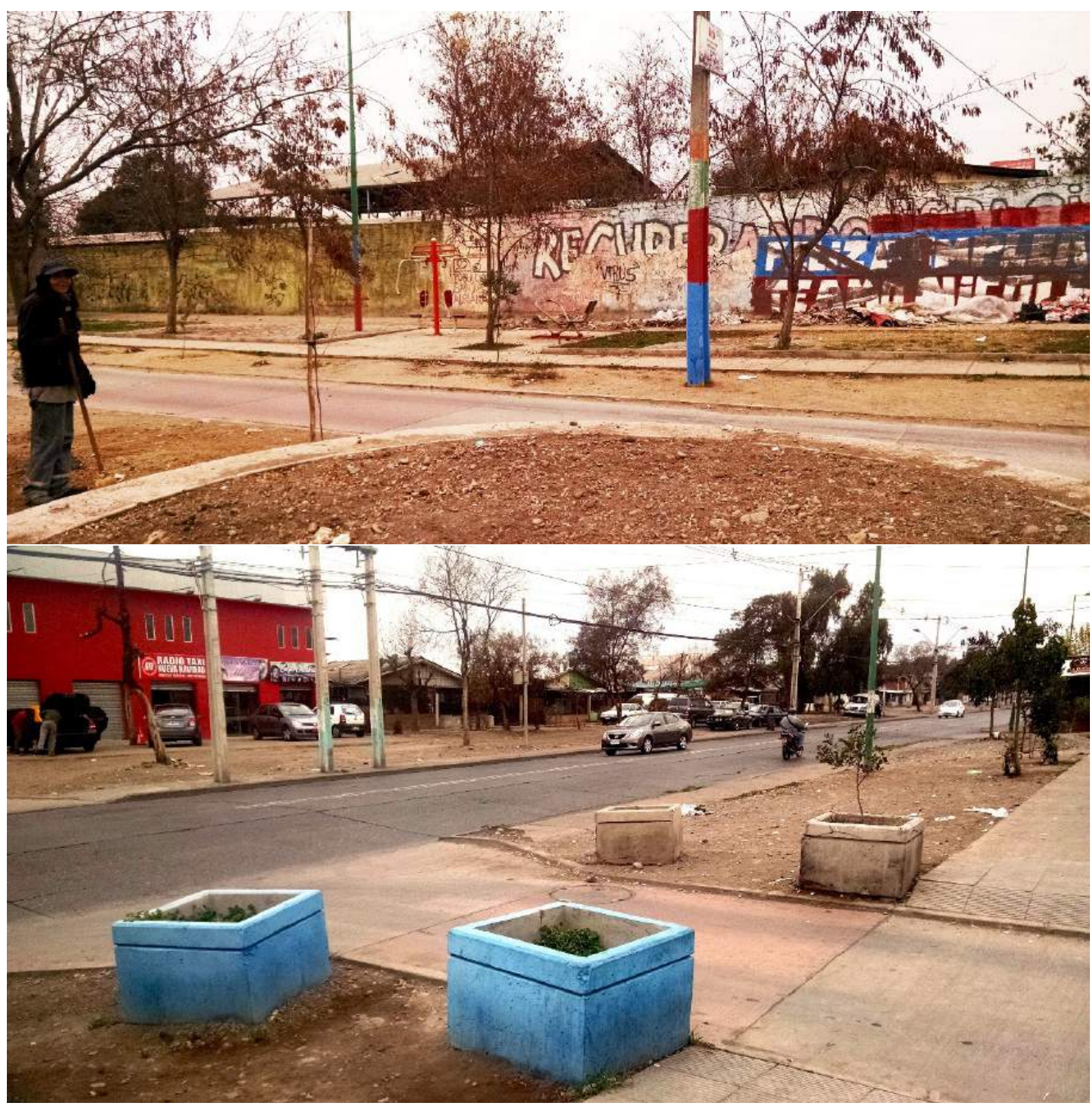

Figuras 174 e 175: Deterioração dos espaços reformados pelo programa Quiero Mi Barrio em Santa Adriana e apropriação de grupos sociais identificados pela utilização de cores. Fotografia da autora, jul. 2015. 
O narcotráfico permanece no setor, e as inseguranças que causaram abandono dos espaços públicos e consequente interiorização das práticas sociais permaneciam presentes, perceptíveis pelo pouco uso, em diferentes momentos do dia, nos espaços reformados pelo programa.

Olate (2012) comenta que há diferentes usos dos espaços livres ao longo do dia. Durante as manhãs, verificam-se deslocamentos cotidianos peatonais e por veículos para os trajetos diários, como para deixar filhos no colégio, realizar compras para o almoço ou ir para o trabalho ou escola. Durante as tardes, o movimento de retorno à residência se faz presente, com singelas apropriações dos bancos nas praças por adultos e jovens, uso que durante a noite se intensifica, com apropriações para consumo e venda de drogas e álcool, com episódios de violência esporádicos, que geram insegurança para outros usuários.

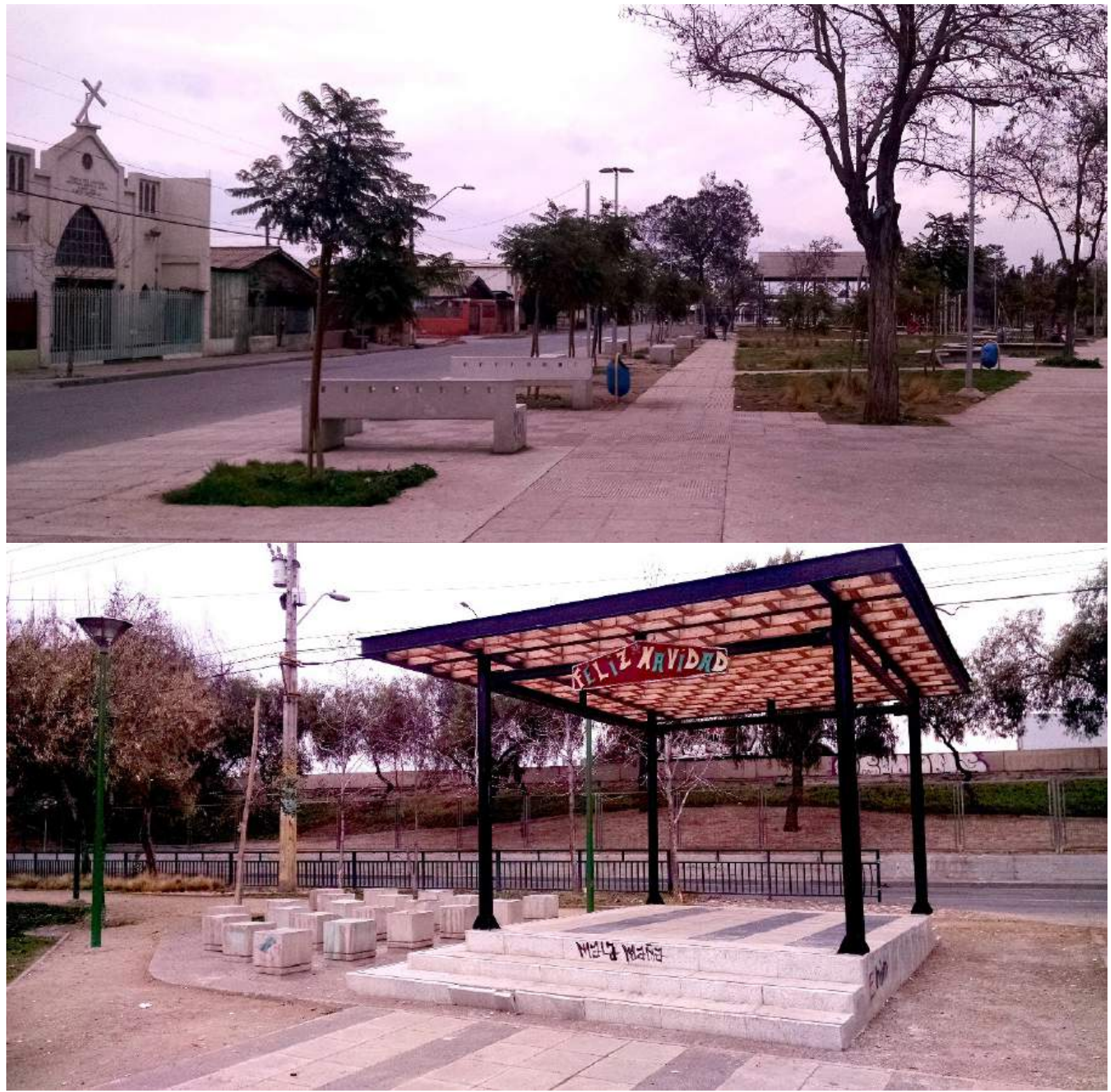

Figuras 176 e 177: Melhorias físicas realizadas pelo programa Quiero Mi Barrio ainda não estimulam o uso e apropriação do espaço no cotidiano. Fotografia da autora, jul. 2015. 
Também foi possível observar a apropriação de algumas calçadas amplas do setor por moradores para a construção de pequenos jardins, cuja manutenção é feita por eles próprios, ou mesmo para a ampliação da unidade habitacional (figura 178).

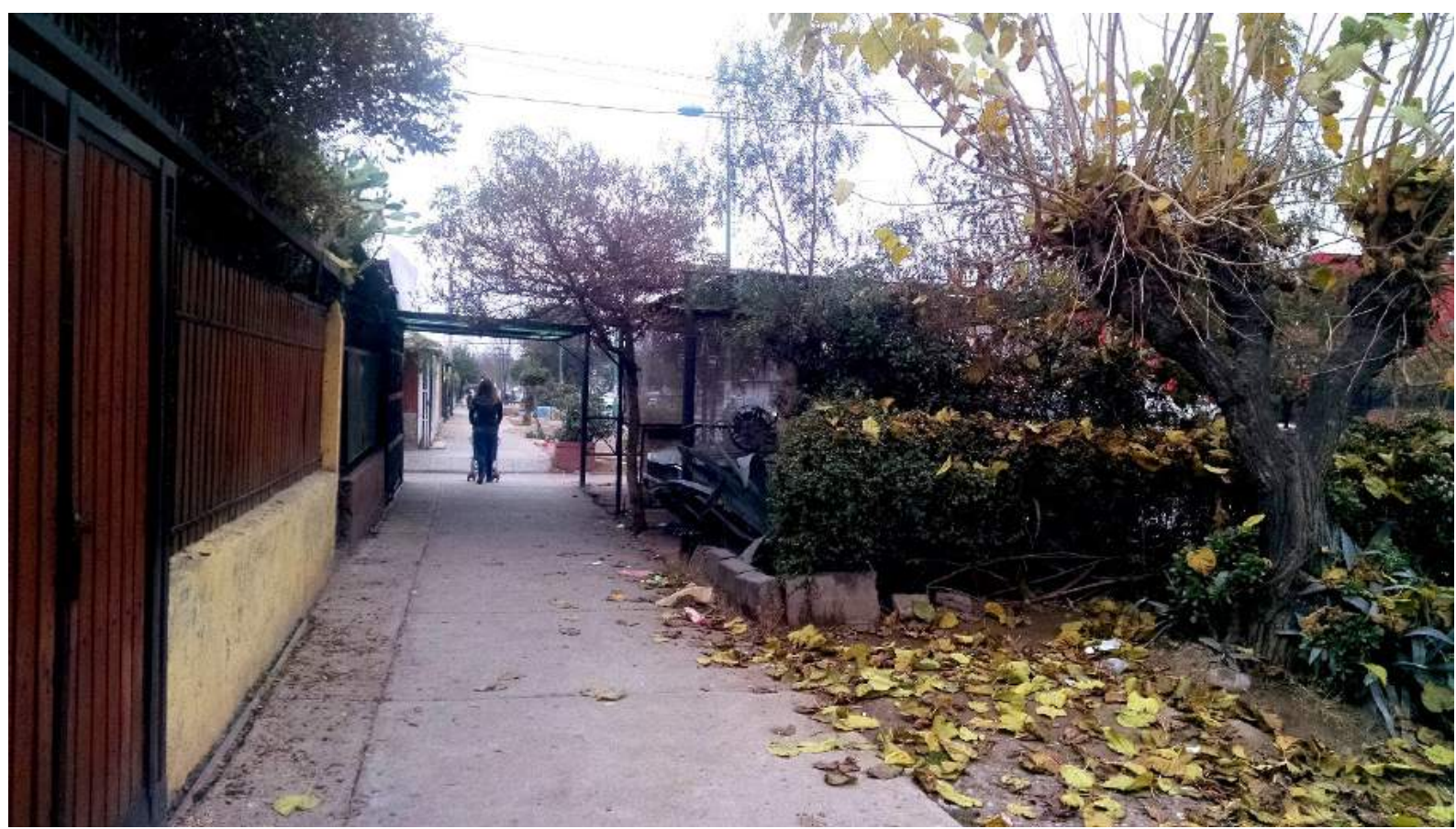

Figura 178: Apropriação da generosa calçada do setor residencial de Santa Adriana para ampliação da unidade habitacional, realizando uma garagem particular no espaço público. Fotografia da autora, jul. 2015.

Se observaram apropriações de caráter emocional e religioso, muitas vezes fazendo alusão ao local onde algum morador perdeu a vida devido a ato violento (figura 179). Essas manifestações também foram vistas em outras comunas de Santiago, em um modo já internalizado culturalmente de reverenciar entes que se foram.

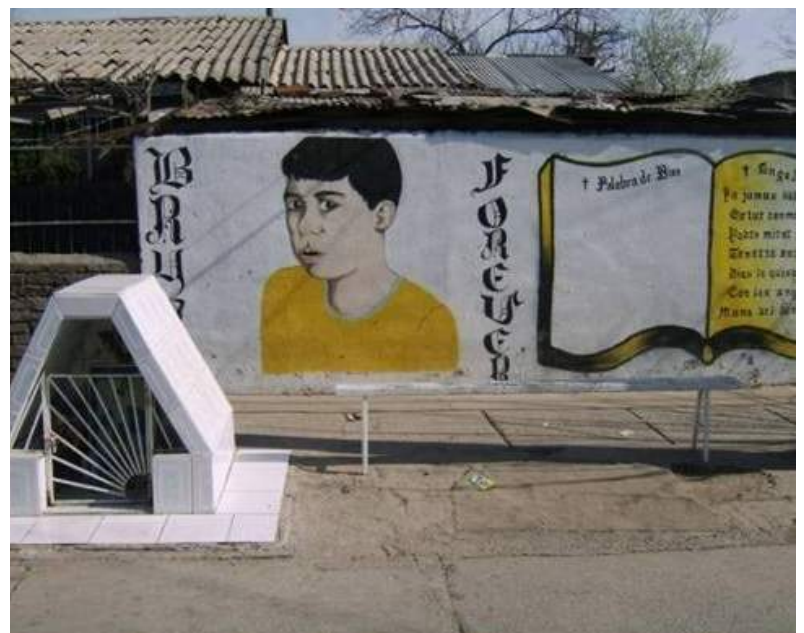

Figura 179: Memorial em homenagem a um jovem vítima de tiroteio. Fonte: LUNECKE, 2012.
O caso de Santa Adriana é exemplo da complexidade das ações em comunidades com diagnósticos físico, sociais e culturais profundos e intrincados. Embora o PQMB tenha atuado por diversos anos, com um montante de recursos altíssimo, com atuação no local e participação popular em frentes sociais e físicas, a análise, no final da intervenção, é de que os resultados não serão sustentáveis com o tempo, indício verificado durante visitas de campo um ano após a conclusão da intervenção: com a saída do Programa (inclusive fisicamente, pelo fechamento do escritório do SEREMI no local), retomaram-se as dinâmicas sociais de delitos, vandalismos, pouco uso do espaço coletivo e apropriações espaciais em 
prol de necessidades individuais.

Também se observou o impacto negativo da concentração da intervenção somente na población de Santa Adriana, não abrangendo poblaciones vizinhas. Essa ausência de ação nos setores vizinhos não teve boa aceitação dos moradores dos outros setores, abandonados até que problemas sociais e urbanos maiores poderão inseri-los nas preocupações ministeriais.

No entanto, apesar das dificuldades observadas na atuação e na manutenção das intervenções, constata-se a necessária implementação de programas que abordem políticas urbanas na escala do bairro, com participação dos grupos sociais, buscando estimular o reconhecimento do papel cidadão enquanto ator político nas mudanças espaciais e culturais.

O caso particular de Santa Adriana, com grande histórico de lutas sociais, fez com que esse caso se tornasse singular dentre as ações do PQMB, com alto conteúdo simbólico e histórico e cujas intervenções urbanas puderam, graças à morfologia do bairro, serem traçadas com bastante liberdade.

Tudo isso, somado ao apego dos habitantes pelo setor, contribuiu para dar um grande passo no desenvolvimento do habitat, mesmo com o difícil contexto invisível dos conflitos sociais e urbanos causados pelos eventos pós-ditadura, de desarticulação do grupo social, tráfico de drogas, disputas territoriais por gangues, violência urbana e consequente abandono das práticas sociais nos espaços públicos e coletivos.

A iniciativa do programa, que parte dos espaços livres para buscar a rearticulação social, trouxe aos moradores incremento notável na qualidade de vida e na organização social, mesmo que nem todas as iniciativas tenham tido continuidade.

Dentre as ações do PQMB, uma se destacou, embora, de início, parecesse deslocada da realidade do local, obtendo resultado surpreendente: a demanda dos jovens do setor por quadras de tênis, esporte tradicionalmente elitista, fez com que se construísse um complexo com duas quadras e mais um centro administrativo do local (figura 180).

Antes do programa, os jovens começaram a praticar o esporte na rua, com raquetes e delimitações fictícias da quadra. Com a construção das quadras de tênis, muitos deles começaram a profissionalizar o esporte, criando a escola Futuros para el Tenis (FPT) em 2003, a qual fomenta a educação e o desenvolvimento humano e social através do esporte (figura 181).

Os jovens se apropriaram das quadras e do centro e são responsáveis por administrar o local. Para tanto criaram, eles próprios, um sistema de aluguel de quadras e etapas competitivas que possibilita geração de renda a qual, por sua vez, permite que eles deem aulas gratuitamente a jovens da comuna e gerem mais interessados no esporte e na manutenção do espaço.

Com bastante esforço, a escola conseguiu adquirir equipamentos para a prática esportiva, que ficam guardados em uma sala técnica adjunta às quadras. Com receio de furtos, os jovens se revezam, diariamente, para dormir no local e cuidar do espaço.

Assim, o acesso ao tênis, antes distante para a maioria dos moradores da Comuna de Lo Espejo, passou a ser cotidiano e colaborativo, trazendo para o esporte jovens e crianças que antes se encontravam em situação de risco social.

Segundo Ribeiro (2013) $)^{101}$, os movimentos de resistência que surgem na contra face da hegemonia capitalista têm sua resistência estimulada pelos espaços sociais. A ação social resistente aos mecanismos de controle tende a ocorrer no cotidiano, emergindo em espaços públicos e privados

101 Ação e seleção social: impulsos globais em contextos metropolitanos. Vol. 4. 
inesperados. Essas práticas sociais resistentes à reprodução sistêmica são depositárias de energias utópicas e de novas formas de exercício de poder, aprofundando a complexidade da esfera da vida coletiva.

A apropriação do espaço pelos jovens e o interesse em manter a prática esportiva no local têm causado mudanças no cotidiano e na possibilidade de mobilidade social e econômica para o grupo envolvido. Esse fato demonstra que, apesar da complexidade, as intervenções físicas e sociais nos espaços livres, embora não garantam nem melhoria nem durabilidade das ações, dão oportunidade para que os próprios moradores sejam os agentes responsáveis pelas mudanças almejadas.

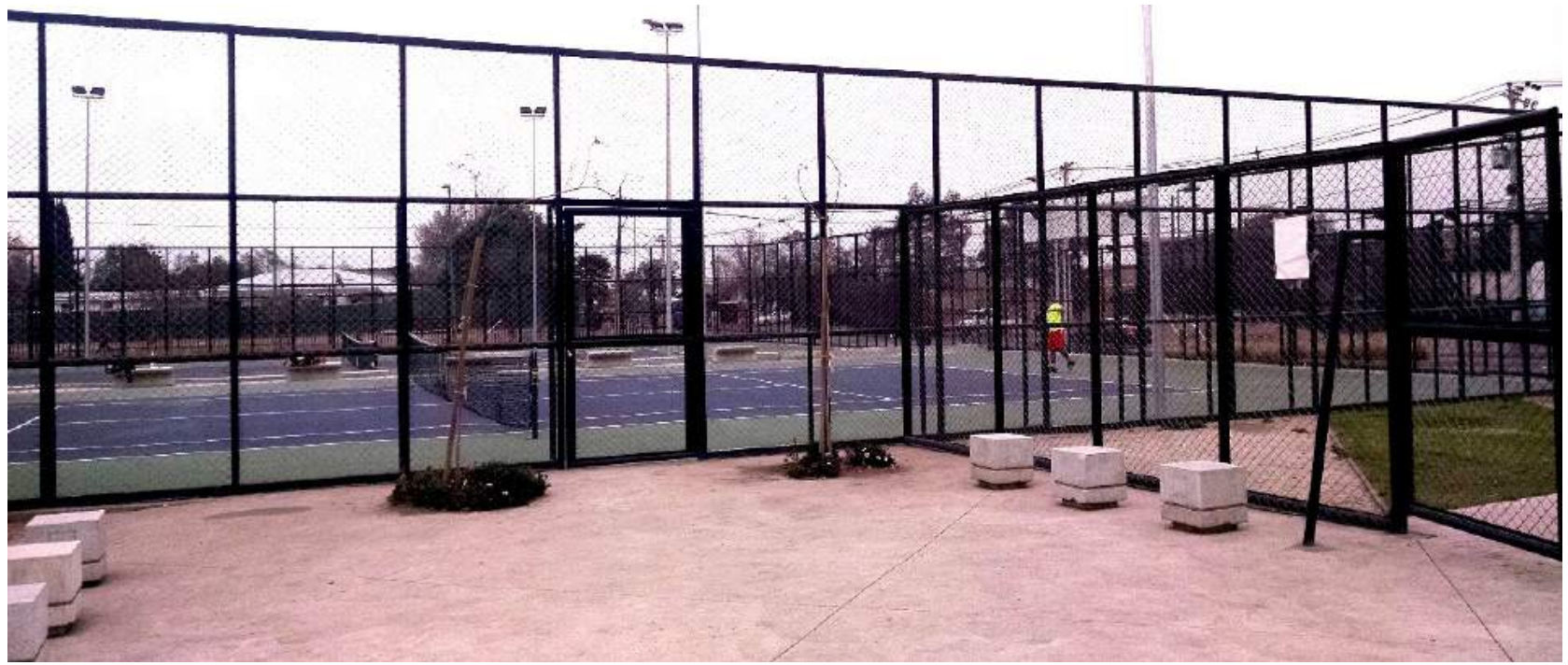

Figura 180: Quadras de tênis em Santa Adriana. Fotografia da autora, de jul. 2015.

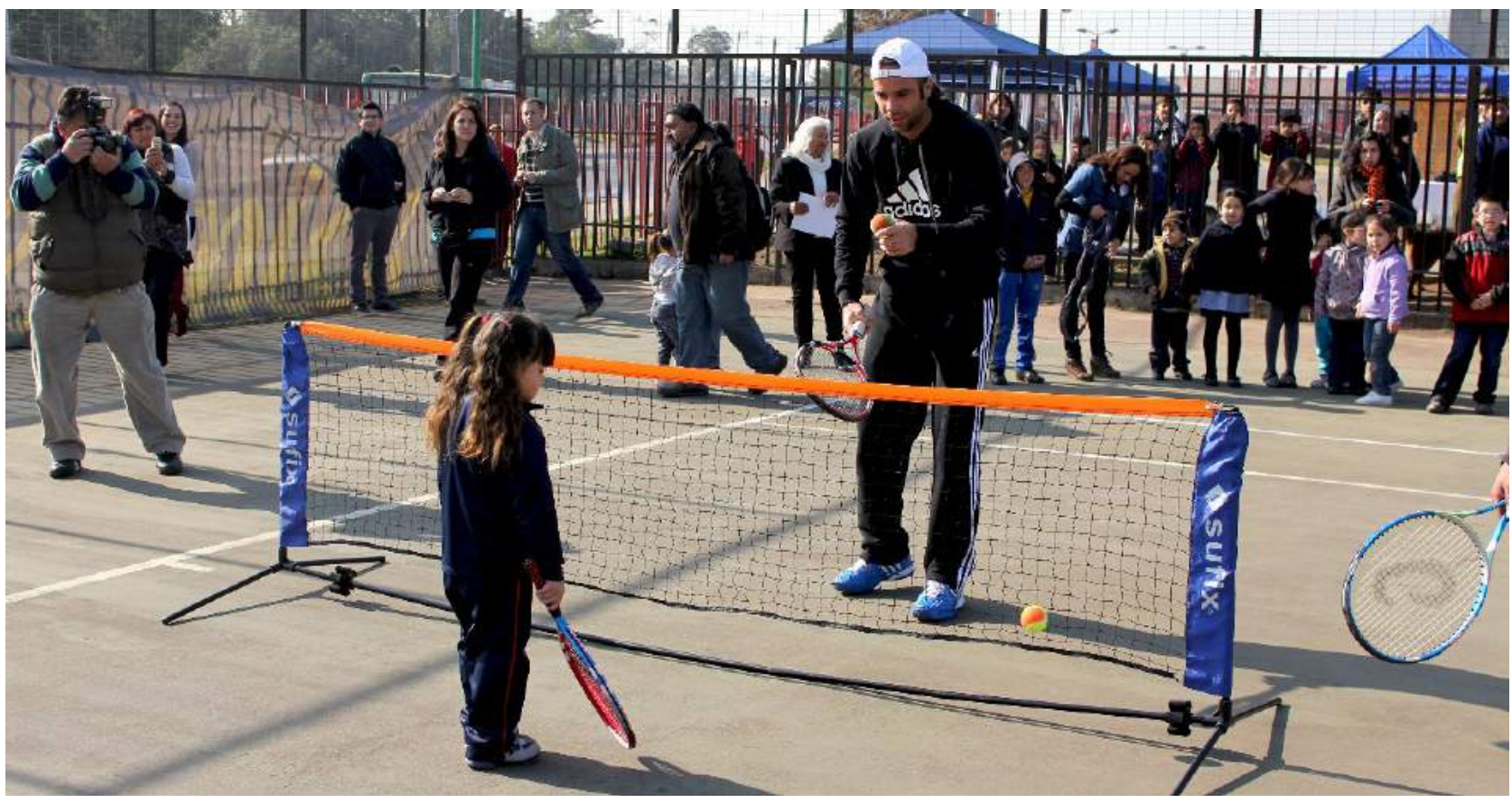

Figura 181: Cerimônia de inauguração das quadras, em parceria com a SEREMI de Vivienda y Urbanismo, Municipalidad de Lo Espejo e escola "Futuros para el Tenis". Fonte: SEREMI, $2015^{102}$.

102 Disponível em: < https://www.flickr.com/photos/quieromibarrio/albums/72157649756664273>. Acessado em 19 dez. 2016. 
Considerações: Contribuições para o desenvolvimento do habitat de interesse social

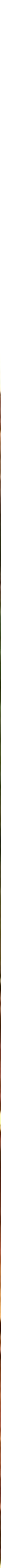


Nesta tese, buscou-se compreender a complexidade das práticas sociais em conjuntos de habitação social nas Regiões Metropolitanas de Santiago do Chile e de São Paulo (SP), reconhecendo, através da observação do cotidiano, a particularidade de cada lugar. Abordaram-se questões estruturais sobre a formação do território, questões essas que foram a base para a compreensão do porquê as políticas, mesmo alteradas ao longo dos anos, continuaram a produzir resultados pouco representativos para a completude das práticas sociais.

O trabalho trouxe avanços para o conhecimento dos programas habitacionais e da realidade latino-americana, contribuindo para a compreensão das limitações das práticas sociais em trechos urbanos de vulnerabilidade urbana e social que concentram habitações sociais. Neste trabalho, tal limitação das práticas foi conceituada como (des)prática, pois aquelas não se realizam de forma completa, sendo bastante dependentes da vulnerabilidade e da subjetividade do contexto social, que se agrava por imposições diversas, sejam oriundas de um modelo habitacional, sejam de um modo de habitar, sejam de normas de conduta estabelecidas. As limitações envolvem diversos aspectos, frutos do contexto e inserção no sistema capitalista global, da formação socioespacial, das lógicas de poder, do individualismo e da luta individual pelo acesso à moradia, em detrimento das conquistas coletivas do grupo social que fortalecem as práticas sociais.

No mesmo eixo de raciocínio da (des)prática, está a proposta em se observar a fragmentação por meio de sua visibilidade e de sua invisibilidade. Os grupos sociais de maior vulnerabilidade, quando isolados ou separados, configuram uma fragmentação visível, que, quando associados à ordem de dominação e lógica patrimonialista (FERREIRA, 2012) de manutenção das desigualdades, configuram-se em um fragmento invisível. Assim, estar fragmentado invisivelmente é fazer parte de uma minoria, a parte do fragmento que não se integra ao outro, mas que, dialeticamente, é a base para que o ciclo econômico continue a ocorrer.

Ser uma minoria é estar segregado, mas não excluído. A noção de exclusão social foi refutada neste trabalho, pois os grupos sociais vulneráveis são parte do sistema econômico, os quais só existem graças às diferenças socioeconômicas, estando, portanto incluídos, ainda que marginalmente, o que conceituamos como inclusão periférica.

Assim, os invisíveis estão incluídos no sistema econômico, mas na periferia dele. A invisibilidade que grupos sociais minoritários - aqueles que se beneficiam das políticas de habitação social - acabam apresentando é parte do cenário e da história latino-americanos, compartiIhados por várias nações que tiveram, em sua história, a "tradição" de estimular a manutenção das diferenças sociais para não haver interferência na hegemonia das classes mais poderosas. Os fragmentos visíveis e invisíveis, dessa forma, são as diferenciações sociais em que se baseia a dominação hegemônica.

Contudo, se, por um lado, perfilam-se o consciente e o inconsciente coletivo que mantêm as diferenças e o ciclo econômico e político, é no cotidiano inconsciente (LEFEBVRE, 1991) que se encontram as possibilidades de exacerbação da condição imposta. A luta de um grupo so- 
cial, de um sujeito corporificado que toma a direção da vida em suas mãos (RIBEIRO, 2013 ${ }^{103}$ ), indo contra imposições de valores, papéis, personagens, entre outros modelos de vida coletiva espetacularizada, é o que Milton Santos chamou de "homem lento" (SANTOS, 1994), aquele que, inconscientemente, torna-se acontecimento em um momento em que a sua individualidade estava em risco de ser apagada.

Para Ribeiro et al $\left(2013^{104}\right)$, a noção de homem lento miltoniana é a "verdadeira categoria da reflexão existencialista dos praticantes de espaços" (p. 154), enquanto que a categoria "território usado" seria "uma segura orientação analítica para leituras do espaço que reconheçam a centralidade das práticas na configuração de projetos políticos alternativos ao agir hegemônico" (p. 154).

Tanto o sujeito corporificado como o homem lento são categorias a observar as práticas sociais que procuram inverter os códigos excludentes e segregacionistas. O homem lento e o cotidiano resistem aos movimentos de alisamento do espaço e de resistência ao agir hegemônico que se apoia nos poderes simbólicos da dominação.

Mesmo inconscientemente, o homem lento busca alternativas e táticas para a sobrevivência das suas relações sociais e, superando os desafios, pratica os territórios. A noção miltoniana de homem lento, retomada nesta parte do trabalho, depende da sua observação junto à categoria de território praticado.

Nos estudos de caso, infelizmente, verificou-se muito mais a (des)prática do que a superação das adversidades, embora essas também tenham sido percebidas. No geral, observaram-se imposições de modelos urbanos e arquitetônicos que impactam negativamente no cotidiano da população, limitando as práticas sociais a partir de regras de convívio, muitas vezes fechando e apartando o espaço livre desse grupo social do espaço livre dos outros.

Enquanto superações, destacaram-se alguns usos de espaços livres públicos e também iniciativas de grupos sociais, como o caso dos jovens da comuna de Santa Adriana, em Santiago, que conseguiram, através do tênis, superar os códigos de conduta individual, inclusive de direcionamento de esportes para grupos sociais de elite ou de periferia. Inconscientemente, esse grupo social representa o homem lento, a resistir. Nos espaços opacos da sociedade, esses jovens se destacam por não quererem se uniformizar ao entorno pobre em que se inserem, resistindo aos poderes simbólicos por meio das práticas sociais.

Questionou-se o modelo condominial devido à limitação que acaba impondo, invisivelmente, às práticas sociais e ao cotidiano, em um cenário já complexo graças às adversidades do dia a dia vivido por grupos sociais em cenários urbanos de oportunidades limitadas. Cenários de violência, medo, relações de dominação e condutas individualistas são comuns em trechos urbanos que concentram habitação social, agravados por ações focadas no indivíduo - e não no grupo - e acentuados por um modelo urbanístico condominial imposto. A junção dessas questões diminui as possibilidades da superação do cotidiano alienado, apesar do potencial

103 Dança de sentidos: na busca de alguns gestos, v. 5, p.63.

104 Por uma cartografia da ação: pequeno ensaio de método, v. 4, p. 149-171. 
dos espaços livres para o encontro e a apropriação cotidiana.

Mais complexo, todavia, são os anos de produção habitacional em grande escala criando territórios homogêneos de pobreza, o modus operandi de produção de grandes concentrações de conjuntos habitacionais, reunindo, em um mesmo trecho urbano, problemas sociais, arquitetônicos, urbanísticos e econômicos. Esse isolamento, planejado, faz parte não só de uma tentativa de resolver as questões das minorias sem teto, mas de ações insensatas de políticas habitacionais quantitativas que não observam o cotidiano do grupo social, muito menos suas práticas sociais.

O impacto desses territórios foi demonstrado por meio da análise dos casos de Bajos de Mena, em Santiago, e da Cidade Tiradentes, em São Paulo, ambos exemplares de uma política habitacional quantitativa, ainda atuante em ambos os territórios e que causa, nos grupos sociais envolvidos, impactos subjetivos que não são resolvidos com a entrega de uma habitação, situação que persiste até os dias atuais.

Como resultado, observa-se a falta de uso dos espaços coletivos e sua consequente depredação, a fragmentação e setorização social e a interiorização das práticas sociais para o espaço privado da habitação ou intramuros condominial.

Dessa forma, agrava-se o individualismo, já estimulado pela conquista individual da casa própria, em cenários em que se privilegia o ambiente interno em detrimento do ambiente externo, devido ao receio causado por um espaço onde as diferenças podem se encontrar e se fazerem notar. O modelo urbanístico condominial, escolhido para habitação de populações de várias classes sociais, é fruto desse receio e do individualismo, trazendo ao espaço intramuros o cotidiano limitado que se pretende normatizar e controlar.

Felizmente, também se observaram iniciativas, em ambos os países, de ações menos individualistas e mais focadas nas práticas sociais. No caso brasileiro, a vertente Entidades do Programa Minha Casa Minha Vida foi uma iniciativa singela, mas relevante, dentro do programa habitacional, pois trouxe para a política nacional a participação de movimentos de moradia, de associações de moradores, de assistências técnicas, entre outras entidades sem fins lucrativos. Porém, essa participação ainda se encontrou entravada pelas limitações do próprio Programa e do agente financiador, que impuseram o modelo condominial para habitação social, e pela pouca ação da gestão municipal em agir contrariamente à imposição do mercado imobiliário na gestão dos terrenos a serem ocupados, havendo pouca - ou nenhuma - ação concretizada para destinar áreas para a criação de habitat.

Também no Chile destacaram-se aspectos positivos, como os avanços políticos dos programas de bairro: inexistentes no Brasil, esses programas buscam, mesmo com suas limitações, envolver moradores e equipes multidisciplinares para melhorar espaços públicos em trechos urbanos vulneráveis, atuando com a comunidade na busca da apropriação dos espaços a partir do sentido de coletividade.

O foco no bairro é ação da política chilena, principalmente a partir do primeiro governo de Michelle Bachelet (2006-2010), pois, após tantos anos de produção habitacional social neoli- 
beral, atingir o déficit de habitações não era mais a prioridade, e sim paliar a má qualidade dos empreendimentos criados desde então.

Concretamente, esse foco se traduziu em políticas de bairro, que foram evoluindo até o atual Programa Quiero Mi Barrio (PQMB), centrado em construir e recuperar espaços públicos em bairros vulneráveis para melhorar a qualidade de vida dos moradores. Embora com um olhar muitas vezes incorreto pelo projetar para o outro, a estratégia chilena traz muitos avanços por, finalmente, mirar na importância dos espaços livres para o cotidiano da população, o que o Brasil ainda não começou a implementar.

Com o contexto político chileno atual favorável para as políticas de bairro, muitos recursos foram destinados a programas que investiam nos espaços públicos, e muitos projetos foram realizados, com participação popular, em algumas comunas com habitação social de Santiago.

Embora muitas vezes as ações objetivassem dar mais visibilidade ao partido político e fossem, portanto, superficiais, algumas se destacaram por atuarem em um tempo e espaço mais adequado às ações urbanas promovedoras de mudanças, não sendo somente investimentos paliativos, mas atuando com maior profundidade, por meio de ações culturais, políticas, econômicas e urbanas, pilares essenciais para maior autonomia e manutenção no tempo das intervenções, como foi o caso da atuação do PQMB em Santa Adriana e em Lomas del Prado.

Contudo, apesar desse avanço político da implementação dos programas de bairro com participação popular no Chile, a análise dos projetos implementados tem demonstrado que o impacto da fragmentação visível e invisível e da reprodução social é muito acentuado, apesar da tentativa de inclusão social e de uma estratégia política de atenção às práticas sociais. Como comentado, esse resultado é fruto da reprodução da estrutura hegemônica histórica, base da sociedade latino-americana.

Uma das principais dificuldades que os programas de recuperação de bairro enfrentam é a sua continuidade, pois de nada adianta recuperar os espaços se não houver comprometimento dos moradores e da gestão pública em mantê-los posteriormente. Nesse sentido, a sustentabilidade dos espaços recuperados fica dependente de ações diversas e, caso diagnóstico e projeto venham carregados de visão hegemônica elitista, haverá a falência da iniciativa e a consequente depredação do espaço criado, além da perda do investimento econômico e cultural. Portanto, não é só uma questão de quem manterá e gerenciará o espaço criado, é também uma questão de método de diagnóstico e de projeto adequados ao contexto específico.

O problema atual chileno é também o problema que o Brasil enfrentará no futuro: com a intensa produção de habitação social desde os anos 1980, a questão não é somente produzir habitação social para as famílias que não têm onde morar, mas também como resolver o problema daquelas que moram em péssimas condições. Essa questão, chamada no Chile de desafio dos con techo (RODRÍGUEZ; SUGRANYES, 2005), demonstra que é necessário estabelecer mais parâmetros para o que está sendo produzido em todo o país, a fim de não permitir que habitats inadequados continuem a ser criados.

Alterar o ideário da casa própria para o ideário de bairro, focando-se nos espaços livres para 
as práticas sociais, é um caminho para reduzir as consequências negativas do modelo de produção habitacional quantitativo. Entretanto, a participação cidadã é essencial no processo, pois incentiva que interesses comuns e o olhar ao outro tragam os valores necessários para incrementar o bairro e a união comunitária.

A meta da construção de unidades habitacionais sociais em ambos os países também deve ser repensada. Qual o resultado que se espera de uma política de produção meramente quantitativa? A simples entrega de unidades, sem que haja maior discussão do futuro social nessas novas áreas, é a estratégia mais rápida, mas não eficaz, pois se pensa mais em atingir o déficit do que em valorizar as práticas sociais. Para Ana Clara Torres Ribeiro, a meta de alcançar a felicidade é abandonada junto com a liberdade (RIBEIRO, 2014 ${ }^{105}$ ).

A inserção da participação dos futuros moradores no planejamento veio justamente auxiliar o conhecimento técnico, trazendo a necessidade de se conhecer a realidade. Porém, o problema, também visível no PMCMV-E, é que a assessoria técnica faz o diagnóstico, e até mesmo o projeto para aprovação nas instituições financeiras e municipais, e só posteriormente se inicia a participação do grupo social, em um instrumento para a manutenção da hegemonia dos interesses dominantes (RIBEIRO, 2014). Quando chega o momento da participação dos futuros moradores, o diagnóstico já está fechado e já se tem uma solução preestabelecida. Resta, minimamente, a participação na escolha dos espaços livres, também diminuta devido à pouca dimensão dos espaços e aos custos de manutenção condominial.

Mais complexo ainda é o que ocorre na vertente empresarial do PMCMV, na qual não há participação alguma, e a direção do projeto e das necessidades das famílias - que ainda não estão nem selecionadas - são definidas pelos construtores e pelo banco financiador, parametrizados por critérios de redução de custos. Assim, não surpreende que essas novas áreas habitacionais não sejam idealizadas para as práticas sociais, e sejam ainda de questionável qualidade urbana, não apenas pela sua localização marginalizada, mas por todo o processo de elaboração e construção marginalizado, de uma agressão extraordinária à liberdade e à individualidade dos futuros moradores.

A racionalização do projeto coloca o direito de se estabelecer a necessidade do outro, impossibilitado de ser sujeito da relação. O sujeito definidor é o "você", e o "outro" passa a ser o objeto, que se tenta satisfazer (RIBEIRO, 2014). O desafio em se analisar os espaços do cotidiano e qualificá-los está também em definir os critérios de análise. Afinal, a qualidade do espaço está sendo analisada a partir da visão de quem? Do arquiteto urbanista, que tem suas definições do que qualifica um espaço, ou da população, que utiliza aquele espaço?

Conhecendo as dificuldades territoriais, culturais, patrimonialistas e mesmo políticas de atuações que se originem da ideologia e entrem no âmbito do possível para a criação de cenários mais sócio heterogêneos e diversos, esclarece-se que somente a criação de programas mais atentos às práticas sociais não é capaz de diminuir a fragmentação invisível das práticas sociais,

105 Sessão IV - A produção do social: atos banais, atos radicais. Aula do dia 21.11.2002, quinta-feira, p. 253. 
já que elas estão intrinsecamente conectadas com a produção e reprodução da estrutura de dominação social (BOURDIEU, 1989). No entanto, muito menos capaz será uma política meramente quantitativa, ou a continuidade de um modelo arquitetônico de condomínio, com práticas cotidianas intramuros, que traz impactos subjetivos e receio na relação com o outro.

A realização desta tese na área da paisagem possibilitou que a observação fosse acrescida da percepção e da sensibilidade do olhar na relação dos usuários com o espaço, pois a observação da paisagem revela a história materializada da sociedade em um território, onde o tempo e as interações sociais possibilitam a compreensão das relações e das práticas sociais no espaço.

Este trabalho não pretende oferecer uma solução para as questões apresentadas, pois estas não são passíveis de resolução com apontamentos ou discussões. Mais do que propor saídas, apresentam-se qualidades e fragilidades de ambos os casos, tanto nos arranjos formais quanto nos cotidianos praticados, e conceituações que avançam no conhecimento do cotidiano e das práticas sociais em situações de vulnerabilidade.

Pretendeu-se contribuir por meio da elaboração do conceito da (des)prática, que representa as limitações das práticas sociais, da fragmentação visível e invisível que considera tanto os aspectos visíveis da segregação urbana como os subjetivos do processo de manutenção das desigualdades. Também foi apresentada a noção de inclusão periférica, segundo a qual os grupos sociais vulneráveis estão segregados dos outros, mas não excluídos, pois fazem parte do sistema econômico.

As fragilidades e potencialidades da segregação invisível e das (des)práticas apontadas nesta tese não são de todo fatalistas, e as práticas sociais, combinadas com ações sociais, são a chave para a superação do dia a dia de grupos sociais incluídos na periferia do sistema. 


\section{Referências}

ABARCA, Ignacio Arce. Contestaciones a la ciudad global: la cuestión urbana en el siglo XXI. Un diálogo con Teresa Caldeira. Íconos. Revista de Ciencias Sociales. Quito, n.56, p. 149-155, Sept. 2016.

ALFARO MALATESTA, Sergio. Análisis del proceso de autoconstrucción de la vivienda en Chile, bases para la ayuda informática para los procesos comunicativos de soporte. 2006. Tese (Doutorado), Universitat Politècnica de Catalunya, nov. 2006.

ALLENDE, Isabel. Mi país inventado - un paseo nostálgico por Chile. Barcelona: Plaza \& Janés, 2003.

ANDERSON, James M. et al. Reducing crime by shaping the built environment with zoning: an empirical study of Los Angeles. University of Pennsylvania Law Review, v. 161, n. 699. 13 fev. 2012.

ARENDT, Hannah. A condição humana. 10. ed. Rio de Janeiro: Forense Universitária, 2001.

ARRETCHE, Marta. Relações Federativas nas políticas sociais. Educação e sociedade, Campinas, v.23, n.80, p. 25-48, setembro/2002. Disponível em <http://www.scielo.br/pdf/es/ v23n80/12922.pdf>. Acesso em mar. 2014.

BACHA, Edmar Lisboa; BONELLI, Regis. Uma interpretação das causas da desaceleração econômica do Brasil. Revista de economia política, São Paulo, v. 25, n. 3, p. 163-189, set. 2005 . Disponível em <http://www.scielo.br/scielo.php?script=sci_arttext\&pi$\mathrm{d}=$ S0101-31572005000300001\&lng=en\&nrm=iso >. Acesso em 27 nov. 2016.

BENVENGA, Bruna Maria de Medeiros. Conjuntos Habitacionais, Espaços Livres e Paisagem. Apresentando o processo de implantação, uso e avaliação de espaços livres urbanos. 2011. Dissertação (Mestrado), Universidade de São Paulo, Faculdade de Arquitetura e Urbanismo, 2011.

BESOAIN, Carolina Arrau. Vivienda social y subjetividades urbanas en Santiago: espacio privado, repliegue presentista y añoranza. 2012. Tese (Doutorado), Pontificia Universidad Católica de Chile, Facultad de Ciencias Sociales, Escuela de Psicología, Programa de Doctorado en Psicología, Santiago do Chile, sept. 2012.

BONDUKI, Nabil. Os pioneiros da habitação social. Cem anos de política pública no Brasil. São Paulo: Editora Unesp; Edições Sesc São Paulo, 2014, v. 1.

La nueva política nacional de vivienda en Brasil: Desafíos y limitaciones. Revista de Ingeniería. Bogotá: Universidad de los Andes. n. 35, p. 88-94, jul. - dic. 2011. ISSN. 0121-4993.

Política de vivienda e inclusión social en Brasil: revisión histórica y nuevas perspectivas en el gobierno de Lula. In: ESPINOSA, Jaime Erazo. (org.). Inter/secciones urbanas: origen y contexto en América Latina. Quito: Flacso Ecuador/Ministerio de Cultura, 2009a, v. 1, p. 95-135. 2009b.

Do Projeto Moradia ao Programa Minha Casa Minha Vida. Teoria e Debate, v. 82, p. 8-14, 
BOURDIEU, Pierre. Social space and symbolic power. Sociological theory, v. 7, n. 1, p. 14-25, 1989. Disponível em: <http://www.jstor.org/stable/202060>. Acesso em 21 ag. 2013.

BOURDIEU, Pierre; INDA, Andrés García; BENEITEZ, María José Bernuz. Poder, derecho y clases sociales. 2. ed., Bilbao: Desclée de Brouwer, 2001. ISBN: 84-330-1495-1.

BOURDIEU, Pierre; WACQUANT, Loïc. Una invitación a la sociología reflexiva. 1. ed. Buenos Aires: Siglo XXI Editores, Argentina, 2005.

BRAIN, Isabel; MORA, Pía. Ajustes a la política habitacional: Elementos para la discusión. Apuntes legislativos. Centro de Políticas Públicas, Pontificia Universidad Católica de Chile. n. 12, Sept. 2011. Disponível em: <http://politicaspublicas.uc.cl/wp-content/uploads/2015/02/ descargar-ajustes-a-la-politica-habitacional.pdf>. Acesso em 25 set. 2015.

BRASIL, Instituto Brasileiro de Geografia Estatística (IBGE). População estimada de 2014. Disponível em: <http://www.ibge.gov.br/home/estatistica/populacao/estimativa2014/estimativa_dou.shtm>. Acesso em 2 dez. 2016.

. PIB/per capita a preços correntes, 2013. Disponível em: < http://www.ibge.gov.br/ home/estatistica/economia/pibmunicipios/2010_2013/default.shtm>. Acesso em 2 dez. 2016.

. Índice de Desenvolvimento Humano Municipal - IDHM, 2010. Disponível em: < http:// www.cidades.ibge.gov.br/>. Acesso em 2 dez. 2016.

. Incidência de Pobreza, 2003. Disponível em: < http://www.cidades.ibge.gov.br/>. Acesso em 2 dez. 2016.

. Censos demográficos de 1950 a 2010. Disponível em: < http://infocidade.prefeitura. sp.gov.br/htmls/7_populacao_recenseada_1950_10552.html>. Acesso em 27 nov. 2016.

. MINISTÉRIO DAS CIDADES, Departamento Nacional de Trânsito (DENATRAN). Frota de veículos, 2014. Disponível em: <http://www.denatran.gov.br/index.php/estatistica/253-frota-2014>. Acesso em 2 dez. 2016.

. TRIBUNAL DE CONTAS DA UNIÃO. Relatório de auditoria. Acórdão 524/2014. Data da Sessão: 12 mar. 2014. Disponível em: <www.tcu.gov.br/consultas/juris/docs/judoc/ acord/20140313/ac_0524_07_14_p.doc>. Acesso em 29 nov. 2016

BRICEÑO, Evelyn. Puente Alto inaugurará en noviembre parques de similar tamaño al Forestal. Diario La Tercera, 23 agosto 2013. Disponível em: < http://www.latercera.com/noticia/santiago/2013/08/1731-539112-9-puente-alto-inaugurara-en-noviembre-parque-de-similar-tamano-al-forestal.shtml>. Acesso em 14 set. 2015.

CALDEIRA, Teresa Pires do Rio. Cidade de muros: crime, segregação e cidadania em São Paulo. São Paulo: Editora 34; Edusp, 2000.

CAMPOS, Ana Cecília Mattei de Arruda. Alphaville-Tamboré e Barra da Tijuca: as ações programadas e a estruturação do sistema de espaços livres. 2008. 526 f. Tese (Doutorado). Faculdade de Arquitetura e Urbanismo. Universidade de São Paulo, São Paulo, 2008.

CAMPOS, Candido Malta; GAMA, Lúcia Helena; SACCHETTA, Vladimir (Org.) São Paulo, Me- 
trópole em trânsito: Percursos urbanos e culturais. São Paulo: Editora Senac, São Paulo, 2004.

CARDOSO, Adauto Lúcio; ARAGÃO, Thêmis Amorim. A reestruturação do setor imobiliário e o Programa Minha Casa Minha Vida. In: MENDONÇA, Jupira Gomes de; COSTA, Heloisa Soares de Moura (org.). Estado e capital imobiliário: convergências atuais na produção do espaço urbano brasileiro. Belo Horizonte: C/ Arte, 2012, v. 1, p. 81-106.

CARVALHO, Higor R. S. A cidade como um canteiro de negócios. A produção da habitação e do espaço urbano pelos grandes promotores imobiliários no Brasil e na França: o caso das aglomerações urbanas de São Paulo e de Paris. 2011. Trabalho de Conclusão de curso em Arquitetura e Urbanismo. Faculdade de Arquitetura e Urbanismo. Universidade de São Paulo. Disponível em: <http://issuu.com/higor_carvalho/docs/higor_carvalho-cidade_como_canteiro_de_negocios>. Acesso em jan. 2013.

CARVALHO, Sidney. Entre o rio e a serra - Forma urbana e sistema de espaços livres na região norte do município de São Paulo. 2011. Dissertação (Mestrado). Faculdade de Arquitetura e Urbanismo, Universidade de São Paulo, 2011.

CASTILLO, María José Couve. Producción y gestión habitacional de los pobladores. La autogestión de vivienda en Peñalolén y La Pintana, Santiago de Chile. Boletín CF+S, n. 54, p. 133-145, 2013. Disponível em: < http://polired.upm.es/index.php/boletincfs/article/view/2041>. Acesso em 24 set. 2015.

CHILE. Carabineros Chile. Informe de Resultados de Gestión Operativa, Métodos y Estadísticas Institucionales, Cuenta pública 2014. Disponível em: <http://centroestudios.carabineros.cl/>. Acesso em 1 dez. 2016.

. Instituto Nacional de Estadísticas (INE). Estimativa Población, 2014. Disponível em: < http://www.ine.cl/canales/chile_estadistico/familias/demograficas_vitales.php>. Acesso em 1 dez. 2016.

. Frota de automóveis, station wagon, motos e similares, ônibus e micro-ônibus, 2014. Disponível em: < http://www.ine.cl/canales/chile_estadistico/estadisticas_economicas/transporte_y_comunicaciones/parquevehiculos.php>. Acesso em 2 dez. 2016.

- Ministerio del Interior y Seguridad Pública, Intendencia Región Metropolitana. Intendente Metropolitana y Ministra de Vivienda participan en inauguración de Parque Juan Pablo Il en Puente Alto. 28 mayo 2014. Disponível em: <http://www.intendenciametropolitana.gov. cl/n5997_28-05-2014.html>. Acesso em 14 set. 2015.

- Ministerio de Desarrollo Social. Estimación de la pobreza por ingresos en comunas, 2013. Disponível em: <http://observatorio.ministeriodesarrollosocial.gob.cl/documentos/ Sintesis-Estimacion-de-la-pobreza-por-ingresos-en-comunas-2011-2013(nuevametodologia)07092015.pdf>. Acesso em dez. 2016.

Ministerio de Vivienda y Urbanisno (MINVU). Ministro Pérez informa plan de intervención por \$44 mil millones en sector Bajos de Mena de Puente Alto. 7 jun. 2012. Disponível em: <http://www.minvu.cl/opensite_det_20120607153314.aspx>. Acesso em set. 2015.

. Serie Analisis de Resultados de la Encuesta de Caracterización Socioeconomica Nacio- 
nal (CASEN, 2006), Santiago, 2007. Disponível em: <http://observatorio.ministeriodesarrollosocial.gob.cl/layout/doc/casen/publicaciones/2006/Imp_Distrib.pdf>. Acesso 15 dez. 2016.

. Ministerio de Planificación y Cooperación (MIDEPLAN). Ingreso Monetario, 2006.

Programa de las Naciones Unidas para el Desarrollo (PNUD). Índice de Desarrollo Humano Comunal, 2003. Disponível em: <http://desarrollohumano.cl/idh/download/IDHC\%20 con\%20portada.pdf>. Acesso 2 dez. 2016.

. Censo Población - 1960 - Resumen País. Organización del XIII Censo de Poblacion y II de Vivienda. Disponível em: <http://www.ine.cl/canales/usuarios/cedoc_online/censos/ pdf/1960_corregido.pdf>. Acesso em 15 jun. 2016.

COELHO, Leonardo Loyolla. Dispersão, fragmentação e paisagem: relações entre dinâmicas naturais e urbanas no vetor oeste da Região Metropolitana de São Paulo. 2015. Tese (Doutorado), Faculdade de Arquitetura e Urbanismo, Universidade de São Paulo.

CRUZ, Eurico. Invadido prédio do 'Minha Casa, Minha Vida' nos Pimentas. Folha Metropolitana, o jornal de Guarulhos. 25 jan. 2016, Caderno Notícias Cidade. Disponível em: <http://folhametro.com.br/ultimas/invadido-predio-do-minha-casa-minha-vida-nos-pimentas/>. Acesso em 01 nov. 2016.

CUSTÓDIO, Vanderli. A Crise Hídrica na Região Metropolitana de São Paulo (2014-2015). GEOUSP: Espaço e Tempo (Online), São Paulo, v. 19, n. 3, p. 445-463, dec. 2015. ISSN 2179-0892. Disponível em: <http://www.revistas.usp.br/geousp/article/view/102136/112852>. Acesso em: 26 nov. 2016. doi:http://dx.doi.org/10.11606/issn.2179-0892.geousp.2015.102136.

DEAK, Csaba; SCHIFFER, Sueli Ramos (org.) O processo de urbanização no Brasil. São Paulo: Editora da Universidade de São Paulo, 1999.

DELGADO VALVERDE, Francisca. Primer llamado 2013: Programa de Recuperación Condominios Sociales Segunda Oportunidad em Bajos de Mena. Santiago de Chile. Prof. Guía: Ricardo Tapia. Seminario de Investigación. Semestre Primavera. Santiago do Chile, 2013.

DE MATTOS, Carlos A. Santiago de Chile, globalización y expansión metropolitana: lo que existía sigue existiendo. EURE - Revista Latinoamericana de Estudios Urbano Regionales, Santiago, v. 25, n. 76, p. 29-56, dic. 1999 . Disponível em <http://www.scielo.cl/scielo.php?script=sci_arttext\&pid=S0250-71611999007600002\&lng=es\&nrm=iso>. Acesso em 27 nov. 2016.

DINGES, John. Os anos do Condor - Uma década de terrorismo internacional no Cone Sul. Trad. Rosaura Eichenberg. São Paulo: Companhia das letras, 2005.

DONOSO, Veronica Garcia. Experiências com habitação popular no Brasil e no Chile. In: LAGOS, Ricardo; DÁVILA, Mireya; ZIBETTI, Fabíola Wüst. (org.). A América Latina no Mundo: Desenvolvimento regional e governança internacional. São Paulo: Edusp, 2013, v. 1, p. 181-194.

. A paisagem e os sistemas de espaços livres na urbanização contemporânea do interior paulista: estudo de caso da área entre São Carlos, Araraquara e Ribeirão Preto. 2011. Dissertação (Mestrado), Faculdade de Arquitetura e Urbanismo, Universidade de São Paulo, 2011.

DUNKER, Christian (palestrante). Mal-estar, sofrimento e sintoma. Café Filosófico. TV Cultura, 
51'14", programa exibido em 3 jul 2016. Disponível em: <https://www.youtube.com/watch?$\mathrm{v}=\mathrm{dn} 9 \mathrm{gw} 12 \mathrm{RBa0}>$. Acesso em 31 ag. 2016.

. Mal-estar, sofrimento e sintoma: uma psicopatologia do Brasil entre muros. 1. ed. São Paulo: Boitempo, 2015.

ESPINOZA, Vicente. Para una historia de los pobres de la ciudad. Santiago: Ediciones SUR, 1988.

ESTADÃO, O Estado de São Paulo. Criminalidade bairro a bairro. 2014. Disponível em: <http:// infograficos.estadao.com.br/cidades/criminalidade-bairro-a-bairro/>. Acesso em 7 maio 2015.

ESTADO DE SÃO PAULO. Secretaria da segurança pública. Dados estatísticos do estado de São Paulo. 2014-5-6. Número de ocorrências policiais registradas de homicídio doloso, latrocínio, lesão corporal dolosa e estupro. Disponível em: <http://www.ssp.sp.gov.br/novaestatistica/ mapas.aspx>. Acesso 10 dez. 2016.

Dados estatísticos do estado de São Paulo. 2014-15-16. Número de ocorrências policiais registradas de tráfico e porte de entorpecente. Disponível em: <http://www.ssp.sp.gov.br/novaestatistica/pesquisa.aspx>. Acesso em 1ㅇ dez. 2016.

FERNÁNDEZ, Oriana G. Suprema ordena reparar con \$1.734 millones a 592 familias por "casas Copeva" de P. Alto. Diario La tercera. 25 oct. 2012 Disponível em: <http://diario.latercera. com/2012/10/25/01/contenido/pais/31-121361-9-suprema-ordena-reparar-con--1734-millones-a-592-familias-por-casas-copeva-de-p.shtml>. Acesso em 14 set. 2015.

FERRAZ, Paulo. CV monta rede de informações na zona leste. Folha de São Paulo, 15 de março de 1994, p. 3-4.

FERREIRA, João Sette Whitaker (coord). Produzir casas ou construir cidades? Desafios para um novo Brasil urbano. São Paulo: LABHAB; FUPAM, 2012.

Cidades para poucos ou para todos? Impasses da democratização das cidades no Brasil e os riscos de um 'urbanismo às avessas'. In: OLIVEIRA, Francisco; BRAGA, Ruy; RIZEK, Cibele (org). Hegemonia às avessas. São Paulo: Boitempo Editorial, 2010, p. 185-213.

FOGO destrói 200 casas em favela de Guarulhos. Folha de São Paulo, Cotidiano. São Paulo, terça-feira, 23 de maio de 1995. Disponível em: < http://www1.folha.uol.com.br/fsp/1995/5/23/ cotidiano/22.html>. Acesso em 12 dez. 2016.

GAETE, Constanza Martínez. Nuevo Parque Juan Pablo II: 20 ha de áreas verdes para Bajos de Mena, en Puente Alto. Plataforma urbana, 25 sept. 2013. Disponível em: <http://www.plataformaurbana.cl/archive/2013/09/25/nuevo-parque-juan-pablo-ii-20-ha-de-areas-verdes-para-bajos-de-mena-en-puente-alto/\#more-63995>. Acesso em 14 set. de 2015.

GALEANO, Eduardo. Programa Sangue Latino entrevista Eduardo Galeano. Canal Brasil. 2009. Programa de TV. Disponível em: <http://www.youtube.com/watch?v=w8rOUoc_xKc $>$. Acesso em 31 de mar. 2016.

GALLEGUILLOS, Patrícia et al. Historias Locales II. Santiago: Jundep; CIC, 1992.

GARCÍA INDA, Andrés. Introducción - la razón del derecho: entre habitus y campo. In: BOUR- 
DIEU, Pierre; INDA, Andrés García; BENEITEZ, María José Bernuz. Poder, derecho y clases sociales. 2. ed., Bilbao: Desclée de Brouwer, 2001. ISBN: 84-330-1495-1.

GOFFMAN, Erving. A representação do eu na vida cotidiana. Tradução de Maria Célia Santos Raposo. Petrópolis: Vozes, 1985.

GONZÁLEZ, Karen T. Sobrevivir entre los escombros. La Tercera, 17 agosto 2014, Caderno Mundo. Disponível em: <http://papeldigital.info/lt/2014/08/17/01/paginas/024.pdf>. Acesso em 6 dez. 2016.

GREENE, Margarita. El Programa de Vivienda Progresiva en Chile 1990-2002. Departamento de Santiago: Desarrollo Sostenible - División de Programas Sociales. Estudio de buenas prácticas en vivienda económica. jul. 2004. Disponível em: <http://www.cepal.org/pobrezaurbana/ docs/foro/Estudio_de_buenas_practicas_en_vivienda_economica.pdf>. Acesso em fev. 2015.

GUIMARAES, Iracema Brandão. Periferias e territórios sob efeitos conjugados da precarização: algumas tendências. Caderno CRH, v. 24, n. spe1, p. 89-104, 2011. Disponível em <http://www. scielo.br/scielo.php?script=sci_arttext\&pid=S0103-49792011000400007\&lng=en\&nrm=iso>. Acesso em 7 maio 2015. http://dx.doi.org/10.1590/S0103-49792011000400007.

GUNN, Philip; CORREIA, Telma de Barros. Vilas Operárias: o mundo fabril penetra na cidade. In: CAMPOS, Candido Malta; GAMA, Lúcia Helena; SACCHETTA, Vladimir (Org.) São Paulo, Metrópole em trânsito: Percursos urbanos e culturais. São Paulo: Editora Senac. São Paulo, 2004.

GUTIERREZ, Patricio Villagrán. El ambicioso proyecto que busca darle nueva vida a Bajos de Mena. Diario La Nación, 17 abr. 2015. Disponível em: <http://www.lanacion.cl/noticias/ pais/obras-publicas/el-ambicioso-proyecto-que-busca-darle-nueva-vida-a-bajos-de-mena/2015-04-16/165902.html>. Acesso em 10 set. 2015.

. El clamor de Bajos de Mena: "No queremos mejoras, queremos irnos de aqui". Diário La Nación, 11 nov. 2014. Disponível em: < http://www.lanacion.cl/noticias/reportajes/historias/el-clamor-de-bajos-de-mena-no-queremos-mejoras-queremos-irnos-de-aqui/2014-11-10/204520.html>. Acesso em 10 set. 2015.

HARDY, Clarisa; LEGASSA, Victoria. La ciudad escindida - Los problemas nacionales y la Región Metropolitana. Programa de Economía del Trabajo (PET). Sociedad Editora e impresora Alborada S.A., 1989.

HIDALGO, Rodrigo. De los pequeños condominios a la ciudad vallada: las urbanizaciones cerradas y la nueva geografía social en Santiago de Chile (1990-2000). EURE - Revista Latinoamericana de Estudios Urbano Regionales, Santiago, v.30, n.91, p. 29-52, dic. 2004. Disponívelem<http://www. scielo.cl/scielo.php?script=sci_arttext\&pid=S0250-71612004009100003\&lng=es\&nrm=iso>. Acesso em 27 nov. 2016. http://dx.doi.org/10.4067/S0250-71612004009100003.

HIDALGO, Rodrigo; ZUNINO, Hugo; ALVAREZ, Lily. El emplazamiento periférico de la vivienda social en el Área Metropolitana de Santiago de Chile: Consecuencias socio espaciales y sugerencias para modificar los criterios actuales de localización. Scripta Nova, Revista Electrónica de Geografía y Ciencias Sociales. Universidad de Barcelona. Vol. XI, n. 245 (27), 1o agosto 2007. HIRAO, Silvia Eri. Ser jovem na Cidade Tiradentes: um estudo exploratório. 2008. Dissertação 
(Mestrado), Faculdade de Educação, Universidade de São Paulo, 2008.

IBGE - Instituto Brasileiro de Geografia e Estatística. Cidades@. 2015. Disponível em: < http:// cidades.ibge.gov.br/v3/cidades/home-cidades>. Acesso em 2 de jan. 2017.

Censo 2010. Domicílios segundo Tipologias Residenciais. Município de São Paulo, Subprefeituras e Distritos Municipais. Disponível em: <http://infocidade.prefeitura.sp.gov.br/ htmls/9_domicilios_segundo_tipologias_residencia_2010_455.html> Acesso em 25 set. 2016.

INE - Instituto Nacional de Estadísticas. Demografía. Proyecciones población 2013-2020. 2015. . Disponível em: < http://www.ine.cl/canales/chile_estadistico/familias/demograficas_vitales. php>. Acesso em 2 de jan. 2017.

JACOBI, Pedro. O futuro do meio ambiente urbano. In: CAMPOS, Candido Malta; GAMA, Lúcia Helena; SACCHETTA, Vladimir (Org.) São Paulo, Metrópole em trânsito: Percursos urbanos e culturais. São Paulo: Editora Senac, São Paulo, 2004, p. 204-211.

JACOBS, Jane. Morte e vida de grandes cidades. São Paulo: Martins Fontes, 2000.

LAGO, Luciana Corrêa do. Autogestão da moradia na superação da periferia urbana: conflitos e avanços. E-metropolis: Revista eletrônica de Estudos Urbanos e Regionais, v. 05, ano 2, jun. 2011. Disponível em: <http://www.emetropolis.net/edicoes/n05_jun2011/emetropolis_n05. pdf>. Acesso em mar. 2014.

LAVOS, Ana Paula Alves de. Sociabilidades em conjuntos habitacionais produzidos pelo Estado: o caso da COHAB Cidade Tiradentes. 2009. Dissertação (Mestrado), Arquitetura e Urbanismo, Escola de Engenharia de São Carlos, Universidade de São Paulo, 2009.

LANGENBUCH, Juergen Richard. A Estruturação da Grande São Paulo: Um estudo de Geografia Urbana. Rio de Janeiro: IBGE, 1971.

LEFEBVRE, Henri. O direito à cidade. Tradução Rubens Eduardo Frias. São Paulo: Centauro, 2001.

A vida cotidiana no mundo moderno. São Paulo: Ática, 1991.

La Production de l'espace. Paris: Éditions anthropos, 1974.

LEMINSKI, Paulo. Toda Poesia. 1. ed. São Paulo: Companhia das Letras, 2013.

LUNECKE, Alejandra Reyes. Violencia urbana, exclusión social y procesos de guetización: La trayectoria de la población Santa Adriana. Revista INVI, Santiago, v. 27, n. 74, p. 287313, mayo 2012. Disponível em <http://www.scielo.cl/scielo.php?script=sci_arttext\&pid=S0718-83582012000100009\&lng=es\&nrm=iso>. Acesso em 29 out. 2015.

. La paradoja de Santa Adriana - Tráfico de drogas en una población emblemática. 2008. Disertación (Máster en Desarrollo Urbano), Instituto de Estudios Urbanos y Territoriales, Facultad de Arquitectura, Diseño y Estudios Urbanos, Pontificia Universidad Católica de Chile, oct. 2008.

MAC LEAN, Gerson Ramírez. Santa Adriana, Lo Espejo (Región Metropolitana): Experiencia de proyecto urbano inclusivo en el contexto de implementación del Programa Recuperación de 
Barrios. Revista Planeo, n. 7, oct. 2012. Disponível em: < http://revistaplaneo.uc.cl/2012/10/01/ santa-adriana-lo-espejo-region-metropolitana-experiencia-de-proyecto-urbano-inclusivo-en-el-contexto-de-implementacion-del-programa-recuperacion-de-barrios/>. Acesso em 07 nov. 2016.

MAGNOLI, Miranda M. E. M. Espaços livres e urbanização: uma introdução a aspectos da paisagem metropolitana. 1982. Tese (Livre-Docência), Faculdade de Arquitetura e Urbanismo, Universidade de São Paulo, 1982.

MARICATO, Erminia. Cidades no Brasil: neodesenvolvimentismo ou crescimento periférico predatório? Revista Política Social e Desenvolvimento, n. 1, p. 16-56, nov. 2013. Disponível em <https://revistapoliticasocialedesenvolvimento.files.wordpress.com/2014/10/revista01.pdf>. Acesso em 28 nov. 2016.

. Por um novo enfoque teórico na pesquisa sobre habitação. Cadernos Metrópole, n. 21, p. 33-52, 2009.

- O Ministério das Cidades e a política nacional de desenvolvimento urbano. IPEA - Políticas Sociais- acompanhamento e análise. v. 12, p. 211-22, 2006.

. Metrópole na periferia do capitalismo. Ilegalidade, desigualdade e violência. HUCITEC: São Paulo, 1996.

MARQUES, Eduardo; CASTELLO, Graziela; BICHIR, Renata. Redes pessoais e vulnerabilidade social em São Paulo e Salvador. Revista USP. n. 92, p. 32-45, Dez./Fev. 2011-2012. Disponível em: <http://www.revistas.usp.br/revusp/article/view/34881>. Acesso em 07 maio 2015.

MARTINS, José de Souza. A sociedade vista do abismo: Novos estudos sobre exclusão, pobreza e classes sociais. Petrópolis: Vozes, 2002.

MARTORELL, Francisco. El millionario error de la ministra de vivienda. Jornal El Periodista, ano 4, n. 118, 24 nov. 2006. Disponível em: < http://www.elperiodista.cl/newtenberg/1881/article-75337.html>. Acesso em 14 set. 2015.

MEDRANO, Ricardo Hernán. São Paulo e Buenos Aires: Urbanismo e Arquitetura 1870-1915. 2003. Tese (Doutorado), Faculdade de Arquitetura e Urbanismo, Universidade de São Paulo, 2003.

MEYER, Regina Maria Prosperi. São Paulo Metrópole. São Paulo: EDUSP/Imprensa Oficial, 2004.

MINEIRO, Edilson Henrique; RODRIGUES, Evaniza. Do Crédito Solidário ao MCMV Entidades: uma história em construção. In: LAGO, Luciana Corrêa (org). Autogestão habitacional no Brasil: utopias e contradições. Rio de Janeiro: Letra Capital; Observatório das Metrópoles, 2012.

MINVU, DITEC. Chile, Un siglo de políticas en Vivienda y Barrio. Ministerio de Vivienda y Urbanismo - MINVU, División Técnica de Estudios y Fomento Habitacional - DITEC. Santiago: Editoral y Diseño, 2004.

MUNICIPALIDAD DE CERRO NAVIA. Historia Comunal, feb. 2012. Disponível em: <http://www. cerronavia.cl/index.php?option=com_content $\&$ view=article\&id=57\&ltemid=80>. Acesso em junho de 2014. 
NAKANO, Anderson Kazuo. 4 COHABs da zona leste de São Paulo: território, poder e segregação. 2002. Dissertação (Mestrado), Faculdade de Arquitetura e Urbanismo, Universidade de São Paulo, 2002.

NOBRE, Eduardo A. C. Precariedade do habitat e política de habitação de interesse social: o caso da Grande São Paulo. In: PEREIRA, Paulo Cesar Xavier; HIDALGO, Rodrigo (ed). Producción Inmobiliaria y reestructuración metropolitana en América Latina. Santiago: Instituto de Geografía, Pontificia Universidad Católica de Chile. SERIE GEOlibros n.11, 2008.

NOVE edifícios implodem hoje em Carapicuíba. Folha de São Paulo, 30 abr. 1991, Cad. Cotidiano, p. 5. Disponível em: <http://acervo.folha.uol.com.br/fsp/1991/04/30/15>. Acesso em 2 dez. 2016.

OCUC - Observatório de cidades. Santiago: Facultad de Arquitetura, Diseño Y Estudios Urbanos da Pontificia Universidad Católica de Chile. Disponível em: <http://ocuc.cl/>. Acesso em 17 dez. 2016.

OLATE, Marco Araya. Patrones sociales ante situaciones de inseguridad en espacios públicos afectados por la delincuencia. El caso de la Población Santa Adriana en la Comuna de Lo Espejo. 2012. Disertación (Máster en Habitat Residencial), Facultad de Arquitectura y Urbanismo, Universidad de Chile, nov. 2012.

OPAZO, Magdalena Bretón. Evaluación de la política de vivienda social en la década de los noventa sobre la segregación y movilidad residencial en Chile. 2014. Tese (Doutorado en Economia), Facultad de Ciencias Económicas y Empresariales, Universidad Autónoma de Madrid, 2014.

PAZ, María Sagredo. Panorama de las EGIS en la Region Metropolitana. Documento de Trabajo. n.8. Marzo, 2010. Disponível em: <www.techo.org/techo/cis/publicaciones/>. Acesso em 24 set. 2015.

PRÉDIOS ficam de pé na implosão de Erundina. Folha de São Paulo, 10 maio 1991, Caderno Cotidiano, p. 1. Disponível em: <http://acervo.folha.uol.com.br/fsp/1991/05/01/15/>. Acesso em 2 dez. 2016.

PREFEITURA DE SÃO PAULO. Infocidade. Disponível em: <http://infocidade.prefeitura.sp.gov. br/index.php?cat=18\&titulo=Trabalho>. Acesso em 25 set. 2016.

PREFEITURA DE SÃO PAULO. Secretaria Municipal de Coordenação das Subprefeituras. Dados demográficos dos distritos pertencentes às Subprefeituras. Disponível em: <http://www. prefeitura.sp.gov.br/cidade/secretarias/subprefeituras/subprefeituras/dados_demograficos/ index.php? $p=12758>$. Acesso em 25 set. 2016.

PRODEMU. Apuntes de reconstrucción histórica. Población Santa Adriana. Mimeo, 2004, apud LUNECKE, Alejandra Reyes. La paradoja de Santa Adriana - Tráfico de drogas en una población emblemática. 2008. Disertación (Máster en Desarrollo Urbano), Instituto de Estudios Urbanos y Territoriales, Facultad de Arquitectura, Diseño y Estudios Urbanos, Pontificia Universidad Católica de Chile, Oct. 2008.

QUEIROGA, Eugenio Fernandes. Dimensões púbicas do espaço contemporâneo: resistências e 
transformações de territórios, paisagens e lugares urbanos brasileiros. 2012. Tese (Livre Docência em Arquitetura e Urbanismo), Faculdade de Arquitetura e Urbanismo, Universidade de São Paulo, São Paulo.

. Por um paisagismo crítico: uma leitura sobre a contribuição de Miranda Magnoli para a ampliação do corpus disciplinar do Paisagismo. Paisagem e Ambiente, n. 21 (especial Miranda Magnoli), p. 55-63, 2006.

QUEIROGA, Eugenio Fernandes; BENFATI, Denio Munia. Sistemas de espaços livres urbanos: construindo um referencial teórico. Paisagem e Ambiente, v. 24, 2007, p.81-87.

RAMALHOSO, Wellington. Destino Itaquera: o metrô rumo aos conjuntos habitacionais da COHAB-SP. 2013. Dissertação (Mestrado), Instituto de Arquitetura e Urbanismo, Universidade de São Paulo, 2013.

REIS FILHO, Nestor Goulart. Notas sobre a urbanização dispersa e novas formas de tecido urbano. São Paulo: Via das Artes, 2006.

RODRÍGUEZ, Alfredo; SUGRANYES, Ana (ed.) Los con techo. Un desafío para la política de vivienda social. Santiago: Ediciones SUR, 2005, 265 p.

RODRÍGUEZ, Jorge. Evolución de la población del Gran Santiago: Tendencias, perspectivas y consecuencias. Notas de Población - Revista Latinoamericana de Demografía. Santiago de Chile, Editorial CEPAL, Ano XXI, n. 58, p. 95-184, dic. 1993. Disponível em: < http://www.cepal. org/es/publicaciones/38132-notas-de-poblacion-vol21-ndeg-58>. Acesso em 15 jun. 2016.

ROLNIK, Raquel. La democracia en el filo de la navaja: límites y posibilidades para la implementación de una agenda de reforma urbana en Brasil. Revista EURE, v. 35, n. 104, p. 5-28, 2009. Disponível em <http://www.scielo.cl/pdf/eure/v35n104/art01.pdf>. Acesso em mar. 2014.

São Paulo, novo século: uma nova geografia? In: CAMPOS, Candido Malta; GAMA, Lúcia Helena; SACCHETTA, Vladimir (Org.) São Paulo, Metrópole em trânsito: Percursos urbanos e culturais. São Paulo: Editora Senac, 2004, p. 172-177.

. Exclusão territorial e violência. São Paulo em perspectiva, São Paulo, v. 13, n. 4, p. 100-111, Dec. 1999 . Disponível em: <http://www.scielo.br/scielo.php?script=sci_arttext\&pid=S0102-88391999000400011\&lng=en\&nrm=iso>. Acesso maio 2015.

ROLNIK, Raquel; IACOVINI, Rodrigo Faria Gonçalves; KLINTOWITZ, Danielle. Habitação em municípios paulistas: construir políticas ou "rodar" programas? R. B. Estudos Urbanos e Regionais. v.16, n. 2, p. 149-165, nov. 2014. Disponível em: <http://unuhospedagem.com.br/revista/rbeur/index.php/rbeur/article/view/4724/4648>. Acesso em jan. 2015.

RIBEIRO, Ana Clara Torres. Por uma sociologia do presente: ação, técnica e espaço. Rio de Janeiro: Letra Capital, 2013, 5 v.

. Teorias da ação. 1. ed. Rio de Janeiro: Letra Capital, 2014.

RIBEIRO et al. Por uma cartografia da ação: pequeno ensaio de método. In: RIBEIRO, Ana Clara Torres. Por uma sociologia do presente: Ação, técnica e espaço. Rio de Janeiro: Letra Capital, 2013, v. 4, p. 149-171. 
RIBEIRO, Ana Paula; BOULOS, Guilherme; SZERMETA, Natalia. Como não fazer política pública. Após anos do Minha Casa Minha Vida, déficit habitacional aumentou em quase 1,5 milhão de moradias. Carta Capital, 30 jan. 2014. Disponível em: < http://www.cartacapital.com.br/politica/como-nao-fazer-politica-urbana-3066.html> Acesso em 28 set. 2015.

SABATINI, Francisco. La dimensión ambiental de la pobreza urbana en las teorías lationoamericanas de marginalidad. EURE - Revista Latinoamericana de Estudios Urbano Regionales. Pontifícia Universidad Catolica de Chile. v. 8, n. 23, dic. 1981.

SANTOS, Milton. Por uma outra globalização: do pensamento único à consciência universal. 6. ed., São Paulo: Record, 2001.

. Metamorfoses do espaço habitado. São Paulo: Hucitec, 1997.

. A natureza do espaço: técnica e tempo, razão e emoção. São Paulo: HUCITEC, 1996.

Técnica, Espaço, Tempo. Globalização e meio técnico-científico-informacional. São Paulo: HUCITED, 1994.

SCHELP, Mathias Xavier. Pequenos Contos Preguiçosos. No prelo.

SECRETARIA DO ESTADO DA SEGURANÇA PÚBLICA DE SÃO PAULO / O ESTADO DE S. PAULO. Criminalidade bairro a bairro. 2014. Disponível em: <http://infograficos.estadao.com.br/cidades/criminalidade-bairro-a-bairro/>. Acesso em 7 maio 2015

SEGOVIA, Olga. Habitar en conjuntos de vivienda social: ¿cómo construir identidad, confianza y participación social? In: RODRÍGUEZ A.; SUGRANYES A. (Eds.) Los con techo. Un desafío para la política de vivienda social. Santiago: Ediciones SUR, 2005. 265 p.

SEHAB/HABISP. Listagem de Favelas do Município de São Paulo. 2015. Disponível em: <http:// infocidade.prefeitura.sp.gov.br/htmls/9_distribuicao_das_favelas_2015_516.html>. Acesso em 25 set. 2016.

SEREMI Metropolitana Vivienda y Urbanismo. Recuperando Barrios de Santiago. 2008.

SHLOMO, Angel; PARENT, Jason; CIVCO, Daniel L.; BLEI, Alejandro. Atlas of urban expansion. Cambridge, Massachusetts: Lincoln Institute of Land Policy, 2012.

SILVA, Luís Octávio da Silva. Verticalização, expansionismo e grandes obras viárias: a modernização limitada. In: CAMPOS, Candido Malta; GAMA, Lúcia Helena; SACCHETTA, Vladimir (Org.) São Paulo, Metrópole em trânsito: Percursos urbanos e culturais. São Paulo: Editora Senac, 2004, p. 100-111.

SILVA, Marcio Rufino. "Mares de prédios" e "mares de gente": território e urbanização crítica em Cidade Tiradentes. 2008. Dissertação (Mestrado), Faculdade de Filosofia, Letras e Ciências Humanas, Departamento de Geografia, Universidade de São Paulo, 2008.

SKEWES, Juan Carlos Vodanovic. De invasor a deudor: el éxodo desde los campamentos a las viviendas sociales en Chile. In: RODRÍGUEZ A.; SUGRANYES A. (Eds.) Los con techo. Un desafío para la política de vivienda social. Santiago: Ediciones SUR, 2005. p 101-122.

SLOMIANSKY, Adriana Paula. Cidade Tiradentes: A abordagem do poder público na construção 
da cidade. Conjuntos Habitacionais de Interesse Social da COHAB-SP (1965-1999). 2002. Tese (Doutorado), Faculdade de Arquitetura e Urbanismo, Universidade de São Paulo, 2002.

SOLANGE, Lea Castillo Valenzuela. Resistencia, Despazamiento y preferencias de localización de vivienda social: Externalidades del Programa Recuperación de Condominios Sociales Segunda Oportunidad. 2014. Disertación (Mestrado), Facultad de Arquitectura y Urbanismo, Universidad de Chile, dic. de 2014.

SOUZA, Diego Beja Inglez de. Tumulto no conjunto: Habitação, utopia e urbanização no limite de duas metrópoles contemporâneas: São Paulo/Paris (1960-2010). 2014. Tese (Doutorado), Faculdade de Arquitetura e Urbanismo, Universidade de São Paulo e Université Paris 1 Panthéon-Sorbonne, 2014.

SUR Profesionales Consultores. Plan de Habilitación Social Post Entrega de Viviendas Lomas del Prado. Informe Final, feb. 2015.

TAPIA ZARRICUETA, Ricardo. Vivienda social en Santiago de Chile: Análisis de su comportamiento locacional, período 1980- 2002. Revista INVI, Santiago, v. 26, n. 73, nov. 2011. Disponível em: <http://www.scielo.cl/scielo.php?script=sci_arttext\&pid=S0718-83582011000300004\&lng=es\&nrm=iso>. Acesso em mai. 2013.

Evolución de la localización de la vivienda social en el Gran Santiago. Período 2003-2010. Editorial, Revista INVI, 27(75), p. 9-18, 2012.

TATAGIBA, Luciana F. et al. Inovações participativas nas políticas habitacionais para população de baixa renda: um estudo de caso sobre o Programa Minha Casa, Minha Vida - Entidades. 2013. Relatório Final de Pesquisa. Programa Regional de Becas de Investigación. CLACSO ASDI Campinas, 2013. Disponível em:<http://biblioteca.clacso.edu.ar/gsdl/collect/clacso/index/assoc/D9244.dir/Clacso_versao_final.pdf>. Acesso em mar. 2014.

VALENCIA, Manuel. Corte Suprema obliga al fisco a indemnizar a 158 familias de Bajos de Mena. Diario El Mercurio. Santiago. 9 mayo 2013. Disponível em: < http://www.plataformaurbana.cl/ archive/2013/05/09/corte-suprema-obliga-al-fisco-a-indemnizar-a-158-familias-de-bajos-de-mena/> Acesso em 14 set. 2015.

VILLAÇA, Flávio. Elites, desigualdade e poder municipal. In: CAMPOS, Candido Malta; GAMA, Lúcia Helena; SACCHETTA, Vladimir (Org.) São Paulo, Metrópole em trânsito: Percursos urbanos e culturais. São Paulo: Editora Senac. São Paulo, 2004, p. 148-163.

YÁNEZ, Leonel. Santa Adriana. 50 años de Territorio y Vida. Programa Recuperación de Barrios. Plan de gestión social, ámbito Identidad y Cultura. Santiago: Ministerio de Vivienda y Urbanismo, 2007. 